ISSN: 2175-9766

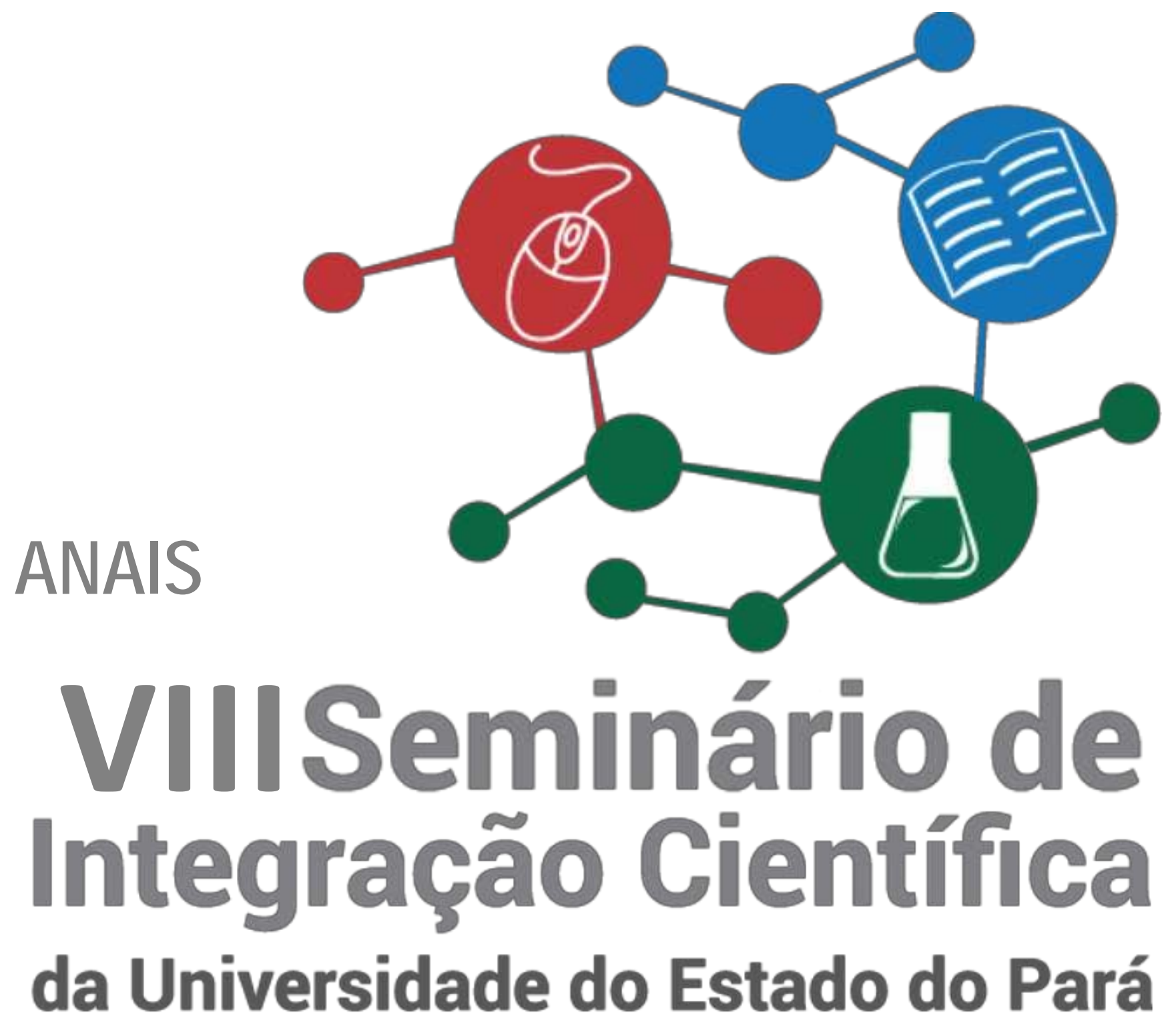




\section{Universidade do Estado do Pará}

Reitor

Vice-Reitor

Pró-Reitora de Pesquisa e Pós-Graduação Pró-Reitora de Graduação

Pró-Reitora de Extensão

Pró-Reitor de Gestão e Planejamento

Diretor do Centro de Ciências Sociais e

Educação

CCSE

Diretora do Centro de Ciências Biológicas e da Saúde

CCBS

Diretora do Centro de Ciências Naturais e

Tecnológica

CCNT
Rubens Cardoso da Silva

Clay Anderson Nunes Chagas

Renato da Costa Teixeira

Ana da Conceição Oliveira

Alba Lucia Ribeiro Raithy Pereira

Carlos José Capela Bispo

Anderson Madson Oliveira Maia

Vera Regina da Cunha Menezes Palácios

Eliane de Castro Coutinho 


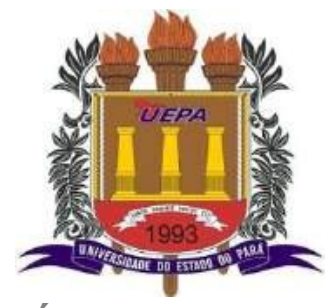

VIII SEMINÁRIO DE INTEGRAÇÃO CIENTÍFICA

\section{Coordenação do Evento}

\section{Renato da Costa Teixeira}

Pró-Reitor de Pesquisa e Pós-Graduação da UEPA

Valéria Marques Ferreira Normando

Diretora de Desenvolvimento à Pesquisa

\section{Seidel Ferreira dos Santos}

Diretor de Desenvolvimento à Pós-Graduação

\section{Equipe Técnica}

Danielle Seabra Negrão da Silva Dayvison Diego Ramos Santos Édina Gonçalves Ferreira Alves Elane Falcão Costa Helen Karla Ribeiro Raiol
Katharina Lemos de SouzaBriano Leonardo Silveira Santos Selma Socorro Jucá dos Santos Selma dos Prazeres Nunes da Fonseca Suene Valente da Silva 
Nota: Os trabalhos apresentados exprimem conceitos de responsabilidade única de seus autores, coincidentes ou não com os pontos de vista de redação do livro. 


\section{APRESENTAÇÃO}

Pensado como espaço de socialização dos resultados da pesquisa científica produzida pelos professores e alunos vinculados aos programas de iniciação científica e de pós-graduação stricto sensu da UEPA, o Seminário de Integração Científica (SIC/UEPA) apresenta-se em sua oitava edição.

A realização deste evento, face à participação maciça do nosso alunado envolvido em atividades de pesquisa, evidencia, antes de tudo, a responsabilidade que a UEPA tem com a formação de futuros pesquisadores. Tal formação - vale lembrar é fortalecida e fomentada tanto pelo investimento que a própria UEPA faz em suas atividades de pesquisa, quanto pelas inúmeras formas de apoio que a UEPA recebe de instituições como CNPq, CAPES, FINEP e FAPESPA.

Portanto, o VIII Seminário de Integração Científica reafirma o compromisso que a Universidade do Estado do Pará tem para com a missão de produzir e socializar conhecimento útil. Neste sentido, este evento procura ser uma demonstração de que produção científica qualificada dentro da UEPA é uma realidade.

Prof. Dr. Renato da Costa Teixeira Pró-Reitor de Pesquisa e Pós-Graduação 


\section{SUMÁRIO}

EFEITOS DA MOBILIZAÇÃO PRECOCE EM CRIANÇAS COM PNEUMONIA ASSOCIADA A VENTILAÇÃO MECÂNICA INVASIVA

CARACTERIZAÇÃO DO PERFIL EPIDEMIOLÓGICO E CLINICO DOS CASOS DE HANSENÍASE TRATADOS COM POLIQUIMIOTERAPIA NO MUNICÍPIO DE SANTARÉM-PA

ELABORAÇÃO DE BIOPOLÍMEROS A BASE DE FÉCULA DE MANDIOCA E AMIDO DE MILHO COM INCORPORAÇÃO DE PIGMENTOS NATURAIS EFEITO DA UTILIZAÇÃO DE POLPA E CASCAS DE PITAYA, TANGERINA E TAPEREBÁ NAS PROPRIEDADES FÍSICO-QUÍMICAS DE HIDROMÉIS

REDE HIDROMÉTRICA DA REGIÃO HIDROGRÁFICA TOCANTINSARAGUAIA

DIVERSIDADE DE INSECTA NO CAMPUS DO CENTRO DE CIÊNCIAS SOCIAIS E EDUCAÇÃO (CCSE) DA UNIVERSIDADE DO ESTADO DO PARÁ

CONSTRUÇÃO DE APLICATIVOS COMO FERRAMENTA DIDÁTICA PARA VISUALIZAÇÃO GRÁFICA DE FUNÇÕES NO MOVIMENTO OSCILATÓRIO

NARRATIVAS SILENCIADAS: UMA ANÁLISE DIALÓGICA DE MEMÓRIAS DE SURDOS LGBT

INTERFACES COMPUTACIONAIS COMO FERRAMENTAS DE EXPLORAÇÃO VISUAL APLICADA AO ENSINO DE FÍSICA NO ENSINO MÉDIO

USO DE EXPERIMENTOS TEMÁTICOS PARA REVITALIZAÇÃO DO LABORATÓRIO DE CIÊNCIAS EM UMA ESCOLA DE BARCARENA-PA DETERMINAÇÃO DO PERFIL QUÍMICO E ATIVIDADES ANTIOXIDANTE DE PLANTAS MEDICIONAIS DE SOURE-PA 
CIÊNCIA, TECNOLOGIA E CIDADANIA: VIVÊNCIAS E DESCOBERTAS EM BIOLOGIA NO CENTRO DE CIÊNCIAS E PLANETÁRIO DO PARÁ UEPA

ATIVIDADE HIPOGLICEMIANTE DE Himatanthus sucuuba EM RATOS DA LINHAGEM WISTAR

AVALIAÇÃO DO EFEITO DO EXTRATO ETANÓLICO DA EUTERPE OLERACEA MART NO REPARO TECIDUAL DE RATOS

MEDIDAS PREVENTIVAS SOBRE PÉ DIABÉTICO DE PACIENTES DA ATENÇÃO PRIMÁRIA Á SAÚDE

PERFIL CLÍNICO-EPIDEMIOLÓGICO DE PACIENTES COINFECTADOS HIVISÍFILIS ATENDIDOS EM UM CENTRO DE REFERÊNCIA

SAÚDE E CONDIÇOES SOCIOECONÔMICAS EM UMA UNIDADE PRISIONAL NO SUDESTE DO PARÁ

PREVALÊNCIA DAS DOENÇAS INFECCIOSAS DE TRANSMISSÃO VERTICAL INVESTIGADAS NO PROJETO GESTAR EM BELÉM-PA NO ANO DE 2015

DESENVOLVIMENTO DE UM DISPOSITIVO DE SUSPENSÃO PÉLVICA DE BAIXO CUSTO PARA TRATAMENTO FISIOTERAPÊUTICO DA LOMBALGIA

AVALIAÇÃO CLÍNICA-LABORATORIAL DOS PACIENTES COM RISCO DE DOENÇA RENAL CRÔNICA CADASTRADOS NO PROGRAMA HIPERDIA EM UM MUNICÍPIO NO INTERIOR DA AMAZÔNIA

UM OLHAR SOBRE A SAÚDE MENTAL DE ACADÊMICOS DA ÁREA DA SAÚDE DE UMA UNIVERSIDADE PÚBLICA

AVALIAÇÃO DE ANSIEDADE, DEPRESSÃO E QUALIDADE DE VIDA EM PACIENTES COM PARKINSON SUBMETIDOS AO MÉTODO WATSU AVALIAÇÃO DA MOBILIDADE E EQUILÍBRIO DE PESSOAS COM DOENÇA DE PARKINSON

ENTRAVES ENFRENTADOS POR RIBEIRINHAS NA PREVENÇÃO DO 
CÂNCER CÉRVICO UTERINO: O LAÇO VIROU NÓ

DESENVOLVIMENTO MOTOR E COMUNICATIVO DE PREMATUROS:

FATORES DE RISCO E DA INTERAÇÃO MÃE-BEBÊ

DESENVOLVIMENTO DE UMA ÓRTESE DINÂMICA DE BAIXO CUSTO PARA PACIENTES COM LESÃO MEDULAR NÍVEL C6 E C7: NOVA POSSIBILIDADE PARA REALIZAÇÃO DAS ATIVIDADES DE VIDA DIÁRIAS.

PREVALÊNCIA E FATORES DE RISCO ASSOCIADOS ÀS ALTERAÇÕES POSTURAIS ENTRE ESCOLARES

A MORTE CELULAR EM LESÕES CUTÂNEAS DA DOENÇA DE HANSEN PERFIL EPIDEMIOLÓGICO DA INFECÇÃO PELO HIV EM GESTANTES INDÍGENAS E NÃO INDÍGENAS E SUA RELAÇÃO COM OS DETERMINANTES SOCIAIS DE SAÚDE

EFEITOS DA REABILITAÇÃO CARDÍACA EM FASE III DE PACIENTES EM PÓS-OPERATÓRIO DE TROCA VALVAR E REVASCULARIZAÇÃO DO MIOCÁRDIO

EFEITO DO LASER DE BAIXA POTÊNCIA E DO PLASMA RICO EM PLAQUETAS NA EXPRESSÃO DE COLÁGENO APÓS CONTUSÃO MUSCULAR

PLANO DE INTERVENÇÃO NA IDENTIFICAÇÃO PRECOCE DE PACIENTES COM HANSENÍASE EM UMA UNIDADE BÁSICA DE SAÚDE NO MUNICÍPIO DE SANTARÉM

ASPECTOS CLÍNICOS E LABORATORIAIS DE PACIENTES COM DOENÇAS LINFOPROLIFERATIVAS CUTÂNEAS ASSOCIADOS AO HTLV

TECNOLOGIA EM SAÚDE E REPRESENTAÇÕES SOCIAIS PARA ABORDAGEM DA SAÚDE MENTAL DE GESTANTES COM CARDIOPATIA FETAL

CARACTERÍSTICAS SOCIODEMOGRÁFICAS E CLÍNICAS DE PESSOAS 
ADOECIDAS POR CÂNCER COLORRETAL SUBMETIDAS AO TRATAMENTO CIRÚRGICO

ESTUDO DA MORTALIDADE NEONATAL EM HOSPITAIS PÚBLICOS DE ALTA E MÉDIA COMPLEXIDADE NO BAIXO AMAZONAS

PAPEL DA NOS-2 NA ELEVAÇÃO DE NITRITO NO TELENCÉFALO DE ZEBRAFISH (DANIO RERIO HAMILTON 1822), EM MODELO DE TRANSTORNO DE ESTRESSE PÓS-TRAUMÁTICO

AVALIAÇÃO DO NÍVEL DE CONHECIMENTO DE GESTANTES ATENDIDAS EM UM SERVIÇO PÚBLICO EM BELÉM-PA SOBRE PRÉNATAL E FATORES DE RISCO NA GRAVIDEZ

INVENTÁRIO DE ADAPTAÇÃO AO ESTOMA (OAI-23): UMA APLICAÇÃO À REGIÃO NORTE DO BRASIL

AVALIAÇÃO DA FUNCIONALIDADE, DA QUALIDADE DE VIDA E DO ÍNDICE DE INCONTINÊNCIA URINÁRIA EM IDOSOS PRATICANTES DE EXERCÍCIOS RESISTIDOS

ANÁLISE DO METABOLISMO OXIDATIVOS E SUA CORRELAÇÃO COM O DESEMPENHO OCUPACIONAL DE PACIENTES COM DOENÇA DE PARKINSON SOB PARÂMETROS DA CLASSIFICAÇÃO INTERNACIONAL DE FUNCIONALIDADE, INCAPACIDADE E SAÚDE EFEITOS DA MOBILIZAÇÃO PRECOCE EM CRIANÇAS COM PNEUMONIA ASSOCIADA A VENTILAÇÃO MECÂNICA INVASIVA 101 AVALIAÇÃO FUNCIONAL, ELETROFISIOLÓGICA E PONDERAL DA REGENERAÇÃO NEURAL PÓS LESÃO DO MEDIANO DE RATOS

A INFLUÊNCIA DO PROTOCOLO DE TREINAMENTO MUSCULAR RESPIRATÓRIO DOMICILIAR EM PORTADORES DO VÍRUS LINFOTRÓPICO

FUNÇÕES SEXUAL E URINÁRIA DE GESTANTES

AVALIAÇÃO DA QUALIDADE AMBIENTAL EM LOCAIS DE RECREAÇÃO NA BACIA HIDROGRÁFICA DO XINGU-PA 
PROPOSTA DE MAPA DE PROCESSOS PARA LOGÍSTICA REVERSA DOS RESÍDUOS GERADOS NA PRODUÇÃO DA POLPA DO AÇAÍ EM BELÉM- PA: UM ESTUDO BASEADO NA POLÍTICA NACIONAL DE RESÍDUOS SÓLIDOS

QUALIDADE DA MADEIRA SERRADA COMERCIALIZADAS EM ESTÂNCIAS DA REGIÃO METROPOLITANA DE BELÉM-PA

PARÂMETROS DE COMPARAÇÃO ENTRE PLANOS DE ROTAS GERADOS PELOS MÉTODOS MAIS CONHECIDOS DE ROTEIRIZAÇÃO DE VEÍCULOS

CONSTRUÇÃO DE UM SECADOR REFRACTANCE WINDOW® PARA PRODUZIR AÇAÍ EM PÓ COM MELHOR RETENÇÃO NUTRICIONAL

ELABORAÇÃO DE HIDROLISADO PROTEICO ENZIMÁTICO A PARTIR DE RESÍDUOS DE PESCADO

EFEITO DE PARAMETROS CLIMÁTICOS NA FENOLOGIA DE ESPÉCIES UTILIZADAS NA ARBORIZAÇÃO URBANA DA CIDADE DE CASTANHAL $-P A$

COMPARAÇÃO DAS PROPRIEDADES DA MADEIRA DE DUAS ESPÉCIES DO GÊNERO CECROPIA

PROPRIEDADES FÍSICAS DA MADEIRA DE LIMÃOZINHO (ZANTHOXYLUM EKMANII (URB.) ALAIN) APÓS TRATAMENTO TÉRMICO

PROPOSIÇÃO DE UM MODELO ESTRUTURAL PARA O CÁLCULO DO GRAU DE ADOÇÃO DO LEAN MANUFACTURING: UM SURVEY NA INDÚSTRIA DE TRANSFORMAÇÃO DO ESTADO DO PARÁ

DESCRIÇÃO ANATÔMICA DA MADEIRA E DO CARVÃO VEGETAL DE ESPÉCIES FLORESTAIS NATIVAS DA AMAZÔNIA COMO SUBSÍDIO PARA A FISCALIZAÇÃO

PRODUÇÃO DE BRIQUETES UTILIZANDO MISTURAS DE BIOMASSA LIGNOCELULÓSICA PARA FINS ENERGÉTICOS 
DESENVOLVIMENTO DE MATERIAIS BIOCOMPÓSITOS A BASE DE PLÁSTICO E PAPEL PÓS CONSUMO

UTILIZAÇÃO DE RESÍDUOS DE AGROINDÚSTRIA DO AÇAÍ PARA POSSÍVEL APLICAÇÃO NA INDÚSTRIA TÊXTIL

CARACTERIZAÇÃO FÍSICO-QUÍMICA DE RESÍDUOS DA PESCADA AMARELA (Cynoscion acoupa) COMERCIALIZADA NO MERCADO DE PEIXE DO VER-O-PESO

CORRELAÇÃO DOS ROYALTIES DA MINERAÇÃO COM AS VARIÁVEIS SOCIOECONÔMICAS E AMBIENTAIS DOS PRINCIPAIS MUNICÍPIOS MINERADORES DO ESTADO DO PARÁ, BRASIL

PLANTAS ALIMENTÍCIAS NÃO CONVENCIONAIS (PANC'S) DA ILHA DO MOSQUEIRO, BELÉM-PARÁ

ESTUDO DA COLEMBOFAUNA DE UMA MONOCULTURA DE DENDÊ NO ESTADO DO PARÁ

A ESCOLARIZAÇÃO DA PESSOA COM DEFICIÊNCIA NAS ILHAS DO COMBU E COTIJUBA

ELABORAÇÃO DE HAMBÚRGUER DE CASTANHA DO BRASIL (BERTHOLLETIA EXCELSA).

ANÁLISE DA QUALIDADE AMBIENTAL DA ÁGUA DOS RIOS PRAINHA E URAIM (PARAGOMINAS-PARÁ): UTILIZANDO INSETOS AQUÁTICOS COMO BIOINDICADORES

TERRITÓRIO E VIOLÊNCIA URBANA: UMA LEITURA GEOGRÁFICA DOS HOMICÍDIOS NO BAIRRO DO CURUÇAMBÁ, ANANINDEUA-PA

PROJETO DE PESQUISA/PIBIC: VINTE ANOS DO CÓDIGO DE TRÂNSITO BRASILEIRO: EDUCAÇÃO PARA O TRÂNSITO, AVANÇOS, DESAFIOS E PERSPECTIVA

MITOS ASSURINI DO TROCARÁ: FONTES DE SABERES INTERDISCIPLINARES

MARCAS DA DIFERENÇA: REFLEXÕES SOBRE A CONTRIBUIÇÃO DO 
NEGRO NA PRODUÇÃO CIENTÍFICA E MATEMÁTICA

PRODUÇÃO DE ENERGIA SOLAR FOTOVOLTAICA COMO FONTE ELÉTRICA COMPLEMENTAR PARA UMA PEQUENA EMBARCAÇÃO PESQUEIRA

FACEBOOK: UMA ANÁLISE DOS PROCESSOS DE SOCIABILIDADES ENTRE OS JOVENS

IMAGENS E SENTIDOS DOS RITOS DE PASSAGENS: ESTUDO DA SÉRIE VIKINKS E A INFLUÊNCIA PARA O PAGANISMO CONTEMPORÂNEO

PUBLISH OR PERISH": O PRODUTIVISMO ACADÊMICO E O ADOECIMENTO DOCENTE

CARACTERIZAÇÃO QUÍMICA DO MEL PRODUZIDO NO MUNICÍPIO DE CACHOEIRA DO ARARI - ILHA DE MARAJÓ, PARÁ

DIÁLOGOS SUL-SUL: OS DESAFIOS DA DEMOCRACIA E EDUCAÇÃO PÚBLICA NA SOCIEDADE BRASILEIRA NOS PENSAMENTOS DE PAULO FREIRE E BOAVENTURA SANTOS

REPRESENTAÇÕES SOCIAIS DE UMA MÃE SOBRE A INCLUSÃO DE SEU FILHO NA EDUCAÇÃO INFANTIL DA EDUCAÇÃO ESPECIAL NO ÂMBITO DA SEMEC-BELÉM

CARACTERIZAÇÃO HISTOPATOLÓGICA EM CASOS POST MORTEM DE EQUINOS E AVES INFECTADOS PELO VÍRUS DA ENCEFALITE DE SAINT LOUIS

USO DE PRIMATAS NEOTROPICAIS DO GÊNERO Sapajus NA PADRONIZAÇÃO DE MODELO EXPERIMENTAL PARA Schistosoma mansoni

CARACTERIZAÇÃO CLÍNICO-EPIDEMIOLÓGICA E MICROBIOLÓGICA DE CASOS DE INFECÇÃO EM SÍTIO CIRÚRGICO PÓS-CESÁREA POR ACINETOBACTER SPP

AÇÃO INIBITÓRIA DO EXTRATO DE AÇAÍ NA INFECÇÃO DO VÍRUS DO 
NILO OCIDENTAL

CORRELAÇÃO DO NOVO PERFIL CITOCÍNICO DE TH22 COM O PADRÃO DE LESÃO HEPATOCÍTARIA NA FEBRE AMARELA

METAGENÔMICA VIRAL DE INSETOS HEMATÓFAGOS COLETADOS NO COMPLEXO MINERADOR DE CARAJÁS, ESTADO DO PARÁ

UNIVERSIDADE DO ESTADO DO PARÁ PRÓ-REITORIA DE PESQUISA E PÓS-GRADUAÇÃO

ESTUDO DA RESPOSTA DE ANTICORPOS PARA FLAVIVIRUS NA POPULAÇÃO BRASILEIRA FRENTE À EMERGÊNCIA DO VZIK NO PAÍS PESQUISA PARA A DETECÇÃO DOS VÍRUS DA FEBRE AMARELA E VÍRUS DO MAYARO EM AMOSTRAS DE ÁRTROPODES

CARACTERIZAÇÃO DO GENOMA MITOCONDRIAL DE QUATRO ESPÉCIES DO GÊNERO Haemagogus (DIPTERA: CULICIDAE)

INFECÇÃO EXPERIMENTAL DE Biomphalaria glabrata DE BELÉM, ESTADO DO PARÁ, COM CEPA SIMPÁTRICA DE Schistosoma mansoni: RECÉM ISOLADA (BE-I) vS. MANTIDA EM LABORATÓRIO (BE) ESTUDO DE POLIMORFISMOS DO GENE DO RECEPTOR DE VITAMINA D NA HANSENÍASE

ANÁLISE CARDIOPULMONAR E FUNCIONAL DE PACIENTES HANSENIANOS

ANÁLISE FENOTÍPICA E MOLECULAR DE ISOLADOS DO COMPLEXO

Mycobacterium avium ASSOCIADOS À CASOS DE DOENÇA PULMONAR NO ESTADO DO PARÁ

INVESTIGAÇÃO DO VIROMA DE MARSUPIAIS E ROEDORES PROCEDENTES DO MUNICÍPIO DE PEIXE-BOI, PARÁ

INFECÇÃO EXPERIMENTAL DE West Nile virus EM Culex quinquefasciatus, SAY 1823

ASPECTOS EPIDEMIOLÓGICOS DA MALÁRIA NO MUNICÍPIO DE TUCURUÍ- PA 
INTERFERÊNCIA HETERÓLOGA ENTRE OS VÍRUS CHIKUNGUNYA E MAYARO

CARACTERIZAÇÃO DAS LESÕES E IDENTIFICAÇÃO DOS TIPOS CELULARES EM CASOS DE INFECÇÃO PELO VÍRUS DO NILO OCIDENTAL

AVALIAÇÃO DO TESTE RÁPIDO POINT-OF-CARE CIRCULATING CATHODIC ANTIGEN (POC-CCA) NO DIAGNÓSTICO DA ESQUISTOSSOMOSE EM ÁREA ENDÊMICA NO ESTADO DO PARÁ E MARANHÃO

AVALIAÇÃO in vitro DO COCULTIVO DE FIBROBLASTOS COM MACRÓFAGOS INFECTADOS POR Leishmania amazonensis E Leishmania braziliensis

ESTUDO METAGENÔMICO DO VIROMA DE MARSUPIAIS E ROEDORES ORIGINÁRIOS DO MUNICÍPIO DE SANTA BÁRBARA DO PARÁ

DISPOSIÇÃO A PAGAR PELA CONSERVAÇÃO DO PARQUE MUNICIPAL DA ILHA DE MOSQUEIRO, BELÉM-PA

DIAGNÓSTICO SOCIOECONÔMICO E AMBIENTAL DA PRODUÇÃO DE AÇAÍ (Euterpe oleracea Mart.) NO MUNICÍPIO DE IGARAPÉ-MIRI, PARÁ

RECURSOS DA SOCIOBIODIVERSIDADE AMAZÔNICA: ETNOCONHECIMENTO DO TUCUMÃ (ASTROCARYUM VULGARE MART.) E DO "ÓLEO DE BICHO", SALVATERRA, PARÁ, BRASIL AVALIAÇÃO DA QUALIDADE DA H2O DE POÇOS DOMÉSTICOS EM COMUNIDADES RURAIS NO MUNICÍPIO DE SALVATERRA, ILHA DE MARAJÓ- PA

A CONDIÇÃO AMBIENTAL DA PRAIA DO ATALAIA, SALINÓPOLIS, PA: BIOINDICAÇÃO POR ZOOPLÂNCTON

USOS, PERCEPÇÕES E SUSTENTABILIDADE DOS MANGUEZAIS DO MUNICÍPIO DE SALVATERRA. 
AVALIAÇÃO E MAPEAMENTO DOS SERVIÇOS ECOSSISTÊMICOS OFERTADOS PELA RESERVA BIOLÓGICA NASCENTES DA SERRA DO CACHIMBO, PARÁ, BRASIL 345

EXPANSÃO DA MINERAÇÃO EM TERRAS INDÍGENAS NA AMAZÔNIA ORIENTAL BRASILEIRA: VULNERABILIDADE SOCIAL E IMPACTOS SOCIOAMBIENTAIS

ANÁLISE DA CONCENTRAÇÃO DE METAIS NO LAGO ÁGUA PRETA (BELÉM-PA) USANDO COMO BIOINDICADOR O GAFANHOTO SEMIAQUÁTICO TETRATAENIA SURINAMA (LINNAEUS, 1764)

A MALÁRIA NO MUNICÍPIO DE CÂNDIDO MENDES, MARANHÃO:

DIAGNÓSTICO E MAPEAMENTO DOS VETORES

O JOVEM, A UNIVERSIDADE E A FÉ: UM ESTUDO SOBRE O ETHOS ACADÊMICO E EXPERIÊNCIAS RELIGIOSAS DO ESTUDANTE DE CIÊNCIAS DA RELIGIÃO EM BELÉM (PA)

TUDO O QUE MEU AMOR DESEJAR: UM ESTUDO SOBRE OS TRABALHOS DE MAGIA NOS TERREIROS EM BELÉM DO PARÁ

A CRÍTICA DA RELIGIÃO EM KANT: CONTRIBUIÇÕES PARA O DEBATE ACERCA DA INTOLERÂNCIA RELIGIOSA

RELIGIOSIDADE NA AMAZÔNIA PARAENSE: UMA ETNOGRAFIA DA COMUNIDADE QUILOMBOLA VILA DO CRAVO, CONCÓRDIA - PA

RELIGIÃO E MIDIA: UM ESTUDO DO IMAGINÁRIO TELEVANGÉLICO DA IGREJA UNIVERSAL DO REINO DE DEUS.

PÓS-SECULARIDADE: UMA REVISÃO CRÍTICA DO CONCEITO DE SECULARIZAÇÃO FRENTE AO PLURALISMO

"PODER DA MATA": UMA ANÁLISE SOBRE A DIMENSÃO CONFLITUOSA NO CAMPO PENTECOSTAL NO CONTEXTO DAS VIGÍLIAS DA MATA

RESSONÂNCIAS DO ENTRELAÇAMENTO DA CONVERSÃO COM A ESCRITA AUTOBIOGRÁFICA EM CONFISSÕES DE SANTO 
AGOSTINHO

398

BANJO, UM OGAN BAIANO EM BELÉM DO PARÁ 403

O BELO RELIGIOSO CONVENIENTE DE ARNOLD SCHÖNBERG

409

O SACRIFÍCIO E O SACRIFICADOR: UM ESTUDO ETNOGRÁFICO NO TERREIRO DE CANDOMBLÉ ILÊ AXÉ OYÁ NIROLÊ IGBALÉ (KWE ZANVIS AVESSAN), ANANINDEUA-PA

RELIGIÃO E PODER: A VISÃO CELULAR NA PRIMEIRA IGREJA BATISTA EM ICOARACI

ENTRE O ÓRUN E O AYÊ: OS ATABAQUES COMO REFLEXO DA COSMOVISÃO IORUBÁ NO TERREIRO ILÉ ASÉ IYÁ OGUNTÉ 424 EDUCAÇÃO AMBIENTAL EM COMUNIDADES TRADICIONAIS PESQUEIRAS DA AMAZÔNIA: UM ESTUDO SOBRE A EXPERIÊNCIA DO GRUPO AMBIENTAL DE FORTALEZINHA (GAF)

ESPAÇO E FORMA NA EDUCAÇÃO BÁSICA

A CHAMA DA ESTRELA QUE PULSA E ARDE: EDUCAÇÃO SENSÍVEL NA PROSA POÉTICA DE ABGUAR BASTOS

NARRATIVAS DE MORADORES DA BAÍA DO SOL-MOSQUEIRO- PA: ATITUDES ÉTICAS E SABERES CULTURAIS 444

ALUNOS COM DEFICIÊNCIA NA EJA: REALIDADES DIVERSAS 450 SABERES DAS ERVEIRAS DO VER-O-PESO 454

CONTRIBUIÇÕES À EDUCAÇÃO INTERCULTURAL NA AMAZÔNIA 458 NA BARRA DE SUA SAIA: D. MARIA PADILHA, A MULHER QUE EDUCA 464 GABINETE DE LEITURA DO GRÊMIO LITERÁRIO PORTUGUÊS: SABERES E PRÁTICAS EDUCATIVAS (1868-1889) LETRAMENTO RELIGIOSO: UMA ANÁLISE DAS PRÁTICAS EDUCATIVAS E SOCIAIS VIVENCIADAS NA COMUNIDADE CATÓLICA SÃO FRANCISCO XAVIER EM BELÉM/PA

RELAÇÕES DE ALTERIDADE: OS ALUNOS COM DEFICÎENCIA EM TURMAS DO ENSINO MÉDIO NA PERSPECTIVA DO SER MAIS DA 
EDUCAÇÃO, RESISTÊNCIA E TRADIÇÃO ORAL: UMA FORMA OUTRA DE ENSINAR E APRENDER NA COMUNIDADE QUILOMBOLA VILA UNIÃO /CAMPINA-SALVATERRA-PARÁ

EDUCAÇÃO DO CAMPO NA AMAZÔNIA: UM ESTUDO SOBRE A ASSOCIAÇÃO DE MULHERES AGRICULTORAS (AMACAMPO).

HANSENÍASE E REPRESENTAÇÕES SOCIAIS: O OLHAR E O CUIDAR DE QUEM VIVENCIA A DOENÇA

AVALIAÇÃO DO ENFERMEIRO AOS SINTOMAS FÍSICOS E PSICOLÓGICOS DE PACIENTES ONCOLÓGICOS EM CUIDADOS PALIATIVOS

QUALIDADE DE VIDA RELACIONADA A SAÚDE DE CRIANÇAS E ADOLESCENTES EM HEMODIÁLISE: PRODUÇÃO E TESTAGEM DE UMA ESTRATÉGIA GAMIFICADA

ANÁLISE DO CUIDADO ÀS CRIANÇAS EXPOSTAS AO RISCO DE INFECÇÃO PELO HIV

CARACTERIZAÇÃO CLÍNICO-EPIDEMIOLÓGICA DE MULHERES COM LESÕES PRECURSORAS DO CÂNCER DO COLO DO ÚTERO EM UM SERVIÇO DE ATENÇÃO SECUNDÁRIA.

COMPREENSÃO FENOMENOLÓGICA SOBRE O COTIDIANO DE MULHERES COM DIAGNÓSTICO DE LESÃO INTRAEPITELIAL ESCAMOSA ALTA

ESPACIALIDADE DO HIV ENTRE DOADORES DE SANGUE ASSOCIADO AOS FATORES DE RISCO 
PIBIC - EM 


\section{EFEITOS DA MOBILIZAÇÃO PRECOCE EM CRIANÇAS COM PNEUMONIA ASSOCIADA A VENTILAÇÃO MECÂNICA INVASIVA}

Nome dos bolsistas: Kathellen Joane Silva Miranda/Beatriz Freitas Launé/Beatriz Costa dos Santos

Nome do (a) Orientador (a): Rodrigo Santiago Barbosa Rocha

Grupo de Pesquisa: Desenvolvimento e Reabilitação na Amazônia

Introdução: As lesões nervosas periféricas ocorrem após traumas como laceração direta, compressão estiramento ou esmagamento, levando ao estresse. O exercício físico surge como potencial para reduzir o estresse após lesão; Objetivo: Verificar a influência do exercício de natação sobre as características comportamentais de ratos após axoniotmese e desnutrição.; Método: Nessa pesquisa, foram utilizados 60Rattus novergicus da linhagem Wistar, machos, adultos (aproximadamente 6- 7semanas de vida), com peso aproximado de $250 \mathrm{~g}$. Os ratos foram randomizados em 3 grupos experimentais. Grupo Controle (C) - animais foram mantidos em gaiola sem nenhuma intervenção, sendo mantidos em gaiola com dieta normoproteica por 75 dias, Grupo Desnutrição + Lesão(D+L) - animais submetidos à desnutrição por 45 dias, seguido de lesão nervosa por esmagamento, sendo submetidos à eutanásia após 30 dias ( $\mathrm{D}+\mathrm{L}$ $30 d$,) da lesão nervosa, Grupo Desnutrição + Lesão + Natação $(D+L+N)$ - animais submetidos à desnutrição por 45 dias, seguido de lesão nervosa por esmagamento, e exercício de natação após 24 horas da lesão nervosa por esmagamento, sendo submetidos à eutanásia após 30 dias $(\mathrm{D}+\mathrm{L}+\mathrm{N}$ 30d) da lesão nervosa. Após 24 horas da lesão nervosa, os animais dos grupos $D+L+N$ 30d foram submetidos à natação diária, em grupos de no máximo 5 animais, utilizando-se apenas do próprio peso corporal, por 30 minutos/dia, 5 vezes por semana, totalizando 30 dias, respeitando-se intervalo de 24 horas a cada sessão de exercício. O comportamento dos animais foi verificado em teste de campo aberto, sendo realizada filmagem por 10 minutos e contados os números de quadrantes que os animais percorreram neste intervalo de tempo; Resultados: a lesão aumenta a ansiedade e o estresse dos animais, mas o exercício é capaz de reduzir os valores, mas mesmo assim não chegaram aos níveis basais $(p<0,05)$; Conclusão: $O$ exercício físico é capaz de reduzir o estresse de ratos submetidos à desnutrição e desenervação.

Palavras-chave: Lesão nervosa, exercício físico, fisioterapia. 


\section{CARACTERIZAÇÃO DO PERFIL EPIDEMIOLÓGICO E CLINICO DOS CASOS DE HANSENÍASE TRATADOS COM POLIQUIMIOTERAPIA NO MUNICÍPIO DE SANTARÉM-PA}

Nome dos bolsistas: Marcos Zander Vieira Sanaid, Yan José Almeida da Gama Costa

Nome do (a) Orientador (a): Valney Mara Gomes Conde

Grupo de Pesquisa: Grupo de Estudos e Pesquisas em Educação e Saúde das populações amazônicas - GEPESPA

Introdução: A Hanseníase é uma doença infectocontagiosa causada pelo Mycobacterium leprae, de evolução crônica, notificação compulsória, curável e de investigação obrigatória em todo território nacional. O tratamento da hanseníase se dá através da poliquimioterapia ( $P Q T)$, que é uma combinação de drogas, distribuída gratuitamente nas Unidades Básicas de Saúde. No entanto, causa diversas reações que podem ser previsíveis (tipo A) ou imprevisíveis (tipo B). Cerca de $80 \%$ das reações são previsíveis, geralmente relacionados com a dose, decorrentes de conhecidas ações farmacológicas da droga e ocorrem em indivíduos normais. Os efeitos colaterais são inevitáveis na dose regular prescrita. As reações do tipo B são responsáveis por menos de $20 \%$ e incluem aquelas imunologicamente mediadas. Objetivo: Analisar o perfil socioeconômico e clínico dos casos de hanseníase no município de Santarém/PA nos anos de 2007 a 2017 tratados com poliquimioterapia $(\mathrm{PQT})$ que abandonaram o tratamento e ou tiveram algum tipo de reação ao tratamento. Materiais e Métodos: Foram avaliados 95 prontuários de pacientes que trataram de hanseníase em 10 Unidades de Saúde na área urbana do município de Santarém. Utilizamos os dados epidemiológicos através dos prontuários de pacientes notificados com Hanseníase, na base do Sistema de Informação de Agravos de Notificação (SINAN) entre os anos de 2007 a 2017 que foram tratados nas Unidades de saúde dos bairros da Nova República; Santarenzinho; Floresta; Matinha; Maracanã, Esperança, Aparecida/Caranazal, Jardim Santarém; Jaderlândia e Maicá. Os dados foram tabulados utilizando média e porcentagem. Resultado e Discussão: Quanto as caraterísticas epidemiológicas, observou-se que a faixa etária desses pacientes estavam entre $>15$ anos e $<60$ anos. A maior concentração ocorreu na faixa de 26 a 40 anos (30,53\%), onde estão as pessoas consideradas economicamente ativas podendo causar impacto sobre o aspecto sócio econômico e psicossocial. Quanto ao gênero a maior ocorrência de casos ocorreu no sexo masculino, com $61,05 \%$ dos casos, e no sexo feminino apenas 38,95\%. No diagnóstico clínico, 34,74\% dos pacientes apresentava-se na forma dimorfa, $23,16 \%$ na forma Virchoviana, 15,79\% na 
forma Indeterminada e $14,74 \%$ na forma Tuberculóide. Quando somadas as formas dimorfa $(34,74 \%)$ e virchowiana $(23,16 \%)$, que são as formas disseminantes da doença, chega-se à maioria dos casos com $57,9 \%$ dos casos. Na classificação operacional (OMS), 29,47\% dos pacientes apresentava-se na forma Paucibacilares, enquanto que $70,53 \%$ na foram diagnosticados como Multibacilares. Conclusão: Os resultados obtidos neste estudo evidenciaram que nos casos analisados a grande maioria era do sexo masculino e que o tratamento para hanseníase está sendo realizado tardiamente, pois apresentavam as formas mais graves da doença com classificação operacional multibacilar, nas formas clínicas Dimorfa e virchoviana.

Palavras-chave: Hanseníase, Mycobacterium leprae, Poliquimioterapia 


\section{ELABORAÇÃO DE BIOPOLÍMEROS A BASE DE FÉCULA DE MANDIOCA E AMIDO DE MILHO COM INCORPORAÇÃO DE PIGMENTOS NATURAIS}

Nome dos bolsistas: Benedito Elivaldo da Silva Tenório; Gabriel Pelais Dias; Marjorie Vitoria Guimarães Freitas

Nome do (a) Orientador (a): Ana Carla Alves Pelais

Grupo de Pesquisa: Ciência e Tecnologia de Alimentos na Amazônia Oriental

Introdução: Tanto no Brasil como mundialmente são produzidas milhões de toneladas de polímeros para a fabricação de embalagens plásticas, derivadas do petróleo. $\mathrm{O}$ aumento da produção de embalagens através deste polímero representa problemas graves de poluição ambiental, uma vez que, trata-se de um material hidrofóbico e de decomposição longa. Dessa forma, objetivou-se nesse trabalho extrair pigmentos (corantes) naturais de matérias primas como açaí, cenoura, couve e urucum e adicionar em biopolímero a base de fécula de mandioca e amido de milho. Os biopolímero de fécula/amidos foram elaborados pela técnica de Casting nas concentrações de féculas e amidos de $3 \%, 4 \%$ e $5 \%$ por cada $100 \mathrm{~g}$ de solução filmogênica, e a de glicerol foi de $10 \%$ em relação à quantidade de fécula /amido. Os biopolímeros foram caracterizados por meio do aspecto visual, solubilidade e permeabilidade de vapor de água. $\mathrm{O}$ aspecto visual dos biopolímeros de amido de milho plastificado com glicerol com incorporação dos corantes naturais apresentou-se, com coloração características dos pigmentos extraídos, homogêneos, transparentes, com bom manuseio e não contendo bolhas ou rachaduras na superfície, com exceção do filme de amido com cenoura a 5\%. Quanto a solubilidade, os valores elevados para as concentrações com $5 \%$ tanto de fécula quanto de amido para todos os pigmentos podem estar relacionados a adição da quantidade de amido utilizado neste trabalho, o que influencia sobre a solubilidade dos filmes, uma vez que, este tem caráter hidrófilo e interage fortemente com a água. Assim, devido à baixa porcentagem da solubilidade da concentração com $3 \%$ de fécula de mandioca e de amido, esta foi a concentração que apresentou melhores resultados tanto para ambos os tratamentos, podendo ser utilizado futuramente como cobertura comestível em alimentos vegetais.

Palavras-chave: Recobrimento; cobertura comestível; corantes naturais; solução filmogênica. 


\title{
EFEITO DA UTILIZAÇÃO DE POLPA E CASCAS DE PITAYA, TANGERINA E TAPEREBÁ NAS PROPRIEDADES FÍSICO-QUÍMICAS DE HIDROMÉIS
}

\author{
Nome do bolsista: Luiz Gonzaga de Oliveira Lima Neto \\ Nome do Voluntários: Danyelly Silva Amorim; Isabelly Silva Amorim \\ Nome do (a) Orientadora: Bruna Almeida da Silva \\ Grupo de Pesquisa: Ciência e Tecnologia de Alimentos
}

Introdução: Hidromel é a bebida com graduação alcoólica de quatro a quatorze por cento em volume, a vinte graus Celsius, obtida pela fermentação alcoólica de uma solução de mel de abelha, sais nutrientes e água potável. A utilização de frutas é uma alternativa de agregar valor nutricional ao hidromel, ampliando as opções de consumo, além de ser um método de conservação de frutas que apresentam alta perecibilidade. O objetivo do trabalho foi avaliar a influência da adição de casca e polpa de pitaya, tangerina e taperebá nas características físico-químicas de hidroméis. Para elaboração dos hidroméis o mosto foi homogeneizado com $37,49 \%$ de mel e $62,47 \%$ de água até atingir $30{ }^{\circ}$ Brix. No pé de cuba foi utilizado $10 \%$ do volume do mosto, este foi pasteurizado a $65{ }^{\circ} \mathrm{C}$ por 30 minutos, resfriado e acrescido a Saccharomyces cerevisiae. O pé de cuba foi mantido em recipiente fechado a $20^{\circ} \mathrm{C}$ por 24 horas, em seguida o restante do mosto foi pasteurizado a $100{ }^{\circ} \mathrm{C}$ por 2 minutos, resfriado e adicionado do pé de cuba. A fermentação foi acompanhada por 24 dias com mensurações de sólidos solúveis, acidez e pH. Quando estes parâmetros se apresentaram constantes foram adicionados a polpa e casca de pitaya $\left(F_{1}\right)$, tangerina $\left(F_{2}\right)$, taperebá $\left(F_{3}\right)$ após esta etapa a fermentação foi mantida por 7 dias em temperatura ambiente. $O$ hidroméis foram posteriormente filtrados, engarrafados $e$ pasteurizados. As análises físico-químicas realizadas foram: acidez total, acidez volátil, acidez fixa, ${ }^{\circ} \mathrm{Brix}, \mathrm{pH}$, densidade, açúcares totais, açúcares redutores, teor alcoólico, vitamina $\mathrm{C}$, carotenóides totais e cor instrumental. Os resultados foram avaliados por meio da aplicação da análise de variância e teste de Tukey a $5 \%$ de significância. Conforme a composição físico-química F1, F2 e F3, respectivamente foram: acidez total (mEq L ${ }^{-1}$ ): 56,10 $, 60,69^{\mathrm{b}}, 92,31^{\mathrm{a}}$; acidez volátil $\left(\mathrm{mEq} \mathrm{L}^{-1}\right): 2,04^{\mathrm{c}}, 3,06^{\mathrm{b}}, 4,08^{\mathrm{a}}$; acidez fixa (mEq L ${ }^{-1}$ ): 54,06 ${ }^{\mathrm{c}}, 57,63^{\mathrm{b}}, 88,23^{\mathrm{a}}$; ${ }^{\mathrm{O} B r i x}$ : $22,00^{\mathrm{b}}, 24,05^{\mathrm{a}}, 23,25^{\mathrm{a}}$; pH: $3,84^{\mathrm{a}}$, $3,47^{\mathrm{b}}, 2,55^{\mathrm{c}}$; densidade $\left(\mathrm{g} \cdot \mathrm{ml}^{-1}\right): 1,07^{\mathrm{a}}, 1,09^{\mathrm{a}}, 1,08^{\mathrm{a}}$; açúcares totais (\%): 2,34a $, 2,30^{\mathrm{a}}$, 2,26 ; açúcares redutores (\%): $1,48^{\mathrm{b}}, 1,86^{\mathrm{a}}, 1,92^{\mathrm{a}}$; teor alcoólico (\%): 5,90 $, 4,40^{\mathrm{b}}$, 4,40 ; vitamina C $\left(\mathrm{mg}^{\mathrm{b}} 100 \mathrm{ml}^{-1}\right): 0,89^{\mathrm{b}}, 1,12^{\mathrm{b}}, 2,47^{\mathrm{a}}$; carotenóides totais $\left(\mathrm{mg} \cdot 100 \mathrm{~g}^{-1}\right)$ : $0,96^{\mathrm{b}}, 2,47^{\mathrm{a}}, 0,71^{\mathrm{b}} ; L^{*}: 19,27^{\mathrm{c}}, 33,58^{\mathrm{a}}, 30,81^{\mathrm{b}} ; \mathrm{a}^{*}: 20,03^{\mathrm{a}}, 1,74^{\mathrm{b}}, 1,84^{\mathrm{b}} ; \mathrm{b}^{*}: 9,37^{\mathrm{b}}, 8,53^{\mathrm{c}}$, $9,68^{\text {a }}$. Ressalta-se que os parâmetros de acidez fixa, total e volátil e teor alcoólico 
estão de acordo com os parâmetros delimitados pela legislação vigente. Esta conformidade deve-se as condições adequadas de fermentação, tais como meio anaeróbico, pH, acidez e sólidos solúveis totais adequados. Os hidroméis elaborados apresentaram os padrões de identidade estabelecidos pela legislação vigente. Portanto, a utilização de polpas e cascas de pitaya, tangerina e taperebá, agregam aos hidroméis propriedades nutricionais e antioxidantes. Além de contribuírem para o aproveitamento dos resíduos de frutas e reduzirem o desperdício.

Palavras-chave: Mel; Resíduo de frutas; Bebida fermentada 


\section{REDE HIDROMÉTRICA DA REGIÃO HIDROGRÁFICA TOCANTINS-ARAGUAIA}

Nome dos bolsistas: Amanda Pereira Lima de Oliveira e Francisca das Chagas Silva Cunha

Nome do (a) Orientador (a): Glauber Epifanio Loureiro

Grupo de Pesquisa: Recursos Naturais de Carajás (Renajás)

Introdução: A Região Hidrográfica Tocantins-Araguaia ganha relevância nacional por ser área de fronteira energética, agrícola, mineral, industrial e turismo. O rio principal, Tocantins, ganha destaque pelos usos múltiplos da água e impactos ambientais sensíveis no ecótono Amazônia/Cerrado. Como forma de conhecer o recurso natural para fins de planejamento é fundamental monitorar a quantidade e qualidade por meio de rede hidrométrica com dados de chuva, vazão, cota, sedimento, telemétricas, dentre outras. Assim esta pesquisa almejou analisar a situação da rede hidrométrica da Região hidrográfica Tocantins-Araguaia quanto estações pluviométricas e fluviométricas. Para tanto, foram obtidos dados do Sistema de informações de recursos Hídricos da Agência Nacional de Águas por meio do portal Hidroweb das estações existentes conforme delimitação DNAEE/ANEEL. Foi feito análise da quantidade de estações ativas e densidade das estações pluviométricas conforme Organização Meteorológica Mundial (OMM), período de dados entre décadas, dados de outras estações fluviométricas como descarga liquida, sedimento, qualidade de água e telemétricas. Os resultados demonstraram uma fraca rede hidrométrica, principalmente, com mínimo 30 anos, em destaque para subbacia 29. A melhor performance devido projetos hidrelétricos é subbacia 25. Constatou-se a necessidade de maiores investimentos na implantação de uma rede ativa com dados que garanta disponibilidade para planejamento de recursos hídricos e subsidio para monitorar e avaliar os impactos ambientais neste recurso natural.

Palavras-chave: Planejamento. Recursos hídricos. Estações pluviométricas. Estações fluviométricas. 


\title{
DIVERSIDADE DE INSECTA NO CAMPUS DO CENTRO DE CIÊNCIAS SOCIAIS E EDUCAÇÃO (CCSE) DA UNIVERSIDADE DO ESTADO DO PARÁ
}

\author{
Nome dos Bolsistas: Adrian Carlos Rodrigues Barbosa; Matheus Castro Batista; \\ Nome dos voluntários Dayne de Nazaré Dias, Gouveia; Herick Leonan de Melo \\ Cardoso \\ Orientadora: Ana Lúcia Nunes Gutjahr \\ Grupo de Pesquisa: Pesquisas Interdisciplinares em Biodiversidade Amazônica
}

Introdução: Os insetos fazem parte da biodiversidade, habitam diversos ambientes do planeta, onde desempenham papéis ecológicos fundamentais para a dinâmica dos ecossistemas e possuem hábitos e comportamentos variados. Estes invertebrados participam de processos como a decomposição de matéria orgânica, reciclagem de nutrientes, polinização, dispersão de sementes e são importantes reguladores de populações de plantas, animais e de outros organismos. Durante a evolução humana os insetos sempre estiveram associados ao homem e trocaram de habitat, para explorar os espaços agrícolas e os ambientes usados por humanos. Nestes, utilizaram os recursos alimentares e os refúgios, proporcionados pelas habitações humanas, nos ambientes urbanos. Portanto, estudos de insetos sinantrópicos são relevantes para proporcionar conhecimento, manejo e controle, para uma vivência harmônica com esses invertebrados. Neste estudo, busca-se determinar a entomofauna que ocorre no Centro de Ciências Sociais e Educação (CCSE), da Universidade do Estado do Pará (UEPA), a fim de gerar informações sobre esses animais que são comumente encontrados nos ambientes urbanos e naturais. A metodologia de coleta empregou três métodos: Coleta com rede de varredura, armadilha Malaise e isca atrativa (doce e salgada), que foram aplicados nos meses de novembro/2018, fevereiro e abril/2019 no campus 1 da UEPA. No CCSE foi coletado durante o estudo um total de 35.326 espécimes de invertebrados sinantrópicos, pertencentes às Classes Insecta ( $\mathrm{n}=$ 35.213), Arachinida ( $n=70)$ e Gastropoda (Mollusca: Caracóis) $(n=43)$. Os insetos amostrados foram capturados por meio de rede de varredura $(n=6.276)$, armadilha Malaise $(n=5.023)$ e pelo uso de iscas $(n=24.027$ : Iscas doce $n=9.796$, Isca salgada $\mathrm{n}=14.230$ ). Os 35.326 insetos coletados no campus do CCSE pertencem a 11 ordens: Coleoptera (besouros), Collembola (pulga da terra), Diptera (Moscas), Hemiptera (Percevejos), Hymenoptera (Formigas), Lepidoptera (Borboletas), Orthoptera (Gafanhotos), Siphonaptera (Pulgas), Thysanoptera (Lacerdinhas), Psocoptera e Trichoptera; e Arachinida: Araneae (Aranhas) e Acari (Ácaros). Entre os grupos taxonômicos citados as formigas corresponderam 73,78 \% do total de invertebrados coletados, enquanto que percevejos e moscas representaram 11,60\% e 10,28\%, 
respectivamente. Ressalta-se que o maior número de formigas coletadas no CCSE ocorreu na área próxima ao bloco IV, indicando que existe uma maior concentração desses insetos nesse local, possivelmente em virtude da existência do restaurante universitário, que se encontra próximo a esta edificação.

Palavras-chave: Insetos sinantrópicos; Invertebrados; UEPA 


\section{CONSTRUÇÃO DE APLICATIVOS COMO FERRAMENTA DIDÁTICA PARA VISUALIZAÇÃO GRÁFICA DE FUNÇÕES NO MOVIMENTO OSCILATÓRIO}

Nome dos bolsistas: Cecilia Abrahão Nascimento de Santi, Lucas Nobre Barbosa, Daralyns Borges Macedo

Nome do (a) Orientador (a): Járlesson Gama Amazonas

Grupo de Pesquisa: Grupo de Pesquisa em Física e em Ensino de Física

Introdução: O ensino de física no Brasil é feito majoritariamente de forma mecânica, conteudista, repetitiva e com atuação estudantil extremamente passiva. Fica evidente a necessidade de atualizar este processo incluindo atividades que agrupem diversos conteúdos a recursos digitais atuais, como tablets e smartphones. Objetivo: Assim, objetivou-se criar aplicativos (apps) web como ferramenta didática para visualização gráfica de funções encontradas na física. Material e Método: Utilizou-se o framework Django para produção de páginas web contendo apps científicos. Escritos em linguagem de programação Python, os apps utilizam as bibliotecas Numpy e Matplotlib responsáveis pela execução de operações e produção de gráficos, nesta ordem. Resultados: Criou-se o aplicativo app mhs [app cap] gerador do gráfico da função harmônica [da descarga de um capacitor] cujas constantes de entrada são fornecidas pelo usuário. Na sequência, clicando no botão Compute, o app mhs [app cap] internaliza os valores de entrada, resolve a equação para cada valor de $\mathbf{t}$ dentro do domínio determinado, produz o gráfico correspondente e o disponibiliza em nova página web. Se o usuário optar por estudar o movimento harmônico simples, basta definir a constante de amortecimento nula $(\mathbf{b}=0.0 \mathrm{~kg} / \mathrm{s})$. Para qualquer valor de $\mathbf{b}$ não nulo, o gráfico correspondente apresenta redução da amplitude evidenciando a curva característica da solução do Movimento harmônico amortecido. Comprovações similares também mostram o excelente funcionamento do app cap. Conclusão: Por fim, contribui-se para formação discente com habilidades interdisciplinares em linguagem de programação e física; enfatiza-se a qualidade funcional dos apps desenvolvidos, apresentam facilidade de acesso via internet além de fácil manuseio, e ainda, apresentam baixo custo computacional. Posteriormente, acredita-se que estes aplicativos possam ser utilizados como ferramentas pedagógicas interativas no ensino física.

Palavras-chave: Física. Python. Django. Aplicativos webs 


\section{NARRATIVAS SILENCIADAS: UMA ANÁLISE DIALÓGICA DE MEMÓRIAS DE SURDOS LGBT}

Nome dos bolsistas: Carlos Fabricio Pereira Costa, Isabela Maria Carvalho Martins de Barros

Nome do Orientador: José Anchieta de Oliveira Bentes

Grupo de Pesquisa: Grupo de Estudos em Linguagens e Práticas Educacionais da Amazônia

Resumo: O objetivo desta pesquisa é analisar a história de vida de duas pessoas surdas. Tem-se como meta obter informações de como esses participantes se veem com relação a estar e sair do armário, a respeito dos familiares, discriminação para obter emprego e das religiões. Utiliza-se como referencial teórico-metodológico a epistemologia dialógica da linguagem do russo Mikhail Bakhtin, a análise dialógica da linguagem cunhada por Beth Brait e a epistemologia do armário de Sedwick. Os resultados apontam para diferentes opressões sofridas pelos participantes nas diversas esferas: familiar, religiosa e mercado de trabalho; sempre com a questão da sexualidade sendo usada como justificativa para tais atos.

Palavras-chave: LGBT; Memória; Narrativas; Análise dialógica. 


\section{INTERFACES COMPUTACIONAIS COMO FERRAMENTAS DE EXPLORAÇÃO VISUAL APLICADA AO ENSINO DE FÍSICA NO ENSINO MÉDIO}

Nome dos bolsistas: Járlesson Gama Amazonas Júnior, Brian Bomfim Amara e Carlos Edmir Marialva do Carmo

Nome do Orientador: José Fernando Pereira Leal

Grupo de Pesquisa: Grupo de Pesquisa em Física e Ensino de Física

Introdução: A maioria dos estudantes não aprendem o esperado em matemática em parte devido ao uso de atividades de ensino mecânico que apresentam conceitos de difícil interpretação, priorizam memorização, repetição e sem contextualização, dificultando o interesse do aluno. Neste sentido, o objetivo do trabalho é desenvolver um(a) gerador/calculadora de gráfico de funções como possível recurso auxiliar para aulas de matemática. Para isso, a metodologia possibilita desenvolver um projeto escrito em linguagem Python cuja computação de dados e construção gráfica foram realizadas através das bibliotecas Numpy e Matplotlib. Adicionalmente, o framework Django possibilitou a criação de aplicativos (apps) que podem ser disponibilizados em página web. Seus resultados são encontrados na página da internet correspondente aos apps harm e log, o usuário insere os dados de entrada que serão internalizados pelo aplicativo, ocorre a computação destes dados, geração dos gráficos e posterior apresentação em nova página com a saída. Dessa forma, a partir do app harm [log] foi produzido um gráfico da função cosseno, $y(x)=A \cos (B x+C)$ [logarítmica, $\left.\boldsymbol{y}(\boldsymbol{x})=\boldsymbol{A}+\boldsymbol{M l o g}_{\boldsymbol{b}} \boldsymbol{x}\right]$ e esta, mostrou-se em acordo com literatura matemática correspondente. Retornando a página inicial, considerando constantes os demais parâmetros e mudando apenas a constante multiplicativa [aditiva] $\boldsymbol{A}$, surge uma nova curva sobreposta à primeira. Claramente, as curvas são similares na forma, no domínio e nos pontos de ordenada nula. Entretanto, esta nova curva apresenta valores da coordenada vertical (ordenada) deslocadas exatamente pelo valor adicional do parâmetro $\boldsymbol{A}$. Várias outras verificações foram realizadas e contribuíram para validação dos aplicativos. Por fim, os aplicativos harm e log apresentam resultados confiáveis, dispõem de interface amigável, fácil acesso via página web, fácil manuseio e podem contribuir como recurso motivacional no estudo de funções em aulas de matemática.

Palavras-chave: Gráfico de funções. Python. Django. Aplicativos web. 


\section{USO DE EXPERIMENTOS TEMÁTICOS PARA REVITALIZAÇÃO DO LABORATÓRIO DE CIÊNCIAS EM UMA ESCOLA DE BARCARENA-PA}

Nome dos Bolsistas: Erick Pereira dos Santos, Deyniff Aysha Cruz Corrêa, Marinaldo Castilho da Silva Junior

Nome do (a) Orientador (a): . Marcos Antonio Barros dos Santos

Grupo de Pesquisa: Estudos e Pesquisas em Ciências da Natureza e Humanas.

Introdução: O projeto foi idealizado a partir das dificuldades encontradas pelos acadêmicos de Licenciatura em Ciências Naturais em utilizar o espaço escolar. Objetivo: Revitalizar o Laboratório de Ciências da Escola Estadual de Ensino Fundamental e Médio Eduardo Angelim/Barcarena-PA por meio do desenvolvimento de atividades práticas nas áreas de Ciências da Natureza. Material e método: A metodologia consiste em pesquisa qualitativa do tipo exploratório, pois trata da aplicação sistemática das etapas que foram planejadas com o objetivo de responder as questões dos eventos educativos em estudo. Resultados. Os resultados obtidos evidenciam que o Laboratório foi efetivamente revitalizado, saindo da condição de depósito de materiais, passando a receber inúmeras atividades didático/científica no espaço. Os bolsistas PIBIC-EM juntamente com os acadêmicos de Licenciatura em Ciências Naturais, com apoio da direção escolar, iniciaram adequação do Laboratório para a exposição de experimentos demonstrativos. A realização da $1^{\mathrm{a}}$ feira de ciências da Escola Eduardo Angelim é um indicador positivo do alcance da meta proposta no trabalho, pois incentivou a popularização da ciência e a melhoria dos ensinos fundamental e médio, além de identificar jovens talentos, para que sigam carreira científica. Outro indicador da revitalização foi a aprovação de trabalhos para exposição na Mostra de Ciência e Tecnologia da Escola Açaí-Abaetetuba (MCTEA). Nesse sentido, os bolsistas foram encorajados a elaboração de um projeto inovador para submissão em outras feiras municipais e estaduais. Reuniões de planejamento e desenvolvimento de experimentos temáticos foram desenvolvidos no laboratório da escola. Os professores começaram a utilizar o laboratório revitalizado em suas aulas. Os estudantes do ensino médio/bolsistas foram inseridos precocemente em atividades acadêmico/científica da Universidade como: participação no projeto de extensão Intervalo da Ciência, cujo objetivo consiste em apresentar experimentos demonstrativos em diversas escolas municipais da Cidade de Barcarena; participação como expositor na UEPA nas Comunidades (PROEX) e aprovação de trabalho na II Jornada Científica da UEPA. Conclusão: O laboratório foi revitalizado. O projeto 
proporcionou o estreitamento entre UEPA e a Escola. Os bolsistas estão elaborando o manuscrito do projeto sacola biodegradável de mandioca para submissão no MCTEA.

Palavras Chave: Atividades práticas. Divulgação cientifica. Feira de ciências. 


\section{DETERMINAÇÃO DO PERFIL QUíMICO E ATIVIDADES ANTIOXIDANTE DE PLANTAS MEDICIONAIS DE SOURE-PA}

Nome dos Bolsistas: Diogo Gabriel Barbosa Pimentel, Filipe Thiago Matos Sacramento e Jonathan Batista de Assunção

Orientador: Ronilson Freitas de Souza

Grupo de Pesquisa: Química, Ensino de Química e Meio Ambiente

Introdução: O reino vegetal é fonte de diversos remédios utilizados pela população, muitos destes obtidos aliando ao conhecimento tradicional com o saber cientifico, e na região da ilha de Marajó, o uso de plantas medicinais é comum entre a população. Neste contexto, este trabalho teve o objetivo de determinar o perfil químico e avaliar o potencial antioxidante de extratos das plantas medicinais: Eleutherine bulbosa (Marupazinho), Fridericia chica (Pariri), Dalbergia monetária (Verônica), Libidibia férrea (Jucá,) Hyptis crenata (Salva do Marajó) e Phyllanthus orbiculatus (Quebra-pedra.) As amostras foram coletadas no município de Soure que possui uma forte tradição do uso das plantas medicinais para curar enfermidades. Os procedimentos utilizados neste trabalho foram: secagem de plantas, extração com solvente, preparo e diluições de soluções, cromatografia comparativa em camada delgada utilizando HPTLC, análise em espectrofotômetro de flavonoides, fenóis totais e antioxidante. Dentre os resultados obtidos destaca-se: a análise com reagente VAS (Etanol $\mathrm{H}_{2} \mathrm{SO}_{4} 10 \%$ + Etanol vanilina 1\%) foi possível identificar Irioides glicosilados, Secoirioides, esteroides e Terpenoides. De acordo com a análise de NP/PEG (Difenilboriloxietilamina/Polietilenoglicol) foram encontradas substâncias ácidos carboxílicos, fenólicos, cumarinas, flavonoides, antronas, antronoides e taninos complexos. De acordo com a análise com reagente de Dragendorff foi detectada a presença de alcaloides em todas as amostras analisadas. Dentre as espécies analisadas, o jucá foi que apresentou o maior teor de compostos fenólicos com 808,99 mg.EAG/g, seguido da verônica que obteve 725,40 mg.EAG/g, pariri como 449,21 mg.EAG/g, Sálvia 349,21 mg.EAG/g, marupazinho 316,67 mg.EAG/g, e o quebra-pedra como 240,48 mg.EAG/g. No presente estudo a espécie jucá apresentou a melhor atividade antioxidante com $\mathrm{CE}_{50} 4,48(\mu \mathrm{g} / \mathrm{mL})$, (concentração efetiva para inibir 50\% dos radicais DPPH), assim tendo a maior quantidade de fenóis e um elevado potencial antioxidante. A nossa região tem uma biodiversidade riquíssima que pode guardar avanços no ramo farmacológico, por isso que é valido investigar de forma cientifica os conhecimentos empíricos disseminados através dos saberes e tradições passados ao longo do tempo de geração para geração. É válido ressaltar que este projeto teve um grande impacto em nossas vidas como bolsistas, pois aprendemos a realizar procedimentos em laboratórios, ler artigos, compartilhar 
das experiências de professores e alunos universitários, certamente enriquecerá o nosso conhecimento, despertou um interesse por pesquisar mais e realizar uma graduação na área de ciências.

Palavras-chave: Compostos bioativos; Perfil químico, Plantas Medicinais 


\section{CIÊNCIA, TECNOLOGIA E CIDADANIA: VIVÊNCIAS E DESCOBERTAS EM BIOLOGIA NO CENTRO DE CIÊNCIAS E PLANETÁRIO DO PARÁ - UEPA}

Nome dos bolsistas: Eduarda Menezes de Oliveira / Lucas Bittencourt Marques da Silva

Nome do (a) Orientador (a): Sinaida Maria Vasconcelos

Grupo de Pesquisa: Ciência, Tecnologia, Meio Ambiente e Educação não formal (CTENF)

Introdução: O presente projeto ao proporcionar aos estudantes de ensino médio a experiência de estudar em um ambiente que se baseia em aspectos não somente teóricos, mas também práticos, revela-se altamente estimulante e motivador, tendo dentre seus objetivos: Promover formação científica, tecnológica e cidadã de estudantes do ensino médio a partir do contato com atividades experimentais, práticas e de pesquisa na área das Ciências Naturais e Exercitar o método da pesquisa científica: Elaboração do Projeto; Desenvolvimento da pesquisa (estudos teóricos e práticos); Elaboração de relatórios. Durante o projeto elaborou-se uma proposta para testar o reaproveitamento dos caroços de açaí para produção de um material que pudesse agir como substituto a objetos produzidos com esponja, plástico e outros materiais que afetam negativamente o meio ambiente. Para testagem do material a ser produzido foram utilizados: Uma saca de caroços de açaí (rejeitos após a extração do sumo); 4,5 litros de tiner (solvente); - Isopor (rejeitos vindos nos eletrodomésticos); 1 recipiente de vidro; 1 colher; Luvas descartáveis; Máscara hospitalar; recipiente para triturar os caroços de açaí. Os procedimentos realizados foram: Os caroços de açaí foram devidamente recolhidos após a extração do sumo e deverão ser lavados com água corrente no primeiro momento; Após a lavagem deixados secar por um ou dois dias, recolher e armazenar; Em um recipiente de vidro foi adicionado tíner e dissolvido o isopor até que se forme um material pastoso; Misturou-se aos caroços de açaí o polímero formado no procedimento; Despejado o material obtido em um recipiente no formato desejado. Aguardaram-se de 2 a 3 dias, até que se forme um material resistente. Até o presente momento se obteve um material economicamente viável e ecologicamente sustentável proveniente de resíduos que atualmente compõe grande parte do lixo da cidade. A partir do caroço de açaí adicionado à mistura de tíner e isopor forma-se um produto sólido e eficaz para diversas finalidades. Pretende-se dar continuidade aos testes com o material produzido para que se defina mais especificamente suas formas de aplicação. Ao concluir nosso projeto, constatamos o forte potencial dos caroços de açaí para a construção de um material resistente que, somado ao isopor e tíner, pode ser utilizada para diversos fins. O reaproveitamento do 
caroço de açaí e de restos de isopor vem se mostrando como um importante alternativo de reaproveitamento e de substituição de materiais que agridem o meio ambiente, como plásticos e esponjas.

Palavras-chave: Ciência e tecnologia; Iniciação Científica; Meio Ambiente. 
PIBIC - PIBITI 


\section{ATIVIDADE HIPOGLICEMIANTE DE Himatanthus sucuuba EM RATOS DA LINHAGEM WISTAR}

Nome do (a) bolsista: Marlyara Vanessa Sampaio Marinho

Nome do (s) Voluntário (s): Françoíse Gisela Gato Lopes, Rafaela Victoria Câmara Soares

Nome do (a) Orientador (a): Adjanny Estela Santos de Souza

Grupo de Pesquisa: Grupo de Estudos e Pesquisas em Educação e Saúde das Populações Amazônicas

Introdução: A utilização de plantas medicinais ocorre desde a antiguidade. De acordo com dados da Organização Mundial da saúde (OMS), o número de pessoas que utilizam as plantas medicinais de forma curativa ou para amenizar alguma sintomatologia, têm crescido cada vez mais. Têm-se realizado estudos para se verificar quais plantas possuem efeitos hipoglicemiantes, com o intuito de gerar novos tipos de terapêuticas para o tratamento da diabetes. Objetivo(s): O objetivo desse estudo foi investigar a atividade hipoglicemiante de Himatanthus sucuuba em modelo experimental. Material e Métodos: Trata-se de um estudo experimental, realizado em Santarém-Pará. Esta pesquisa foi dividida nas seguintes etapas: levantamento etnofarmacêutico; pesquisa bibliográfica das plantas utilizadas como hipoglicemiantes pelos entrevistados; obtenção e preparo da amostra; indução de hiperglicemia em ratos machos da linhagem wistar com o uso de dexametasona $1 \mathrm{mg} / \mathrm{kg}$ por via subcutânea; avaliação da atividade hipoglicemiante. Os animais que apresentaram glicemia superior a $200 \mathrm{mg} / \mathrm{dL}$ foram tratados com leite de Himatanthus sucuuba. Resultados: Foram realizadas 420 entrevistas. A maioria dos participantes foram mulheres (319). A faixa etária variou de 18-85 anos. As entrevistas ocorreram em 22 bairros, 2 comunidades ribeirinhas e 1 distrito, todos localizados em Santarém. Das plantas citadas pelos entrevistados, 43 foram referidas como utilizadas para tratamento da diabetes. A espécie de planta Himatanthus sucuuba, selecionada para o estudo apresentou atividade hipoglicemiante em ratos machos da linhagem wistar. Conclusão: A pesquisa etnofarmacêutica possibilitou o conhecimento sobre as plantas que a população local utiliza, principalmente no tratamento do diabetes. Observou-se que embora muitas plantas sejam utilizadas no tratamento do diabetes, não existem estudos que comprovem seu efeito hipoglicemiante em modelo experimental, abrindo possibilidades para o desenvolvimento de novas pesquisas. Himatanthus sucuuba, apresentou efeito hipoglicemiante em ratos machos da linhagem wistar. Estudos devem ser realizados a fim de identificar e isolar os componentes fitoquímicos dessa espécie de planta, possibilitando a realização de 
testes mais específicos que poderão contribuir para a prospecção de novos medicamentos a partir desses componentes.

Palavras-chave: Plantas medicinais, Hipoglicemiantes, Amazônia. 


\title{
AVALIAÇÃO DO EFEITO DO EXTRATO ETANÓLICO DA EUTERPE OLERACEA MART. NO REPARO TECIDUAL DE RATOS
}

\author{
Nome dos (a) bolsistas: Geovanna Mourão Pantoja, Murilo Eduardo \\ Soares Ribeiro \\ Nome do (a) Orientador (a): Anderson de Bentes Lima \\ Grupo de Pesquisa: Morfofisiologia: Ensino e Pesquisa Aplicada a Saúde
}

Introdução: $O$ açaí (Euterpe oleracea) é um fruto tradicionalmente consumido na região da Amazônia, com seus extratos da polpa e das sementes possuindo uma elevada ação antioxidante, anti-inflamatória e antitumoral. No entanto, ainda poucos estudos avaliam seu efeito sobre cicatrização de feridas. Objetivo: analisar os efeitos do extrato etanólico de Euterpe oleracea Mart. (açaí branco) no processo de reparo tecidual em lesões cutâneas induzidas em ratos. Material e Método: $O$ estudo foi feito por meio da indução de lesões cutâneas em 30 ratos da linhagem Wistar, os quais foram divididos em 2 grupos: um tratamento com o extrato etanólico de Euterpe oleracea Mart., na dose de 50 microlitros com concentração de $50 \mathrm{mg} / \mathrm{ml}$, e outro grupo controle sem tratamento, em que cada um foi subdivido em 3 grupos com 5 ratos com eutanásia nos dias 7, 14 e 21 dias, a fim de avaliar as fases da cicatrização. Somado a isso, foi feito estudo morfométrico da área da lesão, para verificar o índice de redução da lesão, e histológico de H\&E para posterior análise das células inflamatórias. Resultados: $O$ presente estudo demonstrou que o extrato bruto da Euterpe oleracea Mart. (açaí-branco) não apresentou efeito cicatrizante em lesões cutâneas, uma vez que não obteve diferença significante entre o grupo controle e extrato em nenhuma das fases tanto no índice de redução morfométrico, quanto na análise histológica da reepitelização, quantidade de células inflamatórias, vasos neoformados, fibras colágenas maduras e fibroblastos. Conlusão: Dessa forma, foi observado que o extrato etanólico do açaí branco não obteve efeito cicatrizante no reparo cutâneo em ratos, sendo encorajado novos estudos em modelos de cutâneos de inflamação crônica e outras concentrações do extrato.

Palavras-chave: Cicatrização. Euterpe Oleracea. Açaí branco. Açaí. 


\section{MEDIDAS PREVENTIVAS SOBRE PÉ DIABÉTICO DE PACIENTES DA ATENÇÃO PRIMÁRIA Á SAÚDE}

Nome do (a) Bolsista: Deliane Silva de Souza, Angela Maria Rodrigues Ferreira Nome do (a) Orientador (a): Angela Maria Rodrigues Ferreira

Grupo de Pesquisa: Grupo Interdisciplinar de Pesquisas em Saúde Coletiva e controle de Endemias na Amazônia

Introdução: O Diabetes Mellitus (DM) é uma doença de grande importância na atualidade pela sua alta prevalência, evidenciando-se como um grave problema de saúde pública. Objetivo geral do estudo: descrever as medidas preventivas que o doente de DM realiza para o cuidado com o pé diabético. Material e Método: É um estudo epidemiológico, descritivo com abordagem quantitativa, realizado em um Centro de Saúde Escola do município de Belém-PA, os participantes da pesquisa foram 106 pacientes com diabetes mellitus cadastrados no programa HIPERDIA da referida unidade, a coleta de dados aconteceu no período de outubro a fevereiro de 2019. Utilizou-se dois instrumentos para coleta de dados, um formulário que visou coletar dados sociodemográficos e caracterizar clinicamente os doentes e a ficha de avaliação dos pés, que teve como subsídio a avaliação dos pés dos participantes e orientá-los quanto às medidas preventivas, os dados foram submetidos à análise estatística descritiva. Resultados: O gênero masculino apresentou 58\% do total de participantes; quanto a faixa etária foi prevalente 64 a 73 anos com 54,4\% .Em relação ao grau de escolaridade, 35\% possuíam o Ensino Fundamental incompleto, $47 \%$ vivem de 5 a 10 anos com Diabetes Mellitus, 59\% dos entrevistados relatam como complicação de sua doença o aumento de açúcar no sangue e $41 \%$ que mencionam problemas de visão, dos formigamentos e câimbra, 45,3\% dos pacientes não realizam atividades específicas de prevenção. Conclusão: Os resultados obtidos evidenciaram que a maioria dos participantes nunca havia realizado o exame dos pés desde o diagnóstico de diabetes. A maioria destes, tinha a sensibilidade tátil preservada e não apresentava antecedentes de úlcera, porém por ser predominante a pele ressecada e o corte inadequado das unhas, evidencia-se que a avaliação minuciosa dos pés em pessoas com diabetes mellitus é uma ferramenta imprescindível à prevenção Soma-se, para tanto as estratégias de intervenção educativa que favorecem o aprendizado e a adoção de condutas de autocuidado dos pés dos pacientes diabéticos.

Palavras-chave: Prevenção Primária, Pé Diabético, Atenção Primária à Saúde. 


\section{PERFIL CLÍNICO-EPIDEMIOLÓGICO DE PACIENTES COINFECTADOS HIVISÍFILIS ATENDIDOS EM UM CENTRO DE REFERÊNCIA}

Nome dos Bolsistas: Nicole Salomão Lopes; Syenne Pimentel Fayal

Nome do (a) Orientador(a): Carla Andrea Avelar Pires

Grupo de Pesquisa: Pesquisas em dermatoses de interesse sanitário

Introdução: A sífilis ainda se constitui como um problema de saúde pública, apesar do tratamento acessível. É uma doença sintomática ou assintomática, com períodos de atividade e períodos de latência. Com o desenvolvimento dos métodos anticoncepcionais e revoluções nas práticas sexuais as doenças sexualmente transmissíveis como a sífilis e a descoberta da síndrome da imunodeficiência adquirida, os pesquisadores atentaram para uma possível associação entre as formas de transmissão e para as interações entre as doenças. Estudos evidenciaram que a coinfecção de pacientes soropositivos para o HIV com a sífilis diminui a contagem de linfócitos CD4+ e aumenta a carga viral dos mesmos, dificultando o tratamento e alterando a história natural de ambas as doenças. Objetivo: Descrever a epidemiologia básica, apresentações clínicas e abordagens terapêuticas de pacientes com sífilis atendidos pela Unidade de Referência Especializada em Doenças Infecciosas e Parasitárias Especiais (URE DIPE). Material e Métodos: Foi realizado um estudo descritivo, observacional, do tipo série de casos, a fim de descrever a epidemiologia, os aspectos clínicos e o tratamento utilizado em pacientes diagnosticados para sífilis e HIV, acompanhados na URE/DIPE no período de 2016 a 2018, por meio da coleta de dados em fichas e prontuários desses pacientes. Resultados: Foram coletados dados de 138 pacientes. A média de idade foi 36,4 anos, variando dos 20 aos 80 anos. Composto principalmente por homens, de cor parda, solteiros e residentes do estado do Pará. Dos casos de coinfecção de HIV/Sífilis 26\% aconteceram em 2016, 18\% em 2017 e 54\% em 2018. As formas de tratamento mais utilizadas seguem o esquema de três antirretrovirais, sendo dois Inibidores de Transcriptase Reversa Análogos de Nucleosídeos/Nucleotídeos associados a outra classe. O tratamento mais utilizado nos pacientes com sífilis foi o uso da benzilpenicilina benzatina. Conclusão: A coinfecção HIV/sífilis aumentou sucessivamente nos anos da pesquisa. Assim, é imprescindível que haja mais pesquisas sobre o assunto, para potencializar o tratamento precoce e principalmente a prevenção.

Palavras-Chave: HIV, Sífilis, Epidemiologia Grande área: Medicina I 


\section{SAÚDE E CONDIÇOES SOCIOECONÔMICAS EM UMA UNIDADE PRISIONAL NO SUDESTE DO PARÁ}

Nome do(a) Bolsista: Matheus Henrique Santana Botelho

Nome do (s) Voluntário (s): Karina Keila Monteiro Almeida; Jamyle Balla da Silva Nome do (a) Orientador (a): Cilene Aparecida de Souza Melo

Grupo de Pesquisa: Grupo Interdisciplinar De Pesquisa Em Sociedade, Saúde e Meio Ambiente na Amazônia.

Introdução: Existem diversos obstáculos que dificultam a ressocialização e a reeducação dos presos, como a precariedade nos serviços de saúde nos presídios. Dessa forma, as condições sanitárias das penitenciárias do Brasil são, por vezes, impróprias para o bem-estar biopsicossocial dos detentos, os tornando mais vulneráveis às diversas patologias. Objetivo: Sendo assim, o presente estudo tem como objetivo investigar o perfil epidemiológico dos reeducandos do Centro de Recuperação Regional Agrícola Mariano Antunes, entre os anos de 2011 a 2016, com ênfase nas patologias que possivelmente apresentem. Metodologia: Trata-se de uma pesquisa ecológica de série histórica, com abordagem quantitativa realizada com os prontuários dos reeducandos. As variáveis analisadas foram dados sociodemográficos, socioeconômicos, jurídicos e a doença que possuía. Resultados: Entre os reeducandos observou-se uma maioria parda, entre a faixa etária de 19-28 anos, solteiros, que não possuíam o $2^{\circ}$ grau, de poder socioeconômico baixo, filhos de pais separados, com maior incidência de afecções de pele e de doenças sexualmente transmissíveis. Conclusão: Conclui-se que que os apenados têm uma situação desvantajosa e deteriorada comparada a maioria da população, assim, é necessário a efetivação das políticas de saúde especificas para esta população, a fim de garantir o direito da saúde para todos.

Palavras-chave: Presídio, População Privada de Liberdade, Saúde. 


\section{PREVALÊNCIA DAS DOENÇAS INFECCIOSAS DE TRANSMISSÃO VERTICAL INVESTIGADAS NO PROJETO GESTAR EM BELÉM-PA NO ANO DE 2015}

Nome dos Bolsistas: Gisele Moura de Oliveira leite e Josué da Silva Neves Sobrinho Nome dos voluntários: Fernanda do Nascimento Rodrigues e Kevin Vieira Palheta Nome do (a) Orientador (a): Cléa Nazaré Carneiro Bichara Grupo de pesquisa: Doenças Infecciosas na gestação

Introdução: O Ministério da Saúde preconiza que as doenças congênitas, também conhecidas como TORCHS (Toxoplasmose, HTLV, HIV, Hepatite B, Rubéola, Citomegalovírus, Herpes Simples e Sífilis), por meio do Projeto Gestar, sejam pesquisadas ao longo da gravidez a fim de diminuir a mortalidade fetal e neonatal bem como morbidade infantil. Objetivos: Avaliar a prevalência dessas doenças infecciosas de transmissão vertical entre as grávidas atendidas pelo Projeto Gestar. Materiais e métodos: Realizou-se um estudo do tipo transversal, retrospectivo, descritivo e inferencial, sobre os resultados dos exames para rastreamento das doenças de transmissão vertical relativas à Síndrome de TORCHS, no período de 2014 a 2015, dentro do programa de atenção ao pré-natal no Sistema Único de Saúde (SUS), Projeto Gestar, no município de Belém-PA. Foram utilizados dados oficiais de fontes secundárias dos arquivos do Ruth Brazão. Resultados: Nesta pesquisa, foram atendidas 12. 562 gestantes, obteve-se um total de 8.611 gestantes com resultado reagente no teste sorológico para toxoplasmose. Observou-se uma frequência de 0,2\% para infecção pelo vírus HTLV, 0,07\% para infecção por HIV, 0,04\% das gestantes com teses reagentes para Anti-HCV e 0,05\% reagentes para HBsAg. Em contraposição, a taxa de positividade para sífilis foi de $3,62 \%$, sendo maior do que a encontrada em outros estados brasileiros. Conclusão: Conclui-se que as taxas de infecção materna ainda são bastante elevadas e pela importância dos gastos relacionados à morbimortalidade em decorrência de tais infecções, é imprescindível a constante atualização dos dados de prevalência e frequência das TORCHS em gestantes a fim de tomar medidas de prevenção da transmissão vertical.

Palavras-chaves: Transmissão vertical; Infecção congênita; Cuidado Pré-Natal 


\title{
DESENVOLVIMENTO DE UM DISPOSITIVO DE SUSPENSÃO PÉLVICA DE BAIXO CUSTO PARA TRATAMENTO FISIOTERAPÊUTICO DA LOMBALGIA
}

\author{
Nome do (a) Bolsista: Vivian Sussuarana Queiroz Melo \\ Nome do (a) Orientador: Ediléa Monteiro De Oliveira \\ Grupo de pesquisa: Desenvolvimento e Reabilitação na Amazônia
}

Introdução: A dor lombar é uma condição que pode atingir até $65 \%$ das pessoas anualmente e até $84 \%$ das pessoas em algum momento da vida, apresentando uma prevalência pontual de aproximadamente $11,9 \%$ na população mundial (NASCIMENTO e COSTA, 2015). Objetivo: O objetivo deste artigo é apresentar o desenvolvimento de um dispositivo auxiliar ao tratamento Fisioterapêutico da lombalgia, economicamente viável, utilizando materiais simples e ajustável a uma ampla gama de indivíduos. Material e Método: O projeto foi desenvolvido na Unidade de Ensino e Assistência em Fisioterapia e Terapia Ocupacional-UEAFTO da Universidade do Estado do Pará-UEPA. A equipe de pesquisa e desenvolvimento contou com fisioterapeutas, professores, alunos bolsistas e voluntários do curso de Fisioterapia. O processo de projeto do produto consistiu em levantamento informacional através de pesquisa bibliográfica e em bancos de dados, delimitação do problema de projeto e seus fundamentos terapêuticos, pesquisa de similares, estudo de materiais, estudo ergonômico e definição dos requisitos do produto. Em posse dessas definições. O dispositivo foi projetado no software Auto CAD com representações em 2d e maquete eletrônica no software 3d Studio Max. Resultados: O protótipo preliminar passou por testes ergonômicos, apontando correções necessárias, após as quais, obteve-se o desenho definitivo do dispositivo, sendo concluidas duas unidades do protótipo. Conclusão: Após o desenvolvimento do dispositivo, faz-se necessário um estudo de aplicação clínica, com análise de sua utilidade terapêutica e possíveis efeitos relacionados à dor lombar, mobilidade da coluna e capacidade funcional em tarefas relacionadas a cuidados pessoais, vida social e laboral dos usuários.

Palavras-chaves: lombalgia, suspenção pélvica, tração lombar. 


\section{AVALIAÇÃO CLÍNICA-LABORATORIAL DOS PACIENTES COM RISCO DE DOENÇA RENAL CRÔNICA CADASTRADOS NO PROGRAMA HIPERDIA EM UM MUNICÍPIO NO INTERIOR DA AMAZÔNIA}

Nome dos Bolsistas: Ana Carolina Magalhães De Araújo Tolentino, Gabriel Da Costa Soares

Nome dos Voluntários: Miguel Rebouças De Sousa, Edilson Santos Silva Filho Nome do(a) Orientador(a): Edna Ferreira Coelho Galvão

Grupo de pesquisa: Grupo de Estudos e Pesquisas em Educação e Saúde das Populações Amazônicas

Introdução: Na última década, é marcante o crescimento da prevalência geral do Diabetes Melito (DM) e da Hipertensão Arterial Sistêmica (HAS) em meio à população brasileira, duas das condições crônicas mais preocupantes em se falando em Saúde Pública, que estão diretamente relacionadas a lesões sistêmicas secundárias por lesão microvascular. Objetivo: Avaliar clínica e laboratorialmente os pacientes com risco de doença renal crônica cadastrados no programa HIPERDIA numa unidade básica de saúde. Métodos: Estudo de caráter quantitativa, transversal e descritiva, com a apresentação de dados referentes às informações dos prontuários e de informações coletadas através de entrevista aos pacientes cadastrados no programa HIPERDIA. Estudo realizado entre os meses de abril de 2018 a abril de 2019, com amostra composta por cento e oitenta e oito pacientes diabéticos e/ou hipertensos cadastrados no programa HIPERDIA de 4 unidades básicas de saúde do município de Santarém-Pa. Resultados: Notou-se que a idade média é $64,64 \pm 11,51$, a faixa etária mais prevalente foi a faixa etária de 60 a 71 anos (41,49\%). Em relação a classificação da função renal; $18,18 \%$ dos pacientes possuem a TFG classificada dentro do estágio G0/G1 de DRC, de acordo com a equação CKD-EPI. 38,76\% possuem TFG classificada dentro do estágio G2 de DRC. 33,06\% dos pacientes possuem uma TFG estimada menor que $60 \mathrm{ml} / \mathrm{min} / 1,73 \mathrm{~m}^{2}$. Conclusão: A adoção de práticas como as desenvolvidas pelo presente estudo se fazem necessárias, pois a detecção precoce de alterações na função renal de pacientes diabéticos e hipertensos, assim como a utilização de condutas terapêuticas adequadas para o retardo de sua progressão são medidas muito importantes para oferecer uma melhor qualidade de vida para estes pacientes, assim como promove economia o sistema único de saúde. 


\section{INTRODUÇÃO}

Atualmente, as doenças crônicas não transmissíveis (DCNTs) são consideradas como um grave problema de saúde pública, dentre as quais se destacam a hipertensão arterial sistêmica (HAS) e a diabetes melito (DM). Tais patologias são caracteristicamente envolvidos em lesões sistêmicas secundárias por mecanismo de microangiopatia, com acometimento de órgãos-alvo, como o coração e os rins ${ }^{1}$. De fato, globalmente a grande maioria dos casos de Doença Renal Crônica (DRC) acontece em associação com hipertensão, diabetes, doenças cardiovasculares, envelhecimento e obesidade ${ }^{2}$.

\section{OBJETIVOS}

Avaliar clínica e laboratorialmente os pacientes com risco de doença renal crônica cadastrados no programa HIPERDIA numa unidade básica de saúde através de dados antropométricos, risco cardiovascular através do Escore de Framingham e classificação da função renal.

\section{MÉTODOS}

Foi empregada uma abordagem quantitativa, transversal e descritiva, com a apresentação de dados referentes às informações dos prontuários e de informações coletadas através de entrevista aos pacientes cadastrados no programa HIPERDIA no município de Santarém-Pará. O espaço amostral foi composto por 188 pacientes diabéticos e/ou hipertensos cadastrados no programa HIPERDIA das Unidades Básicas de Saúde (UBS) da Esperança, da Matinha, do Santo André e de Fátima, sendo que a última possui três estratégias de saúde da família integradas (Fátima, Laguinho e Aldeia) e os pacientes foram provenientes das três zonas citadas. O estudo foi realizado entre os meses de abril de 2018 a abril de 2019.

A pesquisa respeitou os aspectos éticos dos participantes de acordo com a resolução 466/12 do Conselho Nacional de Saúde, assim como sua individualidade étnica, social e moral. O estudo foi aprovado no Comitê de Ética em Pesquisa da Universidade do Estado do Pará - Campus XII, com CAAE 03285318.7.0000.5168 e parecer $\mathrm{N}^{\circ}$ 3.101.595. Os pesquisadores realizaram uma visita técnica a UBS envolvida para organizar questões logísticas. No dia primeiro dia de execução, os pacientes foram recepcionados na UBS, nesse momento receberam esclarecimentos acerca da pesquisa e foram convidados a participarem do mesmo, mediante a assinatura voluntária do TCLE.

Em seguida, foi aplicada a entrevista baseada em questionário, posteriormente, foram realizadas as medidas da massa corporal, altura, circunferências e índice de massa corporal, assim como da pressão arterial. Ao final, foi agendada a data da coleta dos exames de sangue e urina (Urina tipo 1 - EAS).

Em um outro momento, os pesquisadores voltaram a UBS com os resultados do questionário e do rastreamento da doença renal crônica, nesse momento os pacientes que apresentaram alterações da taxa de filtração glomerular, passaram por um novo exame de urina e de creatinina em três meses a fim de confirmar o diagnóstico de doença renal crônica, como preconiza a edição do KDIKO de 2012. 
Neste mesmo dia, os pesquisadores realizaram uma palestra de curta duração acerca das medidas de prevenção da obesidade, da doença renal crônica e das demais comorbidades oriundas da hipertensão e do diabetes.

Após essa confirmação laboratorial supracitada, esses pacientes foram encaminhados pelo médico da UBS ao médico nefrologista, caso se apresentassem a partir do nível "3b", isto é, se apresentarem taxa de filtração glomerular inferior a 45 $\mathrm{ml} / \mathrm{min}$, resultado obtido através da utilização da creatinina sérica na equação CKD EPI, preconizada pela pelo KDIKO de 2012.

Resultados: O estudo contou com a participação de 188 pacientes de 4 UBS do município de Santarém-PA. A idade média é $64,64 \pm 11,51$, a faixa etária mais prevalente foi a faixa etária de 60 a 71 anos $(41,49$. O sexo mais prevalente foi o feminino $(66,49 \%)$, seguido pelo masculino (33,51\%). 63,30\% eram casados ou em união estável, e 46,28\% dos pacientes tinham DM e HAS concomitantemente. Dos 127 diabéticos, 53,53\% ( $n=68)$ dos pacientes tem diagnóstico de DM há menos de 5 anos e $9,44 \%$ tem o diagnóstico há mais de 10 anos.

Dos 151 hipertensos, 40,40\% ( $n=61$ ) tem diagnóstico de DM de 6 a 10 anos e 20,53\% $(n=31)$ possuem diagnóstico há mais de 10 anos. Apenas $25,82 \%$ dos pacientes tem um IMC considerado normal, sendo o principal grupo o dos pacientes com sobrepeso, representando $39,56 \%$ dos pacientes. Com relação à circunferência abdominal (CA) dos pacientes, apenas $8,13 \%$ das pacientes do sexo feminino e $22,81 \%$ dos homens avaliados não são classificados como obesos. A prevalência de SM é de $71,43 \%$ e no sexo feminino, a prevalência é de $68,80 \%$.

Dentre os participantes da pesquisa, $67 \%$ conhecem a função dos rins, $36 \%$ sabem o que é DRC, $63 \%$ afirmam que o tratamento da DRC leva à cura, $90 \%$ afirmam que o tratamento da HAS e do DM melhora a função renal e $63 \%$ dos participantes afirmaram que o tratamento é para a vida toda. Além disso, $68 \%$ dos participantes sabiam que a HAS causa DRC, $83 \%$ dos participantes sabiam que o DM causa DRC, entretanto apenas $62 \%$ acreditavam ter risco para desenvolver DRC, $88 \%$ afirmaram que o tratamento da HAS e do DM previnem a DRC e $87 \%$ afirmaram que dieta e exercício físico previnem DRC.

Dos participantes, $18,18 \%$ dos pacientes examinados possuem a TFG classificada dentro do estágio G0/G1 de DRC, estimada através da equação CKD- EPI. 38,76\% possuem TFG classificada dentro do estágio G2 de DRC. 33,06\% $(n=40)$ dos pacientes possuem uma TFG estimada menor que $60 \mathrm{ml} / \mathrm{min} / 1,73 \mathrm{~m} 2$. Dos 188 pacientes, foi possível estabelecer o risco pelo Escore de Risco de Framingham (ERF) para 80 pacientes. Desses, 23,75\% foram classificados como sendo de baixo risco, $45 \%$ foram classificados como possuindo risco moderado e $31,25 \%$ foram classificados como tendo alto risco. Pela avaliação do Escore de Risco Global (ERG) foi possível analisar 158 pacientes. Desses, a grande maioria (96,84\%) foi classificada como tendo alto risco para evento cardiovascular em 10 anos, e apenas 3,16\% foram classificados como tendo risco moderado.

Todos os pacientes estratificados como risco moderado no ERF foram estratificados como baixo risco no Escore da American Heart Association (EAHA). Dos que foram 
estratificados como risco alto pelo ERF, $73,91 \%$ foram estratificados também como risco alto pelo EAHA, $21,74 \%$ foi estratificado como risco moderado e $4,35 \%$ foi estratificado como risco baixo pelo EAHA.

Levando em consideração todo o espaço amostral, 80 foram estratificados pelo ERF e pelo ERG simultaneamente. Dos pacientes estratificados como baixo risco

no ERF, $15,79 \%$ foi estratificado como risco moderado no ERG e $84,21 \%$ foi estratificado como risco alto. Todos os pacientes estratificados como risco moderado no ERF foram estratificados como alto risco no ERG. Todos os pacientes estratificados com risco alto no ERF foram estratificados também como risco alto pelo ERG.

Apenas 24 foram estratificados pelo ERG e pelo EAHA simultaneamente. Dos pacientes estratificados como baixo risco no ERG, $50 \%$ foi estratificado como risco moderado no EAHA e 50\% foi estratificado como risco alto no EAHA. Todos os pacientes estratificados como risco moderado no ERG foram estratificados como alto risco no EAHA. Todos os pacientes estratificados com risco alto no ERG foram estratificados também como risco alto pelo EAHA.

Discussão: Em outros estudos publicados em 2015 e 2018, ao estratificarem o risco cardiovascular de hipertensos, houve predominância de mulheres, de idosos e de $32 \%$ de diabéticos, resultados semelhantes aos encontrados no presente estudo ${ }^{3}$. Já em relação ao perfil antropométrico, este estudo encontrou um perfil típico da região, com estaturas médias 152 e 162 para mulheres e homens, respectivamente, que ainda corroboram com a estaturas dos hipertensos e diabéticos atendidos em centro de tratamento no interior de Goiás, que também encontrou IMC médio de $30 \mathrm{~kg} / \mathrm{m}^{2}$ e Circunferência Abdominal de $104 \mathrm{~cm}$, ambos acima dos valores recomendados pela $\mathrm{OMS}^{4}$.

Um estudo realizado em Coimbra (MG) analisou a associação de idosos e síndrome metabólica, também encontraram maior prevalência em mulheres. No estudo realizado em Minas Gerais, a avaliação do conhecimento dos usuários sobre a DRC demonstrou que $54,6 \%$ dos pacientes apresentavam conhecimento insuficiente sobre tal patologia, e que este fato estaria diretamente associado a uma maior probabilidade de não adesão ao tratamento das doenças crônicas já citadas no trabalho e, consequentemente, progressão da injuria renal. ${ }^{5}$

$\mathrm{Na}$ estratificação de risco cardiovascular, através do ERF modificado em hipertensos de Juiz de Fora (MG), constatou-se que o risco era baixo em apenas $22 \%$, médio em $56 \%$ e alto $22 \%$ hipertensos, o presente estudo compartilha dados semelhantes, no entanto ainda apresenta mais pacientes em alto risco $(31 \%)^{6}$. No ERG, baseados na identificação de doença aterosclerótica, na análise do ERG e na reclassificação do risco conforme presença de fatores agravantes, conseguiu enquadrar $96 \%$ dos pacientes em alto risco. Estudos direcionados para a identificação de fatores de risco para doenças cardiovasculares, identificaram que $94 \%$ dos pacientes tinham alto risco, dado que se assemelha bastante ao deste estudo, isto comprova a importância para desenvolver mais educação em saúde a fim de melhorar a qualidade de vida 
desses indivíduos 7 .

Conclusão: Foi possível obter os dados socioeconômicos e antropométricos da maioria dos pacientes dos grupos de HIPERDIA, entretanto, a estratificação nos escores e a análise de dados não foram possíveis para todos os pacientes, pois durante a realização do estudo, foi observado que muitos dos pacientes atendidos na primeira etapa não retornaram com os dados laboratoriais que permitiriam sua estratificação nos escores de risco. Logo, é essencial que em estudos futuros haja o planejamento estratégico de como se obter todos as informações necessárias para a geração de dados que permitam uma análise de todos os pacientes estudados.

Dentro das conclusões da pesquisa, reforça-se a necessidade de mais estudos para estabelecer quais dos escores melhor se aplica à realidade brasileira e quais as medidas devem ser adotadas para reduzir o cenário de alta mortalidade por evento cardiovascular presente no nosso país. Com relação à realidade santarena, mais pesquisas serão necessárias para encontrar como os profissionais de saúde e gestores devem atuar em âmbito regional para que a redução dos fatores de risco seja alcançada de forma rápida e econômica para o Sistema Único de Saúde.

Embora seja necessária a continuação de atividades como a apresentada, a participação ativa dos grupos durante os encontros foi algo positivo e que merece destaque, assim como a boa relação existente entre a equipe multiprofissional e os pacientes, com a realização de um atendimento humanizado e centrado na pessoa. Ressalta-se que a elaboração de um plano de ação após a exposição do presente estudo se faz necessário, para que ações mais efetivas de educação em saúde sejam desenvolvidas no município, e assim melhorar a atenção primária à saúde.

Referências: BRASIL, Ministério da Saúde. Hábitos dos brasileiros impactam no crescimento da obesidade e aumenta prevalência de diabetes e hipertensão. VIGITEL BRASIL 2016.

2 World Health Organization. World Health Statistics 2012. Geneva; 2012

3 SANTOS, Ludmilla Borges dos et al. RISCO CARDIOVASCULAR EM USUÁRIOS HIPERTENSOS DA ATENÇÃO PRIMÁRIA À SAÚDE. Rev Enferm Ufpe On Line, Recife, v. 12, n. 5, p.1303-1309, maio 2018.

4 QUIRINO, Andressa Vieira et al. PERFIL ANTROPOMÉTRICO DE PACIENTES HIPERTENSOS E DIABÉTICOS ATENDIDOS EM CENTRO DE TRATAMENTO NO INTERIOR DE GOIÁS. In: IX SEMINÁRIO REGIONAL DE EXTENSÃO UNIVERSITÁRIA DA REGIÃO CENTRO OESTE, 9., 2018, Rio Verde. Anais. Goiânia: Ufg, 2018. p. $1-6$.

5 CANHESTRO, Mônica Ribeiro et al. Conhecimento de pacientes e familiares sobre a doença renal crônica e seu tratamento conservador. Revista Mineira de Enfermagem, v. 14, n. 3, p. 335-344, 2010.

6 PAULA, Josiane Aparecida Teixeira de et al. Metabolic syndrome prevalence in elderly of urban and rural communities participants in the HIPERDIA in the city of Coimbra/MG, Brazil. Investigación y Educación En Enfermería, [s.I.], v. 33, n. 2, p.325- 
333, 15 jun. $2015 . \quad$ Universidad de Antioquia. http://dx.doi.org/10.17533/udea.iee.v33n2a15.

7 MENDEZ, Roberto della Rosa et al. Cardiovascular risk stratification among hypertensive patients: the influence of risk factors. Revista Brasileira de Enfermagem, [s.l.], v. 71, n. 4, p.1985-1991, ago. 2018. FapUNIFESP (SciELO). http://dx.doi.org/10.1590/0034-7167-2017-0528 


\title{
UM OLHAR SOBRE A SAÚDE MENTAL DE ACADÊMICOS DA ÁREA DA SAÚDE DE UMA UNIVERSIDADE PÚBLICA
}

\author{
Nome do (a) Bolsista: Miguel Paranhos Melo de Melo \\ Nome dos voluntários: Fabíola da Silva Costa; Helder Clay Fares dos Santos Júnior \\ Nome do (a) Orientador(a): Enise Cássia Abdo Najjar \\ Grupo de pesquisa: Terapia Ocupacional e Saúde na Amazônia
}

Introdução: A saúde mental integra a saúde, estabelecendo-se quando há um equilíbrio das interfaces que compõem o sujeito, uma vez que saúde mental, física e social são interdependentes. Nesse âmbito, o suporte social, a satisfação com este e a espiritualidade configuram-se como potentes colaboradores da saúde mental, pois quanto maior a satisfação com o suporte recebido, menor é a incidência de desordens emocionais. A presença de espiritualidade, por sua vez, favorece o enfrentamento de situações estressoras e inevitáveis do cotidiano, gerando um bom estado de saúde, desenvolvido quando o individuo propõe-se a um contato mais específico consigo, com o cosmo e com as demais pessoas. À vista disso, observa-se que nos últimos 15 anos houve crescimento de publicações científicas relacionadas à saúde e/ou sofrimento mentais de universitários, o que aponta para a realidade do adoecimento psíquico dos discentes no Brasil. Objetivo: Este estudo buscou caracterizar a saúde mental de acadêmicos da área da saúde da Universidade do Estado do Pará (UEPA). Material e método: Trata-se de uma pesquisa exploratória, descritiva, de análise quantiqualitativa. A amostra constituiu-se de 60 acadêmicos regularmente matriculados nos cursos de Terapia Ocupacional, Fisioterapia e Medicina da UEPA. A participação no estudo deu-se por meio da aplicação do Inventário de Saúde Mental (ISM), Critério de Classificação Econômica Brasil (CCEB) e uma entrevista semi-dirigida com perguntas referentes às percepções dos participantes acerca de sua saúde mental, assim como do suporte social e espiritualidade.Resultados: $70 \%(n=42)$ dos entrevistados era do sexo feminino e as idades variaram entre 17 e 27 anos.Sobre a classificação econômica, os entrevistados eram de classe B2, com média de 36,03. Acerca do suporte social, 95\% ( $n=57)$ dos entrevistados referiu possuir, contudo, 63,3\% ( $n=38)$ indicou instatisfação ou necessidade de melhorias em relação ao mesmo. 88,3\% $(n=53)$ dos entrevistados afirmou ser espiritualizado. Acerca dos resultados referentes ao ISM, 48,3\% ( $n=29)$ dos participantes pontuou abaixo de 52 pontos, o que significa que grande parte dos entrevistados apresentou sintoma depressivo grave. Ainda, $18,3 \%(n=11)$ dos estudantes obteve escores entre 52 e 60, o que representa sintomas depressivos moderados. Assim, 66,6\% $(n=40)$ dos participantes possui sintomas depressivos, caracterizando a presença de sofrimento psíquico. Conclusão: $O$ estudo caracterizou a saúde mental de acadêmicos da área da saúde da UEPA, lançando luz à urgente discussão acerca da saúde mental dos universitários. Os achados apontam para a presença de sintomas depressivos na maior parte dos entrevistados, o que gera reflexão sobre o acolhimento que a Instituição de Ensino Superior tem dado aos seus discentes. A pesquisa revela que a saúde mental do universitário deve ser tratada como prioridade, pois o sofrimento mental ocasiona adoecimento físico. Ademais, 
ressalta-se a necessidade da inserção de acompanhamento psicológico no âmbito acadêmico, assim como novos estudos que abordem está temática.

Palavras-chave: Universidade; Estudantes; Saúde Mental. 


\title{
AVALIAÇÃO DE ANSIEDADE, DEPRESSÃO E QUALIDADE DE VIDA EM PACIENTES COM PARKINSON SUBMETIDOS AO MÉTODO WATSU
}

\author{
Nome do(a) bolsista: Fernando Lucas Costa de Lima; Thatiane Belém Rosa \\ Nome do (a) Orientador (a): George Alberto da Silva Dias \\ Grupo de Pesquisa: Desenvolvimento e Reabilitação na Amazônia
}

Introdução: A doença de Parkinson (DP) é a segunda doença neurodegertiva mais comum, afetando principalmente indivíduos acima de 50 anos. Ela é caracterizada pela perda de neurônios dopaminérgicos da substancia negra, apresentando sintomas motores e não motores como bradicinesia, alterações de sono, quadros depressivos e ansiedade, levando a perda da qualidade de vida (QV), necessitando de terapias para a redução desses sinais e sintomas. Dentre as formas de tratamento, a fisiotepia aquática por meio do método watsu utiliza técnicas de relaxamento em piscina aquecida com objetivo de minimizar os sintomas motores e também os não motores favorecendo a melhora da percepção da qualidade de vida. Objetivo: Avaliar a ansiedade, depressão e qualidade de vida de paciente com Parkinson submetidos ao Método Watsu. Material e Método: Trata-se de um estudo experimental, realizado no Ambulatório de Hidroterapia Professor Benedito José Ribeiro Duarte, no período de agosto de 2018 a junho de 2019, composta por 9 indivíduos. Para a coleta de dados, os pacientes foram avaliados no inicio do tratamento e reavaliados após a ultima sessão. Os instrumentos utilizados foram: ficha de triagem, inventário de Beck para ansiedade, inventário de Beck para depressão e o Parkinson's Disease Questionnaire - 39 (PDQ-39). O protocolo de tratamento pelo método watsu foi composto por 13 exercicios, realizados duas vezes por semana, com duração de 50 minutos cada. Realizou-se a análise estatística por meio do software BioEstat 5.0, por meio do teste t Student com nível de significância de 5\% ( $p \leq 0,05)$. Resultados: Participaram do estudo 9 indivíduos, sendo 89,0\% $(n=8)$ do gênero masculino e 11,0\% (n=1) do

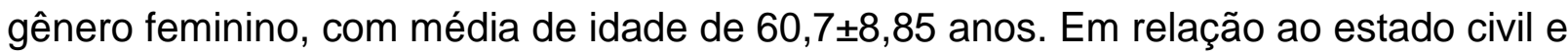
ocupação, observou-se que $100 \%$ dos avaliados eram casados e não possuíam algum tipo de ocupação, contudo, ao que concerne o grau de escolaridade $33,3 \%$ $(n=3)$ concluíram o ensino fundamental, 33,3\% $(n=3)$ o ensino médio e 33,3\% (n=3) o superior. Em relação aos níveis de ansiedade, nota-se uma diminuição dos escores $(24,0 \pm 17,3$ / 22,01 $\pm 14,1)$, refletindo uma melhora nesta variável, contudo, estatisticamente sem relevância $(p=0,48)$. E para depressão, mesmo demonstrando que os pacientes ainda apresentavam sintomas depressivos entre moderados e graves $(17,6 \pm 10,8$ / 15,2 $\pm 10,4 ; p=0,12)$, nota-se ligeira redução das médias obtidas, levando a acreditar que havia uma tendência de melhora ao longo do tratamento. Por fim, em relação a QV pode-se observar redução nos escores após as sessões $(49,7 \pm 14,8$ / 42,0 $\pm 20,2)$, o que significa melhor percepção da QV, contudo, sem significância estatística $(p=0,06)$. Em relação as subcategorias do PDQ-39, Estigma $(p=0,05)$ e Apoio Social $(p=0,04)$ foram as únicas que apresentaram relevância estatística.Conclusão: conclui-se que não houve resultado significante na redução da ansiedade, depressão e qualidade de vida, porém mostrou-se com tendência a 
melhora dos sintomas. Apenas para a qualidade de vida relacionado a Estigma e Apoio Social, foi possível observar relevância estatística. Isso devido ao fato de que o método watsu é uma terapia que não atua apenas nos fatores físicos, como também nos fatores psicológicos e emocionais.

Palavras-chave: Watsu; Ansiedade; depressão; qualidade de vida. 


\section{AVALIAÇÃO DA MOBILIDADE E EQUILÍBRIO DE PESSOAS COM DOENÇA DE PARKINSON}

Nome do (a) Bolsista: Milkeson Mendes de Souza

Nome do (a) Orientador (a):Gileno Edu Lameira de Melo

Grupo de Pesquisa: Grupo Multidisciplinar de Pesquisa em Educação, Saúde e Meio Ambiente na Amazônia

Introdução: A doença de Parkinson compromete o equilíbrio e a mobilidade funcional dos portadores, devida esta doença ser ocasionada por consequência da morte das células dopaminérgicas que afetam o funcionamento dos núcleos da base. Nesse sentido, a avaliação da mobilidade e do equilíbrio de pessoas com doença de Parkinson (DP) é pouco explorada no dia a dia do tratamento e se justifica por poder acompanhar a evolução da doença e com isso proporcionar melhora no desempenho motor, na autoestima e numa maior expectativa de vida. Objetivo: O estudo teve como objetivo de avaliar a mobilidade e equilíbrio de pessoas com DP. Materiais e Métodos: A pesquisa foi desenvolvida com 7 portadores da doença de Parkinson que frequentam a Clínica de Fisioterapia de Altamira - FISIOCLIN. Para avaliar a severidade da doença foram utilizadas duas escalas, a primeira é a Escala Unificada de Avaliação da Doença de Parkinson - UPDRS, A segunda é a Escala de Hoehn e Yahr ( $\mathrm{H} \& \mathrm{Y})$. Para a avaliação do equilíbrio e mobilidade foi utilizado o test Timed Up and Go (TUG), por meio do sensor inercial G-Walk.Os dados foram analisados pela estatistica descritiva atraves da média e desvio padrão. Resultados: Os resultados mostram que os pacientes estavam nos estagios 1 e 2 da escala de H\&Y dos quais foram alocados em grupos de acordo com a severidade da doença, desta forma, foram classificados nos estagios leve a moderado de incapacidade da doença. Na escala de Berg a amostra apresentou media de 49,71 e desvio padrão 7,74. Em relação ao teste de caminhada de 6 minutos os pacientes no estagio 2 da escala de H\&Y apresentaram melhor resultado que os pacientes do estagio 1. Já em relação ao Teste Timed Up and Go a amostra apresentou media de 14,30 e desvio padrão 5,50. Conclusão: Concluise que a amostra não apresenta falta de equilíbrio funcional pelo teste de Berg. Porém, apresentou baixa mobilidade pelo teste de caminhada de 6 minutos e risco de queda pelo teste Timed Up and Go.

Palavras-Chave: Doença de Parkinson. Limitação da Mobilidade. Equilíbrio Postural. 


\title{
ENTRAVES ENFRENTADOS POR RIBEIRINHAS NA PREVENÇÃO DO CÂNCER CÉRVICO UTERINO: O LAÇO VIROU NÓ
}

\author{
Nome do(a) bolsista: Victória Leal Ferreira \\ Nome do(a) voluntária: Victória Maria Barile Sobral \\ Nome do(a) Orientadora: lací Proença Palmeira \\ Grupo de Pesquisa: Grupo de Estudos de Representações Sociais
}

Introdução: O câncer do colo do útero (CCU) é um problema de saúde pública no Brasil e sua identificação precoce aumenta consideravelmente a probabilidade de cura, sendo esse exame o principal meio de detecção precoce desse tipo de câncer. O câncer do colo do útero é o quarto tipo de câncer mais incidente na região norte do Brasil, com 23,97 casos por 100.000 mulheres. São fatores de risco: o baixo nível socioeconômico, a multiplicidade de parceiros sexuais, a baixa imunidade, o tabagismo, infecções por outras IST's, o início precoce da vida sexual e a não realização periódica do exame de PCCU. Tais fatores abrangem grande parte da população brasileira e paraense, dentre estas, as populações tradicionais. As populações ribeirinhas da Amazônia representam uma mistura de diferentes grupos sociais (indígenas, nordestinos e migrantes de outras regiões), vivem em áreas rurais, às margens de rios e lagos na Amazônia brasileira, distribuindo-se em uma área geográfica com cerca de $5.020 .000 \mathrm{~km}^{2}$. O rio não é enxergado apenas como fonte de subsídios para a sobrevivência, mas representa um valor simbólico, uma condição de vida. Sua história e seus saberes encontram-se definidos pelo meio em que vivem e suas culturas. Diante do exposto elegeu-se o preventivo do Câncer Cérvico-Uterino em ribeirinhas como objeto de estudo, se mostrou relevante, por existirem lacunas na produção científica regional. Objetivo: conhecer os problemas vivenciados por mulheres ribeirinhas para a realização do exame preventivo do câncer cérvico uterino (PCCU) para que os cuidados de saúde possam acolher de modo mais eficaz as suas necessidades. Material e Métodos: estudo do tipo qualitativo e exploratório, recorte do relatório final de um PIBIC (Edital n 019/2018 - CNPq/UEPA), realizado na Unidade da Estratégia Saúde da Família (ESF) da ilha do Combú. Participaram 41 mulheres com idade entre 18 e 64 anos de idade, cujas informações foram obtidas de janeiro a fevereiro de 2019 por meio de entrevistas individuais em suas residências. Respeitaram-se os princípios éticos e o TCLE foi assinado em duas vias. A análise dos resultados seguiu os passos de Bardin: pré-análise, exploração do material e tratamento dos resultados. Resultados: Surgiram três eixos temáticos: 1) o que faço para realizar o exame; 2) como me sinto durante o exame; 3) o que eu sei sobre o exame e o câncer de colo de útero. Cabe dizer que esse recorte se refere ao eixo 1, que alude às suas percepções acerca do acesso e da acessibilidade para a realização do exame, abarcando desde os problemas operacionais da ESF e as distâncias de suas residências margeadas pelos rios, a restrição de transporte gratuito para condução à unidade, o descaso de algumas mulheres e o pouco conhecimento sobre a importância do exame. Conclusão: Conclui-se que as ribeirinhas, trazem em sua bagagem cultural questões que dizem respeito às concepções, não só aos espaços 
sociais que ocupam, mas também concepções edificadas pelos seus modos singulares de habitarem as margens dos rios, extraindo daí, alimentação, fonte de renda e saberes próprios oriundos das águas e das florestas. São estas vivências e percepções que precisam ser apreendidas e respeitadas, para, a partir de então, criarem estratégias voltadas às suas reais necessidades de saúde, dentre estas, o PCCU como uma necessidade de todas as mulheres.

Palavras-chave: Câncer de colo do útero; Prevenção e controle; População rural; Acesso aos serviços de saúde; Saúde da mulher; 


\section{DESENVOLVIMENTO MOTOR E COMUNICATIVO DE PREMATUROS: FATORES DE RISCO E DA INTERAÇÃO MÃE-BEBÊ.}

Nome dos Bolsistas: Pedro Victor Oliveira Monteiro, Anderson Braga Rodrigues Cardoso

Nome da orientadora: Ivete Furtado Ribeiro Caldas

Grupo de Pesquisa: Grupo interdisciplinar de pesquisa em sociedade, saúde e meio ambiente na Amazônia

Introdução: A prematuridade é caracterizada como nascimento antes de 37 semanas de gestação, sendo um forte indicador de morbimortalidade neonatal. Essas crianças representam uma população vulnerável às alterações motoras e cognitivas, incluindo alterações sociocomunicativas. Ademais, a qualidade da prestação de cuidados precoce desempenha um papel importante na trajetória do desenvolvimento desses prematuros, e a avaliação no primeiro semestre de vida consiste numa estratégia importante no diagnóstico dessas alterações. Objetivo: Verificar a relação entre prematuridade e comportamento materno no desenvolvimento motor e sociocomunicativo de prematuros no $1^{\circ}, 4^{\circ}$ e $7^{\circ}$ mês de idade corrigida. Método: Trata-se de um estudo longitudinal, prospectivo e quantitativo, aprovado no Comitê de Ética (n. 176.898). Foram recrutadas 22 mães com seus neonatos prematuros nascidos no Hospital Materno Infantil, no município de Marabá, Pará. Porém, devido a inexistência de um cadastro para contatos, a não aceitação em participar da pesquisa e a desistência de algumas mães, a amostra foi reduzida para oito díades. Para a coleta de dados foi utilizado uma ficha clínica e socioeconômica, o Teste de Triagem do Desenvolvimento Denver II e a Escala de Interação Social. As sessões aconteceram aos 3, 6 e 9 meses de idade cronológica e que corresponderam ao primeiro, quarto e sétimo meses de IC. As avaliações se deram no Laboratório de Desenvolvimento Infantil da UEPA, campus de Marabá, Pará. Cada sessão teve duração de vinte e cinco minutos. Foi utilizado o Teste Qui-quadrado de Pearson e o nível de significância ( $p$ valor $<0.05)$. Resultados: No primeiro mês de IC duas crianças apresentaram desenvolvimento geral "questionável", que podem estar relacionados com a menor idade gestacional e o baixo peso ao nascer. A categoria que obteve o melhor desempenho foi a "linguagem" e a pior, o "motor grosso". Já aos 4 e 7 meses de IC todas (100\%) apresentaram desenvolvimento normal. Em relação a EIS, no primeiro mês de IC, a mãe que obteve os escores mais baixos, foi uma mãe primigesta e adolescente (11.5 pontos). Todavia, concomitantemente à melhora no desenvolvimento geral dos prematuros aos 4 e 7 meses de IC, houve aumento nos escores da EIS, com 16.75 pontos em ambas as idades. $E$ ao analisar o efeito da interação entre 0 comportamento materno e o desenvolvimento geral no primeiro, quarto e sétimo mês de idade corrigida, verificou-se presença de interação significativa aos quatro meses ( $x 2=$ $6,966, \mathrm{df}=1, p=0.008)$ e aos 7 meses $(\mathrm{X} 2=6,985, \mathrm{df}=1, p=0.008)$. Conclusão: Os achados evidenciam que a prematuridade e a qualidade das interações mãe-bebê podem interferir no desenvolvimento sociocomunicativo e motor de crianças prematuras.

Palavras chaves: prematuridade; desenvolvimento infantil; interação mãe-criança. 
DESENVOLVIMENTO DE UMA ÓRTESE DINÂMICA DE BAIXO CUSTO PARA PACIENTES COM LESÃO MEDULAR NÍVEL C6 E C7: NOVA POSSIBILIDADE PARA REALIZAÇÃO DAS ATIVIDADES DE VIDA DIÁRIAS.

Nome dos Bolsistas:Maria Vitória Oliveira da Silva, Izabela Oliveira da Silva Lorena Henriete Araújo Dias

Nome do Orientador: Jorge Lopes Rodrigues Junior

Grupo de Pesquisa: Terapia ocupacional e saúde na Amazônia

Introdução: A lesão medular apresenta variadas etiologias dentre elas, violência urbana, acidentes automobilísticos e mergulho em água rasa. Esses acidentes acometem principalmente homens em idade produtiva, causando prejuízos á nível físico-motor e psicossocial, como redução na independência e funcionalidade em suas ocupações. Como forma de auxílio para realização de ocupações e demandas individuais do indivíduo, as Tecnologias Assistivas surgem como possibilidade na realização e desempenho satisfatório de atividades significativas. Dentre as categorias de Tecnologia Assistiva, existe as órteses que agem de forma adjuvante ao tratamento de reabilitação física e social, pois amparam ou auxílio a funcionalidade do membro lesado. Objetivo: Desenvolver uma órtese dinâmica para auxilio funcional de indivíduos lesionados medular á nível C6 e C7. Método: A pesquisa é de caráter exploratório e qualitativa, realizado em um laboratório de referência da região norte. Para a confecção da órtese necessitou-se de 5 fases de fabricação, sendo realizado testes nos pesquisadores. Resultados: Foi desenvolvido um protótipo resistente a força aplicada com material de baixo custo Sendo realizados testes com policloreto de vinila (PVC) e fibra de carbono com resina epóxi, priorizando designer agradável, dentro dos padrões anatômicos e biomecânicos para o acionamento funcional, facilitando a pega palmar e proporcionando pinça polpa a polpa, necessárias essas para desempenho satisfatório das ocupações e atividades. Conclusão: Observou-se a importância do efeito Tenodese e da mola elástica para acionamento ativo e passivo da órtese, a diversidade de materiais que priorizassem o baixo custo e princípios biomecânicos e estéticos que favoreciam a funcionalidade.

Palavras-Chave: Lesão Medular, Equipamentos de Autoajuda, Terapia Ocupacional. 


\section{PREVALÊNCIA E FATORES DE RISCO ASSOCIADOS ÀS ALTERAÇÕES POSTURAIS ENTRE ESCOLARES}

Nome do (a) Bolsista: Sirleide Milhomem Araujo Veloso

Nome dos Voluntários: Joanita de Sousa Pereira e Vanessa Pereira Franco

Nome do(a) Orientador(a): José Robertto Zaffalon Júnior.

Grupo de Pesquisa: Grupo Multidisciplinar de Pesquisa em Educação, Saúde e Meio Ambiente na Amazônia.

\section{RESUMO}

Objetivo: identificar alterações posturais e seus fatores de risco entre escolares do ensino fundamental. Métodos: Trata-se de uma pesquisa de campo com objetivo exploratório e descritivo, apresenta abordagem quantitativa da qual participaram 189 alunos de ambos os sexos dos anos finais do ensino fundamental. Foram analisados o peso, a estatura e a postura corporal, utilizando o protocolo SAPO, bem como o tipo e o peso do material escolar. Os dados foram analisados por meio da estatística descritiva e inferencial com auxílio do software SPSS 20 e as médias foram comparadas pela análise de variância (ANOVA). O nível de significância adotado consiste em $\mathrm{p}<0,05$.

Resultados: identificou-se que $24,4 \%$ encontram-se com peso inadequado, assim como que $93,7 \%$ dos participantes possuem a mochila de duas alças, considerada adequada, sendo que em relação ao peso desta os do sexo masculino carregam em média $3,25 \mathrm{~kg}$ e do sexo feminino $2,74 \mathrm{~kg}$, sendo que pesam em média $46,78 \mathrm{~kg}$ e $45,95 \mathrm{~kg}$ respectivamente. Na avaliação postural, os escolares participantes da pesquisa apresentaram alterações no alinhamento de regiões das vistas anterior, posterior e laterais. Conclusão: a postura corporal inadequada se encontra diretamente relacionada ao acometimento de desconforto, dores e alterações posturais. A soma da postura que vem sendo adotada pelos escolares constitui-se fator de risco às alterações posturais. Ações preventivas devem ser tomadas no ambiente escolar por parte do poder público aliado à comunidade escolar.

Palavras-chave: Estudantes. Fatores de risco. Postura. Serviços de Saúde Escolar

1 Introdução: O ser humano durante o processo de amadurecimento passa por distintas transformações e modificações corporais que podem ocasionar alterações posturais, isto advêm de diversos fatores ao longo da vida ${ }^{1}$.

Ainda na primeira década do século XXI conceituaram a postura como sendo o posicionamento do corpo no espaço de modo a preservar o alinhamento corporal ${ }^{2}$. A postura corporal quando adotada de forma inadequada é um fator relevante para o surgimento de problema posturais ${ }^{3}$. Os fatores de riscos para alterações posturais estão relacionados diretamente com o desequilíbrio biomecânico e, geralmente, ocorre 
na fase da adolescência, uma vez que, nesse período ocorre o desenvolvimento corporal mais acentuado do indivíduo, ou seja, o "estirão de crescimento"1.

Estudos apontam que as alterações posturais estão ligadas a fatores interno e externo, como: hereditariedade, condições físicas e ambientais, emocionais e socioeconômicos ${ }^{1,4}$. Entre esses encontram-se o índice de massa corporal (IMC), estatura, crescimento acelerado na adolescência, a falta de atividade física regular, sedentarismo e a ausência de conhecimentos posturais ${ }^{3}$.

Nessa perspectiva, o presente artigo tem por finalidade identificar alterações posturais e seus fatores de risco entre escolares do ensino fundamental. Para tanto, pretende-se avaliar a postura dos escolares; apontar os fatores de risco para alterações posturais dos escolares; discutir os fatores de risco para as alterações posturais e debater a função/atuação do profissional de educação física na prevenção de problemas posturais entre escolares.

2 Material e método: $O$ trabalho foi realizado por meio de uma pesquisa de campo com objetivo exploratório e descritivo e apresenta abordagem quantitativa ${ }^{5,6}$. Participaram 189 alunos matriculados nos anos finais de escolas de ensino fundamental da zona urbana do município de Altamira, Pará, cujo $\mathrm{N}$ amostral foi definido por meio da fórmula de Tabachnick e Fidell ${ }^{7}$.

Para execução da pesquisa foram o peso, a altura e a postura dos escolares, bem como o tipo e o peso do material escolar. Como instrumentos de coleta de dados foram utilizados uma ficha de anamnese para caracterização dos participantes, balança eletrônica portátil para mensuração, fita métrica afixada na parede verticalmente permitindo a leitura e registro da estatura e, para a avaliação da postura, utilizou-se uma câmera fotográfica semiprofissional de acordo com as recomendações do software SAPO ${ }^{8}$. Após os registros fotográficos, as imagens foram transferidas para o computador para análise fotogramétrica no software SAPO, no qual realizou-se a calibragem da imagem, marcação dos pontos pelo protocolo, geração do relatório de análise e exportação para o software Microsoft Excel para posterior análise estatística. Os dados foram analisados por meio da estatística descritiva e inferencial para comparação das variáveis, com auxílio do software SPSS 20. As médias foram comparadas pela análise de variância (ANOVA). O nível de significância adotado consiste em $p<0,05$. A pesquisa segue todos os aspectos éticos propostos pela resolução 466/12 e aprovação do Comitê de Ética em Pesquisa com Seres Humanos (CEP) sob o parecer número 3.128.680.

3 Resultados: Os dados analisados apresentam-se descritos ao longo do texto. A partir da anamnese feita aos escolares pesquisados 3,2\% fazem ou já fizeram tratamento fisioterapêutico, 0,5\% apresenta alteração de equilíbrio, 2,6\% já obtiveram alguma fratura nos membros inferiores e 1,1\% apontou ter alteração no joelho. Sobre o tipo de material escolar utilizado pelos escolares, associado ao peso deste em relação ao peso corporal, na presente pesquisa foi identificado que $93,7 \%$ dos participantes possuem a mochila de duas alças, sendo que em relação ao peso desta os meninos 
carregam em média $3,25 \mathrm{~kg}$ e as meninas $2,74 \mathrm{~kg}$, sendo que pesam em média 46,78kg e $45,95 \mathrm{~kg}$ respectivamente.

Por meio da verificação do peso e altura dos alunos e posterior análise foi possível constatar que, no que cerne a classificação do índice de Massa Corporal (IMC), uma parcela significativa, 10,6\%, encontra-se abaixo do peso considerado saudável pelo Ministério da Saúde (MS). Em contraponto, o grau de sobrepeso é ainda mais elevado, $13,8 \%$, tornando-se fator de risco ao sobrepeso. Contudo, prevalece o peso adequado verificado em $75,7 \%$ dos escolares.

$\mathrm{Na}$ avaliação postural, os escolares participantes da pesquisa apresentaram alterações no alinhamento de regiões das vistas anterior posterior e laterais. Na vista anterior identificou-se alterações no alinhamento horizontal da cabeça (A1), dos acrômios (A2), das espinhas ilíacas anterossuperiores (A3) e no ângulo entre os dois acrômios e as duas espinhas ilíacas anterossuperiores (A4), assim como diferença no comprimento dos membros inferiores (D-E) (A5) e no alinhamento horizontal das tuberosidades das tíbias (A6), em que ambos os sexos apresentaram, sem diferença significativa entre estes, valores negativos de A1 a A4 e positivos em A5 e A6, todos diferentes de $0^{\circ}$, com exceção de $A 5$ que a medida é dada em $\mathrm{cm}$, sendo o recomendado $0 \mathrm{~cm}$. Os ângulos $Q$ direito (A7) e Q esquerdo(A8) também apresentaram valores inferiores aos 15 graus de referência, sendo o desvio mais acentuado nos meninos, $10,60^{\circ}$ para $12,48^{\circ}$ nas meninas. Em relação à vista posterior alterações foram identificadas na assimetria horizontal da escápula em relação à T3 (A9) em que ambos os sexos apresentaram desvio de $-27 \%$, sendo o valor de referência 0\%. Essa medida descreve o posicionamento da escapula no que cerne a abdução e adução. Nas vistas laterais direita e esquerda alterações foram identificadas no alinhamento vertical da cabeça (acrômio) (A10, A15), sendo nos meninos uma inclinação de 16,68 e 10,20 e nas meninas $15,12^{\circ}$ e $11,49^{\circ}$ respectivamente, distanciando-se de $0^{\circ}$. Nota-se uma diferença de aproximadamente $1^{\circ}$ entre os sexos, de $6,48^{\circ}$ entre as laterais no sexo masculino e $3,63^{\circ}$ no feminino. Em relação ao alinhamento vertical do corpo observouse similitude entre os sexos na lateral direita (A11), 3,370 e 3,17 e dessemelhança na lateral esquerda (A16) $2,09^{\circ}$ e $1,2^{\circ}$. No alinhamento horizontal da pélvis encontrou-se uma desproporção em relação ao sexo, os meninos apresentaram $-3,38^{\circ}$ e as meninas $-10,62$ na vista lateral direitas (A12), repetindo-se a desconformidade na vista lateral esquerda, $-6,09^{\circ}$ no sexo masculino e $-10,04^{\circ}$ no feminino (A17). Ao que cerne a angulação do joelho na vista lateral direita (A13) os meninos apresentaram $-2,91^{\circ}$ e as meninas $-3,29^{\circ}$, sendo na vista esquerda (A18) $-3,98^{\circ}$ e $-2,92^{\circ}$ respectivamente. Todavia, na angulação do tornozelo foram identificados valores semelhantes entre os sexos, na vista lateral direita (A14) $85,68^{\circ}$ nos meninos e $86,62^{\circ}$ nas meninas e na esquerda (A19) $87,51^{\circ}$ e $87,35^{\circ}$ respectivamente. Já em relação a assimetria frontal foram identificados os seguintes valores: $-0,04^{\circ}$ nos meninos e $-0,08$ nas meninas. No que tange a assimetria sagital, encontrou-se para o sexo feminino $0,38^{\circ}$ e $0,33^{\circ}$ para o feminino.

4 Discussão: Em relação ao peso do material escolar, verificou-se que, no que tange ao peso corporal dos escolares, este encontra-se predominantemente dentro dos 
níveis recomendado pela Organização Mundial Da Saúde (OMS), que estabelecem que não se deve ultrapassar $10 \%$ da massa corpórea ${ }^{9}$. Todavia, no que cerne o tipo de material escolar, o uso de mochilas para seu transporte muitas vezes é feito de forma inadequada (quando o aluno carrega o peso em apenas uma das laterais) podendo resultar em alterações posturais e algias ${ }^{10}$. Os mesmos autores detectaram práticas posturais consentâneas no transporte do "[...] material escolar, tanto no meio de transporte quanto no modo utilizado para este transporte"10.

Um estudo realizado pela Pesquisa de Vigilância de Fatores de Risco e Proteção para Doenças crônicas por Inquérito Telefônico (Vigitel) do MS em 2018 mostra que mais da metade da população brasileira, $55,7 \%$ tem excesso de peso, assim como houve um aumento de $67,8 \%$ de obesos no Brasil nos últimos 13 (treze) anos ${ }^{11}$. Tais resultados vão de encontro com os obtidos na presente pesquisa. A obesidade além de estar associada ao surgimento de doenças crónicas como aponta o MS, esta relaciona-se também ao surgimento de "[...] alterações posturais, tanto em adultos como em crianças e adolescentes"12. Por outro lado, a presente pesquisa detectou a prevalência do peso considerável saudável dos escolares, esse fator pode estar associado ao fato que, de acordo com VIGITEL "a população passou a adquirir hábitos mais saudáveis"11.

Relativo aos dados da avaliação postural os resultados apontam alterações no alinhamento corporal dos escolares em ambas as vistas avaliadas. Isso sugere que medidas interventivas devem ser adotadas para reduzir o grau dos desvios e evitar agravos. Um estudo realizado com 59 crianças e adolescentes apontou que 79,7\% dos pesquisados apresentaram alterações posturais podendo provocar algias ${ }^{4}$.

Nessa perspectiva, ações de prevenção e o diagnóstico e tratamento precoce dos desvios posturais e de seus fatores de risco na adolescência torna-se imprescindível, visto que nessa fase a probabilidade de prevenir ou tratar é maior que em outras devido o desenvolvimento musculoesquelético ${ }^{1}$. Nota-se, portanto, a importância da atuação de profissionais da educação, como o Profissional de Educação Física (PEF) que pode se utilizar dos fenômenos da Educação Física, isto é, da ginástica, do jogo, do esporte, da dança, das lutas, das brincadeiras, das atividades interdisciplinares nesse processo de intervenção.

5 Conclusão: A presente pesquisa permitiu perceber que a postura corporal inadequada se encontra diretamente relacionada ao acometimento de desconforto, dores e alterações posturais. A soma da postura que vem sendo adotada pelos escolares constitui-se fator de risco às alterações posturais, provocando o desalinhamento corporal, bem como problemas que podem se tornar graves.

Nesse sentido, sugere-se que ações preventivas sejam tomadas no ambiente escolar. O poder público aliado à comunidade escolar (direção, professores, pais, e demais envolvidos) devem atuar juntos para promoção da boa postura dos escolares.

\section{Referência:}


1. DEBS, P. G. K.; SARNIR, R. O. S.; REATO, L. F. N. Alterações posturais na adolescência. Rev. Adolesc. Saúde. 2016; 13(2): 50-57.

2. DETSCH, C.; CANDOTTI, C. T. A incidência de desvios posturais em meninas de 6 a 17 anos da cidade de Novo Hamburgo. Rev. Movimento. 2001; 15(7): 43-56.

3. NUNES, F. L.; TEIXEIRA, L. P.; LARA, S. Perfil postural de estudantes de escolas urbanas e rurais: um estudo comparativo. Revista brasileira de Ciência e Movimento. 2017; 25(1): 90-98.

4. SEDREZ, J. A. et al. Fatores de risco associados a alterações posturais estruturais da coluna vertebral em crianças e adolescentes. Revista Paulista de Pediatria. 2015; 33(1): 72-81.

5. GIL, A. C. Métodos e técnicas de pesquisa social. 6.ed. São Paulo: Atlas; 2008.

6. TEIXEIRA, Elizabeth. As três metodologias. Petrópolis Rio de Janeiro: Vozes; 2010.

7. TABACHNICK, B. G.; FIDELL, L. S. Using Multivariate Statistics. New York: Harper Collins; 2001.

8. SOUZA, Juliana Alves et al. Biofotogrametria confiabilidade das medidas do protocolo do software para avaliação postural (SAPO). Revista Brasileira de Cineantropometria e Desempenho Humano. 2011; 13(4): 299-305.

9. ORGANIZAÇÃO MUNDIAL DA SAÚDE. Constituição da Organização Mundial da Saúde: OMS/WHO; s/d. Disponível em: <http://www.who.int/chp/topics/rheumatic/en/>. Acesso em: 18/07/2019.

10. NOLL, M. et al. Prevalência de Hábitos Posturais Inadequados de Escolares do Ensino Fundamental da Cidade de Teutônia: Um Estudo de Base Populacional. Revista Brasileira de Ciência e Esporte. 2013; 35(4): 983-1004.

11. BRASIL. Ministério da Saúde. Brasileiros atingem maior índice de obesidade nos últimos treze anos. Brasília/DF: MS; 2019. Disponível em: $<$ http://www.saude.gov.br/noticias/agencia-saude/45612-brasileiros-atingem-maiorindice-de-obesidade-nos-ultimos-treze-anos>.

12. SILVA, Larissa Rosa da et al. Alterações posturais em crianças e adolescentes obesos e não-obesos. Revista Brasileira de Cineantropometria e Desempenho Humano. 2011; 13(6): 448-454. 


\title{
A MORTE CELULAR EM LESÕES CUTÂNEAS DA DOENÇA DE HANSEN
}

\author{
Nome dos Bolsistas: Gabriela Lobato Virgolino e Vinicius Fialho Teixeira \\ Nome dos Voluntários: Francisco Dias Lucena Neto e Matheus Ferreira Santos da \\ Cruz
}

Nome do(a) Orientador(a): Juarez Antônio Simões Quaresma

Grupo de Pesquisa: Dermatopatologia Neoplasica, Imuno-mediada e Infecciosa

\begin{abstract}
Resumo: Na hanseníase, o estudo do fenômeno de morte celular e sua relação com o desfecho clínico da doença ainda precisam de maiores esclarecimentos. Portanto, considerando a importância desta abordagem para o entendimento da patogenia da lepra, foi investigado na presente pesquisa a ocorrência de mecanimos de morte celular, tais como a apoptose, necroptose, autofagia e piroptose em lesões cutâneas de pacientes com lepra e sua possível relação com a evolução clínica da doença. Esta pesquisa é caracterizada como um estudo analítico transversal, ao todo foram selecionados 30 pacientes não tratados com diagnóstico confirmado para lepra com 10 pacientes de cada classificação. Para a análise histopatológica, o material foi submetido a coloração pela hematoxilina-eosina (HE) e a imunomarcação do tecido com os anticorpos pela técnica de imunoistoquímica. O estudo de marcadores apoptóticos e necroptóticos mostrou que a expressão do FasL é bem maior na forma LL comparada a TT e II, Com relação à expressão de caspase 8, RIP1 e RIP3, essa tendência se mantém com predomínio na forma LL comparada a TT e LL, A investigação do MLKL, BAX e de caspase 3 mostrou que expressão destes marcadores se concentra bem mais na forma LL principalmente em macrófagos espumosos com globias, a expressão do Beclin-1, destacamos que a expressão da proteína se acentua na forma TT e declina na LL e II Por fim, a expressão de caspase 1 é predominante na forma LL seguida da TT e II. Por fim nosso estudo aponta para um papel do fenômeno de morte celular na fisiopatologia da lepra, todas contribuindo de forma integrada para o controle da resposta do hospedeiro ao M. leprae, bem como associa-se ao surgimento das lesões características da doença.
\end{abstract}

Palavras chave: Hanseníase; Apoptose; Necroptose

1 Introdução: Considerando o fato de que o fenômeno de morte celular é determinante para o controle do processo infeccioso na Hanseníase, a dicotomia entre apoptose e necrose resume o quão o surgimento de novos mecanismos pode implicar no padrão de interpretação da resposta fisiopatológica do hospedeiro contra $0 M$. leprae.

A relação entre apoptose extrínseca e intrínseca resume classicamente à dependência de ativação de ambas as vias para induzir o processo de morte celular. $\mathrm{Na}$ hanseníase, citocinas como TNF- $\alpha$, TGF- $\beta$ e o próprio FasL já foram documentados como importantes marcadores desencadeadores de tal situação. Na via intrínseca, a resposta antagônica entre proteínas da família BCL-X como BAX e BCL2 implicam no dano mitocondrial (BAX) ou na inibição da cascata apoptótica (BCL2) nas formas 
polares da doença. No caso do BAX, o desfecho da via intrínseca culmina com a apoptose de células de Schwann.

Uma morte celular conhecida por necroptose sugere que exista a preparação para uma necrose programada, que é dependente da produção e de ativação de proteino kinases e de pseudokinase como MLKL.

$\mathrm{Na}$ hanseníase, o estudo do fenômeno de morte celular e sua relação com o desfecho clínico da doença ainda precisam de maiores esclarecimentos. Portanto, considerando a importância desta abordagem para o entendimento da patogenia da lepra, investigamos no presente trabalho a ocorrência de mecanimos de morte celular, tais como a apoptose, necroptose, autofagia e piroptose em lesões cutâneas de pacientes com lepra e sua possível relação com a evolução clínica da doença.

\section{Objetivos}

\subsection{Objetivo geral da pesquisa:}

Avaliar a ocorrência e os tipos de morte celular em lesões cutâneas das formas tuberculóide, virchowiana e indeterminada da doença de Hansen por meio da técnica de imuno-histoquímica.

\subsection{Objetivos específicos da pesquisa:}

- Quantificar a ocorrência de apoptose e necroptose nas lesões através da imunomarcação para caspase 3, caspase 8, caspase 1, FasL, RIP, RIP3, MLKL, BAX, Survivin e Beclin-1.

- Comparar a ocorrência de apoptose e necroptose em cada forma de lesão através da imunomarcação para caspase 3 , caspase 8 , caspase 1 , FasL, RIP, RIP3, MLKL, BAX, Survivin e Beclin-1.

\section{Materiais e Métodos}

\subsection{Tipo de Pesquisa}

Essa pesquisa é caracterizada como analítica, transversal e de abordagem quantitativa.

\subsection{Caracterização da amostra}

Ao todo foram selecionados 30 pacientes não tratados com diagnóstico confirmado para lepra.

\subsection{Análise estatística}

Os resultados obtidos com os experimentos foram armazenados em planilhas eletrônicas construídas com o programa Excel 2007. A análise estatística foi feita pelo programa GraphPad Prism 5.0.

\subsection{Aprovação pelo comitê de ética}

Aprovado pelo Comitê de Ética em Pesquisa do Centro de Ciências Biológicas e da Saúde da Universidade do Estado do Pará, de acordo com a resolução do CNS n ${ }^{\circ}$ 466/12, número do parecer 2.338.865, CAAE: 72635417.6 .0000 .5172 , e todos os procedimentos de biossegurança serão tomados para minimizar os riscos do estudo.

\section{Resultados}


O estudo de marcadores apoptóticos e necroptóticos mostrou que a expressão do FasL é bem maior na forma LL comparada a TT e II. Com relação à expressão de caspase 8, RIP1 e RIP3, essa tendência se mantém com predomínio na forma LL comparada a TT . A investigação do MLKL, BAX e de caspase 3 mostrou que expressão destes marcadores se concentra bem mais na forma LL principalmente em macrófagos espumosos com globias. Comparando as 3 formas clínicas, observamos diferença estatística significante. Quando analisamos a expressão do Survivin, notamos um predomínio de expressão do marcador na forma TT seguida da II e LL. Sobre a expressão do Beclin-1, destacamos que a expressão da proteína se acentua na forma TT e declina na LL e II. Por fim, a expressão de caspase 1 é predominante na forma LL seguida da TT e II.

6 Conclusão: Observou-se que existem diferenças estatísticas significantes nas 3 formas clínicas da Hanseníase, além de que os marcadores atribuídos a este estudo atuam em conjunto para regular o fenômeno de apoptose, necroptose, autofagia e piroptose em ambas as formas. Quanto aos marcadores apoptóticos e necroptóticos, mostrou-se predominância destes na forma lepromatosa (LL), comparada a tuberculóide (TT) e indeterminada (II), por meio da expressão da proteína FasL. Além disso, foi possível quantificar a ocorrência de apoptose nas lesões por meio da imunomarcação da caspase 3 e da necroptose pela molécula de MLKL, marcadores esses que estavam bem mais concentrados na forma LL, principalmente em macrófagos espumosos com globias. Em relação à ocorrência de piroptose nas lesões, observou-se, por intermédio da marcação para a caspase 1, um predomínio dessa na forma LL, seguida da TT e II. Contudo eEstudos adicionais são necessários para a melhor compreensão dos mecanismos de morte celular associados à patofisiologia da doença de Hansen.

Referências: Brito de Souza VN, Nogueira ME, Belone Ade F, Soares CT. Analysis of apoptosis and Bcl-2 expression in polar forms of leprosy. FEMS Immunol Med Microbiol. 2010;60(3):270-4.

Fachin LR, Soares CT, Belone AF, Trombone AP, Rosa PS, Guidella CC, et al. Immunohistochemical assessment of cell populations in leprosy-spectrum lesions and reactional forms. Histol Histopathol. 2017;32:385-96.

Harberts, E., Heitmiller, K., Gaspari, A.A., 2017. Cell Death and Skin Disease. In: Gaspari, A., Tyring, S., Kaplan, D. Clinical and Basic Immunodermatology. Springer, 201-217.

Ma Y, Pei Q, Zhang L, Lu J, Shui T, Chen J, et al. Live Mycobacterium leprae inhibits autophagy and apoptosis of infected macrophages and prevents engulfment of host cell by phagocytes. Am J Transl Res. 2018;10(9):2929-39.

Patnaik N, Agarwal S, Sharma S, Sharma S, Pandhi D. Evaluation of apoptosis in skin biopsies of patients of borderline leprosy and lepra type 1 reaction. Indian J Dermatol. 2015;60(1):60-65. 


\section{PERFIL EPIDEMIOLÓGICO DA INFECÇÃO PELO HIV EM GESTANTES INDÍGENAS E NÃO INDÍGENAS E SUA RELAÇÃO COM OS DETERMINANTES SOCIAIS DE SAÚDE}

Nome dos Bolsista: Elisângela Silva Gomes/ Juarez Távora Guimarães Neto

Nome do (s) Voluntário (s): Nataly Yuri Costa

Nome do (a) Orientador (a): Laura Maria Vidal Nogueira

Grupo de Pesquisa: Grupo de Estudos de Agravos em Populações Tradicionais da Amazônia

Introdução; A Síndrome da Imunodeficiência Adquirida se caracteriza como uma doença oportunista a partir do alojamento do vírus no sistema imunológico humano que progride de forma gradual no ser humano, tornando-o propenso a outros tipos de doenças decorrentes da fragilidade imunológica. A transmissão do vírus pode ocorrer por relação sexual, pela disseminação de fluídos corporais, e de forma transversal (da mãe para o filho). No Brasil houve aumento das taxas do HIV em gestantes, sendo que no ano de 2015 houve um acréscimo de $28,6 \%$ nas taxas de ocorrência em mulheres grávidas considerando os nascidos vivos. Esse fato corrobora com a ideia de que há um espaço preestabelecido para o surgimento de recém-nascidos vivos com HIV. As elevadas taxas identificadas em gestantes podem sofrer influências de grupos humanos distintos, a exemplo dos indígenas que apresentam cosmovisão própria interferindo no modo de vida. Objetivo (s): Analisar o perfil epidemiológico do HIV em gestantes indígenas e não indígenas no estado do Pará, no período de 2013 a 2017; identificar as características sociodemográficas das gestantes indígenas e não indígenas notificadas com HIV nos últimos 5 anos; caracterizar as gestantes infectadas com HIV segundo realização do pré-natal, momento do diagnóstico e utilização da profilaxia específica. Material e Método Trata-se de um estudo descritivo, retrospectivo, com abordagem quantitativa realizado com 2.492 casos confirmados de HIV em gestantes indígenas e não indígenas no período de 2013 a 2017. Os dados foram obtidos no Sistema de Informação de Agravos de Notificação, por meio da Secretaria de Saúde do Estado do Pará, e a análise foi por meio dos softwares Epiinfo 7 e Microsoft Office Exce/® 2010 para a depuração, organização e agrupamento dos dados em planilhas, respectivamente. Resultados: As variáveis sociodemográficas evidenciaram que houve maior prevalência de casos na idade de 20 a 29 anos, tanto pata gestantes indígenas como não indígenas. Tanto as gestantes indígenas como não indígenas apresentaram baixa escolaridade, sendo 42,86\% e 41,97\%, respectivamente. Para ambos os grupos, houve maior prevalência de casos em donas de casa, com $46,40 \%$ para não indígenas, e $57,14 \%$ para indígenas. Entre os anos de 2010 a 2017 foram notificados 2.485 casos de HIV em gestantes não indígenas, e 7 casos em gestantes indígenas. As evidências laboratoriais mostraram que $53,2 \%$ dos casos de HIV em gestantes não indígenas e $66,7 \%$ em gestantes indígenas foram detectados durante o pré-natal, respectivamente. Outro dado relevante foi $16,22 \%$ e $28,57 \%$ de detecção por ocasião do parto, em não indígenas e indígenas, 
respectivamente. Conclusão: A prevalência de casos de HIV em ambos os grupos está diretamente relacionada à baixa qualidade da assistência em saúde, configurada na detecção de casos por ocasião do pré-natal e do parto, fazendo-se necessário a adoção de políticas públicas para assistir mulheres na perspectiva de identificar o vírus antes da gravidez, assim como a oferta de assistência pré-natal eficaz para detecção precoce, tratamento imediato para alcançar a conversão sorológica antes do parto.

Palavras-chave: Vírus da Imunodeficiência Humana; Saúde da População Indígena; Assistência Integral à Saúde da Mulher. 


\title{
EFEITOS DA REABILITAÇÃO CARDÍACA EM FASE III DE PACIENTES EM PÓS- OPERATÓRIO DE TROCA VALVAR E REVASCULARIZAÇÃO DO MIOCÁRDIO
}

\author{
Nome do(a) Bolsista: Talyssa Bia Santos e Santos \\ Nome do(a) Orientador(a): Luiz Fábio Magno Falcão \\ Grupo de pesquisa: Reabilitação, Funcionalidade e Pesquisa em Saúde
}

Resumo: No Brasil, as doenças cardiovasculares são as principais causas de morbimortalidade em pessoas a partir dos 40 anos, estando também associada a um grande número de pessoas com incapacidade física e invalidez. Com a progressão da doença, é comum a necessidade da realização de cirurgias e, consequentemente, complicações associadas ao processo cirúrgico, que impactam diretamente a qualidade de vida. Por outro lado, a reabilitação cardíaca está associada a uma melhora da capacidade funcional, da qualidade de vida, bem como a redução dos fatores de risco. Objetivo: Comparar os achados da Capacidade Funcional, Força Muscular Respiratória, Dispnéia, Escala da Felicidade e Qualidade de Vida, antes e após aplicação de um protocolo fisioterapêutico. Material e Método: Trata-se de um estudo analítico, do tipo ensaio clínico não randomizado. O protocolo fisioterapêutico foi composto por alongamentos, caminhada, treinamento muscular respiratório, exercícios resistidos para membros superiores e inferiores, totalizando 20 sessões. Os dados foram armazenados no software Excel 2010 e analisados no software BioEstat 5.3, sendo o Teste de Shapiro-Wilk utilizado para avaliação da distribuição normal; Teste Wilcoxon para variáveis sem distribuição normal e o Teste $t$ de student para variáveis com distribuição normal ( $p \leq 0.05)$. Resultados: 15 pacientes eram homens $(71,42 \%)$ e 6 pacientes eram mulheres (28,58\%), com média de idade de 61 anos. Houve diferença significativa nas variáveis de Pressão Inspiratória Máxima, Pressão Expiratória Máxima, Teste de Caminhada de 6 minutos e Dispnéia (Escala MRC). Conclusão: Foi observada melhora significativa nas variáveis respiratórias de Pressão Inspiratória Máxima e Pressão Expiratória Máxima, na Capacidade Funcional, na Dispnéia e na Qualidade de vida dos pacientes.

Introdução: As doenças cardiovasculares (DCV) são responsáveis por 17,5 milhões de mortes em todo o mundo. Destas, estima-se que 7,4 milhões ocorrem devido à doença arterial coronariana. No Brasil, as doenças cardiovasculares são as principais causas de morbimortalidade em pessoas a partir dos 40 anos, estando também associada a um grande número de pessoas com incapacidade física e invalidez, onerando significativamente os gastos na saúde pública (CONSENSO SULAMERICANO DE PREVENÇÃO E REABILITAÇÃO CARDIOVASCULAR, 2014).

Com a progressão da doença, é comum a necessidade da realização de cirurgias e, consequentemente, complicações associadas ao processo cirúrgico como a redução da massa muscular pelo repouso prolongado no leito, diminuição da capacidade funcional, dor, dispneia, fadiga, desconforto respiratório, entre outros. Esses fatores impactam diretamente a qualidade de vida e possuem relação direta com o aumento 
da taxa de morbimortalidade em tais pacientes (MAGALHÃES et al 2013; AYKAWA et al, 2014). Por outro lado, a reabilitação cardiovascular possui nível "1" de recomendação e grau "A" de evidência científica, estando fortemente associada ao aumento da capacidade de exercício, melhora da dispneia, da capacidade funcional, da qualidade de vida, diminuição das taxas de morbidade e mortalidade, redução dos fatores de risco e aumento da expectativa de vida em pacientes pós-operatório (MAGALHÃES et al 2013; AYKAWA et al, 2014; MENDES, 2009; SOCIEDADE BRASILEIRA DE CARDIOLOGIA, 2006).

Pacientes com DCV se beneficiam significativamente do programa de Reabilitação Cardiovascular (RCV); durante as últimas décadas acumularam-se muitas evidências científicas relacionados ao benefício do programa de RCV, sendo grau de recomendação $A$. Entretanto, mesmo diante dos benefícios atribuídos à reabilitação cardiovascular, o número de pacientes que participam dos programas de reabilitação é considerado seja por falta desconhecimento dos profissionais de saúde, incluindo o médico, pela baixa condição educacional e financeira dos pacientes, ou devido a distância de deslocamento (SOCIEDADE BRASILEIRA DE CARDIOLOGIA, 2006).

Dessa maneira, a criação de um serviço referenciado de reabilitação cardiovascular contribuirá para o aumento da adesão dos pacientes submetidos a cirurgia cardíaca a reabilitação, o que poderá influenciar diretamente na redução das complicações póscirúrgicas e na melhora dos pacientes.

Objetivos: Comparar os achados da Capacidade Funcional (Teste de Caminhada de 6 minutos), Força Muscular Respiratória (Pressão Inspiratória Máxima e Pressão Expiratória Máxima), Dispnéia (Escala MRC), Felicidade (Escala da Felicidade) e Qualidade de Vida (Instrumento de mensuração do impacto da doença no cotidiano do valvopata), antes e após aplicação de um protocolo fisioterapêutico.

Material e Métodos: Trata-se de um estudo analítico, do tipo ensaio clínico não randomizado, aprovado sob o parecer $n^{\circ} 2.406 .710$, realizado no Ambulatório de Fisioterapia Cardiorrespiratória da Unidade de Ensino e Assistência em Fisioterapia e Terapia Ocupacional, localizada em Belém (PA). Os sujeitos da pesquisa eram pacientes em pós-operatório de cirurgia cardíaca provenientes da Fundação Hospital de Clínicas Gaspar Vianna. O protocolo fisioterapêutico era composto por alongamentos, caminhada, treinamento muscular respiratório, exercícios resistidos para membros superiores e inferiores. Em todos os exercícios realizados foi aplicada a progressão gradual de cargas. $O$ atendimento foi realizado três vezes na semana, totalizando 20 sessões. Acerca do armazenamento de dados e análise estatística, os dados foram armazenados no software Excel 2010 e analisados no software BioEstat 5.0. Foi utilizado o Teste de Shapiro-Wilk para avaliação da distribuição, Teste $T$ de Student para as variáveis com distribuição normal e Teste Wilcoxon para as variáveis sem distribuição normal $(p \leq 0.05)$.

Resultados e Discussão: A coleta de dados ocorreu no período de agosto de 2018 à agosto de 019. Inicialmente, 46 pacientes foram encaminhados, provenientes da Fundação Hospital de Clínicas Gaspar Vianna (FHCGV), sendo 21 permaneceram no 
estudo. 15 pacientes eram homens $(71,42 \%)$ e 6 pacientes eram mulheres $(28,58 \%)$, com média de idade de 61 anos. Dentre os pacientes que não participaram do estudo e foram excluídos da estatística, 11 foram excluídos por abandono, 1 por ajuste no protocolo, 1 por idade, 3 por instabilidade hemodinâmica, 1 por doença neurológica e 5 por doenças ortopédicas. 24 pacientes permaneceram no atendimento fisioterapêutico, sendo que 21 já foram reavaliados e os demais (3) encontram-se em atendimento.

Sobre a caracterização clínico-demográfica dos fatores de risco associados a doença cardiovascular, 11 pacientes apresentavam hipertensão arterial sistêmica (52,38\%); 9 apresentavam Diabetes Mellitus (42,85\%); 5 eram cardiopatas antes do episódio mais recente de infarto agudo do miocárdio (23,80\%); 12 se encaixaram no tabagismo, entre fumantes, ex-fumantes e fumantes passivos $(57,14 \%)$ e 11 se consideraram sedentários (25,38\%).

Após a aplicação do protocolo e reavaliação dos pacientes, foram encontrados os seguintes valores para as variáveis analisadas (tabela 2): Teste de Caminhada de 6 minutos (Pré: 353.85 \pm 85.22 / Pós: 474.80 \pm 74.13 / P-valor: 0.0001); Pressão Inspiratória Máxima (Pré: $92.42 \pm 30.87$ / Pós: 130.85ะ50.76 / P-valor: 0.0008); Pressão

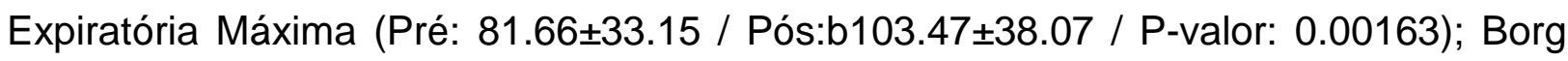
(Pré: 1.28 \pm 1.92 / Pós: 0.66 \pm 1.11 / P-valor: 0.2411); Grau de Dispnéia - MRC (Pré: 3.33 \pm 0.96 / Pós: $1.42 \pm 0.59$ / P-valor: 0.0001); Força Muscular Periférica (Pré: 55.05 \pm 3.40 / Pós: 58.05 \pm 2.61 / P-valor: 0.0025); Escala de Felicidade (Pré: 1.23 \pm 0.88 / Pós: 1.47 $\pm 0.81 /$ P-valor: 0.2040); Qualidade de vida (Pré: $72.04 \pm 8.85$ / Pós: 53.71 \pm 13.71 / P-valor: 0.0001);

Os resultados encontrados no presente estudo sugerem que o protocolo fisioterapêutico aplicado em pacientes no pós-operatório de cirurgia cardíaca fase III, apresentou efetivos positivos na Capacidade Funcional, na Dispnéia, na Força Muscular Respiratória e Força Muscular Periférica dos indivíduos do estudo; Esses resultados corroboram com as orientações expostas na Diretriz Sul-Americana de Prevenção e Reabilitação Cardiovascular (2014), que apresenta como objetivos de um programa de reabilitação cardiovascular a melhora da capacidade funcional dos pacientes, modificações nos fatores de risco e recuperação da autoconfiança do paciente após o evento cardíaco.

Ademais, estudos como de Marques (2004) e Silva (2013), apontaram evidências científicas que a intervenção fisioterapêutica, com a realização de exercícios aeróbicos e exercícios resistidos regulares, reduzem o risco de doença cardiovascular.

Conclusão: $O$ estudo transcorreu da melhor maneira possível, com bons resultados ao final da pesquisa, visto que foi observada melhora significativa na Capacidade Funcional, na Pressão Inspiratória Máxima e Pressão Expiratória Máxima, na Dispnéia e na Qualidade de Vida dos pacientes do estudo. O protocolo de tratamento poderá ser incorporado ao serviço de Fisioterapia Cardiovascular, onde atualmente é inexistente. Este estudo apresenta limitações decorrentes do número de abandono dos pacientes devido à dificuldade no deslocamento, causada pela à baixa condição econômica dos pacientes. Ademais, faz-se necessária a realização de novos estudos 
com pacientes pós-operatório cardíaco em fase III, devido a quantidade de estudos nesta fase ser mais escassa.

\section{Referências Bibliográficas}

AYKAWA P.; et al. Reabilitação Cardíaca em pacientes submetidos a revascularização do miocárdio. Revista Brasileira de Medicina Esportiva. Brasil, v.20, n. 1, p. 55-58, Jan-fev. 2014.

MAGALHÃES S. et al. Avaliação da capacidade funcional após programa de reabilitação cardíaca- efeitos a longo prazo. Revista da sociedade portuguesa de medicina física e de reabilitação, Portugal, v. 24, n. 2, p. 18-24, 2013.

Marques KS. A Interação dos Profissionais de Educação Física e Fisioterapia na Reabilitação Cardiovascular. [monografia] 2004. 61 f. Universidade Federal de Santa Catarina.

MENDES M. Reabilitação cardíaca em Portugal: a intervenção é que Falta! Saude\&Tecnologia, v.3, p. 5-9, 2009.

SILVA M; OLIVEIRA J. Reabilitação cardíaca após infarto agudo do miocárdio: Revisão Sistemática. Corpus et Scientia, v. 9, n. 1, p. 89-100, jan. 2013.

SOCIEDADE BRASILEIRA DE CARDIOLOGIA. Consenso sul-americano de prevenção e reabilitação cardiovascular. Arquivo brasileiro de cardiologia, v. 103, n2, p. 1-42, ago. 2014.

SOCIEDADE BRASILEIRA DE CARDIOLOGIA. Diretriz de Reabilitação Cardiopulmonar e Metabólica: aspectos práticos e responsabilidades. Arquivo Brasileiro de Cardiologia, v. 86, n.1,p. 74-82, 2006.

Palavras-chave: Cirurgia cardíaca; Reabilitação Cardiovascular; Fisioterapia. 


\title{
EFEITO DO LASER DE BAIXA POTÊNCIA E DO PLASMA RICO EM PLAQUETAS NA EXPRESSÃO DE COLÁGENO APÓS CONTUSÃO MUSCULAR
}

\author{
Nome dos Bolsistas:Christian da Silva Costa, July Ellem Paixão Pinheiro \\ Nome do(a) Orientador(a): Márcio Clementino Souza Santos \\ Grupo de Pesquisa: Desenvolvimento e Reabilitação na Amazônia
}

Resumo: o objetivo deste estudo é analisar o efeito do laser de baixa potência e do plasma rico em plaquetas na expressão de colágeno tipo I e III após contusão muscular. Foram utilizados 30 ratos da linhagem Wistar, machos, adultos (8-10 semanas), pesando entre 350 e $450 \mathrm{~g}$, distribuídos randomicamente em 4 grupos: Grupo Lesão (GL), Grupo Laser de Baixa Potência (GLBP), Grupo Plasma Rico em Plaquetas (GPRP), sendo que cada grupo foi dividido em três subgrupos (3, 7 e 14 dias). Foram contundidos o músculo tibial anterior da pata direita dos ratos, por meio de uma prensa lesionadora. Após 24 horas da lesão, no GLBP foi aplicado a laserterapia com comprimento de onda de $658 \mathrm{~nm}$, no modo contínuo, potência de 10 Mw, área de feixe $0,1 \mathrm{~cm}^{2}$, forma de aplicação pontual, realizando dois pontos de 50 segundos, diariamente; já no GPRP foi injetando $100 \mu$ de PRP, por meio de uma seringa descartável, no ventre do músculo tibial anterior. Foi possivel observar que a expressão de colágeno tipo I aumentou até o $7^{\circ}$ dia nos três grupos e teve um decréscimo no GL e GLBP no $14^{\circ}$ dia. Além disso, percebeu-se que a quantidade foi maior no grupo LBP 14 dias. Diante disso, conclui-se que o LBP e o PRP estimularam a síntese de colágeno tipo I, responsável por tornar mais efetivo o reparo tecidual.

Palavras-chaves: Sistema musculoesquelético; Ferimentos e lesões; Terapia com Luz de Baixa Intensidade; Plasma Rico em Plaquetas; Colágeno.

1 Introdução: O reparo das lesões musculoesqueléticas geralmente é um processo lento e frequentemente incompleto. Entre as lesões mais frequentes, pode-se destacar as contusões, que são causadas devido a traumas diretos, abrupto, em um único momento, devido a um fator extrínseco, que comprime o músculo. Geralmente afeta o ventre muscular, e vai apresentar sinais e sintomas como dor, edema, diminuição da força muscular e perda da função ${ }^{1}$. O impacto destas lesões em indivíduos que realizam práticas esportivas afeta a recuperação rápida da eficiência total e o retorno à competição. Assim, a melhoria clínica oferecida pelos tratamentos disponíveis nem sempre é suficiente para estes pacientes retornarem ao seu nível anterior de atividade. Por isso, têm-se a necessidade de pesquisas a fim de verificar recursos mais eficazes, principalmente a esta população ${ }^{1}$. O laser de baixa potência (LBP) é um recurso importante para a cicatrização e analgesia. Quando o LBP interage com o tecido lesado, transmite energia que é absorvida e utilizada para a reparação tecidual. Ademais, outro recurso comumente utilizado é o plasma rico em plaquetas (PRP) um produto com alta concentração de plaquetas e uma pequena quantidade de plasmas, sendo uma técnica atualmente muito utilizada para recuperação de lesões musculares, além das lesões ósseas e tendinosas. Pois, atua como anti-inflamatório, inibindo 
agentes pró-inflamatórios ${ }^{4}$. O PRP e LBP são aplicados a fim de promover o reparo tecidual adequado, prevenindo as possíveis complicações, diminuindo a presença de tecido fibrótico e o estresse oxidativo que o tecido é submetido. Além de possibilitar uma rápida recuperação, causada pela associação desses recursos ${ }^{5}$.

2 Objetivo: Verificar o efeito do plasma rico em plaquetas e do laser de baixa potência sobre a expressão de colágeno tipo I e II após contusão muscular.

3 Metodologia: Este estudo foi aprovado pelo Comitê de Ética Animal da Universidade do Estado do Pará (UEPA), sob o parecer de $n^{\circ} 25 / 2016$. O experimento foi realizado no Laboratório de Morfofisiologia Aplicada à Saúde da UEPA em parceria com o Laboratório de Análises Clínicas da Universidade Federal Rural do Pará (UFRA). Foram utilizados 30 ratos (Rattus novergicus) da linhagem Wistar, machos, adultos (aproximadamente 8-10 semanas de vida), pesando entre 350 e $450 \mathrm{~g}$, provenientes do biotério do Instituto Evandro Chagas e transferidos ao biotério Luiz Carlos de Lima Silveira (UEPA). Os animais foram distribuídos randomicamente em 4 grupos (GL, GPRP, GLBP e GPord), sendo que cada grupo foi dividido em três subgrupos (3d, $7 d$ e 14d), composto por 3 animais cada. O grupo de produção do PRP (GProd), foi composto por 3 animais utilizados para a retirada de sangue e produção do plasma rico em plaquetas. O grupo Lesão (GL) foi submetido apenas ao protocolo de contusão e sem nenhum tipo intervenção terapêutica. Já o grupo Plasma Rico em Plaquetas (GPRP) foi submetido protocolo de contusão e após 24 horas ao tratamento com PRP; e o grupo Laser de Baixa Potência (GLBP) foi submetido ao protocolo de contusão e após 24 horas da lesão ao tratamento com o LBP. Inicialmente os animais foram anestesiados com Cetamina $(60-90 \mathrm{mg} / \mathrm{kg}$ ) e Xilazina $(5-10 \mathrm{mg} / \mathrm{kg})$. Posteriormente, realizou-se tricotomia e assepsia no local a ser lesionado e com auxílio de uma Prensa Lesionadora, na qual foi fixado um peso de 208 gramas e liberado em uma altura de $20 \mathrm{~cm}^{6}$, realizava-se um único trauma no terço médio do ventre do músculo tibial anterior da pata direita do rato ${ }^{7}$. Por meio de uma seringa contendo $1 \mathrm{ml}$ de citrato de sódio a $10 \%$ como anticoagulante, foi realizado a punção cardíaca, com a qual era coletado cerca de $5 \mathrm{ml}$ de sangue de cada animal, correspondendo o $\mathrm{Gprod}^{9,4}$. O sangue coletado era acondicionado em tubo plástico e, em seguida, submetido à centrifugação a $1.800 \mathrm{rpm}$, por 10 minutos. Ao final da centrifugação, ocorreu a separação das células vermelhas, PRP e plasma pobre em plaquetas (PPP). A segunda centrifugação a $3.600 \mathrm{rpm}$, por 10 minutos, resultou em dois componentes: superiormente, correspondendo ao PPP e inferiormente ao PRP. O PRP foi ativado com $0,05 \mathrm{ml}$ de cloreto de cálcio $10 \%$ para cada $1 \mathrm{ml}$ de PRP 9 . O PRP foi submetido a um contador hematológico automático BCvet 2800 para a verificação da concentração de plaquetas presentes no plasma. Sendo a aplicação única do PRP após 24 horas da lesão, no grupo GPRP, injetando $100 \mu l$ de PRP, por meio de uma seringa descartável, no ventre do músculo tibial anterior, protocolo adaptado de Ozaki et $\mathrm{al}^{5}$. Os animais do GLBP após o período de 24 horas da lesão foram imobilizados com auxílio de um contensor artesanal e submetidos ao tratamento de fototerapia, utilizando o aparelho de LASER HTM Compact. Utilizou o comprimento de onda de $658 \mathrm{~nm}$, no modo 
contínuo, potência de $10 \mathrm{Mw}$, área de feixe $0,1 \mathrm{~cm}^{2}$, forma de aplicação pontual, realizando dois pontos de 50 segundos, diariamente até o momento da eutanásia. Ocorreu a morte indolor induzida dos ratos em três períodos distintos, $3^{\circ}, 7^{\circ}$ e $14^{\circ}$ dia após a lesão. A morte induzida foi realizada com dose letal de anestésico, sendo retirado de cada animal o músculo tibial anterior, por meio de incisão anterior nas patas traseira direita dos animais. Durante a dissecação, os músculos foram periodicamente gotejados com solução salina $(\mathrm{NaCl} 0,9 \%)^{5}$. Após a retirada do músculo, ele foi conservado em formol a 10\%, em frascos individuais, identificado em relação ao seu grupo e subgrupo, para a elaboração das lâminas para a análise histológica. Posteriormente as amostras foram processadas, no aparelho histotécnico, para exame histológico, incluído em parafina, cortado em micrótomo rotativo para obtenção de cortes com espessura de $5 \mu \mathrm{m}$. Os cortes foram colocados em lâminas de vidro para a realização da técnica de coloração PicrosiriusRed, sendo realizado segundo o protocolo de Michalany ${ }^{10}$. As lâminas foram visualizadas em microscópio Zeiss, aumento de 100x, com luz polarizada. Foram obtidas 3 fotografias da área de lesão de cada lâmina através do programa Axion Vision. As microfotografias foram analisadas no programa Image $\mathrm{J}$ com o plug-in ThresholdColour. Obtiveram-se o percentual de colágeno por análise de partículas de acordo com seleção e medidas de áreas com base na cor. Foram utilizadas a matriz 0-40 para cor vermelha para o colágeno tipo I (maduro) e 45-120 para cor verde mostrando o colágeno tipo III (imaturo) ${ }^{11}$. As comparações intergrupos e intragrupos foram feitas por meio da ANOVA dois critérios post hoc de Bonferronipara valores paramétricos. Os valores foram considerados significativos quando $p \leq 0,05$. O programa estatístico usado foi o BioEstat 5.3.

\begin{tabular}{ccccccc}
\hline Dias & \multicolumn{5}{c}{ QUANTIFICAÇÃO DO COLÁGENO } \\
\cline { 2 - 7 } & \multicolumn{2}{c}{ GL } & \multicolumn{3}{c}{ GLBP } & GPRP \\
& Tipo I & Tipo III & Tipo I & Tipo III & Tipo I & Tipo III \\
30 Dia & $5,73 \pm 5,68$ & $0,96 \pm 0,4$ & $7,60 \pm 0.52$ & $0,74 \pm 0,73$ & $3,76 \pm 0,42$ & $0,38 \pm 0,31$ \\
70 Dia & $8,00 \pm 1,16$ & $0,67 \pm 0,41$ & $7,90 \pm 1,81$ & $0,53 \pm 0,42$ & $3,79 \pm 1,12$ & $0,50 \pm 0,44$ \\
140 Dia & $4,46 \pm 2,15$ & $0,8 \pm 0,55$ & $7,23 \pm 4,91$ & $0,38 \pm 0,23$ & $6,39 \pm 0,99$ & $0,31 \pm 0,05$ \\
\hline
\end{tabular}

\section{Resultados}

Tabela 1. Quantificação da área de colágeno (\%). Teste ANOVA (dois critério) com post roc de Bonferroni, sendo considerado um $p<0,05$.

Foi encontrada diferença estatisticamente significativa na comparação intergrupo e intragrupo em cada grupo experimental $(p<0,05)$. Na análise intergrupos foi encontrado que o GLBP deve uma maior porcentagem de colágeno tipo I no terceiro e décimo quarto dia após a lesão. Na comparação intragrupo houve uma maior 
expressão de colágeno tipo I no GLBP em todos os períodos, enquanto que no GPRP ocorreu apenas no décimo quarto dia.

Discussão: No estudo analisou-se a ação de distintos recursos (LBP e PRP), aplicados de forma isolada, a fim de verificar sua atuação no processo de regeneração muscular, por meio da expressão de colágeno tipo I e III após os tratamentos. O processo de cicatrização muscular ocorre por meio de três fases: degeneração (processo inflamatório), regeneração e remodelamento. A presença de fibrina e fibronectina no local da lesão, inicia a formação de uma matriz extracelular que é rapidamente invadida por fibroblastos. As citocinas fibrogênicas participam da proliferação excessiva de fibroblastos/miofibroblastos e de um aumento na produção de colágenos tipo I e III, laminina e fibronectina ${ }^{12}$. Em sua fase inicial, a proliferação de colágeno tipo I que causa resposta fibrótica é benéfica, estabilizando o tecido e atuando como um suporte para a regeneração de miofibras. No entanto, uma síntese excessiva de colágeno pós-lesão, muitas vezes resulta em um aumento do tamanho do tecido cicatricial ao longo do tempo que pode impedir a função muscular normal ${ }^{13}$. Neste estudo, notou-se que a deposição de colágeno tipo I aumentou nos três grupos no período do $3^{\circ}$ ao $7^{\circ}$ dia e diminuiu no GL e GLBP no $14^{\circ}$ dia. No entanto, apesar de ter havido uma diminuição deste colágeno no GLBP, a sua quantidade foi maior em relação aos outros dois grupos. Tais dados corroboram com Moreira et $\mathrm{al}^{14}$ que concluíram que a lesão muscular após sete dias apresentou extensa área de deposição de colágeno tanto no grupo AsGaAl 830 nm quanto no AsGa 904 nm. Já após quatorze dias, a expressão de colágeno diminuiu nos dois grupos. Além disso, após quatorze dias de tratamento dois grupos tratados com LBP mostraram maior deposição de colágeno em relação ao grupo controle. Pugliesse et al. ${ }^{15}$ mostraram que a regeneração muscular torna-se mais efetiva quando tratada com laser de baixa intensidade, pois a laserterapia regula a liberação de algumas citocinas responsáveis pela proliferação de fibroblasto e síntese de colágeno. Reis et al. ${ }^{16}$ também descreveram que laserterapia acelera o processo de reparo tecidual associado com aumento na produção de fibroblastos, de fibras colágenas e melhor disposição da matriz extracelular após cinco dias de tratamento.Comparando o GL com o GPRP, constatou-se que a deposição de colágeno tipo I foi maior no $\mathrm{GL}$ até o $7^{\circ}$ dia. Tais dados corroboram com Quarteiro et al. ${ }^{4}$ que induziu lesão no músculo gastrocnêmio de ratos. Alguns destes ratos não receberam tratamento, e outros foram tratados com PRP na perna direita e soro fisiológico na perna direita. Nas lesões tratadas com PRP, a quantidade média de colágeno foi significativamente menor que nos demais grupos (controles e ratos tratados com solução salina) na avaliação realizada no sétimo dia após a lesão. No entanto, houve um aumento significativo nessa quantidade de colágeno do $7^{\circ}$ para o $21^{\circ}$ dia após a lesão apenas no grupo com lesões tratadas com PRP.

No que diz respeito a formação de colágeno tipo III, percebeu-se que durante o período do $3^{\circ}$ ao $14^{\circ}$ dia houve uma diminuição maior deste colágeno no GLBP, no entanto, no $14^{\circ}$ dia a quantidade de colágeno tipo III foi menor no GPRP quando comparado aos outros grupos. Sendo que nos três grupos pode-se observar uma 
diminuição neste tipo de colágeno no período do $3^{\circ}$ ao $14^{\circ}$ dia. De acordo com Campos et al. ${ }^{17}$, a distribuição dos tipos de colágeno no processo de cicatrização tecidual após contusão não é homogêneo, sendo que o colágeno tipo III precede o aparecimento do colágeno tipo I. Contudo, a deposição de colágeno tipo I permanece por mais tempo, já o tipo III tende a diminuir. O estudo mostrou que houve maior expressão de colágeno nas lesões tratadas com o LBP quando comparado ao PRP. Assim, constatou-se o LBP possui efeitos benéficos no processo de cicatrização. Este resultado corrobora com o estudo de Alves et al. ${ }^{18}$, no qual foram realizadas criolesões no ventre muscular dos tibiais anteriores de ratos Wistar, posteriormente tratados com LBP com parâmetros de $780 \mathrm{~nm}$ e 10J/cm2 de densidade de energia, expostos diariamente por 10 segundos. Os resultados mostraram que o LBP foi capaz de reduzir o infiltrado inflamatório e a mionecrose no $1^{\circ}$ dia, e no $3^{\circ}$ dia evidenciou-se a neoangiogênese. Tais eventos são significativos no processo de reparo tecidual. $O$ estudo de Souza al. ${ }^{19}$ também mostra que o LBP com o comprimento de onda de 660 $\mathrm{mn}$ e de $780 \mathrm{mn}$, são eficientes na modulação das atividades celulares como reprodução, metabolismo e maturação, bem como para a redução de mediadores inflamatórios, o que acelera o processo cicatricial, através da permeabilidade vascular aumentada e da proliferação e organização do colágeno. No que diz respeito ao PRP, este demonstrou expressão significativa de colágeno no $14^{\circ}$ dia. No estudo Quarteiro et $\mathrm{al}^{4}$ observou-se que a quantidade de colágeno no período entre o $7^{\circ}$ e o $21^{\circ}$ dias nas lesões tratadas com PRP aumentou significativamente, sugerindo uma restituição tecidual completa, não observando isso no período de 7 dias desse estudo.

Conclusão: A partir do exposto, conclui-se que o LBP e o PRP apresentam efeitos significativos na melhora do processo cicatricial, comprovado através dos efeitos na expressão de colágeno Tipo I e Tipo III, sugerindo-se que, futuramente, pode apresentar benefícios no tratamento fisioterapêutico de lesões musculares, possibilitando melhor recuperação em um menor período de tempo. Entretanto, sugere-se que mais estudos acerca dessa temática sejam desenvolvidos, com amostra maiores, para maior fidedignidade das informações.

\section{Referências}

Kon E, Filardo G, Di Martino A, Marcacci M. Platelet-rich plasma (PRP) to treat sports injuries: evidence to support its use. Knee Surg Sports TraumatolArthrosc. 2011; 19: 516-527.

Macedo ACB, Ywazaki JL, Pacheco J, Gonçalves S, Gomes ARS. Efeitos agudos do alongamento muscular do gastrocnêmio após contusão em ratos. Fisioterapia e Pesquisa. 2014; 1: 53-59.

Luis, A. A. Efeitos do laser de baixa potência no processo de cicatrização de feridas cutâneas: revisão de literatura. 2013. Dissertação (Trabalho de Conclusão de Curso). Centro Universitário de Formiga-UNIFOR, 2013. 
Quarteiro ML, Tognini JRF, Oliveira ELF, Silveira I. The effect of platelet-rich plasma on the repair of muscle injuries in rats. RevistaBrasileira de Ortopedia. 2015; 50 (5): 586595.

Ozaki GAT. et al. Analysis of photobiomodulation associated or not with platelet-rich plasma on repair of muscle tissue by Raman spectroscopy. Lasers MedSci. 2016; 31 (9): 1891-1898.

Sene, G. L. Influência do laser de baixa intensidade nas propriedades mecânicas do músculo gastrocnêmio submetido à lesão muscular por mecanismo de impacto. Dissertação (Mestrado em Engenharia Biomédica) Escola de Engenharia de São Carlos. Faculdade de Medicina de Ribeirão Preto. Universidade de São Paulo, 2004.

Almeida, P. et al. Low-Level Laser Therapy and Sodium Diclofenac in Acute Inflammatory Response Induced by Skeletal Muscle Trauma: Effects in Muscle Morphology and mRNA Gene Expression of Inflammatory Markers. PhotochemistryandPhotobiology, 2013, 89: 501-507.

Oliveira AR, et al. What is the ideal dose and power output of low-level laser therapy $(810 \mathrm{~nm})$ on muscle performance and post-exercise recovery? Study protocol for a double-blind, randomized, placebo-controlled trial. Trial. 2014; 15: 2-7.

Venter NG, Marques RG, Santos JS, Costa AMA Use of platelet-rich plasma in deep second- and third-degree burns. Journal Burns-Elsevier. 2016; 42 (4): 807-814.

Michalany J 1998. Técnica Histológica em Anatomia Patológica: com instruções para o cirurgião, enfermeira e citotécnico. $3^{\mathrm{a}}$ ed. São Paulo: Editora Michalany Ltda.

Mendes, J. B. A. et al. Análise histoquímica e morfométrica de componentes fibrosos da matriz extracelular de biópsia de pele de indivíduos com hanseníase no Estado de Sergipe. Trabalho de conclusão de curso. 2015.

Laumonier T, Menetrey J. Muscle injuries and strategies for improving their repair. J Exp Orthop. 2016.

Mann CJ, Perdiguero E, Kharraz Y, Aguilar S, Pessina P, Serrano AL, Munoz-Canoves P. Aberrant repair and fibrosis development in skeletal muscle. Skelet Muscle. 2011.

Moreira FF, Oliveira ELP, Barbosa FS, Silva JG. Laserterapia de baixa intensidade na expressão de colágeno após lesão muscular cirúrgica. Fisioter Pesqui. 2011.

Pugliese LS, Medrado AP, Reis SR, Andrade ZA. The influence of low-level laser therapy on biomodulation of collagen and elastic fibers. Pesqui Odontol Brás. 2003.

Reis SRA, Medrado AP, Marchionni AMT, Figueira C, Fracassi LD, Knop LAH. Effect of 670-nm Laser Therapy and Dexamethasone on Tissue Repair: A Histological and Ultrastructural Study. Photomed. Laser Surg. 2008

Campos Antonio Carlos Ligocki, Borges-Branco Alessandra, Groth Anne Karoline. Cicatrização de feridas. ABCD, arq. bras. cir. dig. [Internet]. 2007 Mar [cited 2019 Aug 23] ; 20( 1 ): 51-58

Alves AN et al. Modulating effect of low level-laser therapy on fibrosis in the reparir process of the tibialis anterior muscle in rats, Lasers Med Sci, 2014; 29(2):813-821

Souza, N.H.C. et al. Efeito da laserterapia em baixa intensidade na modulação da atividade mitocondrial de macrófagos. Brazilian Journal Physical Therapy. 2014; 18 (4): 308-314 


\section{PLANO DE INTERVENÇÃO NA IDENTIFICAÇÃO PRECOCE DE PACIENTES COM HANSENÍASE EM UMA UNIDADE BÁSICA DE SAÚDE NO MUNICÍPIO DE SANTARÉM.}

Nome do(a): Bolsista: Iris de Barros Vaz Teixeira

Nome dos Voluntários: Luana Carla Lima de Almada, Iracildo Alves Lopes

Nome do(a) Orientador(a): Maria do Socorro da Silva Mota

Grupo de Pesquisa: Grupo de Estudos e Pesquisas em Educação e Saúde das Populações Amazônicas

Introdução: Segundo a sociedade Brasileira de Medicina Tropical, a hanseníase é uma doença infecto-contagiosa de caráter crônico causada pelo Mycobacterium leprae, que possui predileção para a pele e nervos periféricos. Desde 1986, tem disponível a cura por meio da poliquimioterapia, mas mesmo assim, ainda constitui importante problema de saúde pública no Brasil. No Município de Santarém segundo dados da Secretaria de Estado de Saúde Pública do Pará de a Secretária de Saúde do Município foram notificados 41 novos casos só em 2017. Para modificar essa realidade, a Estratégia Saúde da Família (ESF) é de grande importância para que as metas propostas pela OMS sejam alcançadas. A ESF é composta por uma equipe multidisciplinar, que conta com: Médico, Enfermeiro, Técnico de Enfermagem, e os Agentes Comunitários de Saúde (ACS), os quais trabalham em sincronia em prol da melhoria da saúde de uma população de um determinado território. Dessa forma, todos com o seu grau de importância no sistema, contudo as atividades desenvolvidas pelos ACS são de grande relevância para o sucesso do diagnóstico precoce de inúmeros agravos, pois ele exerce papel de "elo" entre equipe e comunidade, proporcionando uma maior proximidade com o cotidiano das famílias atendidas na ESF. Objetivos: Estabelecer um plano de intervenção para aprimorar o diagnóstico, tratamento e acompanhamento de pessoas com Hanseníase avaliando o conhecimento prévio e organizar busca ativa na Unidade Básica de Saúde do Maicá. Material e Método: Este estudo faz parte do edital no 019/2018 - UEPA Programa Institucional de Bolsas de Iniciação Científica e de Desenvolvimento Tecnológico e Inovação 2018. É de um estudo observacional, transversal, quantitativo e intervencionista que teve como objetivo. Resultados: Participaram da pesquisa, todas as Agentes Comunitários de Saúde, da UBS do Maicá. No pré-teste, percebeu-se carência no conhecimento da identificação da hanseníase pelas lesões da pele e transmissão. Após a capacitação realizada pelos acadêmicos de medicina na UBS, foi reaplicado o questionário do início do estudo, em que se pode perceber grande avanço por parte das ACS. Conclusão: Diante dos resultados dos testes, foi possível perceber que as ACS apresentaram algum conhecimento sobre a hanseníase, porém muitas dúvidas sobre a transmissão, sinais e sintomas e a classificação operacional da hanseníase, que puderam ser sanadas com a capacitação que foi oferecida a elas e confirmadas pelo pós-teste. 
Palavras Chaves: Hanseniase, Estratégia de Saúde da Familia, Cuidados Primários da Saúde

\section{CONHECIMENTOS E PRÁTICAS DOS PROFISSIONAIS DE SAÚDE FRENTE A TENTATIVA DE SUICÍDIO INFANTOJUVENIL}

Nome dos Bolsistas: Pablo Stephano Lopes da Silva, Karina Alcântara de Sousa, Nome do(a) Orientador(a): Maria Goreth Silva Ferreira

Grupo de Pesquisa: Grupo de Estudos e Pesquisas em Educação e Saúde das Populações Amazônicas

Introdução: Segundo a Organização Mundial da Saúde (OMS) o suicídio está chegando a mais de 800 mil por ano, e deve aumentar para 1,6 milhão em 2020. No Brasil, a ideação suicida vem ganhando destaque na população infanto-juvenil. No período de 2000 a 2008 foram registrados 43 casos de suicídio em crianças menores de 10 anos e cerca de 6 mil adolescentes na faixa etária de 10 a 19 anos. Segundo o Mapa da Violência 2014, o número de suicídios na população jovem (entre 15 e 29 anos), cresceu numa taxa de $8,9 \%$ entre os anos 2002 e 2012. O comportamento suicida é um fenômeno complexo, em especial o de crianças e adolescentes, o qual envolve repercussões sociais, familiares e econômicas, e na atualidade assume a posição de um grande problema de saúde pública e um desafio para os profissionais que atuam na área. Objetivo: Conhecer como é o processo da assistência à saúde desempenhada pela equipe multiprofissional nos casos de ideação suicida infantojuvenil na atenção primária e secundária. Material e Método: Tratou-se de um estudo descritivo com abordagem qualitativa, realizado por meio de entrevistas semiestruturadas com 12 profissionais de saúde da Atenção Básica e Secundária da cidade de Santarém-PA. Foi utilizado o software IRAMUTEQ 0.7 alpha 2 para o processo de organização e categorização dos dados, através do qual foi realizada a construção da Árvore de Similitude e posterior análise de conteúdo dos discursos. Resultados: Os resultados demonstram o grande desafio profissional no atendimento à criança e ao adolescente com ideação suicida, necessitando de uma Rede interligada para o enfrentamento dos fatores desencadeantes e implementação de estratégias de intervenção preventiva. Conclusão: Faz-se necessário viabilizar recursos específicos, organizar os programas de apoio aos pacientes e às famílias e abranger protocolos de referência e contra referência.

Palavras-chave: Ideação suicida; Criança; Adolescente; Percepção; Saúde. 


\title{
ASPECTOS CLÍNICOS E LABORATORIAIS DE PACIENTES COM DOENÇAS LINFOPROLIFERATIVAS CUTÂNEAS ASSOCIADOS AO HTLV
}

\author{
Nome dos Bolsistas: Mateus Pantoja Rocha e Beatriz Costa Cardoso \\ Nome dos Voluntários: Lucas de Araújo Leão e Natália Pantoja Costa \\ Nome do(a) Orientador(a): Marília Brasil Xavier \\ Grupo de Pesquisa: Pesquisas em dermatoses de interesse sanitário
}

Introdução: O HTLV é um retrovírus de prevalência significativa, com alta oncogenicidade. A transmissão ocorre, por via vertical, sexual, transfusão de sangue e hemoderivados e compartilhamento de seringas. O diagnóstico laboratorial, os testes sorológicos identificam pacientes soropositivos para o HTLV. A infecção é assintomática ou gera patologias, como as doenças linfoproliferativas, podendo ter manifestações dermatológicas. Assim, merece destaque a Leucemia/Linfoma de Células $\mathrm{T}$ do Adulto(ATLL) Objetivos: Deste modo, a presente pesquisa objetivou investigar os aspectos clínicos e laboratoriais de pacientes com doenças linfoproliferativas cutâneas associadas ao vírus HTLV Método: Após aprovação pelo comitê de ética em pesquisa da Universidade Estadual do Pará(UEPA), sob o parecer de número 3.366 .932 foi realizada série de casos retrospectiva, com dados obtidos através dos prontuários de pacientes atendidos no ambulatório de Dermatologia da UEPA, no período de janeiro de 2015 a janeiro de 2018, no município de Belém. Foi formado grupo de pacientes com doenças linfoproliferativas cutâneas, portadores do vírus HTLV e outro grupo com pacientes que possuam apenas doenças linfoproliferativas cutâneas sem associação com o HTLV e estes foram comparados.Resultados: Nesta pesquisa, foram analisados os dados de 11 pacientes, com idade média de 55 anos, sendo 6 mulheres e 1 homem. Tanto no grupo HTLV+, quanto no grupo HTLV-, o eritema foi a manifestação cutânea mais presente, e o sintoma mais referido o prurido, sendo as lesões disseminadas em 11 dos 10 pacientes. Em o diagnóstico das doenças linfoproliferativas levou mais de dois anos, o que reflete o difícil diagnóstico em muitos casos. Quanto as formas clínicas, no grupo HTLV+ não houve predomínio, enquanto no controle 7 pacientes tinham micose fungoide. Dentre os pacientes positivos para o HTLV, todos possuíam quase 10 anos ou mais de diagnóstico, com histórico de transfusão sanguínea e um relatou história pregressa de IST Conclusão: Pacientes com doenças linfoproliferativas cutâneas HTLV+ são em sua maioria mulheres, com mais de 51 anos, oriundas de Belém, enquanto nos somente com doenças linfoproliferativas cutâneas não predominou sexo, tem média de 62 anos de idade, onde 2 eram do interior. Não houve diferença nas manifestações cutâneas, predominou o eritema e o sintoma subjetivo prurido. O tempo de diagnóstico foi mais de dois anos HTLV+ e nos HTLV-. Enquanto no grupo HTLV+ não houve predomínio de formas clínicas das doenças linfoproliferativas, no HTLVpredominou a Micose Fungoide. No grupo HTLV+ a história de transfusão sanguínea é comum aos três.

Palavras-Chaves: Vírus 1 Linfotrópico T Humano; Linfoma; Leucemia de células T; Dermatite. 


\title{
TECNOLOGIA EM SAÚDE E REPRESENTAÇÕES SOCIAIS PARA ABORDAGEM DA SAÚDE MENTAL DE GESTANTES COM CARDIOPATIA FETAL
}

\author{
Nome dos Bolsistas: Claudiane Santana Silveira Amorim, Fernanda Cruz de Oliveira \\ Nome do(a) Voluntário(a): Vaneska Tainá Pinto Barbosa \\ Nome do(a) Orientador(a):Mário Antônio Moraes Vieira \\ Grupo de Pesquisa: Intervenções de enfermagem no processo saúde doença
}

Introdução: O período gestacional é marcado por grandes mudanças em todas as esferas da vida de uma mulher, ocasionando inúmeras repercussões físicas e emocionais, que requerem de cuidado tanto da família quanto dos profissionais da saúde (SANTOS, 2016). E em casos de mães diagnosticadas com cardiopatia fetal esse cenário de mudanças torna-se mais vulnerável a surgimentos de sentimentos como de medos e angústias, pois se torna um fator estressor e desestabilizante para a família. De acordo com Souza (2010) ao deparar com o diagnóstico de cardiopatia, antes ou após o nascimento, os pais passam por momentos de um choque psicológico, e têm que assimilar a perda de uma criança idealizada e aceitar a criança real. A cardiopatia fetal de acordo com o autor supracitado significa uma anormalidade da estrutura cardíaca e inclui uma variedade de malformações anatômicas e, consequentemente funcionais, podendo causar desde alterações simples até as mais graves no funcionamento da bomba cardíaca. A assistência ao pré-natal se torna essencial para o acompanhamento dessas mudanças, a fim de assegurar à promoção a saúde e prevenção de possíveis intercorrências durante a gestação, e o diagnóstico de cardiopatia fetal no pré-natal, torna-se importante para a avaliação e acompanhamento psicológico da gestante (OLIVEIRA, 2017). A respeito da Teoria das Representações Sociais (TRS) de acordo com Santos (2013) é uma teoria ou ciência coletiva destinada à interpretação e intervenção no real, indo além do que é imediatamente dado pela filosofia e na sociologia acerca da classificação de eventos e fatos sociais. A sua utilização se torna relevante para compreensão dos fenômenos físicos e subjetivos que norteiam as gestantes com cardiopatia fetal, levando em consideração os aspectos sociais, culturais e econômicos. A educação em saúde surge como uma estratégia para mediar o cuidado ao paciente, e uma dessas estratégias é o uso das Tecnologias em Saúde (TS), principalmente as Tecnologias Educacionais (TE), com objetivos de intervenção, promoção, diagnóstico de doenças e reabilitação. O uso das TS com gestantes que têm cardiopatia fetal possui como finalidade proporcionar maior compreensão do momento vivenciado, respondendo as suas dúvidas, minimizar o impacto do diagnóstico e os sentimentos de medo (NASCIMENTO, 2012). Do mesmo modo que, proporcionar uma assistência qualificada e integral levando em consideração os aspectos sociais, culturais e emocionais que às norteiam.

Objetivo: Compreender as representações sociais de gestantes em relação à cardiopatia fetal e realizar educação em saúde fazendo uso de uma cartilha educativa. 
Material e Método: Pesquisa descritiva, de levantamentos de dados, com abordagem qualitativa, fundamentada na TRS, com ênfase na abordagem da Teoria do Núcleo Central (TNC), tendo como foco a representação social de gestantes com cardiopatia fetal sobre o feto. A pesquisa foi realizada na Unidade de Obstetrícia (Centro Obstétrico, Ambulatório e Alojamento Conjunto) da Fundação Pública Estadual Hospital de Clínicas "Gaspar Vianna" (FHCV) localizado na região metropolitana de Belém-PA, referência no Estado para atendimento de média e alta complexidade em Cardiologia, Nefrologia e Psiquiatria, com assistência efetivada por uma equipe multiprofissional, no período de novembro de 2018 a março de 2019 sendo entrevistadas 15 gestantes que tinham cardiopatia fetal os quais foram incluídas aquelas que tinham maior de dezoito anos e que tivessem realizado pelo menos uma consulta de pré-natal de alto risco complementar no serviço de ambulatório da instituição cenário da pesquisa (que correspondeu a 100\% das gestantes em atendimentos no período da coleta de dados). A pesquisa foi dividida em dois momentos, sendo o primeiro destinado à aplicação dos instrumentos da coleta de dados, e o segundo para realização da educação em saúde; como instrumento facilitador para a realizar a educação em saúde valeu-se de uma cartilha educativa. Como instrumentos da pesquisa, empregou-se com todas as gestantes, a técnica de evocação livre de palavras, também conhecida como associação livre ou teste por associação livre de palavras (TALP) afim de identificar como se manifesta a estrutura (central e periférica) da frase indutora "O que representa para você quando pensa que seu bebê tem problemas no coração?". Para realizar a TALP, foi construído um formulário para organizar de forma hierárquica as respostas das participantes sobre a frase indutora. Essas respostas foram transcritas levando em consideração também o perfil sócio demográfico das gestantes. Para a análise dos dados referentes ao questionário, utilizou-se a análise do Programa Excel 2010, os resultados foram organizados em tabela. Já para análise do formulário de evocação livre de palavras, realizada a partir da técnica do quadro de quatro casas, utilizou-se o Software openEvoc 0.84 que tem como fundamento a concepção de que toda representação está organizada em torno de um núcleo central, entendido como princípio organizador dos elementos da representação e que the dá sentido. O openEvoc 0.84 é um programa gratuito para coleta, análise e processamento de dados de pesquisa na perspectiva estrutural da TRS, desenvolvido e mantido pelo professor Hugo Cristo Sant'Anna da Universidade Federal do Espirito Santo. A análise das evocações ao estímulo indutor da frase "O que representa para você quando pensa que seu bebê tem problemas no coração?" foi apoiada por um tratamento com o auxílio do software para que fosse obtido o quadro de quatro casas por meio do software openEvoc 0.84. $\mathrm{O}$ quadro de quatro casas discrimina o núcleo central, a $1^{\mathrm{a}}$ periferia, os elementos de contraste e a $2^{\mathrm{a}}$ periferia. O núcleo central agrupa os elementos mais importantes do objeto de representação; na $1^{\mathrm{a}}$ periferia têm-se os elementos periféricos mais importantes; na zona de contraste os elementos com baixa frequência, mas considerados importantes para os sujeitos; na $2^{a}$ periferia os elementos menos importantes e menos frequentes. A pesquisa envolveu seres humanos, o que 
preconiza conformidade com a Resolução $n^{\circ}$ 466/2012 (BRASIL, 2012), sendo submetida ao Comitê de Ética em Pesquisa (CEP) pela Universidade do Estado do Pará-UEPA sob o parecer $n^{\circ} 2.982 .066$ de 25 de outubro de 2018. Foi assegurado o caráter voluntário e anonimato da pesquisa e o Termo Livre e Esclarecido (TCLE) foi lido e assinado por todas as participantes bem como os pelos pesquisadores.

Resultados e Discussão: Caracterizar o perfil sócio demográfico das gestantes com cardiopatia fetal é de grande relevância, por ser elemento de construção das representações sociais. Foram analisadas as variáveis: idade, estado civil, quantidade de filhos, escolaridade, número de gestação e se realizou pré-natal. A maioria das gestantes entrevistadas tinham idade entre 18-23 anos, 6 (37,5\%), 4 (25\%) afirmaram ter entre 24-26 anos, $3(18,75 \%)$ ter entre $27-29$ anos e $2(12,5 \%)$ ter acima de 32 anos. Quanto ao estado civil $8(50 \%)$ correspondia a casada, $5(31,25)$ união estável e $2(12,5 \%)$ solteiras. Para quantidade de filhos $5(31,25 \%)$ afirmaram não ter filhos e 10 $(68,75)$ afirmaram ter filhos. No que se refere a escolaridade $7(43,75 \%)$ ensino médio completo, $3(18,75 \%)$ ensino fundamental, 3 (18,75\%) ensino superior completo, 1 $(6,25 \%)$ ensino superior incompleto, 1 (6,25\%) ensino fundamental incompleto. Entre as 15 gestantes, $7(43,75)$ eram primigestas, $3(18,75 \%)$ eram secundigestas, enquanto que, 4 (25\%) afirmaram terem três gestações e 1 (6,25\%) quatro gestações. Em relação à realização do pré-natal, $14(87,5 \%)$ gestantes afirmaram ter realizado o pré-natal e apenas $1(6,25 \%)$ não realizou. Para realizar a identificação da forma como se manifestou a estrutura das representações sociais tendo como termo indutor a frase "O que representa para você quando pensa que seu bebê tem problemas no coração?", instigou-se a fala das participantes da pesquisa a partir da técnica de evocação livre de palavras, que leva a conhecer a estrutura central e periférica das representações sociais, no que diz respeito ao emergente da mente dos sujeitos da pesquisa ao ouvirem o termo, pela análise da frequência e ordem de importância dos termos evocados. Diante da metodologia proposta para a pesquisa e dos instrumentos utilizados, realizou-se a análise do Corpus formado, onde foram obtidas 75 evocações; após a padronização semântica (dicionário elaborado a partir dos termos evocados) chegou-se a 36 evocações diferentes. A organização do quadro de quatro casas é feita da seguinte forma: a) Quadrante superior esquerdo: Os elementos do núcleo central da representação estudada; garante a coerência e a estabilidade da representação, e função geradora; b) Quadrante superior direito: São os elementos da primeira periferia (ou intermediários), com maior frequência, porém com baixa importância, são as palavras que repetidamente aparecem ligadas aos núcleos centrais, porém com uma Ordem Média das Evocações (OME) alta; c) Quadrante inferior direito: São elementos da segunda periferia com baixa frequência e OME baixa; d) Quadrante inferior esquerdo: São elementos de contraste, com pouca importância, podendo ter alguma ligação com o núcleo central ou ser uma representação diferente advinda de um subgrupo específico dentro do grupo pesquisado (BRAGA, 2013). Assim, quanto ao quadro obtido pela frase indutora "O que representa para você quando pensa que seu bebê tem problemas no Coração?", observou-se no quadrante superior esquerdo ( $1^{\circ}$ quadrante) do quadro de quatro casas os termos Morte, Esperança e Preocupação; o 
termo Morte teve frequência de evocação de 4 , com ordem média de evocação de 0,75; Esperança teve frequência de evocação de 3, com uma ordem média de 0,6; Preocupação teve frequência de evocação de 4, com ordem média de 1,2; e revelam o possível núcleo central das representações sociais sobre cardiopatia fetal entre as gestantes. No quadrante superior direito ( $2^{\circ}$ quadrante) observou-se os termos Fé, Medo, Ansiedade e Tristeza; o termo Fé apresentou uma frequência de evocação de 9 , com uma ordem média de evocação de 2,33; Medo teve frequência de evocação de 7 , com ordem média de evocação de 1,43; Ansiedade teve frequência de evocação de 6 , com ordem média de evocação de 1,5; Tristeza teve frequência de evocação de 5, com Ordem média de evocação de 1,6. No quadrante inferior direito ( $3^{\circ}$ quadrante) constatou-se que é composto pelos termos Desespero e Amor; o termo Desespero teve uma frequência de evocação de 4, com ordem média de evocação de 2; Amor teve frequência de evocação de 2 , com ordem média de evocação de 0 . No quadrante inferior esquerdo ( $4^{\circ}$ quadrante) é formado pelos termos Batalha, Culpa, Dificuldade, Impotência, Provação e Sofrimento; o termo Batalha teve frequência de evocação de 1 , com ordem média de evocação de 1; o termo Culpa teve frequência de evocação de 2, com ordem média de evocação de 1; Dificuldade teve frequência de evocação de 1, com ordem média de evocação de 1; Impotência teve frequência de evocação de 1 , com ordem média de 1; Provação teve frequência de evocação de 1, com ordem média de evocação de 1; Sofrimento teve frequência de evocação de 1, com ordem média de evocação de 1. Para realização da educação em saúde, foi utilizada uma cartilha educativa criada durante a pesquisa, com a finalidade de auxiliar esse processo. Este momento aconteceu individualmente com cada gestante durante sua participação na pesquisa, foi disponibilizada uma via da cartilha para cada participante. Como limitações do estudo destacamos ao processo de coleta de dados às participantes no local da pesquisa, já que, foi destinado mais tempo para coleta com a finalidade de se alcançar um número considerável de gestantes e dessa forma conseguir realizar a metodologia do trabalho.

Conclusão: Como o foco do estudo em questão não foram os resultados da criação da cartilha, os autores se detiveram em discorrer sobre ao entendimento das representações sociais de gestantes com cardiopatia fetal. Nota-se que as representações sociais das gestantes quanto a frase indutora foi de suma importância para a percepção dos aspectos psicossociais que norteiam a gestante com cardiopatia fetal, e que a partir da análise do quadro de quatro casas pode-se obter os elementos do núcleo central das representações e os termos Morte, Esperança e Preocupação corroborando com o que foi pesquisado em diversas literaturas que falam sobre a cardiopatia fetal. Os achados reforçam a necessidade da educação em saúde por meio da equipe multiprofissional, a fim de reduzir as dúvidas, medos e ansiedade de uma mulher com diversos sentimentos relacionados às incertezas. A TRS utilizada como metodologia facilitou a compreensão do assunto, assim como despertou a realização de mais pesquisas para esse fim. Constamos a importância da equipe de saúde estar atenta também às mudanças psíquicas das gestantes, realizando a educação em saúde como facilitadora desse contato profissional-paciente. 
Referências bibliográficas: Braga RL. Representações sociais sobre loucura entre familiares portadores de transtornos mentais. 2013. Monografia (Graduação em Enfermagem) - Centro de Ciências Biológicas e da Saúde, Escola de Enfermagem, Universidade do Estado do Pará, 2013.

Brasil. Resolução n. 466, de 12 de dezembro de 2012. Aprovar as diretrizes e normas regulamentadoras de pesquisas envolvendo seres humanos. Brasília: Planalto; 2012.

Nascimento MHM. Tecnologia para mediar o cuidareducando no acolhimento de "familiares cangurus" em unidade neonatal: estudo de validação. 2012. Dissertação (Mestrado em Enfermagem) -Centro de Ciências Biológicas e da Saúde, Escola de Enfermagem, Universidade do Estado do Pará, Belém, Pará, 2012.

Oliveira MGF. O vínculo mãe-bebê e a malformação fetal. Trabalho apresentado ao Centro Universitário de Brasília- uniCEUB. Faculdade de Ciências da Educação e Saúde - FACES, Curso de Psicologia. Brasília. 2017.

Souza DSB. Avaliação de Estresse e Enfrentamento das Mães de

Crianças com Cardiopatias Congênitas. Dissertação de Mestrado apresentada à Universidade Estadual Paulista Júlio de Mesquita Filho - UNESP, Botucatu. 2010.

Santos MP. A teoria das representações sociais como referencial didáticometodológico de pesquisa no campo das ciências humanas e sociais aplicadas. Emancipação, Ponta Grossa-Paraná, v.13 (1), 9-21, 2013.

Santos ZMSA, Frota MA, Martins ABT. Tecnologias em saúde: da abordagem teórica a construção e aplicação no cenário do cuidado. 1. ed. Fortaleza: UECE, 2016.

Palavras-chave: Cardiopatias, Gestantes, Técnicas de Diagnóstico Cardiovascular, Relações Materno-Fetais, Tecnologias em Saúde. 


\section{CARACTERÍSTICAS SOCIODEMOGRÁFICAS E CLÍNICAS DE PESSOAS ADOECIDAS POR CÂNCER COLORRETAL SUBMETIDAS AO TRATAMENTO CIRÚRGICO}

Nome dos Bolsistas: Marcos José Risuenho Brito Silva, Leticia Almeida de Assunção Nome do(a) Orientador(a): Mary Elizabeth de Santana

Grupo de Pesquisa: Intervenções de Enfermagem no Processo Saúde Doença

Introdução: O câncer colorretal consiste em um tipo de neoplasia que afeta o intestino grosso, especificamente cólon e reto. De acordo com dados epidemiológicos, é o terceiro câncer com maior taxa de mortalidade no mundo e o mais comum no trato gastrointestinal. $O$ tratamento segue o padrão dos outros tipos de câncer que são as cirurgias (curativa ou paliativa), radioterapia e quimioterapia. No tratamento cirúrgico do câncer colorretal é comum a retirada do tumor juntamente com a porção do cólon ou reto e os linfonodos adjacentes, além da confecção de uma estomia para eliminação fecal. Quanto maior o tempo de intenção, maiores são os gastos do sistema de saúde e a exposição do paciente às infecções hospitalares. Objetivo: Analisar as características sociodemográficas e clínicas de pessoas adoecidas por câncer colorretal submetidas ao tratamento cirúrgico em um hospital de referência na Amazônia brasileira. Material e Método: Estudo descritivo, prospectivo, com abordagem quantitativa, utilizando dados secundários de prontuários de pacientes internados na clínica cirúrgica do Hospital Ophir Loyola referência no tratamento do câncer. A coleta de dados ocorreu de outubro de 2018 a abril de 2019, abrangendo pacientes submetidos ao tratamento cirúrgico do câncer colorretal. Resultados: As informações foram obtidas de 33 prontuários, identificou-se as variáveis sociodemográficas e clínicas. Observou-se que $57.5 \%$ (19) dos pacientes são do sexo masculino, 33,3\% (11) com idade entre 48 e 57 anos, 63,6\% (21) casados, 87,8\% (29) são pardos, 63,6\% (21) são provenientes da região Metropolitana I, 33,3\% (11) ensino fundamental completo. É importante ressaltar que 54,5\% (18) foram encaminhados do serviço de urgência, com tempo médio de 11,1 meses entre os primeiros sintomas e o início do tratamento cirúrgico, e a média de 12,2 dias entre a admissão e a realização da cirurgia. A cirurgia mais realizada foi a retossigmoidectomia 33,3\% (11), a dor abdominal foi um dos sintomas mais frequentes $27,4 \%$ (14), $54,5 \%$ (18) dos pacientes tem o histórico de câncer na família e $87,8 \%$ (29) passaram por processo de estomização. Conclusão: Com estes dados, é possível perceber que o câncer colorretal constitui um problema de saúde pública, além de dispor de dados do perfil dos pacientes que melhorem o planejamento assistencial e o atendimento hospitalar. Por fim, é importante incentivar o diagnóstico precoce e o rastreamento do câncer colorretal como formas de tratamento oportuno e prevenção dos estágios mais graves da doença.

Palavras-chave: Neoplasias Colorretais, Epidemiologia, Cuidados Pós-Operatórios, Antropologia Médica. 


\section{ESTUDO DA MORTALIDADE NEONATAL EM HOSPITAIS PÚBLICOS DE ALTA E MÉDIA COMPLEXIDADE NO BAIXO AMAZONAS}

Nome do (a) bolsista: Sandro Murilo Moreira de Lima

Nome dos voluntários: Vítor Alvarenga Siqueira e Susan Karolayne da Silva Pimentel Nome do (a) orientador (a): Milene Duarte Ribeiro Sena

Grupo de Pesquisa: Grupo de estudos e pesquisas em saúde

Introdução: Define-se como taxa de mortalidade neonatal o número de óbitos os quais ocorreram entre 0 e 28 dias de vida por mil nascidos vivos. É considerado um importante indicador de saúde pública. Objetivo Geral: Analisar a taxa de mortalidade neonatal nos hospitais públicos de média e alta complexidade do Baixo Amazonas nos anos 2016 e 2017. Material e Métodos: A presente pesquisa foi realizada por meio de um estudo descritivo-analítico, tendo como base a abordagem quantitativa, transversal, documental e comparativa, com base nos dados de prontuários do Hospital Municipal de Santarém (HMS) e Hospital Regional do Baixo Amazonas (HRBA). Resultados: O percentual de neonatos que evoluíram a óbito na UTI neonatal do HRBA nos anos de 2016 e 2017 foram próximos, com 12,35\% e 11,85\%, respectivamente. O número total de pacientes internados no HMS em 2016 foi de 3192 e em 2017 foram internados 4052. Evoluindo a óbito 82 pacientes em 2016 e 49 pacientes em 2017. Representando um percentual de mortalidade de 2,5\% e 1,3\% respectivamente. Deste último, 45 prontuários foram disponibilizados para análise. No geral, houvera prevalência de mães na faixa etária de 16-20 anos (30,2\%), residentes em Santarém $(59,3 \%)$, raça não informada $(69,8 \%)$, estado civil não informado $(36 \%)$, com ensino médio completo ou incompleto (34,9\%), tiveram gestação única (95,3\%), evoluíram para parto vaginal $(53,5 \%)$ e que realizaram pré-natal $(58,1 \%)$. Quanto aos neonatos, a prevalência fora o sexo masculino $(53,3 \%)$, com baixo peso ao nascer, parto ocorrido no hospital (86\%). As etiologias mais frequentes foram: distúrbios hemodinâmicos e/ou de coagulação (36\%), distúrbios respiratórios (32,6\%), sepse e afecções infecciosas $(22,1 \%)$. Conclusão: Conclui-se que se necessita de políticas públicas para melhor assistência ao período neonatal.

Palavras-chaves: Mortalidade, Neonatologia, Saúde 


\section{PAPEL DA NOS-2 NA ELEVAÇÃO DE NITRITO NO TELENCÉFALO DE ZEBRAFISH (DANIO RERIO HAMILTON 1822), EM MODELO DE TRANSTORNO DE ESTRESSE PÓS-TRAUMÁTICO.}

Nome dos Bolsistas: Wilker Leite do Nascimento, Pedro de Tárcio Guedes de Lima Nome dos Voluntários: Tainá Pontes Brito Dias, Saulo Rivera Ikeda.

Nome do (a) Orientador (a): Monica Gomes Lima Maximino.

Grupo de Pesquisa: Grupo Interdisciplinar de Pesquisa em Sociedade, Saúde e Meio Ambiente na Amazônia

Introdução: O transtorno de estresse pós-traumático (TEPT), caracterizado por sintomas de ansiedade, rememoração e hiperexcitabilidade neuroendócrina e autonômica após a experiência de um evento traumático, encontra-se entre os transtornos psiquiátricos com menor sucesso em termos de tratamento farmacológico. O sistema nitrérgico parece estar envolvido nessa fisiopatologia do TEPT. Objetivo: Avaliar o papel da NOS-2 na elevação de espécies $\mathrm{NO}_{\mathrm{x}}{ }^{-}$no telencéfalo de zebrafish, em um modelo animal de TEPT. Materiais e Método: 120 zebrafishes adultos do fenótipo longfin foram expostos ou não a substância de alarme (SA, um estressor agudo) e tratados ou não com um inibidor da NOS-2 (Aminoguanidina; AG; 50 mg / kg, i.p.). Após dois intervalos de tempo (30 ou 90 minutos depois da exposição à SA), os telencéfalos foram coletados, e seguiu-se a dosagem de nitrito conforme protocolo de de MAXIMINO et al. (2018), sempre em triplicata, e lidos em espectrofotometria com comprimento de onda de 590nm. Os dados obtidos foram analisados por Análise de Variância de duas vias, com post-test de Tuykey, considerando valor de $p$ significativo quando $<0,05$. As análises foram realizadas no software $R$ Studio, versão 3.3.5.Resultados: Os resultados obtidos do analito de $\mathrm{NO}_{\mathrm{x}}^{-}$, nos revelou que a exposição ao agente estressor (SA), no modelo de TEPT utilizado, é capaz de aumentar os níveis teciduais de nitrito ou nitrato, possivelmente em decorrência da produção de óxido nítrico (NO). No intervalo de tempo de 30 minutos após a exposição ao agente estressor (SA), a análises dos dados revelam que houve um efeito do tratamento (houve a sensibilização do comportamento animal pelo fenômeno da SDT; $F[1,6]=8.08, p=0.0295)$, mas não houve efeito da administração de $A G(F[1,6]=$ 0.112, $p=0.7495$ ), ou seja, a SA aumenta nitrito em tanto no grupo veículo (VEH) quanto no grupo no qual foi administrado AG. Já no intervalo de tempo de 90 minutos após a exposição à $S A$, a análises dos dados revelaram que houve um efeito do tratamento $(F[1,7]=23.32, p=0.0019)$, da droga $(A G ; F[1,7]=15.68, p=0.00546)$, e da interação tratamento-droga $(F[1,7]=10.14, p=0.01538)$. O pós-teste detectou aumento de espécies $\mathrm{NO}_{\mathrm{x}}{ }^{-}$, em animais expostos a SA e tratados com VEH ( $\mathrm{p}=$ 0.00469), e reversão parcial pela AG $(p=0.006)$. Conclusão: NOS-2 está participando do processo de consolidação do TEPT nesses animais.

Palavras-chave: TEPT, Sistema Nitrérgico, NOS-2, Neuropsicofarmacologia. 


\title{
AVALIAÇÃO DO NÍVEL DE CONHECIMENTO DE GESTANTES ATENDIDAS EM UM SERVIÇO PÚBLICO EM BELÉM-PA SOBRE PRÉ-NATAL E FATORES DE RISCO NA GRAVIDEZ
}

\author{
Nome dos Bolsistas: Gabriele Arja de Abreu; Rebecca Perez de Amorim. \\ Nome dos Voluntários: Bernardo Amorim Barbalho; Danilo Souza Delgado. \\ Nome do(a) Orientador(a): Nara Macedo Botelho. \\ Grupo de Pesquisa: Processos formativos em Saúde na Amazônia
}

Resumo: O objetivo deste artigo foi avaliar o nível de conhecimento que gestantes têm sobre pré-natal e a identificação de situações de risco à gravidez. Todas em acompanhamento pré-natal de baixo risco em um Centro de Saúde Escola na cidade de Belém, Pará, Brasil. Foi realizado estudo transversal com aplicação de questionário padrão enquanto as entrevistadas aguardavam o atendimento no local. Avaliaram-se aspectos demográficos, socioeconômicos, reprodutivos além do conhecimento sobre o pré-natal e situações de gravidade à gestação. Foram entrevistadas 117 gestantes. Dos 11 exames preconizados 6 não foram referidos de forma espontânea por mais da metade das grávidas. O citopatológico de colo uterino, o toque vaginal e o exame das mamas foram considerados desnecessários por até cerca de $20 \%$ das entrevistadas. Em relação aos sinais de gravidade à gestação apenas o sangramento vaginal foi referido espontaneamente por mais de 50\% das entrevistadas, sinais de hipertensão e pré-eclâmpsia foram referidos por menos de um terço mesmo após induzidas. Concluise que o conhecimento dos procedimentos pré-natais, bem como de situações que indicam risco à gravidez foi bem inferior ao esperado. A melhoria do nível de conhecimento das gestantes pode contribuir para maior qualidade do pré-natal, reduzindo, assim, os altos índices de morbimortalidade materno e infantil, ainda presentes no país.

1. Introdução: Com a humanização na assistência pré-natal houve redução do índice de morbimortalidade materna e perinatal nos últimos anos no Brasil $^{1,2}$. Segundo a Organização Mundial da Saúde (OMS), a razão aceitável de mortalidade materna é de até 20 óbitos por 100 mil nascidos vivos (NV). No Brasil, em 2006 a razão foi de 77,2 óbitos por 100 mil NV e em 2010, 68,2 óbitos por 100 mil NV. Apesar da redução, os valores permanecem muito acima do esperado pela OMS. Assim, após uma década da criação do Programa de Humanização no Pré-natal e Nascimento (PHPN) cabe o questionamento do que ainda falta para redução desses índices se a cobertura prénatal no país é adequada ${ }^{2,3,4}$.

No Brasil, a cobertura da atenção ao pré-natal alcançou 98\% no ano de 2010, chegando a indicadores universais ${ }^{5,6}$. Porém, ao se analisar a qualidade do acesso, avaliando a idade gestacional do início do pré-natal, o número de consultas realizadas e os procedimentos básicos preconizados pelo Ministério da Saúde, há uma grande disparidade regional, sobretudo em populações de vulnerabilidade socioeconômica. Isso ocorre pelo fato de que a assistência à saúde materna envolve tanto atividades exercidas pelos profissionais da saúde, quanto depende do conhecimento da mulher 
acerca dos seus direitos e necessidades ao decorrer da gravidez e pós-parto. Desse modo um bom pré-natal também dependerá de aspectos próprios - idade, local de moradia, escolaridade e renda - e do nível de conhecimento da gestante, que interferirão em comportamentos-chave, como a decisão de iniciar o acompanhamento na gravidez, de mudar de hábitos de vida danosos à criança e de aderir às consultas ${ }^{2}$

\section{Objetivos}

Objetivo Primário: Objetiva-se avaliar o nível de conhecimento que gestantes atendidas na Unidade Maternar no Centro de Saúde Escola do Marco, em Belém-PA, têm sobre o pré-natal e sobre a identificação de situações de risco à gravidez.

Objetivo Secundário: Também será comparado os resultados obtidos por meio de respostas espontâneas ou após estímulo das pesquisadoras, acerca das questões relacionadas ao tema.

\section{Material e Método}

Trata-se de estudo transversal com gestantes que realizavam o acompanhamento de pré-natal de baixo risco em um Centro de Saúde Escola, em Belém, no Estado do Pará, durante o período de fevereiro a agosto de 2019. As participantes foram convidadas a entrar no estudo enquanto aguardavam o seu atendimento no local. As que consentiram, assinaram o Termo de Consentimento Livre e Esclarecido (TCLE) e foram levadas, individualmente a um espaço reservado, para que respondessem a perguntas pré-definidas. A amostra final levantada foi de 117 gestantes, baseado no fluxo de estipulado de 30 gestantes/semana, disponibilidade dos autores que se responsabilizaram pela entrevista, de tempo hábil de coleta, considerando a carência de profissionais e a pausa dos atendimentos durante o mês de julho. As perguntas foram estruturadas em dois protocolos distintos, o primeiro obteve informações a cerca dos (1) aspectos demográficos e socioeconômicos, do (2) histórico obstétrico e da (3) gestação atual, da seguinte forma: Idade; cor da pele/raça; escolaridade; estado civil/conjugal; renda familiar; característica da habitação e endereço. Número de consultas pré-natais anteriormente realizadas, idade que teve o seu primeiro filho; número de gestações, abortamentos - se espontâneos ou provocados, partos vaginais, partos cesáreos, filhos nascidos vivos ou mortos, óbitos na primeira semana ou após a primeira semana; peso do recém-nascido ao nascer, idade gestacional ao nascimento; se amamentou e a sua duração; se ocorreram intercorrências na gestação anterior; como se passou o puerpério. A respeito dos hábitos de vida - se é tabagista, faz ingestão de bebidas alcóolicas ou uso de drogas ilícitas; se ocorreram intercorrências até o presente momento da gestação.

O segundo protocolo, avaliou (1) o nível de conhecimento das gestantes sobre o prénatal - divido também em (a) exames laboratoriais, (b) exames clínicos e (c) imunizações preconizadas - e (2) o conhecimento sobre os sinais e sintomas de gravidade na gestação. Nesse protocolo, as perguntas foram formuladas para que se pudesse avaliar o conhecimento espontâneo das gestantes, sem mencionar as opções 
existentes. Em um segundo momento, as opções não mencionadas eram lidas pelo entrevistador, para que as mesmas julgassem ou não relevante. Esse protocolo foi estruturado como segue: Exame de sangue; exame de urina; exame para HIV; ultrassonografia (USG); exame para diabetes; exame para sífilis; exame para rubéola; exame para hepatite; exame preventivo do câncer de colo do útero. Verificação da pressão arterial; verificação do peso; ausculta do batimento cárdio-fetal; medida da altura uterina; toque vaginal; exame das mamas. Hepatite b; dT (difteria e tétano) / dTpa (difteria, tétano e coqueluche); influenza.

Sangramento vaginal; dores abdominais intensas; contrações fortes; ruptura de bolsa; perda de líquido amniótico; perda do tampão mucoso; hipertensão; perda dos movimentos fetais.

A amostra foi analisa por estatística descritiva, em frequências relativas e absolutas, utilizando o BioEstat 5.4. Para a avaliação da amostra entre categorias foi utilizado o teste do Qui-quadrado de aderência, considerando um p-valor significativo $\leq 0,05$.

\section{Resultados}

Em relação aos aspectos demográficos e socioeconômicos das gestantes, a maior parte delas se encontrava na faixa etária dos 20 aos 29 anos (65,81\%), 16,23\% ainda estavam na faixa etária da adolescência, com 17,94\% apresentando mais de 30 anos. A grande maioria das mesmas se considerava parda $(63,25 \%), 23,08 \%$ consideravamse brancas e $13,68 \%$ negras. Do total, $58,97 \%$ eram casadas ou viviam em união estável com o pai da criança, enquanto $41,02 \%$ eram solteiras. Em relação ao nível de escolaridade, $64,10 \%$ tinham ensino médio completo ou incompleto (57:18, respectivamente), seguido de ensino superior (27,35\%; completo e incompleto, na relação de 9:23) e 8,54\% estudaram até o ensino fundamental (7:3). A renda familiar média de $57,26 \%$ estava entre 1,5 a 3 salários mínimos. A grande maioria disse ter água encanada e sistema de esgoto em sua residência (94,87\%) e cerca de $12,82 \%$ têm gatos em seu domicílio.

No histórico obstétrico, é possível identificar que $60,68 \%$ das mulheres estavam em sua primeira gestação; 5,98\% tiveram abortamento, sendo 5 espontâneos e 2 provocados. Os 2 óbitos ocorridos na primeira semana de vida deveram-se a problemas durante o parto (pós-termo) e a cardiopatia congênita, com o único óbito após a primeira semana de vida devendo-se à eritroblastose fetal. Das 117 mulheres, foi identificado que $11,11 \%$ tiveram seu primeiro filho durante a adolescência. Com relação ao conhecimento a respeito do pré-natal, 97,43\% disse saber a importância do pré-natal. A grande maioria $(81,19 \%)$ acredita que o pré-natal deve ser iniciado assim que se descobre a gravidez. Contudo, apenas $14,52 \%$ souberam o número correto de consultas mínimas que devem ser realizadas no pré-natal, 20,57\% não souberam responder, $9,40 \%$ disseram serem 5 ou menos consultas e $55,55 \%$ afirmaram serem 7 ou mais consultas.

Em relação ao nível de conhecimento sobre os exames laboratoriais, considerando apenas as respostas espontâneas (em aberto), 79,48\% afirmaram que deveriam realizar hemograma/exame de sangue; $78,63 \%$ tipagem sanguínea; $71,79 \%$ exame para HIV; $57,26 \%$ ultrassonografia; $52,13 \%$ exame de urina; $43,58 \%$ sorologia para 
sífilis; $38,46 \%$ glicemia em jejum; 36,75\% para Hepatite B, 25,64\% para toxoplasmose e 22,22\% cultura de urina; e apenas 9,40\% relataram ser necessário realizar o citopatológico do colo do útero. Houve aumento substancial da maioria dos exames listados ao se perguntar se os mesmos seriam ou não importantes.

Em sequência, a investigação dos conhecimentos das gestantes em relação aos exames clínicos e imunizações preconizadas, de forma espontânea, 69,23\% disseram ser necessária a verificação do peso; $63,24 \%$ expressou que era importante aferir a pressão; $62,39 \%$ a ausculta do BCF; 40,17\% a medida da altura uterina e apenas $8,54 \%$ e $19,65 \%$ fez referência ao toque vaginal e ao exame das mamas, respectivamente. Em relação às imunizações, 54,70\% lembraram-se da importância da vacina contra a Influenza; $52,99 \%$ contra a hepatite B; $41,88 \%$ contra o tétano. Também houve aumento considerável da porcentagem ao induzir as opções não mencionadas.

Por fim, quanto ao conhecimento sobre os potenciais sinais de risco gestacional, os principais sinais levantados espontaneamente foram, em sequência, sangramento vaginal, perda de líquido e dor em baixo ventre (76,06\%; 49,57\% e 45,29\%, respectivamente). Contrações regulares, febre e redução dos movimentos fetais (28,20\% 18,80\% e 10,25\%, em sequência) foram pouco mencionadas, embora quando induzidas tenham aumentando consideravelmente. O mesmo ocorreu com sinais de hipertensão e/ou pré-eclâmpsia, embora percentual expressivo (entre 23,93\% a $35,04 \%)$ não as tenham considerado sinal de risco, mesmo após induzidas.

5.Discussão: O nível de conhecimento das gestantes entrevistadas a respeito do prénatal e a identificação de situações de risco à gravidez mostrou-se preocupante no atual estudo. Apesar da maioria saber que o pré-natal deve ser iniciado assim que descobre a gravidez, $85,46 \%$ delas não sabem quantas consultas mínimas são preconizadas.

Quando questionadas a respeitos dos exames laboratoriais a serem realizados, a resposta espontânea foi considerada insatisfatória já que dos 11 exames preconizados 6 não foram referidos por mais da metade das grávidas. Quando foram estimuladas a responder com a referência dos entrevistadores sobre os demais exames, o número de acerto teve grande aumento. Em tal questão, é preocupante a menção espontânea do exame citopatológico do útero por apenas $9,40 \%$ das gestantes. Apesar de não ser um exame de rotina, verificar se a mulher está sendo rastreada é uma forma de não perder a oportunidade de prevenir o câncer de colo de útero².

Com relação ao conhecimento dos exames clínicos, a verificação do peso, aferição da pressão e ausculta dos batimentos do bebê foram recordados espontaneamente por mais de $50 \%$ das gestantes. Porém, apenas $8,54 \%$ disseram espontaneamente que o toque vaginal deveria ser realizado nas consultas, e $22,22 \%$ afirmaram categoricamente que este não era necessário. Apesar de não valorizado pela gestante, no toque bimanual, pode-se avaliar a permeabilidade do colo do útero, o volume uterino, alterações dos anexos e verificar a sensibilidade à mobilização uterina ${ }^{2}$. Outro exame pouco lembrado foi o exame das mamas, sendo referido espontaneamente por um pouco menos de um quinto das gestantes e 9,40\% referindo não ser necessário. 
Se consideradas apenas as respostas espontâneas, os resultados deste estudo refletem uma realidade muito aquém do ideal, pois uma pequena parte das gestantes entrevistas conhecia os procedimentos a serem realizados no pré-natal e os sinais de gravidade à gestação. $O$ conhecimento da gestante em relação a esses aspectos é uma das propostas PHPN, visando garantir uma participação ativa da mulher durante o pré-natal.

Podemos afirmar que houve a ampliação do acesso à assistência pré-natal, porém, a qualidade, como verificado no atual cenário, ainda é um grande desafio a ser vencido a fim de reduzir os desfechos desfavoráveis ${ }^{10}$.

6.Conclusão: Conclui-se que o conhecimento dos procedimentos pré-natais, bem como de situações que indicam risco à gravidez foi bem inferior ao esperado. A melhoria do nível de conhecimento das gestantes pode contribuir para maior qualidade do pré-natal, reduzindo, assim, os altos índices de morbimortalidade materno e infantil, ainda presentes no país.

\section{Referências bibliográficas}

1. Barreto CN, Wilhelm LA, Silva SC, Alves CN, Cremonese L, Ressel LB. "O Sistema Único de Saúde que dá certo": ações de humanização no pré-natal. Rev Gaúcha Enferm. 2015; 36(esp):168-76.

2. BRASIL, Cadernos de Atenção Básica, $n^{\circ}$ 32: Atenção ao pré-natal de baixo risco. Ministério da Saúde. Secretaria de Atenção à Saúde. Departamento de Atenção Básica. - Brasília: Ministério da Saúde, 2012. 318 p.: il. - Série A. Normas e Manuais Técnicos.

3. Handell IBS, Cruz MM, Santos MA. Avaliação da assistência pré-natal em unidades selecionadas de Saúde da Família de município do Centro-Oeste brasileiro, 20082009. Epidemiol. Serv. Saúde, Brasília, 2014. 23(1): 101-110.

4. Cecatti JG, Souza RT, Pacagnella RC, Leal MC, Moura EC, Santos LMP. Maternal near miss among women using the public health system in the Amazon and Northeast regions of Brazil. Rev Panam Salud Publica. 2015;37(4/5):232-8.

5. Nunes JT, Gomes KRO, Rodrigues MTP, Mascarenhas MDM. Qualidade da assistência pré-natal no Brasil: revisão de artigos publicados de 2005-2015. Cad Saúde Colet 2016; 24(2):252-261.

6. Rosa CQ, Silveira DS, Costa JSD. Fatores associados à não realização de pré-natal em município de grande porte. Rev Saúde Pública 2014; 48(6):977-984.

7. Nascimento IB, Pacheco VC, Souza MLR, Pinheiro EB, Ribeiro e Silva T, Fleig R, Silva JC. Prenatal care and perinatal outcome. Rev Bras Promoç Saúde 2017; 30(2):187194. 
8. Tomasi E, Fernandes PAA, Fischer T, Siqueira FCV, Silveira DS, Thumé E, Duro SMS, Saes MO, Nunes BP, Fassa AG, Facchini LA. Qualidade da atenção pré-natal na rede básica de saúde do Brasil: indicadores e desigualdades sociais. Cad. Saúde Pública 2017; 33(3):e00195815.

9. Gonçalves MF, Teixeira EMB, Corsi NM, Ferrari RAP, Pelloso SM, Cardelli AAM. Prénatal: preparo para o parto na atenção primária à saúde no sul do Brasil. Rev Gaúcha Enferm 2017; 38(3):2016-63.

Palavras-chaves: Cuidado Pré-Natal, Saúde Materno-Infantil, Conhecimentos, Atitudes e Prática em Saúde; 


\title{
INVENTÁRIO DE ADAPTAÇÃO AO ESTOMA (OAI-23): UMA APLICAÇÃO À REGIÃO NORTE DO BRASIL
}

\author{
Nome do(a) Bolsista: Aloma Sena Soares - PIBIC-UEPA/CNPQ \\ Nome do(a) Orientador(a): Regina Ribeiro Cunha \\ Grupo de Pesquisa: Intervenções de Enfermagem no Processo Saúde Doença
}

Introdução: A cirurgia geradora de estomia poderá levar a cura de um determinado agravo à saúde. Entretanto, para algumas pessoas poderá ser mais difícil aceitar a estomia, resultando em um processo de adaptação mais demorado, exigindo destas novas formas de autocuidado e enfrentamento de questões emocionais, devido a alteração da imagem corporal. Objetivo: Determinar o grau de adaptação a estomia de pessoas atendidas em um serviço de referência estadual na cidade de Belém, Pará, Brasil.Métodos: Estudo descritivo-exploratório, transversal, realizado com 135 pessoas com estomia de ambos os sexos, maiores de 18 anos, no período de junho de 2014 a fevereiro de 2016. A entrevista e a avaliação clínica dos participantes foram realizadas no Consultório de Enfermagem. Foi aplicado o Inventário de Adaptação ao Estoma (OAl-23). Os dados foram analisados de acordo com o cálculo do Ranking Médio (RM). O estudo atendeu as normas referentes aos aspectos éticos da pesquisa envolvendo seres humanos. Resultados: A aceitação e a preocupação com a estomia foram reveladas entre os participantes deste estudo. A insegurança frente ao compromisso social e as dificuldades quanto a percepção da estomia, superação da doença e da cirurgia, contribuem para o sentimento de raiva por sua condição de saúde. Conclusão: O processo de adaptação demanda atenção especializada em estomaterapia em todos os níveis de atenção à saúde. Verifica-se a necessidade de outros estudos, haja vista que o OAl-23 pode ser utilizado para projetar ou adaptar estratégias educacionais contribuindo ao ajuste psicossocial após a estomia.

Palavras-chave: Adaptação. Ajustamento Social. Estomia. Estomaterapia. 


\section{AVALIAÇÃO DA FUNCIONALIDADE, DA QUALIDADE DE VIDA E DO ÍNDICE DE INCONTINÊNCIA URINÁRIA EM IDOSOS PRATICANTES DE EXERCÍCIOS RESISTIDOS}

Nome dos Bolsistas: Elissa Raissa Siqueira do Nascimento; Joyce Lobato da Costa Nome dos Voluntários: Ana Caroline dos Santos Barbosa; Daniela Ferreira Leite Nome do(a) Orientador(a): Renato da Costa Teixeira Grupo de Pesquisa: Saúde Funcional e Qualidade de Vida

Introdução: O envelhecimento é um fenômeno progressivo, universal, irreversível e subjetivo, no qual ocorre um declínio progressivo dos sistemas, assim como modificações morfofisiológicas e psicossociais. A prática regular de exercíos físicos podem minimizar os efeitos do envelhecimento. O objetivo deste estudo foi de avaliar a capacidade funcional, a qualidade de vida e o índice de incontinência urinária de idosos praticantes de exercícios resistidos. Pesquisa é de caráter transversal, prospectivo e observacional. A coleta de dados foi realizada com idosos praticantes de exercícios resistidos no Laboratório de Exercícios Resistidos e Saúde (LERES), através do preenchimento de questionários validados, selecionados a partir de pesquisas em periódicos. Os dados coletados foram tabulados em planilhas eletrônicas para a confecção dos gráficos e tabelas. Inicialmente, foi verificada as normalidades dos dados através do teste D'Agostino-Pearson ( $k$ amostras). A análise estatística foi feita de maneira descritiva e inferencial. Participaram do estudo 52 idosos, sendo 36 mulheres $(69,23 \%)$ e 16 homens (30,76\%). A idade dos participantes variou entre 60 a 89 anos, com uma média de 71,78 \pm 6,47 anos. Em relação à avaliação da capacidade funcional do grupo, na Medida de Independência Funcional os idosos demonstraram possuir uma boa independência para realização de suas atividades básicas. A média do escore total da escala MIF $(123,24)$ demostrou que o resultado encontra-se próximo do máximo de 126 . No teste de caminhada de dois minutos (TC-2), os idosos reagiram bem à atividade proposta. A distania percorrida nos dois minutos foi em média 146,16 $\pm 33,31$ metros. Em relação, a avaliação da incontinência urinária (IU), apenas 17 idosos relatam possuir IU. Na avaliação da Qualidade de Vida pelo questionário SF-36, as médias encontradas nos 8 domínios foram próximos aos de normailidade. Diante disso, foi possível perceber que os idosos que praticam atividade física regular apresentam uma boa capacidade física que corrobora para uma boa qualidade de vida, todavia foram observados casos de incontinência urinaria, podendo ser explicado pelo processo natural do envelhecimento.

Palavras-chave: Saúde do idoso; atividade física; qualidade de vida; incontinência urionária 


\section{ANÁLISE DO METABOLISMO OXIDATIVOS E SUA CORRELAÇÃO COM O DESEMPENHO OCUPACIONAL DE PACIENTES COM DOENÇA DE PARKINSON SOB PARÂMETROS DA CLASSIFICAÇÃO INTERNACIONAL DE FUNCIONALIDADE, INCAPACIDADE E SAÚDE}

Nome dos Bolsista: Guilherme Henrique Siqueira Oeiras e Esther Samara da Costa Santos

Nome dos Voluntários: Daniel Jun Hayashi

Nome do(a) Orientador(a): Robson José de Souza Domingues

Grupo de Pesquisa: Morfofisiologia: Ensino e Pesquisa Aplicada a Saúde

Introdução: A doença de Parkinson (DP) é uma desordem acarretada pela degeneração dos neurônios dopaminérgicos dos núcleos da base e possui o estresse oxidativo como um dos desencadeadores. A doença gera manifestações clínicas a nível cognitivo e motor, que afetam diretamente o desempenho ocupacional.

Objetivo(s): Correlacionar as alterações no metabolismo oxidativo no sangue de pacientes com DP com estadiamento da doença e a Classificação Internacional de Funcionalidade, Incapacidade e Saúde.

Método: Estudo transversal analítico, aprovado pelo comitê de ética CAEE $\mathrm{n}^{\circ}$ 91076718.0.0000.5174 com aplicação da escala de Classificação Internacional de Funcionalidade (CIF) e a coleta de sangue de 50 indivíduos (25 com DP e 25 do grupo controle (GC), a fim de correlacionar os parâmetros obtidos pela escala com os testes de estresse oxidativo TBARS (Substâncias Reativas ao Ácido Tiobarbitúrico) e TEAC (Capacidade antioxidante trolox equivalente).

Resultados: Houve correlação entre os valores de Hoehn \&Yahr (HOEHN; YAHR, 1967). (indica o estadiamento da doença) e CIF ( $r=0,9525, p<0,0001)$ e diferença estatisticamente significativa $p<0,0001$ entre o GC $1,41( \pm 0,18)$ e o grupo GDP 2,20 $( \pm 0,62)$ na avaliação do TBARS, assim como diferença estatisticamente significativa p<0,0001 entre o GC 2,31 $( \pm 0,02)$ e o GDP $0,14( \pm 0,62)$ na avaliação do TEAC.

Conclusão: Os resultados obtidos sugerem que o estresse oxidativo contribui para 0 desencadeamento da doença de Parkinson. Ao relaciona-lo com funcionalidade e os estadiamentos da DP não houve correlação. Contudo, a partir das análises das escalas é possível associar a perda da funcionalidade com o avanço da DP, o que gera prejuízo no desempenho das Atividades de Vida Diária (AVD's) dos pacientes.

Palavras-Chave: Doença de Parkinson; Estresse Oxidativo; Classificação Internacional de Funcionalidade, Incapacidade e Saúde.

Grande-área: Ciências da Saúde/ Morfologia 


\section{EFEITOS DA MOBILIZAÇÃO PRECOCE EM CRIANÇAS COM PNEUMONIA ASSOCIADA A VENTILAÇÃO MECÂNICA INVASIVA}

Nome dos Bolsistas: Raissa de Souza Natividade Lopes e Elivelton da Costa Fonseca

Nome dos Voluntários: Cássia Oliveira Cabral da Paz

Nome do (a) Orientador (a): Rodrigo Santiago Barbosa Rocha

Grupo de Pesquisa: Desenvolvimento e Reabilitação na Amazônia

Introdução: O paciente pediátrico confinado ao leito sofre efeitos deletérios, particularmente na Unidade de Terapia Intensiva (UTI), submetido a Ventilação Mecânica Invasiva (VMI), resultando, dentre outros prejuízos, na perda de força muscular e redução da variabilidade da frequência cardíaca; Objetivo: Investigar os efeitos de um protocolo de mobilização precoce, na modulação autonômica da frequência cardíaca, no tempo de internação e VMI em crianças com Pneumonia Associada à Ventilação mecânica (PAV) na UTI;Métodos: Trata-se de um ensaio clínico randomizado, de característica longitudinal e prospectivo, participaram do estudo 21 crianças que apresentaram PAV, 10 foram alocadas ao Grupo Controle (GC) submetidas apenas ao protocolo padrão e 11 ao Grupo Experimental (GE) que além do protocolo do padrão, acrescenta-se o protocolo de mobilização precoce. Utilizou-se para a coleta da Variabilidade da Frequência Cardíaca um monitor de frequência cardíaca da marca POLAR ${ }^{\circledR}$ antes, durante e após os protocolos; Resultados: As variáveis pNN50 ( $p=0,001)$ e SDNN $(p=0,05)$ apresentaram aumento significativo no GE. Nos valores de i-RR tanto o GC $(p=0,05)$ quanto o GE $(p=0,001)$ mostraram acréscimo. O GE mostrou resultados significativamente melhores nas variáveis pNN50 $(p=0,01)$ e SDNN $(p=0,01)$ no período após a aplicação do protocolo. O GE também apresentou redução do tempo de VMI $(p=0,02)$, porém não alterou $o$ tempo de internação hospitalar $(p=0,4)$ e nem na UTI $(p=0,1)$; Conclusão: O protocolo de mobilização precoce foi benéfico para a modulação autonômica da frequência cardíaca, reduziu o tempo de VMI, porém não diminuiu o tempo de internação.

Descritores:

Palavras-chave: Unidades de Terapia Intensiva Pediátrica, Mobilização Precoce, Pneumonia Associada à Ventilação Mecânica, Sistema Nervoso Autônomo, Frequência Cardíaca. 


\section{AVALIAÇÃO FUNCIONAL, ELETROFISIOLÓGICA E PONDERAL DA REGENERAÇÃO NEURAL PÓS LESÃO DO MEDIANO DE RATOS}

Nome dos bolsistas: Deivid Ramos dos Santos, Sergio Cunha Trindade Júnior Nome do Voluntário: Luis Fernando Freitas de Sousa

Nome do (a) Orientador (a): Rui Sérgio Monteiro de Barros

Grupo de Pesquisa: Cirurgia Experimental

Introdução: avaliar a regeneração do nervo mediano de ratos após secção e neurorrafia simples através do teste do Grasping, parâmetros eletrofisiológicos e massa do músculo flexor radial do carpo.Método: foram usados 50 Rattus norvegicus (Wistar), machos, adultos, com aproximadamente 120 dias de idade, pesando entre $200 \mathrm{~g}$ a $250 \mathrm{~g}$, distribuídos em 2 grupos: grupo normalidade (GN), n=40; e grupo neurorrafia Simples (GNS), n=10. Resultados: Verificou-se aumento significativo de massa corporal entre todos os animais do GNS. O membro anterior direito do grupo normalidade (GN) mostrou média de força 137,8 N $( \pm 12,9)$. Já os animais do GNS, GNS após 6 semanas e GNS após 12 semanas apresentaram, respectivamente, média de $127 \mathrm{~N}( \pm 6,1), 8,98 \mathrm{~N}( \pm 2,1)$ e $79.4 \mathrm{~N}( \pm 14,2)$. Não houve diferença estatística entre os grupos. Conclusão: A recuperação da função nervosa do nervo mediano pode ser avaliada objetivamente com o equipamento usado no presente trabalho. Há uma tendência ao predomínio da força de preensão no membro anterior direito. No grupo neurorrafia simples foi observada maior volume da massa do MFRC no lado não lesionado devido a sobrecarga

Palavras - chave: nervo mediano; regeneração nervosa; neurorrafia 


\title{
A INFLUÊNCIA DO PROTOCOLO DE TREINAMENTO MUSCULAR RESPIRATÓRIO DOMICILIAR EM PORTADORES DO VÍRUS LINFOTRÓPICO
}

\author{
Nome dos Bolsistas: Amanda Caroline Lobato Dias; Isabelle Farias Gomes \\ Nome do(a) Orientador(a): Valéria Marques Ferreira Normando \\ Grupo de Pesquisa: Desenvolvimento e Reabilitação na Amazônia
}

Introdução: O HTLV-1 age alterando a resposta imune do hospedeiro, tornando-o suscetível a diversas infecções, por exemplo, a Paraparesia Espástica Tropical/Mielopatia associada ao HTLV (PET/MAH) ${ }^{1}$. PET-MAH é uma mielopatia progressiva crônica causada pelo HTLV-1, sobre a qual os indivíduos do sexo feminino, com altos títulos de anticorpos e alta carga proviral são mais propensos a desenvolver ${ }^{2}$. É uma inflamação crônica profunda, mielite de início lento e progressivo, sendo possível observar casos de evolução mais rápida ou até de melhora, porém, não de cura. Esta inflamação crônica é localizada na medula espinhal, embora a propagação seja frequentemente mais extensa ${ }^{3}$. O referido vírus pode gerar alterações morfológicas e funcionais no sistema respiratório ${ }^{4}$. Diante da visão terapêutica, o treinamento muscular respiratório pode ser destacado como uma possibilidade terapêutica preventiva as disfunções respiratórias ${ }^{5,6}$.

Objetivo: Avaliar a força muscular respiratória diante de um protocolo de treinamento muscular respiratório domiciliar supervisionado em portadores do HTLV-1.

Material e método: Trinta indivíduos portadores do HTLV-1 foram convidados a participar de um protocolo de treinamento muscular respiratório domiciliar com a duração de 5 semanas, 3 vezes por semana (dias intercalados), por 30 minutos diários por meio de um treinador muscular inspiratório de carga linear. Para a caracterização da força muscular respiratória, os mesmos foram submetidos a manovacuometria, pré (T0), peri (T3) e pós (T5) tratamento. Destes 30 indivíduos, 10 não foi possível contato, dois por óbito e oito por telefone inexistente; 10 não aceitaram participar da pesquisa; 10 aceitaram participar da pesquisa, porém, 4 desistiram durante o treinamento, resultando a amostra um total de 6 voluntários.Semanalmente o treino era conduzido no primeiro dia sob supervisão dos pesquisadores e os dois seguintes realizados em domicílio, com supervisão a distância (via telefone).

Os voluntários receberam o dispositivo de carga linear Threshold $®$ IMT, e as orientações devidas quanto ao manuseio, postura e assepsia. A carga de treinamento para cada participante foi ajustada em $25 \%{ }^{7}$ da sua PImáx na $1^{\circ}$ semana, $35 \%$ na $2^{a}$ semana; $40 \%$ na $3^{a}$ semana; $45 \%$ na $4^{\mathrm{a}}$ semana; e $50 \%$ na $5^{\mathrm{a}}$ semana de treinamento.

Resultados e discussão: Seis indivíduos concluíram a pesquisa, dos quais 83,33\% $(n=5)$ eram do sexo feminino com média de idade de $58,8 \%$ e $16,33 \%(n=1)$ do sexo masculino com 66 anos. Destes, 50\% não foram classificados como PET/MAH, $33,33 \%$ como PET/MAH definitivo e $16,66 \%$ como PET-MAH provável. 
$\mathrm{Na}$ tabela 1, observa-se a evolução das variáveis estudadas após o treinamento muscular respiratório com aumento significativo da PImáx do T0 ao T5, com a média de $66.8( \pm 12.58)$ e $115.08( \pm 31,78)$, respectivamente, sugerindo que o treinamento foi capaz de provocar significativa melhora na força muscular respiratória dos sujeitos estudados $(p=0.011)$. Ainda assim aponta-se resultados significativos ao comparar os tempos T0 ao T3 ( $p=0.049)$ e T3 ao T5 $(p=0.021)$.

Tabela 1: Valores de PImáx. Coletados em T0, T3 e T5

\begin{tabular}{llllllllll}
\hline Variável T0 & T3 & P-valor & T0 & T5 & P-valor & T3 & T5 & P-valor \\
& & & & & & & & \\
\hline Pimáx & 66.8 & 94.03 & $0.049^{*}$ & 66.8 & 115.08 & $0.011^{*}$ & 94.03 & 115.08 & $0.021^{\#}$ \\
& \pm & \pm & & \pm & \pm & & \pm & \pm & \\
& 12.58 & 33.27 & 12.58 & 31.78 & & 33.27 & 31.78 &
\end{tabular}

Fonte: Protocolo de pesquisa, 2018-2019. Dados expressos como média \pm desvio padrão. Test $t$ de Student pareado $\left(p<0.05^{*}\right)$. ANOVA $\left(p<0.05^{\#}\right)$. PImáx: Pressão inspiratória máxima. T0 Avaliação inicial. T3: avaliação na terceira semana de treinamento. T5:Avaliação final

As médias de PImáx coletadas antes da aplicação do protocolo (T0) e após o tratamento (T5) dos indivíduos estudados foram comparadas com os valores previstos mediante as equações de Neder et al.. Os valores medidos na amostra em T0 foram mais baixos do que os valores previstos, enquanto em T5 os valores se sobrepuseram em relação ao previsto. Pode-se observar essa mudança em cada participante no gráfico 1 abaixo.

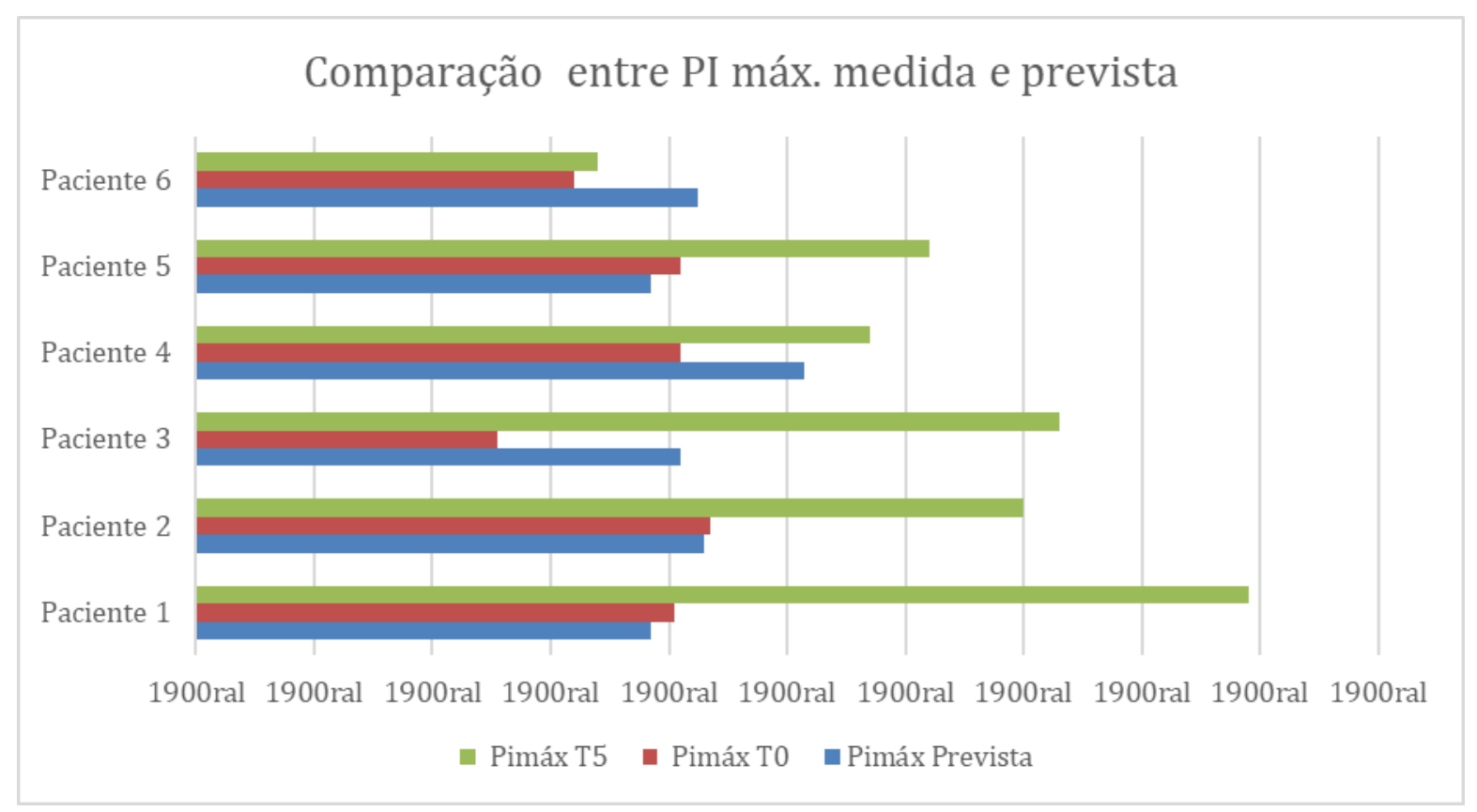

Fonte: Protocolo de pesquisa, 2019 
Observou-se a progressão com significância na PImáx nos três momentos analisados: primeira (T0), terceira (T3) e quinta (T5) semana de treinamento. Considera-se este acréscimo da força muscular inspiratória como um fator de proteção a tolerância aos esforços e consequente prevenção a complicações pulmonares ${ }^{8}$.

A reabilitação não supervisionada, conhecida também como reabilitação ou exercício domiciliar, tem como objetivo principal exercitar pacientes sob supervisão indireta e promover manutenção de benefícios obtidos durante fases supervisionadas de treinamento, por meio de uma forma simples, eficaz, viável e segura $^{9}$

Conclusão: Foi possível identificar ganho na força muscular inspiratória diante de um protocolo de treinamento muscular inspiratório domiciliar supervisionado em portadores do vírus linfotrópico de células T humano tipo I.

\section{Referências bibliográficas}

1 Corrêa VAC, Rocha ACB, Almeida PS, Pinto DS, Falcão LFM, Fuzii HT. Capacidade funcional em indivíduos com paraparesia espástica tropical/mielopatia associada ao HTLV-1. REFACS [Internet]. 2018 [citado em 15 de agosto 2019]; 6(1):7-14.

Disponível em: http://seer.uftm.edu.br/revistaeletronica/index.php/refacs/article/download/2353/ pdf 2. DOI: 10.18554/refacs.v6i1.2353.

2 Fuzii HT, Simões JA, Dias GAS. Imunophatogenesis of HTLV-1 assoaciated myelopathy/tropical spastic paraparesis (HAM/TSP). Life Sci. 2014;104(1-2):9-14 Disponível

em: https://www.sciencedirect.com/science/article/abs/pii/S002432051400366X?via\%3Di hub

3 Virgolino RR. Análise multivariada de características clínicas de PET/MAH e níveis de expressão gênica e derivação de modelos de predição diagnóstica em pacientes infectados com o HTLV-1. 2017. 129 f. Dissertação (Mestrado) - Universidade Federal do Pará, Núcleo de Medicina Tropical, Belém, 2017. Programa de PósGraduação em Doenças Tropicais.

4 Oliveira AG et al. A efetividade do treinamento muscular respiratório com Powerbreathe em atletas de basquete. Fisioterapia em Ação-Anais eletrônicos.2017:21-32.

5 Colla L; Peternella FN; Mendes, FCV. Proposta de Tratamento Fisioterapêutico Para uma Paciente Portadora de Paraparesia Espástica Tropical: Estudo de Caso. Uningá Review 2014; 18(3):17-20

6 Moura DS, et al, Fisioterapia no Atendimento Domiciliar: Enfrentamento e Desafios Dos Profissionais. Id on Line Rev. Mult. Psic. 2018 ;12, (39). - ISSN 1981-1179 Edição eletrônica em http://idonline.emnuvens.com.br/id 
7 Gessain A.; Mahieux R. Tropical spastic paraparesis and HTLV-1 associated myelopathy: clinical, epidemiological, virological and therapeutic aspects. Revue neurologique.2012;168(3): 257-269

8 Ferreira GD, Costa AC,Plentz RD, Coronel CC, Sbruzzi G. Respiratory training improved ventilatory function and respiratory muscle strength in patients with multiple sclerosis and lateral amyotrophic sclerosis: systematic review and meta-analysis. Physiotherapy. 2016;102(3): 221-228.

9 Seixas MB; Ramos PS; Ricardo DR. Reabilitação domiciliar com exercício não supervisionado na DPOC: revisão sistemática. Revista Brasileira de Medicina do Esporte, 2016. 


\section{FUNÇÕES SEXUAL E URINÁRIA DE GESTANTES}

Nome dos Bolsistas: Brenda Beatriz Silva Monteiro; Dayana Prazeres dos Santos Nome dos Voluntários: Carla Daniela Santiago Olibeira; Vitória Maria de Souza Leite Nome do Orientador: Erica Feio Carneiro Nunes

Grupo de Pesquisa: Desenvolvimento e Reabilitação da Amazônia

\section{Resumo}

Introdução: A Sociedade Internacional de Continência afirma que $69 \%$ das mulheres apresentam Incontinência Urinária na gravidez. Além disso, ocorrem mudanças relacionadas a função sexual. Dentre as principais, destaca-se a dispareunia e desconforto durante $\mathrm{o}$ ato sexual. Objetivo: avaliar a função urinária e sexual de grávidas atendidas num centro de saúde escola em Belém/PA. Metodologia: estudo do tipo transversal, quantiqualitativo, realizado entre junho/setembro de 2018. Foram incluídas: mulheres entre 18-40 anos e $9^{\mathrm{a}}-32^{\mathrm{a}}$ semanas de gestação com pré-natal no Centro de Saúde Escola do Marco em Belém/PA, excluídas grávidas com risco gestacional para mãe e feto. Utilizou-se os questionários International Consultation on Incontinence (ICIQ) e Quociente Sexual (QS-F). Resultados: Participaram 50 grávidas estando entre $9^{\mathrm{a}}-32^{\mathrm{a}}$ semana de gestação. De acordo com o ICIQ-SF, 28,00\% das participantes apresentam IU muito grave. De acordo com o QS-F 40,00\% das participantes apresentaram desempenho sexual de bom a excelente, porém 54,00\% apresentou dor durante a relação sexual. Conclusão: As grávidas do estudo apresentam alta prevalênca de IU. Apesar da maioria apresentar bom/excelente função sexual, deve-se atentar à prevenção desses sintomas.

Descritores: Incontinência Urinária. Função Sexual. Gestantes. 


\title{
AVALIAÇÃO DA QUALIDADE AMBIENTAL EM LOCAIS DE RECREAÇÃO NA BACIA HIDROGRÁFICA DO XINGU-PA
}

\author{
Nome do(a) Bolsista:Edinara Freitas Lacerda Filipi \\ Nome do(a) Voluntário(a):Geisom de Souza Cezar \\ Nome do(a) Orientador(a): Ana Karina Moreyra Salcedo \\ Grupo de Pesquisa: Grupo Multidisciplinar de Pesquisa em Educação, Saúde e Meio \\ Ambiente na Amazônia
}

Introdução: As alterações na vegetação das margens dos cursos de água são apontados como um dos principais fatores que causam impactos ambientais. É conhecido a influência direta que exerce a vegetação na manutenção dos habitats aquáticos e que a sua conservação é essencial para a manutenção da qualidade da água e da biodiversidade aquática. A bacia hidrográfica do Xingu tem se volvido atrativa para atividades de lazer. No entanto, com a instalação dos balneários em igarapés, a manutenção da cobertura vegetal nesses locais sofre supressão para uso do espaço pelos visitantes podendo alterar o leito do canal fluvial aumentando a erosão da margem, a cobertura vegetal, e a características físicas dos hábitats que mantêm a integridade ecológica do sistema aquático. O objetivo do trabalho foi avaliar a qualidade ambiental em quatro igarapés da região aplicando um Protocolo de Integridade Física de Habitats verificando alguns dos parâmetros físicos dos hábitats que podem atuar como estruturadores da fauna aquática e avaliar a riqueza da comunidade de macroinvertebrados aquáticos e dos parâmetros físico-químicos nestes locais. Em relação ao ambiente físico a cobertura do dossel no curso de água foi aproximadamente entre $63 \%$ e $77 \%$, desse modo todos os locais apresentaram boa cobertura vegetal permitindo a entrada de matéria orgânica alóctone e fornecendo proteção ao curso de agua. Devido à variação sazonal durante o período de coletas os valores de profundidade e largura média dos igarapés esteve relacionado ao aumento do escoamento da água da chuva em seus respectivos leitos. A velocidade do fluxo da água foi semelhante, no entanto, a vazão dos igarapés foram distintas, apresentando maior vazão o Igarapé Cipó Ambé com 2,33 m³/s. Em relação aos parâmetros físicoquímicos, os igarapés apresentaram valores médios dentro do esperado para ambientes preservados: oxigênio dissolvido acima de $4,5 \mathrm{mg} / \mathrm{l}, \mathrm{o} \mathrm{pH}$ com valores próximos a 6 , turbidez com valores menores de $12 \mathrm{NTU}$, temperatura média $29^{\circ} \mathrm{C}$ e a condutividade elétrica com valores menores a $15,5 \mu \mathrm{S} / \mathrm{cm}$. Os substratos com maior ocorrência em (\%) nos quatro igarapés foram raízes, bancos de folhas e areia, isso denota que esses habitats são capazes de abrigar comunidades de macroinvertebrados. Foram coletados 2455 indivíduos de macroinvertebrados sendo identificados 45 táxons. Houve diferença sazonal na abundancia e na riqueza de táxons sendo encontrados 27 táxons no início da estiagem ( $n=806)$ e 41 no final da estação chuvosa $(n=1649)$. O táxon Chironomidae foi o mais representativo $(53,5 \%)$ nas amostras coletadas seguido dos táxons Elmidae (9\%) e Leptophlebiidae (8\%). Os igarapés apresentaram bons indicadores de preservação da vegetação nas suas margens. Dados sobre a estrutura da comunidade e as características físicas e físico- 
químicas demostram que esses locais podem abrigar comunidades de macroinvertebrados com riqueza taxonômica similar a ambientes preservados.

Palavras chaves: macroinvertebrados, Integridade ambiental, qualidade água 


\title{
PROPOSTA DE MAPA DE PROCESSOS PARA LOGÍSTICA REVERSA DOS RESÍDUOS GERADOS NA PRODUÇÃO DA POLPA DO AÇAÍ EM BELÉM- PA: UM ESTUDO BASEADO NA POLÍTICA NACIONAL DE RESÍDUOS SÓLIDOS
}

\author{
Nome dos Bolsistas: Cleyciane de Lima Cerdeira, Naira Gabriela do Nascimento \\ Vieira \\ Nome do(a) Voluntário(a): João Victor Santana \\ Nome do(a) Orientador(a): André Cristiano Silva Melo \\ Grupo de Pesquisa: Gestão de Sistemas Logísticos e de Sistemas Produtivos para o \\ Desenvolvimento Regional
}

Introdução: Com a relevante geração de resíduos derivados do processamento da polpa do açaí se faz necessário a proposição de processos que viabilizem a revalorização desses resíduos. Assim, este artigo propõe um mapa de processos para logística reversa dos resíduos gerados na produção da polpa do açaí em Belém-PA, sendo o estudo baseado na Política Nacional de Resíduos Sólidos. Com abordagem exploratória, houve o levantamento das atuais etapas e processos da logística reversa (LR) associados à destinação do resíduo, tendo como base materiais publicados em revistas, eventos e sites, a análise de documentos de órgão públicos, além de relatórios obtidos em visitas à Casa do Açaí, AVABEL e pontos de vendas de açaí em Belém. Os dados obtidos foram mapeados por meio de software, utilizando o método As Is e To Be. Os resultados mostram que os elos do atual canal reverso (CR) são formados por Regulação, Geração, Transporte, Qualificação e Organização, Revalorização e Disposição Irregular. Outros possíveis elos que poderiam compor esse CR são as Universidades, Associações de Artesãos e Joalheiros. Entre as alternativas de revalorização mais viáveis, destacam-se a fabricação de biojóias, móveis sintéticos, adubo e compostagem, além do uso como biomassa. Outras possíveis formas de destinação adequada identificadas fora o concreto, o filtro de carvão ativado e o eco painel. As universidades e instituições de pesquisa surgem com importante papel de desenvolvedoras de novas e melhores formas de revalorização desse resíduo, ao Governo cabe melhorar a integração entre os atuais e outros possíveis elos do CR. O fortalecimento desses elos, a eliminação de certos processos e a inclusão de outros são essenciais para que haja efetivação da LR associada a disposição ambientalmente adequada.

Palavras-chaves: RPPA; Beneficiamento; Elos; Processos; Canal reverso; 


\title{
QUALIDADE DA MADEIRA SERRADA COMERCIALIZADAS EM ESTÂNCIAS DA REGIÃO METROPOLITANA DE BELÉM-PA
}

\author{
Nome do(a) Bolsista: Andréia Caroline Lima Lopes \\ Nome dos Voluntários: Maycon da Silva Teixeira e Pablo da Ventura Corrêa \\ Nome do(a) Orientador(a): Cláudia Viana Urbinati \\ Grupo de Pesquisa: Anatomia e identificação de espécies amazônicas
}

Introdução: Em função da notória diferença no padrão de qualidade da madeira serrada comercializada na Região Metropolitana de Belém - PA para o consumo local e externo, a credibilidade do mercado de madeiras do estado do Pará é comprometida, e dada a importância sócio-econômica do mercado madeireiro da região, verifica-se a necessidade de estudos de cunho científico sobre o cenário de produção e comercialização de espécies tropicais, realizando o levantamento de informações referentes ao perfil social dos empregados, à origem de extração das madeiras e destino de comercialização, identificação das espécies comercializadas e classificação das peças serradas quanto aos defeitos. O estudo foi desenvolvido em empresas selecionadas por meio do método de amostragem em bola de neve, onde a coleta de dados foram realizadas com a aplicação de questionários semiestruturados e fichas de mensuração dos defeitos das peças de madeira elaboradas a partir da NBNT ISSO 2301 (2011), referente a medição dos defeitos de madeira serrada de folhosas. Os dados foram tratados em planilhas do Excel, e a classificação da qualidade das peças de madeira feita por meio da NBR ISO 2299 (2010). Observou-se que os estabelecimentos comerciais são de pequeno porte, com número médio de cinco funcionário e nível de mecanização baixo. As madeiras são comercializadas através de seus nomes vernaculares em dimensões comerciais pré-estabelecidas, as principais espécies comercializadas são angelim (Dinizia excelsa) e mandioqueira (Qualia sp.). Foram levantados 11 espécies madeireiras por seu nome vernacular, dentre elas 3 identificadas a nível de espécie, 6 a nível de gênero e 2 não identificadas. Apenas 1 amostra não correspondia a espécie indicada. Observou-se que não há aplicação de tratamento de secagem ou de preservação dos produtos. As peças de madeira são empilhadas e armazenadas em pátios cobertos e ao ár livre. Os defeitos de serragem foram os mais evidentes, seguidos pela presença de fendas no fim da peça e ataque de fungos. A partir das análises observou-se que baixa qualidade da madeira está ligada principalmente ao armazenamento e empilhamento inadequado das peças de madeira, e que medidas simples podem ser implementadas a essas empresas, para que a madeira comercializada apresenta uma qualidade melhor.

Palavras-chaves: Mercado madeireiro; Madeira serrada; Qualidade da madeira; 


\title{
PARÂMETROS DE COMPARAÇÃO ENTRE PLANOS DE ROTAS GERADOS PELOS MÉTODOS MAIS CONHECIDOS DE ROTEIRIZAÇÃO DE VEÍCULOS
}

\author{
Nome dos bolsistas: José Pedro Gomes da Cruz, Matheus Ribeiro da Cunha \\ Nome dos Voluntário: Saulo Damasceno Leite de Macedo \\ Nome do(a) Orientador(a): Denilson Ricardo de Lucena Nunes \\ Grupo de Pesquisa: Gestão de Sistemas Logísticos e de Sistemas Produtivos para o \\ Desenvolvimento Regional
}

Introdução: Existem muitos métodos para resolver problemas de roteirização na logística empresarial buscam otimizar um parâmetro para facilitar decisão de gestores na escolha de um plano de rotas de veículos. Porém observa-se que métodos apresentam plano de rotas diversificados e de difícil avaliação. A diversidade de objetivos dificulta a tomada de decisão, todavia, ao observar a teoria da avaliação do desempenho logístico, conclui-se que pode haver indicadores ainda não considerados na roteirização. Deste modo, o presente estudo objetivou utilizar os referidos indicadores para comparar planos de rotas gerados por três algoritmos propostos por Solomon (1987). Para tanto, em primeiro lugar foi necessário buscar na avaliação de desempenho logístico quais indicadores poderiam ser usados nessa comparação para posterior realização de testes nas instâncias usadas por Solomon (1987). A literatura pesquisada não apresentou métricas para o desempenho logístico de um plano de rotas. Dessa forma, foram propostos 7 indicadores nas dimensões de tempo, custo, qualidade e produtividade. Ao final do experimento observou-se que os indicadores propostos apresentaram correlação fraca entre os indicadores. Além disso, dos métodos testados, a inserção apresentou de forma geral o melhor desempenho segundo os indicadores propostos.

1 Introdução: A definição do plano de rotas para veículos consiste em um importante problema na gestão da cadeia de suprimentos, pois o plano de rotas define quais veículos farão determinadas entregas (paradas programadas) e os trajetos a serem percorridos.

Segundo Ballou (2006), a gestão de cadeia de suprimentos se vê constantemente com o problema de altos custos logísticos. Visando a gestão eficiente dos impactos provocados pelo plano de rotas, muitos autores se dedicaram à solução do problema de roteirização de veículos (VRP - Vehicle Routing Problem), que segundo Matos Junior et al. (2014), possibilita um melhor planejamento de rotas, a partir de parâmetros importantes de decisão, como número de veículos, quilometragem rodada, consumo de combustível, gasto de manutenção, dentre outros.

Por este e outros motivos a literatura apresenta diversos algoritmos (ou métodos) computacionais, cada um seguindo suas próprias linhas de raciocínio e critérios de decisão (objetivos), como é o caso das heurísticas propostas por Solomon (1987). Para Silva Júnior (2013), a existência dos mais diversos métodos possibilita a obtenção de resultados que minimizem a utilização de recursos específicos dentro da cadeia de suprimentos, como a quantidade de veículos utilizada ou mesmo a distância total percorrida. Entretanto, por vezes, a diversidade dos referidos métodos leva à 
existência de uma vasta gama de soluções a serem selecionadas pelo gestor. $\mathrm{O}$ principal agravante é que o gestor não conhece o desempenho dessas soluções em relação aos critérios importantes para sua empresa.

Para avaliar qual dos resultados obtidos é o mais satisfatório, os gestores costumam utilizar parâmetros que atendam aos seus objetivos, como a redução de custos e de tempos de rota, porém por vezes tais parâmetros não são genéricos o bastante para serem reaplicados em outras empresas e nem mesmo para definir quais métodos levam a resultados realmente efetivos.

Objetivo Geral: Comparara planos de rotas proveniente dos métodos mais comuns de roteirização de veículos com janela de tempo a partir dos parâmetros identificados na literatura

Objetivos Específicos: Pesquisar os métodos de roteirização de veículos com janela de tempo mais conhecidos; identificar na literatura os parâmetros de desempenho dos planos de rotas mais difundidos pelos autores; implementação computacional dos principais métodos identificados; Realização de testes com os métodos implementados, visando a comparação dos mesmos a partir dos parâmetros identificados na literatura.

2. Materiais e Métodos: A realização da pesquisa foi realizada em 4 etapas sendo:

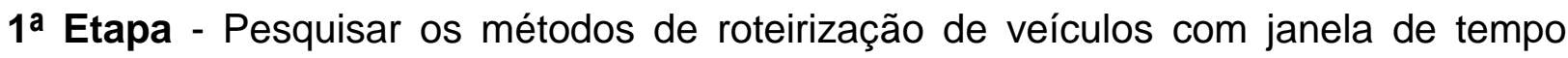
mais conhecidos, realizado levantamento bibliográfico sobre os problemas de roteirização de veículos com janelas de tempo (VRPTW). $\mathbf{2}^{\mathbf{a}}$ Etapa - Identificar na literatura os parâmetros de desempenho dos planos de rotas mais difundidos pelos autores para comparar as soluções dos métodos de VRPTW. $3^{\text {a }}$ Etapa Implementação computacional dos principais métodos identificados no programa SCILAB, devido ser de implementação rápida (por usar linguagem de alto nível) e por te sua distribuição gratuita. $4^{\text {a }}$ Etapa - Realização de testes com os métodos implementados, visando a comparação dos mesmos a partir dos parâmetros identificados na literatura baseados nas 168 instâncias de Solomon (1987) disponibilizadas no site NETWORKING AND EMERGING OPTIMIZATION (2013).

A partir de todas as etapas anteriores, foram avaliados e os indicadores de desempenho que foram utilizados para comparar os algoritmos selecionados para o teste deste estudo, que foram os três propostos por Solomon (1987). No planejamento do experimento foram elaborados 15 casos distintos para os parâmetros Delta, das heurísticas selecionadas, reunidos na Tabela 2 variando-se as constantes entre 0 e 1 , sendo o 1 de muita relevância para o caso e de 0 como não tão relevante para o caso.

Tabela 2: Constantes de ponderação para o experimento

\begin{tabular}{|c|c|c|c|c|c|c|c|c|c|c|c|c|c|c|c|}
\hline \multirow[t]{2}{*}{ Deltas } & \multicolumn{15}{|c|}{ Casos } \\
\hline & 1 & 2 & 3 & 4 & 5 & 6 & 7 & 8 & 9 & 10 & 11 & 12 & 13 & 14 & 15 \\
\hline 1 & 1 & 0 & 0 & 0,25 & 0,25 & 0,5 & 0,25 & 0,25 & 0 & 0 & 0,75 & 0,75 & 0,5 & 0,5 & 0 \\
\hline 2 & 0 & 1 & 0 & 0,25 & 0,5 & 0,25 & 0,75 & 0 & 0,25 & 0,75 & 0 & 0,25 & 0,5 & 0 & 0,5 \\
\hline 3 & 0 & 0 & 1 & 0,5 & 0,25 & 0,25 & 0 & 0,75 & 0,75 & 0,25 & 0,25 & 0 & 0 & 0,5 & 0,5 \\
\hline
\end{tabular}

Fonte: Autores (2018) 
É válido ressaltar que a análise dos dados foi realizada em um primeiro momento, considerando todos os resultados obtidos, independentemente do caso proposto, da quantidade de clientes, de suas janelas e da dispersão dos clientes - Clusters, R e mistas RC.

\section{Indicadores para os Planos de Rota}

Com base no estudo de Grüdtner (2005), Rey (1999), Bowersox e Closs (2001), Ballou (2010), Christopher (1997), Kaplan e Norton (1997), Hijjar, Gervásio e Figueiredo (2005) e Associação ECR Brasil (1998), pode-se categorizar os indicadores de desempenho nas dimensões de Custo, Produtividade, Qualidade e Tempo, expressos os indicadores na Tabela 3.

Tabela 3 - Métricas para plano de rotas

\begin{tabular}{|c|c|c|}
\hline \multicolumn{3}{|c|}{ Métricas para plano de rotas } \\
\hline Dimensões & Indicador & Modo de calcular \\
\hline \multirow{2}{*}{ Custo } & $\begin{array}{l}\text { Custo por distância } \\
\text { percorrida }\end{array}$ & $C_{d}=\theta \times \sum^{V} d_{v}$ \\
\hline & $\begin{array}{l}\text { Custo por tempo } \\
\text { em trânsito }\end{array}$ & $c_{t}=\delta \times \sum_{v=1}^{V} b_{0}, v$ \\
\hline \multirow{3}{*}{ Produtividade } & 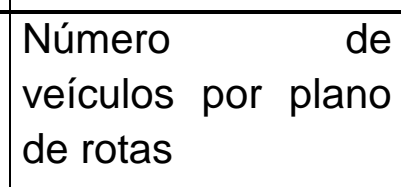 & V \\
\hline & $\begin{array}{l}\text { Ociosidade média } \\
\text { de tempo por } \\
\text { veículo }\end{array}$ & $\begin{array}{l}b_{\text {máx }}=\operatorname{máx}\left\{b_{o_{i}}\right\} / v \in[1, \ldots, V] \\
o_{t}=\frac{1}{V} \times\left(\sum_{v=1}^{V} \frac{b_{o} \operatorname{má} x-b_{o}, v}{b_{\max }}\right)\end{array}$ \\
\hline & 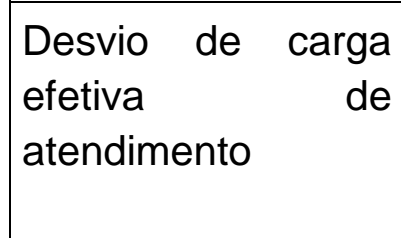 & $\begin{array}{c}D_{w}=\frac{1}{w_{i}} \times \sum_{v=1}^{V}\left|w_{i}-\sum_{\Omega=1} S_{\Omega}, v\right| / \\
\Omega_{v} \in\left[1, \ldots, N_{v}\right] \in[1, \ldots, V]\end{array}$ \\
\hline \multirow{2}{*}{$\begin{array}{l}\text { Qualidade e } \\
\text { Tempo }\end{array}$} & $\begin{array}{l}\text { Agilidade no } \\
\text { atendimento }\end{array}$ & $A g_{i}=\frac{1}{N} \times \sum_{i=1}^{N} \frac{L_{i}-B_{i}}{L_{i}-E_{i}} \times 100 \%$ \\
\hline & \begin{tabular}{|l|} 
Ociosidade \\
Programada
\end{tabular} & $o_{p}=\sum_{v} \sum_{\Omega v} \frac{\operatorname{má} x\left\{E_{\Omega V}-b_{\Omega v}, 0\right\}}{b_{o}, v}$ \\
\hline
\end{tabular}


Fonte:Autores (2018)

Onde: $L_{\bar{i}}=$ Instante do fechamento da janela de tempo; $E_{\bar{i}}=$ Instante de abertura da janela de tempo; $B_{i}=$ Instante efetivo do início do atendimento ao cliente; $V=$ Número total de veículos em um plano de rotas; $v=$ Número de veículos; $b_{i=}$ Instante de chegada do veículo no cliente; $b_{o, v}=$ Instante de chegada do veículo v ao armazém; $b_{o \text { Máx }}=$ Instante máximo de chegada do veículo $\mathrm{v}$ ao armazém; $r=$ Todos os clientes que pertencem à rota desse veículo v; $\theta=$ Estimativa de custo por unidade de distância percorrida; $\delta=$ Estimativa de custo por unidade de tempo que o veículo apresenta quando está fora da empresa; $W I=$ Carga efetiva ideal; $\Omega v=$ Conjunto de clientes pertencentes a rota do veículo $\mathrm{v} ; \Omega \Omega, v=$ Estimativa do tempo de atendimento de cada cliente $v$ para uma determinada rota $\Omega$.

Resultados: Tendo realizado os testes e obtendo os resultados, fez-se testes de correlação entre os indicadores, em que se viu correlações fracas entre eles.

A comparação dos desempenhos em cada indicador foi medida por meio do cálculo do desvio percentual médio do desempenho de cada algoritmo em relação ao método que obteve o melhor desempenho d\%, em que na Tabela 5 está expressa a frequência com que cada heurística foi a melhor em cada indicador e a Tabela 6 expressando a média dos desvios quando não foi o melhor resultado. $\mathrm{O}$ d\% é calculado pela Equação 1 para os indicadores custo com deslocamento, o custo com o tempo e a quantidade de rotas e a Equação 2 para os demais, onde $X_{\text {pideal }}$ é o melhor valor que o indicador recebeu dentro do conjunto de resultados de um mesmo problema. p é o problema estudado dentro de todo o conjunto $\mathrm{P}$ representado pelas instâncias de Solomon (1987) e d\% é o desvio percentual médio:

$$
\begin{aligned}
& \mathrm{d} \%=\frac{\sum_{p=1}^{P}\left(X_{p i}-X_{p i d e a l ~}\right) \div \text { Xpideal }}{\Gamma^{P}} \times 100 \% \quad \text { (Equação 1) } \\
& \mathrm{d} \%=\frac{\sum_{p=1}^{P} X p i}{P_{\text {Xpideal }}} \times 100 \% \quad \text { (Equação 2) }
\end{aligned}
$$

Tabela 5 - Frequência relatíva com que os métodos recebem destaque

\begin{tabular}{|l|l|l|l|l|l|l|l|}
\hline Método & Cd & Ct & V & Ot & Dw & Agi & Op \\
\hline $\begin{array}{l}\text { Vizinho } \\
\text { Próximo }\end{array}$ & $2 \%$ & $10 \%$ & $25 \%$ & $31 \%$ & $30 \%$ & $20 \%$ & $69 \%$ \\
\hline Economias & $88 \%$ & $0 \%$ & $2 \%$ & $12 \%$ & $10 \%$ & $58 \%$ & $11 \%$ \\
\hline Inserção & $10 \%$ & $89 \%$ & $73 \%$ & $56 \%$ & $60 \%$ & $22 \%$ & $20 \%$ \\
\hline
\end{tabular}

Fonte: Autores (2018)

\begin{tabular}{|c|c|c|c|c|c|c|c|}
\hline Método & Cd & $\mathrm{Ct}$ & V & Ot & Dw & Agi & Op \\
\hline $\begin{array}{l}\text { Vizinho Mais } \\
\text { Próximo }\end{array}$ & $82 \%$ & $616 \%$ & $222 \%$ & $13 \%$ & $139 \%$ & $1893 \%$ & $58 \%$ \\
\hline Economias & $2 \%$ & $991 \%$ & $417 \%$ & $15 \%$ & $173 \%$ & $207 \%$ & $468 \%$ \\
\hline Inserção & $80 \%$ & $3 \%$ & $9 \%$ & $9 \%$ & $73 \%$ & $2411 \%$ & $2455 \%$ \\
\hline
\end{tabular}

Tabela 6 - Desvio percentual médio em relação ao melhor resultado

Fonte: Autores (2018) 
Embasando-se nas Tabelas 5 e 6, percebe-se que o método das economias teve destaque no custo de distância total percorrida e na agilidade, com melhor desempenho em $88 \%$ e em $58 \%$ dos casos, respectivamente. Seu desvio médio em relação ao custo de distância foi de $2 \%$, revelando que esse é um bom método para quem tem preocupação em reduzir as distâncias percorridas por seus veículos.

Em contrapartida, o método de inserção teve os melhores resultados em 4 dos indicadores propostos, representando $89 \%$ dos casos em custo com tempo, $73 \%$ em quantidade de rotas, $56 \%$ em ociosidade média e $60 \%$ em carga média, sendo que os desvios em relação ao melhor resultado, se pautaram em 3\% para o custo total, $9 \%$ em quantidade de rotas, $9 \%$ ociosidade média e $73 \%$ em carga média, que apesar de ser alto o desvio foi o menor encontrado quando comparado com os demais métodos. Logo este é o método mais indicado para quem deseje rotas rápidas, com poucos veículos e com baixa ociosidade.

6. Conclusão: A presente pesquisa propôs sete indicadores de desempenhos para Problemas de Roteirização com Janelas de Tempo - VRPTW. Para isso, foi necessário um estudo dos principais métodos existentes de solução para problemas de roteirização de veículos e dos principais conceitos de desempenho das rotas. Obteve-se de resultado do estudo 7 indicadores que medem as dimensões de custo, produtividade, qualidade e tempo.

Vale ressaltar também que dos três métodos testados, a inserção apresentou, de forma geral, o melhor desempenho segundo os indicadores propostos, pois mostrou ser melhor em relação aos demais métodos em $89 \%$ dos casos em custo total, $73 \%$ em quantidade de rotas, $56 \%$ em ociosidade média e $60 \%$ em carga média, sendo que os desvios em relação ao melhor resultado, se pautaram em 3\% para o custo total, $9 \%$ em quantidade de rotas, $9 \%$ ociosidade média e $73 \%$ em carga média. Sendo assim, com este trabalho, é possível que um gerente possa avaliar e escolher um plano de rotas baseado no melhor desempenho que busca.

Referências: ASSOCIAÇÃO ECR BRASIL. ECR: visão geral. São Paulo, 1998. BALLOU, R. H. Gerenciamento da Cadeia de Suprimentos I Logística Empresarial. São Paulo: Bookman, 2006.

BALLOU, Ronald H. Gerenciamento da Cadeia de Suprimentos/ logística. 5 ed. Porto Alegre: Bookman, 2010.

BOWERSOX, Donald; CLOSS, David. Logística empresarial: o processo de integração da cadeia de suprimento. São Paulo: Atlas, 2001.

CHRISTOPHER, Martin. Logística e gerenciamento da cadeia de suprimentos: estratégias para a redução de custos e melhoria dos serviços. São Paulo: Pioneira, 1997.

GRÜDTNER, Israel S. Modelo de avaliação do desempenho logístico de operadores logísticos. 2005. 103 f. Dissertação (Mestrado em Engenharia de Produção) - Programa de Pós-Graduação em Engenharia de Produção, Universidade Federal de Santa Catarina, Florianópolis, 2005.

HIJJAR, Maria F.; GERVÁSIO, Marina H.; FIGUEIREDO, Kleber F. Mensuração de desempenho logístico e o modelo World Class Logistics - Parte 1 e 2. Disponível 
em: <http://www.cel.coppead.ufrj.br/new/fs_pesquisa.htm >. Acesso em: 18 de julho 2018.

HOLMBERG, Stefan. A systems perspective on supply chain measurements. International Journal of Physical Distribution \& Logistics Management, v. 30, n. 10, p. 847-868, 2000.

KAPLAN, Robert S.; NORTON, David P. A estratégia em ação: balanced scorecard. Rio de Janeiro: Campus, 1997.

MATOS JUNIOR, Carlos Alberto et al. A Contribuição da Roteirização na Redução de Custos Logísticos e Melhoria do Nível de Serviços em Empresa do Segmento Alimentício no Ceará. ABCustos, v. 9, n. 3, 2014.

NETWORKING AND EMERGING OPTIMIZATION. Capacitated VRP with Time Windows Instances. São Paulo, 2013. Disponível em: < http://neo.lcc.uma.es/vrp/vrpinstances/capacitated-vrp-with-time-windows-instances/> Acesso: 01/07/2018.

REY, Maria F. Indicadores de desempenho logístico. Revista Logmam, São Paulo, maio/jun. 1999.

SILVA JÚNIOR, Orivalde Soares da. Roteirização Estática e Dinâmica de Veículos com Janelas de Tempo. 2013. Tese de Doutorado. PUC-Rio.

SOLOMON, M. M. Algorithms for the Vehicle Routing and Scheduling Problems with Time Window Constraints. Operations Research, v.35, n.2, p.254-265. 1987.

Palavras-Chave: Otimizar um parâmetro, Indicadores, plano de rotas; Avaliação de desempenho. 


\title{
CONSTRUÇÃO DE UM SECADOR REFRACTANCE WINDOW® PARA PRODUZIR AÇAÍ EM PÓ COM MELHOR RETENÇÃO NUTRICIONAL
}

\author{
Nome do(a) bolsista: Lucileno Rodrigues da Trindade \\ Nome do(a) Orientador(a): Diego Aires da Silva \\ Grupo de Pesquisa: Tecnologia e inovação para a industria de alimentos
}

Resumo: Açaí em pó (Euterpe oleracea Mart.) foi obtido pelo processo de secagem refractance window. As propriedades físico-químicas Umidade (\%), Cinzas (\%), Lipídios (\%), Proteína total (\%), Carboidratos totais (\%), assim como, Compostos Fenólicos Totais (mg/100g), Atividade antioxidante (DPPH) $\mu \mathrm{g} / \mathrm{g}$ DPPH, Atividade antioxidante (ABTS) $\mu$ Mtrolox/g, Antocaninas monoméricas totais (mg/100g). Os resultados demonstraram que os parâmetros avaliados tiveram menor valor no tratamento em estufa com circulação de ar, sendo a maior perda na avaliação química foi com relação às antocianinas monoméricas totais. O sistema Refractence Window proporcionou mais eficiência permitindo a visualização da secagem das amostras de açaí, podendo ser uma alternativa promissora para a obtenção de alimentos desidratados.

Introdução: O açaizeiro é uma palmeira da família Arecaceae bastante difundida e cultivada na Amazônia brasileira. Ocorre de forma espontânea na região amazônica e tem ganhado destaque pela importância econômica regional, sobretudo para o Estado do Pará onde a produção e a comercialização da polpa movimentam grandes mercados (Neves et al., 2015).

O açaizeiro (Euterpe oleracea Mart.) é uma palmeira tropical oriunda da Amazônia. Seus frutos são utilizados principalmente na produção da polpa de açaí, um alimento nutritivo e muito consumido pela população amazônica (Alexandre et al., 2004).

O açaí (Euterpe oleracea) está entre as principais frutas de destaque nacional e internacional, por ser considerada uma "superfruta", devido a sua composição nutricional, rica em fibras, lipídeos e compostos fenólicos, que podem estar associados à prevenção de doenças (Yamaguchi et al., 2015).

No entanto, esse fruto apresenta alta perecibilidade, sendo necessário implementar métodos que permitam seu processamento, de forma a manter suas características nutricionais e físico-químicas, além de permitir seu consumo em localidades longínquas da região produtora (Souza, 2015).

Portanto, optou-se pela produção de açaí em pó utilizando um secador portátil que emprega a tecnologia Refractence WindoW (RW), visando garantir redução de custos com transporte e armazenamento - uma vez que nesse caso o açaí apresenta volume menor - e permitir a obtenção de um produto com características sensoriais similares à polpa, ao ser reidratado. 
Objetivo(s): Nesse contexto, o objetivo deste trabalho foi construir um secador portátil Refractance Window (RW) para a produção de açaí em pó com melhor retenção nutricional, realizando e avaliando sua composição centesimal e de componentes bioativos.

Material e Métodos: O secador portátil foi construído nas instalações do Laboratório de alimentos da Universidade do Estado do Pará, campus XVIII-Cametá, utilizando para sua construção os princípios do equipamento comercial de secagem por Refractance Window, com a diferença de ser em menor escala e operar em regime descontínuo. O secador portátil consiste em uma estrutura metálica com formato retangular, que funciona como um reservatório de água quente, sobre o qual foi preso o filme Teflon (marca YALY) com $0.25 \mathrm{~mm}$ de espessura. O reservatório de água será aquecido de modo indireto através da passagem de água quente por um sistema de circulação acoplado a um banho termostático (modelo, marca) através da serpentina de cobre.

O material utilizado para a confecção da serpentina foi o tubo de cobre $3 / 8$ da marca Eluma, com 9,52 mm de diâmetro e $0,79 \mathrm{~mm}$ de espessura. Foram utilizados tubos siliconados incolores para acoplar o banho à serpentina e para a entrada e saída de água na estrutura metálica. Foram utilizadas peças de alumínio como suporte para ajudar na fixação do filme Teflon à estrutura metálica do reservatório. O filme Teflon foi fixado na parte superior do reservatório, mantendo sua face inferior em contato direto com a água, enquanto sua face superior serve de apoio para o espalhamento das amostras a serem secas. Para a vedação da estrutura metálica do secador foi aplicada cola adesivo silicone cinza, para altas temperaturas da marca Tek Bond. Utilizou-se para a fixação final parafusos metálicos com porcas.

A polpa de açaí foi coletada em estabelecimento comercial do fruto, localizado na cidade de Cametá-PA, e logo encaminhado ao Laboratório de Alimentos da Universidade do Estado do Pará para serem secas por Refractence Window em estufa a $80^{\circ} \mathrm{C}$, e posterior realização da composição centesimal.

O teor de carboidratos foi obtido por diferença, conforme descrito por Brasil (2001). E a aw foi realizada por leitura direta em termohigrômetro digital (Aqualab Séries 3TE, modelo $4 \mathrm{TEV})$, tendo controle interno de temperatura $\left(25^{\circ} \mathrm{C}\right)$. Todas as análises foram realizadas em triplicata.

A umidade foi determinada a partir da secagem em estufa com circulação de ar a $105^{\circ} \mathrm{C}$ durante 12 horas, até obtenção de massa constante e o teor de cinzas das amostras foi realizado a partir do aquecimento em mufla a $550^{\circ} \mathrm{C}$ por 6 horas, de acordo com o Instituto Adolfo Lutz (2008). A determinação do teor de lipídios foi realizada por extração da fração lipídica utilizando solvente orgânico hexano em aparelho extrator tipo Soxhlet durante 4 horas. O método de extração com solvente a quente está baseado em três etapas: extração da gordura da amostra com solvente, eliminação do solvente por evaporação e a gordura foi quantificada por diferença de peso (Instituto Adolfo Lutz, 2008). 
A determinação de proteínas foi realizada pelo método Micro-Kjeldahl, que está baseado na determinação do nitrogênio total, composto pelas etapas de digestão, destilação e titulação com ácido clorídrico a 0,02N.

A caracterização química foi realizada com o objetivo de avaliar quais seriam as perdas resultantes do processamento do suco de açaí em termos de compostos fenólicos, antocianinas monoméricas totais e atividade antioxidante.

A concentração de compostos fenólicos totais foi determinada pelo método o teor de compostos fenólicos totais foi determinado pelo método espectrofotométrico de FolinCiocalteau utilizando ácido gálico como padrão de referência. Foram adicionados 1,25 $\mathrm{mL}$ do reagente Folin-Ciocaulteau (diluído 1:10 em água destilada) em $1 \mathrm{~mL}$ de solução extrato. Após $2 \mathrm{~min}, 1 \mathrm{~mL}$ da solução de carbonato de sódio a 7,5\% foram adicionados, e as absorbâncias lidas no comprimento de onda de $760 \mathrm{~nm}$ após 1,5h sob abrigo de luz em espectrofotômetro. Os resultados foram expressos em $\mathrm{mg}$ de ácido gálico equivalentes por $100 \mathrm{~g}$ de extrato seco em comparação com a curva padrão de ácido gálico.

As antocianinas monoméricas totais foram determinadas utilizando-se o protocolo de espectrofotometria de $\mathrm{pH}$ diferencial (Giusti; Wrolstad, 2001), pelas medidas das absorbâncias à 520 e 700 nm em espectrofotômetro com soluções tampão de pH 1,0 e pH 4,5. A quantificação de antocianinas foi calculada pela equação, sendo expresso em $\mathrm{mg}$ de cianidina-3-glicosídica equivalentes por $100 \mathrm{~g}$.

$c=\frac{A \times M \times F d \times 103}{\varepsilon \times 1}$

Onde C é o conteúdo de antocianinas (mg/100g); A é a diferença de absorbâncias nos comprimentos de onda de 520 e $700 \mathrm{~nm}$ nos dois pHs analisados[A = (A520-A700) $\mathrm{pH} 1,0$ - (A520-A700) $\mathrm{pH} 4,5)]$; $\mathrm{M}$ é a massa molar da cianidina-3-glicosídica $(449,2$ g.mol-1); Fd é o fator de diluição; 103 é a conversão da massa para $\mathrm{mg}$; $\varepsilon$ é a absortividade molar da cianidina-3-glicosídica (26900 L.mol-1.cm-1); 1 é a espessura da cubeta $(\mathrm{cm})$.

\section{Captura do radical livre ABTS}

Preparou-se uma solução estoque de ABTS $7 \mathrm{mM}$ em persulfato de potássio 2,45 mM, que foi armazenada em local escuro e à temperatura ambiente por $12-16$ horas, segundo descrito por Re et al. (1999). Antes da realização das análises, essa solução foi diluída em etanol a fim de obter a absorbância de $0,70 \pm 0,05$ no comprimento de onda de $734 \mathrm{~nm}$. Em seguida, adicionaram-se $3 \mathrm{~mL}$ da solução diluída de ABTS em 30 $\mu \mathrm{L}$ de extrato. $\mathrm{O}$ espectrofotômetro ( $\mathrm{HACH}$, Modelo DR 5000, Alemanha) foi calibrado com a solução de etanol. $O$ cálculo da atividade antioxidante, expresso em $\mu \mathrm{M}$ Trolox por $\mathrm{g}$ de amostra seca, foi realizado a partir da Equação

Inibição $(\%)=($ A controle - Aamostra $) \times 100$

Onde, A controle e A amostra são as absorbâncias do controle (sem extrato) e das amostras com extrato, respectivamente.

Após obtenção de valores calculados, utilizou-se a curva padrão Trolox como comparação, de forma a expressar a atividade antioxidante em $\mu \mathrm{M}$ de Trolox equivalentes por grama de amostra seca.

\section{Captura do radical livre DPPH}


A atividade antioxidante foi determinada pela captura do radical livre DPPH, segundo a metodologia descrita por Re et al., (1999) com adaptações. O extrato foi preparado diluindo-se $2 \mathrm{~g}$ de amostras em balão de $50 \mathrm{~mL}$, utilizando a Sheck (Cielanb, modelo CE-725B) por $2 \mathrm{~h}$ com soluções metanol $50 \%$ e acetona $70 \%$, respectivamente. Posteriormente, alíquotas que variaram de 30 a $100 \mu \mathrm{L}$ de extrato foram adicionadas a 2,9 mL de solução metanólica de DPPH 6×10-5 M. A reação ocorreu por $30 \mathrm{~min}$, ao abrigo da luz em temperatura ambiente. Após esse tempo, as absorbâncias das amostras foram lidas em espectrofotômetro no comprimento de onda de $515 \mathrm{~nm}$, sendo o equipamento calibrado com metanol. Os resultados da atividade antioxidante foram expressos em $\mu \mathrm{g}$ por grama de DPPH.

\section{Resultados e Discussão}

Tabela 1 - Resultados da composição centesimal do açaí em pó e in natura expressos em base seca.

\begin{tabular}{llll}
\hline Parâmetros & Açaí RW & Açaí estufa & Açaí In natura \\
\hline Umidade (\%) & $3,85 \pm 0,24$ & $4,65 \pm 0,30$ & $90,54 \pm 0,01$ \\
Cinzas (\%) & $2,80 \pm 0,06$ & $1,85 \pm 0,06$ & $0,22 \pm 0,03$ \\
Lipídios (\%) & $46,55 \pm 1,36$ & $44,22 \pm 1,13$ & $52,97 \pm 0,96$ \\
Proteína total (\%) & $11,89 \pm 0,11$ & $11,54 \pm 0,28$ & $14,11 \pm 0,10$ \\
Carboidratos totais (\%) & 34,91 & 37,74 & 57,84 \\
Atividade de água & $0,4588 \pm 0,01$ & $0,4866 \pm 0,00$ & $0,9786 \pm 0,01$ \\
\hline
\end{tabular}

Segundo a classificação do padrão de identidade e de qualidade para a polpa de açaí definido pelo Ministério da Agricultura, Pecuária e Abastecimento (Mapa, 2000), a matéria-prima utilizada encontra-se na denominação de açaí popular por apresentar um teor de sólidos de 8 a 11\%.

A amostra em RW analisada quanto ao teor de umidade apresentou baixo valor em comparação com os demais métodos. Souza (2015), encontrou valor de $80,57 \%$ no teor de umidade em estudo sobre a secagem de polpa de açaí pelo método Cast-tape drying, isso pode ser justificado pelo sitema de exaustão presente neste método que pode acelerar o processo de desidratação.

O maior conteúdo de cinzas foi obtido também pelo método de secagem RW, cujo valor foi de $2,80 \%$ e está mais próximo dos resultados obtidos por Souza (2015), sendo este valor igual a 3,53\%. Yuyama et al., (2011) realizou a caracterização físicoquímica do suco de açaí e encontrou como valor de 2,70\% para maior nível de conteúdo de cinzas encontrado. Com relação ao teor de lipídios, Souza (2015) encontrou valor de $46,79 \%$, resultado este similar ao encontrado no presente estudo pelo método RW.

Souza (2015), estudou também o teor de proteína total da polpa de açaí e obteve valor 9,58\% para este parâmetro, resultado este inferior aos obtidos no presente trabalho tanto pelo método RW $(11,89 \%)$ quanto em estufa $(11,54 \%)$.

O menor valor de carboidrato foi obtido pelo método de secagem por RW, havendo, portanto, a possibilidade de consumo do produto como sendo um alimento funcional na dieta. Quanto a atividade de água o sistema de secagem RW apresentou o menor 
valor, isso mostra a eficiência do método levando em consideração o tempo e temperatura de desidratação.

\section{Avaliação química de componentes bioativos}

Tabela 2 - Resultados referentes às análises de componentes bioativos.

\begin{tabular}{|c|c|c|c|c|}
\hline Amostra & $\begin{array}{l}\text { Compostos } \\
\text { Fenólicos } \\
\text { Totais } \\
(\mathrm{mg} / 100 \mathrm{~g})\end{array}$ & $\begin{array}{l}\text { Atividade } \\
\text { antioxidante } \\
\text { (DPPH) } \quad \mu \mathrm{g} / \\
\text { DPPH }\end{array}$ & $\begin{array}{l}\text { Atividade } \\
\text { antioxidante } \\
\text { g }(\text { ABTS) } \\
\mu \text { Mtrolox/g }\end{array}$ & $\begin{array}{l}\text { Antocaninas } \\
\text { monoméricas } \\
\text { totais } \\
(\mathrm{mg} / 100 \mathrm{~g})\end{array}$ \\
\hline In natura & $441,63 \pm 9,85$ & $2381,7 \pm 281,40$ & $138,55 \pm 37,16$ & $47,59 \pm 0,71$ \\
\hline $\mathrm{RW} 80^{\circ} \mathrm{C}$ & $402,85 \pm 1,76$ & $2018,2 \pm 48,31$ & $127,64 \pm 8,26$ & $34,15 \pm 0,89$ \\
\hline Estufa $80^{\circ} \mathrm{C}$ & $284,72 \pm 2,46$ & $1972,6 \pm 35,44$ & $113,11 \pm 4,48$ & $3,55 \pm 0,17$ \\
\hline
\end{tabular}

$\mathrm{Na}$ Tabela 2 estão expressos os valores encontrados para compostos fenólicos totais, antocianinas monoméricas totais e atividade antioxidante determinadas a partir de cada condição estudada no presente trabalho.

O suco de açaí in natura apresentou valores próximos em comparação com o método RW tanto de compostos fenólicos, antocianinas monoméricas totais e atividade antioxidante. Isso pode ser justificado pelo fato de as partículas de pó apresentarem uma maior área superficial, facilitando a extração, o que reflete na sua quantificação, assim como o menor tempo de secagem o que permite uma exposição mais curta da matéria-prima com o meio externo. Houve significativa redução nos compostos fenólicos totais e antocianinas no tratamento em estufa a $80^{\circ} \mathrm{C}$, isso pode ser explicado devido ao tempo maior de secagem e também pelo fato de não haver as três formas de transmissão de calor como em RW.

Silva e Rogez (2013) relataram uma concentração de 397,7 mg/100g de extrato seco e $20,7 \mathrm{mg} / 100 \mathrm{~g}$ extrato seco para o ácido gálico e a cianidina-3-glicosídeo para o extrato vegetal de Euterpe oleracea, respectivamente. Esses valores são inferiores aos encontrados no presente trabalho tanto compostos fenólicos totais quanto em antocianinas monoméricas totais. O açaí in natura permaneceu com uma maior concentração de compostos bioativos em função de não passar por exposição a temperaturas elevadas como nos outros tratamentos.

Mouro (2018), realizou estudo sobre a polpa açaí e obteve como resultado da atividade antioxidante ABTS valor de 236,21 $\mu \mathrm{M}$ Trolox/g. O valor obtido no presente trabalho foi de 127,64 pelo método RW, essa diferença pode ser justificada em virtude de as análises terem sido feitas no período do inverno, estação esta que não é propícia para a colheita de açaí de melhor qualidade.

Conclusão: O secador mostrou-se eficiente para a secagem do suco de açaí, mantendo os valores de composição centesimal, bioativos e sensoriais como principalmente a cor do fruto, próximos ao in natura. O sistema Refractence Window possui simples forma de montagem, baixo custo, proporcionando melhor praticidade e maior eficiência na secagem, apesar do método de avaliação de temperatura tenha sido o mesmo para ambos os casos. Todos os parâmetros avaliados tiveram menor valor no tratamento em estufa com circulação de ar, sendo a maior perda na avaliação química foi com relação às antocianinas monoméricas totais. O sistema Refractence Window além de proporcionar mais praticidade e eficiência permite a visualização da 
secagem das amostras de açaí, podendo ser uma alternativa promissora para a obtenção de alimentos desidratados.

\section{Referências bibliográficas.}

Alexandre, Deise; Cunha, Rosiane L.; Hubinger, Miriam D. Conservação do açaí pela tecnologia de obstáculos. Ciência e tecnologia de Alimentos, v. 24, n. 1, p. 114-119, 2004.

Giusti, M.; Wrolstad, R.E. Characterization and Measurement of anthocyanins by UVVisible Spectroscopy. Current Protocols in Food Analytical Chemistry, vol. 61, p. 322-326, 2001.

Instituto Adolfo Lutz. Métodos Físico-Químicos para Análise de Alimentos. 4. ed. São Paulo: Instituto Adolfo Lutz, 2008.

Mapa. Ministério da Agricultura, Pecuária e Abastecimento. Regulamento Técnico Geral para fixação dos Padrões de Identidade e Qualidade para polpa de fruta. Brasília, 2000.

Mouro, Viviane Gorete Silveira. Ação antioxidante do açaí (Euterpe oleracea MART.) Frente ao estresse oxidativo induzido pelo cádmio no testículo de camundongos adultos. 2018. Tese de Doutorado. Universidade Federal de Viçosa.

Neves, Leandro Timoni Buchdid Camargo et al. Quality of fruits manually processed of açaí (Euterpe oleracea Mart.) and bacaba (Oenocarpus bacaba Mart.). Revista Brasileira de Fruticultura, v. 37, n. 3, p. 729-738, 2015.

$\mathrm{Re}, \mathrm{R}$. et al. Antioxidant activity applying an improved abts radical cation decolorization assay. Free Radical Biology and Medicine, v.26, n.9, p.1231-1237, 1999

Silva, J.J.M.; Rogez, H. Avaliação da estabilidade oxidativa do óleo bruto de açaí (Euterpe oleracea) na presença de compostos fenólicos

puros ou de extratos vegetais amazônicos. Química Nova, vol. 36, p. 400-406, 2013.

Souza, Paula Gimenez de et al. Produção e caracterização de açaí (Euterpe oleracea Mart.) desidratado em pó por cast-tape drying. 2015. Dissertação (mestrado em engenharia de alimentos) - Universidade Federal de Santa Catarina. Florianópolis, 2015.

Yamaguchi, Klenicy Kazumy de Lima et al. Amazon açaí: Chemistry and biological activities: A review. Food Chemistry, vol. 179, p. 137-151, 2015.

Yuyama, Lucia Kiyoko Ozaki et al. Caracterização físico-química do suco de açaí de Euterpe precatoria Mart. oriundo de diferentes ecossistemas amazônicos. Acta Amazonica, v. 41, n. 4, p. 545-552, 2011

Palavras-chave: Açaí, Euterpe oleracea, capacidade antioxidante. 


\section{ELABORAÇÃO DE HIDROLISADO PROTEICO ENZIMÁTICO A PARTIR DE RESÍDUOS DE PESCADO}

Nome dos Bolsistas: Nathalia Rodrigues Cardoso, Sheylle Marinna Martins Garcia Nome do(a) Orientador(a): Elen Vanessa Costa da Silva

Grupo de Pesquisa: Ciência e tecnologia de alimento na Amazônia oriental

Introdução: A hidrólise proteica tem como resultado a solubilização de proteínas, podendo ser desenvolvida com o objetivo de agregar valor, funcionalidade e ampliar a utilização de matérias-primas pouco valorizadas. O objetivo do trabalho foi elaborar um hidrolisado proteico enzimático utilizando resíduos de pescados com as enzimas Protezyn NP 800 e Brauzyn 100. Foram realizadas as análises microbiológicas, composição centesimal e a determinação do grau de hidrolise. As avaliações microbiológicas foram negativas para Salmonella spp, Staphylococcus coagulase positiva, na matéria prima e nos hidrolisados. Os resultados obtidos para umidade, proteínas, lipídios e cinzas para os resíduos foram 78,53\%; 63,21\%; 17,85\%;13,76\%. Os hidrolisados apresentaram teor de proteínas bruta de 60,6\% para Protezyn e $78,88 \%$ para Brauzyn. O controle de grau de hidrólise nos tempos (30,60, 90 e 120 min) ficaram em torno de 13,92\% para Protezyn NP 800 e 16,95\% Brauzyn 100. O estudo realizado utilizando matéria-prima de baixo valor comercial mostrou-se adequado para elaboração de hidrolisados proteicos podendo ser incluídos em produtos alimentícios. 


\title{
EFEITO DE PARAMETROS CLIMÁTICOS NA FENOLOGIA DE ESPÉCIES UTILIZADAS NA ARBORIZAÇÃO URBANA DA CIDADE DE CASTANHAL - PA
}

\author{
Nome dos bolsistas: Flávia Lemos da Silva Oliveira, Valéria Sousa de Lima \\ Nome do(s) Voluntário(s): Tibison da Silva Rocha \\ Nome do(a) Orientador(a): Eliane de Castro Coutinho \\ Grupo de Pesquisa: Análises Ambientais na Amazônia
}

Introdução: O estudo fenológico de espécies utilizadas na arborização urbana reúnem informações sobre mudanças morfológica das espécies, sendo a sazonalidade climática um fator relevante na fenologia urbana. As fenofases indicam presença ou ausência de regularidades, podendo ser base para o planejamento de ações silviculturais para melhorar as condições ambientais urbanas, com isso, objetivo do trabalho consiste em avaliar a influência de parâmetros climáticos na fenofases de espécies arbóreas utilizadas na arborização da cidade de Castanhal - PA. O estudo foi realizado às margens da BR-316, no município de Castanhal. A coleta de dados foi realizada in loco, os indivíduos foram selecionados de forma aleatória, identificados por meio de tinta spray amarela e numerados com plaquetas de plástico. Foi realizada amostragem de 20 indivíduos, sendo 5 indivíduos de 4 espécies diferentes para as avaliações fenológicas. As espécies observadas são a Castanhola, ou Chapéu de Sol (Terminalia catappa L.), Mangueira (Mangifera indica L.), Oiti (Licania tomentosa (Benth.) Fritsch) e Ipê amarelo (Handroanthus serratifolius (Vahl.) G. Nicholson), selecionados segundo o Manual de Arborização da Cidade de Belém. O acompanhamento fenológico e observação do tempo local foram realizados de 14 em 14 dias durante os meses de Outubro /2018 até Julho/2019, totalizando 22 observações. Foram observadas fenofases de Floração (botão floral e flores), Frutificação (frutos verdes, frutos maduros e dispersão) e Mudanças foliares (folhas novas, folhas maduras, desfolha parcial e desfolha total), utilizando o método de avaliação qualitativa, no qual se aplica a observação direta das plantas, considerando a presença (1) ou ausência (0) de apenas um evento biológico da fenofase em questão. Os dados de precipitação $(\mathrm{mm})$, temperatura $\left({ }^{\circ} \mathrm{C}\right)$ e umidade relativa do ar (\%) foram coletados do site do INMET, sendo apresentados por média mensal, fornecidos pela Estação Automática Castanhal A202. O estudo mostra que o período seco e período chuvoso são influentes nas fenofases das espécies, porém, alguns indivíduos não se comportam como encontrados na literatura. As espécies observadas produzem frutos aptos para propagação via semente, servindo de base para o manejo da arborização urbana.

Palavras chave: fenologia urbana, fenofases, parâmetros climáticos, silvicultura urbana 


\title{
COMPARAÇÃO DAS PROPRIEDADES DA MADEIRA DE DUAS ESPÉCIES DO GÊNERO CECROPIA
}

\author{
Nome dos bolsistas: José Cicero Pereira Júnior' Felipe Souza Oliveira \\ Nome do(a) Orientador(a): ledo de Souza Santos \\ Grupo de Pesquisa: Pobreza, educação e desenvolvimento regional
}

Introdução: $O$ objetivo desse trabalho foi avaliar as propriedades de duas das espécies de Cecropia (C. distachya e $C$. sciadophylla). Para cada espécie foram colhidas cinco árvores e confeccionados amostras da madeira para as análises: físicas, químicas e anatômicas das fibras, para física avaliou-se densidade básica e estabilidade dimensional, os testes seguiram a NBR 7190/97. Para a análises químicas as amostras foram transformadas em forma de serragem, para obtenção da fração 40 e 60 Mesh, foram feitas análises dos teores de extrativos totais, lignina e cinzas. Para as análises anatômicas utilizou-se o método de maceração onde se mediu o tamanho de 50 fibras para cada ponto amostrado sentido medula-câmbio. Obtendo-se densidades médias para as espécies de $0,33 \mathrm{~g} / \mathrm{cm}^{3}$ e $0,28 \mathrm{~g} / \mathrm{cm}^{3}$, respectivamente, ambas as espécies a densidade aumentou no sentido da base para o topo e da medula para o câmbio. Para contração linear teve-se 7,61\%, 3,13\% e 0,83\%. As duas espécies apresentam valores de teor de holocelulose de $65,84 \%$ a $77,38 \%$, que são valores próximos aos encontrados para espécies de Cecropia sp. Os valores entre as C. distachya e a C. schiadophylla tiveram variação de $39,53 \%$ em teor de cinzas e $2,08 \%$ em teor de extrativo respectivamente, de maneira geral, foram estatisticamente iguais para as espécies. Foram observadas diferenças estatísticas significativas nas dimensões das fibras entre a madeira juvenil e adulta para ambas as espécies. As espécies apresentam Teores de Cinzas e Lignina favoráveis para a produção de energia em forma de lenha ou carvão.

Introdução: A bacia amazônica, que abrange ecossistemas florestais e savânicos, ocupa uma área de cerca de 5 milhões de $\mathrm{km}^{2}$, incluindo a metade noroeste de Goiás, estima-se que existam na região cerca de 60.000 espécies de plantas, sendo mais de 2.500 espécies de árvores (BRASIL, 2008). Assim com uma enorme quantidade de espécies que se têm o interesse comercial para incluir no mercado.

O gênero Cecropia é uma espécie com grande quantidade na região amazônica, distribuído em 15 espécies, entre elas, Cecropia distachya Huber e Cecropia sciadophylla Mart. comuns em formações secundárias ou florestas degradadas apresentam características que favorecem seu manejo, tais como, alta densidade populacional após intervenções na floresta, rápido crescimento, permitindo ciclos de corte menores e em geral baixos diâmetros (Pereira, 2015), o que atribui a essas espécies um potencial uso como alternativa para produção de madeira que visem o mercado de painéis. 
Considerando-se que espécies do gênero Cecropia vem sendo utilizadas para laminação (Machado et al. 2018), porém ainda são poucas informações tecnológicas sobre a qualidade e a composição da madeira, comprometendo a sua utilização de forma mais eficiente. Os constituintes químicos da madeira estão relacionados à fragilidade da madeira, são os teores de celulose e lignina, uma vez que estão atrelados com as características mecânicas-físicas da madeira e seus subprodutos (BRAZ, et al., 2014).

Objetivo: $O$ objetivo desse trabalho foi avaliar as propriedades de duas das espécies de Cecropia (C. distachya e C. sciadophylla).

Material e Método: Os experimentos foram realizados no Laboratório de Engenharia Florestal, da Universidade do Estado do Pará - Campos VI. Para a realização dos mesmos, foram coletadas árvores das espécies $C$. distachya e $C$. sciadophylla em área de manejo florestal da Fazenda Shet, localizada no município de Dom Eliseu/PA. Para cada espécie foram colhidas cinco árvores, das quais confeccionou-se discos transversais de $5 \mathrm{~cm}$ de espessura nas posições correspondentes a 0,25, 50, 75 e $100 \%$ da altura comercial.

Para a análise das propriedades físicas, densidade básica da madeira e estabilidade dimensional da madeira, seguindo a NBR 7190/97- Projeto de Estruturas de Madeira, utilizou-se as seguintes orientações para confecção dos corpos-de-prova: orientados na seção transversal de dimensões nominais de $2,0 \mathrm{~cm} \times 3,0 \mathrm{~cm}$ e comprimento ao longo das fibras de $5,0 \mathrm{~cm}$.

As amostras foram transformadas em serragem, com o uso de um moinho tipo Wiley, selecionadas em peneiras classificatórias de serragem para obtenção da fração $40 \mathrm{e}$ 60 Mesh, para as análises dos teores de extrativos totais, lignina e cinzas. As normas utilizadas foram as NBR. O teor de holocelulose foi obtido pela diferença, conforme a Equação 1 (Neves et al., 2011):

$$
\text { Holocelulos } \mathrm{e}(\%)=100 \%-\text { Extrativos }(\%)-\text { Lignina }(\%)-\text { Cinzas }(\%)
$$

Para mensuração das dimensões das fibras utilizou-se o método de maceração de Franklin (Franklin 1945, modificado por KRAUS AND ARDUIN 1997). Foram medidas 50 fibras para cada ponto amostrado sentido medula-câmbio, o processo de análise seguiu as recomendações da IAWA Committee (1989).

Os dados foram analisados com estatística descritiva através do software Microsoft Excel, por meio da estimativa da média, desvio padrão e coeficiente de variação.

\section{Resultados e Discussão}




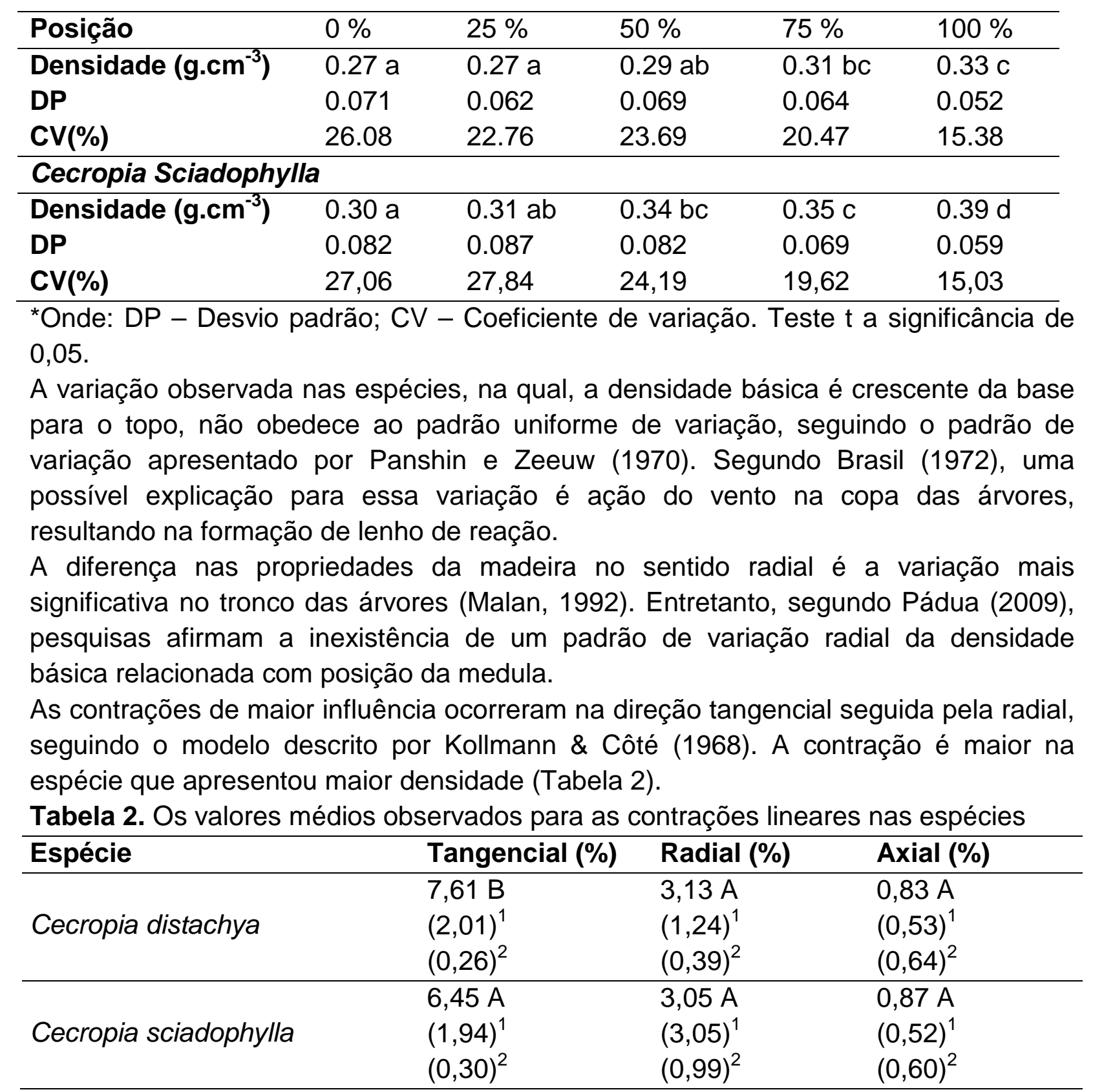

*Médias seguidas da mesma letra na mesma coluna, não diferem entre si, pelo teste de Tukey a $5 \%$ de significância. ${ }^{1}$ Valores entre os parênteses são os desvios-padrão. ${ }^{2}$ Valores entre os parênteses são os coeficientes de variação em (\%).

De acordo com os resultados para contração linear, houve diferença significativa entre as espécies para os valores verificados na direção tangencial, sendo que na direção radial e axial não ocorreu diferença entre si.

Por meio do teste de médias (Tabela 3 e 4), verificou-se as propriedades das duas espécies, sendo a C. sciadophylla que apresentou maior teores em porcentagens de cada teste.

As duas espécies apresentam valores de teor de holocelulose de 65,84\% a 77,38\%, como pode ser observado na tabela 3, que são valores próximos aos encontrados para espécies de Cecropia sp., Barrichelo \& Foelkel (1977) encontraram valores de 64,5\% para o teor de celulose, Pupo (2015) encontrou valor médio de 76,51\% para teor de 
holocelulose e o Teor de Lignina 20,81\% para cecropia palmata e que em comparação com a madeira de Eucalyptus grandis, não se diferenciou muito com teor de holoceluse $73,29 \%$ e Lignina $24,03 \%$.

De acordo com os resultados obtidos pode-se observar que os valores de cinzas de $1,44 \%$ e $1,03 \%$ para as espécies C. distachya e C. sciadophylla respectivamente, conforme Brand et al. (2013) teores de cinzas inferior a 5\%, é uma característica positiva encontrada na madeira para o uso energético, tanto na forma de lenha como para a produção de carvão vegetal.

Tabela 3. Caracterização química da madeira das cinco árvores de Cecropia sciadophylla.

\section{Cecropia distachya Huber}

\begin{tabular}{lllll}
\hline Amostras & TCinzas & Tlig & Textrat & Tholo \\
Médias & 1,44 & 23,19 & 10,63 & 64,74 \\
DP & 0,21 & 2,94 & 0,47 & 3,04 \\
EX & 12,68 & 4,43 & 4,69 \\
\hline Médias & 1,03 & 11,17 & 10,41 & 77,38 \\
DP & 0,09 & 1,90 & 1,17 & 1,12 \\
CV & 8,28 & 16,97 & 11,23 & 1,45
\end{tabular}

*em que: Tcz= teor de cinzas (\%);Tlig= teor de lignina (\%);Thol= teor de holocelulose (\%); Text= teor de extrativos (\%); DP= Desvio Padrão; CV= Coeficiente de Variação.

Foram observadas diferenças estatísticas significativas nas dimensões das fibras entre a madeira juvenil e adulta para ambas as espécies analisadas na tabela 4 , com valores médios maiores principalmente para o comprimento e para a espessura da parede das fibras na madeira adulta.

Tabela 4. Comparação do Comprimento das fibras das espécies.

\begin{tabular}{llllll}
\hline Comprimento das fibras $(\boldsymbol{\mu m})$ & Média & CV & Erro padrão & F/X2 & p-valor \\
\hline Cecropia sciadophylla & & & & & \\
\hline Juvenil & $1267,42 \mathrm{a}$ & $19 \%$ & 33,82 & 23,813 & $3,40 \mathrm{E}-06$ \\
Adulta & $1455,78 \mathrm{~b}$ & $12 \%$ & 21,56 & & \\
\hline Cecropia distachya & & & & & \\
\hline Juvenil & $1313,36 \mathrm{a}$ & $15 \%$ & 26,22 & $0,72919^{*}$ & $8,62 \mathrm{E}-11$ \\
Adulta & $1589,95 \mathrm{~b}$ & $6 \%$ & 17,25 & & \\
\hline
\end{tabular}

Valores médios com letra diferente entre as linhas do mesmo parâmetro anatômico indicam diferenças significativas $(P<0,05)$. $F=$ indica valores onde os GLMs foram feitos pela distribuição de Fisher-Snedecor. $X 2=$ representa os valores $\left({ }^{*}\right)$ nos quais os GLMs foram feitos pela distribuição Quiquadrado.

Conclusão: As espécies apresentam densidade básica baixa aumentando no sentido da base para o topo e da medula para casca. Os valores de contração e retratibilidade volumétrica, de maneira geral, foram estatisticamente iguais para as espécies. $O$ coeficiente de anisotropia elevado indicou que a madeira é bastante instável, devendo haver maior controle durante o processo de secagem. 
As espécies Cecropia distachya e Cecropia schiadophylla possuem características físicas que potencializam o seu uso para essa produção de painéis.

Os valores entre as $C$. distachya e a $C$. schiadophylla tiveram variação de $39,53 \%$ em teor de cinzas e $2,08 \%$ em teor de extrativo respectivamente, de maneira geral, foram estatisticamente iguais para as espécies. As maiores diferenças ficaram entre o teor de lignina onde a $C$. distachya apresentou um maior teor em relação a $C$. schiadophylla. A espessura da parede das fibras foi o melhor predito da variação da densidade na madeira juvenil e adulta em ambas as espécies.

As espécies apresentam Teores de Cinzas e Lignina favoráveis para a produção de energia em forma de lenha ou carvão, além de apresentar o alto rendimento em holoceluloses o que propicia seu potencial uso para produção de celulose.

Referências bibliográficas: Barrichelo, L.E.G.; Foekel, C.E.B. Utilização de Madeiras de Essências Florestais Nativas na Obtenção de Celulose: Bracatinga (Mimosa Bracatinga), Embaúba (Cecropia Sp), Caixeta (Tabebuia Cassinoides) E Boleira (Joannesia Princeps). Instituto de Pesquisas e Estudos Florestais. Piracicaba. 1976. 111p.

BRAND, M. A.; CUNHA, A. B.; CARVALHO, A. F.; BREHMER, D. R.; KÜSTER, L. C. Análise da qualidade da madeira e do carvão vegetal produzido à partir da espécie Miconia cinnamomifolia (De Candolle) Naudin (Jacatirão-açu) na agricultura familiar, em Biguaçu, Santa Catarina. Scientia Forestalis, Piracicaba. v. 41, n.99, p. 401-410, 2013.

Brasil, MAM. Variação da densidade básica da madeira de Eucalyptus propinqua Deane ex Maiden em função do local e espaçamento, 1972.

BRASIL. Plano Amazônia Sustentável: diretrizes para o desenvolvimento sustentável da Amazônia Brasileira. Brasília: MMA, 2008.

BRAZ, R. L. et al. Caracterização anatômica, física e química da madeira de clones de Eucalyptus cultivados em áreas sujeitas à ação de ventos. Ciência da Madeira (brazilian Journal Of Wood Science), Brasil, v. 1, n. 1, p.127-137, set. 2014.

FRANKLIN, G. L. Preparation of thin sections of synthetic resins and wood-resin composites, and a new macerating method for wood. Nature, v. 155, n. 1, p. 51, 1945. International Association of Wood Anatomists. Committee. List of microscopic features for hardwood identification. IAWA Bulletin, v. 10, p. 220 - 332, 1989

Kollmann, Franz Fp; Cote Jr, Wilfred A. Principles of Wood Science and Technology. Vol. I. Solid Wood. In: Principles of Wood Science and Technology. Vol. I. Solid Wood. 1984.

KRAUS, J. E.; ARDUIN, M. Manual básico de métodos em morfologia vegetal. Seropédica, Edur, 1997

Machado, J F; Hillig, E; Watzlawick, LF; Bednarczuk, E; Tavares, EL. Production of plywood panel for exterior use with Paricá and Embaúba timbers. Revista Árvore, v. 42, n. 4, 2018.

Malan, FS; Hoon, M. Effect of initial spacing and thinning on some wood properties of Eucalyptus grandis. South African Forestry .Journal, v. 163, n. 1, p. 13-20, 1992. 
NEVES, T. A. et al.Avaliação de clones de Eucalyptus em diferentes locais, visando à produção de carvão vegetal. Pesquisa Florestal Brasileira, Colombo, v.31, n. 68, p. 319-330, 2011.

Pádua, FA. Amostragem para avaliação da densidade básica da madeira de um híbrido de Eucalyptus grandis W. Hill ex Maiden x Eucalyptus urophylla ST Blake. 2009.

Panshin, AJ; Zeeuw, C. Textbook of Wood Technology. New York: MC Graw-Hill Book, 1970. 705p.

PEREIRA, P. C. G. Determinação do potencial silvicultural de espécies do gênero Cecropia na Flona do Tapajós - PA. 2015. Tese (Mestrado em Ciências Florestais) Universidade Federal Rural da Amazônia.

PUPO, Camyla Heckler. Estudo comparativo das madeiras de cecropia palmata (imbaúba) e eucalyptus grandis para produção de celulose e papel. 2015. ix,80f. Dissertação (mestrado) - Universidade Estadual Paulista Júlio de Mesquita Filho, Faculdade de Ciências Agronômicas de Botucatu, 2015.

Palavras-chave: Embaúba, Física, Química, Extrativos, Lignina. 


\section{PROPRIEDADES FÍSICAS DA MADEIRA DE LIMÃOZINHO (ZANTHOXYLUM EKMANII (URB.) ALAIN) APÓS TRATAMENTO TÉRMICO.}

Nome do(a) bolsista: Dálleth Thauanny de Oliveira Pereira

Nome do(a) Orientador(a): João Rodrigo Coimbra Nobre

Grupo de Pesquisa: Ciência, Inovação e Tecnologia da Madeira

Introdução: O tratamento térmico consiste na aplicação de calor, causando modificações nas propriedades tecnológicas da madeira. O objetivo deste trabalho foi avaliar o efeito da termorretificação sobre as propriedades físicas da madeira de Zanthoxylum ekmanii (URB.) Alain. Foram coletadas 5 árvores de Z. ekmanii, e confeccionados 12 corpos-de-prova para cada árvore e destinados para a análise antes dos tratamentos que serviram como testemunhas. Para a realização dos termotratamentos foram adotadas 4 temperaturas $\left(140{ }^{\circ} \mathrm{C}, 160^{\circ} \mathrm{C}, 180^{\circ} \mathrm{C}\right.$ e $\left.200{ }^{\circ} \mathrm{C}\right)$, no tempo de 3 e 5 horas para cada, e confeccionados 24 corpos de prova por árvore, totalizando 120 corpos-de-prova. As análises físicas foram realizadas de acordo com a norma NBR 7190/1997. A densidade básica média da espécie variou entre 0,48 e 0,54 $\mathrm{g} / \mathrm{cm}^{3}$. Com o tratamento térmico, esse valor geral de densidade variou entre $0,45 \mathrm{e}$ $0,50 \mathrm{~g} / \mathrm{cm}^{3}$, sendo evidente uma redução. Na retratibilidade, as maiores variações dimensionais ocorreram no plano tangencial, seguido do radial e longitudinal. $O$ desvio padrão foi baixo e o coeficiente de variação foi elevado em praticamente todos os planos avaliados, demostrando uma grande heterogeneidade no lenho das amostras. Após o tratamento térmico, essas contrações diminuíram, devido à perda de massa e perda volumétrica. O Fator de Anisotropia apresentou variação de 1,18\% a 1,31\%, considerado excelente, após o termotratamento obteve-se uma redução nesse coeficiente, sendo assim provável a utilização da madeira de Limãozinho sem tendência ao empenamento. Conclui-se, que o tratamento térmico favorece na redução da instabilidade, da higroscopicidade, podendo promover melhorias em algumas propriedades da madeira.

Palavras-chave: Temperatura. Retratibilidade. Estabilidade dimensional 


\section{PROPOSIÇÃO DE UM MODELO ESTRUTURAL PARA O CÁLCULO DO GRAU DE ADOÇÃO DO LEAN MANUFACTURING: UM SURVEY NA INDÚSTRIA DE TRANSFORMAÇÃO DO ESTADO DO PARÁ}

Nome do(a) Bolsista: Igor Santos Costa

Nome do Voluntário: Samuel Neto da Silva Barbosa

Nome do(a) Orientador(a): Léony Luis Lopes Negrão

Grupo de Pesquisa: Gestão de Sistemas Logísticos e de Sistemas Produtivos para

o Desenvolvimento Regional

Introdução; Objetivo(s); Material e Método; Resultados; Conclusão. (estes itens deverão vir no corpo do resumo, o qual deverá conter entre 1500 e 2000 caracteres)

O surgimento e a posterior popularização do lean foi uma das mais significantes contribuições para o desenvolvimento da gestão de operações (HINES; HOLWEG; $\mathrm{RICH}, 2004 ; \mathrm{HOLWEF}, 2007)$. Existe um crescente interesse nos métodos de mensuração do leanness ou grau de adoção lean (COCCA et al., 2018; SANGWA; SANGWAN, 2018). A literatura apresenta uma vasta gama de métodos de avaliação baseados em técnicas de lógica fuzzy (VINODH; BALAJI, 2011; VINODH; CHINTHA, 2011), modelos multicritério (KUMAR et al., 2013; WONG; IGNATIUS; SOH, 2012) e outras (LUCATO et al., 2014; SORIANO-MEIER; FORRESTER, 2002; WAN; CHEN, 2009), mas nenhum baseado em modelagem de equações estruturais. Em vista dessa lacuna, o presente trabalho se propôs elaborar um modelo para mensurar o grau de adoção lean baseado na utilização da modelagem de equações estruturais, além de determinar o leanness das indústrias de transformação do estado do Pará. O método de pesquisa foi divido em duas grandes etapas, a coleta de dados e a aplicação da técnica de transformação. O modelo de variáveis lean utilizado foi o de Shah e Ward (2007), adaptado por Godinho Filho, Ganga e Gunasekaran (2016) em 45 elementos operacionais agrupados em 10 variáveis lean. Participaram da pesquisa 233 indústrias de transformação localizadas na Região Metropolitana de Belém. Um modelo estrutural inicialmente é identificado com 10 constructos. Este foi então avaliado quanto aos critérios de validade convergente e discriminante, coeficiente de determinação de Pearson, relevância preditiva e tamanho do efeito, e aos valores de T-Student. Entretanto, devido os resultados da avaliação em relação aos valores de T-Student, 2 constructos foram eliminados. O modelo estrutural modificado foi avaliado da mesma forma do inicial e por sua vez apresentou resultados positivos em todas as avalições. Desta forma, pode-se afirmar que há relação causal positiva dos constructos analisados com a inserção do lean manufacturing nas empresas.

Palavras-chave: lean; leanness; método de mensuração; modelagem de equações estruturais; indústria de transformação 


\section{DESCRIÇÃO ANATÔMICA DA MADEIRA E DO CARVÃO VEGETAL DE ESPÉCIES FLORESTAIS NATIVAS DA AMAZÔNIA COMO SUBSÍDIO PARA A FISCALIZAÇÃO}

Nome do(a) bolsista: Marcelo Mendes Braga Junior

Nome dos Voluntários: João Vitor Gomes Rocha, Gabriele Melo de Andrade

Nome do(a) Orientador(a): Luiz Eduardo de Lima Melo

Grupo de Pesquisa: Grupo interdisciplinar de pesquisa em sociedade, saúde e meio ambiente na amazônia

Introdução: A Antracologia é a ciência que utiliza as células da madeira para analisar e identificar o carvão vegetal com o princípio de que as características anatômicas do lenho são mantidas após a carbonização, possui finalidades paleoecológicas, paleobotânicas, tecnológicas e também conservacionista. Esta última, subsidia o conhecimento anatômico do carvão de espécies arbóreas cortadas ilegalmente com possibilidade de ser aplicada como ferramenta para a fiscalização e controle de ilegalidades ambientais. Objetivo (s):Desse modo, o trabalho objetivou fornecer subsídio para a identificação do carvão vegetal de espécies arbóreas da Amazônia sob risco de extinção e de Eucalyptus sp., de floresta plantada. Material e Método: As espécies selecionadas para o estudo foram: Hevea brasiliensis (Willd. ex A.Juss.) Müll. Arg., Bertholletia excelsa Bonpl. e Swietenia macrophylla King que são espécies nativas da Amazônia e ameaçadas de extinção, também foi utilizado material genético plantado de um híbrido de Eucalyptus grandis x Eucalyptus urophylla. Realizaram-se coletas não-destrutivas de amostras do lenho a 1,30 m do solo em cinco indivíduos de cada espécie selecionada. A partir das amostras foram confeccionados dois corpos de prova de $2 \times 2$ (plano transversal) $\times 3 \mathrm{~cm}$ (plano longitudinal), destinados ao estudo anatômico da madeira e do carvão. $O$ estudo anatômico da madeira e do carvão foi realizado com o auxílio de estereomicroscópio e microscopia eletrônica de varredura, seguindo recomendações da IAWA COMMITTEE (1989). Resultados:Os resultados obtidos expressam que a carbonização a $450^{\circ} \mathrm{C}$ resultou apenas modificações quantitativas das células, já as características anatômicas qualitativas do lenho se mantiveram após a carbonização fato que possibilitou a determinação taxonômica a partir de material carbonizado, podendo contribuir com os estudos de carvões e fornecer subsídio para a fiscalização de carvão vegetal na Amazônia. As principais características que diferem o carvão das espécies nativas avaliadas comparativamente ao carvão de Eucalyptus sp. foram na macroscopia tipo de parênquima axial, distribuição e frequência dos vasos e na microscopia dimensão dos vasos e dos raios.

Conclusão: Assim, confirma-se a possibilidade de determinação taxonômica a partir de material carbonizado, podendo contribuir com os estudos de carvões e fornecer subsídio para a fiscalização de carvão vegetal no Brasil.

Palavras-chave: Antracologia, Anatomia do lenho, Anatomia comparada, Carvão. 


\title{
PRODUÇÃO DE BRIQUETES UTILIZANDO MISTURAS DE BIOMASSA LIGNOCELULÓSICA PARA FINS ENERGÉTICOS
}

\author{
Nome do(a) Bolsista: Antonio Alberto da Costa Neto \\ Nome do(a) Orientador(a): Marcelo José Raiol Souza \\ Grupo de Pesquisa: Grupo de Estudos em Energia e Processos na Amazônia
}

Introdução: O Brasil é considerado um dos maiores países em geração de energia provenientes de resíduos agrícolas e florestais, e uma forma de melhorar a densidade energética destes resíduos é transforma-los em briquetes e pellets (DIAS et al. 2012). Devido as pressões econômicas e socioambientais para ter uma energia de qualidade e limpa, a biomassa lignocelulósica aparece no cenário energético brasileiro como uma opção barata e com potencial de alavancar energeticamente o país na geração de energia de baixo impacto ambiental (CHRISOSTOMO, 2011; QUIRINO, 2003). A grande variedade e quantidade de resíduos lignocelulósicos provenientes de várias atividades do setor do agronegócio permite o seu aproveitamento utilizando tecnologias mais simples, como a briquetagem, que consiste em aplicar uma pressão exercida na biomassa lignocelulósica, devidamente preparada, com ou sem adição de ligante, no intuito de transforma-la em briquetes energéticos de alta densidade (SALEME, 1992). Com base no exposto, o presente trabalho busca analisar a produção de briquetes de resíduos lignocelulósicos de caroço de açaí e serragem de madeira, com adição de amido de mandioca como aglomerante.

Objetivos: Produção e avaliação da qualidade dos briquetes de Euterpe Oleracea (caroço de açaí) e serragem de madeira, aglutinados com Manihot esculenta (amido de mandioca) em diferentes proporções usando prensa manual.

Material e Método: Os resíduos de caroço de açaí e serragem de madeira foram coletados nas serrarias e pontos comerciais de produção de polpa de açaí ne região metropolitana de Belém. $\mathrm{O}$ amido de mandioca que foi utilizado como aglutinante na produção dos briquetes foi adquirido em feiras comerciais na região metropolitana de Belém-PA. Os resíduos, juntamente, com o amido foram levados ao Laboratório de Madeira do curso de Engenharia Florestal da Universidade do Estado do Pará, Campus $\mathrm{V}$ - Belém para posterior análises.

Figura 1: Serragem e caroço de açaí triturados

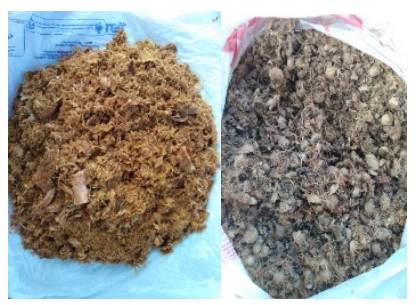

Fonte: Autores, 2019 
Foi realizada uma trituração dos resíduos utilizando um liquidificador modelo Poli e um moinho analítico para alcançar a granulometria apropriada (figura 1), a seleção do material para a fabricação dos briquetes ocorreu após retenção do mesmo na peneira de mesh $24(0,71 \mathrm{~mm})$. Posteriormente, foi utilizado uma balança analítica para pesagem dos materiais (Quadro 1), com objetivo de determinar as proporções de cada material na mistura. Utilizou-se o amido de mandioca para maior efetividade na agregação dos materiais triturados, de acordo com a metodologia seguida por Martins et al. (2016).

Quadro 1 - Massa em gramas dos Materiais

\begin{tabular}{ll}
\hline Componente & Massa $\mathbf{( g )}$ \\
\hline Serragem & 10 \\
\hline Caroço de açaí & 15 \\
\hline Amido & 25 \\
\hline
\end{tabular}

As porcentagens dos componentes na mistura seguiram a seguinte ordem: Tratamento I (85 \% de serragem; $10 \%$ de caroço de açaí e 5\% de amido), Tratamento II (75\% de serragem; $15 \%$ de caroço de açaí e 10\% de amido) e Tratamento III (65 \% de serragem; $20 \%$ de caroço de açaí e $15 \%$ de amido)

A diluição do amido de mandioca ocorreu em $25 \mathrm{ml}$ de água, em seguida o material foi encaminhado para chapa aquecedora a uma temperatura de $150^{\circ} \mathrm{C}$ e misturados até ficar consistente (OLIVEIRA, 2018). Posteriormente, as composições de biomassa dos tratamentos I, II e III foram misturados ao amido e levado à prensa manual, mostrado na figura 2. Após a introdução do material no molde, foram produzidos um briquete por vez. A pressão aplicada foi de 2 toneladas $\left(2.187 \mathrm{kgf} / \mathrm{cm}^{2}\right)$, durante cinco minutos com objetivo de efetivar a adesão das partículas de biomassa ao amido diluído. A produção seguiu os padrões de qualidade da norma alemã DIN 51731 (OLIVEIRA, 2018).

Figura 2: Prensa hidráulica

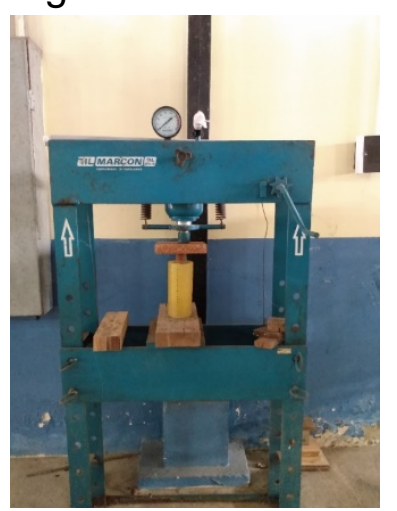

Fonte: Autores, 2019

Os briquetes, após fabricação, foram levados à secagem em estufa com temperatura inicial de $60^{\circ}$ e após trinta minutos reguladas para $120^{\circ}$, com duração de uma hora, totalizando uma hora e meia na estufa e depois colocados em temperatura ambiente 
para o resfriamento, durante 15 dias. Em seguida, ocorreu a pesagem na balança analítica, para observar se houve variação de massa. Para determinar o teor de umidade da amostra foi utilizada a seguinte equação: $U 0=(P 1-P 2) I P 2 \times 100 \%$, onde U0(\%) é o teor de umidade em base seca, P1 é o peso inicial da amostra, em g; e P2 o peso da amostra após a dessecação em estufa, em g. A densidade aparente de cada briquete foi feita, pelo método estequiométrico, com o auxílio de um paquímetro e balança analítica. Primeiro foi encontrado o raio dos briquetes utilizando a equação $C=$ 2. $\boldsymbol{\pi} . \boldsymbol{r}$ e posteriormente, o cálculo do volume utilizando a equação $\boldsymbol{V}=\boldsymbol{\pi} . \boldsymbol{r}^{2} \cdot \boldsymbol{h}$, onde C é o comprimento da região circular, $r$ a medida do raio da região circular e $h$ a altura do cilindro.

Resultados e Discussão: $O$ teor de umidade dos briquetes para uso energético eficiente possui valor máximo de $12 \%$, para não causar instabilidade dimensional (GONÇALVES, 2010). Os briquetes produzidos no presente trabalho são visualizados na figura 3.

Figura 3: tratamento I com $5 \%$ de amido (A), tratamento II com $10 \%$ de amido (B) e o tratamento III à $15 \%$ de amido (C).

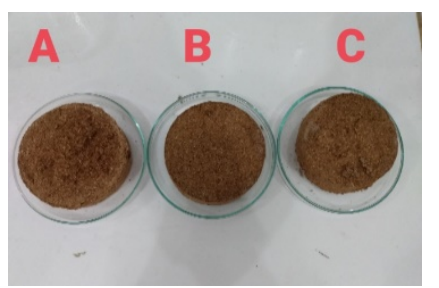

Fonte: Autores, 2019

O tratamento TI apresentou umidade de $18,68 \%$ enquanto os tratamentos TII e TIII na ordem de 19,87 e $21,02 \%$ evidenciando teores acima de $12 \%$. Os briquetes produzidos de resíduos madeireiros sem aglutinantes, possui teor de umidade em média de 18,14\% (Oshiro, 2016), bem próximo da menor taxa de teor de umidade encontrado no presente trabalho, ou seja, o tratamento TI que obteve $18,68 \%$, composto por $5 \%$ de amido, $85 \%$ de serragem e $10 \%$ caroço de açaí. Os teores de umidades alto nas amostras podem ser explicados pela presença de amido diluído com água na fabricação dos briquetes, pois são materiais que conseguem absorver grande quantidade de umidade, e durante o experimento percebeu-se que uma maior quantidade de água na porcentagem de amido diluído influenciou no tempo de pega do briquete. Durante o tempo de secagem na estufa, que foi $1 \mathrm{~h} 30 \mathrm{~min}$ e no ambiente natural, que levaram 15 dias de secagem, os briquetes diminuíram o teor de umidade, mas não chegaram na porcentagem ideal, entre $10 \%$ e $12 \%$ que Lucena (2008) afirma ser ideal para uso industrial, todavia qualquer redução de umidade é considerada excelente para indústria, pois a redução de umidade aumenta o poder calorífico do briquete. A densidade aparente é uma propriedade física que pode demonstrar o desempenho do briquete como combustível, pois com o volume estabelecido pode avalia-lo energeticamente (QUIRINO \& BRITO, 1991). O tratamento TI apresentou densidade aparente $\left(\mathrm{g} / \mathrm{cm}^{3}\right)$ de 0,34 e os tratamentos TII e TIII na ordem de 0,37 e 
0,41 . No trabalho de Gonçalves et al. (2013) com serragens de Eucalyptus grandis foram produzidos briquetes sem aquecimento e aglutinantes, neste trabalho foram encontrado valores de densidade aparente entre $0,96-1,00 \mathrm{~g} / \mathrm{cm}^{3}$, que representa excelentes valores para aproveitamento energético. Em um estudo realizado por Martins et al. (2016) utilizando compostos como serragem, finos de carvão e amido de milho, os briquetes produzidos apenas com finos de carvão vegetal e resíduo celulósico apresentaram valores de densidades com média de $0,72 \mathrm{~g} / \mathrm{cm}^{3}$, e os briquetes com presença de amido de milho apresentaram densidades maiores, com média de $0,98 \mathrm{~g} / \mathrm{cm}^{3}$, comparando esses valores aos desta pesquisa, foi avaliado que no T III valor de densidade foi $0,41 \mathrm{~g} / \mathrm{cm}^{3} \mathrm{com}$ a presença de $15 \%$ de amido de mandioca. Os valores de da densidade aparente foram baixos em virtude da prensa operar em patamares de pressão muito inferior aos praticados na indústria.

Conclusão: Os resultados obtidos mostraram que os briquetes fabricados apresentaram potencial de uso energético, pois houve principalmente uma redução da umidade com aplicação de pressão hidrostática, o que aumenta sua performance energética, logo o briquete pode também substituir combustíveis que causam alto impacto ambiental, como o uso dos combustíveis fósseis.

\section{Referências bibliográficas}

CHRISOSTOMO, Walber. Estudo da compactação de resíduos lignocelulósicos para a utilização de combustível sólido. Universidade de São Carlos. Dissertação.80 fls.

DEUTSCHES INSTITUT FÜR NORMUNG. DIN 51731. Berlin, 1996

GONÇALVES, J.E. Avaliação energética e ambiental de briquetes produzidos com rejeitos de resíduos sólidos urbanos e madeira de Eucalyptus grandis. Tese (Doutorado em Agronomia) - Universidade Estadual Paulista "Júlio Mesquita Filho", Botucatu, p. 104, 2010.

GONÇALVES, B. F.; YAMAJI, F. M.; FERNANDEZ, B. O.; DA RÓZ, A. L.; FLORIANO, F. S. Caraterização e comparação entre diferentes granulometrias de serragem de Eucalyptus grandis para confecção de briquetes. Revista Instituto Floresta, v. 25, n. 2, p. 205-213, 2013.

LUCENA, D. A.; MEDEIROS, R. D.; FONSECA, U. T.; ASSIS, P. S. Aglomeração de moinha de carvão vegetal e sua possível aplicação em alto-forno e geração de energia. Tecnologia em Metalurgia e Materiais. V.4, n.4, p. 1-6, 2008.

MARTINS, M.; BENÍCIO, E.; JÚNIOR, A.; ALMEIDA, R.; CARVALHO, A.; \& YAMAJI, F. Produção e Avaliação de briquetes de finos de carvão vegetal compactados com 
resíduo celulósico proveniente da indústria de papel e celulose. Revista Árvore, v. 40, p. 173-180. 2016.

OLIVEIRA, J. R. M. Produção e Qualidade de briquetes aglutinados com amido de Manihot esculenta (mandioca). Trabalho de conclusão de curso. Universidade do Estado do Pará- UEPA, Paragominas, PA. 2018. 52 p.

OSHIRO, T. L. Produção e Caracterização de briquetes produzidos com resíduos lignocelulósicos. (Monografia Eng. Ambiental) - Universidade Tecnológica Federal do Paraná, Londrina-PR, p. 1-78, 2016.

QUIRINO, W. F.; BRITO, J. O. Características e Índice de Combustão de Briquetes de Carvão Vegetal Laboratório de Produtos Florestais - LPF/IBAMA. Brasília, 1991. $19 p$.

QUIRINO, W. F. Utilização energética de resíduos vegetais. Brasília, Laboratório de Produtos Florestais - LPF/IBAMA, 2003. 14 p.

SALEME, J.E.F. Estudo básico para briquetagem do carvão vegetal. Ouro Preto: Escola de Minas e Metalurgia, 1992. 19p. 


\title{
DESENVOLVIMENTO DE MATERIAIS BIOCOMPÓSITOS A BASE DE PLÁSTICO E PAPEL PÓS CONSUMO
}

\author{
Nome dos Bolsistas: Juliana Fonseca Cardoso, Isabela Liane Carvalho Teixeira \\ Nome do(a) Orientador(a): Márcio Franck de Figueiredo \\ Grupo de Pesquisa: Ciência, Inovação e Tecnologia da Madeira na Amazônia
}

Introdução: Apesar da consciência ecológica a qual a sociedade vem sendo inserida em reaproveitar os resíduos oriundos dos processos, serviços e produtos utilizados para o benefício humano, é crescente a busca por soluções que gerem o emprego e produção de novos materiais tecnológicos oriundos de fontes renováveis, os quais servirão de supressores para os resíduos não renováveis. Segundo pesquisas de empresas do setor de resíduos a grande maioria dos rejeitos coletados não tem tratamento adequado. Nessa conjectura, o desenvolvimento de produtos provenientes de materiais pós consumo ganham cada vez mais força no mercado, a grande sacada do cenário atual é a fabricação dos biocompósitos. Essa nomenclatura vem ganhando força pois abrange o enfoque social, ambiental e econômico, além dos benéficos de produção de um material que ao combinar outros dois forma um terceiro com certas propriedades que não se encontram nos materiais isoladamente. Nesse sentido, 0 presente estudo tem como objetivo desenvolver um material biocompósito a partir de plásticos e papel pós consumo. Para tal, adaptou-se a metodologia de Figueiredo (2016) para a confecção das placas utilizando (PVC) policloreto de vinila pós consume diluído em Metil-Etil-Cetona associada ao papel em concentrações de 0,08 g/ml. Durante as análises das placas foi possível observar a melhora na qualidade das propriedades de resistência e absorção de água a medida em que se aumenta a concentração de polímero, quanto a melhor resistência a mesma se deu em todas as proporções analisadas aumentado de forma gradual, igualmente aconteceu no que se refere ao ensaio de absorção onde as maiores concentrações apresentaram menor taxa de absorção. Contudo, identificou-se a menor absorção de água na concentração 70/30\% PVC/ papel e o aumento gradual da resistência, nesse sentido a capacidade de absorção de umidade pode ser limitada através do correto encapsulamento das partículas pela matriz polimérica.

Palavras-chave: Metil-Etil-Cetona, Residuo, Composito. 


\section{UTILIZAÇÃO DE RESíDUOS DE AGROINDÚSTRIA DO AÇAí PARA POSSÍVEL APLICAÇÃO NA INDÚSTRIA TÊXTIL}

Nome do(a) Bolsista: Emanuely Chaves Luz

Nome do(a) Orientador(a): Nubia Suely Silva Santos

Grupo de Pesquisa: Desenvolvimento de Produtos com Materiais Amazônicos

Introdução: A fibra de açaí é um resíduo que se origina do processamento do fruto do açaí para obtenção da polpa que é bastante consumida na região Norte do Brasil. Objetivo: Neste trabalho de iniciação científica (PIBITI-UEPA) buscou-se desenvolver um não tecido a partir da fibra de açaí (Euterpe oleracea Mart.) e um biopolímero de agar agar. O agar agar é um hidrocolóide extraído de algas marinhas que tem sido extensivamente usado por designers e engenheiros de materiais na obtenção de bioplástico para aplicações em embalagens biodegradáveis ou produtos têxteis. Material e método: A compreensão dos aspectos sensoriais das fibras e das amostras desenvolvidas foi feita pela abordagem do "design conduzido pelo material" (Material Driven Design) que privilegia as experiências dos usuários na interação com o material. $\mathrm{Na}$ metodologia experimental foram realizados procedimentos para determinação do comprimento da fibra, teor de lignina e análise da morfologia de superfície. Na etapa seguinte foram preparadas formulações de biopolímero de agar agar para adição de fibras de açaí já tratadas em solução alcalina a 3\%.Resultados: Amostras foram elaboradas adicionando fibras de açaí pulverizadas e não pulverizadas na matriz de biopolímero de agar agar, que foram colocadas para secar em temperatura ambiente pelo período de 48 a 72 horas. $\mathrm{Na}$ análise dos aspectos sensoriais os entrevistados associaram a amostra a couro sintético e animal, plástico, borracha, tapete, entre outros, sendo que na maioria das vezes relataram toque e textura agradável à pele, além de odor suportável. Conclusão: Essas primeiras impressões são positivas para a continuidade da pesquisa com o material para aplicação em produtos têxteis.

Palavras-chave: Biocompósito; fibras vegetais;agroindústria; Amazônia;materiais sustentáveis 


\title{
CARACTERIZAÇÃO FíSICO-QUÍMICA DE RESÍDUOS DA PESCADA AMARELA (Cynoscion acoupa) COMERCIALIZADA NO MERCADO DE PEIXE DO VER-O-PESO
}

\author{
Nome do(a) bolsista: Ester de Freitas Santos \\ Nome do(s) Voluntário (s):Vitória Micaely Torres Carvalho \\ Nome do(a) Orientador (a): Suezilde da Conceição Amaral Ribeiro \\ Grupo de Pesquisa: Ciência e Tecnologia Agroindustrial da Amazônia
}

Resumo: O mercado do Ver-o-peso é o local responsável pelo maior escoamento de pescado da região nordeste paraense, porém também é nele que há um acúmulo muito grande de resíduos, devido ao volume de comercialização de peixes eviscerados, e beneficiados em filés e postas. Esses resíduos podem gerar grande impacto ao meio ambiente. O objetivo deste trabalho é caracterizar físicoquimicamente resíduos da pescada amarela (Cynoscion acoupa) comercializada no Ver-O-Peso, Belém, Pará para dar melhor destino a uma matéria orgânica rica em nutrientes. Foram realizadas análises de $\mathrm{pH}$, umidade, proteínas, lipídios, cinzas e carboidratos dos seguintes resíduos: cabeça, pele e espinha Após as análises pode-se concluir que a pescada amarela tem a pele com maior quantidade de proteína, cinzas, e lipídios se comparada à cabeça e espinha. Observa-se que o $\mathrm{pH}$ apresentou valor de 7,67 para a cabeça, 7,98 para a pele e 7,22 para a espinha indicado que os resíduos da pescada não estavam em bom estado de frescor, indicando, provavelmente, um armazenamento incorreto

Introdução: A pesca é umas das atividades extrativas mais importantes da região amazônica, devido à abundância dos recursos em seus principais rios e a dependência da população tradicional por esta atividade, tanto para o comércio, quanto para o consumo, sendo o Ver-o-peso, a feira de maior escoamento da produção paraense.

O mercado do Ver-o-Peso, fervilha com as novidades que chegam do estrangeiro, mercadorias, trazidas pelos barcos, navios e vapores que entram e saem do porto. E, é deste ponto pulsante do coração da cidade que adentram as novas ruas, travessas e avenidas que vão compor a área do comércio, com suas lojas, depósitos e diversos estabelecimentos comerciais (SANTOS, 2018). No entanto, o mercado de peixe que faz parte do complexo do Ver-o-peso, convive com problemas sérios sociais e ambientais, pois gera, juntamente com suas postas e filés solicitados pelos seus consumidores, uma quantidade de resíduos de peixes que é rica em nutrientes que acumula nos seus boxes, proporcionando um problema de acúmulo de lixo e produção de odores desagradáveis por ser uma matéria orgânica rica em nutrientes. Estes poderiam ser aproveitados para a elaboração de produtos e assim, melhor destino que não seja o lixo. Dentre os alimentos que possuem uma maior facilidade de atuar na disseminação de agentes patogênicos está o peixe fresco. Além de ser uma das principais fontes de proteína do ser humano, a sua musculatura em geral é mais sensível à deterioração do que a carne dos mamíferos, tendo em vista que o processo autolítico é mais rápido 
devido à composição química, teor de gorduras insaturadas facilmente oxidáveis e ao pH próximo da neutralidade que facilitam a proliferação microbiana (LOBO, 2009).

Mas, para dar o melhor destino é necessário conhecer as caraterísticas físicas e químicas dos resíduos, como umidade, cinzas, proteínas, lipídios, além de parâmetro para avaliar seu índice de frescor.

Objetivo geral: Investigar a composição físico-química dos resíduos em amostras da pescada amarela (Cynoscion acoupa) comercializada no mercado de peixe do Ver-oPeso, já que para reaproveitar os resíduos que são descartados é preciso saber a composição da matéria como da pele, espinha e cabeça.

Material e Método: As informações foram coletadas durante o período de agosto de 2018 até maio de 2019. Onde foram recolhidos $15 \mathrm{~kg}$ no total, das amostras de cabeça, pele e espinha foram recolhidas de nove boxes e misturadas durante as análises. Ocorreu a sanitização dos resíduos com água clorada a $5 \mathrm{ppm}$ durante o tempo de recomendação do fabricante do produto. As análises foram realizadas no Laboratório de Química, Microbiologia e de Alimentos da Universidade do Estado do Pará (UEPA) - Campus V - Centro de Ciências Naturais e Tecnologia (CCNT), Belém-PA.

Análises físico-químicas: Os resíduos de cabeça, pele e espinha da pescada amarela foram feitas as análises em triplicata, utilizando-se as metodologias do Instituto Adolfo Lutz (2008) quanto aos parâmetros: sólidos solúveis por refratometria com o auxílio de um Refractometer (017/IV), pH por leitura direta em pHmetro (017/IV), umidade (012/IV), cinzas (018/IV), proteína (037/IV) e lipídios (032/IV).

Resultados e Discussão: A tabela 1 mostra os resultados físico-químicos das análises realizadas nos resíduos para cabeça, pele e espinha da pescada amarela.

Tabela 1 - Caracterização físico-química dos resíduos.

Análises

\begin{tabular}{llll} 
& Cabeça & Pele & Espinha \\
\hline pH & $7,67 \pm 0,03$ & $7,98 \pm 0,03$ & $7,22 \pm 0,04$ \\
Proteínas (\%) & $15,25 \pm 0,14$ & $35,47 \pm 0,50$ & $12,22 \pm 0,19$ \\
Umidade (\%) & $80,99 \pm 0,17$ & $70,39 \pm 1,50$ & $66,35 \pm 1,67$ \\
Cinzas (\%) & $2,26 \pm 0,03$ & $59,12 \pm 0,03$ & $45,41 \pm 0,39$ \\
Lipídeos (\%) & $0,86 \pm 0,03$ & $7,55 \pm 0,04$ & $2,76 \pm 0,31$ \\
\multicolumn{4}{l}{} \\
Os resultados obtidos na composição centesimal dos resíduos do pescado estão \\
expressos na tabela 1.
\end{tabular}

Observa-se que o $\mathrm{pH}$ apresentou valor de 7,67 para a cabeça, 7,98 para a pele e 7,22 para a espinha o frescor do pescado deve está perto de 7 mas menor que 6,8 os resíduos da pescada já estavam foram do frescor adequado indicando um armazenamento incorreto, pois os feirantes não se preocupam qual será a forma que após o filamento o peixe será aproveitado. Quanto ao resultado para proteínas totais obtidos nas análises, apresentaram valores maiores que os encontrados por Oliveira e Damasceno (2014), que indicaram valores de 14,32 \% de proteína no resíduo e 15,72 $\%$ de proteína no filé. Os resíduos da pescada amarela foram analisados 
separadamente e na tabela 1, é possível avaliar que a pele tem uma quantidade maior de proteína. De acordo com Oetterer (1994) a partir dos resíduos é possível obter farinha, óleo, silagem, hidrolisado e concentrado proteico, pois possuem alto valor nutricional.

Em relação à umidade dos resíduos da pescada amarela, este se apresentou dentro da faixa indicada por Ogawa e Maia (1999). Nos resíduos foram encontrados um alto teor de cinzas para pele e espinha.

A pele se encontra bem distante dos valores de lipídios da tilápia. A pele pode ser utilizada para subprodutos como o colágeno que foi extraído neste artigo além de ser uma ótima fonte de gordura animal.

Os resultados das análises de proteína, carboidratos e cinzas no trabalho de Peixoto et al. (2002) encontraram, para a piramutaba, $17,44 \%, 2,83 \%$ e $1,17 \%$, respectivamente e teor de lipídiosfoi de $0,2 \%$.

Conclusão: Através da composição físico-química da pescada amarela verificou-se que se trata de uma excelente matéria-prima em relação à composição centesimal, devido ao alto teor de proteínas, como a pele que apresenta a maior quantidade de proteínas totais. Mas é possível verificar também que é uma matéria-prima de alto teor de umidade podendo degradar com maior facilidade, no caso do resíduo utilizado o frescor não estava mais adequado.

Referências bibliográficas: INSTITUTO ADOLF LUTZ. Normas Analíticas do Instituto Adolf Lutz. v. 1: Métodos químicos e físicos para análise de alimentos, 3. ed. Sao Paulo: IMESP, 1985. p. 42-43.

LOBO, P.T.D. Avaliação microbiológica do pescado fresco comercializado no Centro de Abastecimento do município de Feira de Santana, Bahia, 2008-2009. 2009. 57p. Monografia (Especialização) Universidade Estadual de Feira de Santana/UEFS, Baía, 2009.

OGAWA, M. e MAIA, E.L. Manual de Pesca: Ciência e Tecnologia do Pescado. $1^{\circ}$ ed. São Paulo: Varela, 1999. 430p.

OLIVEIRA, P.R e DAMASCENO, J.M.B. Propriedades químicas e rendimento da piramutaba (Brachyplastystoma vaillantii, valenciennes, 1840). PUBVET, Londrina, V. 8, n. 14, Ed.263, Art.1750, julho, 2014.

PEIXOTO, M. R. S; SOUZA, C. L; MOTA, E. S. Utilização de pescado (Macrodom ancylodon) de baixo valor comercial para obtenção de surimi empregado na elaboração de salsicha com sabor de camarão. Revista Higiene Alimentar, São Paulo, v.16, n.99, agosto. 2002.

SANTOS, L. L. C S. Ver-o-peso da publicidade de Belém como marca significante de lugar. Asas da palavra. vol. 15. n. 2. dez. 2018.

BRASIL. Ministério da Agricultura, Pecuária e Abastecimento. Secretaria Nacional de Defesa Agropecuária. Laboratório Nacional de Referência Animal. Métodos Analíticos Oficiais físico-químicos para controle de pescados e seus derivados. Brasília, 2012. cap. 5, p.1-3.

Palavras-chave: peixe, resíduo, mercado. 


\section{CORRELAÇÃO DOS ROYALTIES DA MINERAÇÃO COM AS VARIÁVEIS SOCIOECONÔMICAS E AMBIENTAIS DOS PRINCIPAIS MUNICÍPIOS MINERADORES DO ESTADO DO PARÁ, BRASIL}

Nome dos bolsistas: Ronaldo Darlan Gaspar Aquino, Ana Flávia Santos de Brito Nome do Orientador: Altem Nascimento Pontes

Grupo de Pesquisa: Ciências Ambientais

RESUMO: Este estudo teve como objetivo analisar a correlação existente entre os royalties arrecadados nos principais municípios mineradores no estado do Pará com seus indicadores socioeconômicos e ambientais. Os dados discriminados por município, entre os anos de 2007 a 2017, foram a arrecadação da CFEM, Receita Total das prefeituras, os Investimentos em Saneamento e Gestão Ambiental e o índice FIRJAN de desenvolvimento municipal. Para a análise de correlação entre as variáveis utilizou-se a Análise de Componentes Principais. Os Resultados obtidos e discutidos permitem compreender que a arrecadação dos royalties pelas prefeituras não possui relação direta com o desenvolvimento socioeconômico e ambiental da região, o que evidencia que há um baixo nível de eficiência da aplicação dos royalties da mineração nos municípios em análise. Tais resultados podem ser justificados pela falta de instrumentos jurídicos efetivos que condicione a internalização dos recursos arrecadados nos municípios em pauta. Assim, conclui-se que os royalties provenientes da exploração mineral não estão sendo devidamente utilizados para mitigar os possíveis impactos socioambientais inerentes a essa atividade, visto que, os municípios em questão encontram-se com baixos níveis de desenvolvimento. Portanto, faz-se necessário que esses recursos sejam geridos de forma mais eficiente, priorizando-se projetos que estimulem a diversificação econômica e o desenvolvimento sustentável desses municípios.

Palavras-chave: Recursos Minerais; Compensação Financeira; Sustentabilidade Socioambiental. 


\title{
PLANTAS ALIMENTÍCIAS NÃO CONVENCIONAIS (PANC'S) DA ILHA DO MOSQUEIRO, BELÉM-PARÁ
}

\author{
Nome do(a) Bolsista: Cláudia Nogueira Corrêa \\ Nome do(a) Voluntário(a): Karolina Ribeiro dos Santos \\ Nome do(a) Orientador(a): Ana Cláudia Caldeira Tavares Martins \\ Grupo de Pesquisa: Ciências Ambientais
}

Introdução: $O$ aumento na procura por produtos vegetais sem o uso de agrotóxicos tem gerado uma maior demanda para os pequenos agricultores, assim como, para o comércio e a indústria que trabalham com esses produtos. Buscar as PANC's para incrementar a alimentação das pessoas se tornou uma alternativa, uma vez que o principal motivo para tal aumento é a qualidade de vida, que está diretamente ligada à alimentação. Com isso, as pessoas vêm buscando melhorar cada vez mais os produtos que consomem, substituindo principalmente, os fast food por alimentos mais saudáveis e naturais. Este trabalho tem por objetivo registrar as plantas alimentícias não convencionais utilizadas nas comunidades de Caruaru e Mari-Mari, na llha do Mosqueiro em Belém-PA. A pesquisa foi realizada por meio de entrevistas dialogadas, direcionadas por formulários semiestruturados, utilizando a técnica bola de neve, assim como, a lista livre. O material botânico foi coletado por meio de turnê guiada, realizada nas duas comunidades. A identificação das espécies foi realizada através de bibliografias especializadas e confirmadas por especialistas. A análise qualitativa dos dados foi feita através de uma tabulação com o perfil socioeconômico dos informantes. Por meio das plantas citadas, foi elaborada uma tabela com as informações dos vegetais que eles utilizam para se alimentar e, até mesmo, comercializar. Essas informações consistiam em nome popular da planta, origem e propagação, período de consumo, a parte que é consumida, assim como, a forma que é consumida, seja in natura, ou através de algum preparado. Foram indicadas 79 etnoespécies alimentícias em Caruaru e 69 em Mari-Mari, sendo as que mais se destacaram foram das famílias Malvaceae, Humiriaceae, Metteniusaceae, Solenaceae e Apiaceae, isso por terem o número maior de citações pela população das comunidades. Pelo número de etnoespécies citadas como plantas que alimentam, a importância da utilização, manejo, preservação e estudo das PANC's, é fundamental, tanto para a subsistência das comunidades, como para ser comercializada, garantindo uma fonte de renda extra ou até mesmo única para as pessoas que ali residem. As plantas alimentícias não convencionais possuem uma ampla variedade de espécies, onde o modo de cultivo e as novas perspectivas na utilização para a gastronomia mundial, permite a diversificação do cardápio e auxilia na preservação cultural de povos que mantém relações com o ambiente em que vive.

Palavras-chave: Etnobotânica. Plantas úteis. Comunidade. 


\section{ESTUDO DA COLEMBOFAUNA DE UMA MONOCULTURA DE DENDÊ NO ESTADO DO PARÁ}

Nome dos Bolsistas: Heloiza Santos Borges; Stephanie Santos Viana dos Santos

Nome do(a) Orientador(a): Ana Lúcia Nunes Gutjahr

Grupo de Pesquisa: Pesquisas interdisciplinares em biodiversidade Amazônica

Introdução: Os colêmbolos são invertebrados detritívoros pertencentes a classe Hexapoda, ordem Collembola. São animais edáficos abundantes no solo e no folhiço, onde desempenham papel importante no equilíbrio dos ecossistemas, atuando como catalisador na ciclagem de nutrientes. O Brasil possui condições de clima e solo variados, que possibilita a exploração comercial de diferentes culturas, entre elas o dendê (Elaeis guineensis Jacq.) que é uma palmeira, cujos frutos se pode extrair o óleo de palma e o óleo de palmiste. O uso agrícola do solo gera modificações que os organismos edáficos, como os colêmbolos, percebem e por isso, podem ser utilizados como bioindicadores da qualidade do solo. Com isso, o objetivo desse trabalho foi realizar um levantamento da abundância da colembofauna de uma monocultura de Dendê (DENPASA) localizada no município de Santa Bárbara no estado do Pará. Foram realizadas duas coletas de campo, uma na estação mais chuvosa e uma na menos chuvosa, as amostras foram obtidas com armadilha de pitfall (armadilha de queda) e foram coletadas 12 amostras em cada estação, totalizando 24 amostras, que foram triadas e identificadas ao nível de família e preservadas em álcool $70 \%$. Todo material coletado foi acondicionado na Coleção Zoológica Dr. Joachim Adis da UEPA. Durante o período chuvoso e menos chuvoso, foram amostradas um total de 8.932 espécimes de Collembola pertencentes a 13 famílias. No período chuvoso foram coletados 5.861 espécimes e as famílias mais abundantes foram Sturmidae $(n=2.336)$ e Sminthuridae $(n=785)$ e a família que apresentou menor abundância nesse período foi a família Katiannidae $(n=1)$. No período menos chuvoso foram encontrados 3.071 espécimes e as famílias que se apresentaram mais abundantes foram Paronellidae $(n=1.309)$ e Entomobryidae $(n=525)$, e a família que se apresentou em menor abundância foi Onychiuridae $(n=3)$. Dessa forma, pode-se afirmar que é provável que a umidade é um fator abiótico que exerce influência positiva sobre a abundância de Collembola no solo, visto que neste estudo, observou-se que durante o período mais chuvoso houve maior abundância desses invertebrados, quando comparado ao período menos chuvoso. Conclui-se também que a riqueza de famílias observadas para a monocultura de dendê, é grande visto que corresponde a 68,42 \% das famílias que ocorrem no Brasil.

Palavras-chave: Fauna edáfica; Hexapoda; Dendê. 


\section{A ESCOLARIZAÇÃO DA PESSOA COM DEFICIÊNCIA NAS ILHAS DO COMBU E COTIJUBA}

Nome dos Bolsistas: Débora Kátia Ferreira do Carmo, Aleixa Caroline Teixeira Pereira

Nome do(a) Orientador(a): Ana Paula Cunha dos Santos Fernandes

Grupo de Pesquisa: Grupo de Estudos e pesquisa em Educação Especial na Amazônia

Resumo: Este trabalho é um recorte da pesquisa "Educação Especial do Campo: Estudos Iniciais nas Ilhas de Cotijuba e Combu", realizada pelo Grupo de Estudos e Pesquisa em Educação Especial na Amazônia - GEPEEAm, com financiamento pela FAPESPA/CAPES/CNPQ que investiga como é desenvolvida a Educação Especial nas ilhas de Belém. O objetivo é compreender o processo educacional ofertado aos alunos com deficiência num contexto de tensão entre direitos e exclusão educacional, contrastando a legislação vigente. A metodologia é pesquisa de campo, a partir do entendimento de Gil (2002) com abordagem qualitativa na perspectiva de Oliveira (2010). Os participantes foram professores da sala regular e coordenadores pedagógicos. O lócus da pesquisa foi em escolas ribeirinhas situadas nas Ilhas de Cotijuba e Combu, que funcionam sob a responsabilidade da Secretaria Municipal de Educação de Belém - SEMEC. Os resultados e discussões revelam uma realidade educacional que refletem as tensões existentes entre os direitos e a exclusão escolar, que por meio de exemplos mostram a necessidade de mais pesquisas sobre a educação especial do campo.

Introdução: Este trabalho é um recorte da pesquisa intitulada "Educação Especial do Campo: Estudos Iniciais nas Ilhas de Cotijuba e Combu", realizada pelo Grupo de Estudos e Pesquisa em Educação Especial na Amazônia - GEPEEAm, com financiamento pela FAPESPA/CAPES/CNPQ que investiga como é desenvolvida a Educação Especial nas ilhas de Cotijuba e Combu nas escolas vinculadas à Secretaria Municipal de Educação de Belém - SEMEC.

Neste trabalho a abordagem desliza sobre a escolarização da pessoa com deficiência nas ilhas, com foco nos elementos que envolvem esse processo educacional inclusivo nas escolas do campo, aqui estendido à pessoa com deficiência. É notório que existe na Constituição Federal de 1988, o direito à educação a cada cidadão brasileiro, independente de sua condição ou localização geográfica, de maneira que dê conta de prepará-lo "para o exercício da cidadania", no artigo 205, e no 206, incisos I e II, versam sobre "igualdade de condições para o acesso e permanência na escola" e a seguridade da -" liberdade de aprender, ensinar, pesquisar e divulgar o pensamento, a arte e o saber" (BRASIL, 1988).

Seguindo esse princípio, a Lei de Diretrizes e Bases da Educação - Lei 9.394/96, no artigo $4^{\circ}$, inciso III delibera sobre o Atendimento Educacional Especializado - AEE ofertado de forma gratuita e em rede regular de ensino, que no artigo 28, inciso I, 
contempla a população rural, garantindo-Ihe a promoção de conteúdos e metodologias que alcance suas necessidades educacionais e interesses de saberes.

A meta 4 do Plano Nacional de Educação - PNE (2014-2024) determina 'universalizar', para o público alvo da educação especial, "o acesso à educação básica e ao atendimento educacional especializado", com estratégia da garantia de aporte e estruturas que forneçam o suporte necessário à formação pessoal e educacional. Como visto, todas essas questões de direitos educacionais já obstam nas legislações pertinentes, mas o que não fica explícito é de que maneira esses direitos serão garantidos e implementados e qual qualidade dessa formação humana e de trabalho docente, dentro de um contexto de tantos conflitos de interesses e cortes nos investimentos destinados à educação pública?

Sob essa questão, o objetivo deste trabalho é compreender o processo educacional ofertado aos alunos com deficiência num contexto de tensão entre direitos e exclusão educacional.

Metodologia: O delineamento metodológico é de pesquisa de campo, que para Gil (2002) tem a capacidade de alcançar maior profundidade acerca do objeto pesquisado. A abordagem é de cunho qualitativo, que segundo Oliveira (2010) consiste em refletir e analisar a realidade em seu ambiente concreto, considerando métodos e técnicas que possibilitem compreender o objeto de estudo no contexto histórico e estrutural. A partir desses, a pesquisa se utilizou de visitas técnicas, observação in locus, diário de campo e entrevistas semiestruturadas, a fim de reunir o máximo de elementos e informações que fosse base de investigação e análise sobre o objeto pesquisado.

Foram participantes professores da sala regular e coordenadores pedagógicos, atuantes nas escolas pesquisadas das Ilhas, sendo dois coordenadores e dois professores das escolas do Combu e, três coordenadores e sete professores das escolas de Cotijuba, destacando mais uma entrevista com a assistente social que atende as UP's situadas nessa Ilha, com a função de fazer a articulação intersetorial entre as demandas dos alunos e as instituições assistenciais, mas que, além disso, atua também na mediação dos conflitos de comportamentos dos alunos das escolas ribeirinhas. Todos os profissionais participantes o fizeram espontaneamente, mediante leitura e aceitação do Termo de Consentimento Livre e Esclarecido - TCLE, que garantia sigilo de identidade.

O lócus da pesquisa foi em escolas ribeirinhas situadas nas Ilhas de Cotijuba e Combu, que funcionam sob a responsabilidade da Secretaria Municipal de Educação de Belém - SEMEC, e ocorreu em quatro Unidades Pedagógicas - UP's, compreendendo duas instituições em cada Ilha. Para garantir o anonimato das unidades pedagógicas pesquisadas, a identificação é por meio das letras $A B C$ e $D$, sendo $A$ e $B$, situadas na Ilha do Combu; $C$ e $D$, localizadas na Ilha de Cotijuba.

Resultados e Discussão: Os resultados da pesquisa evidenciam que essas escolas ribeirinhas possuem matrículas de alunos com deficiência, mas não há uma política municipal de educação que subsidie a oferta de AEE para as unidades pedagógicas da Ilhas. Há inexistência de atendimento educacional especializado nas unidades 
pedagógicas do Combu, ou ocorre com descontinuidade, como é o caso das escolas da Ilha do Cotijuba, o que corrobora para o fortalecimento da exclusão social nas regiões campesinas.

As escolas: A escola $A$ tem 170 alunos matriculados, incluindo os alunos com deficiência, entretanto não foi obtido a quantidade de matrícula do público da educação especial, embora tenham informado de um aluno surdo matriculado. Escola $B$ possui 86 alunos matriculados, com 2 alunos com deficiência, sendo que um aluno possui deficiência física e locomove-se por cadeiras de rodas e a outra criança possui deficiência intelectual, com comprometimento comportamental. A escola $C$ possui 225 alunos matriculados, sendo 4 alunos com deficiência, e a escola $D$ tem 101 alunos matriculados, com um aluno com suspeita.

Em virtude desse quadro, a situação é preocupante, e que pode comprometer desfavoravelmente o processo de escolarização das pessoas com deficiência matriculadas nas unidades pedagógicas, mostrando uma realidade que reflete um contexto de tensão existente entre os direitos da pessoa com deficiência BRASIL (2008) e a exclusão educacional que acontece nas instituições pesquisadas nessas ilhas.

\section{O Atendimento Educacional Especializado nas ilhas}

$\mathrm{Na}$ Ilha do Combu, há inexistência de AEE para aos alunos da educação especial, e a justificativa usada pela coordenação geral das Ilhas, tem causa na falta de formação específica dos candidatos aprovados em processo seletivo simplificado - PSS -, promovido pela SEMEC, que não preenchem os requisitos necessários para esse atuar. Sobre esse aspecto, a entidade não explica quais as estratégias de intervenção pedagógica ou atendimento terapêuticos são adotadas com os alunos com deficiência. Essa postura institucional demostra a falta de uma estrutura política para atender essa especificidade educacional dos alunos das escolas ribeirinhas.

Nas UP's da Ilha de Cotijuba, existe um sistema intermitente de atendimento educacional especializado, que atende os alunos com deficiência, de acordo com um cronograma, estrategicamente organizado para atender outras UP's localizadas nos arredores da llha, que não foram locus da pesquisa, mas o funcionamento é deficiente, o que afeta negativamente a escolarização dos alunos com deficiência.

Dessa forma, houve o encerramento das atividades antes do final do período letivo, o que causou a interrupção do atendimento educacional especializado, reverberando a avaliação processual aos professores de sala regular, considerando que estes não possuem suporte teórico metodológico, específico da educação especial, e estes profissionais não receberam apoio pedagógico sobre o atendimento dos alunos, e, portanto, não conseguem avaliar o aluno de modo a garantir uma apresentação de resultados pedagógicos que dê conta de suas conquistas, avanços, necessidades, ou o que ainda precisa superar, dentro de seu real perfil educacional.

\section{Formação Continuada em Educação Especial}

Sobre a formação continuada ofertada aos professores pela SEMEC, foi observado que não são trabalhadas questões sobre a Educação Especial, salvo aspectos pontuais. De maneira geral, as demandas por estratégia de ensino inclusivo, parte da 
busca própria do professor para compreender e atender a necessidade educacional do aluno, como no caso da alfabetização do aluno surdo por meio da Libras - Língua Brasileira de sinais (BRASIL, 2002), que estabelece o direito da pessoa surda de usar a Libras como língua primeira para se comunicar e aprender a Língua Portuguesa como segunda língua e assim, o possibilitar o avanço do processo de inclusão escolar, cultural e social do educando.

Neste caso, a professora da sala regular foi aprender a Libras com objetivo de romper a comunicação e usá-la como meio de alfabetização da criança. Essa atitude docente gerou um resultado exitoso de inclusão educacional na UP. Em outro caso, a professora não conseguiu manejar o comportamento de uma criança com deficiência intelectual, que necessitava de intervenção terapêutica e apoio exclusivo em sala, e sem haver nenhum desses auxílios, a criança frequentou somente as primeiras aulas de 2018, e em 2019 os pais não mais a matricularam na escola, evento passível de interpretar como expulsão - exclusão educacional e cerceamento dos direitos dessa criança a os serviços sociais, terapêuticos e educacionais a que tem direito.

No tocante a Educação do Campo, essa temática é abordada na perspectiva restrita da educação ambiental, que representa a concepção genérica considerada por boa parte dos docentes nas escolas das llhas.

Sobre esse assunto, Fernandes (2017) destaca que o fato de não ser oferecida "formação continuada para os professores sobre educação do campo contribui para que eles cheguem às ilhas com uma visão urbanocêntrica e burguesa, querendo transferir os elementos urbanos para o campo" (FERNANDES, 2017, p. 80).

O resultado da abordagem rasa e pouco problematizada sobre os aspectos da vivência e contexto rural, no tocante a Educação do Campo, além de estar em desacordo às orientações sobre a educação básica para a população campesina, disposta na LDB 9.394/96, artigo 28, inciso I, dispõe que os conteúdos curriculares e estratégias pedagógicas devem alinhar-se aos interesses do aluno, dando entender a limitada formação educativa crítica e pouco significativa para os alunos, e que não estão explicadas nas estratégias da meta 4 do PNE, em relação as suas singularidades regionais e locais, e assim, desfavorece a escolarização e potencializa a barreira da exclusão social, pela negação de direitos aos diferentes sujeitos do campo.

Considerações Finais: Esse trabalho buscou compreender o processo educacional ofertado aos alunos com deficiência num contexto de tensão entre direitos e exclusão educacional. Por meio das informações coletadas no locus, em contato com os participantes e observando o contexto escolar, a interpretação da realidade contraditória mostra a tensão existente entre garantia dos direitos e a exclusão educacional que ocorre no processo de escolarização da pessoa com deficiência, destacando, prioritariamente, a ausência de Atendimento Educacional Especializado, ou o caso do funcionamento ser deficitário, nas escolas pesquisadas, $A, B, C$ e $D$, nas Ilhas do Combu e Cotijuba, respectivamente.

Entende-se que a pesquisa sobre como acontece o processo de escolarização da pessoa com deficiência nas regiões campesinas, das llhas, deve continuar e se intensificar, de maneira que cada vez mais alcance o maior e mais profundo 
conhecimento sobre o crescimento e desenvolvimento das pessoas e de seus lugares, de valorização do modo de viver em comunidade, das representações sociais, culturais e políticas, como nas comunidades ribeirinhas de Belém do Pará.

\section{Referências}

BRASIL. Constituição Federal de 1988. Disponível em: $<$ http://www.planalto.gov.br/ccivil 03/constituicao/constituicao.htm>. Acesso em: 05 de agosto de 2019.

. Lei 13.005/2014. Plano Nacional da Educação (2014-2024). Disponível em: http://pne.mec.gov.br/18-planos-subnacionais-de-educacao/543-plano-nacional-deeducacao-lei-n-13-005-2014. Acesso em 5 de agosto de 2019.

. Lei 9.394/1996. Lei de Diretrizes e Base da Educação. Disponível em: https://www2.senado.leg.br/bdsf/bitstream/handle/id/70320/65.pdf. Acesso em 6 de agosto de 2019.

. Plano Nacional de Educação (2014-2024). Brasília: MEC, 2014. Disponível em: <http://pne.mec.gov.br/18-planos-subnacionais-de-educacao/543-plano-nacionalde-educacao-lei-n-13-005-2014>. Acessado em 6 de agosto de 2019.

. Língua Brasileira de Sinais - Libras. Lei no 10.436, de 24 de abril de 2002. Disponível em: <http://www.planalto.gov.br/ccivil 03/leis/2002/10436.htm>. Acesso em 19 de agosto de 2019.

FERNANDES, Ana Paula da Cunha dos Santos. Diálogo sobre a formação docente: o ser e o saber-fazer com o público-alvo da educação especial. In: CAIADO, Kátia Regina Moreno (org.). Educação Especial no Campo - Uberlândia: Navegação Publicações, 2017.

GIL, Antonio Carlos. Como elaborar projetos de pesquisa. $4^{\mathrm{a}}$ ed. São Paulo: Atlas, 2002.

OLIVEIRA, Maria Marly de. Como fazer pesquisa qualitativa. 3. ed. revista ampliada - Petrópolis, RJ: Vozes, 2010.

Palavras-chave: Educação Especial do Campo. Formação de Professores. Exclusão Educacional. 


\section{ELABORAÇÃO DE HAMBÚRGUER DE CASTANHA DO BRASIL (BERTHOLLETIA EXCELSA).}

Nome do(a) Bolsista: Daniela Queiroz Leite

Nome do(s) Voluntário(s): Ana Luiza Sousa de Lima

Nome do(a) Orientador(a): Benedito Lobato

Grupo de Pesquisa: Grupo de Estudo em Energia e Processos na Amazônia

Introdução; A castanha-do-brasil é considerada uma fonte rica de metionina, um aminoácido essencial e que não é encontrado em muitas proteínas de origem vegetal, além de fonte de vitamina $E$, complexo $B$, e de minerais como fósforo, potássio, magnésio, cálcio e selênio, um importante antioxidante relacionado à redução de risco de câncer (BEZERRA; DAMASCENO, 2018). O hambúrguer de castanha-do-Brasil, produto elaborado a base de proteína texturizada de soja e a amêndoa da castanheira, têm como fundamento questões como a utilização do fruto da biodiversidade amazônica para inovar um dos alimentos que possuem crescimento constante no consumo das comidas rápidas - o hambúrguer - e que agrade o paladar da população, que cada vez mais busca compor suas refeições com alimentos que ofereçam boa base nutricional; além de incentivar com o objeto de estudo a valorização da matéria regional em uma aplicação que foge do convencional. O trabalho teve como objetivo elaborar o hambúrguer de castanha do Brasil submetendo o produto á analises físico-químicas (composição centesimal), e análises microbiológicas. Os resultados obtidos para análises físico-químicas foram: Umidade $59,82 \%( \pm 0,77)$, Proteína 23.39\% ( \pm 0.62$)$, Cinzas 2.2\% $( \pm 0.0)$, lipídeos 7,63\% $( \pm 0,03)$, carboidratos 6,96\%, valor calórico 190,07 Kcal/100g, $\mathrm{pH} \mathrm{6,52}( \pm 0,02)$ resultados esses tidos como satisfatório. Das análises microbiológicas, salmonella, coliformes a $45^{\circ} \mathrm{C}$, staphylococcus aureus e bolores e leveduras todas se mostraram ausentes ou abaixo do valor limite, encontrando-se, portanto, dentro dos critérios exigidos pela legislação brasileira. Concluindo, assim, com os estudos feitos e parâmetros encontrados que o produto elaborado se encaixa nos requisitos pressupostos respondendo positivamente ao esperado.

Palavras-chave: Inovação; Vegano; Biodiversidade; Físico-química; Regional. 


\section{ANÁLISE DA QUALIDADE AMBIENTAL DA ÁGUA DOS RIOS PRAINHA E URAIM (PARAGOMINAS-PARÁ): UTILIZANDO INSETOS AQUÁTICOS COMO BIOINDICADORES}

Nome dos Bolsistas: Eldeline Nascimento Lopes e Letícia Ferreira Freitas Nome do(a) Orientador(a): Carlos Elias de Souza Braga Grupo de Pesquisa: Pesquisas Interdisciplinares em Biodiversidade Amazônica

Introdução: Os ecossistemas aquáticos (rios, lagos e demais corpos d'água) são fundamentais à sobrevivência humana e para milhares de organismos vivos que neles habitam. As ações humanas sobre as águas, como o descarte irregular, provocam efeitos sob a qualidade hídrica e expressiva perda da biodiversidade, causando desestabilização nesses ambientes. Por isso, o biomonitoramento da qualidade da água de ecossistemas aquáticos é de extrema importância para sua conservação e preservação. Os insetos, assim como ou macroinvertebrados, são utilizados como bioindicadores de qualidade ambiental, por ter uma grande diversidade de espécies e relevância nos processos ecossistêmicos naturais. Pelo exposto, o presente estudo tem como objetivo inventariar os insetos aquáticos de forma a caracterizar a qualidade da água de dois rios da região de Paragominas, o Rio Uraim e Rio Prainha (conhecido popularmente como Igarapé Paragominas). As coletas foram realizadas em três pontos de amostragem em cada rio (Rio Uraim: P1, P2 e P3; Rio Prainha: P4, P5 e P6), sendo que em cada ponto forma realizadas coletadas nas margens direita e esquerda, todos os exemplares foram triados e armazenados em álcool 70\% e depositados na Coleção Zoológica da UEPA. Foram coletados 1.225 exemplares (74,3\% no Rio Prainha e $25,7 \%$ no Rio Uraim) e 20 famílias de Insecta, pertencentes às ordens Odonata ( $n=$ $666)$, Diptera $(n=368)$, Ephemeroptera $(n=99)$, Hemiptera $(n=52)$, Hymenoptera $(n=$ 25), Coleoptera $(n=13)$, Trichoptera $(n=1)$ e Dermaptera $(n=1)$. No Rio Uraim foram regsitradas 18 famílias e Rio Prainha 15 famílias. As famílias mais abundantes foram Chironomidae $(n=366)$ da ordem Diptera; Coenagrionidae $(n=310)$ e Libellulidade $(n=$ 268) da ordem Odonata. Em ambos os rios foram encontrados macroinvertebrados sensíveis, tolerantes e resistentes indicando que os mesmos podem ser classificados como um Ecossistema Natural/Alterado. Além de ambos serem classificados, segundo o índice BMWN (Biological Monitoring Working Party Score System), no nível III (satisfatório) de qualidade da água.

Palavras-chave: Biomonitoramento, Entomofauna aquática, Qualidade da água. 


\title{
TERRITÓRIO E VIOLÊNCIA URBANA: UMA LEITURA GEOGRÁFICA DOS HOMICÍDIOS NO BAIRRO DO CURUÇAMBÁ, ANANINDEUA-PA
}

\author{
Nome dos Bolsistas: Roberta Carolina Maués do Nascimento, Anaclara Silva Braga \\ Nome do(a) Orientador(a): Clay Anderson Nunes Chagas \\ Grupo de Pesquisa: Laboratório de Geografia da Violência e do Crime.
}

Introdução: No Brasil, a violência urbana tem se manifestado de forma latente e decorre principalmente do crescimento urbano desordenado e da falta de infraestrutura necessária para as cidades, sobretudo as grandes cidades brasileiras, em que o processo de urbanização ocorreu de forma acelerada, ocasionando diversos problemas sociais. Um desses problemas sociais é a criminalidade, que vem se intensificando cada vez mais nos últimos anos, criando situações de medo e insegurança na população. A Criminalidade pode estar associada a diversos fatores, porém, não há como mencionar um fator preponderante para tal fato, mas fatores como: desigualdade socioespacial e socioeconômica, e a ineficácia de serviços públicos, saúde, educação, saneamento básico e segurança pública contribuem para o aumento da criminalidade. Nesse sentido, nota-se que o município de Ananindeua se encontra com essas características e enfrenta problemas dessa natureza. Deste modo, a pesquisa tem como objetivo analisar a dinâmica dos homicídios no bairro do Curuçambá, em Ananindeua-Pa, no período de 2013 a 2018. Para isso, realizou-se um estudo dos conceitos de produção do espaço urbano, território, violência e criminalidade. A metodologia aplicada consistiu em levantamento bibliográfico, realização de trabalhos de campo com aplicação de entrevistas aos agentes micro e macro territoriais (moradores, comerciantes, delegados, policiais, representantes de entidades religiosas, lideranças comunitárias, etc). Para o levantamento documental, utilizou-se o banco de dados do IBGE e da Secretaria Adjunta de Inteligência e Análise Criminal-SIAC, que fornecem as informações sobre os registros de homicídios nos anos de 2013 a 2018. Esses dados nos possibilitam criar as manchas criminais de homicídios-hot spot, auxiliando nas análises da Cartografia do crime. A Geografia se faz muito importante para compreender temáticas como violência urbana e criminalidade, pois a partir de seus conceitos e estudos sobre espaço urbano e território, é possível compreender o recorte espacial estudado e ter um melhor entendimento da realidade local do bairro do Curuçambá. Assim, o presente estudo faz-se necessário, diante do crescimento desses fenômenos socais que geram diversas mazelas sociais e inúmeras mortes, o que ocasiona medo e insegurança na população do bairro. Dessa forma, percebe-se que a dinâmica da criminalidade está associada as precariedades em algumas áreas no bairro, onde os investimentos sociais como a educação, saúde e segurança são quase inexistentes. Através dessas falhas do Estado percebe-se a proliferação do tráfico de drogas e o aumento das práticas de assaltos e homicídios impulsionando a sociedade a se "proteger" com a presença de muros altos e grades (SOUZA, 2008). 


\title{
PROJETO DE PESQUISA/PIBIC: VINTE ANOS DO CÓDIGO DE TRÂNSITO BRASILEIRO: EDUCAÇÃO PARA O TRÂNSITO, AVANÇOS, DESAFIOS E PERSPECTIVAS.
}

\author{
Nome do(a) bolsista: Rejane Pinheiro Chaves \\ Nome do(a) Voluntário(a): Jessyca Moraes de Oliveira \\ Nome do(a) Orientador(a): Diana Lemes Ferreira \\ Grupo de Pesquisa: Grupo de Estudos e Pesquisas Pedagogia em Movimento
}

Introdução: $O$ projeto buscou estudar os avanços, desafios e perspectivas no que concerne à educação para o trânsito, a partir da instituição, em 1997, do Código de Trânsito Brasileiro (CTB) o qual incluiu um capítulo sobre a educação para o trânsito. Teve como objetivo geral investigar as ações e programas educacionais promovidos para cumprir o que apregoa o capítulo sobre a educação para o trânsito do CTB em vigor, tendo como foco de análise a política de formação continuada dos professores da Rede Municipal de Educação de Belém (RMEB). Especificamente buscou analisar a aplicação do CTB, no que concerne à educação para o trânsito em Belém do Pará; pesquisar ações, programas e legislações sobre a formação de professores no que concerne à educação para o trânsito; fazer um recorte analítico com os professores em exercício na RMEB, acerca dos suportes e formação continuada que receberam no que tange a educação para o trânsito. Teve como questões norteadoras: Após vinte anos do CTB o que avançou? Quais são os desafios? Quais são as perspectivas? O que a política de formação continuada dos professores da RMEB construiu neste processo? A metodologia utilizada se baseia nos princípios da pesquisa qualitativa. Os instrumentos utilizados foram pesquisa bibliográfica, pesquisa documental e entrevistas. A análise de dados realizou-se por meio da técnica de análise de conteúdo. Os resultados revelaram que não houve avanços significativos para implementação de uma política para formação do professor promovido pela RMEB em parceria com outras instituições no que tange ao tema educação para o trânsito. A pesquisa de campo revelou que as escolas dos docentes entrevistados foram comtempladas com ações e projetos de educação para o trânsito por meio de ações e projetos da UEPA. DETRAN e SEMOB. No entanto os projetos extensão e estágio supervisionado da UEPA/DETRAN, bem como as poucas campanhas educativas da SEMOB, têm como público alvo as crianças da RMEB, e não o professor diretamente. $\mathrm{O}$ que nos potencializa afirmar que ainda há um caminho longo a ser percorrido na construção de uma politica de formação continuada que aborde a temática educação para o trânsito.

Introdução: Transitar nas vias de circulação com veículos cada vez mais modernizados e potentes tem sido fortalecido por uma cultura do capitalismo a qual propicia ainda mais o consumismo exacerbado, e torna-se uma conquista almejada por muitos. Quando atendida esses anseios individuais do consumo não se percebe as consequências para outras pessoas. O transitar precisa ser visto de forma macro na 
qual envolve os usuários, a engenharia do tráfego nas vias, a mobilidade, a saúde pública, a educação, entre outros.

Acreditamos na concepção de que as vias de circulação, por ser pública, tem o objetivo de que todos venham usufruir, das mesmas de acordo com as suas necessidades. No entanto, o que se pode observar, é uma disputa desigual por espaço, entre os atores que fazem no trânsito no dia a dia. O que vem ocasionando impasses com um número elevado de acidentes, o qual tem despertado de forma gradativa os órgãos públicos o anseio em reverter o quadro dessa situação.

Dessa maneira, o atual Código de Trânsito Brasileiro (CTB) que passou a vigorar em 1998, diante dessa demanda da sociedade, foi instituído um capítulo exclusivo sobre a educação para o trânsito. O que o torna mais evidente e eficaz o papel educativo e também traz a tona a questão do professor como parceiro e mediador de aprendizagens desses conhecimentos que venham contribuir para redução de acidentes nas regiões brasileiras.

No entanto, para que o capítulo do CTB venha ser uma realidade nas cidades e escolas, exige que os professores venham ter uma formação específica para atuar nas instituições de ensino, haja vista que o tema tem relevância social, abrange todas as áreas brasileiras, alcança todos os níveis de ensino e pode ter participação social (BRASIL, 1998). Consolidando assim, a importância que há em aprender e ensinar, pois estamos diante de vidas.

Por meio do Programa Institucional de Bolsa de Iniciação Científica (PIBIC), o qual dispõe do intuito de incentivar a iniciação científica nas instituições de ensino e/ou pesquisa, pudemos investigar a aplicação do CTB, no que concerne à educação para o trânsito em Belém do Pará durante esses vinte anos de vigência. Bem como, ações, programas e legislações sobre a formação de professores no munícipio de Belém.

Para este resumo, socializamos as ações realizadas durante o PIBIC (Edital 019/2018) vinculado a Universidade do Estado do Pará (UEPA) referente ao período da pesquisa que durou um ano, o qual teve seu início em agosto de 2018 e término em agosto de 2019. Dessa forma, a pesquisa traz a reflexão de que a educação para o trânsito perpassa pela subjetividade de vidas, e o professor é um ator primordial na consolidação desse processo educativo.

\section{Caminhos inicias da pesquisa bibliográfica e documental}

Os estudos bibliográficos sobre educação para o trânsito recebida na formação continuada dos professores da RMEB foi realizada na base de dados dos sites da "Revista Ensaio: avaliação e políticas em educação", "Conselho Nacional de Desenvolvimento Científico e Tecnológico-CNPq", "Associação Nacional de Pósgraduação e Pesquisa em Educação-ANPEd", Scielo Brasil, bem como, no site da Prefeitura Municipal de Belém (PMB), da Secretaria Municipal de Educação de Belém (SEMEC), da Superintendência Executiva de Modalidade Urbana de Belém (SEMOB) e do Departamento de Trânsito do Estado do Pará (DETRAN/PA). Além da busca on line fizemos o estudo bibliográfico em livros.

Nos estudos realizados não encontramos artigos ou matérias referentes a educação para o trânsito na formação do professor, e nem programa ou projeto de formação continuada de professores da Semec/Belém que trata especificamente da temática. $\mathrm{O}$ 
que foi identificado foi a ações da antiga Companhia de Trânsito de Belém (CTBEL) no projeto intitulado "Cidade Criança" na gestão executiva municipal no período de 1997 a 2000 e 2001 a 2004 e posteriormente a realização de algumas palestras e ações pontuais na Semana Nacional de Trânsito de 2015 coordenadas pela SEMOB em parceria com a SEMEC e da Secretaria Municipal de Saúde (SESMA).

Diante disso, decidimos procurar os temas "Educação para o Trânsito" e "Formação de Professores", separadamente, dessa maneira conseguimos encontrar alguns artigos, trabalhos de conclusão de curso e dissertações. Vale ressaltar, no que tange o primeiro item, encontramos poucas publicações nos dados fornecidos pelo Google Acadêmico e também em outros sites de pesquisa acadêmica citados anteriormente, diferentemente, do outro item pesquisado que existe mais publicações.

Após esse percurso acima referido, realizamos a pesquisa documental com o jornal $\mathrm{O}$ Liberal, com a finalidade de investigar possíveis programas, projetos ou ações realizadas pela PMB sobre Educação para o Trânsito. Foram selecionados os meses de Maio e Setembro entre 1998 a 2018 para fazer o recorte analítico. A escolha dos referidos meses se deu por dois motivos centrais. O primeiro motivo da escolha do recorte de coleta de informações e análises refere-se ao fato de consideramos meses significativos em que o tema trânsito está evidência nas campanhas educativas sobre trânsito. O mês de Maio é referência mundial para chamar atenção da sociedade sobre o tema trânsito com o movimento chamado "Maio Amarelo" (2019), enquanto que o mês de Setembro é realizado a Semana Nacional do Trânsito de acordo com o estabelecido no CTB (BRASIL, 1997). O segundo motivo da escolha foi de cunho metodológico. Em virtude do tempo do projeto de pesquisa PIBIC ser de um ano, não teríamos tempo hábil para fazer uma análise de 20 anos do CTB em sua totalidade de forma consecutiva.

Vale ressaltar que o primeiro ano da implementação do CTB (1998), foi analisado o ano inteiro. Foi apontado segundo o jornal que a implementação do "novo" CTB em 1998, houve grande tumultos e dúvidas entre motoristas e ciclistas que precisavam se adequar as novas normas de conduta frente a circulação nas vias. Para os pedestres, a atuação seria educativa, o que de fato pouco aconteceu. Outro fato são os índices de colisões no trânsito em Belém/PA sendo bastante enfatizados nas notícias pesquisadas, principalmente, entre pedestres e ciclistas.

Durante o período da pesquisa, pudemos verificar que foram realizados alguns seminários, com a integração de alguns órgãos como DETRAN, CTBel, cujo o público alvo era educadores, diretores de escolas e professores do Ensino fundamental. Em setembro/2008, DETRAN/PA, SEDUC/PA, CETRAN e duas escolas particulares assinaram um protocolo de um projeto a criação da disciplina "Trânsito" (Opcional) para 2009 para crianças e adolescentes, em escolas estaduais e particulares. As aulas ministradas nessa disciplina para os alunos do ensino médio substituiriam as aulas teóricas nos centros de formação de condutores. No entanto, não foi apontado quem ministraria as aulas. No entanto, o protocolo não se evidenciou na prática. Também foram apontados alguns projetos pontuais e campanhas, todos referentes a semana do trânsito promovido pelo órgão de trânsito.

\section{Análise das entrevistas com professores da RMEB}


Realizamos entrevistas semiestruturadas com dez professoras em duas escolas municipais, uma localizada no bairro de São Braz e outra na Pratinha. As perguntas estavam organizadas em categorias de trânsito, educação para o trânsito, formação de professor e sugestão de ação para avanço dessa temática na formação continuada dos docentes.

Constatamos que o trânsito está presente nos diferenciados deslocamentos diários como ir ao trabalho, a igreja, a casa, a escola, dentro de casa. No entanto é relatada de forma negativa por $90 \%$ professoras a qual percebem a imprudência dos usuários e os transtornos causados tanto na via, quanto a vida pessoal resultando para o aumento de acidentes. Somente $10 \%$ percebeu a diminuição desse quadro alarmante, o que pode estar associado às políticas de segurança no trânsito.

O que é preocupante, já que em 2020 completa a década para redução de acidentes de trânsito, proposta pela Organização das Nações Unidas (ONU). Em relação a isso apenas $20 \%$ das professoras sabiam dessa informação, devido a construção do projeto bimestral para educação infantil. As demais professoras (80\%) desconheciam totalmente. Conhecer essa temática independe da profissão, precisamos estar informados e atentos às notícias sobre o trânsito, ainda que exista pouca divulgação pelos órgãos de trânsito. Diante de tantas repercussões na mídia e no cotidiano de dados estatísticos sobre acidentes com mortes e/ou sequelas, deve-se ampliar esse assunto principalmente.

Dentre as participantes, 30\% revelaram que receberam formação para trabalhar a educação para o trânsito, ainda que de forma esporádica, para construção de projeto ou mesmo para aprofundamento de conhecimento sobre a temática. O primeiro, oferecido pela coordenadora pedagógica da escola, outro pela equipe de educação do DETRAN/PA e a última na graduação e pós-graduação. As demais participantes (70\%) evidenciam que não receberam formação continuada da SEMEC e nem pelos órgãos de trânsito. Porém dentre essas 30\% receberam em sua sala de aula algumas ações como o projeto de extensão da UEPA, Pedagogia em Movimento: educação para o trânsito em Belém/PA e campanhas educativas da SEMOB. O primeiro projeto não atuou especificamente na Semana Nacional do Trânsito, embora coincidisse em alguns momentos. Já o segundo desenvolve as campanhas nessa época e também no período de volta aulas.

Em uma análise geral, ambas as participantes receberam de forma indireta ações de projetos pelas instituições como a SEMOB, UEPA-PROEX/GEPPEM, UEPADETRAN/PA. As duas últimas instituições atuam por meio de ações extensionistas e com projeto de ação do Estágio Supervisionado em Instituições não Escolares e Ambientes Populares.

Em se tratando das experiências profissionais com o tema em sala de aula, o trabalho pedagógico desenvolvido pelas entrevistadas se deu em decorrência da semana do trânsito, mas sem continuidade após esse período. Com exceção de uma participante que devido uma formação no DENTRA/PA, teve que desenvolver após a formação um projeto para aplicação na escola que não era nesse período, mas que, segundo a professora, não houve continuidade. 
Segundo o CTB, art. 76, a educação para trânsito deve ser desenvolvida de forma interdisciplinar em todos os níveis de ensino com conteúdo de segurança no trânsito. Tratando-se disto, $100 \%$ das participantes sugerem que seja dessa forma e tenha ludicidade, pois tem impacto aos alunos/as e seu ambiente de convivência social, pois são multiplicadores/as.

Além disso, foi constatado, que embora o tema tenha aceitabilidade pelos alunos/as, para promovê-lo as docentes entrevistadas afirmaram que encontram dificuldades no acesso ao referencial teórico sobre a temática tanto online quanto impresso.

Outra situação encontra-se nas dificuldades em relação aos recursos materiais com a questão do dinheiro para comprar os aparatos necessários para as atividades lúdicas. Uma vez que a SEMEC, bem como, os órgãos executivos de trânsito não disponibilizam recursos necessários para a confecção de materiais educativos para se propagar a educação para o trânsito contínua nas escolas.

Outra dificuldade apontada pelas professoras é com relação aos recursos humanos, a problemática trata-se da ausência de parceria aos docentes posterior a Semana Nacional de Trânsito. Além do dilema das campanhas educativas dos órgãos de trânsito contemplar somente às crianças e poucas escolas em Belém e agrava-se em relação ao Estado do Pará.

Conclusão: Diante das informações obtidas na pesquisa bibliográfica, documental e entrevistas existe a necessidade de ampliar e aprofundar as discussões sobre educação para o trânsito na formação dos docentes e nas escolas. Sendo um dos caminhos para se alcançar essa meta seria a intensificação das ações dos órgãos de trânsito nas escolas municipais, estaduais e federais com a criação de projetos envolvendo a família e alunos. E, para, além disso, é crucial oferecer formações ao professor com foco nesse tema, a fim de consolidar práticas interdisciplinares mais contínuas na sala a partir de parcerias com órgãos competentes e também inclusão da educação para o trânsito no Projeto Político Pedagógico da escola.

Podemos compreender a partir dos apontamentos da pesquisa que durante os vinte anos do CTB, não foi implantada oficialmente nenhuma política de formação continuada de professores que contemplasse diretamente esta categoria de profissionais da educação na cidade de Belém. Embora as ações tivessem sido realizadas nas escolas isso não significou algo específico de formação continuada para os professores. Entendemos que os professores e demais sujeitos sociais são diferentes atores no trânsito, e que cada conhecimento é importante na formação da cidadania. No entanto, é necessário estabelecer políticas de formações com essa temática a nível macro e micro que propicie o trabalho humano e preventivo.

O desafio posto diante dessa pesquisa é que precisamos avançar na formação continuada de professores/as. Somente o docente não tem recursos suficientes para desenvolver propostas pedagógicas interdisciplinares, é necessário parcerias entre os sistemas de ensino, saúde e de trânsito a fim de formar educadores multiplicadores que possam ressignificar esse cenário.

Referências: BRASIL, Código de Trânsito Brasileiro: Instituído pela Lei n. 9503, de 239-97,1. ed. Brasília: DENATRAN, 2008. 
BRASIL, Ministério da Educação e do Deporto. Secretária de Educação Fundamental. Parâmetros Curriculares Nacionais: terceiro e quarto ciclos do ensino fundamental: introdução aos parâmetros curriculares nacionais. Brasília: MEC, 1998.

MAIO AMARELO. O movimento maio amarelo. Disponível em: https://maioamarelo.com/ Acesso em 09 de maio de 2019.

Palavras chave: Trânsito. Educação para o trânsito. Formação de professores. Política de Formação Continuada de Professores. 


\section{MITOS ASSURINI DO TROCARÁ: FONTES DE SABERES INTERDISCIPLINARES}

Nome dos Bolsistas: Vanderleia Assurini, Waremoa Assurini

Nome do(s) Voluntário(s): Moiratsin Assurini, Torrossa Assurini

Nome do (a) Orientador (a): Eliete de Jesus Bararuá Solano

Grupo de Pesquisa: Linguística, Educação e Literatura

Introdução: Este artigo intitulado "Mitos Assurini do Trocará: fontes de saberes interdisciplinares" constituiu-se como um relato de experiência da aplicação do projeto de Iniciação Científica que teve como um de seus objetivos principais, documentar em língua materna (Assurini do Trocará e/ou língua Assurini/Português se for interesse da comunidade) os principais mitos e/ ou os mitos mais significativos para essa comunidade, de forma a contribuir não somente para o fortalecimento da língua materna dessa etnia, mas também para o fomento de materiais didáticos interculturais e interdisciplinares, que utilizem dessas mitologias para as três grandes áreas do conhecimentos (ciências humanas e sociais, ciências da natureza e matemática e linguagens e artes) presentes nas escolas indígenas, em especial a escola Indígena da Aldeia Trocará, próximo ao município de Tucuruí-Pa. Os autores que fundamentam o presente trabalho são: Muller (1876), Rocha (1996), Bandeira (2009), DIEGUES (2000).Os procedimentos metodológicos foram desenvolvidos, a partir de uma abordagem de pesquisa qualitativa, caracterizada como uma prática de Etnopesquisa, que foi realizada pelos discentes indígenas Assurini, na aldeia indígena Trocará, junto aos anciãos Assurini, que por meio de suas narrativas orais ou mitos demonstraram valores e conhecimentos acumulados do povo indígena Asurini referentes às relações humanas, o mundo natural, cosmologias, danças, músicas, rezas, práticas de produção e reprodução de diferentes concepções e visões de mundo.

Palavras-chave: Língua Assurini. Mitos. Saberes interdisciplinares. Material Didático 


\title{
MARCAS DA DIFERENÇA: REFLEXÕES SOBRE A CONTRIBUIÇÃO DO NEGRO NA PRODUÇÃO CIENTÍFICA E MATEMÁTICA
}

\author{
Nome dos Bolsistas: Clebson Carvalho de Oliveira, Luciane Gonzaga Peniche \\ Nome do(a) Orientador(a): Emerson Batista Gomes \\ Grupo de Pesquisa: Grupo de Estudos e Pesquisas da Didática da Matemática
}

Introdução: Não é atual o debate em que se enquadra a temática racial, é uma discussão que se fomenta e vem se arrastando ao longo dos anos com o objetivo de tentar acabar ou ao menos amenizar com a desigualdade racial que perdura há muitas décadas. São reflexos daquilo que foi um dos regimes mais horrendos já praticado pelo homem para com o próprio homem.

Um passado que traz marcas da exploração, opressão, humilhação, e, principalmente, desumanidade, que resultaram em consequências nefastas para os negros. Com isso, atribuiu-se à imagem do negro um sentido pejorativo e que hoje, em pleno século XXI, ainda apresenta reflexos de todo esse passado horrendo, gerando desigualdades na vida da população negra mundial e, em particular, no Brasil.

Todo esse passado e a imagem criada por conta dele acaba ofuscando toda uma brilhante cultura e avanços na construção de saberes que se agregam e entrelaçam na formação de nossa sociedade, o que acaba gerando um pensamento errôneo a respeito dos negros, ou seja, associando-o a um pensamento de inferioridade, o qual o negro não é capaz de construir conhecimento, associando sua uma imagem apenas à mão de obra para trabalho braçal, como os escravos no passado.

Os resquícios da história que permeiam a sociedade acabam por gerar marcas de diferenças que têm reflexo direto na vida das comunidades de etnia negra. Afinal, ao contrário do que se pensa, com a abolição da escravatura, o negro não passou a ser inserido na sociedade. O que se teve, em verdade, foram os registros de uma nova fotografia da social, na qual o negro, por ser discriminado pela sociedade, migra e se estabelece nas periferias, dando origem às favelas, e com isso, nessas condições, acabam criando um espaço de pobreza, desprovido de oportunidades.

Somente décadas mais tarde, por meio de grupos e movimentos negros, que se dera o início às mudanças no panorama situacional dos negros, pois cansados de tanta desigualdade, organizaram-se e se mobilizam para irem em busca dos direitos que Ihes foram negados. Temos então a criação das chamadas ações afirmativas políticas públicas que visam coibir séculos de desigualdades sofridas pelos negros. Nosso intuito, porém, não é o de retratar passo a passo essa história de lutas dos movimentos sociais. Mas, a partir de certos resultados, avaliar como se tem discutido e apresentado a produção do conhecimento matemático pelos negros no ambiente escolar. Neste caso, nos são de interesse duas ações afirmativas, por acreditarmos serem impactantes no avanço do negro na sociedade. A primeira, trata-se da Lei 12.711/2012, a Lei de Cotas que fora responsável pelo aumento do acesso dos negros ao ensino superior, política esta que auxilia na ascensão dos negros na sociedade, pois rompe com barreiras sociais, culturais e econômicas opressoras, dando-lhes mais 
oportunidades. A segunda, trata da Lei 10.639/2003, que estabelece a obrigatoriedade do ensino da História e Cultura Africana e Afro-Brasileira no currículo escolar. Desta forma, podemos trazer para a sala de aula o discurso étnico-racial, apresentando a história dos africanos e sua importância para a formação da sociedade brasileira, quebrando com uma concepção de conhecimento estritamente eurocêntrica e possibilitando a visibilidade das contribuições dos povos negros.

Visando dar visibilidade às contribuições dos negros que estão ocultas da sociedade, engajamo-nos na busca de referências bibliográficas que nos possibilitassem tirar os negros do anonimato e romper com a lógica implícita de que o conhecimento é uma construção apenas do homem branco e despertando na sociedade a consciência da importância dos povos negros no desenvolvimento científico.

Objetivo(s): De modo a nortear nosso trabalho, pautamo-nos no seguinte objetivo geral: Investigar, para compreender e divulgar, em que termos se evidenciam as contribuições dos negros na produção do conhecimento matemático. Em especial, interessamo-nos pelas evidências de contribuições dos negros à produção científicomatemática e como estas têm sido tratadas no ambiente escolar.

Como objetivos pedagógicos e de contribuição social, também buscamos dar visibilidade às contribuições dos negros na construção científico-matemática, retirandoas da obscuridade e (re)apresentando-as à sociedade, iniciando por reflexões propícias à conscientização dos alunos nas escolas básicas, bem como na formação de professores de matemática. Contribuindo, assim, para a valorização do negro como construtor de conhecimento.

Material e Método: Este trabalho apresenta os resultados de um estudo bibliográfico e análise de livros didáticos, que tece considerações acerca da efetivação de uma ideia de igualdade à memória cultural e científica em matemática, fazendo-se justiça a um povo a muito injustiçado - os negros. A pesquisa se enquadra sob uma abordagem qualitativa e toma por referências Silva et al (2011) e Vieira (2017) no tocante à cartografia sobre a produção do conhecimento pelo negro e Almeida (2018) como suporte à construção histórica e epistemológica da matemática. Assim como Eves (2011) e Boyer (1974) que nos dão suporte histórico na busca pelas contribuições dos negros.

Para sustentar nossas buscas pelas contribuições na história, encontramos em Walter Benjamin (2013) um aparato metodológico que entendemos atender ao que buscamos realizar, uma vez que procuramos evidenciar os fragmentos da história que contenham vestígios das contribuições dos negros na produção do conhecimento matemático. Deste modo, emprestamos de Benjamin a categoria Rastros que, na sua visão, são marcas deixadas por indivíduos no espaço-tempo, e que não necessariamente compõem uma narrativa linear da história. Assim, vamos ao encontro da história em busca de rastros dos povos e indivíduos negros que contribuíram para o desenvolvimento matemático, com o intuito de trazer luz sobre os feitos dos negros e desconstruir a imagem pejorativa inerente a esse grupo étnico, bem como os 
pensamentos que taxam o negro como incapaz de produzir conhecimento, causada por um passado marcado pela exploração, desigualdade e sofrimento.

Resultados: Hoje temos uma grande quantidade de mecanismos e ferramentas que nos possibilitam a difusão de informações, no entanto, pouco se sabe sobre a influência que os povos negros tiveram para o desenvolvimento de muito do que julgamos importante na sociedade atual.

Voltando-nos para o campo da matemática, pouco se encontra sobre as contribuições dos negros para o desenvolvimento desta, ou, quando se encontra, dissocia-se a ideia de que foram os negros que elaboraram tal saber. Por exemplo, é o que acontece quando se refere ao Egito nos livros didáticos de matemática, não nos é transmitida a ideia de que este país pertence ao Continente Africano e que, portanto, são negros que compõem essa civilização.

O que podemos perceber é um desvio de informações, uma camuflagem que não nos permite atribuirmos os méritos aos devidos contribuintes na formação de determinados conhecimentos matemáticos. Essa atitude não ajuda na desconstrução da imagem pejorativa que a sociedade possui a respeito do negro, impossibilitando este de ser visto como construtor de conhecimento e ter contribuído para o desenvolvimento das ciências.

De posse de evidências históricas, tomadas por referência, analisamos à luz de Silva et al (2011), Vieira (2017), Almeida (2018), dentre outras produções, três coleções de livros didáticos utilizados na rede municipal de ensino de Igarapé-Açu-PA. Estas análises nos oportunizam tratar de questões como invisibilização de produção do conhecimento e falsa democracia racial.

A conduta de ocultamento nos livros didáticos é algo preocupante. Muito embora o contexto de produção dos negros nas ciências e matemáticas não constitua uma obrigatoriedade, e mesmo os autores das coleções não estejam atentos a esta questão, entendemos que perdem uma excelente oportunidade para promoverem abordagens diferenciadas, explorações dos conteúdos que poderiam contribuir para a desconstrução da imagem pejorativa do negro em relação à produção em matemática. Podemos elencar a exclusão das contribuições dos negros ao pensamento do conhecimento abissal proposto por Santos (2007), o qual estabelece que os conhecimentos produzidos do outro lado da linha abissal, linha que dividia o novo do velho mundo, ou seja que não pertença ao ocidente, é taxado como inexistente, sem relevância em seu conteúdo e com isso é excluído.

Nesses estudos percebemos que as estruturas de exposição dos objetos matemáticos nos livros didáticos ocultam quaisquer presenças dos negros na construção da matemática, inviabilizando qualquer chance de uma representatividade negra.

Os autores das coleções analisadas poderiam se utilizar das descobertas arqueológicas, como o osso de "Ishango" e outros, para apresentarem como os povos do continente Africano tiveram, por exemplo, participação no processo de desenvolvimento da contagem e da geometria. Todavia, o que presenciamos, de acordo com Vieira et al (2017), é a utilização da falsa "democracia racial", ou seja, os livros trazem uma série de figuras representando os negros e a diversidade étnica com 
o objetivo de que sejam aprovados pelo Programa Nacional do Livro Didático, entretanto, não dão crédito aos negros por sua produção e/ou contribuição científicomatemática.

Em relação a esses aspectos discriminatórios, Gonçalves (1988, apud Silva, 2011, p. 77) ressalta que devemos ter atenção não apenas aos conhecimentos que são transmitidos, mas para aqueles que não são proferidos, resultando na desinformação dos alunos, o que gera uma imagem pejorativa a qual o negro não pode ser capaz de produzir conhecimento.

Concordamos com Vieira et al (2017, p. 220) que os livros didáticos são carentes de elementos que "possibilitem aos negros legitimidade nos diversos espaços", não os colocando como protagonistas no desenvolvimento de diversas áreas, por exemplo, na matemática. Ao nosso entender, o que observamos nos livros didáticos, a respeito dos grupos negros, configura-se como um sério problema social.

Conclusão: O negro ao longo de muitos anos sofreu - e ainda sofre - em razão de um passado escravizado que repercutiu em séculos de desigualdades. Esse passado carregou pelo tempo consequências que agregaram ao negro uma imagem pejorativa que o limita almejar um posicionamento de prestígio na sociedade.

As ações afirmativas significaram avanços, tardios, que buscam corrigir séculos de desigualdades. Das ações que apresentamos, todas tiveram uma grande repercussão, pois significaram o avanço e reconhecimento dos negros, bem como a compreensão de que se fazia/faz necessário políticas públicas para corrigir o erro da sociedade em discriminar e banalizar os grupos étnicos negros, sobretudo sobre sua capacidade de produção intelectual.

A Lei 10.639, que garante a obrigatoriedade do ensino da Cultura Africana e AfroBrasileira em todas as disciplinas do currículo escolar, nos faz entender que a matemática não deveria estar de fora e que seu ensino deveria trazer essa discussão à tona. Ao que nos questionamos: Em que termos evidenciamos as contribuições dos negros na produção do conhecimento matemático?

Por meio da história percebemos que os povos negros tiveram grandes participações no desenvolvimento da matemática e contribuíram para os campos da Aritmética, Álgebra, Geometria, Trigonometria e etc., parcelas significativas e importantes da matemática, mas que não nos são apresentadas nas escolas, mesmo constituindo informações de grande valor para a construção social dos alunos, especialmente para as minorias negras que compõem as escolas públicas.

A explicitação das contribuições dos negros é necessária para se combater o currículo escolar eurocêntrico que desinforma os alunos. Na matemática estamos habituados a vivenciar nas escolas os conhecimentos como sendo frutos do homem branco. Precisamos nos desnudar do "embranqueamento", de séculos de opressão, resgatando nossos valores para vivenciarmos uma sociedade como realmente somos, negros, descendentes de africanos e capazes de produzir conhecimento científico e matemático de qualidade. 


\section{Referências Bibliográficas}

ALMEIDA, Manoel de Campos. As Mais Antigas Evidências Conhecidas do Emprego de Talhas Numéricas Associadas a Processos de Contagem. Fev. 2018. Disponível em: https://www.researchgate.net/project/Prehistory-of-Mathematics

BENJAMIN, Walter. O anjo da história. Autêntica, 2013.

BRASIL. Lei $n^{\circ}$ 10.639, de 9 de janeiro de 2003. Diário Oficial da União.

BRASIL. Lei $n^{\circ}$ 12.711, de 29 de agosto de 2012. Dispõe sobre o ingresso nas universidades federais e nas instituições federais de ensino técnico de nível médio e dá outras providências. Diário Oficial [da] República Federativa do Brasil, Brasília, DF, v. 30, 2012.

BOYER, Carl Benjamin. História da matemática. tradução: Elza F. Gomide. São Paulo, Edgard Blucher, Ed. da Universidade de São Paulo, 1974.

EVES, Howard. Introdução à história da matemática/ Howard Eves: Tradução Hygino H. Domingues. 5a ed. - Campinas, sp: Editora da Unicamp, 2011.

SANTOS, Boaventura de Souza. Para além do pensamento abissal: Das linhas globais a uma ecologia de saberes. Novos Estudos 79. CEBRAP 2007. pp. 71-94.

SILVA, Ana Célia da. A representação social do negro no livro didático: o que mudou? Por que mudou? - Salvador: EDUFBA, 2011.

VIEIRA, Odair Alves; ROHDEN, Josiane Brolo; PAULA, Claudemir da Silva. Relações étnico-raciais nos livros didáticos de Matemática do $1^{\circ}$ ao $5^{\circ}$ anos do Ensino Fundamental. Rev. Educ., Cult., Soc., Sinop/MT/Brasil, v. 7, n. 1, p. 218-231, jan./jun. 2017.

Palavras-chave: Educação, Rastros, Valorização do Negro, Negro na Matemática. 


\title{
PRODUÇÃO DE ENERGIA SOLAR FOTOVOLTAICA COMO FONTE ELÉTRICA COMPLEMENTAR PARA UMA PEQUENA EMBARCAÇÃO PESQUEIRA
}

\author{
Nome dos bolsistas: Janaina Laura Barboza Santos, Jessica Karine Barros dos \\ Santos \\ Nome dos Voluntários: Joás Murilo Nunes, Wesley Lins Pimentel \\ Nome do(a) Orientador: José Fernando Pereira Leal \\ Grupo de Pesquisa: Grupo de Pesquisa em Física e Ensino de Física
}

As matrizes energéticas de fontes renováveis se mostram como uma alternativa promissora, tanto na preservação do meio ambiente e aumento da qualidade de vida social, quanto ao custo/benefício. Nesse sentido, há interessantes possibilidades econômicas para entidades públicas e privadas quando investem em estudo científico e possível implantação de protótipos de sistemas geradores de energia elétrica alternativa e limpa em suas embarcações pesqueiras. Assim, a proposta deste trabalho é estudar a viabilidade técnica de implantação e demanda energética (lâmpadas e aparelhos eletrônicos) de um possível sistema híbrido diesel-solar em embarcação pesqueira de pequeno porte cadastrada nos sindicatos ou associações do município de Vigia de Nazaré-PA, a partir de módulos geradores constituídos de células fotovoltaicas de silício, considerando a melhor relação custo/benefício ao proprietário da embarcação. A metodologia usa de princípios comparativos entre sensoriamento da corrente elétrica gerada por protótipo fotovoltaico funcional de baixa potência instalado no campus XX da Universidade do Estado do Pará e implantação de possível sistema fotovoltaico funcional constituído por placas de silício policristalino. As coletas de dados dos sistemas fotovoltaicos de baixa potência são registradas a partir de microcontrolador Arduíno, analisadas com abordagens qualitativas e quantitativas, com registros em curvas de sensoriamento de corrente, com monitoramento estatístico e organizados em gráficos, para posteriores discussões qualitativas. Dentre as principais contribuições, destaca-se a potencial diminuição dos impactos ambientais produzido pela redução de consumo anual de óleo diesel pelos motores das embarcações, e consecutivamente, a redução dos rejeitos despejo nos afluentes dos rios e mar, a partir da inserção do protótipo fotovoltaico em embarcações pesqueiras. No aspecto econômico, a vida média do um sistema fotovoltaico é 30 anos, permitindo que o custo benefício se justifique com o tempo. Contudo, as análises feitas indicam a necessidade de ampliação do sistema fotovoltaico de baixa potência como o aumento no número de placas e suas potências para que sua eficiência energética seja satisfatoriamente comparável com o protótipo dimensionado para instalação na embarcação pesqueira. Mesmo assim, o sistema de baixa potência se mostra funcional e se torna um bom parâmetro indicativo para a eficiência energética, a viabilidades econômicas e a preservação ambiental em sistemas fotovoltaicos dimensionados à embarcação pesqueira de pequeno porte. 


\title{
FACEBOOK: UMA ANÁLISE DOS PROCESSOS DE SOCIABILIDADES ENTRE OS JOVENS
}

\author{
Nome do(a) Bolsista: Adriano Gonçalves Serrão Junior \\ Nome do(a) Orientador(a): Lucélia De Moraes Braga Bassalo \\ Grupo de Pesquisa: Juventude, educação e sociabilidades
}

Introdução: Primeiramente ressalta-se que o objetivo central deste trabalho é analisar de que forma ocorrem os processos de construção de sociabilidade entre jovens dentro dos espaços do Facebook. Para tanto esta pesquisa contou com o acompanhamento de páginas e grupos situados dentro do site Facebook para que por meio deste acompanhamento fossem coletados dados que permitissem demonstrar de que modo se desenvolvem os processos de construção de sociabilidades dentro deste espaço virtual. Vale destacar que foram selecionadas para esta pesquisa um total de 4 páginas ou grupos dentro do Facebook para serem acompanhados, sendo as seguintes: a) Movimento União Pela Democracia - Mude, b) Desconstruindo Conceitos, c) Jovens de Esquerda d) Total Vôlei. O acompanhamento e a reunião dos dados nos referidos espaços se deu através do uso da Netnografia, que consiste em um método de reunião de dados com vínculos com a etnografia, no entanto a Netnografia se propõe a ser utilizada dentro de situações que envolvam o uso do espaço virtual. O texto. Destaca-se ainda que é uma pesquisa qualitativa, pois pretende analisar construções de sociabilidades dentro de espaços virtualizados a partir das trocas efetivadas pelos sujeitos. O texto se inicia explicando mais detalhadamente sobre o Facebook e o processo de seleção das páginas e grupos que compõem a pesquisa em questão. Em um segundo momento são feitas considerações sobre a concepção de juventude sustentada neste trabalho, tendo em vista que este é um estudo sobre jovens internautas. Posteriormente são apresentados e analisados os dados coletados durante o acompanhamento das páginas e grupos selecionados. O trabalho encerra-se com as considerações finais a respeito da pesquisa desenvolvida. Quanto a isto é possível dizer que o Facebook se apresenta como um site de rede social que, por possuir diversas funcionalidades pode ser utilizado de diferentes modos pelos sujeitos. Com relação a construção de laços de sociabilidade entre os internautas dentro deste espaço nota-se que este processo se dá por meio do interesse dos usuários em assuntos específicos que os levam a procurar espaços dentro do site que abordem a questão desejada. É necessário destacar que nem sempre as interações entre os usuários se deram de forma harmônica. Isso aponta que o espaço virtual comporta-se também como um local onde os jovens podem se expressar, porém sem a garantia de que tal fato seja bem aceito entre todos os membros de páginas ou grupos do Facebook. Viu-se também esta plataforma sendo utilizada como espaço para o debate politico de forma bastante acentuada.

Palavras-chave: FACEBOOK, JUVENTUDE, ESPAÇO VIRTUAL, SOCIABILIDADE 


\title{
IMAGENS E SENTIDOS DOS RITOS DE PASSAGENS: ESTUDO DA SÉRIE VIKINKS E A INFLUÊNCIA PARA O PAGANISMO CONTEMPORÂNEO
}

\author{
Nome do(a) Bolsista: Luiz Henrique Patrício Xavier \\ Nome do(a) Orientador(a): Maria Roseli Sousa Santos \\ Grupo de Pesquisa: Arte, Religião e Memória
}

Resumo: O estudo realiza estudo dos ritos de passagens a partir das representações imagéticas religiosas presentes na série Vikings e suas influências nas práticas dos grupos do paganismo contemporâneo paraense (wicca, asatrú, druidismo) e se expressa como possibilidades de novos "olhares" sobre o cenário dos que são lidos como novos movimentos religiosos. Os resultados indicam as bases teóricas e de natureza histórica. Apresenta estudo de campo com abordagem inicial junto aos praticantes dos segmentes mencionados. Destacamos ritos de passagem que remetem a antiga sociedade nórdica estabelecendo relações às práticas contemporâneas. Os estudos se desdobram para a análise do simbolismo religioso presente na série, identificando a influências nas práticas religiosas pagãs dos entrevistados.

Introdução: Este artigo trata sobre mitologia nórdica e simbolismo em ritos de passagens, sendo parte do estudo teórico desenvolvido na pesquisa apresentada no PIBIC CNPq- UEPA, 2018 que trata sobre o projeto "Imagens e sentidos dos ritos de passagens: estudo da série vikings e a influência para o paganismo contemporâneo". O estudo destaca os ritos de passagens a partir das representações imagéticas religiosas presentes na série Vikings e estabelecemos relações com as possíveis influências nas práticas dos grupos do paganismo contemporâneo paraense. É um estudo que privilegia o campo das ciências da religião e vinculado ao Grupo de Pesquisa Arte, Religião e Memória-ARTEMI certificado pelo CNPqUEPA. Destacamos a cultura nórdica, com enfoque para os elementos do simbolismo relacionado aos ritos de passagens, sem a pretensão de adentrar o conteúdo do estudo da série os Vikings sem sua totalidade com referência a todas as temporadas, mas especificamente às que efetivamente remetem a determinados ritos como: casamento, morte. O recorte deu-se após assistirmos a séries e analisarmos tendo como base ao que os autores indicam como ritos de passagens que veremos mais adiante. A princípio é positivo a compreensão de que o conteúdo ficcional apresentado no roteiro, no cenário, figurino, elenco, fotografia e trilha sonora que compõe a narrativa audiovisual da série, em seu corpo narrativo que remete ao imaginário de um tempo histórico cheios de tensão, medo, espiritualidade e guerra. As questões que nortearam o estudo são: que ritos da cultura nórdica presentes na série Os Vikings indicam ritos de passagens? Que simbolismos estão presentes nos ritos de passagens e suas relações enquanto fenômeno religioso? É possível que os ritos presentes na série influenciem os praticantes do paganismo na atualidade? Para dar conta das questões a metodologia centrou-se em: 1) estudo teórico e bibliográfico de referenciais que estudam a sociedade nórdica antiga e medieval e, ainda de estudos acerca do simbolismo religioso no contexto da linguagem da religião; 2)na análise do discurso visual do 
documento série: Os Vikings e por fim, em entrevistas semi-estruturadas a praticantes do paganismo em Belém, Pará.

Objetivos: Objetivo geral da pesquisa consistiu em: analisar os ritos de passagens presentes na série Vikings, nas temporadas $1^{\mathrm{a}}$ a $5^{\mathrm{a}}$ e suas influências em grupos religiosos, Belém, Pará Objetivos específicos da pesquisa centrados em: realizar estudos teóricos e bibliográficos sobre paganismo nórdico com destaque para os ritos de passagens; descrever os imagens e sentidos sobre ritos de passagens presente nas cenas e fotografias da $1^{a}$ e $5^{a}$ temporadas da série Vikings estabelecendo relações com as referências históricas e documentais nórdicas estudadas; levantar dados junto aos praticantes do paganismo contemporâneo sobre elementos da cultura nórdica apresentado nas séries Vikings; realizar análises e interpretação das narrativas visuais da série vikings (conteúdo e discurso) destacando os ritos de passagens e estabelecendo relações entre conteúdo, histórico e discurso dos entrevistados. E por fim, socializar os resultados parciais e finais em eventos nacionais e internacionais, com publicação de artigos, anais e resumos.

Materiais e métodos: Os pressupostos teórico-metodológicos estão ancorados uma abordagem qualitativa de pesquisa, cujos procedimentos consistem em três etapas: a primeira etapa consistiu em estudos documentais e bibliográfico de referenciais que estudam a sociedade nórdica antiga e medieval e dos referenciais de simbolismo religioso no contexto da linguagem da religião. Estudos de produção acadêmica sobre o tema dispostos no bando de dados da Uepa e de instituições de Ciências da religião no contexto brasileiro. A segunda etapa estabeleceu a produção e Analise de dados; os estudo do roteiro histórico que compõe a narrativa da série. Seleção dos episódios da série com destaque para os ritos de passagens: as cenas, figurino e fotografias que compõe a obra; análise das representações presentes nos conteúdo e discurso dos elementos visuais destacados. Elaboração de relatório de pesquisa parcial. E, participação em eventos locais, nacionais e internacionais na área da ciência da religião e afins favorecendo a socialização dos resultados (parciais e finais). Outrossim, publicação em anuais, periódicos e sites especializados na área.

A terceira etapa dos estudos foram a partir dos produzidos sendo: as análises feitas, partimos para a interpretação e sistematização dos resultados da pesquisa a apresentando os quadros e os textos interpretativos a luz da teoria apresentada. Participação em eventos locais, nacionais e internacionais na área da ciência da religião e afins favorecendo a socialização dos resultados (parciais e finais). Outrossim, publicação em anuais, periódicos e sites especializados na área.

Resultado e Discussão: Os resultados dos estudos indicam que: Os ritos de passagem possuem o papel de demarcador de mudanças significativas na vida do sacerdote. Simbolizam uma nova fase na vida, entrelaçando fases fundamentais como inícios e fins da vida, influenciando na relação com a comunidade que vive os discursos dos neopagãos apontam ainda que, os principais ritos dentro de suas práticas religiosas são:ritos de iniciações, nascimentos com apresentação das crianças as deidades; ritos relacionados às mudanças no próprio corpo físico (maturação), como o inicio da puberdade, que demarca a passagem para a maioridade, onde são revelados os mistérios do feminino às meninas e do masculino aos meninos. 
Quando solicitado a falar sobre o rito que lhe parece ser "principal" remetem: a passagem da infância para a puberdade, a menarca para meninas, handfasting (casamento), e o réquiem. E nesse aspecto, um dos praticantes destacou um dos ritos da série como o mais importante: o rito de maturidade que consiste em provar com a língua a terra e o sal, fazendo a ligação entre terra e mar. Nota-se que há uma preocupação de retomada ao legado do passado, sem ser reconstrucionista. Indicam ressignificar, porém de forma atualizada e respondendo o tempo presente. Neopagãos pesquisam e se aproximam dos ritos antigos, em conexão, como eles dizem, com a ancestralidade, sendo a terra, as deidades, ou o próprio corpo.

A relação dos ritos de passagem da antiguidade e influência nos ritos atuais além de retomar o legado do passado através de reconexão com a ancestralidade. Destacaram símbolos que remetem aos ritos, indicando sua função em cada um deles. Símbolos como o sol para iniciação aos mistérios dos meninos; as fitas que são importantes para o handfasting (casamento), o caldeirão simbolizando o útero da deusa, e símbolos da morte que estão ligados aos ritos de passagem e por significações atribuídas que representam: mistérios, uniões, vínculos e honra aos deuses e passagens de ciclos. Destaca-se que os resultados foram socializados em vários eventos com destaque para I Simpósio Internacional Religiosidades Pan-Amazônicas, em 2019, com publicação em anais.

Conclusão: É possível ver os meandros de natureza religiosa presente nos ritos e ter os resultados acerca da influência desta série canadense junto aos praticantes do paganismo em Belém. Todos os entrevistados assistiram a série, e destacamos questões especificamente relativas a importância desta para a comunidade pagã. É perceptível a valoração das práticas antigas que a série remete a ritos voltados a terra, assim como ritos de morte, e a relação entre o paganismo e o cristianismo, tendo como relevância a informação passada sobre a cultura viking. É possível afirmar que, para os neopagãos, a série possui relevância do ponto de vista do imaginário causado pelo efeito midiático. Também é importante destacar a relação entre o paganismo e cristianismo tendo como ponto principal o processo de colonização e o modo como as duas religiões conversavam na série, e a importância da noção de sagrado que o povo viking possuía, em relação a terra, com as deidades e ancestralidade.

É possível notar a relação da série com a prática no sentido da ancestralidade, dos ritos voltados a terra e representação da antiguidade, porém,do ponto de vista neopagão, valores como machismo e imposição do patriarcado, são incisivos que não devem ser retomados. E por fim, os neopagãs não veem a influências da série nas práticas religiosas na atualidade e sim, apenas referencias de autores que contribuíram com estudos históricos e antropológicos.

Referências bibliográficas: BAUER, M. W.; GASKELL, G. (org.).Pesquisa qualitativa com texto, imagem e som: um manual prático. Trad.: P. A .Guareschi. 2. ed. Petrópolis, RJ: Vozes, 2002.

BEZERRA, O. Karina. A WICCA NO BRASIL: Adesão e permanência dos adeptos naRegião Metropolitana de Recife.Recife, 2012.

CROATTO, José Severino. As Linguagens da Experiência Religiosa: uma introdução àfenomenologia da religião. São Paulo: Paulinas, 2001. 
ELIADE, Mircea. Historia das Crenças e das Ideias Religiosas Vol. Ii: de Gautama Buda ao Triunfo do Cristianismo. Zahar: 2011.

GOTO, Tommy Akira.O fenômeno religioso: a fenomenologia em Paul Tillich. São Paulo.Paulus, 2004.

HIGUET, E. A. Prefácio. In. GOTO, T.A. O Fenômeno Religioso. São Paulo: Paulus, 2004.

LANGER, Johnni. Morte, Sacrifício Humano e Renascimento: Uma interpretação Iconográfica da Runestone Viking de Hammar. Dezembro, 2003.

Johnni. Religiãoe Magia entre os Vikings: Uma

SistematizaçãoHistoriográfica.

,Johnni. Revelando a religiosidade Viking. Sæculum - REVISTA DE HISTÓRIA[12]; João Pessoa, jan./ jun. 2005 , Johnni. A Religiosidade dos Celtas e Germanos. São Luís,2009.

Paulo.2010. , Johnni. Símbolos religiosos dos Vikings: guia iconográfico. São

Hedra.2015.

SCHMITT, Jean-Claude. O corpo das imagens: ensaios sobre a cultura visual na Idade Média. São Paulo: Edusc, 2007

TILLICH, P.. A Era Protestante. São Bernardo Campo: Ciências da Religião, 1992.

Palavras-chave: Novos Movimentos Religiosos; Neopaganismo; Ritos. 


\title{
PUBLISH OR PERISH": O PRODUTIVISMO ACADÊMICO E O ADOECIMENTO DOCENTE
}

\author{
Nome dos Bolsistas: Flavia Benedita da Costa Correa, Érika da Cruz Bararuá \\ Nome do(a)Voluntária: Sylvianne Costa Rodrigues \\ Nome do(a) Orientador(a): Raimundo Sérgio de Farias Júnior \\ Grupo de Pesquisa: Lingüística, Educação e Literatura
}

Introdução: Na educação superior os docentes são cada vez mais compelidos a produzirem pesquisas, publicarem artigos, orientarem dissertações de mestrado e teses de doutorado, além de acumularem aulas na pós-graduação: é a lógica produtivista do "Publish or perish" (publique ou pereça), e que colabora para processos de adoecimento. Essa pesquisa apresenta como problema: que relações se estabelecem entre a intensificação do trabalho docente no ensino superior e o processo de adoecimento de professores que atuam em cursos de Pós-Graduação? (UFPA). Objetivo:Analisar as relações que se estabelecem entre a intensificação do trabalho na educação superior e o processo de adoecimento dos docentes. Material e método: foi um estudo ancorado no materialismo histórico dialético e se desenvolveu em duas etapas. Primeiramente a pesquisa bibliográfica, complementada por uma empírica. A pesquisa empírica foi realizada em duas universidades públicas: UEPA e UFPA, especificamente junto a professores que atuam em programas de pósgraduação Stricto Sensu. O recorte amostral foi delimitado a oito cursos de pósgraduação, quatro de cada instituição e pertencentes a diferentes áreas do conhecimento e cuja atuação docente em cursos de pós-graduação tenha ultrapassado 5 (cinco) anos. O material de coleta de dados foi a entrevista semiestruturada, aplicada a 16 (dezesseis) docentes, sendo dois de cada programa selecionado e cujo regime de trabalho seja Tempo Integral e Dedicação Exclusiva (UEPA) e dedicação exclusiva (UFPA). O material foi analisado conforme orienta a análise de conteúdo e adotou-se o padrão de validação transformacional. Resultados: Percebeu-se que a intensificação do labor tem íntima correspondência com o adoecimento dos professores, resultando em enfermidades físicas e, sobretudo, mentais. Se na educação básica a incidência de doenças osteomusculares é mais frequentes, na superior a ocorrência maior são de doenças mentais (como a depressão, transtorno bipolar, estresse, ansiedade e burnout). Conclusão: é oportuno que estudos futuros possam dar ênfase a aspectos quantitativos e meta-analíticos, tendo em vista o cenário sociopolítico em que são orquestradas determinadas políticas públicas educacionais, que evidenciem mais profunda e especificamente processos de adoecimento docente, em razão da intensificação do trabalho a que são submetidos. "Viver não cabe no Lattes".

Palavras-chave: Produtivismo acadêmico. Adoecimento docente. Educação superior 


\section{CARACTERIZAÇÃO QUÍMICA DO MEL PRODUZIDO NO MUNICÍPIO DE CACHOEIRA DO ARARI - ILHA DE MARAJÓ, PARÁ}

Nome dos Bolsistas: Endril Pablo Brasil de Freitas e João Marcos Batista de Assunção

Nome do(a) Voluntário(a): Rayana Silva Craveiro

Nome do(a) Orientador(a): Ronilson Freitas de Souza

Grupo de Pesquisa: Ciências e Tecnologias Aplicadas à Educação, Saúde e Meio

Ambiente

Resumo: O presente estudo objetivou avaliar o teor totais de fenóis, flavonoides, atividade antioxidante e parâmetros físico-químicos dos méis de abelhas dos gêneros Apis sp. e Melipona sp. produzidos no município de Cachoeira do Arari - PA, como forma de verificar a composição química deste produto, fornecendo dados que possam contribuir para sua valorização diante dos consumidores. Foram selecionadas 30 amostras de méis sendo quinze de abelhas com ferrão e quinze de abelhas sem ferrão, obtidas diretamente com os produtores do referido município. As amostras foram encaminhas para o Laboratório de Ciências Naturais da Universidade do Estado do Pará/Campus XIX - Salvaterra, onde foram analisadas e obtiveram os seguintes resultados para os parâmetros físico-químicos: Cor âmbar escuro para maioria das amostras (77\%), pH (3,06 a 3,99), acidez livre (43,06 a 186,79 meq. $\left.\mathrm{kg}^{-1}\right)$, umidade (20,0 a 26,7\%), cinzas (0,02 a 0,58\%), açúcares redutores (47,75 a 88,89\%). Para compostos fenólicos obtiveram-se para méis de Apis sp. valores entre 51,22 e 125,03 mg EAG/100g e para méis de Melipona sp. uma variação de 23,02 a 109,21 mg EAG/100g. Em relação a Flavonoides 7,51 a 41,28 mg ER/100g para Apis sp. e 4,87 a 22,09 mg ER/100g para Melipona sp. Os valores para capacidade antioxidante expressos em $\mathrm{CE}_{50}$ de abelhas com ferrão variaram de 28,79 a 80,59 mg/mL, já para as abelhas sem ferrão a concentração eficiente variou de 24,20 a 541,94 mg/mL. Os méis analisados demonstram uma boa empregabilidade terapêutica, entretanto ainda necessitam de alguns cuidados durante as fases de processamento do produto.

Introdução: O mel é um produto natural de origem primária botânica, resultante de processos metabólicos do organismo das abelhas, que transformam o néctar e as secreções açucaradas presentes em partes dos vegetais em um fluído viscoso de aroma e sabor variáveis (ROLIM et al., 2018). Conforme Sohaimy et al. (2015), as propriedades do mel estão diretamente relacionadas com sua composição química, que pode variar de acordo a época de colheita, origem botânica, geográfica e condições ambientais do local onde é produzido. Dentre as inúmeras substâncias presentes em sua composição destacam-se os compostos fenólicos e os flavonoides, que são responsáveis por conferir ao mel a capacidade de inibição dos efeitos deletérios ocasionados pelos radicais livres advindos do desequilíbrio funcional de um organismo (DAS et al., 2015). Nessa perspectiva, baseada na busca por alimentos que, quando incluídos na dieta tornem-se aliados à saúde, verifica-se que é essencial 
realizar a averiguação de méis com possíveis impactos benéficos, bem como certificar a adequação destes ao consumo humano, contribuindo assim para a segurança alimentar e nutricional da população.

Objetivo Geral: Avaliar o conteúdo totais de fenóis, flavonoides e atividade antioxidante dos méis de abelha produzido no município de Cachoeira do Arari.

Material e Métodos: $O$ estudo foi desenvolvido com 30 amostras de méis de abelhas dos gêneros Apis sp. (com ferrão) e Melipona sp. (sem ferrão), produzidos no município de Cachoeira do Arari - PA. Para a determinação da cor dos méis foi utilizado o método espectrofotométrico descrito por Gomes et al. (2017). Os parâmentos pH, acidez livre, umidade e cinzas foram determinados conforme os procedimentos descritos pelo Instituto Adolfo Lutz (2008). O teor de açúcares redutores foi realizada através do método de Lane-Eynon, com a utilização do reagente de Fehling. Para avaliação dos dados obtidos foi utilizado a Análise de Variância (ANOVA), as médias foram comparadas entre si pelo teste de Tukey, ao nível de $5 \%$ de significância. Além da estatística multivariada realizando a Análise Hierárquica de Agrupamento ( $\mathrm{HCA}$ ) e Análise de Componentes Principais (PCA), por meio do software MINITAB 18.

Para determinação do teor total de fenóis, utilizou-se como base o método espectrofotométrico Folin-Ciocalteau (GOMES; MURIBECA e SOUZA, 2017). Diluiu-se $5 \mathrm{~g}$ de mel em $50 \mathrm{~mL}$ de água destilada. Retirou-se uma alíquota de $0,5 \mathrm{~mL}$ desta solução e misturou-se com $2,5 \mathrm{~mL}$ do reagente Folin-Ciocalteau (10\%), $2 \mathrm{~mL}$ de carbonato de sódio (7,5\%) e $3 \mathrm{~mL}$ de água destilada. A solução foi homogeneizada em vortex e aquecida em banho-maria (Hermoquímica ${ }^{\circledR}$ ) na temperatura de $50^{\circ} \mathrm{C}$ por 15 minutos. A leitura foi realizada na absorbância de $760 \mathrm{~nm}$ no espectrofotômetro (Thermo Scientific $®$ ). $O$ ácido gálico foi utilizado como padrão e o teor de compostos fenólicos foi expresso em mg EAG/100g de mel. A quantificação de flavonoides foi determinada segundo o método descrito por Meda et al. (2005). Diluiu-se $5 \mathrm{~g}$ de mel em $25 \mathrm{~mL}$ de água destilada. Misturou-se $0,8 \mathrm{~mL}$ dessa solução com $0,8 \mathrm{~mL}$ de cloreto de alumínio (2\%) e 2,4 $\mathrm{mL}$ de metanol $(\mathrm{MeOH})$. A solução foi homogeneizada em vortex e após $25 \mathrm{~min}$ realizou-se a leitura na absorbância de $413 \mathrm{~nm}$ no espectrofotômetro (Thermo Scientific $®$ ). A rutina foi utilizada como padrão e o teor de flavonoides foi expresso em mg ER/100g de mel. As médias (Fenóis e Flavonoides) foram comparadas entre si pelo teste de Tukey.

Para avaliar a capacidade antioxidante, utilizou-se o método descrito por Pontis et al. (2014), com modificações. Preparou-se soluções metanólicas de méis que variaram nas concentrações entre 5 a $360 \mathrm{mg} / \mathrm{mL}$. Retirou-se uma alíquota de $1 \mathrm{~mL}$ de cada concentração e misturou-se com $1,5 \mathrm{~mL}$ de solução $\mathrm{DPPH}$. Juntamente com as amostras foi preparado um controle negativo, constituído de $1 \mathrm{~mL}$ de metanol e $1,5 \mathrm{~mL}$ de DPPH. Os ensaios foram homogeneizados em vortex e colocados em repouso, abrigados da luz por 30 minutos. A absorbância foi lida no espectrofotômetro (Themo Scientífic $\left.{ }^{\circledR}\right)$ a $517 \mathrm{~nm}$ contra um branco contendo apenas metanol. Os valores obtidos na leitura foram convertidos em porcentagem da inibição por meio da equação: \% de 
Inibição do DPPH = (Abs. controle negativo - Abs. amostra / Abs. controle negativo) $\mathrm{x}$ 100. O qual permitiu estimar a concentração de mel eficiente para reduzir a quantidade inicial de DPPH em 50\% (CE 50$)$.

Resultados e Discussão: Os valores obtidos (média \pm desvio padrão) para os Parâmetros Físico-químicos estão apresentados na Tabela 1.

Tabela 1 - Resultados dos Parâmetros Físico-químicos das 30 amostras de méis analisadas.

\begin{tabular}{|c|c|c|c|c|c|c|c|}
\hline $\begin{array}{l}\text { Amost } \\
\text { ras }\end{array}$ & Cor & $\mathbf{m m}$ & pH & $\begin{array}{l}\text { Acidez } \\
\text { Livre }\end{array}$ & $\begin{array}{l}\text { Umidad } \\
\text { e }\end{array}$ & Cinzas & $\begin{array}{l}\text { Açúcares } \\
\text { Redutores }\end{array}$ \\
\hline A1 & $\begin{array}{l}\text { Âmb } \\
\text { ar- } \\
\text { escu } \\
\text { ro } \\
\text { Âmb }\end{array}$ & $\begin{array}{l}236,25 \pm 5,0 \\
7^{f g}\end{array}$ & $\begin{array}{l}3,63 \pm 0,14 \\
\text { defgh }\end{array}$ & $\begin{array}{l}54,22 \pm 0,0 \\
3^{\operatorname{lm}}\end{array}$ & $\begin{array}{l}23,6 \pm 0,0 \\
0^{h}\end{array}$ & $\begin{array}{l}0,40 \pm 0,07^{\mathrm{ab}} \\
\text { cde }\end{array}$ & $\begin{array}{l}75,00 \pm 0,00 \\
\text { bcd }\end{array}$ \\
\hline M2 & $\begin{array}{l}\text { ar- } \\
\text { escu } \\
\text { ro } \\
\text { Âmb }\end{array}$ & $\begin{array}{l}139,81 \pm 3,6 \\
1^{\operatorname{lmn}}\end{array}$ & $\begin{array}{l}3,57 \pm 0,02 \\
\text { efgh }\end{array}$ & $\begin{array}{l}111,64 \pm 0 \\
10^{\text {de }}\end{array}$ & $\begin{array}{l}23,8 \pm 0,0 \\
0^{g h}\end{array}$ & $\underset{\text { ghijk }}{0,23 \pm 0,05^{\text {ef }}}$ & $\begin{array}{l}71,88 \pm 5,41 \\
\text { cdef }\end{array}$ \\
\hline A3 & $\begin{array}{l}\text { ar- } \\
\text { escu } \\
\text { ro }\end{array}$ & $\begin{array}{l}135,11 \pm 6,4 \\
4^{\mathrm{mno}}\end{array}$ & $\begin{array}{l}3,53 \pm 0,03 \\
\text { ghi }\end{array}$ & $\begin{array}{l}55,82 \pm 0,1 \\
8^{\operatorname{lm}}\end{array}$ & $\begin{array}{l}20,5 \pm 0,2 \\
3^{\mathrm{kl}}\end{array}$ & $0,07 \pm 0,01^{\mathrm{jkl}}$ & $\begin{array}{l}68,75 \pm 5,41 \\
\text { defgh }\end{array}$ \\
\hline M4 & $\begin{array}{l}\text { Âmb } \\
\mathrm{ar} \\
\hat{A} m b\end{array}$ & $\begin{array}{l}87,57 \pm 3,54 \\
q\end{array}$ & $\begin{array}{l}3,24 \pm 0,08^{1} \\
\mathrm{mn}\end{array}$ & $\begin{array}{l}146,72 \pm 5 \\
52^{\mathrm{c}}\end{array}$ & $\begin{array}{l}25,0 \pm 0,0 \\
0^{\text {ef }}\end{array}$ & $0,09 \pm 0,04^{\mathrm{jkl}}$ & $\begin{array}{l}60,79 \pm 4,05 \\
\text { fghi }\end{array}$ \\
\hline A5 & $\begin{array}{l}\text { ar- } \\
\text { escu } \\
\text { ro } \\
\text { Âmb }\end{array}$ & $\begin{array}{l}156,28 \pm 4,8 \\
6^{\mathrm{jk}}\end{array}$ & $\begin{array}{l}3,54 \pm 0,03^{f} \\
\text { ghi }\end{array}$ & $\begin{array}{l}52,63 \pm 0,1 \\
5^{\operatorname{lm}}\end{array}$ & $\begin{array}{l}20,6 \pm 0,0 \\
0^{k l}\end{array}$ & $0,09 \pm 0,06^{\mathrm{ijk}}$ & $\begin{array}{l}72,14 \pm 0,00 \\
\text { bcdef }\end{array}$ \\
\hline M6 & $\begin{array}{l}\text { ar } \\
\text { extra } \\
- \\
\text { claro } \\
\text { Âmb }\end{array}$ & $\begin{array}{l}37,43 \pm 2,60 \\
t\end{array}$ & $\begin{array}{l}3,32 \pm 0,01 \\
\mathrm{klm}\end{array}$ & $\begin{array}{l}125,82 \pm 0 \\
12^{\mathrm{d}}\end{array}$ & $\begin{array}{l}25,0 \pm 0,0 \\
0^{\text {ef }}\end{array}$ & $0,06 \pm 0,07^{\mathrm{jkl}}$ & $\begin{array}{l}72,14 \pm 0,00 \\
\text { bcdef }\end{array}$ \\
\hline A7 & $\begin{array}{l}\text { ar- } \\
\text { escu } \\
\text { ro } \\
\text { Âmb }\end{array}$ & $\begin{array}{l}130,49 \pm 4,8 \\
4^{\text {no }}\end{array}$ & $\begin{array}{l}3,07 \pm 0,05 \\
n\end{array}$ & $\begin{array}{l}44,66 \pm 2,7 \\
6^{m}\end{array}$ & $\begin{array}{l}22,6 \pm 0,0 \\
0^{i j}\end{array}$ & $0,04 \pm 0,01^{\mathrm{kl}}$ & $\begin{array}{l}84,17 \pm 0,00 \\
a b c\end{array}$ \\
\hline M8 & $\begin{array}{l}\text { ar- } \\
\text { escu } \\
\text { ro }\end{array}$ & $\begin{array}{l}245,15 \pm 5,7 \\
7^{f}\end{array}$ & $\begin{array}{l}3,32 \pm 0,02 \\
\mathrm{klm}\end{array}$ & $\begin{array}{l}167,46 \pm 4 \\
78^{\mathrm{b}}\end{array}$ & $\begin{array}{l}20,0 \pm 0,0 \\
0^{1}\end{array}$ & $0,47 \pm 0,02^{\mathrm{ab}}$ & $\begin{array}{l}58,45 \pm 4,05 \\
\text { ghij }\end{array}$ \\
\hline
\end{tabular}


Âmb

A9

$\begin{array}{lll}\text { ar- } & 137,34 \pm 4,2 & 3,06 \pm 0,03 \\ \text { escu } & 2^{\text {mmo }} & n\end{array}$

$43,06 \pm 0,1$

$20,6 \pm 0,0$

$0,18 \pm 0,02^{\mathrm{fg}}$

$66,13 \pm 5,21$

ro

Âmb

M10

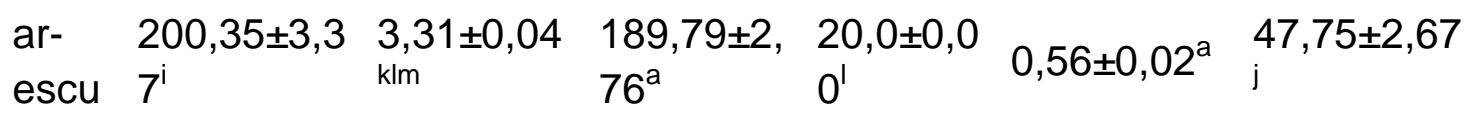
ro

Âmb

A11

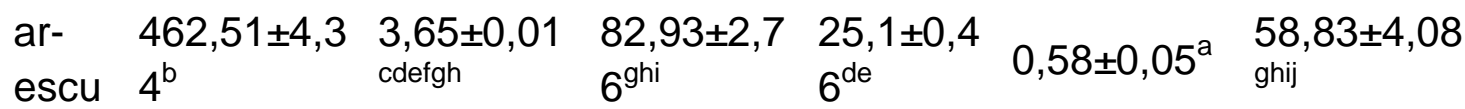
ro

Âmb

M12

ar- $\quad 192,80 \pm 1,4$

escu $1^{\mathrm{i}}$

$3,16 \pm 0,03$

$189,79 \pm 2$

$25,8 \pm 0,0 \quad 0,13 \pm 0,07^{\text {hij }}$

$61,19 \pm 4,08$

ro

Âmb

A13

ar- $\quad 130,90 \pm 3,6 \quad 3,51 \pm 0,03$

escu $6^{\text {no }}$

$76^{a}$

$0^{\text {cd }}$

$\mathrm{e}^{\text {fghi }}$

ro

Âmb

M14

ar-

escu $4^{\circ}$

ghij $\quad 6^{\mathrm{kl}}$

$65,39 \pm 2,7 \quad 20,9 \pm 0,4$

$0,18 \pm 0,02^{f g}$

$72,62 \pm 0,00$

$6^{\mathrm{kl}} \quad 6^{\mathrm{k}}$

bcdef

ro

Âmb

A15

ar-

escu $2^{\mathrm{j}}$

$163,83 \pm 5,9$

$3,99 \pm 0,02$

$111,64 \pm 2, \quad 23,8 \pm 0,0 \quad 0,33 \pm 0,04^{\mathrm{bc}}$ $76^{\text {de }}$

$0^{\text {gh }}$

defgh

$58,83 \pm 4,08$ ghij

ro

Âmb

M16

ar-

escu $4^{\text {d }}$

$366,36 \pm 6,7 \quad 3,61 \pm 0,05$

$76,80 \pm 2,8 \quad 24,3 \pm 0,4$

$0,25 \pm 0,03^{\mathrm{de}}$

$61,19 \pm 4,08$

ro

$3^{\text {hijk }}$

$6^{\mathrm{fg}}$

fghijk

efghi

A17

Âm

ar a

$85,72 \pm 1,8$

$3,39 \pm 0,03^{i j}$

Âm $\mathrm{kl}$

$86,60 \pm 2,8$ $3^{\text {fgh }}$

$22,6 \pm 0,0$

$0,19 \pm 0,02^{f g}$

hijkl

$63,54 \pm 0,00$

$3,72 \pm 0,03$

0

$0,34 \pm 0,25^{\mathrm{bc}}$ defghi

M18 ar bcdef

$0^{\text {hijk }}$

$0^{\text {ef }}$

$69,59 \pm 5,24$

Âmb

A19

ar-

56

claro

$3,46 \pm 0,03$

$80,07 \pm 2,8 \quad 22,5 \pm 0,2$ $3^{\text {hijk }}$

defg

defg

Âmb $109,61 \pm 1,8$ ar $7^{\mathrm{p}}$ hijk

$$
75
$$

$75,16 \pm 2,8 \quad 22,5 \pm 0,4$ $3^{\text {hijk }}$ $6^{\mathrm{ij}}$

$0,05 \pm 0,02^{\mathrm{kl}}$ $63,54 \pm 0,00$ defghi

M20

$3,76 \pm 0,02$
bcd

$60,01 \pm 4,99$ fghi 
Âmb

A21

$\begin{array}{lllllll}\text { ar- } & 495,36 \pm 1,5 & 3,87 \pm 0,02 & 66,98 \pm 4,7 & 21,1 \pm 0,2 & 0,44 \pm 0,02^{\text {ab }} & 84,72 \pm 0,00 \\ \text { escu } & 8^{\mathrm{a}} & \mathrm{ab} & 8^{\mathrm{jkl}} & 3^{\mathrm{k}} & \mathrm{cd} & \mathrm{ab}\end{array}$ ro

Âmb

M22

ar- $148,11 \pm 1,0$ escu $5^{\mathrm{kl}}$

$3,32 \pm 0,04$

$98,88 \pm 2,7 \quad 26,3 \pm 0,2$

$0,15 \pm 0,03^{\text {gh }} 54,60 \pm 3,26$

ro

Âmb

A23

ar- $\quad 406,04 \pm 0,7 \quad 3,83 \pm 0,02$

$6^{\mathrm{ef}}$

$0^{\mathrm{abc}}$

ijkl

ij

escu 9

abc $\quad 8^{\operatorname{lm}}$

$52,63 \pm 4,7 \quad 21,1 \pm 0,1$

$0,42 \pm 0,02^{\mathrm{ab}}$

$64,80 \pm 4,32$

ro

Âmb

M24

ar$71,23 \pm 6,69$

$3,35 \pm 0,05^{j}$

$74,96 \pm 5,5 \quad 25,9 \pm 0,2 \quad 0,30 \pm 0,08^{\text {bc }} \quad 64,80 \pm 4,32$ claro $2^{\text {hijk }}$ $0^{\mathrm{bc}}$ defghi

Âmb

A25

ar- $226,47 \pm 1,9$

$3,71 \pm 0,03$

$71,77 \pm 4,7 \quad 23,1 \pm 0,2$

$0,38 \pm 0,01^{\text {ab }}$

$72,10 \pm 6,80$ escu $7^{\text {gh }}$

bcdef $\quad 8^{\mathrm{ijk}}$ $3^{\text {hij }}$ bcdef

ro

Âmb

M26

ar- $131,40 \pm 0,5$

escu $3^{\text {no }}$

$3,61 \pm 0,21$

$81,70 \pm 2,8 \quad 26,7 \pm 0,3$ $3^{\text {ghij }}$

$4^{\mathrm{a}}$

$64,80 \pm 4,32$

ro

Âmb

A27

ar- $\quad 289,24 \pm 1,9$

escu $7^{\mathrm{e}}$

bcde

$84,97 \pm 5,6 \quad 23,2 \pm 0,0$

$0,35 \pm 0,05^{\mathrm{bc}}$

$73,70 \pm 5,55$

ro

$6^{\text {fghi }}$

$0^{\text {hi }}$

bcde

Âmb

M28

ar-

escu $3^{\text {h }}$

$218,30 \pm 6,8$

$3,28 \pm 0,04^{1}$

$74,44 \pm 2,8$

$0^{\text {hijk }}$

$25,8 \pm 0,2$

$0,26 \pm 0,11^{\text {cd }}$

$56,82 \pm 4,23$

ro

Âmb

A29

ar-

escu $4^{\mathrm{klm}}$

$146,07 \pm 1,8$

$3,73 \pm 0,02$

$71,20 \pm 5,6$ $1^{\mathrm{ijk}}$

$22,7 \pm 0,2$

$3^{\mathrm{ij}}$

$88,89 \pm 7,70$

ro

Âmb

ar- $\quad 135,36 \pm 4,3 \quad 3,26 \pm 0,03 \quad 76,05 \pm 5,6 \quad 26,5 \pm 0,1$ escu $0^{\text {Imno }}$

$1^{\text {hijk }}$ $1^{a b}$

$66,11 \pm 5,50$ defghi

ro

\begin{tabular}{lllllll}
\hline Média & 185,18 & 3,51 & 89,43 & 23,3 & 0,26 & 66,92 \\
\hline Mínimo & 37,43 & 3,06 & 43,06 & 20,0 & 0,02 & 47,75 \\
\hline Máximo & 495,36 & 3,99 & 189,79 & 26,7 & 0,58 & 88,89 \\
\hline${ }^{1}$ Legisl. & $\star$ & $*$ & $\leq 50,0$ & $\leq 20,0$ & $\leq 0,6$ & $\leq 65,0$ \\
\hline
\end{tabular}




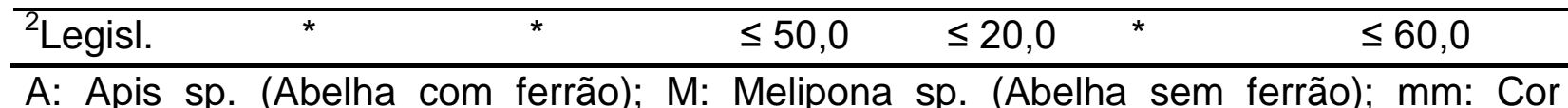
segundo a escala milimétrica proposta por Pfund; $\mathrm{pH}$ : Potencial Hidrogeniônico; Acidez Livre (meq. $\mathrm{kg}^{-1}$ ); Umidade (\%); Cinzas (\%); Açúcares Redutores (\%); ${ }^{*}$ Ausência de limites nas legislações; ${ }^{1}$ Legislação Brasileira (BRASIL, 2000); ${ }^{2}$ Legislação Internacional (CODEX, 2001). Médias com letras iguais na mesma coluna não diferem significativamente de acordo com o teste de Tukey a $p \leq 0,05 \%$.

A qualidade dos méis mostraram-se satisfatória para os parâmetros de cor, $\mathrm{pH}$ e cinzas. Contudo, 50\% das amostras apresentaram baixo teor de açúcares redutores. Além disso, demonstraram altos teores de acidez e umidade na maioria dos méis. $\mathrm{O}$ parâmetro acidez livre, ressalta-se que os altos índices indicam manipulação e armazenamento inadequados que pode provocar a deterioração do produto ocasionada pela fermentação dos açúcares. Em relação à umidade as amostras necessitam de cuidados especiais durante os períodos de extração.

Para a análise de Agrupamento Hierárquico (HCA), foi aplicada a distância Euclidiana e o método de Ligação Completa. Por meio deste foi estabelecido o dendrograma, o qual permitiu verificar o grau de similaridade entre os grupos formados. A partir dos resultados obtidos pode ser observada a formação de quatro agrupamentos distintos (A, B, C e D), os quais possuem 9 subgrupos superiores a $75 \%$ de similaridade (Gráfico 1).

Gráfico 1: Dendrograma obtido das 6 variáveis (Parâmetros físico-químicos).

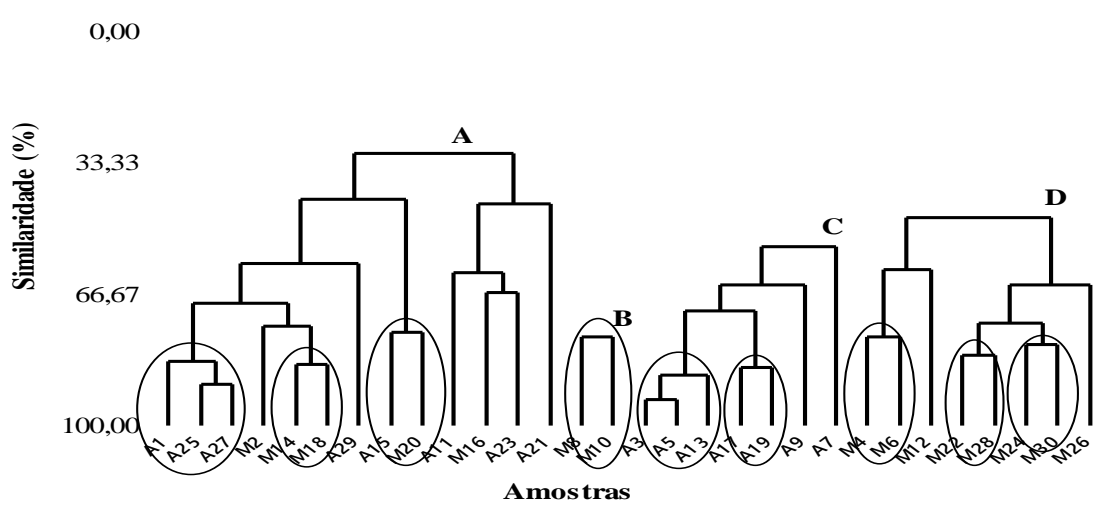

Ao analisar acima de $80 \%$ de similaridade, percebe-se a formação de 5 subgrupos (A1, A25 e A27; M14 e M18; A3, A5 e A13; A17 e A19; M22 e M28), e acima de 90\% de similaridade apenas um único subgrupo (A3 e A5), este demonstra que a maioria das amostras não são tão similares.

Com a aplicação da Análise de Componentes Principais (PCA) observou-se que o primeiro componente principal (CP1) explica $35,9 \%$ e a segunda (CP2) $24,6 \%$ da variância total dos dados. As duas primeiras componentes principais conseguem juntas explicar $62,3 \%$ do total da variância e podem ser consideradas suficientes para descrever os dados (Gráfico 2). Podem-se observar no gráfico dos Loadings (Gráfico 3), os parâmetros responsáveis pelas as separações e as uniões das amostras. 
Gráfico 2: Gráfico dos scores para as 30 amostras de méis. Gráfico 3: Gráfico de loadings
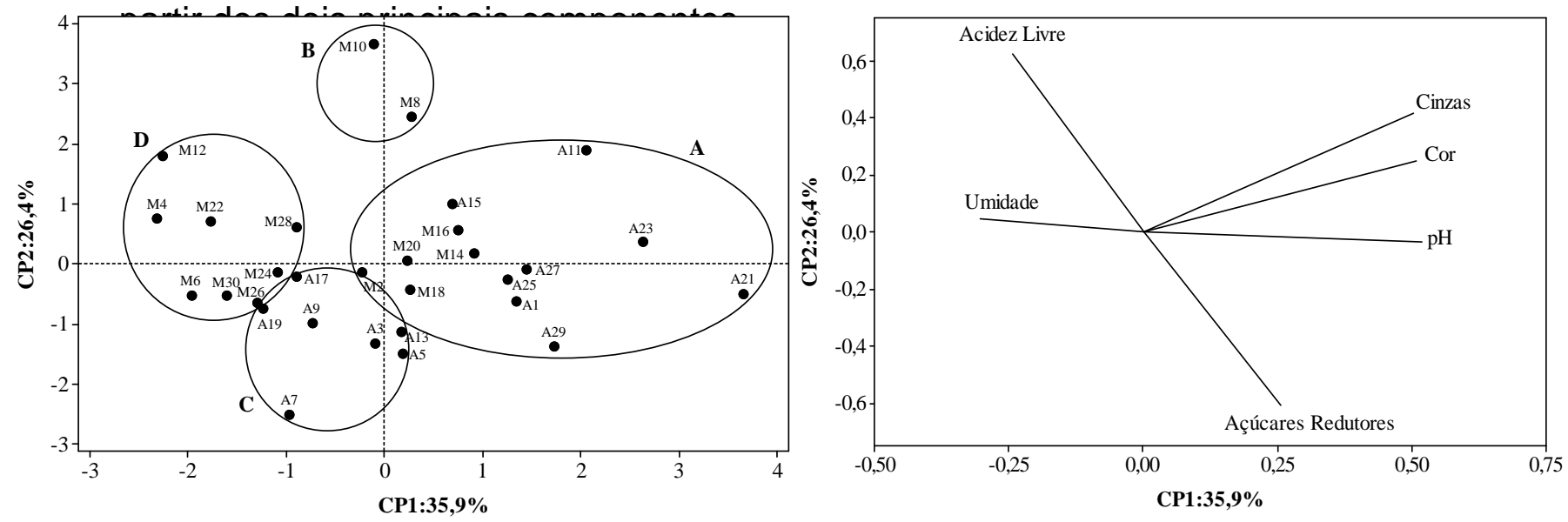

O teor de Fenóis Totais, Flavonoides e Capacidade Antioxidante das amostras de méis de abelhas Apis sp. e Melipona sp. estão expressos na Tabela 2.

Tabela 2 - Resultados obtidos para Fenóis Totais, Flavonoides e Capacidade Antioxidante.

\begin{tabular}{|c|c|c|c|c|c|c|c|}
\hline $\begin{array}{l}\text { Amostr } \\
\text { as }\end{array}$ & $\begin{array}{l}\text { Fenóis } \\
\text { Totais } \\
\text { (mg } \\
\text { EAG/100g) }\end{array}$ & $\begin{array}{l}\text { Flavonoid } \\
\text { es } \\
\text { (mg } \\
\text { ER/100g) }\end{array}$ & $\begin{array}{l}\mathrm{CE}_{50} \\
(\mathrm{mg} / \mathrm{m} \\
\text { L) }\end{array}$ & $\begin{array}{l}\text { Amostr } \\
\text { as }\end{array}$ & $\begin{array}{l}\text { Fenóis } \\
\text { Totais } \\
\text { (mg } \\
\text { EAG/100g } \\
\text { ) }\end{array}$ & $\begin{array}{l}\text { Flavonoid } \\
\text { es } \\
\text { (mg } \\
\text { ER/100g) }\end{array}$ & $\begin{array}{l}C_{50} \\
(\mathrm{mg} / \mathrm{m} \\
\text { L) }\end{array}$ \\
\hline A1 & $\begin{array}{l}108,99 \pm 3,8 \\
4^{\mathrm{cd}}\end{array}$ & $\begin{array}{l}18,99 \pm 0,3 \\
3^{d}\end{array}$ & 28,79 & M2 & $\begin{array}{l}76,75 \pm 0,3 \\
4^{c}\end{array}$ & $\begin{array}{l}12,90 \pm 1,16 \\
\text { cde }\end{array}$ & 24,20 \\
\hline A3 & $\begin{array}{l}111,27 \pm 4,0 \\
4^{\text {bcd }}\end{array}$ & $\begin{array}{l}18,79 \pm 0,5 \\
4^{d}\end{array}$ & 44,56 & M4 & $\begin{array}{l}23,02 \pm 0,9 \\
0^{g}\end{array}$ & $\begin{array}{l}9,36 \pm 0,56^{\mathrm{fg}} \\
\mathrm{h}\end{array}$ & 541,94 \\
\hline A5 & $\begin{array}{l}117,54 \pm 3,2 \\
5^{\mathrm{abc}}\end{array}$ & $7,51 \pm 0,64^{\mathrm{g}}$ & 48,12 & M6 & $\begin{array}{l}27,10 \pm 2,7 \\
5^{\mathrm{g}}\end{array}$ & $\begin{array}{l}8,48 \pm 1,41^{g} \\
h i\end{array}$ & 420,93 \\
\hline A7 & $\begin{array}{l}105,03 \pm 4,5 \\
1^{\text {de }}\end{array}$ & $\begin{array}{l}11,26 \pm 0,3 \\
8^{f}\end{array}$ & 77,17 & M8 & $\begin{array}{l}79,31 \pm 2,5 \\
5^{c}\end{array}$ & $\begin{array}{l}16,81 \pm 0,76 \\
b\end{array}$ & 77,17 \\
\hline A9 & $\begin{array}{l}105,29 \pm 3,9 \\
0^{\text {de }}\end{array}$ & $\begin{array}{l}12,12 \pm 0,5 \\
9^{f}\end{array}$ & 38,87 & M10 & $\begin{array}{l}55,66 \pm 2,4 \\
7^{d}\end{array}$ & $\begin{array}{l}12,28 \pm 0,37 \\
\text { def }\end{array}$ & 35,87 \\
\hline A11 & $\begin{array}{l}91,38 \pm 4,72^{f} \\
g\end{array}$ & $\begin{array}{l}34,08 \pm 0,7 \\
3^{b}\end{array}$ & 46,69 & M12 & $\begin{array}{l}45,29 \pm 0,8 \\
7^{\text {ef }}\end{array}$ & $\begin{array}{l}10,75 \pm 0,43 \\
\text { efg }\end{array}$ & 53,90 \\
\hline A13 & $\begin{array}{l}83,65 \pm 2,10^{g} \\
h\end{array}$ & $\begin{array}{l}12,86 \pm 0,7 \\
0^{f}\end{array}$ & 32,08 & M14 & $\begin{array}{l}46,67 \pm 1,2 \\
4^{\mathrm{e}}\end{array}$ & $\begin{array}{l}13,11 \pm 1,86 \\
\text { cde }\end{array}$ & 58,99 \\
\hline A15 & $51,22 \pm 2,73^{i}$ & $\begin{array}{l}13,20 \pm 0,8 \\
3^{f}\end{array}$ & 80,59 & M16 & $\begin{array}{l}109,21 \pm 1 \\
72^{\mathrm{a}}\end{array}$ & $\begin{array}{l}22,09 \pm 0,92 \\
a\end{array}$ & 35,39 \\
\hline A17 & $\begin{array}{l}83,81 \pm 1,30^{g} \\
h\end{array}$ & $\begin{array}{l}11,42 \pm 1,1 \\
0^{f}\end{array}$ & 56,20 & M18 & $\begin{array}{l}82,96 \pm 2,6 \\
1^{c}\end{array}$ & $\begin{array}{l}15,63 \pm 1,04 \\
b c\end{array}$ & 36,25 \\
\hline A19 & $79,84 \pm 0,42^{h}$ & $\begin{array}{l}11,40 \pm 0,7 \\
9^{f}\end{array}$ & 59,78 & M20 & $\begin{array}{l}93,73 \pm 6,8 \\
5^{b}\end{array}$ & $\begin{array}{l}14,92 \pm 1,59 \\
\text { bcd }\end{array}$ & 32,47 \\
\hline
\end{tabular}




\begin{tabular}{|c|c|c|c|c|c|c|c|}
\hline A21 & $\begin{array}{l}118,31 \pm 2,9 \\
5^{\mathrm{abc}}\end{array}$ & $\begin{array}{l}41,27 \pm 0,6 \\
4^{\mathrm{a}}\end{array}$ & 24,03 & M22 & $\begin{array}{l}27,62 \pm 1,5 \\
1^{g}\end{array}$ & $\underset{j}{6,47 \pm 0,80^{h i}}$ & 119,28 \\
\hline A23 & $\begin{array}{l}125,03 \pm 3,9 \\
2^{a}\end{array}$ & $\begin{array}{l}41,28 \pm 0,2 \\
4^{\mathrm{a}}\end{array}$ & 40,17 & M24 & $\begin{array}{l}24,97 \pm 1,5 \\
4^{\mathrm{g}}\end{array}$ & $4,87 \pm 0,74^{j}$ & 266,50 \\
\hline A25 & $96,98 \pm 4,23^{e}$ & $\begin{array}{l}21,47 \pm 1,0 \\
4^{c}\end{array}$ & 35,66 & M26 & $\begin{array}{l}24,23 \pm 3,1 \\
2^{\mathrm{g}}\end{array}$ & $6,58 \pm 0,36^{h i}$ & 185,50 \\
\hline A27 & $\begin{array}{l}119,84 \pm 5,0 \\
9^{a b}\end{array}$ & $\begin{array}{l}22,79 \pm 0,7 \\
1^{\mathrm{c}}\end{array}$ & 30,81 & M28 & $\begin{array}{l}39,15 \pm 1,5 \\
4^{f}\end{array}$ & $6,28 \pm 0,08^{\mathrm{ij}}$ & 122,68 \\
\hline A29 & $\begin{array}{l}119,15 \pm 1,8 \\
6^{a b}\end{array}$ & $\begin{array}{l}16,35 \pm 0,7 \\
4^{\mathrm{e}}\end{array}$ & 32,63 & M30 & $\begin{array}{l}39,63 \pm 2,6 \\
7^{f}\end{array}$ & $6,14 \pm 1,30^{\mathrm{ij}}$ & 139,31 \\
\hline Média & 101,15 & 19,65 & 45,08 & Média & 53,02 & 11,11 & 143,36 \\
\hline Mínimo & 51,22 & 7,51 & 24,03 & Mínimo & 23,02 & 4,87 & 24,20 \\
\hline Máximo & 125,03 & 41,28 & 80,59 & Máximo & 109,21 & 22,09 & 541,94 \\
\hline
\end{tabular}

Os resultados de compostos bioativos são comparativamente elevados em relação a outros estudos (GOMES; MURIBECA e SOUZA, 2017; GOMES et al. 2017). Observou-se também que os méis produzidos pelas abelhas com ferrão apresentaram atividade antioxidante superiores aos méis provenientes das abelhas sem ferrão.

Conclusão: Os dados obtidos por meio deste estudo vêm contribuir com informações relevantes para o incremento da produtividade e da garantia do controle de qualidade dos produtos oriundos do mel do município de Cachoeira do Arari - PA, viabilizando a produção em escala comercial e fomentando o desenvolvimento sustentável nessa região.

Referências Bibliográficas: BRASIL. Ministério da Agricultura Pecuária e Abastecimento. Instrução Normativa no 11, de 20 de outubro de 2000. Estabelece 0 regulamento técnico de identidade e qualidade do mel. Diário Oficial da República Federativa do Brasil, Brasília, p.16 - 17, out. 2000.

CODEX Alimentarius. Revised Codex Standard for Honey Codex Stan. Codex Alimentarius Commission, 2001.

GOMES, P.W.P.; MURIBECA, A.B.J.; SOUZA, R.F.D. Méis De Abelha Produzidos No Marajó PA: compostos fenólicos e atividade antioxidantes. 1. ed. Novas Edições Acadêmicas, 2017.

GOMES, V. V.; DOURADO, G. S.; COSTA, S. C.; LIMA, A. K. O. SILVA, D. S.; BANDEIRA, A. M. P.; VASCONCELOS, A. A.; TAUBE, P.S. Avaliação da Qualidade do Mel Comercializado no Oeste do Pará, Brasil. Revista Virtual de Química, v. 9, n. 2, p. 815-826, Fev. 2017.

INSTITUTO ADOLFO LUTZ. Normas analíticas, métodos químicos e físicos para análises de alimentos. 4. ed. 1. Edição Digital. São Paulo: IAL, 2008. 1020 p. 
MEDA, A. et al. Determination of the Total Phenolic, Flavonoid and Proline Contents in Burkina Fasan Honey, as well as their Radical Scavenging activity . Food Chemistry, v .91, p. 571-577, 2005.

PONTIS, J. A.; COSTA, L. A. M. A.; SILVA, S. J. R.; FLACH, A. Color, phenolic and flavonoid content, and antioxidant activity of honey from Roraima, Brazil. Food Science and Technology, Campinas, v. 34, p. 69-73, 2014.

ROLIM, M. B. D. Q.; et al. Generalidades sobre o mel e parâmetros de qualidade no Brasil: revisão. Medicina Veterinária, v.12, n.1, prolim. 73-81, Jan. 2018.

SOHAIMY, S. A. E. L. et al. Physicochemicalcharacteristics of honey from different origins. Annals of Agricultural Science, v. 60, p. 279-287, 2015.

Palavras-chave: Mel; Compostos Fenólicos; Flavonoides; Atividade Antioxidante. 


\title{
DIÁLOGOS SUL-SUL: OS DESAFIOS DA DEMOCRACIA E EDUCAÇÃO PÚBLICA NA SOCIEDADE BRASILEIRA NOS PENSAMENTOS DE PAULO FREIRE E BOAVENTURA SANTOS
}

\author{
Nome dos Bolsistas: Emerson Silva Caldas' Luzia Camila S. dos Santos \\ Nome do(a) Orientador(a): Sérgio Roberto Moraes Corrêa \\ Grupo de Pesquisa: Grupo de Estudo e Pesquisa em Ações Coletivas, \\ Desenvolvimento e Educação na Amazônia.
}

Introdução: Este artigo apresenta as contribuições do pensamento de Paulo Freire e Boaventura Santos, para analisar as questões da democracia e da educação pública da sociedade brasileira, à luz dos sentidos das lutas dos movimentos sociais contrahegemônicos que atuam no processo de democratização da sociedade. Como objetivo, essa pesquisa buscou Identificar e analisar qual a contribuição do pensamento de Paulo Freire e Boaventura Santos, para analisar as questões da democracia e da educação pública da sociedade brasileira, com ênfase nas lutas dos movimentos sociais. Como referencial teórico e epistemológico, a pesquisa se embasou no pensamento dos referidos autores, por meio da ideia do Diálogo SulSul. Como metodologia, foi realizado levantamento bibliográfico, a fim de se construir um quadro referencial amplo e consistente sobre o objeto de estudo e a temática em questão e uma fundamentação teórico-metodológica deles e também através da abordagem qualitativa. Alguns dos resultados a serem expostos ao longo da temática pesquisada é a afirmação do diálogo entre os autores, além do fato que as postulações e conceitos em contato os movimentos sociais contra-hegemônicos, revela a potência da ecologia de saberes da qual nos fala Boaventura de Sousa Santos e dos círculos de cultura e a educação como pratica da liberdade de Paulo Freire, estas formulações são significativas para compreensão dos processos presentes na estrutura da sociedade e os seus impactos nos grupos mais vulneráveis. Sendo assim, as lutas e cobranças realizadas pelos movimentos sociais contrahegemônicos, tem muito a contribuir para o debate da democracia e da educação pública, pelo caráter de transformação e emancipação. Onde estão presentes os questionamentos sobre a realidade vivenciada proposta por Paulo Freire. E a percepção da existência de uma pluralidade de conhecimentos, pois para Boaventura de Sousa Santos, os saberes estão além dos que são impostos pelos modelos de educação hegemônica abissal, mas se fazem também através das lutas de resistência, da ancestralidade e da relação com a natureza.

Palavras-chave: Democracia. Educação. Movimentos Sociais. Paulo Freire. Boaventura Santos 


\section{REPRESENTAÇÕES SOCIAIS DE UMA MÃE SOBRE A INCLUSÃO DE SEU FILHO NA EDUCAÇÃO INFANTIL DA EDUCAÇÃO ESPECIAL NO ÂMBITO DA SEMEC-BELÉM}

Nome dos Bolsistas: Fábio Augusto Teixeira Rodrigues, Islane Araújo Chaves

Nome do(a) Voluntário(a):Luiza Rebeca Salustiano Costa

Nome do(a) Orientador(a):Tânia Regina Lobato dos Santos

Grupo de Pesquisa: Núcleo de Educação Popular Paulo Freire

Resumo: Por compreender a inclusão como um processo dialógico, constituído de uma teia de ações com a finalidade de uma real inserção da pessoa com deficiência, opta-se por direcionar as atenções para os pais, pois a participação destes nos processos escolares de seus filhos é imprescindível para o estabelecimento da educação inclusiva. Dessa forma, este trabalho tem por objetivo compreender as representações sociais de uma de mãe sobre a inclusão do seu filho da educação infantil na educação especial no âmbito da Secretária Municipal de Educação SEMEC de Belém. Sobre a metodologia, trata-se de uma pesquisa qualitativa e de campo que ancora no processo teórico-metodológico da teoria das representações sociais subsidiada em Moscovici (2009) e Spink (1993). A técnica de pesquisa utilizada para a coleta dos dados foi a entrevista semiestruturada com base em Oliveira; Fonseca; Santos (2010). Com subsídios teóricos da inclusão fundamentados em Mantoan (2015), Mazzotta (2010), Oliveira (2004), Freire (2011). Os resultados apontam para representações em caráter de denúncia e indignação sobre a ausência de um fazer pedagógico efetivo dos professores, a necessidade da flexibilização de materiais pedagógicos, ações dialógicas e relevância da realização de formações continuadas com mais frequência.

Palavras-chave: Representações sociais; Inclusão; Mãe de uma criança com deficiência. 


\section{Programa de Pós- Graduação em Biologia Parasitária na Amazônia}




\title{
CARACTERIZAÇÃO HISTOPATOLÓGICA EM CASOS POST MORTEM DE EQUINOS E AVES INFECTADOS PELO VÍRUS DA ENCEFALITE DE SAINT LOUIS
}

\author{
Nome do(a) bolsista: Adrielle Thaís Monteiro dos Santos \\ Nome do(a) Orientador(a): Dr. Arnaldo Jorge Martins Filho
}

Resumo: O Vírus da Encefalite de Saint Louis (SLEV, família Flaviviridae, gênero Flavivirus) é um arbovírus transmitido por mosquitos do gênero Culex amplamente distribuído no território nacional, tem causado pequenos surtos principalmente relacionados a equinos e aves, deixando a população brasileira exposta à infecção por esse vírus. Esta pesquisa objetiva caracterizar a histopatologia em amostras de órgãos de equinos e aves infectados naturalmente com o SLEV durante surtos ocorridos nos estados de Minas Gerais e Espirito Santo. Para isso serão utilizados cinco equinos e cinco aves, provenientes da demanda de Vigilância Epidemiológica desses estados, e incluem amostras de tecido nervoso, fígado, baço, rim, pulmão e coração que foram submetidas a colorações de hematoxilina-eosina para avaliação histopatológica. Os resultados mostraram tecido neural com espongiose, congestão e gliose, além de infiltrado inflamatório perivascular. Neurônios apresentando cromatólise, aspecto apoptótico e necrótico. Meninges com congestão, edema e infiltrado inflamatório de linfócitos, plasmócitos e neutrófilos foram observados. Imunoexpressão positiva para o vírus foi observado tanto em neurônios quanto em células gliais. Espera-se que com os achados histopatológicos e através destes descreveremos lesões patognomônicas da doença que ajudarão no diagnóstico para o SLEV, conhecendo o tropismo do vírus, associando com as lesões que são fundamentais para conhecer a patogenia da doença.

Introdução: O Vírus da Encefalite de Saint Louis (SLEV) é um arbovírus encefalitogênico e neurotrópico, da família Flaviviridae, gênero Flavivirus, membro do Complexo das Encefalites Japonesas (JEC), causa uma doença infecciosa que pode atingir humanos, equinos, aves e outros vertebrados, considerada endêmica nas Américas e na América do Sul é uma arbovirose reemergente com casos humanos relatados na Argentina e no Brasil (ROSA, 2013; MONDINI et al, 2007; ROCCO et al, 2005).Tem ciclo zoonótico, transmitido principalmente por mosquitos Culex e podem causar um amplo espectro de doenças, incluindo febre hemorrágica, doença febril ou encefalite. Além disso, esses vírus pode causar um impacto significativo nos sistemas públicos de saúde (PACCA et al., 2017; HEINEN et al, 2015). Em 2018, houve um surto de doença neurológica sem etiologia conhecida. Muitos equinos apresentaram sinais clínicos de encefalite viral, evoluindo a óbito ou sendo eutanaziados após diagnóstico clínico veterinário; quanto às aves, que são animais sentinelas para epidemia de SLEV, diversas foram encontradas mortas. Dessa forma, as amostras dos casos foram submetidas à investigação laboratorial e foi evidenciada infecção pelo SLEV através de método molecular. 
A patogênese da doença que o SLEV causa, ainda é bem limitada e principalmente inferida pelo estudo de outras infecções por flavivírus. Os mecanismos que levam a invasão do SLEV no SNC, uma etapa crítica da patogênese viral, tem sido estudados usando modelos de infecções experimentais, como camundongos e hamster. Porém, estudos de casos reais são bastante escassos. Essa é uma oportunidade para aumentarmos nosso conhecimento sobre a patologia da infecção pelo SLEV (MARQUES et al, 2017)

Objetivo geral: Caracterizar a histopatologia e o perfil imuno-histoquimíco em casos pós mortem de equinos e aves diagnosticados com infecção pelo Vírus da Encefalite de Saint Louis.

Objetivos específicos: Descrever os achados histopatológicos em vísceras de equinos e aves (rim, fígado, baço, pulmão, coração e cérebro) diagnosticados com infecção pelo Vírus da Encefalite de Saint Louis a fim de se verificar a possível ocorrência de lesões patognomônicas, analisados com coloração por hematoxilina e eosina; Padronizar um protocolo de diagnóstico imuno-histoquimíco para o SLEV, utilizando o método adaptado de Hall e colaboradores (1994) para titulação do anticorpo anti-SLEV em amostras de controle positivo; Caracterizar o perfil imunohistoquimíco dos casos positivos de encefalite letal causada por SLEV em equinos e aves, em amostras de rim, fígado, baço, pulmão, coração e cérebro, por meio da técnica padronizada; Padronizar um protocolo de diagnóstico post mortem de infecção pelo SLEV através do método de imuno-histoquímica; Comparar os achados histopatológicos e imuno-histoquímicos entre amostras de aves e de equinos nos casos estudados.

Material e Método: Foram selecionados cinco equinos e cinco aves, provenientes da demanda de Vigilância Epidemiológica da Seção de Patologia do Instituto Evandro Chagas, Belém-PA, incluindo amostras de tecido nervoso, fígado, baço, rim, pulmão e coração.

A descrição dos achados histopatológicos será feita de acordo com o protocolo adaptado de Hall e colaboradores (1994). As amostras são armazenadas em solução de formaldeído $10 \%$ tamponado, depois são analisadas macroscopicamente e seccionadas em tamanho de aproximadamente $0,5 \mathrm{~cm}^{3}$. Em seguida, as amostras são desidratadas e diafanizadas em soluções alcoólicas e em xilol, e posteriormente impregnadas em parafina a $56-58^{\circ} \mathrm{C}$. Depois as amostras são incluídas em bloco de

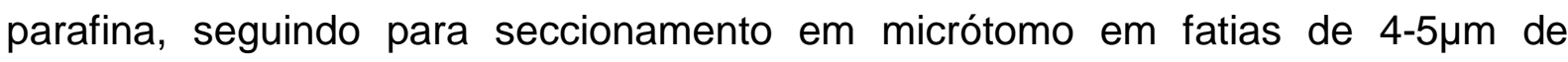
espessura, sendo estas montadas em lâminas histológicas em pares, para realização de coloração por Hematoxilina e Eosina (HE) e para o teste imunohistoquímico.

Será feito o cultivo do SLEV para montagem dos blocos controle a partir de cultura de células C6/36 infectadas e mantidas em cultura por aproximadamente sete dias in vitro. Em seguida a elaboração de blocos de parafina a partir da cultura de SLEV, e a preparação das lâminas para imuno-histoquímica. Para a padronização de titulação do anticorpo anti-SLEV, as lâminas serão divididas em grupos de acordo 
com o tipo de recuperação antigênica a ser testada. Serão testados quatro tipos de recuperação antigênica: (i) protease $0,05 \%$ em solução salina tamponada (3 min$37^{\circ} \mathrm{C}$ ); proteinase $\mathrm{K} 0,05 \%$ em solução salina tamponada (15 min-temperatura ambiente); (iii) tampão citrato (pH 6,0) a $110^{\circ} \mathrm{C}$ (15minutos); e (iv) tampão EDTA (pH $9,0)$ a $110^{\circ} \mathrm{C}$ (15 minutos).

Após essa padronização, o protocolo será testado em amostras de 20 casos testados previamente para infecção por SLEV através de métodos de biologia molecular e/ou isolamento viral em vísceras.

Resultados Preliminares: Descrição dos achados histopatológicos

Todas as amostras foram submetidas aos testes histopatológicos e foi possível identificar as características histopatológicas no qual incluíram principalmente alterações meníngeas, perivasculares e parenquimatosas. Congestão vascular, infiltrado inflamatório consistindo principalmente de linfócitos foi observado nas meninges, sugestivas de meningite viral. $\mathrm{O}$ ambiente perivascular exibiu congestão de intensidade variável e infiltração inflamatória de células mononucleares, infiltrada linfocitário, acentuada hemorragia. A análise do ambiente cerebral mostrou alterações de intensidade variável, incluindo gliose, calcificações, neuronofagia, necrose neuronal, degeneração neuronal, nódulos microgliais, vacuolização, focos hemorrágicos e vasocongestão.

Estudos experimentais corroboram com os achados deste estudo, no qual mostram que o SLEV causa alterações patológicas progressivas em cérebros de camundongos, apresentando sinais de meningite, morte neuronal, leucócitos infiltrantes, microgliose, degeneração tecidual e inflamação (MARQUES et al, 2017). O envolvimento do SNC está diretamente correlacionado com a extensão e duração da viremia, embora o mecanismo de neuroinvasão permaneça incerto. É provável que o movimento do tecido nervoso periférico para o central seja passivo de transporte através do citoplasma dos neurônios e depois através das membranas associadas após a lise celular. A depuração viral depende de um sistema imunológico funcional e da produção rápida de anticorpos neutralizantes, que geralmente aparece dentro de sete dias após a infecção (REISEN W, 2014).

Conclusão: Observamos que a infecção por SLEV leva a encefalite nos equinos. A patologia do SNC consiste em necrose de neurônios e células da glia e alterações inflamatórias que são tipicamente mais importantes na doença progressiva ou subletal do SNC com sequelas. Nosso estudo indica que a inflamação, a hemorragia e o edema são componentes importantes da doença induzida pelo SLEV, principalmente no SNC.

Mais estudos são necessários para elucidar detalhadamente os mecanismos patogênicos e os fatores imunes envolvidos na resposta do hospedeiro contra a infecção do SNC pelo SLEV.

Referências bibliográficas: ROCCO IRAY M.; CECÍLIA LS SANTOS I; IVANI BISORDI I et al. St. Louis encephalitis vírus: first isolation from a human in São Paulo 
state, Brasil. Revista do Instituto de Medicina Tropical de São Paulo, v. 47, n. 5, p.281-285, out. 2005.

MARQUES, RAFAEL ELIAS et al. Development of a model of Saint Louis encephalitis infection and disease in mice. Journal Of Neuroinflammation, v. 14, n. 1, p.145-148, 22 mar. 2017.

ROSA, ROBERTA et al. Isolation of Saint Louis Encephalitis Virus from a Horse with Neurological Disease in Brazil. Plos Neglected Tropical Diseases, v. 7, n. 11, p.25372600, 21 nov. 2013. Public Library of Science (PLoS).

HEINEN, Letícia Borges da Silva et al. SAINT LOUIS ENCEPHALITIS VIRUS IN MATO GROSSO, CENTRAL-WESTERN BRAZIL. Rev. Inst. Med. Trop. S. Paulo, São Paulo, v. 57, n. 3, p.1678-9946, maio 2015.

REISEN, WILLIAM K. Epidemiology of St. Louis encephalitis virus. Advances In Virus Research Volume 61, p.139-183, 2003.

Palavras-chave: Saint Louis, Encefalite, diagnóstico, histopatologia, equinos Grande-área: Ciências Biológicas

Área: Ciências Biológicas III 


\title{
USO DE PRIMATAS NEOTROPICAIS DO GÊNERO Sapajus NA PADRONIZAÇÃO DE MODELO EXPERIMENTAL PARA Schistosoma mansoni
}

\author{
Nome do(a) Bolsista: Álvaro Luan Santana Fonseca \\ Nome do(a) Orientador(a): Martin Johannes Enk
}

Resumo: Estabelecer um modelo de experimental de esquistossomose em um gênero de primatas não humanos neotropicais, verificando métodos diagnósticos mais eficazes na detecção e acompanhamento da infecção, possibilitando assim o desenvolvimento de novos estudos que auxiliem a cura e controle desta doença.

Materiais e Métodos: Foram utilizados seis primatas adultos do gênero Sapajus, distribuídos randomicamente em dois grupos experimentais de igual número. Três animais foram infectados por via intradérmica e três por via transcutânea, com suspensão de cercárias obtidas de caramujos Biomphalaria glabrata infectados naturalmente. Para acompanhamento da infecção, eram coletadas amostras de fezes diretamente das gaiolas e urina via sonda ou punção direta, com o animal anestesiado. As amostras de urina foram examinadas com o Teste Rápido de Urina (Point of Care Cathodic Circulating Antigen - POC-CCA) e as amostras de fezes com os exames de Sedimentação Espontânea Das Fezes - HPJ e Kato-Katz (KK) para verificação da infecção. Resultados: Dos animais infectados por via transcutânea, apenas um manteve-se negativo para presença de ovos de $S$. mansoni. Semelhantemente, dos animais infectados por via intradérmica, apenas um manteve-se negativo. O exame POC-CCA foi o primeiro a detectar positivos (210 dia), seguido dos exames de HPJ (350 dia) e KK ( $42^{\circ}$ dia), respectivamente. Conclusão: Este modelo apresenta-se viável para reprodução em diferentes estudos sobre esquistossomose mansônica, pois os animais responderam de maneira satisfatória à infecção em ambas as vias utilizadas. Os métodos diagnósticos empregados possibilitaram a detecção de positivos em diferentes períodos pós-infecção.

Introdução: A esquistossomose é uma doença infecto-parasitária causada por helmintos da classe dos trematódeos e do gênero Schistosoma. Por ser uma doença de características subclínicas, o que lhe confere baixa visibilidade e baixo impacto, carece de uma maior atenção das autoridades (Carvalho et al., 2008). Estudos acerca deste parasito vêm sendo desenvolvidos desde a década de 50 no Brasil e trouxeram grandes contribuições, principalmente, nos aspectos clínicos e epidemiológicos da doença (Andrade, 2002). Diante disto, surgem diferentes modelos utilizando animais como alguns roedores (principalmente camundongos), mamíferos como coelho (Sylvilagus floridanus) e primatas de diferentes espécies (Andrade et al., 1988; Cheever et al., 2002). Esta crescente demanda por investigações experimentais com o S. mansoni levou a busca pela avaliação desta infecção em modelos animais que pudessem se assemelhar ao máximo aos 
humanos. O modelo primata surge como uma saída, pois estes animais apresentam características morfológicas e biológicas semelhantes às do homem, possibilitando formas de infecção similares (Brener \& Alvarenga, 1962; Cheever et al., 2002). Portanto, seria cabível estabelecer um modelo de estudo de esquistossomose em espécies de primatas não humanos neotropicais, possibilitando a obtenção de novos conhecimentos acerca de melhores formas para prevenção através do uso de novas drogas e vacinas, que possibilitem sua cura e controle, além da possibilidade de estabelecer métodos diagnósticos mais eficazes.

\section{OBJETIVO}

\subsection{OBJETIVO GERAL}

Desenvolver e padronizar um modelo experimental em primatas neotropicais para infecção com Schistosoma mansoni.

\subsection{OBJETIVOS ESPECÍFICOS}

1. Comparar os métodos de infecção, com ênfase na carga parasitária, em primatas do gênero Sapajus;

2. Verificar a presença e ausência de antígeno circulante pelo teste POC-CCA antes e após tratamento, respectivamente;

3. Quantificar o número de cercárias necessárias para infecção em primatas do gênero Sapajus;

\section{METODOLOGIA}

\subsection{ASPECTOS ÉTICOS}

Este projeto foi elaborado e submetido à apreciação do Comitê de Ética em Pesquisa com Animais (CEUA) do Instituto Evandro Chagas (IEC), sendo aprovado pelo mesmo sob o Certificado $n^{0}$ 25/2018 registrado com o $n^{0}$ 10/2018.

\subsection{ANIMAIS}

Foram utilizados seis primatas adultos do gênero Sapajus, três machos e três fêmeas de identificação, todos provenientes do biotério destinado ao manejo de primatas do Centro Nacional de Primatas (CENP-SVS/MS) localizado no Instituto Evandro Chagas-Belém/PA (IEC). Os animais foram mantidos em gaiolas individuais $(70 \times 70 \times 80 \mathrm{~cm})$ no galpão de experimentação animal do CENP-SVS/MS.

\subsection{INFECÇÃO EXPERIMENTAL COM S. mansoni}

3.3.1 Obtenção das Cercárias: Para a obtenção das cercárias, foram utilizados espécimes de Biomphalaria glabrata naturalmente infectados, obtidos durante coleta de rotina em bairros da cidade de Belém - PA e mantidos no Laboratório de Parasitoses Intestinais, Esquistossomose e Malacologia (LPIEM), pertencentes a Seção de Parasitologia do Instituto Evandro Chagas (IEC-SVS/MS). Os caramujos infectados foram expostos a lâmpadas incandescentes de 60W para liberação de 
cercárias. Cerca de $1 \mathrm{ml}$ desta solução foi retirada para visualização e contagem em lupa eletrônica.

3.3.2 Infecção Experimental: Os primatas foram distribuídos randomicamente em dois grupos experimentais de igual número para infecção. Dentro destes, também foram randomizadas as formas de infecção de cada animal.

$\mathrm{Na}$ infecção por via transcutânea, cada animal teve o pêlo do seu abdômen e raspados, então foi colocada gota a gota uma solução com cerca de 500 cercárias sobre a pele depilada por 45 minutos (Brener \& Alvarenga ,1962; Britto et al., 1971). $\mathrm{Na}$ infecção por via intradérmica, uma suspensão é retirada e o volume referente a quantidade de 500 cercárias é ajustado por uma seringa com agulha calibre 22 para então ser injetado nos animais (Peters \& Warren, 1969).

Com o objetivo de diminuir o estresse dos animais durante a infecção e dos exames de rotina, era induzida anestesia por via intramuscular de $4,4 \mathrm{mg} / \mathrm{kg}$ de Zoletil®. Para prevenção de possíveis efeitos adversos provocados pelo uso destes medicamentos, foi aplicado Sulfato de Atropina a 1\%, na dose de 0,05 mg/kg por via subcutânea (Miranda et al., 2011).

3.3.3 Coletas do Material Biológico: Anterior à infecção dos animais, foram coletadas amostras de urina, sangue e fezes para atestar que os animais estavam livres de qualquer tipo de contaminação. Após infecção, foram coletadas semanalmente durante seis semanas $\left(7^{\circ}, 14^{\circ}, 21^{\circ}, 28^{\circ}, 35^{\circ}, 42^{\circ}\right.$ dia pós-infecção) amostras de urina e fezes para detecção de antígeno e ovos de S. mansoni, respectivamente. Posteriormente, foram coletadas mensalmente $\left(70^{\circ}, 98^{\circ}, 126^{\circ}\right.$, $154^{\circ}$ dia pós-infecção) uma amostra de urina, sangue e fezes para monitoramento da infecção. Os animais foram tratados no $161^{\circ}$ dia pós-infecção.

3.3.4 Coleta das Amostras de Fezes: As amostras de fezes foram coletadas diretamente de papéis esterilizados posicionados nos fundos das gaiolas e armazenadas em potes de plástico estéreis para análise diagnóstica.

3.3.5 Coleta das Amostras de Urina: Para coleta de urina dos animais, foi utilizada sonda uretral Tom Cat 1.8mm estéril lubrificada com gel para inserção na uretra do animal, para remoção de $2 \mathrm{~mL}$ de urina. Em caso de impossibilidade da obtenção de urina via sonda, a mesma era coletada por meio de punção com auxílio do equipamento de ultrassonografia Logic E (GE Medical Systems, China) ${ }^{\circledR}$ e transdutor multifrequencial de banda larga linear com frequência de 8 a 18Mhz. Após coleta, os recipientes contendo as urinas eram etiquetados e armazenados para posterior análise.

\subsection{MÉTODOS DIAGNÓSTICOS}




\subsubsection{Método de Sedimentação Espontânea Das Fezes - HPJ (Adaptado)}

O método de sedimentação espontânea descrito por Lutz (1919) e padronizado por Hoffman, Pons \& Janer (1934) consiste na homogeneização das fezes, as quais são filtradas em gaze e suspensas em água, retendo resíduos fecais e aumentando a concentração de ovos dos demais detritos encontrados ${ }^{9}$.

3.4.2 Método de Kato-Katz: É um método qualitativo e quantitativo que permite a determinação de número de ovos por grama de fezes, estimando assim a intensidade da infecção. As lâminas de Kato-Katz são preparadas usando o Helm Test $\mathrm{Kit}^{\circledR}$. O número de ovos encontrados durante a leitura das lâminas é multiplicado por 24 para quantificação do número de ovos por grama de fezes, considerando que o orifício da placa perfurada contém 43,7 miligramas de fezes (Katz et al., 1972).

\subsubsection{Teste Rápido de Urina (Point of Care Cathodic Circulating Antigen - POC-} CCA) Este é um teste imunocromatográfico destinado a detecção presuntiva qualitativa de uma infecção ativa por S. mansoni com objetivo de detectar antígenos CCA (Circulating Cathodic Antigen) do verme adulto na urina do paciente (de Clercq et al. 1997).

4. Resultados e discussão: Os animais infectados por via transcutânea foram AMAXB03, AM-APR05 e AM-APW06. Destes, o espécime AM-AXB03 manteve-se negativo para presença de ovos de $S$. mansoni tanto no exame de Kato-Katz quanto no exame HPJ durante todo o período anterior ao tratamento. O espécime AMAPR05 mostrou presença de ovos de S. mansoni no exame de Kato-Katz a partir do $42^{\circ}$ dia pós-infecção, apresentando 8 ovos por grama de fezes. No exame HPJ, o espécime foi positivo para presença de ovos de $S$. mansoni a partir do $35^{\circ}$ dia pósinfecção. O espécime AM-APW06 apresentou ovos de S. mansoni no exame de Kato-Katz a partir do $126^{\circ}$ dia pós-infecção, apresentando 8 ovos por grama de fezes. No exame HPJ, o animal foi positivo a partir do $98^{\circ}$ dia pós-infecção.

Os animais infectados por via intradérmica foram AM-BDL01, AM-ALO02 e AMABV04. Destes, o espécime AM-BDL01 foi positivo para presença de ovos de $S$. mansoni no exame de Kato-katz a partir do $70^{\circ}$ dia pós-infecção, apresentando 24 ovos por grama de fezes. No exame HPJ, o animal foi positivo a partir do $35^{\circ}$ dia pós-infecção.

O espécime AM-ALO02 foi negativo para presença de ovos de S. mansoni tanto no exame de Kato-katz quanto no exame HPJ durante todo o período anterior ao tratamento. O espécime AM-ABV04 foi positivo para presença de ovos de $S$. mansoni no exame de Kato-katz a partir do $70^{\circ}$ dia pós-infecção, apresentando 104 ovos por grama de fezes. No exame HPJ, o animal foi positivo a partir do $42^{\circ}$ dia pós-infecção. 
Acerca das vias de infecção, apesar de terem sido igualmente eficientes com 500 cercárias, a via transcutânea além de ser potencialmente perigosa por apresentar risco de derramamento de cercárias, demanda maior tempo para aplicação. Em contrapartida, a forma intradérmica reduz o tempo necessário o que reflete também na dosagem do anestésico, tornando-a mais prática ${ }^{7}$.

O método de HPJ detectou positivos a partir do $35^{\circ}$ dia pós-infecção, resultado diferente dos obtidos nas lâminas de KK, que apresentaram positividade a partir do $42^{\circ}$ dia pós-infecção. Este resultado indica que o método detectou mais positivos ao utilizar todo o material fecal disponível, diferente dos $43,7 \mathrm{~g}$ por lâmina utilizados pelo KK. Entretanto, a vantagem deste último método está em estimar a quantidade de ovos por grama de fezes, podendo dessa maneira acompanhar possíveis flutuações na carga parasitária do indivíduo. Neste sentido a junção das técnicas melhora a deteç̧ão de positivos, entretanto, somente a técnica de KK quantifica a carga parasitária para verificação de morbidade

O teste POC-CCA indicou positividade para os espécimes AM-APR05 e AM-BDL01 a partir do $21^{\circ}$ dia pós-infecção. O espécime AM-ABV04 foi positivo a partir do $28^{\circ}$ dia pós-infecção. Já o espécime AM-APW06 foi positivo apenas a partir do $98^{\circ}$ dia pós-infecção. Os espécimes AM-ALO02 e AM-AXB03 permaneceram negativos até o fim do estudo.

A coleta de urina nos machos foi possível com o uso de sondas uretrais sem dificuldades. Entretanto, nas fêmeas, este mesmo processo foi inviável, sendo necessária realização de punção na bexiga, com auxílio de aparelho de ultrassonografia.

A aplicação do teste POC-CCA demonstrou resultados positivos a partir do $21^{\circ}$ dia pós-infecção, fato que o torna uma importante ferramenta de auxílio, pois identifica um indivíduo positivo bem mais cedo em comparação a outros métodos diagnósticos. Entretanto, o manejo dos animais para coleta de urina exige sedação e, após procedimento, todos os espécimes precisam ser acompanhados até total recuperação. Além disto, por vezes a bexiga dos animais estava vazia, o que impossibilitou a coleta e realização do exame. Deste modo, reconhece-se a validade deste teste, porém sua aplicação torna-se difícil neste modelo de estudo.

Os animais que não foram positivos ao final do estudo poderiam ser facilmente reinfectados posteriormente para realização de estudos de reinfecção e de avaliação de susceptibilidade.

6. Conclusões: Concluímos então que os animais responderam de maneira satisfatória a infecção com 500 cercárias de S. mansoni em ambas as vias de infecção, eliminando números significativos de ovos sem desenvolver patologias graves relacionadas a doença durante todo o período de observação. Além disto, foi possível verificar a praticidade da via Intradérmica quando comparada a transcutânea. Para otimização na detecção inicial da infecção, recomenda-se o uso do método de HPJ visualizando todo material fecal seguido pela realização do 
exame de Kato-Katz para quantificação e acompanhamento da flutuação da carga parasitária durante o período estudado. Em suma, este modelo apresenta-se viável para reprodução em diferentes estudos relacionados a esquistossomose mansônica.

Referências: ANDRADE, Z. A. A esquistossomose no Brasil após quase um século de pesquisas. Rev. Soc. Bras. Med. Trop. 35(5): 509-513, 2002.

ANDRADE, Z. A; RAMOS, E; REIS, M. G. A patologia da esquistossomose no coelho. Mem. Inst. Oswaldo Cruz. 83: 323-332 1988.

BRENER, Z; ALVARENGA, R. J. Susceptibilidade do Cebus apella MACROCEPHALUS SPIX, 1983 a infecções experimentais pelo Schistosoma mansoni. Rev. Inst. Med. Trop. 4(3): 180-186, 1962

BRITO, T; GUNJI, J; CAMARGO, E; CERAVOLO, A; DA SILVA, L. C. Glomerular Lesions in Experimental Infections of Schistosoma mansoni in Cebus apella. Bull. Wld. HIth. Org. 45: 219-422, 1971.

CARVALHO, O. S; COELHO, P. M. Z; LENZI, H. L. Schistosoma mansoni e esquistossomose: uma visão multidisciplinar. $20^{a}$ ed. Rio de Janeiro: FIOCRUZ; 2008.

CHEEVER, A. W; LENZI, J. A; LENZI, H. L; ANDRADE, Z. A. Experimental models of Schistosoma mansoni infection. Mem. Inst. Oswaldo Cruz. 97(7): 917-940, 2002.

de CLERCQ, D; SACKO, M; VERCRUYSSE, J; BUSSCHE, V. V; LANDOURÉ, A; DIARRA, A; GRYSEELS, B; DEELDER, A. Assessment of cure by detection of circulating antigens in serum and urine, following schistosomiasis mass treatment in two villages of the Office du Niger, Mali. Acta Tropica. 68: 339-346, 1997.

HOFFMAN, W. A; PONS, J. A; JANER, J. L. Sedimentation concentration method in Schistosomiasis mansoni. PR. J. Public. Health. Trop. Med. 9: 283-298, 1934

KATZ, N; CHAVES, A; PELLEGRINO, J. A simple device for quantitative stool thicksmear technique in Schistosomiasis mansoni. Rev. Inst. Med. Trop. 14(6): 397-400, 1972. 
MIRANDA, C. B; CABALA, R. W; ATAN, J. B. C. D; MÜLLER, L. C. C. M; SILVA, P. C; VIVAS, L. A. M; FERREIRA, M. L. Contenção farmacológica em primatas nãohumanos com emprego de ketamina e xilazina. Uma revisão bibliográfica. PUBVET. 5: 1045, 2011.

PETERS, P. A; WARREN, K. S. A rapid method of infecting mice and other laboratory animals with Schistosoma mansoni: Subcutaneous injection. J. Parasitol. 55: 558, 1969.

RAPIDMEDICAL DIAGNOSTICS. For qualitative detection of Bilharzia (Schistosomiasis). 2015.

Palavras-chave: Schistosoma mansoni, Modelo Experimental, Primatas Neotropicais, Sapajus.

Grande Área: Parasitologia

Área: Helmintologia 


\title{
CARACTERIZAÇÃO CLÍNICO-EPIDEMIOLÓGICA E MICROBIOLÓGICA DE CASOS DE INFECÇÃO EM SÍTIO CIRÚRGICO PÓS-CESÁREA POR ACINETOBACTER SPP.
}

\author{
Nome do(a) Bolsista: Blenda Gonçalves Cabral \\ Nome do(a) Orientador(a): Karla Valéria Batista Lima
}

Resumo: As infecções de sitio cirúrgico são consideradas a terceira causa de infecção hospitalar mais frequente no Brasil, sendo mais comuns as infecções de cesárea. O objetivo foi caracterizar o perfil clínico-epidemiológico e microbiológico de casos de infecção de sítio cirúrgico por Acinetobacter spp., em mulheres póscesárea internadas no hospital de Referência à Assistência Materno-Infantil, no Estado do Pará. Foi um estudo observacional analítico, retrospectivo e transversal. Com amostragem por conveniência $\mathrm{N}=69$, no período de 2012 a 2015. Os dados sócio demográficos e clínicos foram obtidos por análise de prontuários. O perfil de suscetibilidade das amostras foi determinado pelo Sistema automatizado VITEK-2. Os genes de resistência para oxacilinases foram detectados pela técnica de PCR multiplex. Para a genotipagem dos isolados foi utilizada a técnica Rep-PCR pelo Sistema automatizado DiversiLab. Os dados foram analisados com estatística descritiva e testes não paramétricos como Teste Exato de Fisher, pelo programa BioEstat versão 5.0. Os resultados foram faixa etária média de 25 anos, variando de 12 a 46 anos, procedência de 33\% $(n=23)$ do município de Belém/PA; 54\% $(n=37)$ em união estável. E escolaridade $28 \%(n=19)$ com ensino fundamental incompleto, e $43 \%(n=30)$ com ocupação de dona do lar. A identificação molecular das espécies foi 49 isolados de $A$. baumannii (71\%), 19 de $A$. nosocomialis (28\%) e um isolado de $A$. colistiniresistens (1\%). O teste de suscetibilidade aos antimicrobianos demonstrou taxas de resistência de $A$. baumannii significativas. Os fatores de risco para infecção pós-cesárea foram: parto prematuro $(n=25)$, idade materna de risco $(n=20)$, doenças crônicas não transmissíveis $(n=16)$, para morbidades pessoais. Doenças hipertensivas $(n=14)$ e sofrimento fetal agudo $(n=14)$, para indicação de cesárea. $E$ complicações ginecológicas $(n=35)$. As complicações decorrentes da infecção póscesárea: antibioticoterapia inadequada, uso prolongado de antibióticos, sepse e ressuturas mostraram dados significativos (valor de $p<0,05$ ). A genotipagem revelou nove grupos clonais de $A$. baumannii presente por longos períodos em diversas enfermarias obstétricas e dois grupos clonais de A. nosocomialis. As parturientes com infecção por $A$. baumannii multirresistente tiveram maiores complicações relacionadas a cirurgia cesariana, no entanto aquelas com infecção por $A$. nãobaumanni demonstraram alta patogenicidade. Tal fato pode estar relacionado com a submissão das mulheres a cesárea de emergência, considerada um fator de risco para infecções pós-cesárea. Ressalta-se que este é o primeiro relato sobre infecção pós-cesárea por Acinetobacter spp. com surto por longo períodos, identificação de grupos clonais com resistência a bla OXA-23. 
Introdução: A infecção do sítio cirúrgico (ISC) é definida como uma infecção que ocorre dentro de 30 dias após operação cirúrgica podendo afetar apenas a pele no local da incisão ou tecidos profundos, envolvendo órgãos/espaço corporal[1, 2]. E as infecções relacionadas à gravidez é aquela que ocorre entre o início da ruptura de membranas em trabalho de parto e o $42^{\circ}$ dia após o parto. A cirurgia cesariana é considerada, dentre as ISC e as infecções relacionadas à gravidez, como a terceira causa de infecção hospitalar mais frequente e considerada o fator de risco mais importante para infecção pós-parto [3]. Além disso, está associado ao aumento da morbidade, mortalidade, internação prolongada, infertilidade secundária e aumento dos custos no atendimento ao paciente[4]. Estudo realizado em vários países da África Subsaariana, relatou risco de ISC relacionado à cesárea de 7,3\%[5]. A cirurgia cesariana possui uma maior probabilidade de infecção bacteriana pós-parto, as taxas de infecção variam de $1 \%$ a $25 \%$, cerca de 5 a 20 vezes maior que a do parto vaginal[6]. Porém, o parto cesáreo é um dos procedimentos mais comumente realizados em mulheres no mundo, com taxas de incidência variando de $15 \%$ a mais de $60 \%$ em alguns países[7]. Há vários fatores associados as infecções de sítio cirúrgico pós-parto, sendo eles: idade, índice de massa corporal (IMC), visitas prénatais limitadas, tabagismo, diabetes, distúrbios hipertensivos, várias gestações[11,12]. Outros fatores de risco são cesárea de emergência, trabalho de parto prolongado, excesso de toques vaginais, corioamnionite, cirurgia prolongada[13,14,15]. E existem também as complicações geradas pela ISC póscesárea que inclui cicatrização prolongada da ferida, deiscência da ferida, admissão prolongada, uso prolongado de antibióticos etc. As infecções no local cirúrgico também prejudicam os aspectos físicos, emocionais, sociais e econômicos da puérpera[1]. Sabe-se ainda que os principais agentes bacterianos isolados em ISC pós-cesárea são Staphylococcus aureus sendo responsável por 20 a 30\% das ISC hospitalares. Outros organismos regularmente isolados são bacilos Gram-negativos, como Pseudomonas aeruginosa, Klebsiella spp. e Escherichia coli[16]. No entanto, estudos recentes demonstram o patógeno $A$. baumannii relacionado a casos de partos cesáreo. Tal descoberta é preocupante por se tratar de um patógeno oportunista pertencente ao complexo Acinetobacter calcoaceticus. Que apresenta resistência a diversas classes de antibióticos de largo espectro, devido aos seus mecanismos de resistência adquiridos[17,18]

Objetivos: Caracterizar o perfil clínico-epidemiológico e microbiológico de casos de infecção de sítio cirúrgico por Acinetobacter spp. em mulheres pós cesárea internadas em um hospital de Referência na Assistência Materno-Infantil no estado do Pará.

Material e métodos: Trata-se de um estudo observacional analítico, retrospectivo e transversal, envolvendo mulheres com infecção de sítio cirúrgico pós-cesárea por Acinetobacter spp., internadas nas enfermarias obstétricas de um Hospital público 
referência no atendimento à Gestante de Alto Risco e ao Recém-Nascido, na cidade de Belém-Pará, no período de 2012 a 2015. A amostragem foi realizada por conveniência, obtendo como $\mathrm{N}=69$. Levando em consideração os seguintes critérios de inclusão: pacientes com infecção em sítio cirúrgico pós-cesárea por Acinetobacter spp., internadas nas enfermarias obstétricas do hospital público de Belém-PA, no período de 2012 a 2015. Para obtenção de dados sócio-demográficos e clínicos da população em estudo foi desenvolvido um formulário estruturado. O perfil de suscetibilidade das amostras foi determinado utilizando o Sistema automatizado VITEK 2. As amostras foram testadas para os seguintes antibióticos: Ampicilina-sulbactam (ASB), ceftazidima (CAZ), Cefepima (CPM), Imipenem (IPM), Meropenem (MER), Gentamicina (GEN), Amicacina (AMI), Ciprofloxacina (CIP). Após o resultado final, os isolados foram classificados como sensíveis (S), intermediários (I) ou resistentes (R) aos antimicrobianos testados, seguindo as recomendações do Clinical and Laboratory Standards Institute. Foi considerado como multirresistente o isolado que apresentou suscetibilidade reduzida para três ou mais classes de antimicrobianos. Para a identificação das espécies foi realizado PCR para o gene bla OXA-51, específico da espécie A. baumannii. Quando não amplificadas as amostras para o gene bla OXA-51 eram submetidas à amplificação para gene $r p o B$ (350 e 450 pares de bases), e posteriormente à purificação utilizando o kit wizard sv gel and PCR clean system (PROMEGA) e sequenciamento da região variável 1 e/ou 2 do gene rpoB[19]. As sequencias obtidas foram comparadas às sequencias contidas no banco de dados do Genbank, utilizando a ferramenta de pesquisa BLAST (http://blast.ncbi.nlm.nih.gov/Blast.cgi). A detecção dos genes de resistência para oxacilinases bla OXA-51, bla OXA-23, bla pela realização da técnica de PCR multiplex[20]. Para a genotipagem dos isolados de Acinetobacter spp. foi utilizada a técnica Rep-PCR por meio do Sistema automatizado DiversiLab, e os produtos de eletroforese foram analisados utilizando o equipamento Agilent Bioanalyzer 2100 em que cada isolado apresenta um único perfil rep-PCR com múltiplas bandas de intensidade variável que são separados e detectados utilizando um LabChip. A relação de similaridade definida entre os isolados de Acinetobacter baumannii e $A$. não-baumannii foi de $\geq 95 \%$ [22]. Os dados gerados foram tabulados no Programa Microsoft Office Excel versão 2013 e expressos sob a forma de frequência simples e relativa de acordo com a estatística descritiva, também foi usado testes não paramétricos como Teste Exato de Fisherl teste $\mathrm{G}$ de independência (análise de resíduos do qui-quadrado) usando o programa BioEstat versão 5.5 ou GraphPad Prism[23,24] sendo que os resultados com $p \leq 0,05$ foram considerados estatisticamente significativos. Os resultados foram apresentados sob a forma de gráficos e tabelas. O projeto de pesquisa foi aprovado pelos Comitês de Ética em Pesquisa em Seres Humanos do Instituto Evandro Chagas e do hospital em estudo. 
Resultados e discussão: No âmbito global, a prevalência de cirurgias cesarianas é de aproximadamente 18,6\%, variando de 6 a 27,2\%. Quanto aos dados sócio demográficos observou-se faixa etária média de 25 anos, com variação de 12 a 46 anos, com procedência de 33\% $(n=23)$ do município de Belém/PA; 54\% $(n=37)$ alegando viver em união estável. Em relação à escolaridade, 28\% $(n=19)$ relataram formação no ensino fundamental incompleto, e como ocupação 43\% (n=30) alegou ser dona do lar. Nossos dados sócio demográficos assemelham-se aos descrito em outros estudos $[1,6,11,13]$, especialmente em países subdesenvolvidos da África.

As infecções pós-cesárea foram mais frequentes em primigestas com $49 \%(n=34)$.

Durante o período de gestação $51 \% \quad(n=35)$ das mulheres apresentaram complicações ginecológicas como infecção do trato urinário e leucorréia. No puerpério, as Infecções do Trato Urinário (ITU) são consideradas de alto risco por ocasionarem alterações fisiológicas e hormonais que inibem as defesas do trato urinário contra bactérias invasoras. A passagem de sonda vesical é comum em mulheres submetidas ao parto cesariano, tal procedimento traz um risco diário de 3 a $8 \%$ de bacteriúria, aumentando acentuadamente o risco de ITU[35]. Foi comprovado que mulheres com diagnóstico de ITU durante a gravidez tiveram três vezes maior risco de desenvolver ISC pós-cesárea[35]. Houve também casos de infecções sexualmente transmissíveis (IST) com total de 14\% $(n=10)$, destacando-se $4 \%(n=3)$ para hepatite $B, 6 \%(n=4)$ para HIV. Todas as 69 pacientes durante 0 período de internação foram submetidas a exames de cultura de secreção da ferida cirúrgica de cesárea, com isolamento de Acinetobacter como único agente infeccioso presente em 81\% $(n=56)$ das pacientes, enquanto que para $19 \%(n=13)$ houve co-infecção de outros agentes microbianos com Acinetobacter, sendo eles: $S$. aureus $(n=3)$, E. coli $(n=4), S$. agalactiae $(n=1), P$. vulgaris $(n=1), S$. hominis $(n=1)$, $P$. mirabilis $(n=1), K$. pneumoniae $(n=1)$ e $P$. aeruginosa $(n=1)$. Segundo a literatura as bactérias $E$. coli, K. pneumoniae e $S$. aereus são os principais isolados identificados em infecções pós-cesárea com percentagem de 8,5\%[1,25]. Ressaltase que o patógeno Acinetobacter não é um isolado comumente encontrado em ISC de pós-cesárea em populações jovens, porém por ser um patógeno de alta adaptação e permanência em ambientes hospitalares, com mecanismos de resistência complexos torna-se um agravante para os pacientes hospitalizados[34]. A identificação molecular das espécies de Acinetobacter revelou: 49 isolados de $A$. baumannii (71\%), 19 de $A$. nosocomialis (28\%) e um isolado de $A$. colistiniresistens (1\%). Foi observado no teste de suscetibilidade aos antimicrobianos diferenças significativas entre as taxas de resistência de isolados $A$. baumannii e $A$. nãobaumannii ( $A$. nosocomialis e $A$. colistiniresistens). Em relação aos antimicrobianos ampicilina-sulbactam (ASB), ceftazidima (CAZ) e cefepima (CPM), foram observadas taxas de resistência de 37\%, 65\% e 69\% respectivamente no grupo de $A$. baumannii, e para os carbapenêmicos a taxa de resistência de 61\%. Quando verificado resistência aos carbapenêmicos, foram identificados 31 isolados, sendo 30 da espécie $A$. baumannii e um $A$. nosocomialis, e quanto a presença dos genes 


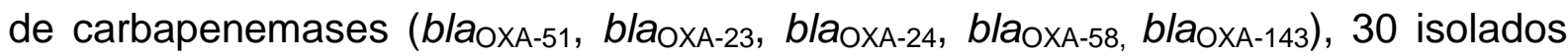
foram positivos apenas para os genes bla OXA-23 e bla OXA-51. E um isolado ( $A$. nosocomialis) foi negativo para todos os genes bla resistência intrínseca para o gene bla $a_{\mathrm{IMP}}$ de metalobetalactamase. Quanto à análise dos dados clínicos observou-se que algumas variáveis são consideradas fatores de risco para ISC pós-cesárea, destacando-se em nosso estudo idade materna ( $<17$ e >35 anos), diabetes mellitus e cesárea de emergência, sendo os principais diagnósticos apresentados sofrimento fetal, ruptura prematura de membranas, e doenças hipertensivas da gravidez. As mulheres submetidas a cirurgias cesarianas de emergência sofrem um risco de 5 a 20 vezes maior de infecção em comparação àquelas que tiveram parto normal[28]. Houve um prolongamento no tempo de internação hospitalar das mulheres, que variou de 7 a 80 dias (média de 30 dias de internação), embora, o preconizado seja três dias de internação para cirurgias póscesárea[31]. Para caracterizar ISC pós-cesárea, de acordo com a CDC (2018) a ferida operatória deve manifestar um dos sintomas: edema, rubor, dor e secreção purulenta. Em nosso estudo o sintoma mais frequente foi secreção purulenta, presente em $69 \%(n=48)$ das mulheres. Observou-se que a evolução dos casos de ISC pós-cesárea para o grupo de isolados Acinetobacter resistentes aos carbapenêmicos foi mais complicada e prolongada quando comparada ao grupo sensível. E o início da infecção em ambos os grupos se deu no $2^{\circ}$ dia de PósOperatório Cesariano (POC), sendo que no grupo sensível o início da infecção variou do $1^{\circ} \mathrm{POC}$ ao $20^{\circ} \mathrm{POC}$ e para o grupo resistente variou do $1^{\circ} \mathrm{POC}$ ao $47^{\circ} \mathrm{POC}$. O desfecho para todas as pacientes foi de cura e alta hospitalar, não houve óbitos. Houve $31(45 \%)$ casos em que as parturientes foram readimitidas com quadro de infecção no local da cesárea, tais fatos podem estar associados a falta de medidas de prevenção no bloco cirúrgico, nos instrumentos utilizados durante a cirurgia, como também na equipe de profissionais. Já que estudos demonstram que a contaminação ambiental e de itens hospitalares com $A$. baumannii são a causa principal de transmissão cruzada, os principais itens responsáveis por essa transmissão são: equipamento de sucção, travesseiros, colchões, pias e lavatórios[38]. Além disso, o patógeno é capaz de causar complicações graves as pacientes com ISC pós-cesárea como cicatrização prolongada da ferida, deiscência da ferida, dor na ferida, fasceíte necrosante, abscesso pélvico, admissão prolongada, uso prolongado de antibióticos, a possibilidade de re-admissão, cirurgia de reparo secundário (ressutura), hérnia incisional, cicatriz desfigurante e, casos de sepse e mortalidade[1]. Foram estatisticamente significativos o número de ressuturas com frequência maior que o esperado, tanto no grupo resistente, com realização de até duas ressuturas quanto no grupo sensível com uma ressutura. Vale ressaltar que 93\% do total de mulheres com infecção pós-cesárea realizaram pelo menos uma ressutura. Para a realização de outras cirurgias (histerectomia total, laparotomia exploratória, debridamento, drenagem de hematomas, ligadura de vasos e enxerto) demonstraram dados significativos com valor de $p \leq 0,05$ no grupo resistente. Sobre 
a variável cicatrização prolongada da ferida cirúrgica também obteve-se dados significativos com valor de $p \leq 0,05$, no grupo resistente para o intervalo de 21 a 40 dias demonstrou frequência acima do esperado $(n=18)$. A obtenção do resultado da cultura demonstrou resultados significativos para os grupos resistente e sensível. Para os casos de sepse presente somente no grupo resistente houve dados significativo com valor de $p=0,0364$. A sepse puerperal é considerada uma das infecções mais comuns e também causadora de morbidez e mortalidade $(10,7 \%)$ das puérperas, em todo o mundo[25, 33]. Além disso, todos os casos de sepse foram de pacientes com infecção por Acinetobacter baumannii multirresistente (MRAb). A variável admissão prolongada também demonstrou resultados significativos com valor de $p=0,0060$ no grupo resistente com 18 mulheres com internação acima de 30 dias. Em nosso estudo, as ISC pós-cesárea por MRAB foram associadas a uma internação prolongada de 6 a mais de 30 dias com média de 28 dias de internação após a infecção, semelhante a relatos anteriores[37]. Essa alta taxa de internação prolongada provavelmente está relacionada à gravidade das pacientes, à disseminação da infecção e à ineficácia da antibioticoterapia contra esses organismos multirresistentes. Observou-se valor de $p \leq 0,05$ no grupo resistente com 10 mulheres em uso de antibióticos acima de 36 dias. Em relação a antibioticoterapia no grupo resistente houve 29 casos considerados como terapia inadequada com valor de $p<0,0001$. Foram identificados que 31 mulheres pertencentes ao grupo de isolados de Acinetobacter multirresistente aos betalactâmicos, realizaram antibioticoterapia de 12 a mais de 36 dias, com significância. Além disso, 29 delas receberam antibioticoterapia inadequada. Fato preocupante por se tratar de pacientes com infecções por Acinetobacter multirresistente aos betalactâmicos. Há várias diretrizes que encorajam as equipes de profissionais a obter conhecimento prévio sobre a resistência bacteriana do hospital ao prescrever antibióticos para tratamento e profilaxia da infecção pósparto[37]. Foi possível relacionar o número de infecções pós-cesárea com os anos de internação das mulheres e identificou-se um aumento no número de casos do ano de $2012(n=12,17 \%)$ para o ano de $2013(n=21,31 \%)$ e esta taxa se manteve durante o ano de $2014(n=21,31 \%)$ e diminuiu no período de $2015(n=15,21 \%)$. Todos os 49 isolados de $A$. baumannii identificados no estudo foram submetidos a genotipagem por Rep-PCR, e a análise dos agrupamentos revelou a presença de nove grupos clonais (com similaridade $\geq 95 \%$ ). Os grupos mais prevalentes foram o grupo A, com quatro isolados e similaridade de $96 \%$, o grupo B com cinco isolados e similaridade de $98 \%$ e o grupo C com sete isolados, similaridade de $97 \%$. Ressaltase que os isolados de $A$. baumannii resistentes aos carbapenêmicos produtores de bla OxA-23 apresentaram expansão clonal, com alguns clones mantendo-se por longos períodos no hospital em estudo como os grupos clonais ( $A, C$ e $D)$. $E$ a disseminação entre diferentes enfermarias presente nos grupos clonais (A, C, D e E). Após a análise dos grupos clonais foi possível verificar em que ano cada grupo clonal se manifestou e por quanto tempo permaneceu nas enfermarias e outros 
setores como as UTI. O grupo clonal D foi o que permaneceu por mais tempo (anos de 2012, 2014 e 2015) em três enfermarias diferentes. O grupo C foi o maior grupo clonal com 7 isolados e permaneceu em três enfermarias diferentes durante os anos de 2014 e 2015. Destaca-se que os grupos clonais A e E tiveram isolados com internações em UTI, devido a quadro de sepse. É sabido que as infecções por MRAB são difíceis de tratar e estão associadas a alta mortalidade e morbidade e estadias hospitalares mais longas. Tornando-se necessário identificar os fatores de risco relacionados a essas infecções hospitalares para ajudar a reduzir sua ocorrência. Além disso, devido à sua capacidade de sobreviver na pele e nas superfícies ambientais dos pacientes, o MRAB é conhecido por promover a disseminação epidêmica e a transmissão nosocomial[37]. Isso foi percebido em nosso estudo de acordo com os resultados de genotipagem por Rep-PCR que demonstraram clones de MRAB disseminados em várias enfermarias obstétricas e até em UTI e com permanência por mais de dois anos. Portanto, a introdução de cepas Acinetobacter Baumannii em um setor do hospital tem um potencial elevado para causar surtos e até ocorrer o fechamento de unidades hospitalares afim de interromper epidemias[37].

Todos os 19 isolados de $A$. nosocomialis identificados foram submetidos a genotipagem por Rep-PCR com agrupamento de dois grupos clonais (com similaridade $\geq 95 \%$ ), cada um contendo dois isolados. A disseminação entre diferentes enfermarias foi identificada no grupo clonal B. Este grupo clonal mantevese por um período de três anos no hospital, entre 2013 e 2015. Vale ressaltar que não houve positividade para o gene de bla $a_{\mathrm{OXA}-23} \mathrm{em}$ isolados de Acinetobacter nosocomialis. No entanto, um isolado demonstrou resistência aos carbapenêmicos, sugerindo possuir outro mecanismo de resistência diferente de bla оха23. Um dado interessante em nosso estudo foi que os isolados de $A$. não-baumannii mesmo sendo em maioria, sensíveis aos antimicrobianos causaram complicações nas mulheres como a realização de ressuturas, devido a deiscência da ferida cirúrgica, e a maioria realizou uma ressutura, sendo um dado novo.

Conclusão: Em nosso estudo foi identificado o perfil epidemiológico das mulheres internadas em enfermarias obstétricas do Hospital de Referência na Assistência Materno-Infantil no estado do Pará, com infecção em sitio cirúrgico de cesárea por Acinetobacter spp. Pode-se observar que as parturientes com infecção por Acinetobacter baumannii multirresistente tiveram maiores complicações relacionadas a cirurgia cesariana em comparação as mulheres infectadas por $A$. não-baumannii. Ressalta-se que este é o primeiro estudo que apresenta ISC pós-cesárea por Acinetobacter spp. com surto por longo períodos. No entanto, nosso estudo teve algumas limitações por se tratar de um estudo retrospectivo, não houve a possibilidade de obter coleta de cultura dos ambientes e comparar com os resultados de genotipagem isolados das pacientes, possibilitando afirmar como a transmissão ocorreu realmente. Portanto ressalta-se que novas pesquisas devem 
ser desenvolvidas nesta área, os partos cesarianos são considerados um fator de risco para ISC e instituições hospitalares, principalmente em Belém, Pa devem implementar e realizar as medidas de prevenção a fim de evitar que patógenos como $A$. baumannii altamente resistentes aos principais antimicrobianos se disseminem nas enfermarias e agravem a saúde das parturientes.

\section{Referências Bibliográficas}

1. Njoku CO, Njoku AN. Microbiological Pattern of Surgical Site Infection Following Caesarean Section at the University of Calabar Teaching Hospital. Maced J Med Sci. 2019; 7(9): 1430-1435. https//doi: 10.3889/oamims.2019.286

2. Delamou A, Camara BS, Sidibé S, Camara A, Dioubaté N, Ayadi AME, Tayler-Smith $\mathrm{K}$, Beavogui $\mathrm{AH}$, Baldé MD, Zachariah R. Trends of and factors associated with cesarean section related surgical site infections in Guinea. J Public Health Afr. 2019; 10(1):818. https//doi: 10.4081/jphia.2019.818.

3. Van DJ, Zwart J, Schutte J, van Roosmalen J. Sepse materna: epidemiologia, etiologia e resultado. Opinião Atual em Doenças Infecciosas. 2010; (23): 249-54.

4. Lapinsky SE. Infecções obstétricas. Clínicas de cuidados intensivos. Epub. 2013; 29 (3): 509-20. https//doi: 10.1016 / j.ccc.2013.03.006

5. Akinkunmi EO, Adesunkanmi AR, Lamikanra A. Pattern of pathogens from surgical wound infections in a Nigeria hospital and their antimicrobial susceptibility profiles. Afr Health Sci. 2014; 14(4):802-9. https://doi.org/10.4314/ahs.v14i4.5

6. Sway A, Nthumba P, Solomkin J, Tarchini G, Gibbs R, Ren Y, Wanyoro A. Burden of surgical site infection following cesarean section in sub-Saharan Africa: a narrative review. Int J Womens Health. 2019; 11:309-318. https//doi: 10.2147/IJWH.S182362.

7. Molina G, Weiser TG, Lipsitz SR, et al. Relationship between cesarean delivery rate and maternal and neonatal mortality. JAMA 2015; 314(21):2263-2270.

11. Saeed KB, Corcoran P, O'Riordan M, Greene RA. Risk factors for surgical site infection aftercesarean delivery: A case-control study. American journal of infection control. 2018.

12. San Lazaro Campillo IS, Meaney S, O'Donoghue K, Corcoran P. Ectopic pregnancy hospitalisations: A national population-based study of rates, management and outcomes. European Journal of Obstetrics \& Gynecology and Reproductive Biology. 2018; 231:174-9. 
13. Krieger $Y$, Walfisch $A$, Sheiner E. Surgical site infection following cesarean deliveries: trends and risk factors. The journal of maternal-fetal \& neonatal medicine: the official journal of the European Association of Perinatal Medicine, the Federation of Asia and Oceania Perinatal Societies, the International Society of Perinatal Obstet. 2017; 30:812.

14. Killian CA, Graffunder EM, Vinciguerra TJ, Venezia RA. Risk factors for surgical-site infections following cesarean section. Infection control and hospital epidemiology. $2001 ; 22: 613-7$

15. Avila C, Bhangoo R, Figueroa R, Santorelli J, Ogburn P, Desan PH. Association of smoking with wound complications after cesarean delivery. Journal of Maternal-Fetal and Neonatal Medicine. 2012; 25:1250-3.

16. Agboeze J, Onoh RC, Umeora OUJ, Ezeonu PO, Ukaegbu C, Onyebuchi AK, et al. Microbiological pattern of post caesarean wound infection at Federal Teaching Hospital, Abakaliki. Afr J Health Sci. 2013; $12 \quad$ (2):99102. https://doi.org/10.4103/2384-5589.134905

17. Fitzpatrick MA, Ozer E., Bolon MK, Hauser AR (2015). Influência das genoespécies do complexo ACB nos resultados clínicos em um hospital dos EUA com altas taxas de resistência a múltiplas drogas. J. Infect. 70:144-152. https//doi:10.1016 / j.jinf.2014.09.004

18. Nemec A., Krizova L., Maixnerova M., van der Reijden TJ, Deschaght P., Passet V., et al. (2011). Caracterização genotípica e fenotípica do complexo Acinetobacter calcoaceticus-Acinetobacter baumannii com a proposta de Acinetobacter pittii sp. nov. (anteriormente espécies genômicas de Acinetobacter 3) e Acinetobacter nosocomialis sp. nov. (anteriormente espécie genômica de Acinetobacter 13TU) . Res. Microbiol. 162:393-404. https//doi.10.1016 / j.resmic.2011.02.006

19. La Scola B, Gundi VA, Khamis A, Raoult D. Sequenciação do gene rpoB e espaçadores flanqueadores para identificação molecular de espécies de Acinetobacter. J Clin Microbiol . 2006; 44 (3): 827-832. doi: 10.1128 / JCM.44.3.827832.2006 .

20. Woodford $\mathrm{n}$, ellington $\mathrm{mi}$, coelho im, turton if, ward me, brown $\mathrm{s}$, amyes sg, livermore dm. PCR multiplex para genes que codificam carbapenemases prevalentes de OXA em Acinetobacter spp. Int j antimicrob agents. 2006; 27 (4):351-3. Epub. 
22. BORBA MP; BALLARINI AE; SAND SVD. Uso da técnica de Rep-PCR na identificação de isolados de actinomicetos. Simpósio Brasileiro de Microbiologia Aplicada 8, 2015, Porto Alegre; RS: SBM; 2015.

23. Ayres $M$ et al. Bioestat 5.5. Aplicações estatísticas nas áreas das ciências biológicas e médicas:Belém: UFPA,2015. (Sofware).

24. GraphPad Prism versão 8.00, GraphPad Software, LA Jolla Califórnia USA, www.graphpad.com

25. Bebell LM, Ngonzi J, Bazira J, et al. Antimicrobial-resistant infections among postpartum women at a Ugandan referral hospital. PLoS One. 2017;12(4):e0175456. Published 2017 Apr 13. doi:10.1371/journal.pone.0175456

27. Van Dillen, Jeroen; Zwart, Joost; Schutte, Piada; van Roosmalen, Jos. Sepse materna: epidemiologia, etiologia e desfecho Opinião Atual sobre Doenças Infecciosas: Junho de 2010 - Volume 23 - Edição 3 - p 249-254. doi: 10.1097 / QCO.0b013e328339257c

28. Intra-abdominal infection (IAI) following cesarean section: a retrospective study in a tertiary referral hospital in Egypt Ahmed R. Abdelraheim, Khaled Gomaa, Emad M. Ibrahim, Mo'men M. Mohammed, Eissa M. Khalifa, Ayman M. Youssef, Ahmed K. Abdelhakeem, Heba Hassan, Ahmed Abd Alghany and Saad El Gelany. Abdelraheim et al. BMC Pregnancy and Childbirth (2019) 19:234 https://doi.org/10.1186/s12884019-2394-4

29. Nowak P, Paluchowska P. Acinetobacter baumannii: biology and drug resistancerole of carbapenemases. Folia Histochem Cytobiol. 2016, 54 (2):61-74. https://doi.org/10.5603/fhc.a2016.0009

30. Kawakita T, Huang CC, Landy HJ. Escolha de antibióticos profiláticos e infecções de sítio cirúrgico após parto cesáreo. Obstet Gynecol . 2018 Oct; 132 (4): 948-955. doi: 10.1097 / AOG.0000000000002863. PMID: 30204697; PMCID: PMC6353631.

31. CDC. Center for Disease prevention and Control. Guia para prevenção de infecção do sítio cirúrgico. 2018.

32. Ngonzi J, Tornes YF, Mukasa PK, Salongo W, Kabakyenga J, Sezalio M, Wouters K, Jacqueym Y, Geertruyden JP. Sepse puerperal a principal causa de mortes em um hospital universitário terciário da universidade de Uganda. BMC Gravidez e parto. 2016, 16 (207). 
33. Miller AE, Vyankandondera. Causas de sepse puerperal e neonatal em contexto de restrição de recursos e advocacia para uma abordagem pós-natal baseada na comunidade integrada. https://doi.org/10.1016/j.ijgo.2013.06.006

34. Wodajo S, Belayneh M, Gebremedhin S. Magnitude and factors associated with post-cesarean surgical site infection at Hawassa University Teaching and referral hospital, southern Ethiopia: a cross-sectional study. Journal home, 27 (3). 2017.

35. Lale S, Chou D, Gemmill A, Tuncalp O, Moller AB, Daniels J. Causas globais de morte materna: Uma análise sistemática da OMS. The Lancet Global Health. 2014; 2 (6):323-333

36. Warde E, Davies E \& Ward, A. Control of a multidrug-resistant Acinetobacter baumannii outbreak. British Journal of Nursing. 2019; 28(4):242248. https//doi:10.12968/bjon.2019.28.4.242

37. Saeed, Khalid BM et al. Incisional surgical site infection following cesarean section: A national retrospective cohort study. European Journal of Obstetrics and Gynecology and Reproductive Biology, (ANO) 240:256 - 260

38. OMS. Recomendações da OMS para prevenção e tratamento de infecções periparto maternas Genebra: Organização Mundial da Saúde; 2015 Disponível em: http://www.who.int/reproductivehealth/publications/maternal perinatal health/per ipartum-infections-guidelines/en/

Palavras-chave: Cirurgia cesariana. Fatores de risco. Acinetobacter. Infecção puerpera 


\title{
AÇÃO INIBITÓRIA DO EXTRATO DE AÇAÍ NA INFECÇÃO DO VÍRUS DO NILO OCIDENTAL
}

\author{
Nome do(a) Bolsista:Bruna Novais Teixeira \\ Nome do(a) Orientador(a): Dr. Carlos Alberto Marques de Carvalho
}

Resumo: O Vírus do Nilo Ocidental (VNO) é um arbovirus emergente nas Américas cuja capacidade epidêmica é potencializada pelo desenvolvimento de vetores competentes e a disseminação de aves migratórias, seu principal hospedeiro. $\mathrm{O}$ açaí (Euterpe oleracea) é uma palmeira típica da Amazônia de interesse econômico e nutracêutico uma vez que seu principal produto, o fruto, é rico em compostos bioativos com efeitos antioxidantes, anti-inflamatórios e antivirais. O presente estudo objetivou investigar o potencial antiviral do extrato aquoso do fruto de Euterpe oleracea e estipular em que etapa do desenvolvimento da infecção pelo VNO ocorre sua interferência. Para os ensaios, foi utilizado o primeiro isolado do vírus no Brasil e cultivo de células VERO em placa, padronizando-se diferentes concentrações teste do extrato $(0,0,25,0,5,1$ e $2 \mathrm{mg} / \mathrm{mL})$, bem como diferentes etapas de interação na infecção experimental, referente ao contato do composto com o espécime viral (nunca, antes, durante, depois, ao longo de todo o processo de infecção). Houve uma redução média de $55,6 \%( \pm 22,8 \%)$ de halos de destruição celular na concentração de $2 \mathrm{mg} / \mathrm{ml} ; 0,25,0,50$ e $1 \mathrm{mg} / \mathrm{mL}$ reduziram o potencial citolítico do VNO em $20 \% \quad( \pm 37,2 \%), \quad 17,1 \% \quad( \pm 46,1 \%)$ e $24,9 \% \quad( \pm 39,9 \%)$, respectivamente.

Redução notável de 55,7\% $( \pm 16,3 \%)$ após infecção experimental; Decréscimo importante de $48,9 \%( \pm 11,53 \%)$ ao longo do processo. Grupos de contato antes e durante a interação vírus célula apresentaram reduções de 30,3\% $( \pm 15,9 \%)$ e $4,2 \%( \pm 21 \%)$, respectivamente. Estes resultados demonstram um potencial promissor na redução dos efeitos causados pelo desenvolvimento da infecção do VNO.

Introdução: O vírus do Nilo Ocidental (VNO) é um vírus transmitido por artrópodes, sendo chamado arbovírus. É carreado por mosquitos do gênero Culex afetando principalmente aves, sendo o ser humano apenas um hospedeiro acidental (FLORES e WEIBLEN, 2009). A enorme diversidade avifauna do bioma amazônico, o grande fluxo de aves migratórias, principais hospedeiros do agente, e outros importantes aspectos naturais que favorecem o desenvolvimento de vetores competentes para a disseminação do agente, fazem com que o estudo do VNO seja crucial para favorecer a vigilância em saúde, evitando possíveis epidemias e surtos (EXPEDITO et al., 2003). O primeiro isolado do vírus no Brasil ocorreu em 2018, em Pedra Grande, no município de São Mateus, Espírito Santo (MARTINS et al., 2019). Euterpe oleracea, conhecida como açaí ou açaizeiro, é uma palmeira nativa de regiões tropicais. Estudos já demonstraram a atividade antioxidante de alguns dos componentes do fruto do açaí (CEDRIM et al., 2018), como flavonoides, que agem 
diminuindo ou inibindo os efeitos de radicais livres e moléculas oxidantes, reduzindo danos causados ao DNA e outras macromoléculas que podem desencadear doenças e síndromes (SANFELIU, 2001; LIMA et al., 2012). Além disso, foi demonstrada a atividade antiviral de alguns de seus componentes, as antocianinas, através da ligação destas estruturas com as neuraminidases na superfície de vírus Influenza (H1N1), impedindo sua internalização e, portanto, infecção (SWAMINATHAN et al., 2013). Estas moléculas também apresentam propriedades anti-inflamatórias (SHAIK et al., 2018). Tais aspectos mostram potencial do fruto do açaí na área de saúde, podendo-se conferir ao fruto a característica de alimento funcional ou nutracêutico (MORAES e COLLA, 2006).

\section{Objetivo (s)}

Geral

Investigar o potencial antiviral do extrato aquoso do fruto de Euterpe oleracea na infecção pelo VNO.

Específicos

Comprovar a eficiência do extrato na inibição do efeito citopático e citolítico em cultura de células, identificando a concentração inibitória mediana $\left(\mathrm{IC}_{50}\right)$;

Estipular em qual etapa do desenvolvimento da infecção do WNV ocorre a ação inibitiva do composto e dimensionar sua interferência;

Demonstrar a ausência de efeitos nocivos, determinando a concentração citotóxica $\left(\mathrm{CC}_{50}\right)$ do composto natural.

\section{Material e método:}

Foram utilizadas $700 \mathrm{mg}$ de extrato purificado e liofilizado de Euterpe oleracea (Evolution Slimming) diluído em água ultrapura Milli- ${ }^{\circledR}$ em tubo estéril, filtrado em membrana PES de $0,45 \mu \mathrm{m}$, resultando em solução estoque de $100 \mathrm{mg} / \mathrm{mL}$. Foi utilizada a cepa de VNO de registro BeAn854747 (Instituto Evandro Chagas), advindo a partir de uma amostra do município de São Mateus, no Espírito Santo, o primeiro isolado de VNO no Brasil (MARTINS et al., 2019). Usou-se o protocolo geral básico para propagação e manutenção Células VERO (AMMERMAN et al., 2009), adaptado para o uso de meio 199.

Para determinação das concentrações ideais de ensaio de interferência, células VERO foram infectadas em placa de 12 poços de fundo chato. Padronizou-se uma multiplicidade de infecção (MOI) de 0,1, de modo a determinar a quantidade de inóculo viral necessário em cada ensaio. $100 \mu \mathrm{L}$ da amostra viral foi misturada ao extrato aquoso de açaí em diferentes concentrações $(0,0,25,0,5,1$ e $2 \mathrm{mg} / \mathrm{mL})$, em duplicata. Procedeu-se à incubação por uma hora com homogeneização a cada 15 minutos. Terminado o processo, as células foram lavadas com meio puro e mantidas com $1 \mathrm{~mL}$ de meio semissólido (199 2x acrescido de carboximetilcelulose a 3,2\%, numa proporção de 1:1, combinado a 5\% de SBF e 1\% de antibióticos). Após 72 horas, as células foram coradas e fixadas, fazendo-se um comparativo do número de halos de destruição celular (PFU). 
Definiu-se o processo de infecção experimental em três diferentes etapas referentes ao contato com o vírus. A primeira onde as células são incubadas com $250 \mu \mathrm{L}$ de meio puro comum em cada poço por uma hora (antes). Na segunda etapa, cada poço foi submetido ao contato com $100 \mu \mathrm{L}$ de meio contendo clarificado viral por mais uma hora e com homogeneização a cada 15 minutos (durante). E a terceira (depois), onde as células seguem em cultivo com $1 \mathrm{~mL}$ de meio semissólido até a fixação e coloração após 72 horas. Assim, os ensaios foram feitos usando uma placa de 12 poços dividida em 5 diferentes grupos de dois poços (nunca, antes, durante, depois, ao longo de todo o processo de infecção) referente ao contato do extrato sempre à uma concentração final de 2 $\mathrm{mg} / \mathrm{mL}$. Para o comparativo da ação de diferentes concentrações do extrato, também foram conduzidos ensaios utilizando uma placa de 12 poços com células VERO onde o extrato foi misturado ao meio de cultura puro à diferentes concentrações teste $(0,0,25,0,50,1$ e $2 \mathrm{mg} / \mathrm{mL})$, com contato do composto ao longo de todas as etapas de infecção experimental.

Para aferir o nível de integridade celular na presença do extrato de Euterpe oleracea em diferentes concentrações, células VERO em microplacas serão submetidas à adição e homogeneização de reagente CellTiter-Fluor ${ }^{\mathrm{TM}}$ (Promega, Fitchburg,EUA), contendo peptídeo fluorogênico glicilfenilalanilaminofluorocumarina (GF-AFC). Células íntegras preservam proteases que clivam o substrato reagente, liberando produto fluorescente (AFC) leitor multimodo GloMax-Multi + Microplate ${ }^{\circledR}$ (Promega).

Resultados preliminares: Na determinação da concentração ideal a ser usada, obteve-se uma tendência descendente proporcional o aumento da concentração administrada, com uma redução média de 55,6\% (₫22,8\%) no número de placas de destruição ao usar $2 \mathrm{mg} / \mathrm{ml}$ de extrato se comparada à cultura sem o composto. As concentrações de $0,25,0,50$ e $1 \mathrm{mg} / \mathrm{mL}$ tiveram uma redução no potencial citolítico do VNO de $20 \%( \pm 37,2 \%), 17,1 \%( \pm 46,1 \%)$ e $24,9 \%( \pm 39,9 \%)$, respectivamente.

$\mathrm{Na}$ interação do composto em diferentes etapas de infecção do vírus, observou-se uma diminuição do potencial do VNO especialmente após o contato com o vírus, havendo uma redução de $55,7 \%( \pm 16,3 \%)$, também houve decréscimo importante de $48,9 \%( \pm 11,53 \%)$ quando o composto foi administrado ao longo de todo o processo de infecção experimental em relação ao grupo de células sem o composto. Os outros grupos de pré-contato e contato durante a interação vírus

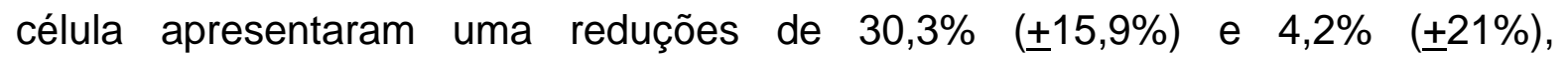
respectivamente.

Conclusão: Ainda que estudos mais aprofundados sejam necessários para determinar sua eficiência, o extrato aquoso do fruto de Euterpe oleracea demonstra um potencial promissor na redução dos efeitos citolíticos causados pela infecção do VNO em cultivo de células VERO. 
Referências bibliográficas

- AMMERMAN NC, BEIER-SEXTON M, AZAD AF. Growth and maintenance of Vero cell lines. Curr Protoc Microbiol. 2008; Appendix 4: Appendix-4E.

- CAMPBElL, G. L., MARFIN, A. A., LANCIOTTI, R. S., \& GUBLER, D. J. (2002). West Nile virus. The Lancet Infectious Diseases, 2(9), 519 -529.

- CEDRIM, P. C. A. S., Barros, E. M. A., \& Nascimento, T. G. Propriedades antioxidantes do açaí (Euterpe oleracea) na síndrome metabólica. Brazilian Journal of Food Technology, 21, e2017092. Epub August 16, 2018.

- HAIL, N., JR.; CARTER, B.Z.; KONOPLEVA, M.; ANDREEFF, M. Apoptosis effector mechanisms: a requiem performed in different keys. Apoptosis 2006, 11, 889-904.

- JACKMAN, R. YADA, R. TUNG, M., SPEERS, R.. (1987). Anthocyanins as food colorants - A review. Journal of Food Biochemistry. 11. $201-247$. 10.1111/j.1745-4514.1987.tb00123.x.

- KRUGER, M. J., DAVIES, N, MYBURGH, K.H. LECOUR, S. Proanthocyanidins, anthocyanins and cardiovascular diseases. Food Research International, Volume 59, 2014. p. 41-52. ISSN 0963-9969.

- LIM, S. M., KORAKA, P., OSTERHAUS, A. D. M. E., \& MARTINA, B. E. E. (2011). West Nile virus: Immunity and pathogenesis. Viruses, 3(6), 811828.

- LANCIOTTI, R. S. et al. (2002). Complete genome sequences and phylogenetic analysis of West Nile virus strains isolated from the United States, Europe, and the Middle East. Virology 298(1): 96-105.

- MARTINS, L. C. et al . First isolation of West Nile virus in Brazil. Mem. Inst. Oswaldo Cruz, Rio de Janeiro , v. 114, e180332, 2019. Epub Jan 17, 2019.

- SWAMINATHAN, K. et al. (2013). Binding of a natural anthocyanin inhibitor to influenza neuraminidase by mass spectrometry. Analytical and bioanalytical chemistry. 405. 10.1007/s00216-013-7068-x.

Palavras-chave: Vírus do Nilo Ocidental, Estratégias antivirais, Açaí (Euterpe oleracea)

Grande-área: Ciências Biológicas

Área: Ciências Biológicas III 


\title{
CORRELAÇÃO DO NOVO PERFIL CITOCÍNICO DE TH22 COM O PADRÃO DE LESÃO HEPATOCÍTARIA NA FEBRE AMARELA
}

\author{
Nome do(a) Bolsista: Caio Cesar Henriques Mendes \\ Nome do(a) Orientador(a): Juarez Antônio Simões Quaresma
}

Resumo: A febre amarela ( $F A$ ) é uma doença febril hemorrágica provocada pelo Vírus da febre amarela (VFA). A doença é endêmica em áreas florestais da África e na América Latina, levando a epizootias em primatas não humanos (PNH) que constituem o reservatório da doença. A resposta imune por Th22 vem sendo descrita em diversas patologias e regula mecanismos inatos para eliminação de microrganismos invasivos que entram em contato células do fígado, intestino e trato respiratório. Com o objetivo de correlacionar as alterações histopatológicas e a resposta imunológica de células Th22 vinte e uma amostras de fígados de indivíduos que evoluíram ao óbito por FA foram analisadas por histopatologia e imunomarcadas por imunoistoquímica (IHQ) paras as citocinas IL-22, IL-13, TNF- $\alpha$ e FGF-b. As lesões foram mais intensas na zona mediozonal (Z2) quando comparada as demais zonas do ácino hepático; o trato porta (TP) apresentou infiltrado inflamatório com intensidade leve a moderada e desproporcional ao observado no parênquima hepático; o perfil Th17 foi caracterizado pela expressão das citocinas IL22, IL-13, FGF-b e TNF- $\alpha$ com predileção pela Z2; a sinergia da IL-22 com o TNF- $\alpha$ atuou diretamente na atividade das células de Kupffer haja vista que elas implicam na formação de uma cascata inflamatória que pode resultar no desenvolvimento dos mecanismos de necrose e de apoptose; o FGF-b e a IL-13 participam ativamente do processo de diferenciação e ativação das células de Kupffer com fenótipo $\mathrm{M}^{2}$ o que ocorre no parênquima hepático dos casos fatais de FA em humanos.

Introdução: A febre amarela (FA) é uma doença febril hemorrágica, causada pelo Virus da febre amarela (VFA) pertencente à família Flaviviridae e ao gênero Flavivirus (ICTV, 2016). A FA possui um papel importante na história da África, Américas e Europa devido às epidemias e a sua alta taxa de letalidade. O VFA possui três ciclos de transmissão: silvestre, urbano e periurbano, sendo este último relatado somente em pequenas regiões da África (VASCONCELOS, 2003). Em 1930, foi criada uma vacina segura, eficaz e barata, porém 130 países notificam casos da doença e destes, 44 países são considerados endêmicos/zoonóticos para FA. Tal cenário torna a FA um problema de saúde pública mundial. No Brasil, a FA tem sido relatada fora da sua área considerada endêmica (região Amazônica) juntamente com o padrão sazonal de ocorrência de casos humanos (MONATH; VASCONCELOS, 2015). Após a inoculação do vírus no hospedeiro, a replicação viral ocorre nos gânglios linfáticos próximos a área de repasto sanguíneo. Em seguida, o vírus é liberado na corrente sanguínea atingindo múltiplos órgãos sendo o fígado o principal órgão afetado induzindo uma lesão hepatocelular caracterizada por necrose eosinofílica, apoptose 
de células hepáticas, macro e micro esteatose. A resposta imune celular é complexa e envolvem células T CD4+ e em menor grau linfócitos T CD8+ ou citotóxicas, bem como células polimorfonucleares, células $\mathrm{S} 100+$, macrófagos CD68+ e células NK CD57+ que são encontradas nas áreas dos ácinos, principalmente na zona mediozonal (Z2) (QUARESMA et al.2005, 2006). Embora o volume dessas células seja limitado quando comparadas com o agravo tecidual intenso, sua atividade parece ser fundamental na caracterização da evolução e resultado da enfermidade (QUARESMA et al., 2007). As células Th22 foram identificadas pela produção de interleucina 22 (IL-22) sem INF-y, IL-4 e IL-17 de células T auxiliares. A IL-22 atua sobre células da superfície de barreiras como pele, células epiteliais e do sistema digestivo, respiratório, hepático, renal, pâncreas, articulações, bem como tipos especiais de fibroblastos (TRIFARI et al., 2009). Em hepatócitos, a ação de IL-22 induz proteínas de fase aguda e a proteção contra danos além de possuir efeitos sobre células progenitoras / tronco hepáticas que permitem a recuperação hepática após grave lesão (FENG, 2014). Dessa forma o presente estudo tem como objetivo correlacionar as alterações histopatológicas e a resposta imunológica de células Th22 no fígado de indivíduos com FA.

Materiais e métodos: O estudo foi aprovado pelo Comitê de Ética em Pesquisa do Instituto Evandro Chagas (IEC), sob o parecer $n^{\circ}$ 2.462.701. Se trata de um estudo retrospectivo analítico onde 21 amostras de fígados de indivíduos que evoluíram ao óbito por FA, pertencentes ao acervo do IEC, foram analisadas por histopatologia e imunomarca por imunoistoquímica (IHQ) para as IL-22, IL-13, TNF- $\alpha$ e FGF-b (QUARESMA et al., 2007).Foram utilizados os testes ANOVA one-way, Turkey e a correlação de Pearson através do programa GraphPad Prism 5.0, onde foi considerado um nível de significância de $5 \%(p \leq 0,05)$.

Resultados e discussão: Os ácinos hepático apresentaram tumefação, macro e micro esteatose, necrose lítica e coagulativa, corpúsculos de Councilman (corpos apoptóticos); as células de Kupffer hiperplásicas e hipertróficas, alterações no endotélio sinusoidal e veia centrolobular e infiltrado inflamatório (linfócitos, plasmócitos e macrófagos) sendo a Z2 a mais afetada pelo VFA (Figura 1). Achados esses que corroboram com outros estudos (Quaresma et al., 2005, 2006). As citocinas IL-22, TNF- $\alpha$, FGF-básico, IL-13 foram expressas em todas as amostras e a expressão foi significante $(p<0,05)$ na Z2 quando comparada as zonas periportal e centro lobular e controle (Figura 2). 

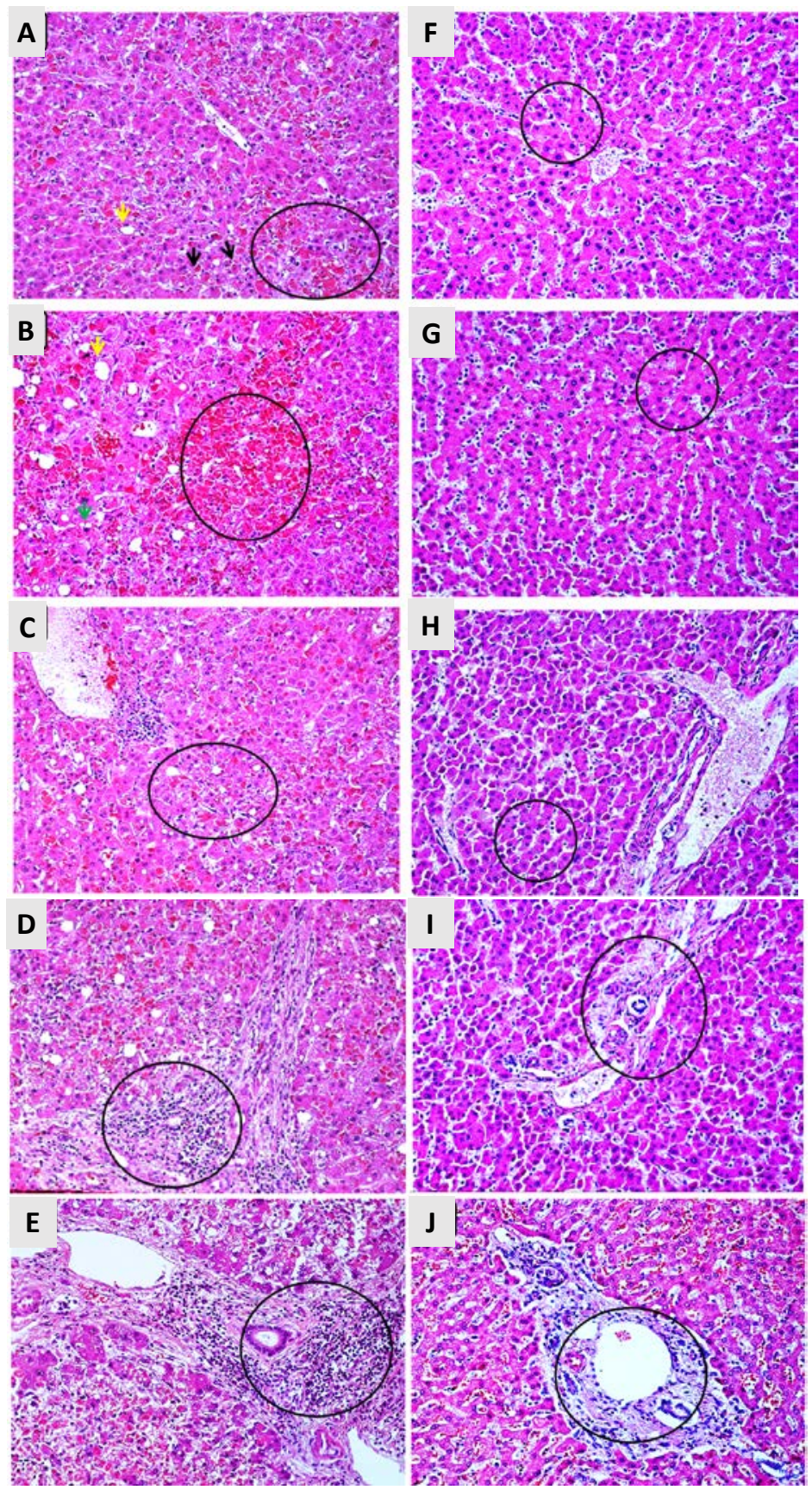

Figura 1: Alterações histopatológicas nas regiões Z1, Z2 e Z3. (A) esteatose (seta amarela), corpúsculos de Councilman (seta preta), necrose hemorrágica (círculo); (B) esteatose macrogoticular (seta amarela), esteatose microgoticular (seta verde), intensa necrose hemorrágica (círculo); (C) leve necrose hemorrágica e esteatose (círculo (D-E) macro e micro esteatose, necrose hemorrágica e intenso infiltrado inflamatório (círculo); F-J controle. 


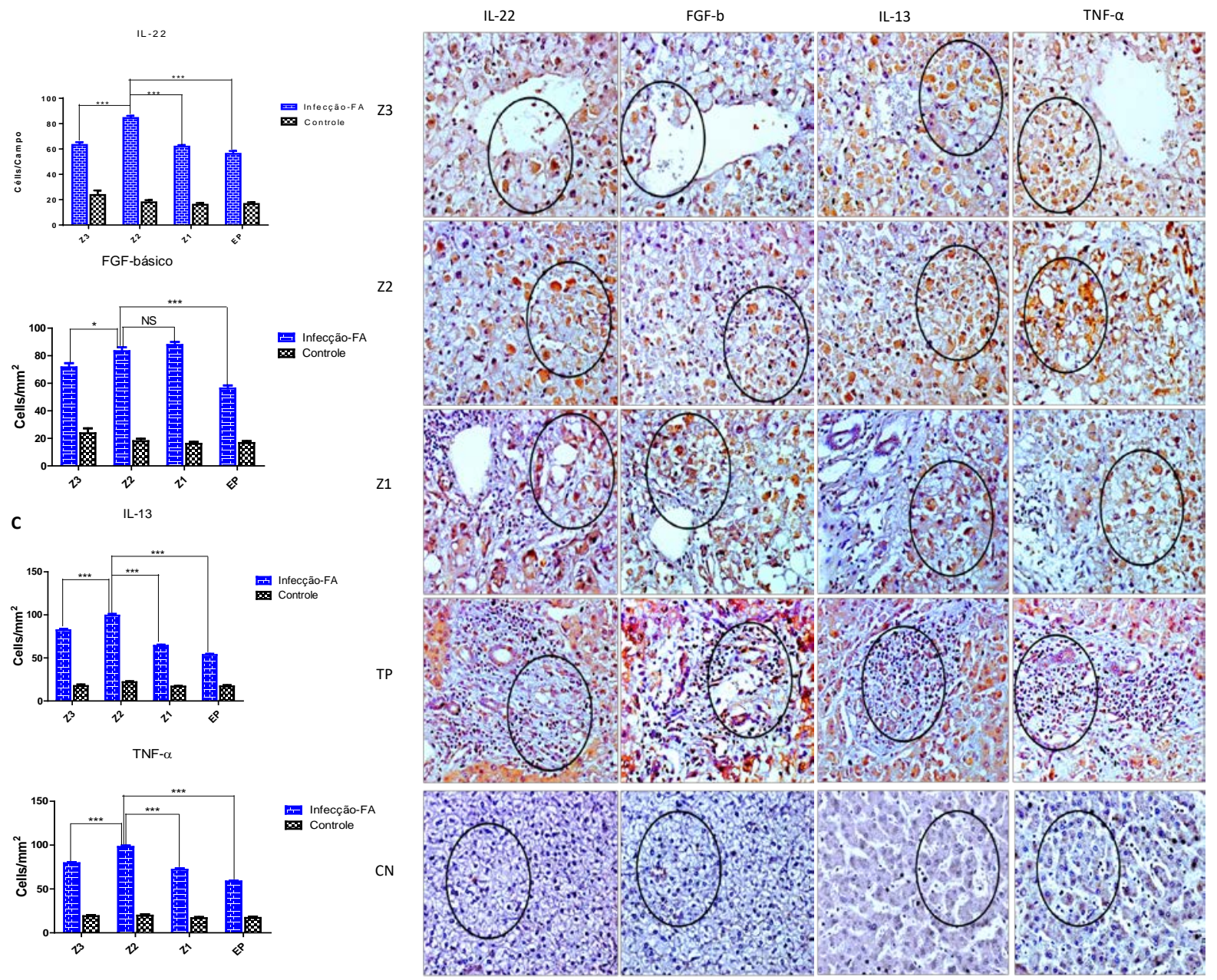

Figura 2: Semi-quantificação e imunomarcação para IL-22, FTF-b, IL-13 e TNF-a na Z1, Z2, Z3 e TP em casos fatais de FA, onde a área demarcada (círculo) demonstra a positividade das citocinas e o infiltrado inflamatório no PT.

IL-22, na tentativa de regeneração do fígado promovendo a proliferação celular ou atuando como antimicrobiano contra patógenos intracelulares (FENG, 2014). O aumento quantitativo da IL-13 pode estar relacionado ao fato de funcionar como a IL-4 induzindo a ativação alternativa de macrófagos, contribuindo para a manutenção e fibrose do tecido (MOHNING, 2019). Já a expressão do FGF-b pode ser explicado em resposta ao fator de crescimento em lesões teciduais, onde tem a capacidade de regular a participação de diferentes funções celulares. Entretanto, o alto grau de TNF- $\alpha$ devido a intensa presença de apoptose (RIBATTI, 2014). As citocinas avaliadas também são expressas na dengue e Zika, e outras doenças hepatotrópicas, reforçando os resultados deste estudo (JEEWANDARA et. al., 2014; YI, et al, 2017). 
Conclusão: Este é um estudo pioneiro de investigação do perfil TH22 em resposta a infecção pelo VFA. Estudos dessa natureza são essenciais para a elucidação da patogênese do vírus. Traçar o perfil imunológico em resposta ao VFA, bem como esclarecer a atuação de novos componentes imunológicos pode vir a contribuir para a elaboração de novas estratégias terapêuticas.

\section{REFERÊNCIAS BIBLIOGRÁFICAS}

INTERNATIONAL COMMITTEE ON TAXONOMY OF VIRUSES (ICTV). Disponível em: $<$ https://talk.ictvonline.org/taxonomy/> acessado em 17/05/2018.

VASCONCELOS, P. F. Febre amarela. Revista da Sociedade Brasileira de Medicina Tropical, v. 36, n. 2, p. 275-293, 2003.

MONATH, T. P.; VASCONCELOS, P. F. C. Yellow fever. Journal of Clinical Virology, v. 64, p. 160-173, 2015.

MOHNING, M. P. et al. Mechanisms of Fibrosis. Elsevier Inc., 2019.

QUARESMA, J. A. S. et al. Reconsideration of histopathology and ultrastructural aspects of the human liver in yellow fever. Acta Tropica, v. 94, n. 2, p. 116-127, 2005.

QUARESMA, J. A. S. et al. Revisiting the liver in human yellow fever: Virus-induced apoptosis in hepatocytes associated with TGF- $\beta$, TNF- $\alpha$ and NK cells activity. Virology, v. 345, n. 1, p. 22-30, 2006b.

QUARESMA, J. A. S. et al. Hepatocyte lesions and cellular immune response in yellow fever infection. Transactions of the Royal Society of Tropical Medicine and Hygiene, v. 101, n. 2, p. 161-168, 2007.

TRIFARI, S. et al. Identification of a human helper $\mathrm{T}$ cell population that has abundant production of interleukin 22 and is distinct from TH-17, TH1 and TH2 cells. Nature Immunology, v. 10, n. 8, p. 864-871, 2009.

RIBATTI, Domenico. The discovery of angiogenic growth factors: the contribution of Italian scientists. Vasc Cell, v. 6, n. 1, p.1-6, abr. 2014.

YI, P. et al. IL-22 signaling contributes to modulate the pathogenesis of Zika virus infection. Journal of Immunology. v. 198, n. 1, 2017.

Palavras-chaves: Febre amarela, citocinas, Th22.

Grande área: Arbovirologia

Área: Imunologia 


\title{
METAGENÔMICA VIRAL DE INSETOS HEMATÓFAGOS COLETADOS NO COMPLEXO MINERADOR DE CARAJÁS, ESTADO DO PARÁ
}

\author{
Nome do(a) Bolsista: Camila Margalho Braga \\ Nome do(a) Orientador: Lívia Carício Martins \\ Coorientador: Sandro Patroca da Silva
}

Resumo: A região amazônica apresenta fatores ambientais favoráveis para a existência e manutenção dos vírus transmitidos por insetos hematófagos e algumas ações antrópicas contribuem principalmente para a dispersão dos vetores que são os reservatórios e transmissores desses vírus. O objetivo do presente trabalho é determinar a ocorrência de vírus (DNA e RNA) circulantes na área de influência do Complexo minerador de Carajás em amostras de insetos hematófagos coletados nos anos de 2018 e 2019. As amostras coletadas serão submetidos a extração do RNA viral, cDNA fita dupla e sequenciamento com a tecnologia Illumina HiSeq. A montagem De Novo das sequências virais será realizada com os montadores Spades e IDBA-UD. O pipeline Metavic foi adaptado para esse estudo e utiliza os programas TRim Galore, Prinseq, CD-HIT, SortMeRNA, Diamond, Megan e filter fastq. Para a filogenia, serão usados os programas JModelTest, RaXML e a curadoria será realizada com o Geneious e Megan.

Introdução: Os insetos hematófagos estão inseridos na classe insecta do filo Arthropoda (do grego arthros: articulado e podos: pés, patas), o filo mais abundante existente correspondente a aproximadamente $80 \%$ de toda a diversidade animal. Nesse filo, encontra-se a classe Insecta, e a ordem Diptera. Essa ordem engloba várias subordens, incluindo a Nematocera, que contém insetos hematófagos, os quais estão distribuídos nas famílias Ceratopogonidae, Culicidae, Psychodidae e Simuliidae. Estima-se que existam 200 milhões de insetos para cada ser humano na terra. Dentre as famílias da subordem Nematocera, a de maior relevância para a saúde pública, em razão do elevado número de espécies e por serem vetores de várias doenças, é a família Culicidae, uma das mais primitivas famílias da ordem Diptera, conhecidos também como pernilongos, muriçocas ou carapanãs, na qual se reconhecem mais de 3.500 espécies e subespécies distribuídas por todo o mundo, exceto Antártida. Os membros dessa família são vetores de doenças virais como dengue, zika e Chikungunya (MARCONDES, 2009; FRANSOZO; FRANSOZO, 2017 NÚNCIO; ALVES, 2014; CONSOLI; OLIVEIRA, 1994 O surgimento, a reemergência, o controle e até a erradicação de doenças estão ligados a fatores como o relacionamento da população humana com a natureza (fonte de agentes infecciosos), a estrutura dos serviços de saúde e as condições de vida das pessoas, determinam o nível de exposição a organismos patogênicos. A natureza, com todos os seus elementos animais, vegetais e minerais, funciona de maneira harmônica, e 
tal equilíbrio é responsável por um mundo saudável, em que o fenômeno da doença é minimizado. Quando, pelos mais diferentes motivos, o equilíbrio natural é interrompido, seja por destruição ambiental ou invasão de ambientes isolados, aumenta a possibilidade da ocorrência de doenças (LOPES et al., 2015).

A Região Amazônica apresenta fatores favoráveis para a existência e manutenção dos arbovírus, seja pela diversidade de espécies dípteros hematófagos e vertebrados silvestres, ou ainda por apresentar condições ambientais que permitem a manutenção do ciclo de transmissão desses vírus. Em especial, as áreas que integram a região de Carajás apresentam um ecossistema rico em arbovírus, contudo vem passando por processos de transformações ambientais, onde estudos ecoepidemiológicos são necessários para entender a magnitude dos impactos na fauna local e na população, bem como o risco de dispersão dos vírus presentes nessas áreas. Muitos vírus novos para o mundo já foram descobertos na Amazônia, e certamente muitos ainda estão por ser descritos. Assim a utilização da ferramenta da metagenômica é ideal para a investigação desses novos agentes virais, em que a partir do sequenciamento de nova geração há a possibilidade de identificação de vírus não caracterizados fornecendo dados genômicos virais mais precisos e completos o que é particularmente favorável para a ecologia, diversidade e evolução viral. Nesse âmbito, a utilização de novas técnicas de detecção viral nas amostras, como a metagenômica viral, otimizam o processo e aumentam a sensibilidade nos resultados (MOKILI, 2012).

Objetivo: Esse trabalho tem como objetivo determinar a ocorrência de vírus (DNA e RNA) circulantes na área de influência do Complexo minerador de Carajás em amostras de insetos hematófagos coletados nos anos de 2018 a 2020.

Material e Métodos: $O$ estudo será realizado na região mineradora de Carajás/PA, onde diversos projetos de mineração estão instalados em diferentes municípios que compõe essa região. Os municípios de coleta serão os seguintes: Floresta Nacional do Tapirapé-Aquiri (Marabá-PA), Serra Sul (Canaã dos Carajás) e Serra Leste (Curionópolis). A coleta será realizada em áreas de mata e áreas urbanas da região. As capturas dos insetos hematófagos serão realizadas em duas expedições a campo por ano nos meses de Abril e Novembro. Os procedimentos básicos para a captura dos vetores serão: captura noturna usando armadilhas luminosas, tipo CDC, (18:00-06 h). Na captura diurna foi usada a atração humana protegida e esclarecida.

Neste procedimento os mosquitos são atraídos pelo odor humano e quando se aproximam são capturados com um puçá e coletados com aparelho de sucção oral. Uma vez capturados, os artrópodes serão colocados em criotubos etiquetados com as informações adequadas e colocados em botijão contendo nitrogênio líquido, sendo transportados até o IEC em Ananindeua e serão identificados sob mesa fria $\left(-20^{\circ} \mathrm{C}\right)$ com o uso de microscópios entomológicos e 
chaves de identificação, agrupados em lotes de acordo com data, local de captura, e espécie. Os critérios de inclusão para esse estudo são: espécies de Culicidae (Aedes aegypti, Aedes albopictus, Haemagogus janthinomys, Haemagogus leucocelaenus, Sabethes glaucodaemon, Sabethes chloropterus, Culex melaconion e Culex quinquefasciatus), Ceratopogonidae e Psychodidae.

Para os procedimentos laboratoriais os artrópodes serão colocadas individualmente em microtubos para serem maceradas juntamente com o tampão de homogeneização do kit de extração e uma esfera metálica no equipamento TissueLyser II (QIAGEN) com uma frequência de $30 \mathrm{hz}$ por 2 minutos. A extração do RNA total será realizada utilizando o kit Maxwell ${ }^{\circledR} 16$ Tissue LEV simplyRNA Tissue Kit, com o sistema de extração automatizado Maxwell 16 (PROMEGA) seguindo a recomendação do fabricante para preparo. As amostras de DNA serão extraídas utilizando 0 kit DNeasy Blood and tissue. As amostras serão quantificadas através do Qubit ${ }^{\circ} 2.0$ Fluorometer (Life Technologies) seguindo o protocolo do fabricante. A qualidade do material genético foi avaliada pelo 2100 Bioanalyzer usando o kit pico 6000 RNA (Agilent Technologies, ADS Agilent, Santa Rosa, CA, EUA). A síntese do cDNA foi realizada utilizando o kit cDNA Synthesis System (Roche Diagnostics) conforme orientação do fabricante. A purificação foi realizada por esferasmagnéticas AMPure bead.

Para o preparo da biblioteca de cDNA será utilizado o kit de preparação NEXTERA XT DNA sample preparation e sequenciada na plataforma Miniseq de acordo com as remomendações do fabricante (Illumina, INC). $O$ kit de sequenciamento utilizado será o Miniseq high output reagent kit (300 ciclos).

Os gráficos serão desenvolvidos através de scripts em linguagem de programação $\mathrm{R}$ no sistema operacional Ubuntu/linux. A edição/manipulação das imagens será realizada com o programa gráfico Inkscape. Na etapa de Pré-processamento (limpeza) das leituras ocorre a remoção de organismos conhecidos de nivel superior e leituras bacterianas, o pipeline foi adaptado de METAVIC (SEJMODHA, 2016) . O material extraído não será tratado para depleção do RNA ribossômico (rRNA), por este motivo fez-se necessário realizar a remoção das leituras de rRNA nessa etapa com o SortMeRNA (KOPYLOVA; NOÉ; TOUZET, 2012). Os arquivos Fastq_clean, obtidos na etapa de pré-processamento das amostras, serão usados para realizar a montagem de novo com um script que utiliza os montadores SPAdes (BANKEVICH et al., 2012) e IDBA-UD (PENG et al., 2012). Os contigs gerados pela montagem e que apresentaram alguma identidade com grupos virais já conhecidos serão analisados e curados utilizando o programa Geneious e serão analisados utilizando

a ferramenta online blast disponível no site do NCBI. Para a análise filogenética serão utilizados os programas JmodelTest (DARRIBA et al., 2012), RaxML (STAMATAKIS, 2014) e visualização das árvores filogenéticas com o MEGAN. 


\section{Resultados}

Tabela 01: Amostras coletadas na expedição de Novembro de 2018

\begin{tabular}{|c|c|c|c|c|}
\hline AR & Local de Coleta & Espécie & $\begin{array}{l}\text { Modalidade } \\
\text { de captura }\end{array}$ & $\begin{array}{l}\text { Período } \\
\text { e captura }\end{array}$ \\
\hline 860264 & \begin{tabular}{|ll} 
Marabá & (Igarap \\
do & é \\
Mano) &
\end{tabular} & $\begin{array}{ll}\text { Hg. } & \text { (Hag.) } \\
\text { janthinomy } & \\
\text { s } & \end{array}$ & $\begin{array}{l}\text { Atração } \\
\text { humana- } \\
\text { COPA }\end{array}$ & $\begin{array}{l}29 / 11 \quad \mathrm{e} \\
01,04,05,06 / 12 / 20 \\
18\end{array}$ \\
\hline 820266 & \begin{tabular}{|ll} 
Marabá & (Igarap \\
do & é \\
Mano) &
\end{tabular} & $\begin{array}{l}\text { Sa. (Sbo.) } \\
\text { chloropteru } \\
\text { s }\end{array}$ & $\begin{array}{l}\text { Atração } \\
\text { humana- } \\
\text { COPA }\end{array}$ & $\begin{array}{l}29 / 11 \quad e \\
01,04,05,06 / 12 / 20 \\
18\end{array}$ \\
\hline 860270 & $\begin{array}{ll}\text { Marabá } & \text { (Igarap } \\
\text { do } & \text { é } \\
\text { Mano) } & \\
\end{array}$ & Cx. (Cux.) species & CDC SOLO & \begin{tabular}{|l}
$30 / 11$ \\
$01,04,05,06 / 12 / 20$ \\
18
\end{tabular} \\
\hline 860275 & $\begin{array}{ll}\text { Marabá } & \text { (Igarap } \\
\text { do } & \text { é } \\
\text { Mano) } & \\
\end{array}$ & Ceratopogonidae & CDC SOLO & $30 / 11$ \\
\hline 860279 & $\begin{array}{ll}\text { Marabá } & \text { (Igarap } \\
\text { do } & \text { é } \\
\text { Mano) } & \\
\end{array}$ & Flebotominae & CDC SOLO & \begin{tabular}{|l}
$30 / 11$ \\
$01,04,05,06 / 12 / 20$ \\
18
\end{tabular} \\
\hline 860161 & $\begin{array}{lr}\text { Canaã } & \text { dos } \\
\text { Carajás } & \text { (Faz. } \\
\text { Cajarana) } & \\
\end{array}$ & \begin{tabular}{|ll} 
Hg. & (Hag.) \\
janthinom & \\
ys &
\end{tabular} & \begin{tabular}{|l} 
Atração \\
a COPA Human
\end{tabular} & $\begin{array}{l}08,09,10,12,13,14 \\
15, \\
16 / 11 / 2018\end{array}$ \\
\hline 860164 & $\begin{array}{lr}\text { Canaã } & \text { dos } \\
\text { Carajás } & \text { (Faz. } \\
\text { Cajarana) } & \\
\end{array}$ & $\begin{array}{ll}\text { Sa. } & \text { (Sbo.) } \\
\text { chloropter } \\
\text { us }\end{array}$ & $\begin{array}{l}\text { Atração } \\
\text { a COPA Human }\end{array}$ & $\begin{array}{l}09,13,15,16 / 11 / 20 \\
18\end{array}$ \\
\hline 860196 & $\begin{array}{lr}\text { Canaã } & \text { dos } \\
\text { Carajás } & \text { (Faz. } \\
\text { Cajarana) } & \\
\end{array}$ & Cx. (Mel.) species & CDC SOLO & $\begin{array}{l}07,09,10,13,14,15 / \\
11 / \\
2018\end{array}$ \\
\hline 860204 & $\begin{array}{lr}\text { Canaã } & \text { dos } \\
\text { Carajás } & \text { (Faz. } \\
\text { Cajarana) } & \\
\end{array}$ & Flebotominae & CDC SOLO & $15 / 11 / 2018$ \\
\hline 860213 & $\begin{array}{|lr|}\text { Canaã } & \text { dos } \\
\text { Carajás } & \text { (Faz. } \\
\text { Cajarana) } & \\
\end{array}$ & Ceratopogonidae & CDC COPA & $08 / 11 / 2018$ \\
\hline 860227 & \begin{tabular}{l}
\multicolumn{2}{|c|}{ Curionópolis } \\
a Leste)
\end{tabular} & $\begin{array}{ll}\mathrm{Hg} . & \text { (Hag.) } \\
\text { janthinom } & \\
y s & \end{array}$ & $\begin{array}{l}\text { Atração } \\
\text { a COPA Human }\end{array}$ & $19 / 11 / 2018$ \\
\hline 860228 & $\begin{array}{r}\text { Curionópolis } \\
\text { (Serr }\end{array}$ & \begin{tabular}{|ll} 
Hg. & (Hag.) \\
janthinom &
\end{tabular} & \begin{tabular}{|l} 
Atração \\
\\
\\
Human
\end{tabular} & $\begin{array}{l}20,23,26,27 / 11 / 20 \\
18\end{array}$ \\
\hline
\end{tabular}




\begin{tabular}{|c|c|c|c|c|}
\hline & a Leste) & ys & a COPA & \\
\hline 860231 & $\begin{array}{l}\text { Curionópolis } \\
\quad \text { (Serr } \\
\text { a Leste) }\end{array}$ & \begin{tabular}{|ll} 
Sa. & (Sbo.) \\
chloropter & \\
us &
\end{tabular} & $\begin{array}{l}\text { Atração } \\
\text { a COPA Human }\end{array}$ & $\begin{array}{l}19,23,26,27 / 11 / 20 \\
18\end{array}$ \\
\hline 860235 & $\begin{array}{l}\text { Curionópolis } \\
\text { (Serr } \\
\text { a Leste) }\end{array}$ & Cx. (Cux.) species & CDC SOLO & $24 / 11 / 2018$ \\
\hline 860236 & $\begin{array}{l}\text { Curionópolis } \\
\text { a Leste) }\end{array}$ & Cx. (Cux.) species & CDC SOLO & $\begin{array}{l}20,22,23,27,28 / 11 / \\
201 \\
8\end{array}$ \\
\hline 860243 & $\begin{array}{l}\text { Curionópolis } \\
\text { (Serr } \\
\text { a Leste) }\end{array}$ & Ceratopogonidae & CDC SOLO & $\begin{array}{l}20,22,24,27,28 / 11 / \\
201 \\
8\end{array}$ \\
\hline 860244 & $\begin{array}{l}\text { Curionópolis } \\
\text { a Leste) }\end{array}$ & Flebotominae & CDC SOLO & $\begin{array}{l}20,22,23,24,27,28 / \\
11 / \\
2018\end{array}$ \\
\hline 860251 & $\begin{array}{l}\text { Curionópolis } \\
\text { a (Serr }\end{array}$ & Ceratopogonidae & CDC COPA & \begin{tabular}{|l|}
$20,22,23,24,27,28 /$ \\
$11 /$
\end{tabular} \\
\hline
\end{tabular}

\begin{tabular}{|l|l|l|l|l|}
\hline & Leste) & & & 2018 \\
\hline 860252 & Curionópolis & Flebotominae & CDC COPA & $20,22,23,24,27,28 /$ \\
& & & $11 /$ \\
& a Leste) & & & 2018 \\
\hline
\end{tabular}

O material coletado na expedição de Março a Abril de 2019 está sendo identificado taxonomicamente e no mês de Novembro está ocorrendo a segunda expedição para coleta de campo, com início dia 21 de Outubro à 23 de Novembro de 2019.

\section{Referências Bibliográficas:}

BANKEVICH, A. et al. Spades: a new genome assembly algorithm and its applications to single-cell sequencing. Journal of computational biology, Mary Ann Liebert n. 5, p. 455- 477, 2012

CONSOLI, R. A.; OLIVEIRA, R. L. de. Principais mosquitos de importância sanitária no Brasil. [S.I.]: SciELO-Editora FIOCRUZ, 1994.

DARRIBA, D. et al. jmodeltest 2: more models, new heuristics and parallel computing. Nature methods, Nature Research, v. 9, n. 8, p. 772-772, 2012.

FRANSOZO, A.; FRANSOZO, M. L. N. Zoologia dos Invertebrados. [S.I.]: GEN Roca, 2017. 
KOPYLOVA, E.; NOÉ, L.; TOUZET, H. Sortmerna: fast and accurate filtering of ribosomal rnas in metatranscriptomic data. Bioinformatics, Oxford University Press, v. 28, n. 24, p. 3211-3217, 2012.

LOPES, N.; NOZAWA, C.; LINHARES, R. E. C. Características gerais e epidemiologia dos arbovírus emergentes no brasil. Revista Pan-Amazônica de Saúde, Instituto Evandro Chagas/Secretaria de Vigilância em Saúde/Ministério da Saúde, v. 5, n. 3, p. 55-64, 2014.

MARCONDES, C. B. Doenças transmitidas e causadas por artrópodes. In: Doenças transmitidas e causadas por artropodes, 2009.

MOKILI, J. L.; ROHWER, F.; DUTILH, B. E. Metagenomics and future perspectives in virus discovery. Current opinion in virology, Elsevier, v. 2, n. 1, p. 63-77, 2012.

NÚNCIO, M. S.; ALVES, M. J. Doenças associadas a artrópodes vetores e oedores. [S.I.]: Instituto Nacional de Saúde Doutor Ricardo Jorge, 2014.

PENG, Y. et al. Idba-ud: a de novo assembler for single-cell and metagenomic sequencing data with highly uneven depth. Bioinformatics, Oxford University Press, v. 28, n. 11, p. 1420-1428, 2012.

SEJMODHA. GitHub - sejmodha/MetaViC: Virus metagenomics pipeline for unknown host or in absence of a host genome.

STAMATAKIS, A. Raxml version 8: a tool for phylogenetic analysis and postanalysis of large phylogenies. Bioinformatics, Oxford University Press, v. 30, n. 9, p. 1312-1313, 2014.

Palavras-Chave: Vírus, Metagenômica, insetos

Grande Área: Ciências Biológicas

Área: Virologia 


\title{
INVESTIGAÇÃO DA INFECÇÃO POR EPSTEIN BARR VÍRUS (EBV) EM PACIENTES PORTADORES DE LEUCEMIA LINFOCÍTICA CRÔNICA (LLC)
}

\author{
Nome do(a) Bolsista: Camile Irene Mota da Silva \\ Nome do(a) Orientadora: Patrícia Danielle Lima de Lima
}

Introdução: A leucemia linfocítica crônica (LLC) é uma doença linfoproliferativa clonal de apresentação heterogênea, variando desde o achado fortuito de linfocitose isolada no sangue periférico, até quadros com grandes massas tumorais, e sinais de insuficiência medular grave. A LLC está ainda associada a distúrbios do sistema imunológico que se manifestam na forma de fenômenos autoimunes e deficiência imune. Contudo, esses distúrbios do sistema imunológico podem aumentar a suscetibilidade de infecções oportunistas ou reativar patógenos latentes. As infecções que ocorrem são em sua maioria de origem viral. Entretanto, infecções por Epstein-Barr vírus (EBV) são desenvolvidas como resultado de reativação viral. O EBV, designado formalmente como Gamaherpesvírus humano 4 (ICTV, 2018), é um agente amplamente disseminado em populações humanas. Após a infecção primária o vírus estabelece latência e persiste ao longo da vida do hospedeiro em linfócitos B. Em indivíduos saudáveis, o número de células B infectadas é controlado pelas respostas imunes do hospedeiro, no entanto, indivíduos imunocomprometidos que apresentam deficiência no número e função de células $T$, pode dificultar a detecção e destruição de células B infectadas com EBV. Assim, o vírus pode desempenhar um papel importante na indução de efeitos de proliferação e possivelmente na progressão da doença em pacientes com LLC (GRYWALSKA et al, 2015).O envolvimento potencial do EBV no curso clínico da LLC ainda é inexplicável. Como o EBV pode ativar as células B, estimular sua proliferação e inibir sua apoptose, supõe que o vírus possa contribuir para um curso clínico desfavorável da LLC e pode ser uma das razões para a heterogeneidade da doença observada. Portanto, a detecção da infecção do EBV é de extrema importância para o prognóstico, que poderia aumentar significativamente a sobrevida do indivíduo acometido.

Objetivo: O objetivo geral: Diagnosticar a infecção pelo EBV em pacientes portadores de LLC. Objetivos específicos: Determinar a taxa de infecção pelo EBV em pacientes portadores de LLC diagnosticados no HOL; Quantificar a carga viral (avaliação quantitativa do DNA viral) do EBV em pacientes portadores de LLC; Avaliar a associação da infecção pelo EBV com fatores epidemiológicos e sorológicos dos pacientes portadores de LLC; Correlacionar a infecção pelo EBV com variáveis citogenéticas dos portadores de LCC. 
Material e Método: Trata-se de um estudo transversal e será realizado no Hospital Ophir Loyola (HOL), centro de referência no tratamento da doença no Estado do Pará. Serão incluídas amostras de 100 pacientes diagnosticados com LCC, de acordo com os critérios adotados no Laboratório de Biologia Molecular deste Hospital. Serão utilizadas, de cada paciente, amostras de sangue total coletadas em tubos contendo EDTA K2 como anticoagulante. Após a coleta, todas as amostras serão submetidas à centrifugação por $10 \mathrm{~min}$, a $1.400 \mathrm{~g}$ (3.000 rpm) para a separação do plasma e porção celular (buffy coat). Posteriormente, as amostras serão armazenadas a $-70^{\circ} \mathrm{C}$ até o momento do uso. Para a extração de DNA das frações sangue total, será utilizado o kit QIAamp DNA Mini (QIAGEN), de acordo com o protocolo recomendado pelo fabricante. O método consiste em três principais etapas: Lise, lavagem e eluição e baseia-se na capacidade que a sílica tem de formar ligação com o DNA viral em meios com alta concentração de sal combinada à centrifugação em alta velocidade (8.000 a $14.000 \mathrm{rpm})$. Ao final desse processo, 0 DNA extraído foi armazenado a $-20^{\circ} \mathrm{C}$ até o momento do teste de detecção e quantificação. $O$ teste de deteç̧ão qualitativa e quantitativa de EBV será realizado a partir do DNA extraído do plasma, utilizando a metodologia de reação em cadeia da polimerase (PCR), por meio do kit comercial Ludwig Biotec, de acordo com o protocolo do fabricante. Todas as reações serão executadas no equipamento 7500 Real-Time PCR System, da Applied Biosystems e as análises de amplificação serão feitas no software do equipamento. Este estudo foi aprovado pelo Comitê de Ética em Pesquisa com Seres Humanos da Universidade do Estado do Pará, parecer $n^{\circ}$ 3.497.245/ CAAE: 15025519.4.1001.5174 e todos os pacientes/participantes serão informados de sua participação neste projeto de pesquisa mediante assinatura do Termo de Consentimento Livre e Esclarecido tendo todos seus direitos de privacidade observados. Para a organização e análise dos dados o teste de Quiquadrado será utilizado para testar associação de variáveis categóricas com os desfechos de positividade para os vírus estudados e seus marcadores. O teste será conduzido com o auxílio do pacote estatístico BioEstat v5.043. A significância estatística será definida quando o valor de p apresentar-se inferior a 0,05.

Resultados esperados: Espera-se que a avaliação da associação de infeção pelos vírus EBV e HTLV possa fornecer informações que auxilie no tratamento e conduta clínica diferenciada para pacientes portadores de LLC, visando melhor prognóstico para estes pacientes.

\section{Referências bibliográficas}

ALI, A.S.; AL-SHRAIM, M.; AL-HAKAMI, A.M.; JONES, I.M. Epstein- Barr Virus: Clinical and Epidemiological Revisits and Genetic Basis of Oncogenesis. Open Virol J. 9: 7-28, 2015. 
GENG, L.; WANG, X. Epstein-Barr Virus-associated lymphoproliferative disorders: experimental and clinical developments. Int. J. Clin. Exp. Med., v. 8, n. 9, p. 1465614671, 2015.

GRYWALSKA, E.; ROLIŃSKI, J.; PASIARSKI, M.; KORONA-GLOWNIAK, I. et al., High Viral Loadsof Epstein-BarrVirus DNA in Peripheral Blood of Patients with Chronic Lymphocytic Leukemia Associated with Un favorable Prognosis. PLoSONE10 (10): e0140178, 2015.

ICTV - International Committee on Taxonomy of Viruses. Virus taxonomy list 2018. Disponível em: <http://www.ictvonline.org>.

KIMURA, H.; COHEN, J.I. Doença Viral Doença De Epstein-Barr Crônica. Frente Immunol.; 8: 1867, 2017.

KIPPS, T.J.; STEVENSON, F.K.; WU, C.J.; CROCE C.M.; PACKHAM, G.; WIERDA, W.G.; O'BRIEN, S.; GRIBBEN, J.; RAI, K. Chronic lymphocytic leukaemia. Nat Rev Dis Primers 19 (3): 2017.

RAI, K.R.; JAIN, P. Chronic lymphocytic leukemia (CLL)-Then and now. Am J Hematol, 2016.

SCARFÒ, L.; FERRERI, A.J.M.; GHIA, P. Chronic lymphocytic leukaemia. Critical Reviews in Oncology/Hematology, 104: 169-182, 2016.

SOARES ALMEIDA, A.L.; CAMPOS DE AZEVEDO, I.S.; REGO, P.C.D.P.; FORTES, V.A.; PEREIRA, S.V.E.; FERREIRA JR, M.A. Aspectos clínicos e epidemiológicos da leucemia. Rev Cubano Hematol Immunol Hemoter, 33 (2): 114, 2017.

Palavras-chave: EBV, leucemia, infecção.

Grande-àrea: Ciências Biológicas

Área: Ciências Biológicas III 


\section{ESTUDO DA RESPOSTA DE ANTICORPOS PARA FLAVIVIRUS NA POPULAÇÃO BRASILEIRA FRENTE À EMERGÊNCIA DO VZIK NO PAÍS.}

Nome do(a) Bolsita: Carla Pinheiro da Silva

Nome do(a) Orientador(a): Lívia Caricio Martins;

Co orientadora: Daniele Freitas Henriques

Introdução: Os arbovírus circulantes no Brasil constitui um grande desafio não só para o diagnóstico laboratorial, como também para a vigilância, em suas ações de identificação de casos suspeitos. Neste estudo estão em destaque o Vírus Dengue (VDEN), o Vírus da Febre Amarela (VFA), e o Vírus Zika (VZIK), pertencentes à família Flaviviridae, gênero Flavivirus. A circulação simultânea de diferentes flavivírus no país tem dificultado a interpretação dos resultados sorológicos para este gênero, elevada taxa de anticorpos com reatividade cruzada tem sido observada e essa situação agravou com a emergência do VZIK no país. OBJETIVO: Avaliar a resposta sorológica de anticorpos contra flavivírus na população brasileira frente a emergência do VZIK no País. METODOLOGIA PROPOSTA: Submetido e aprovado pelo comitê de ética em pesquisas com seres humanos (CEP). $O$ painel de amostras foi baseada nos resultados do teste padrão ouro para diagnóstico, RT- qPCR e/ou o teste sorológico considerado o mais específico, o PRNT, ambos realizados pela SAARB/IEC. Os métodos realizados para detecção de anticorpos: a) Teste de Neutralização por Redução de Placas (PRNT); b) Ensaio Imunoenzimático para Captura de Anticorpos IgM (ELISA IgM); c) KIT Comercial ELISA IgM. RESULTADOS ESPERADOS: É esperado determinar possívies variáveis na resposta imonólogica em uma população como a do Brasil, exposta a mais de dez flavivírus; Atestar especifividade e sensibilidade esperada para técnicas sorologicas semi-quantitiva ELISA IgM "in house" e PRNT para os VDEN, VFA e VZIK; Atestar se os Kits comerciais ELISA IgM VDEN, VFA e VZIK disponíveis no mercado garentem a alta sensibilidade e especificidade descritas, frente a um painel de amostras de soros humanos bem caracterizado com uma população exposta e diversos flavivírus; Apresentação da situação atual dos Kits ELISA IgM para VDEN, VFA e VZIK utilizados pela rede pública e privada do Brasil; Orientar a CGLAB/MS para utilização dos Kits ELISA IgM para VDEN, VFA e VZIK, avaliados que apresentarem resultados satisfatórios 
Introdução: O Vírus Dengue (VDEN), o Vírus da Febre Amarela (VFA), e o Vírus Zika (VZIK), são arbovírus pertencentes à família Flaviviridae, gênero Flavivirus (GUBLER et al., 2002, CAMPOS et al., 2015) A circulação simultânea de flavivírus no Brasil constitui um grande desafio não só para o diagnóstico laboratorial, como também para a vigilância, em suas ações de identificação de casos suspeitos, e no desencadeamento das ações de prevenção e controle (MUSSO et al., 2016a, CAMARA, 2016).

Para diagnostico das infecções virais, é usada frequentemente métodos sorológicos, pois é considerado útil para determinar o estado imunológico do paciente, e se dá por meio da pesquisa de anticorpos específicos contra um determinado vírus. (SANTOS et al 2008; KIKUTI et al. 2018; ESTRELA et al 2017)

A circulação simultânea de diferentes flavivírus no Brasil tem dificultado a interpretação dos resultados sorológicos para este gênero (FALCÃO et al., 2016), elevada taxa de anticorpos com reatividade cruzada tem sido observada e essa situação agravou com a emergência do VZIK no país, tornou-se difícil distinguir sorologicamente infecção por VDEN de infecção por VZIK. (DEJNIRATTISAI et al., 2016; BHAT et al., 2013).

Com mais de dez diferentes flavivírus isolados no Brasil e com a emergência do VZIKA, se faz necessário o entendimento da resposta sorológica de anticorpos na população do Brasil, bem como, validar o desempenho das técnicas sorológicas ELISA IgM e PRNT em uma população previamente infectada por algum flavivírus, dessa forma, podendo sugerir padrões que colaborem na distinção entre os vírus em estudo.

\section{Objetivo geral}

Avaliar a resposta sorológica de anticorpos contra flavivírus na população brasileira frente a emergência do VZIK no País.

\section{Objetivo específico}

- Avaliar o desempenho das técnicas sorológicas ELISA IgM e PRNT90 frente ao painel de amostras de soros humanos previamente selecionado;

- Analisar as taxas de anticorpos com reações monotípicas e reações cruzadas obtidas nos resultados sorológicos deste estudo;

- Avaliar a efetividade da utilização do PRNT90 como diagnóstico conclusivo para flavivírus;

- Relacionar o tempo de coleta das amostras de soros com a identificação dos agravos pelas técnicas sorológicas em estudos;

- Avaliar sensibilidade e especificidade dos kits comerciais para ELISA IgM recomendados pela CGLAB entre outros;

- Comparar o desempenho da técnica ELISA IgM "in house" com alguns Kits comerciais disponibilizados no mercado. 
Metodologia proposta: Aspectos éticos.

Este estudo foi submetido ao comitê de ética em pesquisas com seres humanos (CEP) do Instituto Evandro Chagas (IEC), sendo registrado na plataforma Brasil e seguindo todas as orientações da resulução $N^{0}$ 466/2012, do Conselho Nacional de Saúde e Aprovado com o numero do parecer : 3.189.489

Plano de amostragem: $O$ painel de amostras de soros humano sabidamente positivo e negativos para o VDEN, VFA e VZIK será obtido em uma fase : seleção das amostras retrospectiva.Serão selecionados amostras de soros sabidamente positivas e negativas para VDEN, VFA e VZIK provenientes de diversos estados do Brasil, recebidas no IEC até o ano de 2018. Essa seleção será baseada nos resultados RT $q \mathrm{PCR}$ das amostas coletadas para estudos virologicos ( $1^{\mathrm{a}}$ amostra) e que tenham amostras coletadas para estudos sorologicos ( $2^{\mathrm{a}}$ amostras).As amostras selecionadas serão divididas em dois grupos: amostras coletadas antes da entrada do VZIK no Brasil, antes de 2014, e amostras coletadas após a entrada do VZIK no Brasil, após 2014. Definido então cinco anos antes do VZIK - 2009 a 2013 (Grupo 1), e 5 anos pós VZIK - 2014 a 2018 (Grupo 2).

Tamanho Amostral: O tamanho amostral (N) a ser utilizado neste projeto será determinado com base nas técnicas para populações finitas de até 100.000, segundo a fórmula abaixo, onde $Z$ é o nível de confiança de $95 \%$, $P$ é a quantidade de acerto esperado (95\%), Q a quantidade de erro esperado de 5\%, $\mathrm{N}$ a população total, que será referente á incidência dos agravos estudados com base na demanda do SAARB/IEC para os períodos pré e pós entrada do VZIK no Brasil e, e nivel de precisão de $5 \% .0 \mathrm{~N}$ amostral será de no máximo 1.300 amostras de soros humanos, levando em consideração a demanda de amostras para analises sorologicas da SAARB/IEC.

\section{Detecção de anticorpos}

\section{Teste de Neutralização por Redução de Placas (PRNT)}

As amostras de soros de humanos selecionados para a construção do painel de amostras serão processadas no PRNT para detecção de anticorpos neutralizantes para o VDEN, VFA e VZIK. O PRNT será realizado simultaneamente de acordo com o protocolo aplicado para detecção de anticorpos contra flavivírus - Seção de Arbovirologia e Febres Hemorrágicas do Instituto Evandro Chagas. (SII/SAARB/IEC/SVS/MS).

\section{Ensaio Imunoenzimático para Captura de Anticorpos IgM (ELISA IgM).}

As amostras de soro selecionadas serão testadas pelo ELISA IgM "in house" seguindo a técnica descrita por MARTIN et al., (2000), adaptada e padronizada pelo Laboratório de Sorologia II da Seção de Arbovirologia e Febres Hemorrágicas do Instituto Evandro Chagas. (SII/SAARB/IEC/SVS/MS).

\section{KIT Comercial ELISA IgM}

Serão selecionados Kits comerciais de ELISA IgM para os vírus, VDEN, VFA e VZIK, os recomendados pela Coordenação Geral de Laboratórios de Saúde Pública (CGLAB) entre outros. O painel de soros humanos selecionados, serão testados pelos Kits ELISA IgM seguindo orientações de fabricante.

Os resultados obtidos serão armazenados em planilhas eletrônicas do 
programa EXCEL 2007. Para análises dos dados será utilizado o programa BioEstat (versão 5.0). Os gráficos das análises dos dados serão produzidos utilizando o GraphPadPrism 6.0 para Windows (GraphPad sottware, San Diego, Estados Unidos).

\section{Resultados e discussão}

Determinar possívies variáveis na resposta imonólogica em uma população como a do Brasil, exposta a mais de dez flavivírus;

Atestar especifividade e sensibilidade esperada para técnicas sorologicas semiquantitiva ELISA IgM "in house" e PRNT para os VDEN, VFA e VZIK;

Atestar se os Kits comerciais ELISA IgM VDEN, VFA e VZIK disponíveis no mercado garentem a alta sensibilidade e especificidade descritas, frente a um painel de amostras de soros humanos bem caracterizado com uma população exposta e diversos flavivírus;

Apresentação da situação atual dos Kits ELISA IgM para VDEN, VFA e VZIK utilizados pela rede pública e privada do Brasil;

Orientar a CGLAB/MS para utilização dos Kits ELISA IgM para VDEN, VFA e VZIK, avaliados que apresentarem resultados satisfatórios.Referências bibliográficas:

ARAÚJO, T. P.; RODRIGUES, S. G.; COSTA, M. I. W. A.; VASCONCELOS, P. F. C;

TRAVASSOS DA ROSA. A. P.A. Diagnóstico sorológico de infecção por dengue e febre amarela em casos suspeitos no Estado do Pará Brasil. Revista da Sociedade Brasileira de Medicina Tropical 35(6):579-584, nov-dez, 2002.

BHAT, S. et al. The global distribution and burden of dengue. Nature, v. 496, n. 7446, p. 504-507, 2013.

CAMARA T. N. L. Arboviroses emergentes e novos desafios para a saúde pública no Brasil. Rev. Saúde Pública. Departamento de Epidemiologia. Faculdade de Saúde Pública. Universidade de São Paulo. Rev Saúde Pública. São Paulo, SP, Brasil 2016.

CAMPOS, G. S.; BANDEIR, A. C.; SARDI, S. I. Zika Virus Outbreak, Bahia, Brazil. Emerging Infectious Diseases, v. 21, n. 10, p. 1885-188, 2015.

DEJNIRATTISAI W., SUPASA P., WONGWIWAT W., et al. Dengue virus serocross- reactivity drives antibodydependent enhancement of infection with zika vírus. Nature Immunology 17(9):1102-8, 2016.

ESTRELA, J. F. Estrutura e patogênese das principais arboviroses humanas no Brasil. 2017. 18 f. Monografia (Graduação em Biomedicina) - Faculdade de Ciências da Educação e Saúde, Centro Universitário de Brasília, Brasília, 2017. GUBLER D. J. The Global Emergence/Resurgence of Arboviral Diseases As Public Health Problems. Disease Control and Prevention (CDC), Fort Collins, CO, USA Received for publication February 25, 2002.

KIKUTI M., et al.; Diagnostic performance of commercial IgMand IgG enzymelinked immunoassays(ELISAs) for diagnosis of Zika virus infection. Virology Journal, 2018. MUSSO D, et al. Molecular detection of Zika virus in blood and RNA load determination during the French Polynesian outbreak. J Med Virol. 2016a.

SANTOS N. S. O. ROMANOS M. T. V.; WIGG M. D. Livro Introdução à 
Virologia Humana. $2^{\circ}$.ed, Rio de Janeiro: Guanabara Koogan, 2008.

Palavras chaves: Flavivírus; Diagnóstico; Anticorpos; Reação cruzada. Grande-área:Ciências Biológicas

Área: Ciências Biológicas 


\title{
PESQUISA PARA A DETECÇÃO DOS VÍRUS DA FEBRE AMARELA E VÍRUS DO MAYARO EM AMOSTRAS DE ÁRTROPODES
}

\author{
Nome do(a) Bolsista: Emylly Barrozo Caldas \\ Nome do(a) Orientador(a): Ana Cecília Ribeiro Cruz
}

Introdução: As arboviroses são doenças causadas por vírus transmitidos por vetores artrópodes infectados à vertebrados suscetíveis em um ciclo enzoótico que é mantido em ambiente silvestre. Neste grupo, encontram-se as do gênero Flavivirus, que possuí cerca de 53 espécies e estrutura esférica, com cerca de $50 \mathrm{~nm}$ de diâmetro, onde encontra-se o vírus da Febre amarela, conhecido por ser causador de uma doença infecciosa aguda, não contagiosa. Além do VFA, a febre do Mayaro (FM) destaca-se como arbovirose causadora de surto, sendo causada pelo vírus do Mayaro que é pertencente à família Alphavirus e apresenta-se como uma síndrome febril acompanhada de artralgias severas, edema articular, linfadenopatias além de exantema maculo-papular. A região Amazônica é considerada o maior reservatório de arbovírus do mundo, abrangendo mais de um terço dos arbovírus já descobertos cuja emergência e reemergência, ocorre com grandes modificações ambientais dentre as quais observou-se a construção de hidrelétricas que, em regiões anteriormente preservadas, ocasionaram aumento da população de artrópodes durante e após a formação do lago o que pode resultar na emergência e reemergência de arbovírus.

Objetivos gerais: Verificar se há circulação de VFA e/ou VMAY em mosquitos coletados de região próxima às hidrelétricas de Santo Antônio e Jirau. Objetivos específicos: Pesquisar o RNA do VMAY e do VFA em amostras de mosquitos da família Culicidae, coletados em regiões próximas as Hidrelétricas de Santo Antônio e Jirau por intermédio do projeto Mansonia.

Materiais e métodos: Foram analisadas 29 amostras de pool de mosquito por meio de RT-PCR para Flavivirus, e RTqPCR para o VFA e VMAY. As amostras positivas foram submetidas a tentativa de isolamento viral. Resultados: Das 29 amostras, uma apresentou positividade para o VFA no teste de RTqPCR porém a tentativa de isolamento não foi bem sucedida.Conclusão: Por meio deste estudo, pode-se detectar positividade para o VFA em amostra de pool de mosquitos da espécie Uranotaenia geométrica, sinalizando a circulação viral na região de Nova Mutum, nas proximidades da UHE de Jirau.

Introdução: As arboviroses são doenças causadas por vírus transmitidos por vetores artrópodes infectados à vertebrados suscetíveis em um ciclo enzoótico que é mantido em ambiente silvestre (AZEVEDO et al., 2007). Contudo, este ciclo de manutenção pode sofres variações influenciadas pela ação do homem no ambiente selvagem, principalmente devido ao desmatamento, que gera desequilíbrio no ecossistema silvestre e modificam as condições naturais de manutenção dos arbovírus, o que influencia na sua dispersão, para além deste ambiente (KOWALEWSKI et al., 2011).

Dentre as Arboviroses de maior importância em saúde pública, encontram-se a Febre amarela e a Febre do Mayaro, ambas causadas por vetores da família de 
insetos Culicidae. Os mosquitos desta família são delgados, possuem pernas compridas além de uma longa probóscide e escamas pelo corpo. As larvas distinguem-se de outros insetos aquáticos pela presença de patas e ausência de antenas, além de um tórax bulboso, mais largo que a cabeça (HARBACH, 2008). A proliferação deste vetor aumenta de forma significativa mediante as ações antrópicas, principalmente as que causam grande impacto ambiental. Verificou-se que a construção de hidrelétricas (UHE) em regiões anteriormente preservadas, ocasionaram aumento da população de artrópodes durante e após a formação do lago o que pode resultar na emergência e reemergência de arbovírus (VASCONCELOS et al, 2001). Como exemplo de UHE, pode-se destacar as usinas hidrelétricas (UHE) de Santo Antônio e Jirau (figura), fazem parte do complexo hidrelétrico e hidroviário do rio Madeira, no estado de Rondônia. As instalações dessas UHE causaram impactos em grandes extensões de terra assim como os alagamentos consequentes, são de água parada, o que favorece a reprodução de vetores causadores de Arboviroses emergentes e o surgimento de novas. Além disso, a proximidade da UHE de Santo Antônio com a capital traz a preocupação com as épocas de cheia do rio madeira, onde são detectados aumento de notificações de doenças endêmicas devido o alagamento causado (SCABIN, 2015).

OBJETIVOS: Objetivos gerais: Verificar se há circulação de VFA e/ou VMAY em mosquitos coletados de região próxima às hidrelétricas de Santo Antônio e Jirau.

Objetivos específicos: Pesquisar o RNA do VMAY e do VFA em amostras de mosquitos da família Culicidae, coletados em regiões próximas as Hidrelétricas de Santo Antônio e Jirau por intermédio do projeto Mansonia.

MATERIAL E MÉTODOS

Amostragem: Foram utilizadas amostras de artrópodes hematófagos oriundos da demanda do projeto intitulado: Desenvolvimento de uma metodologia de monitoramento da dinâmica comportamental de Mansonia spp. e sua relevância no aproveitamento hidrelétrico da Amazônia, sendo este realizado em colaboração do IEC e o Instituto de pesquisas da Amazônia (INPA), e outras instituições parceiras. Este projeto possuí autorização do IBAMA, sob número 58855, que o autoriza a realizar capturas de mosquitos.

Extração de RNA: O processo de extração de RNA foi utilizado em dois momentos: para a obtenção de controle positivo, e para a obtenção de RNA das 29 amostras de mosquito utilizadas neste estudo.

Para a realização deste procedimento, foi utilizado o kit de purificação de RNA Trizol® PLUS (Thermo Fisher Scientific), que utiliza o método de coluna de sílica, respeitando-se as proporções indicadas pelo fabricante.

\section{RT-qPCR para VFA e VMAY:}

A pesquisa do genoma do VFA e do VMAY foi realizada por RT-qPCR utilizando o protocolo adotado no Laboratório de Biologia Molecular/SAARB/IEC para diagnóstico do referido vírus, o qual emprega o iniciadores e sondas para VFA (DOMINGUES et al., 2012) e para VMAY (CELESTINO JÚNIOR et al, 2013) apresentados no quadro1 e kit de RT-qPCR SuperScript ${ }^{\mathrm{TM}}$ III Platinum ${ }^{\mathrm{TM}}$ One-Step $R T$-qPCR (Thermo Fisher Scientific), segundo as especificações do fabricante.

RT-PCR para Flavivirus: Para a detecção de genoma de Flavivirus, foi empregada a técnica de RT-PCR convencional utilizando iniciadores gênero-específicos, com 
hibridização de regiões conservadas do gene da proteína viral não-estrutural nsP1 desse gênero.

Isolamento viral: As amostras consideradas positivas, foram submetidas à tentativas de isolamento viral em células C6/36 que são células de mosquito, e células VERO que são provenientes de rim de macaco de acordo com protoloco já utilizado para diagnóstico no laboratório de cultura de células da seção de arbovirologia e febres hemorrágicas.

Resultados e discussão: Após o processamento das amostras pelo RtqPCR para VFA e VMAY, e pelo RT-PCR convencional para Flavivirus, apenas a amostra AR 855916 apresentou positividade para o VFA. Contudo, esta não apresentou positividade no teste de RT-PCR convencional para Flavivirus. A amostra foi processada duas vezes pelo método de RTqPCR para VFA para garantir a reprodutibilidade do resultado. A mesma apresentou CT 34/35 no primeiro teste, e CT de 33 quando repetida sendo considerada positiva para o VFA e, portanto, apta a ser submetida à tentativa de isolamento viral. O restante das amostras processadas, não apresentaram positividade para nenhum dos alvos testados. A amostra AR855916 trata-se de um pool de mosquitos da espécie Uranotaenia (Uranotaenia) geométrica, coletada em junho de 2018, no aterro sanitário de nova Mutum, Porto Velho, próximo a UHE de Jirau, durante a primeira excursão do projeto (quadro). Esta amostra foi submetida à tentativa de isolamento viral tanto em células C6/36 quanto em células VERO. Após a inoculação, observou-se que não houve a ocorrência de efeito citopático nas células de ambas culturas sendo confirmado pelo método de IFI, que não ocorreu o isolamento. Os resultados encontrados indicam circulação de VFA em áreas próximas à UHE de Jirau, que localiza-se a 120 km da capital. A amostra de pool Uranotaenia geométrica, foi coletada no Aterro sanitário de nova Mutum, à apenas de 18 minutos de Porto velho sinalizando o risco de proximidade da capital com a área de circulação e principalmente risco de contaminação da população residente no distrito de Nova Mutum e a possibilidade de o VFA se estabelecer no meio urbano (Capital), visto que este pode manter-se por meio um ciclo urbano, utilizando o Aedes aegypt como vetor de transmissão nestes casos.

Conclusão: Por meio deste estudo, pode-se detectar positividade para o VFA em amostra de pool de mosquitos da espécie Uranotaenia geométrica, sinalizando a circulação viral na região de Nova Mutum, nas proximidades da UHE de Jirau. Estes resultados demonstram a importância de manter-se boa cobertura vacinal na região, além de acionar medidas de controle vetorial visto trata-se de uma área com circulação viral comprovada e com fatores que favorecem a emergência e reemergência de Arboviroses.

Referências: HARBACH, R.E. The Culicidae (Diptera): a review of taxonomy, classification and phylogeny. Zootaxa .1668: 591-688, 2007.

KOWALEWSKI, M.; SALZER, J.; DEUTSCH, J et al .Black and gold howler monkeys (Alouatta caraya) as sentinels of 10 ecosystem health: patterns of zoonotic protozoa infection relative to degreee of human-primate contact. American Journal of primatology.73: 75-83, 2011. 
VASCONCELOS, P.; COSTA, Z., TRAVASSOS DA ROSA, E et al. Epidemic of jungle yellow fever in Brazil 2000: Implications of climatic alterations in disease spread. Journal of medical Virology.65: 598-604; 2001.

SCABIN, F; JUNIOR, N.N.P; DA CUNHA CRUZ, J.C. Judicialização de grandes empreendimentos no Brasil: uma visão sobre os impactos da instalação de usinas hidrelétricas em populações locais na Amazônia. Revista Pós Ciências Sociais.11, 2015.

Palavras chave: Vigilância epidemiológica, Vírus da febre amarela, Vírus do Mayaro, Hidrelétricas de Santo Antônio e Jirau.

Grande área: Microbiologia

Área: Virologia 


\title{
CARACTERIZAÇÃO DO GENOMA MITOCONDRIAL DE QUATRO ESPÉCIES DO GÊNERO Haemagogus (DIPTERA: CULICIDAE).
}

\author{
Nome do(a) Bolsista: Fábio Silva da Silva \\ Nome do(a) Orientador(a): Joaquim Pinto Nunes Neto
}

Introdução: O gênero Haemagogus compreende espécies de mosquitos de grande importância médico-epidemiológica na transmissão de arboviroses, tal como a Febre Amarela, atuando primariamente em ciclos de transmissão silvestre. Diante da ausência de informações relacionadas aos aspectos de biologia evolutiva deste gênero, o presente estudo realizou o sequenciamento completo do genoma mitocondrial de quatro espécies. Métodos: Foi realizado o sequenciamento completo do genoma das espécies Haemagogus albomaculatus, Haemagogus leucocelaenus, Haemagogus spegazzinii e Haemagogus tropicalis com o uso da plataforma lon Torrent PGM (Life Technologies), em seguida montadas e notadas as regiões correspondentes ao mtDNA, sendo posteriormente realizada uma análise comparativa incluindo 21 táxons com sequências completas do mtDNA disponíveis no GenBank. Foram estipuladas ao todo sete filogenias foi pela metodologia de Maximum Likelihood (MV), bootstrap $=1000$.

Resultados: Foram obtidas sequências de tamanho médio 15.038 pb para as quatro espécies de Haemagogus trabalhadas, com um genoma mitocondrial constituído de 37 subunidades funcionais, contudo, não tendo sido obtidos dados de sequenciamento correspondentes à região controle $(A+T)$. A identidade nucleotídica média com base às treze regiões codificadoras de proteínas foi de $85,3 \%$ entre as sequências obtidas e os demais táxons. Os resultados das análises de filogenia apresentaram semelhantes padrões de topologia, com parcial concordância à taxonômia baseada em morfologia externa das espécies sequenciadas. Conclusões: Foram obtidos com sucesso dados de sequenciamento do mtDNA das espécies de Haemagogus propostas, com grande semelhança genética e composição estrutural comparadas a outras espécies de Culicidae já sequenciadas.

Introdução: O gênero Haemagogus WILLISTON, 1896 (Diptera: Culicidae) caracteriza-se como um dos três grupos de mosquitos pertencentes à tribo Aedini (junto aos gêneros Aedes e Psorophora) que se encontra restrito em ocorrência à faixa neotropical do globo, albergando cerca de 28 espécies, e classificadas em dois subgêneros: Conopstegus DYAR, 1925, com quatro espécies, e Haemagogus WILLISTON, 1896, albergando 24 espécies. No Brasil, há registros de ocorrência para nove espécies de mosquitos pertencentes a este gênero, com representantes para ambos os subgêneros (Arnell, 1973).

O gênero Haemagogus apresenta grande importância médico- epidemiológica por conta de sua elevada capacidade vetorial, com representantes envolvidos ativamente em ciclos de transmissão de agentes infecciosos em natureza, tais como o vírus da Febre Amarela (Flaviviridae, Flavivirus), que apresenta como vetor primário de transmissão a espécie Haemagogus janthinomys DYAR, 1925, atuante 
na dispersão endêmica em grande parte das regiões do Brasil assim como nas demais áreas do continente americano (Arnell, 1973; Alencar et al., 2016).

A compreensão de fatores condizentes às relações de filogenia e parentesco entre artrópodes, particularmente aqueles de reconhecida importância médica, é fundamentalmente necessária para a elaboração de estratégias e medidas voltadas ao combate e controle vetorial (Hiragi et al., 2009). Apesar da grande importância que as espécies do gênero Haemagogus apresentam na transmissão de agentes infecciosos em natureza, em revisão de literatura, ainda se têm poucas informações referentes aos aspectos de biologia evolutiva deste grupo.

Um dos principais marcadores genômicos utilizados na realização de estudos evolutivos em abordagem aos mecanismos de variabilidade genética, de filogenia e dispersão filogeográfica de organismos artrópodes tem sido o genoma mitocondrial (mtDNA), a qual, devido sua grande facilidade de amplificação, e características próprias como uma grande conservação estrutural, elevadas taxas de substituição nucleotídica, elevado polimorfismo intraespecífico, possibilitando a visualização de informações em diferentes níveis evolutivos (Boore, 1999).

Diante do exposto, este trabalho apresenta como proposta metodológica a apresentação de dados de caracterização molecular em base ao genoma mitocondrial das espécies Haemagogus albomaculatus THEOBALD, 1903, Haemagogus leucocelaenus, Haemagogus spegazzini BRÈTHES, 1912 e Haemagogus tropicalis CERQUEIRA \& ANTUNES, 1938.

Objetivos: Caracterizar o genoma mitocondrial das espécies Haemagogus albomaculatus, Haemagogus leucocelaenus, Haemagogus spegazzinii e Haemagogus tropicalis; Verificar os padrões de identidade nucleotídica com base às 13 regiões codificadoras de proteínas do genoma mitocondrial entre sequências nucleotídicas obtidas neste estudo e outros táxons de Culicidae; Analisar as relações de filogenia das quatro espécies avaliadas dentro do gênero Haemagogus com base no uso das subunidades mitocondriais COXI, COXII, CytB, NADH4 e NADH5, de forma concatenada e em análises individualizadas para cada gene; Avaliar quais subunidades apresentam resultados com maior proximidade topológica à filogenia baseada em cinco subunidades mitocondriais; e analisar as relações filogenéticas das quatro espécies avaliadas dentro do gênero Haemagogus com base à concatenação das 13 regiões codificadoras de proteínas.

Material e métodos:Foram realizadas coletas de campo para Haemagogus leucocelaenus, em Canaã dos Carajás, Pará (S 0649'75" W 4987'83"), de 11 a 18 de novembro de 2016, e Haemagogus tropicalis, na Ilha do Combú (S 01²51'97" W 48 49'28", de 27 de fevereiro a 13 de março de 2018. A aquisição de amostras biológicas das espécies Haemagogus albomaculatus e Haemagogus spegazzinii se deu pela consulta de informações de atividades de coletas anteriores, disponíveis nos boletins de campo e livros de registro de artrópodes do Laboratório de Entomologia Médica - SAARB/IEC. Haemagogus albomaculatus foi coletado no munícipio de Jaborandi - BA (S 1358'92" W 4453'36"), em 05 de março de 2013, e Haemagogus spegazzinii foi coletado no município de Coribe - BA (S 1382'94" W 4444'92"), em 02 de dezembro de 2016. De lotes das espécies contendo, 
respectivamente, cinco e trinta mosquitos, e já tendo sido macerados anteriormente para a realização de testes de rotina (Isolamento viral) da SAARB/IEC, foram retirados de cada lote $180 \mu \mathrm{L}$ para a realização dos procedimentos de extração genômica.

Para a extração genômica, foram colocados em tubos separados seis mosquitos de cada espécie coletada em campo, e em outros dois tubos separados foram depositados os $180 \mu \mathrm{L}$ de cada espécie já macerada, utilizando o Kit comercial DNeasy ${ }^{\circledR}$ Blood \& Tissue kit, seguindo as normas protocolares do fabricante. As bibliotecas genômicas foram construídas de forma automatizada no equipamento $A B$ Library Builder ${ }^{\mathrm{TM}}$ System (Thermo Fisher Scientific), com o kit Ion Xpress Plus Fragment Library Kit, seguindo as recomendações do fabricante. Por fim, as bibliotecas passaram por uma nova amplificação, por emulsion $P C R$, utilizando o Sistema Ion OneTouch ${ }^{\mathrm{TM}} 2$ System, sendo após enriquecidas com a utilização dos kits Ion Xpress template kit (Life Technologies) e Ion sequencing kit (Life Technologies). O sequenciamento das amostras foi realizado na plataforma de sequencimento Next-Generation ION Torrent PGM, utilizando o kit ION PGM Hi-Q Sequencing Kit (Thermo Fisher Scientific), com o Ion 318 ${ }^{\mathrm{TM}}$ Chip Kit v2 BC, seguindo as orientações estabelecidas pelo fabricante.

A montagem dos dados de sequenciamento foi realizada utilizando os sofwares IDBA UD 1.1.1 e SPAdes 3.10.1. A seleção das regiões do mtDNA foi feita com o programa Diamond. A visualização dos contigs do mtDNA foi realizada com o uso do software MEGAN. A curadoria das sequências obtidas foi realizada utilizando o software Geneious v.9.1.8. Por fim, as sequências foram notadas automaticamente utilizando a ferramenta online MITOchondrial genome annotation Server (MITOS).

Foram extraídas em conjunto as 13 regiões codificadoras de proteínas do (CDS) do mtDNA de cada sequência de Haemagogus obtida, seguido do alinhamento destas pelo programa $M A F F T$, junto às regiões equivalentes extraídas de sequências completas do mtDNA de 21 táxons disponíveis no banco de dados genômicos do National Center for Biotechnology Information (NCBI: GenBank). O melhor modelo de substituição nucleotídica (GTR+GAMMA) foi definido pelo uso do software jModelTest v2.1.7, e o software RaxML v8.2.11 foi utilizado para a estruturação da filogenia em base à metodologia de Maximum Likelihood (MV), com um valor de bootstrap $=1000$. A visualização e edição da árvore filogenética gerada se deu com o uso do software FigTree v1.4.3.

Resultados e discussão: Os genomas mitocondriais obtidos apresentaram igualmente uma conformação de DNA circular, com sequências nucleotídicas de tamanho médio de 15.038 pb, constituídos em sua totalidade de 37 subunidades funcionais, contendo 13 regiões codificadoras de proteínas (CDS), 22 subunidades de tRNA e duas subunidades de RNA ribossomal (12S rRNA e 16S rRNA). As subunidades mitocondriais demonstraram padrões similares de posicionamento ao longo das fitas J (Foward) e N (Reverse), para os quatro genomas obtidos, contudo, neste estudo, não se obteve dados de sequenciamento da região controle $A+T$, assim como observado num estudo realizado por LEMOS et al. (2015), possilvemente devido a dificuldade de processamento, por parte da tecnologia de sequenciamento, de regiões com elevadas taxas homopoliméricas do genoma mitocondrial. 
Quando alinhadas as sequências de Haemagogus, foram registrados 4.494 sítios polimórficos, 12.990 sítios conservados, e uma identidade pareada de 92,1\%. Adicionalmente, quando alinhadas e comparadas as 13 regiões codificadoras de proteínas (CDS) de cada uma das espécies sequenciadas em relação aos 21 táxons selecionados para a estruturação filogenética, foi gerada uma matriz de identidade nucleotídica, resultando na média de $85,3 \%$ de identidade entre os táxons avaliados, com percentuais variando entre $72,9 \%$ e $95,2 \%$. O táxon que apresentou a maior média de identidade em relação às sequências obtidas foi Haemagogus janthinomys, com 93,2\%, enquanto que o táxon de menor percentual médio de identidade registrado foi Chironomus tepperi, com 73,5\%. Em média, as subunidades CDS que apresentaram os menores e maiores percentuais de identidade nucleotídica entre os 21 táxons analisados e os quatro genomas de Haemagogus obtidos foram, respectivamente, ATP8 (78,6\%) e NADH1 (88,9\%).

A utilização inicial de cinco subunidades mitocondriais concatenadas conduziu à obtenção de um resultado com relativa concordância à organização taxonômica conhecida até a disposição dos clados superiores. Contudo, nesta primeira análise, o subclado correspondente ao gênero Haemagogus apresentou uma relação de parafilia, por conta do distanciamento do táxon Haemagogus tropicalis do agrupamento de espécies de seu subgênero (Haemagogus), discordando assim da classificação taxonômica morfológica conhecida para esta espécie.

As subunidades COXI, NADH4 e NADH5 foram as que mais apresentaram resultados de organização topológica próximos à primeira avaliação realizada. Embora apresentando diferentes padrões de topologia quando avaliadas individualmente, estas apresentaram a formação de agrupamentos monofiléticos em níveis de tribo, gênero, subfamília e família, corroborando com a classificação taxonômica baseada em caracteres morfológicos, assim como observado em outros estudos que também utilizaram estes genes (Navarro et al., 2013; Chu et al., 2018). Em função dos resultados obtidos na análise de concatenação das cinco subunidades mitocondriais inicialmente selecionadas, decidiu-se ampliar a quantidade de genes em uma próxima análise. Dessa forma, quando gerada a filogenia com base à concatenação ampliada de todas as 13 subunidades mitocondriais, os resultados demonstraram uma maior robustez na estruturação da árvore, onde, em particular para os mosquitos do gênero Haemagogus, obteve-se uma organização dos táxons esperada e concordante à taxonomia morfológica, onde Haemagogus tropicalis passou a estar mais proximamente relacionado aos táxons do subgênero Haemagogus. Em outros estudos, a utilização de todas as treze regiões codificadoras de proteínas do mtDNA também resultou em estruturações filogenéticas robustas e em grande parte corroborando aos achados de taxonomia morfológica (Demari - Silva et al., 2015; Luo et al., 2016).

Conclusões: Os genomas mitocondriais de cada uma das espécies de Haemagogus avaliadas foram obtidos com sucesso a partir da utilização da plataforma de sequenciamento ION torrent PGM. De forma geral as sequências apresentaram uma disposição concordante das 37 subunidades mitocondriais conhecidas. Contudo, neste estudo não foram obtidos dados de sequenciamento para a região controle $A+T$, necessitando sua complementação em estudos futuros. 
A identidade nucleotídica média com base às treze regiões codificadoras de proteínas foi de $85,3 \%$, com Haemagogus janthinomys e Chironomus tepperi apresentando, respectivamente, as maiores e menores médias de identidade nucleotídica em relação às sequências obtidas (93,2\% e 73,5\%).

A análise de filogenia das espécies do gênero Haemagogus com base à concatenação das subunidades mitocondriais COXI, COXII, CytB, NADH4, NADH5 apresentou grande concordância à classificação taxonômica baseada em morfologia externa. Contudo, nesta análise, o posicionamento em particular do táxon Haemagogus tropicalis apresentou-se como discordante em relação à classificação taxonômica em base à morfologia externa destes organismos.

As análises filogenéticas baseadas na utilização individualizada das subunidades COXI, NADH4 e NADH5 foram as que apresentaram maior proximidade à filogenia de cinco subunidades mitocondriais concatenadas.

A análise de classificação filogenética baseada na concatenação das treze subunidades codificadoras de proteínas apresentou um arranjo estrutural semelhante ao obtido na análise de concatenação de cinco subunidades. Contudo, nesta análise, foi observada uma melhora nos valores de ancoragem na formação dos clados, bem como grande concordância à classificação taxonômica baseada na morfologia externa das espécies do gênero Haemagogus avaliadas.

Referências bibliográficas: ALENCAR, J.; MELLO, C. F. D.; BARBOSA, L. S.; GILSANTANA, H. R.; MAIA, D. D. A.; MARCONDES, C. B.; SILVA, J. D. S. Diversity of yellow fever mosquito vectors in the Atlantic Forest of Rio de Janeiro, Brazil. Revista da Sociedade Brasileira de Medicina Tropical, v. 49, n. 3, p. 351-356, 2016.

ARNELL, J. H. Mosquito Studies (Diptera, Culicidae). XXXII. A revision of the genus Haemagogus. Estudios sobre zancudos (Diptera, Culicidae). XXXII. Una revisión del género Haemagogus. Contributions of the American Entomological Institute., v. 10, n. 2, p. 1-174, 1973.

BOORE, J. L. Animal mitochondrial genomes. Nucleic acids research, v. 27, n. 8, p. 1767-1780, 1999.

CHU, H.; LI, C.; GUO, X.; ZHANG, H.; LUO, P.; WU, Z.; WANG, G.; ZHAO, T. The phylogenetic relationships of known mosquito (Diptera: Culicidae) mitogenomes. Mitochondrial DNA Part A, v. 29, n. 1, p. 31-35, 2018.

DEMARI - SILVA, B.; FOSTER, P. G.; DE OLIVEIRA, T. M.; BERGO, E. S.; SANABANI, S. S.; PESSÔA, R.; SALLUM, M. A. M. Mitochondrial genomes and comparative analyses of Culex camposi, Culex coronator, Culex usquatus and Culex usquatissimus (Diptera: Culicidae), members of the coronator group. BMC genomics, v. 16, n. 1, p. 831, 2015.

HIRAGI, C.; SIMÕES, K.; MARTINS, E.; QUEIROZ, P.; LIMA, L.; MONNERAT, R. Variabilidade genética em populações de Aedes aegypti (L.) (Diptera: Culicidae) utilizando marcadores de RAPD. Neotrop Entomol, v. 38, n. 4, p. 542-547, 2009.

LEMOS, P. D. S.; MONTEIRO, H. A. O.; CASTRO, F. C.; LIMA, C. P. S. D.; SILVA, D. E. A. D.; VASCONCELOS, J. M. D.; OLIVEIRA, L. F.; DA SILVA, S. P.; CARDOSO, J. F.; VIANEZ-JÚNIOR, J. L. S. G.; NUNES, M. R. T. Characterization of mitochondrial genome of Haemagogus janthinomys (Diptera: Culicidae). Mitochondrial DNA Part A, v. 28, n. 1, p. 50-51, 2015. 
LUO, Q. C.; HAO, Y. J.; MENG, F.; LI, T. J.; DING, Y. R.; HUA, Y. Q.; CHEN, B. The mitochondrial genomes of Culex tritaeniorhynchus and Culex pipiens pallens (Diptera: Culicidae) and comparison analysis with two other Culex species. Parasites \& vectors, v. 9, n. 1, p. 406, 2016.

NAVARRO, J. C.; QUINTERO, L.; ZORRILLA, A.; GONZÁLEZ, R. Molecular tracing with mitochondrial NADH5 of the invasive mosquito Aedes (Stegomyia) albopictus (Skuse) in Northern South America. J Entomol Zool Stud, v. 1, n. 4, p. 32-39, 2013.

Palavras-chave: Culicidae, Haemagogus, Sequenciamento, Genoma Mitocondrial, Filogenia.

Grande-área: Zoologia

Área: Entomologia 
INFECÇÃO EXPERIMENTAL DE Biomphalaria glabrata DE BELÉM, ESTADO DO PARÁ, COM CEPA SIMPÁTRICA DE Schistosoma mansoni: RECÉM ISOLADA (BE-I) vs. MANTIDA EM LABORATÓRIO (BE)

\author{
Nome do(a) Bolsista: Isabelle Helena Lima Dias \\ Nome do(a) Orientador(a): Martin Johannes Enk
}

Introdução: A esquistossomose é uma doença parasitária que afeta cerca de 240 milhões de pessoas mundialmente. Dentre os países nas américas onde ocorre a transmissão da esquistossomose, o Brasil é considerado o de maior área endêmica, onde Biomphalaria glabrata (Say, 1818) é hospedeira intermediária natural de $S$. mansoni. Epidemiologicamente, $B$. glabrata é considerada a espécie mais importante em relação a ocorrência da esquistossomose, devido sua vasta distribuição geográfica além de apresentar altas taxas de suscetibilidade à infecção pelo trematódeo S. mansoni. Neste cenário, estudos de experimentais fornecem dados importantes acerca de parâmetros como a infectividade e suscetibilidade de parasitos a seus hospedeiros, sejam eles definitivos ou intermediários por exemplo, para assim compreender de forma mais clara o comportamento do mesmo em seu ciclo. Este estudo tem como objetivo avaliar alterações no grau de infectividade nos hospedeiros intermediário (caramujos LAB e SEL) e definitivo (camundongos Swiss) com cepa de S. mansoni, uma obtida há 35 anos em Belém do Pará e mantida em laboratório e outra coletada recentemente na mesma localidade. Um total de 400 caramujos foram utilizados neste experimento, sendo: 100 caramujos da linhagem LAB infectados com cepa BE, 100 caramujos LAB com cepa BE - I, 100 caramujos SEL com cepa BE e 100 caramujos SEL com cepa BE - I. Também foram utilizados 30 camundongos, 15 foram infectados com cepa BE e 15 com cepa BE-I. A partir do cruzamento entre cepas e linhagens de caramujos, foi possível observar flutuações nos valores dos grupos teste destes hospedeiros intermediários. De acordo com os dados obtidos, observa-se que os espécimes mantidos em laboratório possivelmente adaptaram-se um ao outro, de modo a preservar sua perpetuação. As diferenças notadas a partir dos cruzamentos das cepas e caramujos podem ser reflexo de pressões provenientes de ambiente laboratorial, ou externo, ou ambos, os quais viriam a ser determinantes no comportamento da cepa em seu ciclo.

Introdução: A esquistossomose é uma doença parasitária que afeta cerca de 240 milhões de pessoas mundialmente. Reportada em 78 países, esta é considerada uma das doenças tropicais negligenciadas (World Health Organization - WHO, 2019, McManus, 2018). Dentre os países nas américas onde ocorre a transmissão da esquistossomose, o Brasil é considerado o de maior área endêmica onde foram registradas onze espécies e uma subespécie do gênero Biomphalaria (Preston, 1910). Destas, Biomphalaria glabrata (Say, 1818) é hospedeira intermediária natural de S. mansoni (Brasil, 2014). No Pará já foi identificada a ocorrência de 4 espécies de Biomphalaria, com destaque para B. glabrata participando ativamente como hospedeiro intermediário da esquistossomose na capital Belém (Goveia et al., 2019). Epidemiologicamente, B. glabrata é considerada a espécie mais importante em relação a ocorrência da esquistossomose, devido sua vasta distribuição geográfica 
além de apresentar altas taxas de suscetibilidade à infecção pelo trematódeo $S$. mansoni. (Souza et al., 2001). O desenvolvimento de uma patologia depende diretamente da suscetibilidade do hospedeiro intermediário acometido. Estudos de experimentais fornecem dados importantes acerca dos agentes envolvidos na transmissão de doenças e também servem como subsídios para se determinar o potencial endêmico de uma região (Coimbra Jr., 1981), além de nos permitir visualizar de uma melhor forma parâmetros como a infectividade e suscetibilidade de parasitos a seus hospedeiros, sejam eles definitivos ou intermediários por exemplo, para assim compreender de forma mais clara o comportamento do mesmo em seu ciclo.

\section{OBJETIVOS}

\subsection{GERAL}

Avaliar alterações no grau de infectividade nos hospedeiros intermediário e definitivo com cepa de S. mansoni, uma obtida há 35 anos em Belém do Pará e mantida em laboratório e outra coletada recentemente na mesma localidade.

\subsection{ESPECÍFICOS}

- Comparar a taxa de infecção experimental nos grupos de moluscos infectados;

Comparar a taxa de infecção experimental nos grupos de camundongos infectados;

- Comparar a taxa de mortalidade dos grupos de hospedeiros intermediários B. glabrata infectados;

- Comparar a taxa de mortalidade dos grupos de hospedeiros definitivos, utilizando camundongos Mus musculus Swiss (Linnaeus, 1758);

- Definir o período pré-patente nos grupos de moluscos infectados;

- Quantificar as cercárias eliminadas nos grupos de moluscos infectados;

- Avaliar a presença de vermes nos camundongos infectados;

- Avaliar quantidade dos ovos nas fezes dos camundongos infectados, definindo o número de ovos por grama de fezes;

\section{METODOLOGIA}

\subsection{CEPA MANTIDA EM LABORATÓRIO (BE)}

Após registrar novos focos de transmissão de esquistossomose no Pará, Paraense e colaboradores (1984) isolaram cercárias de S. mansoni a partir de 16 moluscos infectados, coletados no bairro do Telégrafo, região metropolitana de Belém. Esta linhagem vem sendo mantida no Laboratório de Referência Nacional em Malacologia do Instituto Oswaldo Cruz (LRNEM/IOC/Fiocruz), no Rio de Janeiro.

\subsection{CEPA RECÉM ISOLADA (BE-I)}

Bianualmente, coletas malacológicas de rotina são realizadas pelo LPIEM/IEC para obtenção de caramujos, objetivando o monitoramento destes espécimes e de sua possível infecção por S. mansoni. Em junho de 2018 foi realizada a captura de caramujos também no bairro do Telégrafo, em Belém-PA. Esta será analisada comparativamente a cepa $\mathrm{BE}$, por ser mais recente e não ter outras passagens em camundongos.

\subsection{OBTENÇÃO DOS CARAMUJOS}


Os caramujos utilizados neste estudo foram provenientes de duas criações, a primeira a partir da colônia pré-existente no LRNEM/IOC/Fiocruz, no Rio de Janeiro, com animais pertencentes à linhagem coletada por Paraense, em 1984, em Belém do Pará, sendo denominados neste estudo como caramujos LAB.

A segunda foi utilizada a partir da coleta das desovas de caramujos de Belém, retirados de seu ambiente natural em junho de 2018, sendo denominados neste estudo como caramujos SEL.

\subsection{INFECÇÃO EXPERIMENTAL DAS CEPAS BE E BE-I DE Schistosoma} mansoni EM CARAMUJOS Biomphalaria glabrata

Ao atingirem entre 2 até 3 meses de idade, os moluscos foram expostos individualmente à 5 miracídios, em placa com poços de $3 \mathrm{~mL}$ de água desclorada (Fernandez, 1997) para infecção. A busca por cercárias se deu a partir do $25^{\circ}$ dia após a infecção (Frandsen, 1979), por exposição à luz para verificar a presença desta forma infectante (Paraense \& Corrêa, 1989). Para caracterizar a quantidade de cercárias, $1 \mathrm{~mL}$ da água obtida pós exposição à luz por cerca de 1 hora e 30 minutos, foi analisada individualmente. Para contagem, a solução de cercárias foi corada com lugol e contadas em lupa eletrônica. Um total de 400 caramujos foram utilizados neste experimento, obtendo-se gerações F1 das duas linhagens, sendo: 100 caramujos da linhagem LAB com cepa BE, 100 caramujos da linhagem LAB com cepa BE - I, 100 caramujos SEL com BE e 100 caramujos SEL com BE - I (Frandsen, 1979). Neste ciclo, foi comparado para ambos os grupos as taxas de infecção, o período pré-patente, a taxa de mortalidade e o número de cercárias eliminadas nos moluscos.

\subsection{INFECÇÃO DAS CEPAS BE E BE-I DE Schistosoma mansoni EM CAMUNDONGOS}

Foram utilizados um total de 30 camundongos não isogênicos Mus musculus (Swiss) fêmeas, entre 20 a 25 dias de nascidos. Destes, 15 foram infectados com cepa BE e 15 com cepa BE-I, individualmente, por via subcutânea, com média de 120 cercárias contadas em microscópio estereoscópio, recuperadas a partir de moluscos da espécie B. glabrata infectados (Anderson \& Cheever, 1972; Martinez et al., 2003; Yoshioka et al., 2002). No $60^{\circ}$ dia, todos os animais infectados foram eutanasiados para recuperação de vermes (Azevedo, 1976; Magalhães et al., 1986).

\subsubsection{Sedimentação espontânea (HPJ) para coleta de ovos}

Para obtenção de ovos de S. mansoni, foi utilizada a técnica descrita por Hoffman, Pons e Janner (1934) a qual consiste na retirada de ovos a partir de sedimentação de fezes em cálice. Os camundongos infectados foram colocados em grupos de no máximo 4 animais por vez em gaiolas de dimensão $30 \times 20 \times 13 \mathrm{~cm}$ com cerca de $100 \mathrm{ml}$ de água no fundo, de forma a cobrir apenas as patas dos animais, para colheita do total de 4,0g de fezes frescas, segundo técnica descrita por BRASIL, em 2008 (Adaptado). Esta técnica para obtenção de ovos viáveis é uma vantagem pois permite padronizar a origem dos miracídios nos experimentos de suscetibilidade, assim como a manutenção dos animais vivos no laboratório (BRASIL, 2008). 


\subsubsection{Método de Kato Katz}

O Método de Kato-Katz é um teste qualitativo e quantitativo, o qual permite determinar o número de ovos por grama de fezes (OPG) de um indivíduo parasitado, assim como calcular a intensidade da infecção (Katz et al., 1972). O método consiste na filtragem de uma pequena amostra de fezes através de tela de nylon, o qual será depositado com auxílio de espátula plástica em placa perfurada sobre uma lâmina de vidro, de forma a preencher todo o espaço. Posteriormente, posiciona-se lamínula de celofane previamente embebida em solução de verde malaquita, pressionando de forma a espalhar uniformemente toda a amostra na lâmina, facilitando sua leitura, feita após 30 minutos em microscópio óptico em objetivas de 10x para detecção de ovos de parasitos. A contagem final do número de ovos encontrados é multiplicada por 24, quantificando o OPG, haja vista que o orifício na placa perfurada corresponde a 43,7 miligramas de fezes (Katz et al., 1972).

\subsubsection{Perfusão dos camundongos}

Os parasitos foram recuperados no $60^{\circ}$ dia pós inoculação de cercárias, a partir de perfusão dos camundongos, pelo sistema porta-hepático, segundo técnica de Yolles et al. (1947). Os espécimes foram eutanasiados utilizando associação anestésica de Cloridrato de Cetamina $(100 \mathrm{mg} / \mathrm{Kg})$ e Cloridrato de Xilazina (10 $\mathrm{mg} / \mathrm{Kg}$ ), por via intramuscular, segundo a Resolução Normativa do CONCEA No 37/2018 (CONCEA, 2018; Yoshioka et al., 2002).

\subsection{CONSIDERAÇÕES ÉTICAS}

O projeto foi encaminhado para a Comissão de Ética no Uso de Animais (CEUA) do Instituto Evandro Chagas, obtendo certificado de aprovação no 45/2019 (Anexo III). O uso de caramujos não requer submissão ou avaliação por comitê devido não se encaixar nos parâmetros do Conselho Nacional de Controle de Experimentação Animal (CONCEA), nas normas previstas na Lei $n^{0} 11.794$, de 2008, a qual inclui vertebrados vivos, não humanos, das espécies classificadas no filo Chordata, subfilo Vertebrata.

\section{RESULTADO E DISCUSSÃO}

\subsection{INFECÇÃO EM CARAMUJOS B. glabrata}

Antes do $25^{\circ}$ dia após infecção, o grupo com maior número de mortos foi o de caramujos LAB infectados com cepa BE - I (25 moluscos), sendo os grupos com menor número de mortos os de caramujos $L A B$ infectados com cepa BE (8 moluscos) e caramujos SEL infectados com cepa BE - I (8 moluscos). A partir da primeira exposição à luz, no $25^{\circ}$ dia, os grupos com o maior número de moluscos positivos foram os de caramujos SEL, tanto infectados com cepa BE quanto com cepa BE-I (42 moluscos, respectivamente). O grupo com o menor número de animais infectados foi o de caramujos LAB infectados com cepa BE-I (13 moluscos). O grupo com maior número de moluscos negativos na primeira exposição foi o de caramujos LAB infectados com cepa BE (63 moluscos), sendo o grupo com menor o de caramujos SEL infectados com cepa BE (39 moluscos). O grupo com maior taxa de infecção foi o de caramujos SEL infectados com cepa BE $(51,9 \%)$ e o grupo com menor taxa foi o de caramujos LAB infectados com cepa BE - I (17\%). Dentre os moluscos positivos, o grupo qual apresentou maior mortalidade foi o de caramujos $L A B$ infectados com cepa BE - I e o grupo com menor mortalidade foi o de caramujos LAB infectados com cepa BE. 
A produção de cercárias máxima observada em um único dia foi encontrada na infecção de caramujos $L A B$ com cepa BE, no $50^{\circ}$ dia após exposição aos miracídios. Já o menor número de cercárias observadas em um dia foi encontrada na infecção de caramujos SEL com cepa BE - I, no $25^{\circ}$ dia após exposição. Quanto ao período pré-patente pôde-se observar a liberação de cercárias a partir do $25^{\circ}$ dia em todos os experimentos, com exceção de quatro espécimes de caramujos LAB infectados com cepa $\mathrm{BE}$, onde houve soltura a partir do $40^{\circ}$ dia. Observou-se maior número na produção de cercárias no grupo de caramujos SEL infectados com cepa BE, com menor produção observada no grupo de caramujos LAB infectados com cepa BE - I.

\subsection{INFECÇÃO EM CAMUNDONGOS Mus musculus}

Para o Grupo 1, infectado com cepa BE, um total de cinco animais apresentaram ovos nas fezes, com medidas de OPG máxima de 312 e mínima de 96. Para o Grupo 2 infectado com cepa BE - I, um total de sete animais apresentaram ovos nas fezes, com medidas de OPG máxima de 936 e mínima de 24. Pôde-se observar 22 camundongos parasitados, 11 em ambos os grupos, com pelo menos um verme recuperado durante a perfusão, correspondendo a uma taxa de infecção aproximada de $73 \%$ cada. No Grupo 1 o maior número de vermes machos encontrados foi 44 (animal BE - RJ 7) e fêmeas 51 (animal BE - RJ 1). No Grupo 2 o maior número de vermes machos encontrados foi 5 (animal BE-I - BEL 2) e fêmeas também 5 (animais BE-I - BEL 5 e BE-I - BEL 14). Durante o período do estudo nenhum dos camundongos dentro dos grupos infectados morreu, portanto, não houve cálculo de taxa de mortalidade.

Todos os quatro grupos de caramujos expostos aos miracídios resultaram em espécimes com soltura de cercárias, fato qual indica sucesso nas infecções, possivelmente relacionado à forma de infecção dos moluscos, assim como também observado por Bastos, em 1978, onde confirmou que caramujos submetidos a técnica de infecção individual apresentavam taxas de infecção maiores quando comparadas com os resultados de infecção em massa. No entanto, a partir do cruzamento entre cepas e linhagens de caramujos, foi possível observar flutuações nos valores dos grupos teste destes hospedeiros intermediários. Os resultados deste estudo nos permitem inferir que, assim como o trematódeo pode ter se adaptado ao caramujo, é possível supor o mesmo ocorrendo de forma contrária (Silva et al., 1994). As taxas de mortalidade observadas neste estudo foram baixas em relação a animais negativos, porém altas em animais positivos.

\section{Conclusão:}

De acordo com os dados obtidos, observa-se que os espécimes mantidos em laboratório possivelmente adaptaram-se um ao outro, de modo a preservar sua perpetuação. Quando se cruza as cepas e caramujos, é possível verificar que a cepa de laboratório consegue maiores números de infecção em caramujos selvagens, possivelmente pois este molusco não possui mecanismos de resistência a infecções normalmente ocorrentes no ambiente. As diferenças notadas a partir dos cruzamentos podem ser reflexo de pressões provenientes de ambiente laboratorial, ou externo, ou ambos, os quais viriam a ser determinantes no comportamento da cepa em seu ciclo.

\section{Referência bibliográfica:}


ANDERSON LA; CHEEVER AW. Comparison of geographical strains of Schistosoma mansoni in the mouse. Bull Org. Mond. Santé, 46: 233-242;1972

AZEVEDO, D.S. Infecção experimental do camundongo albino pelo Schistosoma mansoni: I - Estudo comparativo da eficácia de diferentes vias de infecção. Rev.

Soc. Bras. Med. Trop, 10(4): 213-216, 1976.

BASTOS, O. de C. Estudo do comportamento parasitológico e imunológico das linhagens humana e silvestre do Schistosoma mansoni Sambon, 1907. Campinas, 1975. [Dissertação de Mestrado — Instituto de Biologia da Unicamp].

BASTOS, O. de C. et al. [Susceptibility of an albinic variant of Biomphalaria glabrata from Belo Horizonte (MG), to infection by Schistosoma mansoni, from wild rodents of the Paraíba do Sul River Valley] Rev. Saúde públ., S. Paulo, 12:179-83, 1978.

BRASIL. Ministério da Saúde. Secretaria de Vigilância em Saúde. Departamento de Vigilância Epidemiológica. Vigilância e controle de moluscos de importância epidemiológica: diretrizes técnicas. Editora MS - 2ªed. Brasília, 2008.

BRASIL. Ministério da Saúde. Secretaria de Vigilância em Saúde. Departamento de Vigilância Epidemiológica. Vigilância da Esquistossomose mansoni: diretrizes técnicas. Editora MS - 4ªed. Brasília, 2014.

COIMBRA JR., C.E.A. Suscetibilidade à infecção pelo Schistosoma mansoni, de Biomphalaria glabrata e Biomphalaria tenagophila do Distrito Federal, Brasil. Rev. Saúde Pública. 15: 485-9, 1981.

CONCEA. BRASIL. Ministério da Ciência, Tecnologia, Inovações e Comunicações. Conselho Nacional de Controle de Experimentação Animal. Resolução Normativa do CONCEA No 37, de 15 de fevereiro de 2018. Referente aos procedimentos de eutanásia realizados em animais incluídos em atividades de ensino ou de pesquisa científica. Brasília: MS, 49p., 2018. Disponível em <http://www.mctic.gov.br>. Acessado em 23/04/2019.

FERNANDEZ, M. A. Schistosoma mansoni Infections in the First Three Months of Life of Sympatric Intermediate Hosts from Brazil. Mem Inst Oswaldo Cruz, 92 (1): 27-29, 1997.

FRANDSEN, F. Studies of the relationships between Schistosoma and their intermediate hosts. I. The genus Bulinus and Schistosoma haematobium from Egypt. J Helminthol, 53, 15-2, 1979.

GOVEIA, C. DE O.; GUIMARÃES, R. J. DE P. S.; NUNES, M. R. T.; DIAS, I. H. L.; ENK, M. J. Schistosomiasis Mansoni in the Amazon Region: Malacological Surveys of Intermediate Hosts for the Identification of Disease Transmission Areas in Belém, Pará, Brazil. J. Pharm. \& Pharm. 7: 51-60; 2019. doi: 10.17265/23282150/2019.02.002

HOFFMAN, W. A.; PONS, J. A.; JANER, J. L. Sedimentation concentration method in Schistosomiasis mansoni. Puerto Rico. Journal of Public Health \& Tropical Medicine, 9: 283-298, 1934.

KATZ, N; CHAVES, A; PELLEGRINO, J. A simple device for quantitative stool thicksmear technique in Schistosomiasis mansoni. Rev. Inst. Med. Trop. 14(6): 397-400, 1972

MAGALHÃES, L.A.; GUARALDO, A. M A.; ZANOTTI-MAGALHÃES, E. M.; CARVALHO J. F.; SGARBIERI, V. C.; ALCÂNTARA, F. G. Esquistossomose 
mansônica em camundongos experimentalmente subnutridos. Rev. Saúde Públ 20: 362-368, 1986.

MARTINEZ, E. M.; NEVES, R. H.; OLIVEIRA, R. M. F.; MACHADO-SILVA, J. R; REY, L. Características biológicas e morfológicas de cepas brasileiras de Schistosoma mansoni em Mus musculus. Rev. Soc. Bras. Med. Trop. 36 (5):557564; 2003.

MCMANUS, D. P.; DUNNE, D. W.; SACKO, M.; UTZINGER, J.; VENNERVALD, B. J.; ZHOU, X-N. Schistosomiasis. Nature Reviews. 4:(1)1-19; 2018. doi:10.1038/s41572-018-0013-8

PARAENSE, W. L.; SOUZA, P. E. F. P.; BRAUN, R. F. Novos focos de transmissão do Schistosoma mansoni no Estado do Pará. Mem. Inst. Oswaldo Cruz. 79 (3): 389-391, 1984.

PARAENSE, W. L.; CORRÊA, L. R. A Potential Vector of Schistosoma mansoni in Uruguay. Mem. Inst. Oswaldo Cruz. 84 (3): 281-288, 1989.

SILVA, R. E.; MELO, A. L.; PEREIRA, L. H. Suscetibilidade de Biomphalaria tenagophila e Biomphalaria glabrata de uma mesma região a duas cepas de Schistosoma mansoni. Rev. Inst. Med. Trop. São Paulo. 36 (5): 409-415, 1994.

SOUZA, C. P.; CALDEIRA, R. L.; DRUMMOND, S. C.; MELO, A. L.; GUIMARÃES, C. T.; SOARES, D. M.; CARVALHO, O. S. Geographical Distribution of Biomphalaria Snails in the State of Minas Gerais, Brazil. Mem. Inst. Oswaldo Cruz. 96 (3): 293302, 2001.

WORLD HEALTH ORGANIZATION (WHO). Schistosomiasis: Key facts. http://www.who.int/news-room/fact-sheets/detail/schistosomiasis. Acessado em 08 de novembro de 2019.

YOLLES, T. K.; MOORE, D. V.; DEGIUSTI, D. L.; RIPSOM, C. A.; MELENEY, H. E. A Technique for the Perfusion of Laboratory Animals for the Recovery of Schistosomes. J. Parasitol. 33 (5): 419-426, 1947.

YOSHIOKA, L; ZANOTTI-MAGALHÃES, E. M.; MAGALHÃES, L. A.; LINHARES, A. $X$. Schistosoma mansoni: Estudo da Patogenia da Linhagem Santa Rosa (Campinas, SP, Brasil) em Camundongos. Rev. Soc. Bras. Med. Trop. 35 (3):203$207 ; 2002$.

RESOLUÇÃO NORMATIVA N. 15, de 16 de dezembro de 2013 - "Baixa a Estrutura Física e Ambiente de Roedores e Lagomorfos do Guia Brasileiro de Criação e Utilização de Animais para Atividades de Ensino e Pesquisa Científica", CONCEA.

Palavras-chave: Esquistossomose; Infecção Experimental; Biomphalaria glabrata, Schistosoma mansoni.

Grande área: Parasitologia

Área: Helmintologia 


\title{
ESTUDO DE POLIMORFISMOS DO GENE DO RECEPTOR DE VITAMINA D NA HANSENÍASE
}

\author{
Nome do(a) bolsista: Jasna Leticia Pinto Paz \\ Nome do(a) orientador(a): Luana Nepomuceno Gondim Costa Lima
}

Resumo: A evolução da hanseníase depende de aspectos imunológicos e genéticos do hospedeiro, sendo forma ativa da vitamina $D$ fundamental para a regulação do sistema imune. Estudos implicaram a variação de polimorfismos de nucleotídeo único (SNPs) no gene do receptor de vitamina D (VDR) com a susceptibilidade a doenças como a hanseníase. O objetivo desta pesquisa é verificar a relação entre os SNPs Fokl (rs2228570), Taql (rs731236) e Apal (rs7975232) do gene do VDR e a hanseníase. O estudo foi realizado com indivíduos dos municípios de Altamira, Curionópolis, Redenção, Rondon do Pará, Parauapebas, Goianésia e Canaã dos Carajás, no estado do Pará, Brasil. Foram inclusos 405 indivíduos, sendo 100 multibacilares (MB), 57 paucibacilares (PB) e 248 contatos saudáveis. Foi realizado sequenciamento genético a partir de amostras de sangue. Não houve associação de alelos com a hanseníase. Para o SNP Fokl, não foi observada associação com a doença. Para o SNP Taql, indivíduos com o genótipo mutante G/G apresentaram maior chance de progressão para a forma MB da hanseníase que para a forma PB e não adoecimento do. Para o SNP Apal, o genótipo A/C foi associado a proteção para forma $M B$ quando comparado à $P B$ e o genótipo $A / A$ foi associado a susceptibilidade à forma $M B$ quando comparado à forma $\mathrm{PB}$ e não adoecimento do indivíduo. Os indivíduos com o genótipo $A / C$ apresentaram menor chance de desenvolverem a forma $M B$ quando comparados a forma $P B$ e não adoecimento e menor chance de desenvolverem a forma MB comparada a forma PB.

Introdução: A hanseníase é uma doença infectocontagiosa causada pela bactéria $M$. leprae. O caminho da infecção por $M$. leprae se inicia nas vias aéreas, principal forma de contaminação (MONTOYA; ALZATE; CASTRO, 2017). Em 2015, o Brasil foi o país mais endêmico (WORLD HEALTH ORGANIZATION, 2016). A resposta inicial do hospedeiro, através da imunidade inata, envolve alguns receptores, dentre os quais, receptores de vitamina D (VDR) (MAZINI et al., 2016). Tanto os níveis de vitamina D3, quanto de expressão de mRNA de VDR apresentam relações com a ocorrência de hanseníase (MANDAL et al., 2015; JOLLIFFE et al., 2016). Estudos mostram que diferentes populações apresentam diferentes configurações genéticas do gene VDR (VELARDE FÉLIX et al., 2009; PEPINELI et al., 2019). Portanto, estudos genéticos da hanseníase em determinadas regiões endêmicas brasileiras se fazem necessários, principalmente dadas as dimensões continentais do país e sua configuração populacional, que advém de grande mistura étnica.

Objetivo geral: Verificar a relação entre os SNPs Fokl (rs2228570), Taql (rs731236), Apal (rs7975232), do gene do receptor de vitamina D (VDR) e a hanseníase. 
Objetivos específicos: Determinar a associação da idade, gênero e estado vacinal (BCG) com as formas multibacilares, paucibacilares e contatos saudáveis de pacientes hansenianos; determinar as frequências dos genótipos e alelos dos SNPs Fokl (rs2228570), Taql (rs731236), Apal (rs7975232) do gene VDR na população de estudo; avaliar a associação dos genótipos e alelos dos SNPs Fokl (rs2228570), Taql (rs731236), Apal (rs7975232) com as formas multibacilares, paucibacilares e contatos saudáveis de pacientes hansenianos; determinar as associações de risco entre genótipos e alelos dos SNPs Fokl (rs2228570), Taql (rs731236), Apal (rs7975232) nas formas multibacilares, paucibacilares e contatos saudáveis de pacientes hansenianos.

Material e métodos: Nesta pesquisa do tipo caso-controle foram incluídos 405 indivíduos de municípios endêmicos do estado do Pará, Altamira, Curionópolis, Redenção, Rondon do Pará, Parauapebas, Goianésia e Canaã dos Carajás, que aceitaram participar deste estudo e assinaram um termo de consentimento livre esclarecido. Os indivíduos foram divididos em contatos e pacientes, classificados em paucibacilares (PB) ou multibacilares (MB). Esta pesquisa de mestrado foi vinculada ao projeto de pesquisa "Avaliação da transmissão do Mycobacterium leprae e suscetibilidade genética à hanseníase em regiões endêmicas do Estado do Pará" aprovado pelo Comitê de Ética e Pesquisa do IEC, com o número do parecer: 1.255.80. Amostras de sangue foram coletadas de pacientes e contactantes saudáveis, das quais foram realizadas as extrações de DNA e análise dos polimorfismos, submetidos a técnica da reação em cadeia da polimerase (PCR), tipificados através do sequenciador ABI 3130 Genetic Analyzer (Applied Biosystems ${ }^{\circledR}$ ) e lidas no programa BioEdit Sequence Alignment Editor versão 7.2 com posterior realização de BLAST no site da National Center for Biotechnology Information (NCBI). As análises estatísticas foram realizadas com o auxílio do programa GraphPad Prism versão 8.00.

\section{Resultados e discussão:}

De acordo com a idade os grupos foram separados em faixas etárias de 0-15 anos, 16-31, 32-46 e acima de 46 anos. Constatou-se uma relação entre a ocorrência da doença e a faixa etária ( $p=0.0001$ ). Houve maior prevalência de indivíduos com idades entre 32 e 46 anos no grupo Contato (28,22\%), enquanto no grupo Paciente, prevaleceram indivíduos das maiores faixas etárias, especialmente de idade acima dos 46 anos (44,59\%). Todas as faixas etárias a partir de 16 anos apresentaram maiores chances para desenvolvimento da hanseníase em comparação com crianças e adolescentes de 0 a 15 anos. Entre o grupo MB e PB, verificou-se que 0 primeiro grupo foi composto em sua maioria por pessoas acima de 46 anos $(p=0.0210)$. Os dados corroboram com estudos anteriores, que mostram ser comum no Brasil que a hanseníase tenha suas mais altas taxas de concentração entre as faixas etárias de maior idade (SERRA et al., 2019). O longo período de incubação do bacilo, a falta de diagnóstico e/ou diagnóstico tardio podem ser fatores de influência sobre o elevado número de pessoas mais velhas com a doença (SHUMET; DEMISSIE; BEKELE, 2015).

Com relação ao gênero, o grupo de contatos foi composto em sua maioria pelo sexo feminino (66,53\%), enquanto no grupo de pacientes a maior parte dos integrantes foi do sexo masculino $(50,96 \% ; p=0,0007)$, que apresentaram também maior chance de 
desenvolvimento da hanseníase $(\mathrm{OR}=2.065)$. Pela classificação de formas da doença, verificou-se prevalência do sexo masculino em MB (58\%), com maior chance de manifestação da forma multibacilar da hanseníase (OR=2.197), e do sexo feminino em PB (61,40\%; $p=0,0298)$. A relação apontada por essa pesquisa entre 0 sexo masculino e a ocorrência da hanseníase e, especificamente, o desenvolvimento da forma $\mathrm{MB}$ da doença foi apontada também por pesquisa realizada no nordeste brasileiro (SERRA et al., 2019) e levanta as questões sociais que envolvem a saúde do homem, como a imagem de virilidade e incompatibilidade do horário de funcionamento das unidades de saúde com o horário livre do trabalho destes indivíduos (Berger et al., 2018).

Foi verificada a quantidade de doses da vacina BCG recebidas pelos indivíduos, sendo 0, 1, 2 ou mais. A maioria dos contatos recebeu uma dose de BCG (58,54\%). Entre os pacientes, a maioria também foi vacinada uma vez $(48,29 \%)$, contudo, nesse grupo, a frequência de pessoas que não receberam nenhuma dose da vacina foi muito alta $(43,87 \%, p=0,0001)$. Os grupos de pacientes que receberam uma ou nenhuma dose da vacina apresentaram maiores chances de desenvolvimento da hanseníase, comparados ao grupo que recebeu duas ou mais doses. O grupo PB apresentou maior frequência de uma dose da vacina $(57,89 \%)$, diferente destes, nos MB foi observada a ausência de vacinação $(52,04 \%)$ na maior parte dos integrantes $(p=0,0506)$. O grupo que não recebeu nenhuma dose da vacina apresentou maior chance de manifestação da forma multibacilar da doença, em comparação com o grupo que recebeu duas ou mais doses da vacina. Estudos apontam que a vacinação com BCG aumenta a proteção contra a doença, chegando a aumentar para 95\% a diminuição do risco relativo com a aplicação da segunda dose (ARAUJO et al., 2015; GILLINI et al., 2017).

No SNP Fokl, a distribuição genotípica foi semelhante entre os grupos, onde os genótipos $\mathrm{C} / \mathrm{C}$ e $\mathrm{C} / \mathrm{T}$ foram os mais prevalentes em diferentes comparações $(p>0,05)$. Não foram observadas associações de risco entre os genótipos e a hanseníase. Porém, Singh et al. (2018), observam o genótipo C/C como mais frequente entre os pacientes hansenianos e $\mathrm{C} / \mathrm{T}$ mais frequente em controles. De forma semelhante, nosso estudo apresentou o genótipo $\mathrm{C} / \mathrm{T}$ como mais frequente nos controles, já no grupo de pacientes as frequências dos genótipos $\mathrm{C} / \mathrm{T}$ e $\mathrm{C} / \mathrm{C}$ foram iguais, assim como nos subgrupos MB e PB. No artigo de Sapkota et al. (2010), o genótipo C/T apareceu também em destaque entre os indivíduos controles e entre os pacientes com hanseníase, proteção observada também em um estudo realizado no Brasil (MARQUES, 2010).

Quando analisado o genótipo G/G do polimorfismo Taql, observou-se maiores índices em multibacilares em todas as comparações ( $p>0,05)$. Indivíduos com $o$ genótipo $G / G(O R=2.462)$ apresentaram mais de duas vezes a chance de progressão para a forma $M B$ da hanseníase que para a forma $P B$ ou não adoecimento, comparado ao genótipo selvagem A/A. O genótipo G/G favoreceu em 2,3 vezes $(O R=2.394)$ as chances de adoecimento sob a manifestação multibacilar, comparado a PB. G/G foi associado a pacientes com hanseníase per se no estudo de Singh et al (2018) em indianos, segundo os autores devido à baixos níveis de expressão do VDR, já que os pacientes apresentam resposta imune prejudicada. Em um trabalho realizado em Minas Gerais esse genótipo foi tido como promotor de 
susceptibilidade à hanseníase. De acordo com os autores, é possível que o polimorfismo afete a diferenciação de células $T$, o que compromete a eficácia da resposta imune celular (GOULART; FERREIRA; GOULART, 2006). Em estudo sobre infecções por $M$. tuberculosis na Índia, o genótipo G/G foi associado ao alto risco de baciloscopia positiva e ao aumento da carga bacilar (SHARMA et al., 2011).

Quanto ao Apal, houve destaque do genótipo A/C $(62,79 \%)$ no grupo PB, enquanto no grupo $M B$ a maior frequência foi do genótipo $A / A(41,98 \%)$, evidenciando a proteção de $A / C$ contra o pior desfecho da doença $(p=0,0031)$. Entre multibacilares e um grupo formado de paucibacilares junto com contatos, o genótipo A/A segue prevalente em $\mathrm{MB}$, reforçando sua associação com a susceptibilidade à forma grave da doença $(p=0,0088)$. Na Índia, o genótipo $A / A$ foi associado à ocorrência da hanseníase per se por suas maiores frequências entre pacientes, porém, no mesmo estudo o genótipo $\mathrm{A} / \mathrm{C}$, foi relacionado também à hanseníase per se (NEELA et al., 2015). Comparado ao desenvolvimento da forma clínica paucibacilar juntamente com a resistência (através dos contatos), é possível notar que entre $A / C$ e 0 genótipo selvagem $\mathrm{C} / \mathrm{C}$, os indivíduos com $\mathrm{A} / \mathrm{C}$ apresentam chance 0,4 vezes menor $(\mathrm{OR}=0.4245)$ para a forma MB. Na comparação apenas entre os grupos MB e PB é observado que os indivíduos com o genótipo $A / C$ apresentam chance 0,1 vez menor $(\mathrm{OR}=0.1834)$ de desenvolvimento da forma MB. Esse genótipo, em pesquisa chinesa, apresentou menor risco ao desenvolvimento do vitiligo (LI et al., 2012). Porém, Neela et al., (2015) associaram esse genótipo à hanseníase per se. No presente trabalho, não foram identificadas associações de risco entre os alelos dos polimorfismos e a hanseníase.

Conclusão: Foi observada relação entre a ocorrência da doença e a faixa etária, com maior prevalência de indivíduos com idade acima dos 46 anos no grupo de pacientes e no subgrupo MB. Verificou-se maior frequência de PB na faixa etária de 32 a 46 anos. Observou-se relação da doença e o gênero, com contatos e paucibacilares representados em sua maioria pelo sexo feminino e os grupos de pacientes e multibacilares pelo sexo masculino, assim como a doença e o estado vacinal, com maior frequência de não vacinados entre pacientes, enquanto uma grande quantidade de contatos apresentou pelo menos uma vacina. O grupo PB apresentou maior frequência de uma dose da vacina enquanto nos MB foi observada, principalmente, a ausência de vacinação. Não foram observadas associações de alelos com a hanseníase. Para o SNP Fokl, não foi observada associação com a doença. Para o SNP Taql, indivíduos com o genótipo mutante G/G apresentaram maior chance de progressão para a forma MB da hanseníase que para a forma PB e não adoecimento do indivíduo. Para o SNP Apal, nas comparações entre MB e PB, o genótipo A/C foi associado a proteção e o genótipo A/A foi associado a susceptibilidade. Os indivíduos com o genótipo $A / C$ apresentaram menor chance de desenvolverem a forma $\mathrm{MB}$ quando comparados a forma PB e não adoecimento e somente à forma PB.

REFERÊNCIAS

ARAUJO, S. et al. Risk-benefit assessment of Bacillus Calmette-Guérin vaccination, anti-phenolic glycolipid I serology, and Mitsuda test response: 10-year follow-up of household contacts of leprosy patients. Revista da Sociedade Brasileira de Medicina Tropical, v. 48, n. 6, p. 739-745, dez. 2015. Disponível em: 
<http://www.scielo.br/scielo.php?script=sci_arttext\&pid=S0037-

86822015000600739\&lng=en\&tlng=en>. Acesso em: 31 jul. 2019.

COELHO, E. B. S. et al. Política Nacional de Atenção Integral à Saúde do

Homem UFSC 2018. [s.l: s.n.]. Disponível em:

<http://portalarquivos2.saude.gov.br/images/pdf/2018/novembro/07/livroPol--ticas-

2018.pdf>. Acesso em: 28 jul. 2019.

GILLINI, L. et al. Global practices in regard to implementation of preventive measures for leprosy. $2017 . \quad$ Disponível em: <https://doi.org/10.1371/journal.pntd.0005399>. Acesso em: 31 jul. 2019.

GOULART, L. R.; FERREIRA, F. R.; GOULART, I. M. B. Interaction of Taql polymorphism at exon 9 of the vitamin $D$ receptor gene with the negative lepromin response may favor the occurrence of leprosy. FEMS Immunology and Medical Microbiology, v. 48, n. 1, p. 91-98, 2006.

JOLLIFFE, D. A. et al. Single nucleotide polymorphisms in the vitamin D pathway associating with circulating concentrations of vitamin D metabolites and non-skeletal health outcomes: Review of genetic association studies. Journal of Steroid Biochemistry and Molecular Biology, v. 164, p. 18-29, 2016.

$\mathrm{LI}, \mathrm{K}$. et al. The association of vitamin D receptor gene polymorphisms and serum 25hydroxyvitamin D levels with generalized vitiligo. British Journal of Dermatology, v. 167, n. 4, p. 815-821, out. 2012. Disponível em: <http://www.ncbi.nlm.nih.gov/pubmed/22762534>. Acesso em: 11 ago. 2019.

MANDAL, D. et al. Vitamin D receptor expression levels determine the severity and complexity of disease progression among leprosy reaction patients. New Microbes and New Infections, v. 6, p. 35-39, 2015. Disponível em: <http://linkinghub.elsevier.com/retrieve/pii/S2052297515000311>.

MARQUES, C. D. S. Estudo de Associação entre o Gene VDR e a Hanseníase. 2010. Instituto Oswaldo Cruz, 2010. Disponível em: $<$ http://arca.icict.fiocruz.br/handle/icict/5723>.

MAZINI, P. S. et al. Gene association with leprosy: A review of published data. Frontiers in Immunology, v. 6, n. JAN, p. 1-17, 2016.

MONTOYA, M. R.; ALZATE, J. C. B.; CASTRO, N. C. Evaluation and Monitoring of Mycobacterium leprae Transmission in Household Contacts of Patients with Hansen's Disease in Colombia. PLoS Neglected Tropical Diseases, v. 11, n. 1, p. 1-11, $2017 . \quad$ Disponível em: <http://journals.plos.org/plosntds/article?rev=1\&id=10.1371/journal.pntd.0005325>.

NEELA, V. S. K. et al. Association of Taq I, Fok I and Apa I polymorphisms in Vitamin D Receptor (VDR) gene with leprosy. Human Immunology, v. 76, n. 6, p. 402-405, 2015. Disponível em: <http://dx.doi.org/10.1016/j.humimm.2015.04.002>.

PEPINELI, A. C. et al. Vitamin D Receptor Gene Polymorphisms Are Associated With Leprosy in Southern Brazil. Frontiers in Immunology, v. 10, 4 out. 2019.

SAPKOTA, B. R. et al. Association of TNF, MBL, and VDR polymorphisms with leprosy phenotypes. Human immunology, v. 71, n. 10, p. 992-8, out. 2010. Disponível em: <http://www.ncbi.nlm.nih.gov/pubmed/20650301>. Acesso em: 17 ago. 2019.

SERRA, M. A. A. de O. et al. Factors Associated with Multibacillary Leprosy in a Priority Region for Disease Control in Northeastern Brazil: A Retrospective 
Observational Study. Journal of Tropical Medicine, v. 2019, p. 1-7, 18 fev. 2019. Disponível em: <http://www.ncbi.nlm.nih.gov/pubmed/30911302>. Acesso em: 27 jul. 2019.

SHARMA, P. R. et al. Coding and non-coding polymorphisms in VDR gene and susceptibility to pulmonary tuberculosis in tribes, castes and Muslims of Central India. Infection, genetics and evolution: journal of molecular epidemiology and evolutionary genetics in infectious diseases, v. 11, n. 6, p. 1456-61, ago. 2011. Disponível em: <https://linkinghub.elsevier.com/retrieve/pii/S1567134811002073>. Acesso em: 12 ago. 2019.

SHUMET, T.; DEMISSIE, M.; BEKELE, Y. Prevalence of Disability and Associated Factors among Registered Leprosy Patients in All Africa Tb and Leprosy Rehabilitation and Training Centre (ALERT), Addis Ababa, Ethiopia. Ethiopian journal of health sciences, v. 25, n. 4, p. 313-20, out. 2015. Disponível em: <http://www.ncbi.nlm.nih.gov/pubmed/26949295>. Acesso em: 28 jul. 2019.

SINGH, I. et al. VDR polymorphism, gene expression and vitamin D levels in leprosy patients from North Indian population. PLoS neglected tropical diseases, v. 12, n. 11, p. $\quad$ e0006823, 2018. Disponível em: <http://www.ncbi.nlm.nih.gov/pubmed/30481178>. Acesso em: 17 ago. 2019.

VELARDE FÉLIX, J. S. et al. Relación del polimorfismo Taql del gen del receptor de la vitamina $D$ con la lepra lepromatosa en población mexicana. Salud Publica de Mexico, v. 51, n. 1, p. 59-61, 2009. Disponível em: <https://scielosp.org/pdf/spm/2009.v51n1/59-61>.

WORLD HEALTH ORGANIZATION. Weekly epidemiological record Relevé épidémiologique hebdomadaire. [s.l: s.n.].

Palavras chave: Hanseníase. Mycobacterium leprae. VDR. Grande área: Biologia de agravos infecciosos na Amazônia Área: Fisiopatologia humana e experimental de processos infecciosos 
Nome do(a) Bolsista: Karina Carvalho Marques

Nome do(a) Orientador(a): Luiz Fábio Magno Falcão

\section{RESUMO}

Objetivo: Avaliar a prevalência de alterações cardiopulmonares e funcional nas diferentes formas clínicas de hanseníase. Material e Métodos: Trata-se de um estudo quantitativo do tipo observacional transversal de caráter descritivo e analítico. O projeto obedecerá a resolução 466/12 do conselho Nacional de Saúde com aprovação do comitê de ética em pesquisa da Universidade do Estado do Pará sob o $n^{\circ}$ 3.496.135. Serão incluídos os indivíduos com idade $\geq$ a 18 anos, ambos os sexos, divididos em grupos: formas clínicas indeterminada, tuberculóide, dimorfa e virchowiana ou em paucibacilar e multibacilar; e grupo controle com indivíduos saudáveis. Os pacientes serão triados do laboratório de dermatologia da Universidade do Estado do Pará e a avaliação será realizada na Unidade de EnsinoAssistência de Fisioterapia e Terapia Ocupacional da mesma universidade. A coleta de dados e anamnese será através de ficha de identificação. Os instrumentos utilizados: análise da variabilidade da frequência cardíaca, teste de caminhada de 6 minutos, espirometria e manovacuometria. Os dados serão armazenados no banco de dados do Microsoft Excel ${ }^{\circledR}$ 2010. Na estatística será utilizada o software Biostat $5.3^{\circledR} \mathrm{com}$ valor de alfa de 0,05 para rejeição de hipótese nula, as variáveis com distribuição normal serão utilizadas teste t de Student e as sem distribuição normal utilizados pelo Man Whitney ou Qui quadrado. Resultados Esperados: Espera-se verificar possíveis alterações nas variáveis analisadas e com isso demonstrar a importância das medidas avaliativas de forma precoce pelos profissionais da área da saúde para minimizar ou sanar as incapacidades encontradas.

Introdução: A Hanseníase é uma doença infecciosa crônica causada pelo agente etiológico Mycobacterium Leprae (M leprae), o microrganismo parasita intracelular obrigatório é um bacilo resistente que realiza tropismo por macrófagos cutâneos e células de Schwann do Sistema Nervoso Periférico. Ocasiona déficits sensitivos, motores e incapacidades físicas com potencial de gerar importante perda de massa muscular. Quando a patologia não é tratada inicialmente a doença torna-se transmissível, com caráter de evolução lenta e progressiva. Mesmo sendo considerada doença evitável, a patologia é considerada uma das principais causas de deficiência no mundo (MINISTÉRIO DA SAÚDE, 2017; ZANELLA et al., 2018).

No Brasil são realizados esforços significativos para a redução na prevalência dos casos existentes, embora ainda não exista impactos na transmissão da doença. A patologia persiste e acredita-se que 1 entre 2 milhões de pessoas globalmente venha apresentar déficits. A grande preocupação deve ser voltada na transmissão da doença, manejo, detecção precoce e principalmente em políticas públicas globais. Por ser considerada patologia crônica com a presença de inúmeras incapacidades e consequentes ônus públicos e aos próprios indivíduos (FREITAS; DUARTE; GARCIA, 2016; LOCKWOOD, 2019). 
A importância de avaliar a população com diagnóstico clínico de hanseníase é medida de políticas públicas de saúde fundamental. A falta de capacitação de profissionais da saúde, bem como a falta de insumos necessários para via de tratamento e as altas taxas da não adesão ao tratamento ou sucessivas faltas justificam as crescentes incidências da patologia (SOUSA; SILVA; XAVIER, 2017).

Por isso, precisamos relatar que como a hanseníase ocasiona grandes desafios no diagnóstico e na detecção das alterações nos diversos sistemas biológicos, as alterações na função pulmonar, cardiovascular e na funcionalidade de indivíduos portadores de hanseníase apresentam escassez de dados descritos na literatura e não estão totalmente claras. Portanto investigar possíveis alterações nos presentes sistemas pretende nortear uma melhor compreensão de como o patógeno pode influenciar nos presentes sistemas. Além do que as pesquisas na região Amazônica são de fundamental importância, assim como Costa et al. (2017), por exemplo, relataram que ao conhecer a população local, bem como utilizar métodos investigativos para detecção precoce vai permitir com isso a redução da transmissão da infectividade e ajudar no alcance das metas no controle da hanseníase.

Portanto, este estudo terá como objetivo avaliar a prevalência de alterações cardiopulmonares e funcional nas diferentes formas clínicas de hanseníase.

Objetivos geral: Avaliar a prevalência de alterações cardiopulmonares e funcional nas diferentes formas clínicas de hanseníase.

\section{ESPECÍFICOS}

- Avaliar o funcionamento autônomo cardíaco nas diferentes formas clínicas de hanseníase e em indivíduos saudáveis.

- Examinar a força muscular respiratória nas diferentes formas clínicas de hanseníase e em indivíduos saudáveis.

- Verificar a funcionalidade através do teste de caminhada de seis minutos comparado entre as diferentes formas clínicas de hanseníase e em indivíduos saudáveis.

- Correlacionar as diferentes variáveis supracitadas nas diferentes formas clínicas da hanseníase e em indivíduos saudáveis.

\section{MATERIAL E MÉTODOS}

O projeto encontra-se submetido ao Comitê de Ética em Pesquisa da Universidade do Estado do Pará e aprovado sob o número de parecer 3.496.135. Os participantes da pesquisa serão informados quanto ao caráter metodológico dos testes, e assinarão o termo de consentimento livre e esclarecido (TCLE) concordando em participar dos mesmos, conforme Resolução 466/12 e da 510/16 do Conselho Nacional de Saúde (CNS). O participante receberá uma via do TCLE em igual teor do pesquisador.

Trata-se de um estudo quantitativo do tipo observacional transversal de caráter descritivo e analítico. A seleção dos indivíduos da amostra será por conveniência.

Os participantes serão triados do laboratório de especialidades dermatologia da Universidade do Estado do Pará (UEPA) e as avaliações dos participantes serão realizadas na Unidade Especializada e Assistência de Fisioterapia e Terapia 
Ocupacional (UEAFTO) da mesma instituição. Situada na Avenida Rômulo Maiorana, no 2558 - Belém (Pará).

Os grupos serão compostos: grupo 1 hanseníase pertences as formas clínicas indeterminada, tuberculóide, dimorfa e virchowiana ou grupo paucibacilar e multibacilar, e um grupo controle composto de indivíduos saudáveis.

Serão incluídos no estudo: indivíduos com idade maior ou igual a 18 anos, ambos os sexos, confirmados do diagnóstico de hanseníase por histopatológico e/ou baciloscópico e o grupo controle que obedecer aos critérios de exclusão. Serão excluídos os indivíduos com hipertensão arterial sistêmica não controlada, diabetes mellitus não controlada, doenças de cardiopatias, pulmonares e traumatológicas que inviabilize a marcha, uso de dispositivo de marcha, tabagistas e os que apresentarem coinfecção.

Os indivíduos passarão inicialmente por uma ficha de avaliação contendo dados pessoais e anamnese. Posteriormente executarão os testes para avaliação cardiológica, da função pulmonar e da funcionalidade.

$\mathrm{Na}$ avaliação da Variabilidade da Frequência Cardíaca será utilizado o monitor de frequência cardíaca POLAR ${ }^{\circledR}$, modelo RS800CX (Polar Electro Oy, Finlândia), os indivíduos ficarão em repouso por 10 minutos e será captado o sinal da FC e suas variações do intervalo RR. As coletas serão nas posições supina, sedestação e em bipedestação durante 10 minutos em cada postura. A análise será realizada pelos domínios de tempo, frequência e pelo plot de poincaré.

A função pulmonar será realizada pela espirometria e manovacuometria. A espirometria analisa a presença de distúrbios ventilatórios utilizara-se do espirometro Spirobank $I^{\circledR}$ (Estados Unidos - EUA) Após a execução da prova de função pulmonar os valores obtidos serão comparados a valores preditos através do Aplicativo ProCalc - Espirometria ${ }^{\circledR} 3.5$ (Uninove Medicina - Brasil) que utiliza como referência as equações de Pereira et al. (1992), o teste será executado através de manobra lenta e manobra rápida com duração maior que 6 segundos, os testes serão repetidos 3 vezes cada. Os parâmetros analisados são Capacidade Vital Forçada (CVF), Volume Expiratório Forçado no Primeiro Segundo (VEF1), Fluxo Expiratório entre 25\% e 75\% (FEF25-75\%) da curva de CVF, Pico de Fluxo Expiratório (PFE) e Índice de Tiffeneau (VEF $/$ CVF). A manovacuometria analisa a força muscular respiratória através da do manovacuometro MVD300-U (Global med digital, Porto Alegre-RS), os indivíduos utilizarão um bocal para coleta de pressões pressão inspiratória máxima (Pimáx) e pressão expiratória máxima (Pemáx) e os valores preditos da manovacuometria serão realizados através das equações de Neder et al (1999).

E a funcionalidade será analisada através do Teste de Caminhada de 6 minutos (TC6) onde os voluntários percorrerão uma distância de 30 metros por 6 minutos, analisando frequência cardíaca, saturação de oxigênio e nível de dispneia através da escala de borg. O teste de caminhada avalia o sistema cardiorrespiratório e funcionalidade da deambulação através da distância percorrida.

A análise estatística será realizada após a tabulação no banco de dados do Microsoft Excel ${ }^{\circledR} 2010$ (Microsoft Office, Estados Unidos) e analisadas por meio do software Biostat $5.3^{\circledR}$ (Instituto Mamirauá, Brasil). As variáveis numéricas com distribuição normal serão analisadas por meio do teste t de Student. As variáveis 
sem distribuição normal serão analisadas por meio do teste de Man Whitney ou Qui quadrado. Será adotado o nível alfa de 0,05 para rejeição da hipótese nula.

Resultados esperados: Espera-se verificar possíveis alterações nas variáveis analisadas e com isso demonstrar a importância das medidas avaliativas de forma precoce pelos profissionais da área da saúde para minimizar ou sanar as incapacidades encontradas. Pois, frente aos estigmas que a hanseníase ainda vem apresentando na sociedade com as informações obtidas é possível incentivar a comunidade científica nas pesquisas nos diversos sistemas biológicos no intuito de encaminhar para serviços de referências quando necessários.

\section{Referências bibliográficas}

BRASIL. Ministério da Saúde. Secretaria de Vigilância em Saúde. Departamento de Vigilância de Doenças Transmissíveis. Guia Prático sobre a Hanseníase. Brasília, DF, 2017.

COSTA, L. A.; BORBA-PINHEIRO, C. J.; REIS, J. H. dos; REIS JÚNIOR, S. H. dos. Análise da epidemiológica da hanseníase na Microrregião de Tucuruí, Amazônia Brasileira, com alto percentual de incapacidade física e de casos entre jovens. Rev. Pan-Amaz. Saúde. Ananindeua, v. 8, n.3, p. 9-17. 2017.

FREITAS, L. R. S.; DUARTE, E. C.; GARCIA, L. P. Trends of main indicators of leprosy in Brazilian municipalities with high risk of leprosy transmission, 2001-2012. BMC Infect Dis. Brasília, Brasil, 16:472, p. 1-10, september. 2016.

SOUSA, G. S. de; SILVA, R. L. F. da; XAVIER, M. B. Hanseníase e atenção primária à saúde: uma avaliação de estrutura do programa. Saúde em Debate, Rio de Janeiro, v. 41, n. 112, p. 230-242, jan./mar. 2017.

TAGLIETTI, M.; PERES, C. P. A. Exercise capacity and pulmonary function in individuals with leprosy. Fisioter mov, Curitiba, v. 27, n. 1, p. 29-38, jan./mar. 2014.

ZANELLA, L. F.; SOUSA, I. B. A. de; BARBOSA, M. dos S. B.; FACCENDA, O.; SIMIONATTO, S.; MARCHIORO, S. B. High detection rate of News of multibacillary leprosy in Mato Grosso do Sul, Brazil: an observational study from 2001-2005. Rev Inst Med Trop São Paulo. São Paulo, v. 60, e67, p 1-9. 2018.

PEREIRA, C. A. C. et al. Valores de referência para espirometria em uma amostra da população brasileira adulta. J. bras. Pneumol. v. 18, n.1, p. 10-22. 1992.

NEDER JA, ANDREONI S, LERARIO MC, NERY LE. Reference values for lung function tests. II. Maximal respiratory pressures and voluntary ventilation. Braz. J. Med. Biol. Ribeirão Preto, v.32, n, 6, p. 719-727. 1999.

Palavras chaves: Hanseníase; Teste de Caminhada; Sistema Nervoso Autônomo. Grande-área: Ciências Biológicas.

Área: Biológicas III. 


\title{
ANÁLISE FENOTÍPICA E MOLECULAR DE ISOLADOS DO COMPLEXO Mycobacterium avium ASSOCIADOS À CASOS DE DOENÇA PULMONAR NO ESTADO DO PARÁ
}

\author{
Nome do(a) bolsista: Kariny Veiga dos Santos \\ Nome do(a) Orientador(a): Ana Roberta Fusco da Costa
}

Introdução: $M$. avium e $M$. intracellulare são as espécies do complexo Mycobacterium avium de maior valor epidemiológico na doença pulmonar, indistinguíveis quanto ao aspecto clínico da doença sendo necessários métodos de diagnóstico molecular para identificação de espécies e subespécie No Brasil há poucos estudos sobre a prevalência da doença pulmonar causada por Micobactérias não Tuberculosas, porém os estudos que se propuseram a discutir este assunto relataram MAC como importante patógeno. Em pesquisas realizadas no Rio Grande do sul, Rio de Janeiro, Rondônia, São Paulo, Bahia e Pará foi relatado que as espécies mais isoladas de micobactérias não tuberculosas (MNT) eram $M$. avium e $M$. intracellulare.

Objetivos: Objetivo geral: Caracterizar genotipicamente os membros do complexo M. avium e investigar sua relação com os fenótipos clínicos na micobacteriose pulmonar em residentes do estado do Pará, Brasil. Objetivos específicos: Identificar as linhagens de MAC entre os isolados clínicos pulmonares investigados; Determinar o perfil de resistência antimicrobiana dos isolados de importância clínica; Descrever os fenótipos clínicos encontrados para as linhagens/genótipos caracterizados.

Material e método: Trata-se de uma pesquisa transversal, de abordagem quantitativa descritiva, com análise de isolados pulmonares do complexo M. avium provenientes de residentes do Estado do Pará, o estudo será composto por 50 amostras do período de 2014 a 2018 encaminhados para fins diagnósticos ao Instituto Evandro Chagas (IEC).

Resultados parciais: Foi realizada a caracterização de 29 amostras e as espécies encontradas foram: M. avium (37,93\%), M. intracellulare (37,93\%), M. colombiense $(10,34 \%)$ e $13,80 \%$ não foram classificadas ao nível de espécie. Um total de $27,58 \%$ foi resistente à claritromicina, $34,48 \%$ à amicacina, $79,31 \%$ ao moxifloxacino e $48,27 \%$ a linezolida. Os isolados de $M$. avium exibiram maior resistência aos antimicrobianos testados, em especial claritromicina, moxifloxacino e linezolida, enquanto a espécie $M$. intracellulare apresentou maior resistência a amicacina. Foi detectada pan-resistência em quatro isolados, de acordo com os critérios do Clinical and Laboratory Standards Institute - CLSI (2011)

Discussão: O MAC é o principal grupo de MNT associadas às infecções pulmonares, com variável diversidade genética e sensibilidade antimicrobiana. 
Atualmente, não há correlação bem estabelecida entre os resultados de sensibilidade antimicrobiana in vitro e desfechos clínicos, exceto para macrolídeos e amicacina que representam principais fármacos utilizados no esquema terapêutico da doença pulmonar por MAC.

Conclusão: Os resultados demonstram a necessidade de identificação dos isolados de MAC com a tipagem fenotípica da resistência aos antimicrobianos, de forma a auxiliar no tratamento, em busca de melhores desfechos clínicos.

Introdução: As micobactérias do complexo Mycobacterium avium (MAC) são microrganismos ambientais, causadores de infecções oportunistas, parasitas intracelulares, de crescimento lento, bacilo álcool-ácido resistente (BAAR), aeróbios, imóveis e hidrofóbicos, capacidade conferida por sua parede espessa rica em lipídios e ácidos micólicos que propiciam a formação de biofilme garantindo resistência a antibióticos, desinfetantes e metais pesados, além de facilitar sua aerossolização (Johnson \& Odell, 2014; Saldias et al., 2013). M. avium e M. intracellulare são as espécies do complexo Mycobacterium avium de maior valor epidemiológico na doença pulmonar, indistinguíveis quanto ao aspecto clínico da doença sendo necessário métodos de diagnóstico molecular para identificação de espécies e subespécie (Kobayashi, 2014). Em doenças causadas por MNT cerca de $\mathbf{8 0 \%}$ dos casos são originados por infecções causadas por MAC, com isolados de diferentes espécies em variados contextos geográficos (Busatto et al., 2019). No Brasil há poucos estudos sobre a prevalência da doença pulmonar causada por MNT, porém os estudos que se propuseram a discutir este assunto relataram MAC como importante patógeno (Carneiro et al., 2018). Em pesquisas realizadas no Rio Grande do sul, Rio de Janeiro, Rondônia, São Paulo, Bahia e Pará foi relatado que as espécies mais isoladas de MNT eram $M$. avium e $M$. intracellulare (Carneiro et al., 2018; Mello et al., 2013; Lima et al., 2013; Costa et al., 2013; Matos et al., 2004; Marques et al., 2019).

Objetivos: Objetivo geral: Caracterizar genotipicamente os membros do complexo M. avium e investigar sua relação com os fenótipos clínicos na micobacteriose pulmonar em residentes do estado do Pará, Brasil. Objetivos específicos: Identificar as linhagens de MAC entre os isolados clínicos pulmonares investigados; Determinar o perfil de resistência antimicrobiana dos isolados de importância clínica; Descrever os fenótipos clínicos encontrados para as linhagens/genótipos caracterizados.

Material e método: Trata-se de uma pesquisa transversal, de abordagem quantitativa descritiva, com análise de isolados pulmonares do MAC de residentes do Estado do Pará. Foram incluídas as amostras provenientes de espécimes clínicos de origem pulmonar, encaminhadas ao IEC/SVS/MS, no período de janeiro de 2014 a dezembro de 2018 que atenderam aos critérios diagnósticos de doença pulmonar por MNT sugeridos pela American Thoracic Society (ATS): cultura positiva em duas amostras diferentes de expectoração; ou uma cultura positiva por escovado ou lavado broncoalveolar (Griffith et al, 2007). Os dados clínico- 
epidemiológicos dos indivíduos do estudo serão obtidos a partir da análise das fichas de encaminhamentos dos pacientes ao laboratório. Os dados serão depositados em planilha eletrônica, sem identificação dos pacientes e protegida com senha. Dentre os ensaios laboratoriais, foi realizado o teste de sensibilidade pelo método de microdiluição em caldo, de acordo com as recomendações do CLSI (2011), cuja concentração inibitória mínima (CIM) foi determinada em microplacas comerciais Sensititre SLOMYCO (Thermofisher). Para extração de Ácido Desoxirribonucleico (DNA) foi utilizado o Kit Wizard SV Genomic DNA Purification System (Promega), seguindo as recomendações do fabricante. A caracterização das espécies e subespécies de MAC será baseada na análise

das sequências de inserção IS900, IS901 e IS1311, e elemento cromossômico DT1, conforme a descrição de Shin et al. (2010). A genotipagem dos isolados será realizada pela análise de VNTR (variable number tandem repeat loci) de acordo com protocolo descrito previamente (Inagaki et al., 2009). Os dados coletados serão tabulados em banco de dados Microsoft Excell ${ }^{\circledR} 2010^{\text {TM }}$ (Microsoft Corporation, Redmond, USA) e analisados por meio do software Graphpad Prism versão $5.0^{\mathrm{TM}}$ (Graphpad software, Inc., San Diego, USA). As variáveis categóricas serão expressas por meio de valores absolutos e percentagens (\%), e as variáveis contínuas, através de média e desvio padrão. Os testes Qui-quadrado e exato de Fisher serão utilizados para avaliar a prevalência de cada genótipo do Complexo $M$. avium entre as amostras do estudo, a prevalência da resistência antimicrobiana (sensível, intermediário e resistente) dentro de cada genótipo e entre os genótipos, bem como a prevalência das formas clínicas bronquiectásica e cavitária entre os grupos genotípicos do estudo e entre os grupos de resistência antimicrobiana. Será adotado o valor de $5 \%$ para significância estatística $(p \leq 0,05)$.

Resultados parciais: Foi realizada a caracterização de 29 amostras e as espécies encontradas foram: M. avium (37,93\%), M. intracellulare (37,93\%), M. colombiense $(10,34 \%)$ e $13,80 \%$ não foram classificadas ao nível de espécie. Um total de $27,58 \%$ foi resistente à claritromicina, 34,48\% à amicacina, $79,31 \%$ ao moxifloxacino e 48,27\% a linezolida. Os isolados de $M$. avium exibiram maior resistência aos antimicrobianos testados, em especial claritromicina, moxifloxacino e linezolida, enquanto a espécie $M$. intracellulare apresentou maior resistência a amicacina. Foi detectada pan-resistência em quatro isolados, de acordo com os critérios do Clinical and Laboratory Standards Institute - CLSI (2011).

Discussão: O MAC é o principal grupo de MNT associadas às infecções pulmonares, com variável diversidade genética e sensibilidade antimicrobiana (DALEY, 2017). Atualmente, não há correlação bem estabelecida entre os resultados de sensibilidade antimicrobiana in vitro e desfechos clínicos, exceto para macrolídeos e amicacina que representam principais fármacos utilizados no esquema terapêutico da doença pulmonar por MAC (GRIFFITH, 2018). No entanto, recomenda-se o teste de sensibilidade para linezolida e moxifloxacino, como possíveis alternativas no esquema terapêutico.

Conclusão: Os resultados demonstram a necessidade de identificação dos isolados de MAC com a tipagem fenotípica da resistência aos antimicrobianos, de 
forma a auxiliar no tratamento, em busca de melhores desfechos clínicos. Além disso, é importante a associação desses resultados com os genótipos de MAC e perfis clínicos dos pacientes, para investigação de padrões sobre a doença na região.

Referências: BUSATTO, C.; VIANNA, J.S.; SILVA, L.V.J.D.; RAMIS, I.B.; SILVA, P.E.A.D.

Mycobacterium Avium: an overview. Tuberculosis. 114: 127-134, 2019.

CARNEIRO, M.D.S.; NUNES, L.D.S.; DAVID, S.M.M.D.; DIAS, C.F.; BARTH, A.L.; U,G. Doença pulmonar por micobactérias não tuberculosas em uma região de alta incidência de tuberculose no Brasil. J Bras Pneumol.44(2): 108111, 2018.

COSTA, A.R.F.; FALKINHAM III, J.O.; LOPES, M.L.; BARRETTO, A.R.; FELICIO, J.S.; SALES, L.H.; BAHIA, J.R.C.; CONCEIÇÃO, E.C.; LIMA, K.V.B.

Occurrence of nontuberculous mycobacterial pulmonary infection in an endemic area of tuberculosis. PLoS Negl Trop Dis. 7(7): e2340, 2013.

DALEY, C.L. Mycobacterium avium Complex Disease. MicrobiolSpectrum. 5(2): 135, 2017.

GRIFFITH, D.E.; AKSAMIT, T.; BROWN-ELLIOTT B.A.; CATANZARO, A.; DALEY, C.; GORDIN, F.; HOLLAND, S.M.; HORSBURGH, R.; HUITT, G.; IADEMARCO, M.F.; ISEMAN, M.; OLIVIER, K.; RUOSS, S.; VON, R.C.F.;

WALLACE, R.J.J.; WINTHROP, K. An official ATS/IDSA statement: diagnosis, treatment, and prevention of nontuberculous mycobacterial diseases. Am J Respir Crit Care Med. 175(4): 367-416, 2007.

INAGAKI, T.; NISHIMORI, K.; YAGI, T.; ICHIKAWA, K.; MORIYAMA, M.; NAKAGAWA, T.; SHIBAYAMA, T.; UCHIYA, K.; NIKAI, T.; OGAWA, K.

Comparison of a variable-number tandem-repeat (VNTR) method for typing Mycobacterium avium with mycobacterial interspersed repetitive-unit-VNTR and IS1245 restriction fragment length polymorphism typing. J Clin Microbiol. 47(7): 2156-64, 2009.

JOHNSON, M. M.; ODELL, J.A. Nontuberculous Mycobacterial pulmonary infections. J Thorac Dis. 6(3): 210-220, 2014.

KOBAYASHI, K. Serodiagnosis of Mycobacterium avium Complex Disease in Humans: Translational Research from Basic Mycobacteriology to Clinical Medicine.

Jpn. J. Infect. Dis. 67: 329-332, 2014.

MATOS, E.D.; SANTANA, M.A.; SANTANA, M.C.; MAMEDE, P.; LIRA, B.B.; PANÃO, E.D.; FILHO,C.S.; LEMOS, A.C. Nontuberculosis mycobacteria at a multiresistant tuberculosis reference center in Bahia: clinical epidemiological Aspects. Braz J Infect Dis. 8(4): 296-304, 2004.

KWON, Y. S; KOH, W.J. Diagnosis and Treatment of Nontuberculous Mycobacterial 
Lung Disease. JKMS. Coréia, v. 31, p. 649-659, mai. 2016.; GRIFFITH, D.E. Treatment of Mycobacterium avium Complex (MAC). Semin Respir Crit Care Med. Estados Unidos, v. 39, n. 3, p. 351-361, ago. 2018.

LIMA, C.A.; GOMES, H.M.; OELEMANN, M.A.; RAMOS, J.P.; CALDAS, P.C.; CAMPOS, C.E.; PEREIRA, M.A.; MONTES, F.F; OLIVEIRA, M.D.S.; SUFFYS, P.N.; MOURA, M.M. Nontuberculous mycobacteria in respiratory samples from patients with pulmonary tuberculosis in the state of Rondônia, Brazil. Mem Inst Oswaldo Cruz. 108(4): 457-462, 2013.

MARQUES, L.R.M.; FERRAZOLI, L.; CHIMARA, E. Micobacterioses pulmonares: diagnóstico presuntivo pelos critérios microbiológicos internacionais adotados no estado de São Paulo, Brasil, 2011-2014. J Bras Pneumol. 45(2): 1-5, 2019.

MELLO K.G.; MELLO, F. C.; BORGA, L.; ROLLA, V.; DUARTE, R. S.; SAMPAIO, E.P.; HOLLAND, S.M.; PREVOTS, D.R.; DALCOLMO, M.P. Clinical and therapeutic features of pulmonary nontuberculous mycobacterial disease, Brazil, 1993-2011. Emerg Infect Dis. 19(3):393-399, 2013.

SHIN, S.J.; LEE, B.S.; KOH, W.J.; MANNING, E.J.; ANKLAM, K.;

SREEVATSAN, S.; LAMBRECHT, R.S.; COLLINS, M.T.; Efficient differentiation of Mycobacterium avium complex species and subspecies by use of five-target multiplex PCR. J Clin Microbiol. 48(11): 4057-62, 2010.

SALDIAS, F.P.; TIRAPEGUI, F;S.; DÍAZ, P.O. Infección pulmonar por Mycobacterium avium complex en el huésped inmunocompetente. Rev Chil Enf Respir. 29: 162-167, 2013.

Palavras-Chave: Mycobacterium avium; Pneumopatias; Testes de sensibilidade microbiana.

Grande-área: Ciências Biológicas

Área: Ciências Biológicas III 


\title{
INVESTIGAÇÃO DO VIROMA DE MARSUPIAIS E ROEDORES PROCEDENTES DO MUNICÍPIO DE PEIXE-BOI, PARÁ
}

\author{
Nome do(a) bolsista: Leonardo Henrique Almeida Hernández \\ Nome do(a) Orientador(a): Ana Cecília Ribeiro Cruz
}

Resumo: O Estado do Pará tem se mostrado como o que mais desmata em toda a Amazônia, tendo acumulado uma área que corresponde a 34\% de toda a Amazônia Legal desmatada entre 1988 e 2018. Peixe-Boi, no nordeste do Pará, encontra-se desmatado em mais de $80 \%$ de seu território. A redução dos limites entre populações humanas e de animais silvestres, sobretudo roedores e marsupiais, gera exposições que podem favorecer a transmissão de infecções de origem zoonótica, como as arboviroses e hantaviroses. Estudos metagenômicos permitem a varredura dos genomas presentes em qualquer tipo de amostra, servindo como método para o estudo do viroma de animais silvestres que vivem lado a lado de populações humanas. Objetiva-se identificar o viroma de marsupiais e roedores procedentes do município de Peixe-Boi via análise metageômica. Serão estudadas amostras de órgãos de 3 roedores e 13 marsupiais. Elas serão maceradas e, depois, terão o RNA total extraído. A qualidade e a quantidade do RNA serão mensuradas antes de prosseguir com a síntese da fita de cDNA e purificação da mesma. Purificado, o cDNA será utilizado para preparação da biblioteca genômica. Enfim, então, o material estará pronto para ser sequenciado através da plataforma NextSeq, Illumina. As leituras geradas pela plataforma serão montadas em contigs pelos programas metaSPAdes e IDBA-UD e as montagens de ambos serão alinhados entre si. A sequência consenso será alinhada contra as sequências de referência para vírus para filtração apenas das sequências virais presentes na amostra. Os genomas virais detectados e de interesse para o trabalho serão importados no programa Geneious Prime, para montagem dos contigs em scaffold. As sequências serão traduzidas e comparadas com um banco de proteínas para escolha do melhor modelo de substituição aminoacídica para construção da árvore filogenética, a ser montada pelo método de Máxima Verossimilhança por meio do pipeline RAxML, com bootstrap fixando em 1000 réplicas. Espera-se que o presente estudo contribua para o fortalecimento da vigilância de arbovírus e outros vírus causadores de epizootias em marsupiais e roedores na região amazônica.

Introdução: Dados disponibilizados pelo Instituto Nacional de Pesquisas Espaciais (INPE) indicam que a Amazônia Legal, que se estende por uma área de 5.217.423 $\mathrm{km}^{2}$, tem apresentado taxas de desmatamento reduzidas em comparação às últimas três décadas. No entanto, a perda de vegetação ainda é considerável, gerando impactos irreparáveis à vida animal e vegetal. Estimativas indicam que no ano de 2018 houve desflorestamento de uma área de $7.536 \mathrm{~km}^{2}$, um aumento de quase 8\% em relação ao ano anterior (INPE, 2019a).O Estado do Pará, segundo maior do 
Brasil e que abriga a região amazônica em cada canto de seu território, tem se mostrado como o que mais desmata em todo o Brasil, tendo acumulado uma área desflorestada de $148.303 \mathrm{~km}^{2}$, o que corresponde a 34\% de toda a Amazônia Legal desmatada entre 1988 e 2018 (INPE, 2019a).

Dentro do Estado do Pará, o município de Peixe-Boi - localizado no Nordeste do Estado, a 157 km de Belém -, mostra-se como um dos municípios com menos áreas preservadas em proporção ao tamanho de seu território. Até o ano de 2018, 80,11\% $\left(363,7 \mathrm{~km}^{2}\right)$ da área total $\left(454 \mathrm{~km}^{2}\right)$ do município encontrava-se desmatada, existindo apenas $62,1 \mathrm{~km}^{2}$ (13,68\% do território) de floresta sobrevivendo em meio à antropização da localidade (INPE, 2019b).

O desmatamento associado a todos os seus fatores socioeconômicos contribui para a redução dos limites entre as populações humanas e os animais residentes nas áreas florestais. Com seus habitats destruídos e nichos ecológicos afetados, os animais, a exemplo de pequenos mamíferos como marsupiais e roedores, invadem áreas urbanas em busca de comida e abrigo, gerando uma exposição que pode garantir a transmissão de infecções de origem zoonótica (Mesquita et al., 2018).

Segundo Vasconcelos e Calisher (2016), 60\% das doenças infecciosas emergentes identificadas desde 1940 consistem em zoonoses. A maior parte destas zoonoses são causadas por vírus e se originaram dentro das florestas, nas quais já se encontram bem determinadas dentro de um ciclo silvestre. Ao adentrar áreas de mata, o homem pode interferir no ciclo e atuar, inicialmente, como hospedeiro acidental destas infecções - como as por arbovírus, arenavírus e hantavírus -, resultando em casos isolados ou surtos na região.

Neste contexto, a estratégia da realização de estudos ecoepidemiológicos em áreas de fragmentos florestais entremeados a populações humanas mostra-se como essencial para realizar a vigilância de epizootias - inclusive de zoonoses emergentes - que podem vir a ameaçar a saúde pública e gerar impactos socioambientais (Antonhy et al., 2013).

A análise metagenômica, apesar de ainda não consistir em uma metodologia muito acessível por se basear no sequenciamento de nova geração, mostra-se como uma boa e confiável ferramenta de investigação de genomas, realizando uma varredura dos fragmentos de material genético presente em amostras do ambiente - água, solo ou sedimento - e biológicas - como amostras de soro, sangue e tecido, que são o foco deste trabalho (Simon; Daniel, 2009). Seria, portanto, um método adequado para a realização do estudo ecoepidemiológico em questão.

Objetivo: Identificar o viroma de marsupiais e roedores procedentes do município de Peixe-Boi, Pará, via análise metagenômica, correlacionando os achados de acordo com a espécie de origem da amostra.

Material e Método:Trata-se de um estudo observacional, analítico e transversal, visto que será estudada a distribuição de uma variável (infecção por vírus de RNA) em populações de roedores e marsupiais cujas amostras (definidas pela captura aleatória) foram coletadas em instantes temporais específicos.

As amostras de estudo foram coletadas em Vila Ananin e arredores, no município de Peixe-Boi, localizado na microrregião Bragantina, mesorregião do Nordeste 
Paraense. O município foi escolhido para o estudo por conta da alta taxa de desmatamento (INPE, 2019b). Dentro do município foram selecionadas áreas que possuíssem pelo menos seis hectares de mata e que, por conseguinte, fossem vizinhas de comunidades humanas. Chegou-se, por fim, à área vizinha a da comunidade de Vila Ananin.

Comporão o grupo de amostras a serem analisadas, órgãos de 16 pequenos mamíferos, sendo três roedores e treze marsupiais, coletados pela equipe técnica da Seção de Arbovirologia e Febres Hemorrágicas (SAARB) do Instituto Evandro Chagas (IEC) durante o projeto Pró-Amazônia. As coletas foram realizadas em duas expedições: uma em setembro de 2015 (época de seca) e em maio de 2016 (época chuvosa), durante períodos de dez dias. As armadilhas para captura dos animais foram dispostas em dois pontos: borda da mata e dentro da mata.

Como critérios de inclusão, listam-se a localização da amostra na soroteca da SAARB, a disponibilidade de volume suficiente para a realização da extração de RNA e a qualidade do RNA extraído e, também, do cDNA analisado na preparação da biblioteca genômica. Excluir-se-ão amostras não encontradas, insuficientes e com fragmentos de RNA e cDNA de má qualidade.

As amostras terão seu RNA total extraído a partir do uso do kit comercial Maxwell 16 LEV simplyRNA Tissue kit. Um fragmento de cerca de $5 \mathrm{mg}$ de tecido de cada amostra de órgãos será colocado em microtubos de $2 \mathrm{ml}$, estéreis. Serão acrescidos $350 \mu \mathrm{l}$ do tampão de homogeneização e uma esfera de tungstênio de $3 \mathrm{~mm}$ de diâmetro. A mistura será macerada no equipamento TissueLyser II (Qiagen) a $25 \mathrm{~Hz}$ por 1 minuto. Após a maceração, a extração seguirá com o uso do sistema de extração automatizado Maxwe//® 16 (Promega) de acordo com as instruções de preparo do fabricante.

Após a extração, o RNA total será quantificado com o equipamento Qubit ${ }^{\circledR} 2.0$ Fluorometer (Invitrogen) - a partir do kit Qubit ${ }^{\circ}$ RNA HS Assay - e Bioanalyzer 2100 (Agilent Technologies) - a partir do kit Agilent RNA 6000 Pico -, seguindo o protocolo do fabricante, respectivamente. Em seguida, o RNA será armazenado à $80^{\circ} \mathrm{C}$ até a realização da etapa seguinte.

O RNA extraído seguirá para a etapa de síntese de DNA complementar (cDNA). Ela será realizada a partir do kit cDNA Synthesis System (Roche Diagnostics) e de iniciador randômico, seguindo as instruções do fabricante. O cDNA, então, será purificado com o auxílio de esferas magnéticas AMPure bead, que o separa do restante da reação.

O cDNA purificado será utilizado na preparação da biblioteca genômica (coleção de fragmentos tagmentados e que são aderidos a adaptadores em cada extremidade) empregando a metodologia descrita pelo kit Nextera XT DNA Library Preparation (Illumina). Antes do sequenciamento o produto da biblioteca será avaliado em uma etapa de checagem, quanto a sua qualidade e quantidade.

A quantidade de moléculas de cDNA será estimada usando o equipamento Qubit ${ }$ 2.0 Fluorometer e o kit Qubit ${ }^{\circledR}$ dsDNA HS Assay Kits. O tamanho dos fragmentos produzidos na biblioteca será observado usando o kit High Sensitivity DNA Analysis kits (Agilent Technologies) e o equipamento Bioanalyzer 2100 (Agilent Technologies). Com a constatação de que a biblioteca contém quantidade e tamanho desejáveis de fragmentos, o sequenciamento será realizado utilizando a 
metodologia de síntese através da plataforma NextSeq (Illumina) com a utilização do kit NextSeq 500/550 Mid Output (300 ciclos) (Illumina) de acordo com as instruções do fabricante.

Os dados gerados pelo NextSeq (Illumina) em formato .bcl serão transformados em formato .fastq usando o programa bcl2fastq2, resultando, assim, em no mínimo dois arquivos, R1 e R2, que serão concatenados em um único arquivo. Este servirá de entrada para os programas de processamento de dados. Posteriormente, serão utilizados os programas metaSPAdes (Bankevich et al., 2012) e IDBA-UD (Peng et al., 2012) para montagem das leituras brutas. Os arquivos de saída de ambos, que contam com as leituras organizadas em contigs, serão alinhados no programa Lasergene Molecular Biology, unidos por merge, retirando-se a redundância e extraindo-se a sequência consenso.

$\mathrm{O}$ arquivo unido contendo contigs das montagens, será alinhado junto às sequências de referência para vírus disponíveis no banco de dados do RefSeq usando o programa DIAMOND (Buchfink; Xie; Huson, 2015). O produto do alinhamento será, então, importado em formato .daa para o programa MEGAN6 (Huson et al., 2007) para visualização dos contigs que apresentarem correspondência com algum genoma viral já descrito e depositado no banco de dados. A mesma visualização no MEGAN6 também será feita diretamente do arquivo de dados brutos, também alinhados no DIAMOND, apenas para verificar a presença de possíveis leituras para vírus que não foram montados pelo SPAdes e IDBA-UD.

No MEGAN6, os contigs que apresentarem identidade com algum grupo viral conhecido (segundo as sequências de referência) serão extraídos e exportados para o programa Geneious Prime 2019 para que possam ser ordenados (scaffolding) de acordo com um genoma de referência (map to reference). Este tipo de alinhamento baseado em referência também nos permitirá observar regiões de $\mathrm{N}$ (gaps), que poderão ser estendidos a partir de interações múltiplas contra as leituras brutas.

Todos as sequências acuradas manualmente serão traduzidas no próprio Geneious Prime 2019 e comparadas no banco de dados de proteínas Swiss-Prot, que consiste em uma base fidedigna que fornece um elevado nível de anotação de proteínas, mínima redundância e alto grau de integração com outras bases (Bairoch; Apweiler, 2000).

Para realizar a seleção estatística do melhor modelo de substituição aminoacídica que será aplicado na análise filogenética, será utilizado o programa ProtTest v.3 (Darriba et al., 2012). Posteriormente será empregada a metodologia de estimação de Máxima Verossimilhança (MV) por meio do pipeline RAxML (Randomized Axelerated Maximum Likelihood) utilizado para a construção da árvore filogenética (Stamatakis, 2014). No processo de construção, será feito o uso do teste estatístico de bootstrap, fixando-se 1000 réplicas para testar o grau de confiabilidade das árvores agrupadas na árvore consenso (Felsenstein, 1985).

Resultados esperados: Espera-se que o presente estudo contribua para a identificação da circulação de vírus em hospedeiros vertebrados provenientes do município de Peixe-Boi, Pará. Além de fortalecer a vigilância de arbovírus e outros vírus causadores de epizootias em vertebrados não voadores na região amazônica, 
o estudo pode contribuir para a detecção de vírus ainda não descritos na região e novas espécies virais.

\section{Referências bibliográficas:}

- ANTHONY, S. J. et al. A strategy to estimate unknown viral diversity in mammals. mBio, [s.I.], v. 4, n. 5, set. 2013.

- BAIROCH, A; APWEILER, R. The SWISS-PROT protein sequence database and its supplement TrEMBL in 2000. Nucleic Acids Research, [s.I.], v. 28, n. 1, p. 4548,2000 .

- BANKEVICH, A. et al. SPAdes: a new genome assembly algorithm and its applications to single-cell sequencing. Journal of Computational Biology, Nova Rochelle, v. 5, p. 455-477, 2012.

- BUCHFINK, B.; XIE, C.; HUSON, D. H. Fast and sensitive protein alignment using DIAMOND. Nature Methods, Nova lorque v. 12, n. 1, p. 59-60, 2015.

- DARRIBA, D. et al. jModelTest 2: more models, new heuristics and parallel computing.Nature Methods, Nova Iorque, v. 9, n. 8, p. 772-772, 2012.

- FELSENSTEIN, Joseph. Confidence limits on phylogenies: an approach using the bootstrap. Evolution, Hoboken, v. 39, n. 4, p. 783-791, 1985.

- HUSON, D. H. et al. MEGAN analysis of metagenomic data. Genome research, Woodbury, v. 17, n. 3, p. 377-386, 2007.

- INSTITUTO BRASILEIRO DE GEOGRAFIA E ESTATístICA. IBGE. Peixe-Boi: histórico. Disponível em: https://cidades.ibge.gov.br/brasil/pa/peixe-boi/historico. Acesso em: 01 set. 2019b.

- INSTITUTO NACIONAL DE PESQUISAS ESPACIAIS. INPE. TerraBrasilis:

Desmatamento. Projeto PRODES. Disponível em:
http://terrabrasilis.dpi.inpe.br/app/dashboard/deforestation/biomes/legal_amazon/r ates. Acesso em: 01 set. 2019a.

- INSTITUTO NACIONAL DE PESQUISAS ESPACIAIS. INPE. Desflorestamento nos municípios da Amazônia Legal para o ano de 2017. Projeto PRODES. Disponível em: http://www.dpi.inpe.br/prodesdigital/prodesmunicipal.php. Acesso em: 01 set. $2019 b$.

- MESQUITA, G. S. S. et al. Detection of antibodies against Leptospira spp in freeliving marsupials caught in the Eastern Amazon. Revista da Socidade Brasileira de Medicina Tropical, Uberaba, v. 51, n. 3, p. 368-371, maio/jun. 2018.

- PENG, Y. et al. IDBA-UD: a de novo assembler for single-cell and metagenomic sequencing data with highly uneven depth. Bioinformatics, [s.I.], v. 28, n. 11, p. 1420-1428, 2012.

- SIMON, C; DANIEL, R. Achievements and new knowledge unraveled by metagenomic approaches. Applied Microbiology and Biotechnology, [s.I.], v. 85, n. 2, p. 265-276, nov. 2009.

- STAMATAKIS, Alexandros. RAXML version 8: a tool for phylogenetic analysis and post-analysis of large phylogenies. Bioinformatics, [s.I.], v. 30, n. 9, p. 13121313, 2014. 
- VASCONCELOS, P. F. C.; CALISHER, C. H. Emergence of human arboviral diseases in the Americas, 2000-2016. Vector-borne and zoonotic diseases, Nova Rochelle, v. 16, n. 5, p. 295-301, maio 2016.

Palavras-chave: Marsupiais, metagenômica, roedores, viroma.

Grande-Área: Ciências Biológicas

Área: Ciências Biológicas III 
INFECÇÃO EXPERIMENTAL DE West Nile virus EM Culex quinquefasciatus, SAY 1823

Nome do(a) Bolsista: Lúcia Aline Moura Reis

Nome do(a) Orientador(a): Joaquim Pinto Nunes Neto

Introdução: O West Nile virus (WNV) é um arbovirus neurotrópico transmitido por mosquitos do gênero Culex, em seu ciclo de transmissão as aves silvestres atuam como hospedeiros naturais e os mamíferos como hospedeiros acidentais. No Brasil, o primeiro caso humano ocorreu em 2014 no estado do Piauí e seu primeiro isolamento ocorreu em 2018 de amostra de cérebro de equino proveniente do Espírito Santo. O estudo objetivou avaliar a susceptibilidade do Culex quinquefasciatus a infecção pelo WNV isolado no Brasil.

Metodologia: Utilizou-se 150 fêmeas para a alimentação oral infectante contendo a cepa (VNOBEAN 854747) de WNV a um título de $1,42 \times 10^{8} \mathrm{PFU} / \mathrm{mL}$ e a uma proporção de $1,5 \mathrm{~mL}$ de vírus para $3,0 \mathrm{~mL}$ de sangue de carneiro desfibrinado. Ao final, as fêmeas ingurgitadas $(n=85)$ foram separadas em gaiola entomológica e segmentadas em lotes de cabeça e corpo em $7^{\circ}, 14^{\circ}$ e $21^{\circ}$ dias de pós-infecção (dpi), seguido de maceração e inoculação em células $\mathrm{C}_{6 / 36}$ e analise por técnica de Isolamento Viral.

Resultados: Os lotes de cabeça do $7^{\circ} \mathrm{dpi}$ apresentaram resultado negativo e os de corpo resultado positivos. Das amostras do $14^{\circ}$ dpi apenas um lote de cabeça e todos os lotes de corpo apresentaram positividade. Todos os lotes de cabeça e corpo do $21^{\circ}$ dpi apresentaram resultado positivo.

Conclusão: O Cx. quinquefasciatus da região metropolitana de Belém é susceptível a infecção artificial com WNV, fazendo-se necessário estudos mais detalhados em regiões anatômicas como intestino médio, glândula salivar e saliva para caracterizalo como possível vetor para transmissão do WNV no Brasil.

Introdução: O arbovirus West Nile virus (WNV) caracteriza-se como um patógeno neurotrópico causador da febre do Nilo Ocidental e de encefalites. É um flavivírus transmitido por mosquitos, principalmente do gênero Culex, cujo RNA possui sentido positivo, de cadeia simples (Colpitts et al. 2012; CDC, 2002).

Foi isolado pela primeira vem em 1937 de um caso humano no distrito de West Nile na Uganda e em 1999 uma cepa encontrada na Tunísia e em Israel foi introduzida no Hemisfério Ocidental, na cidade de Nova York, levando a um alto número de óbitos de humanos, aves e equinos por encefalite e desde então o vírus dispersouse por outros países como Canadá, México, Caribe e Venezuela (Arjona et al., 2011; WHO, 2017).

Muitos mosquitos foram identificados portando o vírus, contudo, mosquitos do gênero Culex são atualmente aceitos como os principais vetores de WNV, dentre eles o Cx. pipiens e Cx. quinquefasciatus (WHO, 2017). 
A espécie $C x$. quinquefasciatus é principalmente encontrada em países de clima tropical, sendo amplamente adaptada ao ambiente urbano, com atividade de hematofagia realizada noturna e as fêmeas realizam sua oiposição em pequenas coleções de água estagnada contendo alto teor de matéria orgânica, tornando assim tal espécie resistente a efeitos da poluição da água nos grandes centros urbanos (Andreadis, 2012; Zittra et al., 2016).

O Cx. quinquefasciatus possui quatro fases de desenvolvimento, a fase de ovo, quatro estadiamentos larvais, fase de pupa e fase alada (adulto). Seus ovos apresentam formato alongado e são ovipostos na superfície das coleções de água em formato de jangada, as formas larvais alimentam-se da matéria orgânica presente na água, além de nesse período realizarem o armazenamento dos nutrientes necessários a maturação do exoesqueleto na fase de pupa e início da fase adulta (Brasil, 2011).

Tais artrópodes possuem seu tubo digestivo subdividido em três regiões, intestino anterior, médio e posterior. Na região do intestino anterior ocorre o processo de ingestão do alimento, condução e armazenamento, o intestino médio é responsável por realizar grande parte do processo de digestão, no qual ocorrem a absorção de nutrientes e secreção de enzimas digestivas e o intestino posterior, por sua vez, realiza o processo de excreção dos resíduos da digestão (Bolognesi \& Terra, 2005; Silva et al., 2012).

Desse modo, os mosquitos possuem em sua anatomia diversos métodos de proteção, dentre eles há a barreira de infecção do intestino médio (MIB) que tem por finalidade evitar que os patógenos infectem as células epiteliais mesenteronais, a barreira de escape do intestino médio (MBE) que busca impedir que o agente invasor atravesse a lâmina basal do mesentério adentrando a hemocele, meio este propicio para a multiplicação das partículas virais e a barreira de infecção da glândula salivar tem a função de impedir a entrada dos patógenos na glândula salivar e posterior saída para a luz da glândula (Amaral \& Dansa-Petretski, 2012; Souza-Neto et al., 2019).

Assim, a competência vetorial define-se como a capacidade de um vetor em infectarse com um patógeno (susceptibilidade a infecção), mantê-lo em multiplicação pelos tecidos (período de incubação extrínseco - PIE) e transmiti-lo a partir de uma alta viremia nas glândulas salivares e na saliva (Colpitts et al., 2012; Vogels et al., 2017).

Objetivo: A presente pesquisa objetivou avaliar a susceptibilidade do $C x$. quinquefasciatus a infecção pelo WNV isolado no Brasil.

Material e Método: A infecção foi realizada no Laboratório de Entomologia Médica do IEC, a alíquota viral foi cedida pelo Laboratório de Cultura de Células da SAARB (cepa: VNO BE AN 854747) e o sangue de carneiro desfibrinado foi cedido pelo Biotério do IEC.

Foram utilizadas 150 fêmeas de $C x$. quinquefasciatus da geração F3 ( $1^{\circ}$ coleta) com idade entre cinco a 10 dias. A fonte de glicose foi suspensa por um período de 24 horas antes do início do experimento e as fêmeas permaneceram expostas ao sangue infectado por um período de 50 minutos. A suspensão sangue/vírus foi 
preparada a uma proporção de $3 \mathrm{~mL}$ de vírus para 1,5 $\mathrm{mL}$ de sangue de carneiro desfibrinado $(3: 1,5)$.

Ao final desse período, um total de 85 fêmeas ingurgitadas foram separadas e transferidas para gaiola dupla e as 64 fêmeas não ingurgitadas foram congeladas em freezer a -20C por 24 horas, em seguida foram descartadas em lixo infectante.

A segmentação das fêmeas foi realizada no $7^{\circ}, 14^{\circ}$ e $21^{\circ}$ dia de pós-infecção (dpi), sendo observado no $6^{\circ}$ dpi a morte de três fêmeas, totalizando na gaiola 82 fêmeas vivas. Desse modo, montou-se lotes de cabeça (CA) e corpo (CO), cada lote contendo nove amostras de cabeça ou corpo.

Para o isolamento viral em cultura de células, os lotes de mosquitos foram macerados com auxílio do equipamento TissueLyser, de acordo com o protocolo do Laboratório de Cultivo celular baseado na metodologia estabelecida por Kim et al. (2009).

Após a maceração, as amostras foram transferidas para o freezer -70C por um período de 24 horas, em seguida foram inoculadas em cultura de células do clone $\mathrm{C}_{6 / 36}$ provenientes de Aedes albopictus. Após a inoculação, acompanhou-se diariamente por sete dias a ocorrência de efeito citopático (ECP), as amostras foram colhidas para realização do teste de Imunofluorescência Indireta (IFI).

Resultado e Discussão: Com base nos resultados obtidos a partir dos testes de isolamento viral e IFI, identificou-se que $100 \%$ dos lotes de corpo do $7^{\circ}, 14^{\circ}$ e $21^{\circ}$ dias de pós-infecção (dpi) apresentaram positividade para a infecção pelo WNV.

Para as amostras de cabeça, aplicou-se o teste estatístico do Qui-quadrado, utilizando o aplicativo BioEstat 5.0, com nível de significância de $\alpha=0,05$. Para as amostras de corpo, assumiu-se como $\mathrm{H}_{0}$ (hipótese nula) que o WNV não ultrapassa as barreiras do organismo, não disseminando-se pelo corpo até a região da cabeça e como $\mathrm{H}_{1}$ (hipótese alternativa), o WNV possui a capacidade de romper as barreiras do organismo do mosquito, disseminando-se pelo organismo do mosquito, até chegar na região da cabeça.

Ao aplicar-se o teste do Qui-quadrado, obtém-se um valor de $p=0,075$ ou seja $p \geq \alpha$, desse modo, então rejeita-se a hipótese $\mathrm{H}_{0}$ e aceita-se a hipótese $\mathrm{H}_{1}$ de que o WNV possui a capacidade de romper as barreiras do organismo do mosquito, disseminando-se pelo organismo do mosquito, até chegar na região da cabeça.

Em estudo similar realizado por Richards et al. (2014) de avaliação da competência vetorial de mosquitos $C x$. quinquefasciatus para isolados de WNV da Flórida demonstrou altas taxa de infecção e disseminação (95\%) e baixas taxas de transmissão. Dados esses que assemelham-se aos encontrados por Kent et al. (2010) no qual a taxa de infecção foi de 100\%, de disseminação de $98 \%$ e $69 \%$ de transmissão.

Girard et al. (2004) em estudo realizado objetivando identificar os tecidos e organismos os quais o WNV possui maior tropismo, verificou a persistência do vírus em diversos tecidos como intestino médio, glândula salivar e sistema nervo mesmo após 27 dias de pós-infecção, havendo apenas um declínio nas células epiteliais do intestino médio, demonstrando assim que o vírus possui alta capacidade de disseminação e que por manter-se no organismo do mosquito por um longo período, possibilita sua transmissão a diversos hospedeiros. 
Conclusão: A partir da análise dos resultados obtidos no isolamento viral em cultura de células, pôde-se concluir que a espécie $C x$. quinquefasciatus criada em laboratório, caracteriza-se como um provável vetor competente para a transmissão do West Nile virus, confirmando a dinâmica do vírus no organismo do mosquito e evidenciando que o WNV possui mecanismos que o permitem ultrapassar as barreiras físicas e imunológicas do hospedeiro disseminando-se assim por todo o corpo do mosquito.

Contudo, destaca-se a necessidade de testes mais detalhados em regiões anatômicas específicas, como intestino médio, glândula salivar e saliva, para confirmação da infecção, disseminação e transmissão do vírus pelo mosquito vetor.

Agências Financiadoras: Instituto Evandro Chagas (IEC), Universidade do Estado do Pará (UEPA), Coordenação de Aperfeiçoamento de Pessoal de Nível Superior (CAPES), Conselho Nacional de Desenvolvimento Científico e Tecnológico (CNPq)

Referências: AMARAL, R. J. V.; DANSA-PETRETSKI, M. Interação Patógeno-Vetor: Dengue. In: INSTITUTO NACIONAL DE ClêNCIA E TECNOLOGIA EM ENTOMOLOGIA MOLECULAR (Rio de Aneiro). Universidade Federal do Rio de Janeiro. Topicos Avançados em Entomologia Molecular: Instituto Nacional de Ciência e Tecnologia em Entomologia Molecular. Rio de Aneiro: Itabajara da Silva Vaz Junior, 2012. Cap. 14. P. 1-35. Disponível em: <http://www.inctem.bioqmed.ufrj.br/images/documentos/biblioteca/Capitulo_14_Inter acao_Patogeno_Vetor_-_Dengue.pdf>. Acesso em: 26 set. 2019.

ANDREADIS, T. G. The Contribution of Culex pipiens Complex Mosquitoes to Transmission and Persistence of West Nile virus in North America. Journal Of The American Mosquito Control Association, [s.I.], v. 28, n. 4, p.137-151, dez. 2012. The American Mosquito Control Association. Disponível em: <http://dx.doi.org/10.2987/8756-971x-28.4s.137>. Acesso em: 13 out. 2019.

BOLOGNESI, R.; TERRA, C. F. Síntese, degradação e funções da membrana peritrófica dos insetos. 2005. 172f. Tese (Doutorado) - Curso de Bioquímica, Instituto de Química, Universidade de São Paulo, São Paulo, 2005. Disponível em: <10.11606/T.46.2005.tde-23072007-111911>. Acesso em: 18 jun. 2019.

BRASIL. Ministério da Saúde. Secretaria de Vigilância em Saúde. Departamento de Vigilância Epidemiológica. Guia de vigilância do Culex quinquefasciatus / Ministério da Saúde, Secretaria de Vigilância em Saúde, Departamento de Vigilância Epidemiológica, Coordenação Francisco Anilton Alves Araújo, Marcelo Santalucia. $3^{a}$ ed. - Brasília: Ministério da Saúde, 2011. 76 p.: il. - (Série A. Normas e manuais técnicos).

em: $<$ http://bvsms.saude.gov.br/bvs/publicacoes/guia vigilancia culex quinquefasciatus. pdf>. Acesso em: 30 out. 2019. 
COLPITTS, T. M. et al. West Nile virus: Biology, Transmission, and Human Infection. Clinical Microbiology Reviews, [s.I.], v. 25, n. 4, p.635-648, 1 out. 2012. American Society for Microbiology. Disponível em: <http://dx.doi.org/10.1128/cmr.00045-12>. Acesso em: 24 fev. 2019.

CENTERS FOR DISEASE CONTROL AND PREVENTION - CDC. 2002. Laboratoryacquired West Nile virus infections-United States, 2002. MMWR Morb. Mortal. Wkly. Rep. 51:1133-1135. Disponível em: <https://www.cdc.gov/mmwr/preview/mmwrhtml/mm5150a2.htm>. Acesso em: 25 fev. 2019.

GIRARD, Y. A.; KLINGLER, K. A.; HIGGS, S. West Nile virus Dissemination and Tissue Tropisms in Orally Infected Culex pipiens quinquefasciatus. Vector-borne And Zoonotic Diseases, [s.I.], v. 4, n. 2, p.109-122, jun. 2004. Mary Ann Liebert Inc. Disponível em: <http://dx.doi.org/10.1089/1530366041210729>. Acesso em: 02 set. 2019.

KENT, R. J.; CRABTREE, M. B.; MILLER, B. R. Transmission of West Nile virus by Culex quinquefasciatus Say Infected with Culex Flavivirus Izabal. Plos Neglected Tropical Diseases, [s.I.], v. 4, n. 5, p.1-13, 2010. Public Library of Science (PIoS). Disponível em: <http://dx.doi.org/10.1371/journal.pntd.0000671>. Acesso em: 03 jun. 2019.

RICHARDS, S. L.; ANDERSON, S. L.; LORD, C. C. Vector competence ofCulex pipiens quinquefasciatus (Diptera: Culicidae) for West Nile virus isolates from Florida. Tropical Medicine \& International Health, [s.I.], v. 19, n. 5, p.610-617, 12 fev. 2014. Wiley. Disponível em: <http://dx.doi.org/10.1111/tmi.12277>. Acesso em: 02 set. 2019.

SILVA, C. P.; LEMOS, F. J. A.; SILVA, J. R. Digestão em Insetos. In: SILVA NETO, M. A. C (Rio de Janeiro). Instituto Nacional de Ciência e Tecnologia em Entomologia Molecular. Tópicos Avançados em Entomologia Molecular.Rio de Janeiro: Universidade Federal do Rio de Janeiro, 2012. Cap. 5. P. 1-32. Disponível em: <http://www.inctem.bioqmed.ufrj.br/images/documentos/biblioteca/Capitulo_5_Digest ao_em_Insetos.pdf>. Acesso em: 18 jun. 2019.

SOUZA-NETO, J. A.; POWELL, J. R.; BONIZZONI, M. Aedes aegypti vector competence studies: A review. Infection, Genetics and Evolution, [s.I.], v. 67, p.191-209, jan. 2019. Elsevier BV. Disponível em: <http://dx.doi.org/10.1016/j.meegid.2018.11.009>. Acesso em: 06 mar. 2019.

VOGELS, C. B. F. et al. Vector competence of northern European Culex pipiens biotypes and hybrids for West Nile virus is differentially affected by temperature. Parasites \& Vectors, [s.I.], v. 9, n. 1, p.1-7, 7 jul. 2016. Springer Science and Business Media LLC. Disponível em: <http://dx.doi.org/10.1186/s13071016-1677-0>. Acesso em: 11 jun. 2019. 
WORLD HEALTH ORGANIZATION - WHO. West Nile virus. 2017. Disponível em: <https://www.who.int/news-room/fact-sheets/detail/west-nile-virus >. Acesso em: 06 mar. 2019.

ZITTRA, C. et al. Ecological characterization and molecular differentiation of Culex pipiens complex taxa and Culex torrentium in eastern Austria. Parasites \& Vectors, [s.l.], v. 9, n. 1, p.1-9, 11 abr. 2016. Springer Science and Business Media LLC. Disponível em: <http://dx.doi.org/10.1186/s13071-016-1495-4>. Acesso em: 15 out. 2019.

Palavras-chave: Competência Vetorial; Infecção Experimental; Culex quinquefasciatus; West Nile virus.

Grande-área: Zoologia

Área: Entomologia 


\section{ASPECTOS EPIDEMIOLÓGICOS DA MALÁRIA NO MUNICÍPIO DE TUCURUÍ- PA.}

Nome do(a) bolsista: Maira Cibelle da Silva Peixoto

Nome do(a) orientador(a): Nelson Veiga Gonçalves

Resumo: A malária é uma doença infecciosa, considerada a principal doença parasitária endêmica do mundo. Na Região Amazônica coexistem fatores que favorecem a manutenção de altos índices, nesse cenário, o município de Tucuruí sofreu grandes alterações socioambientais em seu território. O objetivo deste estudo é descrever aspectos epidemiológicos dos casos notificados de malária no município de Tucuruí, Pará, no período de janeiro de 2014 a dezembro de 2018. Estudo transversal e descritivo com o uso de dados do Sistema de Informação da Vigilância Epidemiológica da Malária. Foram analisadas as variáveis epidemiológicas e clínicas. A análise estatística foi realizada com auxílio do programa Bioestat 5.0 e calculado o indicador epidemiológico de prevalência anual. A análise evidenciou maior percentual de casos em indivíduos do sexo masculino $(65,3 \%)$, faixa etária de 19 a 59 anos (49,6\%), raça/etnia parda (88,8\%), escolaridade ensino fundamental $(73,0 \%)$ e ocupação doméstica (41,9\%), provável local de infecção a zona rural $(91,2 \%)$, o exame diagnóstico foi a gota espessa/esfregaço $(99,9 \%)$ e o Plasmodium vivax a espécie de maior ocorrência $(99,8 \%)$. Foi verificado um agravamento no quadro epidemiológico da malária em Tucuruí se caracterizando como grande problema de saúde pública.

Introdução: A malária é uma doença infecciosa febril aguda produzida por espécies de protozoários unicelulares pertencentes ao gênero Plasmodium e transmitida pela picada da fêmea de mosquitos gênero Anopheles quando infectada pelo Plasmodium spp. (BRASIL, 2019). Esse agravo é considerado a principal doença parasitária endêmica do mundo, estando presente nos países tropicais e subtropicais, eengloba o grupo das cinco doenças infecciosas responsável por maior mortalidade (VERONESI, 2015).

No Brasil a malária, desde a década de 1960, apresenta diminuição no número de casos, estando 99,7\% concentrados na Região Amazônica (SOUSA, et al., 2018). A integração das ações de controle da malária foi responsável por muitos avanços para diminuição da incidência de casos. Entretanto na Região Amazônica coexistem fatores que favorecem a manutenção de altos índices da doença.

Nesse contexto, o município de Tucuruí que sofreu grandes alterações socioambientais devido a diferentes atividades antrópicas ocorridas em seu território, entre as quais, a construção de barragens e urbanização crescente, é caracterizada como de alto risco para malária, pela existência de áreas de floresta e grupos de risco

em constante movimento, fatores que favorecem a transmissão da doença mesmo 
na fase de operação da hidrelétrica e apresentou, entre os anos de 2016 a 2018, aumento em mais de $200 \%$ do número de casos (BRASIL, 2018, 2019; COUTO, 2007).

Nesse sentido, investigar e mensurar as características epidemiológicas e clínicas e mensurar a taxa de prevalência da malária, é importante para auxiliar o planejamento de políticas públicas e o Programa Nacional de Controle da Malária.

Objetivo (s):Descrever os aspectos epidemiológicos e clínicos da malária no município de Tucuruí, Pará, baseado nos casos notificados no período de janeiro de 2014 a dezembro de 2018.

Material e Método: O presente estudo foi transversal e descritivo com o uso de dados do Sistema de Informação da Vigilância Epidemiológica da Malária. Os dados utilizados neste trabalho foram disponibilizados pelo Laboratório de Epidemiologia e Geoprocessamento da Amazônia (EPIGEO). Os casos foram notificados durante o período compreendido entre 2014 a 2018, registrados para o município de Tucuruí. O município de Tucuruí corresponde a 2.084,289 km², está localizado a margem do Rio Tocantins, latitude $03^{\circ} 45^{\prime} 58^{\prime \prime} \mathrm{S}$ (-3.76953) e longitude 490 40' 21" W (49.6741), a 39 m de altitude do nível do mar, na mesorregião do sudeste do Estado do Pará e microrregião de Tucuruí (CIDADE-BRASIL, 2019).

São objetos do estudo as variáveis epidemiológicas e clínicas (sexo, faixa etária, etnia/raça, escolaridade, ocupação, diagnóstico e resultado do exame) e realizada a depuração dos bancos de dados obtido para filtrar o conjunto de variáveis para execução das análises, este processo possibilitou a retirada de possíveis causadores de vieses, como incompletudes, redundâncias e inconsistências de dados, a partir da utilização do programa TabWin do Ministério da Saúde (MS).

Foi aplicado o teste estatístico qui-quadrado de proporções esperadas iguais, buscando verificar a existência de possíveis diferenças de proporções entre as diversas variáveis relacionadas ao adoecimento por malária, com auxílio do programa Bioestat 5.0. A interpretação dos testes foi feita de acordo com a convenção científica, sendo considerado resultado estatisticamente significante quando o valor-p (nível descritivo) for menor que 0,05, visto que o nível de significância $\alpha$, alpha, pré- estabelecido de $5 \%$.

O indicador epidemiológico de prevalência anual da malária será analisado utilizando-se como numerador o total de casos confirmados, e como denominador a população da área de estudo, multiplicada por um fator adequado a base populacional do município e múltiplo de 10, para cada ano de estudo. Os dados epidemiológicos foram dispostos em tabelas e gráficos para realização das análises quantitativas e descritiva.

Resultado e Discussão: Foram notificados e confirmados 1.392 casos de malária no município de Tucuruí, estado do Pará, no período de 2014 a 2018. O ano de 2015 apresentou o menor número de casos, com 6 e 2018 o maior número, com 1.176 casos confirmados. Quanto à prevalência de malária no período de 2014 a 2018, foi verificado que entre os anos de 2014 a 2015 ocorreu a diminuição desse indicador $(16,1$ - 5,6), no entanto, a partir desse biênio é evidente uma elevação 
O Brasil apresentava diminuição gradual no número de casos até 2015, porém os indicadores têm apontado para um aumento expressivo da malária, e que pode estar relacionado a fragilidades políticas que somado às características ambientais, como a presença de vetores, áreas de floresta densa; e demográficas, como o estabelecimento de moradias e atividades laborais próximo às áreas de circulação de Anopheles favorecem o estabelecimento da doença na área de estudo (FARIA, LUZ, BETIN, 2019; RECHT et al., 2017).

A análise do perfil dos pacientes evidenciou maior percentual de indivíduos do sexo masculino (65,3\%), com faixa etária de 19 a 59 anos (49,6\%), raça/etnia parda (88,8\%), com escolaridade ensino fundamental $(73,0 \%)$ e a principal ocupação foi doméstica (41,9\%), e como provável local de infecção a zona rural (91,2\%). Estes resultados apresentaram significância estatística (p-valor <0,05).

Foi observado um predomínio de casos em indivíduos do sexo masculino, em idade ativa, sendo possível relacionar que a atividade laboral possa contribuir com a maior exposição de grupos com essas características, achado comumente encontrado (FARIA, LUZ, BETIN, 2019; MACIEL; OLIVEIRA, 2014).

O acometimento de indivíduos da raça/etnia parda pode estar relacionado à formação étnica de miscigenação ocorrida no Brasil e no Estado, sendo que 73\% da população paraense se autodeclara parda (IBGE, 2010). Quanto a escolaridade mais encontrada, essa pode indicar maior vulnerabilidade e assinala que as medidas para prevenção da malária devem ser ofertadas de maneira coerente com o entendimento e contexto de vida (MACIEL; OLIVEIRA, 2014).

Para além disso, a exposição em decorrência do trabalho ou mesmo em áreas peridomiciliares, principalmente nas

áreas rurais, são fatores que potencializam o risco de transmissão devido ao comportamento endofílico do mosquito Anopheles, vetor da malária (BRAZ; BARCELLOS, 2018; MACIEL; OLIVEIRA, 2014).

Os casos foram diagnosticados principalmente pela gota espessa/esfregaço $(99,9 \%)$. O diagnóstico não difere do que tem sido identificado em outros estudos, devido ser um método mais barato e com maior disponibilidade nos serviços, mas que exige o auxílio de equipamentos e profissionais capacitados, embora exista o teste rápido, mais simples, mas que ainda não é comumente encontrado na rotina dos serviços de saúde (BRASIL, 2019; FARIA, LUZ, BETIN, 1019; GLÓRIA et al., 2018).

O Plasmodium vivax foi a espécie de maior ocorrência no município (99,8\%). Ainda que essa espécie predominante nas infecções ocorridas no município seja considerada benigna, a sua morbidade é elevada e tem estabelecido maior dificuldade para o controle da transmissão da doença e maior risco de adoecimento às localidades municipais (BRASIL, 2019; NASCIMENTO et al., 2019).

Sendo assim, a partir dos resultados encontrados, verifica-se que as medidas implementadas para vigilância e controle da malária no município requerem esforços contínuos dos agentes envolvidos e exigem o fortalecimento das ações para diminuição do número de casos e controle da doença, que ainda é caracterizada como importante problema de saúde em Tucuruí. 
Conclusão: Considerando a malária um grande problema de saúde pública nos municípios paraenses, neste estudo, foi analisado o perfil epidemiológico e clínico dessa doença, com a verificação de um agravamento no quadro epidemiológico da malária em Tucuruí referente aos anos considerados neste estudo e que pode ser caracterizado em função da observação do aumento progressivo do número de casos de malária. A caracterização epidemiológica para avaliar a prevalência se faz necessária para

analisar os fatores causais, com o objetivo de identificar situações de risco e auxiliar o planejamento de políticas para fortalecimento das medidas de controle da doença.

Referências bibliográficas: BRASIL. Ministério da Saúde. Guia de vigilância em saúde. 3. ed. Brasília: Ministério da saúde, 2019.

Sala de Apoio à Gestão Estratégica. Brasília: Ministério da Saúde, 2019. Disponível em: http://sage.saude.gov.br/\#. Acesso em: 01 ago. 2019

BRAZ, R. M.; BARCELLOS, C. Análise do processo de eliminação da transmissão da malária na Amazônia brasileira com abordagem espacial da variação da incidência da doença em 2016*. Epidemiol. Serv. Saúde, v. 27, n. 3, 2018.

CIDADE-BRASIL. Município de Tucuruí. Cidade-Brasil, 2019. Disponível em: https://www.cidade-brasil.com.br/municipio-tucurui.html. Acesso em: 12 ago. 2019

COUTO, R. C. Saúde e Hidrelétricas na Amazônia: O caso Tucuruí-PA.(*). 2007. Disponível em: http://www.ecsb2007.ufba.br/layout/padrao/azul/ecsb2007/arquivos_anteriores/st5 _1 0.pdf. Acesso em: 19 ago. 2019.

FARIA, G.; LUZ, G. S.; BETIN, T. A. Aspecto Epidemiológico das Notificações de Malária entre 2012 a 2017 no Município Rondolândia-MT. Rev. Aten. Saúde, São Caetano do Sul, v. 17, n. 60, p. 83-90, abr./jun., 2019.

GLÓRIA, J. C. et al. Métodos para diagnóstico de Malária: Atualização e desafios. Scientia Amazonia, v. 7, n.2, B24-B31, 2018.

INSTITUTO BRASILEIRO DE GEOGRAFIA E ESTATÍSTICA. Censo 2010 [Internet]. Rio de Janeiro: IBGE; 2010. Disponível em: http://censo2010.ibge.gov.br/. Acesso em: 01 ago. 2019.

MACIEL, G. B. M. L.; OLIVEIRA, E. C. Perfil entomológico e epidemiológico da 
malária em região garimpeira no norte do Mato Grosso, 2011. Epidemiol. Serv. Saúde, v. 23, n. 2, p. 355-360, 2014.

NASCIMENTO, T. L. et al. Prevalência de recaída por malária: revisão sistemática com metanálise. Rev. Latino-Am. Enfermagem, v. 27, p. e3111, 2019.

RECHT J. et al. Malaria in Brazil, Colombia, Peru and Venezuela: current challenges in malaria control and elimination. Malar J, v. 16, p. 273, 2017

SOUSA, T. C. M. et al. Doenças sensíveis ao clima no Brasil e no mundo: revisão sistemática. Rev Panam Salud Publica, v. 42, p. 1-10, 2018.

VERONESI. Tratado de infectologia. 5. ed. São Paulo: Atheneu, 2015

Palavras-chave: Malária. Epidemiologia. Saúde Pública.

Grande-Área: Ciências da Saúde

Área: Saúde Coletiva 


\title{
INTERFERÊNCIA HETERÓLOGA ENTRE OS VÍRUS CHIKUNGUNYA E MAYARO
}

\author{
Nome do(a) Bolsista: Mauricio Gabriel Everton Lindoso Silva \\ Nome do(a) Orientador(a): Carlos Alberto Marques Carvalho
}

Resumo: A região Amazônica abriga uma enorme biodiversidade, com isso, uma complexa inter-relação ecológica traz a emergência de novas ameaças ao homem, como é o caso dos arbovirus. O estudo objetiva avaliar o perfil de interferência viral in vitro, entre dois tipos diferentes de Alphavirus, um do novo mundo, vírus Mayaro e outro do velho mundo, vírus Chikungunya em uma mesma linhagem de células onde no estudo em questão serão empregadas células do tipo VERO oriundas do rim de macacos do gênero Chlorocebus. Trata-se de uma pesquisa experimental, de caráter qualitativo e quantitativo, os resultados serão analisados com base na análise de variância comparando-se as médias das medidas dos grupos amostrais com pós-teste de Tukey para múltiplas comparações utilizando um software específico. Por meio desta análise, será possível compreender de forma mais clara os processos que envolvem os fenômenos que ocorrem em natureza, como é o caso das coinfecções e superinfecções. Além de possibilitar uma correlação entre complexidade clínica e o fenômeno da coinfecção, contribuindo para o levantamento de hipóteses em relação a forma como esses processos podem afetar o prognóstico de pacientes nesta condição.

Introdução: A introdução de novos meios de transporte e inovações tecnológicas, viabilizaram o processo de globalização trazendo consigo uma enorme malha de intercomunicação, não só de informação, mas também de doenças importadas de locais até então isolados, que a partir daí vieram a se configurar como novas ameaças à saúde pública em diversos países (Weaver \& Lecuit, 2015).

A região amazônica, devido à sua vasta extensão territorial, possui uma enorme biodiversidade associada ao clima tropical úmido além de aspectos meteorológicos e geográficos característicos. Soma-se a isso a heterogeneidade entre espécies de vertebrados silvestres e artrópodes hematófagos, mais especificamente os dípteros, que servem, respectivamente, como hospedeiros e vetores, e a grande diversidade de agentes infecciosos, entre os quais os arbovírus (Leão, 2013).

Vale ressaltar que um dos aspectos condicionantes para o estabelecimento de diferentes tipos de arboviroses no país é a grande densidade vetorial, que se configura, atualmente, como um dos maiores desafios a serem solucionados. Destaca-se a presença dos vetores Aedes aegypti e Aedes albopictus dispersos em, praticamente, toda a extensão territorial do país, além da presença de hospedeiros acidentais em comum (ser humano) somado a fatores ecológicos e econômicos que favorecem a ocorrência do fato em questão (Vogels et al., 2019; Weaver \& Lecuit, 2015).

O Brasil enfrenta, atualmente, vários desafios em saúde pública quanto à circulação de "novos" arbovírus, merecendo o vírus Mayaro (MAYV) e o vírus Chikungunya 
(CHIKV) especial destaque. Caracterizam-se por serem agentes etiológicos de doenças infecciosas agudas transmitidas por artrópodes; nesse caso, os vetoresevolvidos serão, principalmente, mosquitos do gênero Aedes, no caso do CHIKV, e mosquitos do gênero Haemagogus, no caso do MAYV. Ambos os vírus possuem genoma constituído de ácido ribonucleico (RNA) e pertencem ao gênero Alphavirus da família Togaviridae, compondo o grupo antigênico do vírus da Floresta de Semliki (SFV) (Figueiredo, M.L.G \& Figueiredo, L.T.M, 2014).

A transmissão de ambas as espécies de alfavírus ao homem ocorre através da picada de fêmeas de mosquitos hematófagos infectados. Esses animais participam do ciclo como hospedeiros definitivos, permanecendo infectados até o fim da vida, sendo, por isso, considerados também reservatórios da doença (Leão, 2013).

Historicamente, o primeiro caso isolado de Chikungunya foi na África, mais especificamente na Tanzânia, em 1952; já o vírus Mayaro foi isolado pela primeira vez em 1954, em Trinidad, sendo posteriormente associado a surtos na América do Sule no Caribe. Em virtude do forte fluxo migratório entre países, seja pelo turismo ou devido a relações comerciais entre os mesmos, a presença cada vez mais notória de novas doenças, em especial arboviroses, tornam o Brasil um grande e vasto território com fatores favoráveis ao estabelecimento dessas enfermidades (Figueiredo, M.L.G \& Figueiredo, L.T.M, 2014).

O MAYV possui dois genótipos principais ( $D$ e $L$ ) que se relacionam filogeneticamente com o vírus Una (UNAV), também pertencente ao grupo antigênico do SFV. Os surtos envolvendo o MAYV na região amazônica estão ligados ao genótipo $D$, responsáveis pelos quadros de febre agudos nessa região, e afetam, tipicamente, indivíduos que residem ou trabalham próximo a áreas de floresta; contudo, surtos também em regiões urbanas já foram reportados (AcostaAmpudia et al., 2018).

Muito tem sido esclarecido em relação à patogenia das arboviroses e características peculiares de cada uma têm demonstrado alguma heterogeneidade sintomática. Porém, em relação à infecção por CHIKV, a presença de um quadro artritogênico exacerbado, caracterizando muitas das vezes um quadro de poliartralgia incapacitante e, em alguns casos, comportando-se de forma crônica, torna-a muito semelhante quando comparada aos quadros agudos de infeç̧ão por MAYV (Acosta-Ampudia et al., 2018; Dupuis-Maguiraga et al., 2012). No entanto, no ano de 2018, foram confirmados três óbitos por CHIKV, nos estados da Paraíba, Rio de Janeiro e Mato Grosso, o que demonstra a sua ampla complexidade clínica (Brasil, 2019).

Soma-se a isso a sobreposição entre os dois tipos de vírus através do compartilhamento de vetores em comum, o que pode, eventualmente, acarretar em episódios de coinfecção, com piora acentuada do prognóstico clínico (Vogels et al., 2019; Tsetsarkin \& Weaver, 2011). Os mosquitos do gênero Aedes, como o Aedes aegypti e o Aedes albopictus, configuram-se como os principais vetores envolvidos na transmissão do CHIKV, além de possuírem a capacidade de transmitir outras espécies de arbovírus, como o vírus Dengue (DENV) e o vírus Zika (ZIKV). Além disso, apesar do vetor mais associado aos casos de infecção por MAYV ser o Haemagogus janthinomys, alguns estudos de competência vetorial têm demonstrado que esse vírus também pode compartilhar do mesmo vetor responsável pela 
transmissão do CHIKV, apesar de isso ainda não ter sido comprovado na natureza (Naveca et al., 2019; Figueiredo, M.L.G \& Figueiredo, L.T.M, 2014).

Em várias áreas do mundo, os alfavírus representam uma grande ameaça para a saúde humana. O CHIKV já é sabidamente causador de milhares de infecções no Velho Mundo e, assim como o MAYV, compõe o grupo dos alfavírus conhecidos como artritogênicos. Tais agentes constituem uma ameaça emergente devido aos fatores que contribuem para que eles estejam eventualmente ligados à ocorrência de grandes epidemias (Lopes et al., 2014; Figueiredo, M.L.G \& Figueiredo, L.T.M, 2014).

Ambas as arboviroses estão relacionadas a surtos epidêmicos, no entanto, em relação ao MAYV, um dos maiores entraves está ligado à sua subnotificação em relação a outras arboviroses artritogênicas, o que implica em uma vigilância insuficiente nos países onde a doença causada por esse vírus se manifesta de forma endêmica, resultando em uma subestimação no número de casos notificados (Lopes et al., 2014). A circulação do MAYV está estrita à América Central, América do Sul e Caribe. A circulação tanto do MAYV quanto do CHIKV ocorre de forma endêmica em áreas tropicais, estando o MAYV mais associado às áreas de mata, tendo em vista que o seu principal vetor, o Haemagogus janthinomys, encontra-se ligado, principalmente, ao ciclo silvestre (Lorenz et al., 2017).

Episódios epidêmicos somados a pequenos surtos estão principalmente associados a países amazônicos, entre eles o Brasil. O maior evento epidêmico do MAYV ocorreu no município de Belterra/PA no ano de 1978, com a confirmação de centenas de casos por meio da técnica de isolamento viral e testes sorológicos (Abad-Franch et al., 2012). Já no caso do CHIKV, o Ministério da Saúde reporta casos desde 2010, porém o primeiro caso autóctone foi detectado em setembro de 2014 no município de Oiapoque, no estado do Amapá. A sua circulação na América do Sul foi primeiramente reportada na Colômbia, alcançando também a Guiana Francesa e a Venezuela. Já a segunda introdução do CHIKV foi identificada no município de feira de Santana, Bahia, em outubro de 2014, com 722 casos suspeitos (Figueiredo, M.L.G \& Figueiredo, L.T.M, 2014; Brasil, 2019).

As semelhanças sintomatológicas das doenças causadas pelos alfavírus podem tornar a detecção de um surto epidêmico ainda mais difícil, somada à possível cocirculação, o que pode, eventualmente, mascarar a presença de uma possível emergência do MAYV em áreas urbanas. É importante ressaltar que, apesar de não haver o compartilhamento do mesmo vetor envolvido nos respectivos ciclos de transmissão, o homem se configura como sendo o hospedeiro acidental no caso do MAYV, sendo pertencente ao ciclo urbano já bem estabelecido do CHIKV. Portanto, torna-se de fundamental importância a elucidação dos possíveis fatores de interferência entre esses dois espécimes virais quando estes compartilham ao mesmo tempo da maquinaria celular de mamíferos, em especial, nos casos de coinfecção.

\section{Objetivos}

GERAL

Investigar o processo de interferência heteróloga entre CHIKV e MAYV em esquema de coinfecção e superinfecção. 


\section{ESPECÍFICOS}

- Avaliar a interferência da infecção mista no efeito citopático;

- Avaliar a interferência da infecção mista na viabilidade celular;

- Avaliar a interferência da infecção mista na replicação dos genomas virais.

\section{MATERIAIS E MÉTODOS}

O projeto será desenvolvido na Seção de Arbovirologia e Febres Hemorrágicas (SAARB) do Instituto Evandro Chagas (IEC). As manipulações das amostras virais serão realizadas em cabines de biossegurança classe II (B2), preconizando sempre atenção estrita às normas de biossegurança definidas pela Comissão Interna de Biossegurança.

Estoque viral em cultivo celular:

Os estoques virais foram preparados utilizando-se células do tipo VERO, oriundas de macacos do gênero Chlorocebus, o período de infecção foi de 72 horas para ambos os espécimes virais, com garrafas médias com $75 \mathrm{~cm}^{2}$, contendo aproximadamente $80 \%$ de confluência celular. $O$ volume de amostra viral foi definido de forma que a sua

M.O.I (Multiplicidade de infecção) fosse menor que 1, neste caso: 0.1. Os sobrenadantes de ambas as expansões virais foram clarificados através de centrifugação a $5000 \mathrm{rpm}$ durante um período de tempo de 30 minutos a uma temperatura de $4 \mathrm{C}^{\circ}$, após este processo o volume de amostra viral foi aliquotado devidamente identificado e armazenado em freezer $-70 \mathrm{C}^{\circ}$. As cepas virais utilizadas foram CHIKV-BeH807658 e MAYV-BeAR20290, cedidas pela Seção de Arbovirologia e Febres Hemorrágicas do Instituto Evandro Chagas.

\section{TITULAÇÃO VIRAL EM CULTIVO CELULAR}

Foram utilizadas placas de 6 poços cultivadas com células VERO contendo $3 \times 10^{5}$ células $/ \mathrm{mL}$ por poço. O meio utilizado foi o meio de manutenção 199 (GIBCO, Califórnia, EUA) suplementado com $2 \%$ de soro bovino fetal e solução de antibióticos (penicilina e estreptomicina) a 1\%. As placas foram mantidas em estufa (Thermo Scientific) a $37{ }^{\circ} \mathrm{C}$ e $\mathrm{CO}_{2}$ a $5 \%$ e, após haver a formação completa da monocamada em cada poço, as placas eram consideradas prontas para o ensaio.

Prosseguindo com o ensaio de placa, foram feitas diluições seriadas de dez vezes em meio 199 puro. Em cada placa, foram inoculados $0,2 \mathrm{~mL}$ de cada diluição, sendo encaminhadas à estufa com atmosfera de $\mathrm{CO} 2(5 \%)$ a uma temperatura de $37^{\circ} \mathrm{C}$ durante 1 hora para adsorção das partículas virais, homogeneizando a placa a cada 15 minutos, evitando, dessa forma, o ressecamento da monocamada em virtude do baixo volume de meio utilizado nesta etapa além de distribuir a carga viral de forma homogênea em toda a extensão da monocamada.

Após esse período, foram adicionados $2 \mathrm{~mL}$ de meio semissólido (carboximetilcelulose a 1,5\% em meio 199) suplementado com $2 \%$ de soro bovino fetal (SBF) e $1 \%$ de solução antibiótica, em cada poço das placas. Após isso, as placas retornaram à estufa a $37{ }^{\circ} \mathrm{C} \operatorname{com~CO} 2$ a $5 \%$ por 48 horas, que é o prazo que os espécimes virais demoram, em média, para formar placas de destruição celular na monocamada.

A fixação e coloração foi feita através da adição de uma solução contendo cristal 
violeta a 0,1\% diluído em solução de etanol a 30\%, formalina a 20\% e PBS 50\%, por 1 hora. Após esse tempo, as placas foram lavadas com água corrente e secas em estufa. Através da contagem do número de placas formadas pelo vírus devido ao seu efeito citopático (ECP) característico nessa linhagem celular, o título foi calculado pelo método segundo o CDC, 2006, expresso em unidades formadoras de placas por mililitro (PFU/mL).

\section{MICROSCOPIA ÓTICA DE CONTRASTE DE FASE}

Este tipo de contraste permite a visualização detalhada de amostras não coradas (transparentes) e será utilizada para a verificação da presença ou não de efeitos citopáticos na monocamada, permitindo avaliar a formação de vesículas intracitoplasmáticas além de mudanças na conformação celular. Será utilizado para a detecção visual da formação de efeitos citopáticos, com utilização de lente objetiva de 20x com lente ocular de 10x, resultando em uma magnificação total de imagem de 200x.

\section{FLUORIMETRIA}

Serão semeadas monocamadas de células VERO em placas de 96 poços (NEST $\left.{ }^{8}\right)$, incubadas em diferentes temperaturas. Após isso serão analisadas quanto a clivagem do peptídeo fluorogênico, permeante celular glicilfenilalanilaminofluorocumarina (GF- AFC), fornecida no Cell Titer-Fluor Cell ensaio de viabilidade (Promega, Fitchburg,EUA), por uma protease conservada e constitutiva presente no leitor, multimodo GloMax-Multi + Microplate (Promega).

\section{COINFECÇÃO e SUPERINFECÇÃO}

Neste estudo, foram utilizadas placas de 12 poços para a experimentação dos resultados preliminares, onde foram inoculados os volumes virais de acordo com a densidade de células por $\mathrm{cm}^{2}$, tendo em vista que o M.O.I seja de 0.1. Sob estas condições, a placa em questão, quando em 100\% de confluência, possuía 3,8 x $10^{5}$ células por poço. Com isso, o volume para infecção foi definido com base no título viral, no caso do MAYV o título foi de $9,4 \times 10^{6}$ e para o CHIKV $1,1 \times 10^{7}$. Para a adsorção foi utilizada uma pequena quantidade de meio 199 puro somado ao meio contendo o vírus em questão, fechando um volume de $100 \mu \mathrm{L}$ para esta fase. $\mathrm{O}$ volume retirado das amostras virais foi de 4,1 $\mu \mathrm{L}$ para o MAYV e de 3,54 para o CHIKV, diluídos 10x para que houvesse melhor acurácia na proporção viral a ser utilizada para a adsorção. Já no caso das infecções consecutivas, o tempo utilizado entre as infecções foi de 1 hora, mimetizando assim o fenômeno de superinfecção in vitro.

\section{RT-QPCR}

Serão semeadas células Vero em placas de 6 poços (NEST) e incubadas com MAYV ou CHIKV com MOI definido de 0,1 durante 1 hora a $37^{\circ} \mathrm{C}$ com posterior lavagem para remoção de partículas infecciosas remanescentes. Após 24 e 48 horas de infecção em cultura os meios serão colhidos, clarificados e submetidos ao isolamento de RNA. Transcrição reversa e amplificação de DNA serão realizadas no 7500 Real- time PCR System (Applied Biosystems, Foster City, EUA) utilizando 
o Kit qRT-PCR (SuperScript ${ }^{\mathrm{TM}}$ III Platinum ${ }^{\mathrm{TM}}$ One-Step qRT-PCR Kit).

\section{ANÁLISE ESTATÍSTICA}

A análise estatística utilizada será feita com base na análise de variância (ANOVA), comparando-se as médias das medidas dos grupos amostrais com pós-teste de Tukey para múltiplas comparações no Software Prism 6 (GraphPad, San Diego, EUA). Os dados serão expressos como média \pm desvio padrão (DP). Valores de $P$ inferiores a 0,05 serão considerados indicativos de diferenças estatiscamente significativas.

\section{RESULTADOS PRELIMINARES}

Observou-se acentuada morte celular após o processo de infecção, tanto por MAYV como por CHIKV mesmo após um curto período de tempo pós-infecção (24 h). Além disso, foi evidente o aumento no processo de destruição da monocamada quando os dois espécimes virais foram adsorvidos jutos, mimetizando o processo de coinfecção in vitro (Figura:8). No caso das infecções consecutivas (Figura:9) não foram observadas mudanças significativas em comparação ao que se evidenciou no processo de coinfecção, havendo a presença do mesmo grau de efeitos citopáticos quando visualizados pela técnica de microscopia empregada no estudo.

\section{Referências Bibliográficas:}

ABAD-FRANCH, F.; GRIMMER, G.H.; PAULA, V.S. de; FIGUEIREDO, L.T.M.; BRAGA, W.S.M.; LUZ, S.L.B. Mayaro Virus infection in Amazonia: a multimodel inference approach to risk factor assessment. PLoS Negl Trop Dis. 6 (10): 1-9, 2012.

ACOSTA-AMPUDIA, Y.; MONSALVE, D.M.; RODRÍGUEZ, Y.; PACHECO, Y.; ANAYA, JM.; RAMÍREZ-SANTANA, C. Mayaro: an emerging viral threat? Emerg Microbes Infect. 7 (163): 1-11, 2018.

ALENCAR, J.; MORONE, F.; MELLO, C.F.; DÉGALLIER, N.; LUCIO, P.S.; SERRAFREIRE, N.M.; GUIMARÃES, A.E. Flight height preference for oviposition of mosquito (Diptera: Culicidae) vectors of sylvatic yellow fever virus near the hydroelectric reservoir of Simplício, Minas Gerais, Brazil. J Med Entomol. 50 (4): 791-795, 2013.

ALPHAVVIRUS. Disponível em: <https://viralzone.expasy.org/625> Acesso em: 23/08/2019.

AMARAL, J.K.; TAYLOR, P.C.; TEIXEIRA, M.M.; MORRISON, T.E.T.; SCHOEN, R.T.

The clinical features, pathogenesis and methotrexate therapy of chronic chikungunya arthritis. Viruses. 11 (3): 1-12, 2019.

ARAGÃO, C.F; CRUZ, A.C.R.; NUNES NETO, J.P.; MONTEIRO, H.A.O.; SILVA, E.V.P.; SILVA, S.P.; ANDRADE, S.T.S.; TADEI, W.P.; PINHEIRO, V.C.S. Circulation 
of Chikungunya virus in Aedes aegypti in Maranhão, Northeast Brazil. Acta Trop. 186: 1-4, 2018.

ASSUNÇÃO-MIRANDA, I.; OLIVEIRA-CRUZ, C.; POIAN, A.T. Molecular mechanisms

involved in the pathogenesis of Alphavirus-induced arthritis. Biomed Res Int. 2013: 1- 11, 2013.

AZEVEDO, R.S.S.; SILVA, E.V.P.; CARVALHO, V.L.; RODRIGUES, S.G.; NUNES NETO, J.P.; MONTEIRO, H.A.O.; PEIXOTO, V.S.; CHIANG, J.O.; NUNES, M.R.T.;

VASCONCELOS, P.F.C. Mayaro fever virus, Brazilian Amazon. Emerg Infect Dis. 15

(11): 1830-1832, 2009.

BADAWI, A.; RYOO, S.G.; VASILEVA, D.; YAGHOUBI, S. Prevalence of chronic comorbidities in chikungunya: A systematic review and meta-analysis. Int $\mathbf{J}$ Infect Dis. 67: 107-113, 2018.

BARA, J.J; MUTURI,E.J. Effect of mixed infections of Sindbis and La Crosse viruses on replications of each virus in vitro. Acta Tropica. 130: 71-75, 2014.

BOSCO-LAUTH, A.M.; HARTWIG, A.E.; BOWEN, R.A. Reptiles and amphibians as potential reservoir hosts of Chikungunya Virus. Am J Trop Med Hyg. 98 (3): 841844, 2018.

BRASIL. Ministério da Saúde. Secretaria de Vigilância em Saúde. Monitoramento dos casos de arboviroses urbanas transmitidas pelo Aedes (Dengue, Chikungunya e Zika)

até a semana epidemiológica 12 de 2019 e levantamento rápido de índices para Aedes aegypti (LIRAa). Bol. Epidemiol. 50: 1-18, 2019.

BRONZONI, R.V.M.; MORELI, M.L.; CRUZ, A.C.R.; FIGUEIREDO, L.T.M. Multiplex nested PCR for Brazilian Alphavirus diagnosis. Trans R Soc Trop Med Hyg.98 (8): 456-461, 2004.

BRONZONI, R.V.M.;BALEOTTI, F.G.; NOGUEIRA, R.M.R.; NUNES, M.; FIGUEIREDO, L.T.M. Duplex reverse transcription-PCR followed by Nested PCR assays for detection and identification of Brazilian Alphaviruses and Flaviviruses. J Clin Microbiol. 43 (2): 696-702, 2005.

BRUNINI, S.; FRANÇA, D.D.S.; SILVA, J.B.; SILVA, L.N.; SILVA, F.P.A.; SPADONI, M.; REZZA, G. High frequency of Mayaro Virus IgM among febrile patients, Central Brazil. Emerg Infect Dis. 23 (6): 1025-1026, 2017.

BRUSTOLIN, M.; PUJHARI, S.; HENDERSON, C.A.; RASGON, J.L. Anopheles 
mosquitoes may drive invasion and transmission of Mayaro virus across geographically diverse regions. PLoS Negl. Trop. Dis. 12 (11) 1-11, 2018.

CELESTINO JÚNIOR, A.F. Desenvolvimento de técnica de RT-PCR em Tempo Real para detecção do Virus Mayaro (Togaviridae: Alphavirus). Tese (Doutorado em Biologia de Agentes infecciosos e parasitários) - Belém, Universidade Federal do Pará, 2013. 64p.

CHAHAR, H.S.; BHARAJ, P.; DAR, L.; GULERIA, R.; KABRA, S.K.; BROOR, S. Coinfections with Chikungunya Virus and Dengue Virus in Delhi, India. Emerg Infect Dis. 15 (7): 1077-1080, 2009.

CHEN, R.; MUKHOPADHYAY, S.; MERITS, A.; BOLLING, B.; NASAR, F.; COFFEY, L.L; POWERS, A.; WEAVER, S.; ICTV Virus taxonomy profile: Togaviridae. J Gen Virol. 99 (6): 761-762, 2018.

CHUONG, C.; BATES, T.A.; WEGER-LUCARELLI, J. Infectious cDNA clones of two strains of Mayaro virus for studies on viral pathogenesis and vaccine development. Virology. 535: 227-231, 2019.

DAPALMA, T.; DOONAN, B.P.; TRAGER, N.M.; KASMAN, L.M. A systematic approach to virus-virus interactions. Virus Res. 149 (1): 1-9, 2010.

DEV, N.; KUMAR, R.; GOGNA, A.; SHARMA, S. Chikungunya-induced inflammatory myositis: a case report in India. Trop Doct. 49 (3): 241-243, 2019.

DONALISIO, M.R.; FREITAS, A.R.R. Chikungunya no Brasil: um desafio emergente. Rev. bras. epidemiol. 18 (1): 283-285, 2015.

DUPUIS-MAGUIRAGA, L.; NORET, M.; BRUN, S.; LEGRAND, R.; GRAS, G. ROQUES, P. Chikungunya disease: infection-associated markers from the acute to the chronic phase of arbovirus-induced arthralgia. PLoS Negl Trop Dis. 6 (3): 1-10, 2012.

EDELMAN, R.; TACKET, C.O.; WASSERMAN, S.S.; BODISON, S.A.; PERRY, J.G.; MANGIAFICO, J.A. Phase II safety and immunogenicity study of live Chikungunya Virus vaccine Tsi-Gsd-218. Am J Trop Med Hyg. 62 (2): 681-685, 2000.

ERASMUS, J.H.; AUGUSTE, A.J.; KAELBER, J.T.; LUO, H.; ROSSI, S.L.; FENTON, K.; LEAL, G.; KIM, D.Y.; CHIU, W.; WANG, T.; FROLOV, I.; NASAR, F.; WEAVER, S.C. A Chikungunya fever vaccine utilizing an insect-specific virus platform. Nat Med. 23 (2): 192-199, 2017.

ESPOSITO, D.L.A.; FONSECA, B.A.L. Will Mayaro virus be responsible for the next outbreak of an arthropod-borne virus in Brazil? Braz J Infect Dis. 21 (5): 540-544, 2017. 
FIGUEIREDO, M.L.G.; FIGUEIREDO, L.T.M. Emerging alphaviruses in the Americas: Chikungunya and Mayaro. Rev. Soc. Bras. Med. Trop. 47 (6): 677-683, 2014.

FIGUEIREDO, L.T.M.; NOGUEIRA, R.M.R.; CAVALCANTI, S.M.B.; SCHATZMAYR, H.; ROSA, A.T. Study of two different enzyme immunoassays for the detection of mayaro vírus antibodies. Mem. Inst. Oswaldo Cruz 84 (3): 303-307, 1989.

FUMAGALLI, M.J.; SOUZA, W.M.; ESPÓSITO, D.L.A.; SILVA, A.; ROMEIRO, M.F.; MARTINEZ, E.Z.; FONSECA, B.A.L.; FIGUEIREDO, L.T.M. Enzymelinked

immunosorbent assay using recombinant envelope protein 2 antigen for diagnosis of Chikungunya vírus. Virol J. 15 (112) 1-7, 2018.

GONZÁLEZ-SÁNCHEZ, J.A.; RAMÍREZ-ARROYO, G.F. Chikungunya virus: history, geographic distribution, clinical picture, and treatment. P R Health Sci J. 37 (4): 187- 194, 2018.

GOYAL, M.; CHAUHAN, A.; GOYAL, V.; JAISWAL, N.; SINGH, S.; SINGH, M. Recent

development in the strategies projected for chikungunya vaccine in humans. Drug Des Devel Ther. 12 : 12: 4195-4206, 2018.

GUBLER, D. The global emergence/resurgence of arboviral diseases as public health problems. Arch Med Res. 33 (4): 330-342, 2002.

HALSEY, E.S.; SILES, C.; GUEVARA, C.; VILCARROMERO, S.; JHONSTON, E.J.; RAMAL, C.; AGUILAR, P.V.; AMPUERO, J.S. Mayaro virus infection, Amazon Basin Region, Peru, 2010-2013. Emerg Infect Dis. 19 (11): 1839-1842, 2013.

HENSS, L.; YUE, C.; KANDLER, J.; FADDY, H.M.; SIMMONS, G.; PANNING, M.; LEWIS-XIMENEZ, L.L.; BAYLIS, S.A.; SCHNIERLE,B.S. Establishment of an Alphavirus-specific neutralization assay to distinguish infections with different members of the semliki forest complex. Viruses. 11 (82): 1-13, 2019.

HONNOLD,S.P.; MOSSEL, E.C.; BAKKEN, R.R.; FISCHER, D.; LIND, C.M.; COHEN, J.W.; ECCLESTON, L.T.; SPURGERS, K.B.; ERWIN-COHEN, R.; BRADFUTE, S.B.; MAHESHWARI, R.K.; GLASS, P. J. Eastern equine encephalitis virus in mice I: clinical course and outcome are dependent on route of exposure. Virol J. 12: 1-14, 2015.

HONÓRIO, N.A.; WIGGINS, K.; EASTMOND, B.; CÂMARA, D.C.P.; ALTO, B. W. Experimental vertical transmission of Chikungunya Virus by Brazilian and Florida Aedes Albopictus populations. Viruses. 11 (4): 353, 2019

HOTEZ, P.J.; MURRAY, K.O. Dengue, West Nile virus, Chikungunya, Zika - and now 
Mayaro?. PLoS Negl Trop Dis. 11 (8): 1-5, 2017.

JUAREZ. D.; LONG, K.C.; AGUILAR, P.; KOCHEL T.J.; HALSEY, E.S. Assessment of

plaque assay methods for alphaviruses. J Virol Methods. 187 (1): 185-189, 2013

KARPF, A.R.; LENCHES, E.; STRAUSS, E.G.; STRAUSS, J.H.; BROWN, D.T.

Superinfection exclusion of alphaviruses in three mosquito cell lines persistently infected with sindbis Virus. J Virol.71 (9): 7119-7123, 1997

KUNO, G.; MACKENZIE, J.S.; JUNGLEN, S.; HUBÁLEK, Z.; PLYUSNIN, A.; GUBLER, D. J. Vertebrate reservoirs of arboviruses: myth, synonym of amplifier, or reality? Viruses. 9 (7): 185, 2017.

LEÃO, R.N.Q. Medicina tropical e infectologia na Amazônia. Belém (PA): Samauma, 2013. 2 v.

LOPES, N.; NOZAWA, C.; LINHARES, R.E.C. Características gerais e epidemiologia dos arbovírus emergentes no Brasil. Rev Pan-Amaz Saude 5 (3) 5564, 2014.

LORENZ, C.; AZEVEDO, T.S.; VIRGINIO, F.; AGUIAR, B.S.; CHIARAVALLOTINETO, F.; SUESDEK, L. Impact of environmental factors on neglected emerging arboviral diseases. PLoS Negl Trop Dis. 11 (9): 1-19, 2017.

LWANDE, O.W.; OBANDA, V.; BUCHT, G.; MOSOMTAI, G.; OTIENO, V.; AHLM, C.; EVANDER, M. Global emergence of Alphaviruses that cause arthritis in humans. Infect Ecol Epidemiol. 5 (1): 29853, 2015.

MACKAY, I.M.; ARDEN, K. E. Mayaro virus: a forest virus primed for a trip to the city?.

Microbes Infect. 18 (12): 724-734, 2016

MAIA, L.M.S.; BEZERRA, M.C.F.; COSTA, M.C.S.; SOUZA, E.M.; OLIVEIRA, M.E.B; RIBEIRO, A.L.M.; MIYAZAKI, R.D.; SLHESSARENKO, R.D. Natural vertical infection by dengue virus serotype 4, Zika virus and Mayaro virus in Aedes (Stegomyia) aegypti and Aedes (Stegomyia) albopictus. Med Vet Entomol. 33 (3): 437-442, 2019.

MARCONDES, C. B.; CONTIGIANI, M.; GLEISER, R. M. Emergent and reemergent arboviruses in South America and the Caribbean: why so many and why now. J Med Entomol. 54 (3):509-532, 2017.

MASCARENHAS, M.; GARASIA, S.; BERTHIAUME, P.; CORRIN, T.; GREIG, J.; NG,

V.; YOUNG, I.; WADDELL, L. A scoping review of published literature on 
chikungunya virus. PLoS One. 13 (11): 1-40, 2018.

MATUSALI, G.; COLAVITA, F.; BORDI, L.; LALLE, E.; IPPOLITO, G.; CAPOBIANCHI, M. R.; CASTILLETTI, C. Tropism of the Chikungunya Virus. Viruses. 11 (2): 175, 2019.

MAVALE, M.; PARASHAR, D.; SUDEEP, A.; GOKHALE, M.; GHODKE, Y.; GEEVARGHESE, G.; ARANKALLE, V.; MISHRA, A.C. Venereal transmission of Chikungunya Virus by Aedes aegypti mosquitoes (Diptera: Culicidae). Am J Trop Med Hyg. 83 (6): 1242-1244, 2010.

MEHTA, R.; GERARDIN, P.; BRITO, C.A.A. de; SOARES, C.N.; FERREIRA, M.L.B.; SOLOMON, T. The neurological complications of chikungunya virus: a systematic review. Rev Med Virol. 28 (3): 1-24, 2018.

MOSQUERA, J.; ADLER, F.R. Evolution of virulence a unied framework for coinfection and superinfection. J Theor Biol.195 (3) 293-313, 1998.

MOTA, M.T.O.; TERZIAN, A.C.; SILVA, M.L.C.R.; ESTOFOLETE, C.; NOGUEIRA, M.L. Mosquito-transmitted viruses - the great Brazilian challenge. Braz J Microbiol. 47 (Suppl 1): 38-50, 2016.

NASAR, F.; PALACIOS, G.; GORCHAKOV, R.; GUZMAN, H.; ROSA, A.P.T.; SAVJI, N.; POPOV, V.L.; SHERMAN, M.B.; LIPKIN, W.I.; TESH, R.B.; WEAVER, S.C. Eilat

virus, a unique alphavirus with host range restricted to insects by RNA replication Proc Natl Acad Sci U S A. 109 (36): 14622-14627, 2012.

NAVECA, F.G.; CLARO, I.; GIOVANETTI, M.; JESUS, J.G.; XAVIER, J.;IANI, F.C.M.; NASCIMENTO, V.A; SOUZA, V.C.; SILVEIRA, P.P.; LOURENÇO, J.; SANTILLANA, M.; KRAEMER, M.U.G.; QUICK, J.; HILL, S.C.; THÉRÉ, J.; CARVALHO, R.D.O.;

AZEVEDO, V.; SALLES, F.C.S.; NUNES, M.R.T.; LEMOS, P.S.; CANDIDO, D.S.; PEREIRA, G.C.; OLIVEIRA, M.A.A.; MENESES, C.A.R.; MAITO, R.M.; CUNHA, C.R.S.B.; CAMPOS, D.P.S.; CASTILHO, M.C.; SIQUEIRA, T.C.S.; TERRA, T.M.; ALBUQUERQUE, C.F.C.; CRUZ, L.N.; ABREU, A.L.; MARTINS, D.V.; SIMO ES, D.D.M.V.; AGUIAR, R.S.; LUZ, S.L.B.; LOMAN, N.; PYBUS, O,G.; SABINO, E.C.;

OKUMOTO, O.; ALCANTARA, L.C.J.; FARIA, N.R. Genomic, epidemiological and digital surveillance of chikungunya virus in the Brazilian Amazon. PLoS Negl Trop Dis. 13 (3): 1-21, 2019.

ORGANIZAÇÃO genômica dos alfavírus. Disponível em: <https://viralzone.expasy.org/625> Acesso em: 23/08/2019.

POWERS, A.M.; LOGUE, C.H. Changing patterns of chikungunya virus: reemergence of a zoonotic arbovirus. J Gen Virol. 88 (Pt 9): 2363-2377, 2007. 
POWER, A.M.; AGUILAR, P. V.; CHANDLER, L.J.; BRAULT, A.C.; MEAKINS, T.A.; WATTS, D.; RUSSELL, K.L.; OLSON, J.; VASCONCELOS, P.F.C.; ROSA, A.T.; WEAVER, S.C.; TESH, R.B. Genetic relationships among Mayaro and Una viruses suggest distinct patterns of transmission. Am J Trop Med Hyg 75 (3): 461-469, 2006.

REINHOLD, J.; LAZZARI, C. R.; LAHONDÈRE, C. Effects of the environmental temperature on Aedes aegypti and Aedes albopictus Mosquitoes: a review. Insects. 9 (4) 158, 2018.

SANTIAGO, G.A.; VÁZQUEZ, J.; COURTNEY, S.; MATÍAS, K.; ANDERSEN, L.E.; COLÓN, C.; BUTLER, A.E.; ROULO, R.; BOWZARD, J.; VILANUEVA, J.M.; MUÑOZ-

JORDAN, J. Performance of the Trioplex real-time RT-PCR assay for detection of Zika, dengue, and chikungunya viruses. Nat Commun. 9 (1): 1391, 2018.

TAURO, L.B.; CARDOSO, C.W.; SOUZA, R.L.; NASCIMENTO, L.C.J.; SANTOS, D.R. dos; CAMPOS, G.S.; SARDI, S.; REIS, O.B.dos; REIS, M.G.; KITRON, U.; RIBEIRO, G.S. A localized outbreak of Chikungunya virus in Salvador, Bahia, Brazil. Mem. Inst. Oswaldo Cruz 114: 1-4, 2019.

TESH, R.B.; WATTS, D.M.; RUSSELL, K.L.; DAMODARAN, C.; CALAMPA, C.; CABEZAS, C.; RAMIREZ, G.; VASQUEZ, B.; HAYES, C.G.; ROSSI, C.A.; POWERS, A.M.; HICE, C.L.; CHANDLER, L. J.; CROPP, B.C.; KARABASTOS, N.; ROEHRIG,

J.T.; GUBLER, D.J. Mayaro virus disease: an emerging mosquito-borne zoonosis in tropical south america. Clin Infect Dis. 28 (1): 67-73, 1999.

THARMARAJAH, K.; MAHALINGAM, S.; ZAID, A. Chikungunya: vaccines and therapeutics [version 1; referees: 2 Approved]. F1000Res. 6 (2114): 1-7, 2017.

THEILACKER, C.; HELD, J.; ALLERING, L.; EMMERICH, P.; SCHMIDT-CHANASIT, J.; KERN, W.V.; PANNING, M. Prolonged polyarthralgia in a German traveler with Mayaro virus infection without inflammatory correlates. BMC Infect Dis. 13 (369): 14, 2013.

TSETSARKIN, K. A.; VANLANDINGHAM, D.L.; McGEE, C.E.; HIGGS, S. A single mutation in Chikungunya virus affects vector specificity and epidemic potential. PLoS Pathog. 3 (12): 1-12, 2007.

TSETSARKIN, K. A.; WEAVER, S. C. Sequential adaptive mutations enhance efficient vector switching by Chikungunya virus and its epidemic emergence. PLoS Pathog. 7 (12): 1-15, 2011.

VASCONCELOS, P.F.C. Emergência do vírus Chikungunya: risco de introdução no Brasil. Rev Pan-Amaz Saude 5 (3): 9-10, 2014. 
VAZEILLE, M.; MOUTAILLER, S.; COUDRIER, D.; ROUSSEAUX, C.; KHUN, H.; HUERRE, M.;THIRIA, J.; DEHECQ, JS.; FONTENILLE, D.; SCHUFFENECKER, I.; DESPRES, P.; FAILLOUX, AB. Two Chikungunya isolates from the outbreak of la reunion (Indian Ocean) exhibit different patterns of infection in the mosquito, Aedes albopictus. PLoS One. 2 (11): 1-9, 2007.

VOGELS, C.B.F.; RUCKERT, C.; CAVANY, S.M.; PERKINS, T.A.; EBEL, G.D.; GRUBAUGH, N.D. Arbovirus coinfection and co-transmission: a neglected public health concern?. PLoS Biol 17 (1): 1-16, 2019.

WEAVER, S.C.; OSORIO, J.E.;LIVENGOOD, J.A.; CHEN, R.; STINCHCOMB, D.T. Chikungunya virus and prospects for a vaccine. Expert Rev Vaccines. 11 (9): 1087- 1101, 2012.

WEAVER, S.C.; WINEGAR, R.; MANGER, I. D.; FORRESTER, N.L. Alphaviruses: population genetics and determinants of emergence. Antiviral Res. 94 (3): 242-257, 2012.

WEAVER, S.C. Arrival of Chikungunya Virus in the New World: prospects for spread and impact on public health. PLoS Negl Trop Dis. 8 (6): 1-4, 2014.

WEAVER, S. C.; LECUIT, M. Chikungunya virus and the global spread of a mosquito- borne disease. N Engl J Med. 372 (13): 1231-1239, 2015.

YAP, G;, POK, KY; LAI, YL; HAPUARACHCHI, HC; CHOW, A.; LEO, YS; TAN, LK; NG, LC. Evaluation of Chikungunya diagnostic assays: differences in sensitivity of serology assays in two independent outbreaks. PLoS Negl Trop Dis. 4 (7): 1-9, 2010.

YAP, M. L.; KLOSE, T.; URAKAMI, A.; HASAN, S. S.; AKAHATA, W.; ROSSMANN, M. G. Structural studies of Chikungunya virus maturation. Proc Natl Acad Sci U S A. 114 (52): 13703-13707, 2017.

Palavras chave: Infecções por Alphavirus, Arbovirus, Coinfecção, Superinfecção. 


\title{
CARACTERIZAÇÃO DAS LESÕES E IDENTIFICAÇÃO DOS TIPOS CELULARES EM CASOS DE INFECÇÃO PELO VÍRUS DO NILO OCIDENTAL
}

\author{
Nome do(a) Bolsista: Sélly Socorro dos Praseres Lira \\ Nome do(a) Orientador: Arnaldo Jorge Martins Filho
}

Introdução: O vírus do Nilo Ocidental (VNO) vem gerando preocupação no que se refere ao seu potencial endêmico. Trata-se de um flavivírus que participa de um complexo ciclo enzoótico, cuja transmissão é realizada pelo mosquito do gênero Cullex sp. e apresenta hospedeiros de amplificação - aves migratórias - e hospedeiros acidentais - equinos e humanos. A complexidade da relação hospedeiro-patógeno-vetor, tropismo celular, diversidade estrutural, capacidade de induzir lesão e reconhecimento e evasão do sistema imunológico, são fatores importantes a serem estudados no que se refere à infecção causada pelo VNO. Objetivos: Caracterizar o perfil de lesão e os tipos celulares em casos de infecção pelo VNO em equinos, no Brasil. Material e Métodos: Para este estudo, foram selecionados 6 equinos, os quais foram submetidos à investigação do agente etiológico de doença neurológica, sendo confirmado infecção pelo VNO tanto nos métodos moleculares, isolamento viral e Imuno-histoquímica. Para a caracterização histopatológica, será usado o método de coloração por Hematoxilina e Eosina (HE). Além disso, será realizado teste de imunohistoquímica, utilizando anticorpos policlonais anti-VNO, para a verificação da presença de antígenos virais em diferentes órgãos e, também, por meio do método de imunoflueorecência realizar a determinação dos alvos celulares, utilizando os anticorpos primários OX-42 (Microglia), GFAP (Astrócito) e NeuN (Neurônio). Também será feito a análise microscópica, seguida de análise dos dados por meio de testes estatísticos paramétricos e não paramétricos.

Resultados esperados: Por se tratar de um arbovírus neurotrópico e que causa infecções graves em hospedeiros vertebrados, principalmente, nos equinos e humanos, espera-se gerar mais informações sobre o tropismo celular, bem como, das lesões que VNO causa tanto no SNC quanto em órgãos sistêmicos.

Introdução: Entre os arbovírus emergentes que apresentam importância para a saúde pública, pode-se citar o Vírus do Nilo Ocidental (VNO). Sendo uma doença zoonótica, o vírus pode infectar diferentes hospedeiros vertebrados, como mamíferos, aves, roedores, equídeos, humanos, primatas não humanos, répteis e anfíbios (TANTELY et al., 2016). 
O VNO foi isolado pela primeira vez em 1937, em amostra de sangue de uma paciente com sintomas de doença febril inespecífica no Distrito de West Nile, em Uganda. Em 1940, outros isolamentos do vírus foram realizados por meio do material biológico de crianças egípcias e em 1951 em adultos israelenses. Em 1953, o VNO foi caracterizado como o agente causador da chamada "Febre do Nilo Ocidental", doença febril e autolimitante, apresentando sintomas leves. Já em 1957, houve os primeiros relatos da associação entre o VNO e doenças neuroinvasivas, em um grupo de idosos israelenses, alertando que o vírus causaria muito mais que um simples quadro febril (CIOTA, 2017).

O VNO pertence à família Flaviviridae e ao gênero Flavivirus, assim como os outros representantes desse gênero, apresenta grande importância à saúde pública. Além disso, é classificado como sendo do mesmo sorocomplexo da encefalite japonesa, vírus Rocio, encefalite de Murray Valley e vírus da encefalite St. Louis (CHANCEY et al., 2015; TANTELY et al., 2016).

A manutenção do vírus em natureza é feita por meio da relação entre o vetor, os quais envolvem algumas espécies do mosquito Culex, tais como Culex pipiens, Culex restuans e Culex quinquefasciatus e hospedeiros amplificadores, como os pássaros, principalmente da ordem Passeriformes, visto que apresentam viremia suficientemente elevada para infectar outros vetores e continuar o ciclo de transmissão (TÉLLEZ et al., 2009; SILVA et al., 2018).

Nessa relação ecológica, o vírus pode infectar uma população de pássaros, replicar-se e posteriormente reinfectar outras aves, disseminando ainda mais a infecção enzoótica. Além disso, os insetos hematófagos podem, no ato da hematofagia, infectar outros animais, mais comumente os humanos e cavalos. E é nessa relação que ocorre um alerta para o potencial disseminador do VNO, gerando preocupação a saúde pública (DAVID; ABRAHAM, 2016).

A compreensão da patogênese do VNO ainda se encontra limitada em estudos de modelos experimentais, principalmente em roedores. Apesar de nos Estados Unidos apresentar uma elevada prevalência e circulação do vírus, ainda assim, os estudos sobre a patogenia e replicação do VNO não estão totalmente definidos, principalmente no que se refere aos quadros de encefalites, seja em cavalos ou em humanos, que são hospedeiros acidentais de interesse em saúde pública (DAVID; ABRAHAM, 2016; KOVATS et al., 2016).

Os cavalos são animais muito susceptíveis às infecções por flavivírus, demonstrando uma importância no que se refere à vigilância desses vírus na natureza (PAUVOLIDCORRÊA et al., 2014). Para o VNO, os cavalos são considerados animais sentinelas, uma vez que é de fácil identificação o quadro de infecção e a doença, além da coleta dos espécimes biológicos nestes animais (DAVID; ABRAHAM, 2016).

Em comparação com as aves, os equinos apresentam baixa viremia, entretanto a infecção pode acometer o sistema nervoso central e ocasionar quadros de encefalites, com sintomatologia semelhante a outras desordens neurológicas por isso a necessidade de diagnóstico diferencial para esses animais (WARD et al., 2006; JOHNSON, 2011).

A importância dos equinos na vigilância epidemiológica do VNO se dá em nível de saúde pública, como também econômica. Pois, o Brasil contém um dos maiores rebanhos de cavalos da América Latina, cuja população é estimada em aproximadamente 8 milhões de cabeças, equivalente a US\$3,2 bilhões. Dessa maneira, surtos de infecções nesses 
animais geram impactos negativos na economia do país e preocupação na saúde humana e veterinária (OMETTO et al., 2013).

Apesar de ser um vírus encefalitogênico, o VNO apresenta tropismo por outros órgãos sistêmicos, como o rim, baço e fígado, onde ocorrerá a replicação secundária, especialmente em macrófagos e células epiteliais (RIOS et al., 2006). Entretanto, a disseminação desse vírus para outros órgãos depende muito da viremia e das condições imunológicas.

\section{OBJETIVOS}

GERAL

Caracterizar o perfil das lesões e os tipos celulares em casos de infecção pelo vírus do Nilo Ocidental em equinos, oriundos da Vigilância Epidemiológica da Seção de Patologia do Instituto Evandro Chagas.

\section{ESPECÍ́FICOS}

$\checkmark$ Descrever os achados histopatológicos em vísceras de equinos (rim, fígado, baço, pulmão, coração e cérebro) infectados pelo VNO;

$\checkmark$ Padronizar um protocolo de diagnóstico imuno-histoquimíco para o VNO, utilizando o método adaptado de Hall e colaboradores (1994);

$\checkmark$ Investigar os alvos celulares para VNO nas amostras dos casos estudados.

\section{MATERIAL E MÉTODOS}

\section{- CASOS ESTUDADOS}

Para este estudo, foram selecionados 6 equinos, sendo 4 cavalos e 2 burros, provenientes da demanda de Vigilância Epidemiológica da Seção de Patologia do Instituto Evandro Chagas, Belém-PA.

Em 2018, houve um surto de doença neurológica sem etiologia conhecida. Os animais apresentaram sinais clínicos como dificuldade de mastigação e deglutição, ataxia dos membros anteriores, decúbito lateral, movimento de pedalagem, evolução e paralisia dos membros. A evolução do quadro clínico foi em média $24 \mathrm{~h}$ após o início dos sintomas e apenas 1 animal foi a óbito 72h após o início dos sintomas e os demais foram eutanasiados. Dessa forma, foram submetidos a investigação laboratorial e foi evidenciada a infecção pelo vírus do Nilo Ocidental através de método molecular nos equinos do estudo. Esses animais são provenientes de propriedades rurais localizadas no Estado do Espírito Santo, comportando os municípios de Nova Venécia e Baixo Gandu.

\section{- CARACTERIZAÇÃo dOS ACHADOS HISTOPATOLÓGICOS}

A caracterização histopatológica será realizada através de coloração pelo método da Hematoxilina e Eosina (HE).

\section{- AVALIAÇÃo IMUNO-HISTOQUÍMICA}


A princípio, será feito o cultivo do VNO para montagem dos blocos controle, no qual o vírus VNO será amplificado e obtido a partir de cultura em células C6/36 infectadas, mantidas em cultura por aproximadamente sete dias in vitro, até apresentarem efeito citopático em $50 \%$ das células. As culturas infectadas serão gentilmente cedidas pela Seção de Arbovirologia e Febres Hemorrágicas (SAARB).

Em seguida será feito a elaboração de blocos de parafina a partir da cultura de VNO para utilização nos testes de imuno-histoquímica para a padronização com anticorpo policlonal anti-VNO. Após a padronização, o protocolo que apresentar melhor desempenho em controles positivos e negativos será testado em amostras de casos diagnosticados previamente para infecção por VNO através de métodos de biologia molecular e/ou isolamento viral em vísceras, realizados na SAARB. Serão selecionados casos positivos e negativos de VNO em equinos, bem como controles positivos de outros flavivírus, a fim de se avaliar possíveis reações cruzadas do anticorpo anti-VNO com outros vírus, podendo assim, estimar a sensibilidade e especificidade do método.

Para cada caso, serão obtidas secções se vísceras a partir de blocos de parafina como descrito anteriormente. O protocolo será testado em amostras de coração, pulmão, rim, fígado, baço e cérebro.

\section{- ANÁlise doS ALVOS CELULARES PARA VNO}

Por se tratar de um vírus encefalitogênico, será realizada análise dos alvos celulares em tecido nervoso, a fim de se evidenciar possíveis alvos celulares no órgãoalvo.

Para isso, utilizaremos a técnica de imuno-histoquímica para evidenciar ativação microglial, células astrocíticas e neurônios, utilizando os anticorpos primários OX-42 (Microglia), GFAP (Astrócito) e NeuN (Neurônio).

\section{- ANÁLISE MICROSCÓPICA}

Após a preparação das lâminas de HE e realização dos testes de imunohistoquímica, será realizada a análise em microscopia de óptica para descrição histopatológica e verificação do resultado da reação.

Para o controle positivo, será escolhido o tipo de recuperação antigênica, bem como a titulação do anticorpo primário que apresentar boa reatividade, bem como não apresentar marcação inespecífica. Para histopatologia, os resultados serão analisados com auxílio de um patologista da SAPAT, o Dr. Juarez Quaresma.

\section{- AVALIAÇÃo DOS DADOS}

Os resultados dos controles positivos e das amostras serão coletados, registrados através de micrografias e armazenados em banco de dados e analisados em estação de trabalho na Seção de Patologia do Instituto Evandro Chagas, prevenindo qualquer possibilidade de extravio e/ou compartilhamento inadequado dos mesmos. Os dados dos controles positivos serão agrupados de acordo com titulação do anticorpo primário e com o tipo de recuperação antigênica. Os casos das amostras estudadas serão avaliados de acordo com a víscera analisada a fim de se escolher o melhor alvo para diagnóstico.

Os dados coletados serão incluídos no Programa EPIINFO, versão 3.5.2 (2010) e 
os resultados terão análise estatística descritiva e analítica utilizando o Software BioEstat 5.0, adotando-se 5\% como nível de decisão para hipótese de nulidade. Segundo a natureza das variáveis, serão adotados testes estatísticos paramétricos e não paramétricos.

Resultados esperados: Por se tratar de um arbovírus neurotrópico e que causa infecções graves em hospedeiros vertebrados, principalmente, nos equinos e humanos, a investigação do tropismo celular, bem como, das lesões que VNO causa tanto no SNC quanto em órgãos sistêmicos é muito importante para se obter mais informações acerca desse vírus. Dessa forma, espera-se caracterizar o perfil histopatológico das lesões pelo VNO em casos séries; gerar um protocolo de controle positivo a partir de cultivo celular; validar uma padronização da técnica de imuno-histoquimica para VNO em anticorpos policlonais; gerar mais informações acerca da patogênese da doença.

\section{Referências bibliográficas:}

CIOTA, A.T. West Nile virus and its vectors. Current Opinion in Insect Science, v. 22, p. 1-9, 2017.

CHANCEY, C.; GRINEV, A.; VOLKOVA, E.; RIOS, M. The Global Ecology and Epidemiology of West Nile Virus. Biomed Res. Int., p. 1-20, 2015.

DAVID, S.; ABRAHAN, A.M. Epidemiological and clinical aspects on West Nile virus, a globally emerging pathogen. Infect Dis (Lond)., v. 48, n. 8, p. 571-86, 2016.

JOHNSON, A.L. Update on infectious diseases affecting the equine nervous system. Vet. Clin. North Am. - Equine Pract., v. 27, p. 573-587, 2011.

KOVATS, S. et al. West Nile virus-infected human dendritic cells fail to fully activate invariant natural killer T cells. Clin Exp Immunol., v. 186, n. 2, 214-226, 2016.

OMETTO, T.; DURIGON, E.L.; DE ARAUJO, J.; APRELON, R.; DE AGUIAR, D.M.; CAVALCANTE, G.T. et al. West Nile virus surveillance, Brazil, 2008- 2010. Trans R Soc Trop Med Hyg., v. 107, n. 11, 723-30, 2013.

PAUVOLID-CORRÊA, A. et al. Neutralising antibodies for West Nile virus in horses from Brazilian Pantanal. Mem. Inst. Oswaldo Cruz., v. 106, p. 467-474, 2011.

RIOS, M.; ZHANG, M.J.; GRINEV, A.; SRINIVASAN, K.; DANIEL, S.; WOOD, O. et al. Monocytes-macrophages are a potential target in human infection with West Nile virus through blood transfusion. Transfusion, v. 46, p. 659-667, 2006. 
SILVA, A.S.G.; MATOS, A.C.D.; DA CUNHA, M.A.C.R.; REHFELD, I.S.; GALINARI, G.C.F.; MARCELINO, S.A.C. et al. West Nile virus associated with equid encephalitis in Brazil, 2018. Transbound Emerg Dis., p. 1-9, 2018.

TANTELY, M.L.; GOODMAN, S.M.; RAKOTONDRANAIVO, T.; BOYER, S. Review of West Nile virus circulation and outbreak risk in Madagascar: Entomological and ornithological perspectives. Parasite, v. 23, p. 49, 2016.

TÉlLEZ, I.; CALDERÓN, O.; FRANCO-PAREDES, C.; RíO, C. El virus del Oeste del Nilo: una realidad en México. Gac Méd Méx., v. 142, n. 6, 2009.

WARD, M.P. Epidemic West Nile virus encephalomyelitis: A temperaturedependent, spatial model of disease dynamics. Prev Vet Med., v. 71, p. 253-264, 2005.

Palavras-chave: Arbovírus; Equinos; Patogênese; Vírus do Nilo Ocidental.

Grande Área: Ciências Biológicas

Área: Ciências Biológicas III 


\title{
AVALIAÇÃO DO TESTE RÁPIDO POINT-OF-CARE CIRCULATING CATHODIC ANTIGEN (POC-CCA) NO DIAGNÓSTICO DA ESQUISTOSSOMOSE EM ÁREA ENDÊMICA NO ESTADO DO PARÁ E MARANHÃO
}

\author{
Nome do(a) Bolsista: Sergei Rodrigo Magalhães de Sousa \\ Nome do(a) Orientador(a): Martin Johannes Enk
}

Introdução: O objetivo desse estudo é avaliar o desempenho do teste POC-CCA em comparação com a técnica Kato-Katz e Helmintex® em áreas endêmicas no estado do Pará e Maranhão. Metodologia: Realizou-se uma avaliação do desempenho do POCCCA, em relação aos métodos de Kato-Katz e Helmintex®, verificando níveis de taxa de positividade, sensibilidade, especificidade e valores preditivos positivos (VPP) e negativos (VPN). A taxa de positividade foi determinada em 16 lâminas de Kato-Katz e resultados do Helmintex ${ }^{\circledR}$. O estudo foi aprovado pelo comitê de ética. Resultado: A prevalência da esquistossomose determinado pelo método Kato-Katz com 16 lâminas foi de $9,41 \%$ e a de POC-CCA foi de 23,92\%, para um total de 372 pessoas. As taxas de positividade reveladas pelo método Kato-Katz variaram de 2,42\% para 9,41\%, de acordo com aumento de lâminas e amostras. Ao comparar os resultados de 16 lâminas de amostras diferentes com resultados do POC-CCA, observou-se sensibilidade de 65,71\%, especificidade de $80,42 \%$, VPP de 25,84\% e VPN de 95,76\%. Conclusão: Apesar do teste imunocromatográfico não apresentar bons resultados de acurácia, menos casos positivos são perdidos quando comparado com os resultados da técnica de Kato-Katz, revelando uma alternativa em potencial para o combate da esquistossomose no Brasil.

Financiamento: CAPES, Instituto Evandro Chagas, DECIT.

Introdução: Sabe-se que o método para diagnóstico da esquistossomose intestinal, indicado pelo Ministério da Saúde, tanto em áreas de alta a baixa prevalência, é a técnica quantitativo e qualitativo de Kato-Katz, que tem por finalidade a detecção de ovos do verme presente nas fezes dos indivíduos infectados (Katz et al., 1972; Sousa, 2017).

Todavia, a técnica de Kato-Katz apresenta falhas na detecção de infecção entre indivíduos com baixa carga parasitária que vivem em áreas com baixa taxa de transmissão da doença (Gryseels, 1996; Enk et al., 2008, Sousa, 2017).

Descrito por Teixeira e colaboradores (2007), o método parasitológico de Helmintex® utiliza 30 gramas de material fecal para análise de presença de ovos de helmintos nas fezes de infectados. A técnica consiste primeiramente na sedimentação das fezes coletadas e posteriormente na atração de ovos de parasitas, caso existente, por meio de esferas paramagnéticas que geram campo magnético. Apesar do método ainda está em avaliação, estudos vêm demonstrando resultados promissores no diagnóstico auxiliar da esquistossomose no Brasil.

Apesar da alta sensibilidade, o método apresenta limitações como a quantidade do número de lâminas a serem analisadas, tornando o processo demorado e inviável para aplicação na rotina clínica. Sendo assim, Favero e Colaboradores em 2017 realizaram um estudo buscando acelerar o processo metodológico do Helmintex®. Com adição de 
detergente Tween - 20 e coloração por ninidrina o volume final das fezes foi reduzido, decrescendo o tempo de confecção para 10 minutos por amostra, além disso, mais ovos foram detectados.

Métodos mais rápidos estão em desenvolvimento para facilitar o diagnóstico por meio da detecção de antígenos específicos do S. mansoni. Esses testes, chamados Point of care $(\mathrm{POC})$, são testes imunocromatográficos que detectam a presença de antígenos circulantes (polissacarídeos de alto peso molecular regurgitados) do verme no soro ou na urina, tais como, circulating anodic antigen (CAA) e o circulating cathodic antigen (CCA), respectivamente (De Clercq et al.,1997).

Dificuldades de diagnósticos têm alertado para o uso do teste rápido POC-CCA que, por ter maior praticidade para diagnóstico, pode futuramente ser uma importante ferramenta na detecção de infectados por S. mansoni.

\section{OBJETIVO}

\subsection{OBJETIVO GERAL}

Avaliar acurácia e aplicabilidade do teste imunocromatográfico POC-CCA em comparação com o método coproscópico de Kato-Katz no Estado do Pará e de KatoKatz e Helmintex® no Maranhão para o diagnóstico de esquistossomose em áreas consideradas endêmicas.

\subsection{OBJETIVOS ESPECÍFICOS}

Calcular e interpretar a sensibilidade, especificidade, concordância do teste POC-CCA em relação ao método Kato-Katz nas localidades de Pará e Maranhão;

Calcular e interpretar a sensibilidade, especificidade e concordância do teste POC-CCA em relação ao método Kato-Katz e Helmintex® no Maranhão;

Avaliar taxa de cura na população do Maranhão 30 dias após tratamento, utilizando técnicas coproscópicas e POC-CCA;

Avaliar taxa de cura, reinfecção e casos novos nas populações de Pará e Maranhão 365 dias após tratamento;

Interpretar os resultados classificados como traços em relação ao método Kato-Katz das populações de Pará e Maranhão.

Testar a aplicabilidade do teste POC-CCA para uso em larga escala.

3. METODOLOGIA

\section{1. ÁREAS DE ESTUDO}

A pesquisa foi realizada no Município de Primavera no estado do Pará e no Município de Turiaçú no estado do Maranhão. Áreas pertencentes a Amazônia legal, endêmicas para esquistossomose.

\subsection{POPULAÇÃO DE ESTUDO}

A pesquisa envolveu a população total das comunidades, não havendo necessidade de um cálculo amostral. Foram excluídos indivíduos que não entregaram as três amostras de fezes e nenhuma amostra de urina, além de crianças menores de 2 anos de idade, o que levou a redução da população participante do estudo para 372 pessoas em Primavera e 217 em Turiaçú. 
Foram coletadas três amostras de fezes e uma amostra de urina participantes remanescente do estudo.

\subsection{PROCESSAMENTO DAS AMOSTRAS}

Todas as amostras de fezes foram utilizadas para confecção de lâminas de Kato-Katz e Helmintex®, mas apenas uma amostra de urina foi necessária como a realização do teste rápido. As amostras de fezes foram coletadas em três dias consecutivos, tanto antes do tratamento, quanto 30 dias e 365 dias após.

\subsection{PADRÃO DE REFERÊNCIA}

A taxa de positividade do método de Kato-Katz foi determinada com 16 lâminas, sendo 12 da primeira amostra, 2 da segunda e 2 da terceira amostra de fezes, em Primavera. Em Turiaçú o padrão foi definido pela junção de positivos detectados com 16 lâminas e mais os positivos detectados pelo Helmintex®.

\subsection{CÁLCULOS ESTATÍSTICOS}

Foi calculado a taxa de positividade, sensibilidade, especificidade, valores preditivos positivos e negativos e acurácia geral. Para avaliação da concordância entre os resultados obtidos na comparação dos resultados do POC-CCA e do método Kato-Katz foi utilizado à estatística KAPPA não ponderado. Foi calculado taxa de cura, reinfecção e casos novos.

\subsection{CONSIDERAÇÕES ÉTICAS}

O estudo faz parte de um projeto multicêntrico, com participantes do Pará, Minas Gerais e Santa Catarina, financiado pela CAPES, Instituto Evandro Chagas, CNPQ/ DECIT. O projeto foi submetido ao comitê de ética e aprovado, com CAAE: 21824513.9.0000.5091. Todos os positivos foram tratados com doses de Praziquantel.

\section{RESULTADO PRELIMINARES E DISCUSSÃO}

A taxa de positividade da esquistossomose determinado pelo método Kato-Katz com 16 lâminas foi de 9,41\%, ou seja, 35 indivíduos positivos. A taxa de positividade obtida pela técnica de Kato-Katz aumentou de 2,42\% (9 positivos com 1 lâmina) para 9,41\% (35 positivos com 16 lâminas.

A taxa de positividade determinada pelo teste imunocromatográfico POC-CCA foi de 23,92\%, ou seja, 89 indivíduos positivos detectados.

A maior sensibilidade $(65,71 \%)$ foi detectada com nosso valor de referência, utilizando 16 lâminas de amostras diferentes. Este aumento da sensibilidade ocorreu pelo aumento de "verdadeiros positivos" no POC-CCA, chegando a 23 positivos em ambos os testes, em um total de 35 positivos pelo padrão de referência.

O padrão de referência em Turiaçú revelou um total de 63 (29.0\%) positivos. O POCCCA identificou 79 (36.4\%) indivíduos infectados. A avaliação do POC-CCA em relação ao padrão de referência mostrou uma sensibilidade de $61.9 \%$, especificidade de $74.0 \%$, acurácia de $70.5 \%$ e coeficiente kappa de 0.33 . Dos 53 positivos que permaneceram no estudo após 30 dias de tratamento,um total de 45 (81.1\%) indivíduos revelaram-se negativose 8 (18.9\%) permaneceram positivos de acordo com o padrãoUm total de 5 (9.4\%) positivos e $37(69.8 \%)$ negativos foram detectados quando o POC-CCA foi aplicado.

Conclusões: A utilização do teste imunocromatográfico tem potencial para ser uma ferramenta importante para o controle da esquistossomose em região endêmica, além da praticidade e aplicabilidade serem vantajosas para programas que almejam eliminar 0 
mais breve possível a esquistossomose como problema de saúde pública no Brasil. Entretanto, o teste imunocromatográfico revelou baixa especificidade e sensibilidade para verificar taxa de cura após tratamento com Praziquantel em Turiaçú.

\section{REFERENCIAS}

DE VLAS, S. J. \& GRYSEELS B. Underestimation of Shistosoma mansoni Prevalences. Parasitol. Today. 8 (8), 1992.

ENK, M. J., LIMA, A. C., MASSARA,C, L., COELHO, P. M., SCHALL ,V. T. A combined strategy to improve the control of schistosoma mansoni in areas of low prevalence in Brazil. Am. J. Trop. Med. Hyg. 78 (1): 140-6, 2008.

GRYSEELS, B. DE VLAS, S. J. Worm Burdensin Schistosome Infections. Parasitol. Today. 12 (3), 1996.

KATZ, N; CHAVES, A; PELLEGRINO, J. A simple device for quantitative stool thicksmear technique in Schistosomiasis mansoni. Rev. Inst. Med. Trop. 14: 397-400, 1972.

KITTUR, N.; CASTLEMAN, J. D.; CAMPBELL JR, C. H.; KING, C. H.; COLLEY, D. G. Comparison of Schistosoma mansoni prevalence and intensity of infection, as determined by the circulating cathodic antigen urine assay or by the Kato-Katz fecal assay: A systematic review. Am. J. Trop. Med. Hyg. 94 (3): 605- 610, 2016.

Palavras chave: Diagnóstico; Esquistossomose; Kato-Katz; POC-CCA.

Grande área: Parasitologia

Área: Epidemiologia 


\title{
AVALIAÇÃO in vitro DO COCULTIVO DE FIBROBLASTOS COM MACRÓFAGOS INFECTADOS POR Leishmania amazonensis E Leishmania braziliensis.
}

\author{
Nome do(a) bolsista: Tarcisio Navegante de Queiroz Filho \\ Nome do(a) Orientador(a): Ana Paula Drummond Rodrigues de Farias
}

\begin{abstract}
Resumo: A leishmaniose tegumentar americana (LTA) é causada por protozoário intracelular da espécie do gênero Leishmania. As células mais comuns no local da infecção são macrófagos, embora haja relatos da presença de formas promastigotas e amastigotas em fibroblastos. Além disso, o processo de cicatrização desempenha um papel crucial na recuperação da pele durante LTA. Portanto, no estudo pretende-se avaliar a ação dos sobrenadantes e do co-cultivo de macrófagos infectados com Leishmania amazonensis e Leishmania braziliensis em fibroblastos murinos. Como resultados preliminares, foram detectadas as citocinas IL-4, IL-6 e TNF- $\alpha$ no meio condicionado de macrófagos infectados. Por outro lado, fibroblastos incubados com meio condicionado, após 24 horas, a IL-6 foi detectada em todos os grupos. Após 48 horas de incubação, houve um aumento de IL-6 para todos os grupos comparados ao tempo dos grupos após 24 horas. Além disso, os fibroblastos incubados com meio condicionado de macrófagos infectados com L. amazonensis tiveram a ocupação de $64 \%$ da área da lesão in vitro por fibroblastos, enquanto os fibroblastos incubados com meio condicionado de macrófagos infectados com $L$. braziliensis ocuparam $54 \%$ da área da ranhura in vitro. Concluem-se até o momento que os fibroblastos incubados com meio condicionado de macrófagos infectados por $L$. braziliensis apresentou a menor migração para o centro da lesão.
\end{abstract}

Introdução: As Leishmanioses compõem um grupo de antropozoonoses transmitidas a seres humanos e a outros mamíferos por vetores flebotomíneos fêmeas. Sabe-se que são consideradas doenças tropicais negligenciadas, causadas por cerca de 20 espécies de protozoários do gênero Leishmania, Ordem Kinetoplastida, Família Trypanosomatidae. A doença é endêmica em 102 países e existem 1,3 milhão de novos casos de leishmaniose e 20.000 a 30.000 mortes a cada ano. Em relação às manifestações tegumentares, 95\% dos casos de Leishmaniose Cutânea estão ocorrendo entre as Américas, Mediterrâneo, Ásia Central e Oriente Médio.Em 2017, 98,9\% (49.395) dos casos reportaram a forma clínica cutânea, sendo que destes 3,78\% (1.882) foram casos da forma mucocutânea, considerada a mais grave por causar complicações clínicas, deficiências e mutilações ${ }^{1}$. A Leishmaniose Cutânea ou Leishmaniose Tegumentar Americana, no Brasil, é causada por diferentes espécies, dentre elas, a Leishmania (L.) amazonensis, Leishmania (Viannia) braziliensis, L. (V.) guyanensis, L. (V.) shawi, L. (V.) lainsoni, entre outras. Essa doença pode apresentar diferentes perfis clínicos que estão diretamente relacionadas ao perfil imunogenético do hospedeiro 
e a interação deste com o parasito ${ }^{2}$. A Leishmania sendo um parasito intracelular obrigatório tem como principais células hospedeiras macrófagos, neutrófilos e células dendríticas. Os macrófagos são células frequentes no local da infecção causada por Leishmania e apresentam múltiplas funções: servem como células hospedeiras na multiplicação ou eliminação do parasito, como célula apresentadora de antígenos e como células produtoras de citocinas moduladoras da resposta mediada por linfócitos T. Embora os macrófagos sejam as principais células hospedeiras da Leishmania, existem relatos da presença, tanto de formas promastigotas como amastigotas em fibroblastos e que estas células estão relacionadas, principalmente a forma crônica da doença ${ }^{2,3}$. Dessa maneira, sugerindo que os fibroblastos serviriam como abrigo seguro para o parasito em formas latentes da Leishmaniose. O processo de cicatrização é uma resposta complexa que envolve, dentre outros mecanismos, a produção de citocinas, colágeno, fatores de crescimento, metaloproteinases, além da presença de células como fibroblastos e macrófagos que atuam em conjunto para resolução da lesão tecidual $^{4}$. Assim, tendo em vista que os macrófagos liberam uma série de moléculas que auxiliam no processo de proliferação celular e que o processo de cicatrização está relacionado à cura clínica da doença e, ainda, que a ação imunomoduladora das diferentes células que estão presentes no microambiente da infecção, pode contribuir para respostas mais elaboradas contra o parasito no durante a infecção por Leishmania. Portanto, o presente estudo pretende avaliar in vitro os pontos chaves na resposta produzida por fibroblastos incubados com meio condicionado de macrófagos infectados, bem como de fibroblastos cocultivados com macrófagos infectados com duas espécies de Leishmania causadoras de diferentes formas clínicas.

Objetivo: Avaliar a ação dos sobrenadantes e do cocultivo de macrófagos infectados com Leishmania amazonensis e Leishmania braziliensis em fibroblastos murinos.

Material e Método: Os macrófagos foram obtidos do lavado peritoneal de camundongos Balb/c, logo depois semeados em placas de 24 poços para a infecção por L. amazonensis e L. braziliensis. Após o tempo de 24 horas, foram coletados os sobrenadantes de macrófagos e armazenados a $-80^{\circ} \mathrm{C}$. Esses sobrenadantes foram denominados meio condicionado. Em seguida, foi realizado 0 semeio de fibroblastos para formação de uma monocamada em placa de 24 poços para ser feito a lesão com uma ponteira de $1 \mathrm{~mL}$, posteriormente, a incubação com o meio condicionado durante o tempo de 24 e 48 horas, e, então, coletados os sobrenadantes dos fibroblastos submetidos ao meio condicionado. Sendo feita a análise do tamanho da área da lesão in vitro por ImageJ. Além disso, foram feitas as dosagens de citocinas no meio condicionado e nos sobrenadantes de fibroblastos e serão feitas análise do tamanho da área celular dos fibroblastos e atividade gelatinolítica da MMP-2 e da MMP-9 do sobrenadante. No segundo momento será feito a cocultura entre macrófagos infectados por $L$. amazonensis e 
L. braziliensis e fibroblastos e aplicadas às mesmas metodologias para analise da área da lesão in vitro, proliferação celular e citocinas, área celular, atividade gelatinolítica dos meios condicionados e sobrenadantes para os tempos de 24 e 48 horas. Os dados serão análisados no Graphpad prims 7 utilizando o teste estatístico teste $t$-student, considerando estatisticamente significativo quando ${ }^{*} \mathrm{p}<$ 0,05 .

Resultados preliminares: A fim de saber quais citocinas estavam, primeiramente, presentes nos meios condicionados de macrófagos infectados por 24 horas, foram detectadas três citocinas das oito pesquisadas. A IL-4, IL-6 e o TNF- $\alpha$ foram encontrados em todos os grupos (macrófagos não infectados e infectados com as diferentes espécies de Leishmania). Porém, a IL-4 e a IL-6 não apresentaram diferença estatística significativa entre os grupos. Por outro lado, o grupo de macrófagos infectados com $L$. amazonensis produziu a maior concentração de TNF- $\alpha$ comparado aos macrófagos infectados com L. braziliensis e macrófagos não infectados. Os fibroblastos incubados com meio condicionado de macrófagos infectados com $L$. amazonensis tiveram a ocupação de $64 \%$ da área da lesão in vitro, não apresentando diferença estatística em relação aos outros grupos. Entretanto, os fibroblastos incubados com meio condicionado de macrófagos infectados com $L$. braziliensis ocuparam $54 \%$ da área da ranhura in vitro e foi observada uma diminuição na migração destas células quando comparadas ao grupo de fibroblastos incubados apenas com meio condicionado de macrófago não infectado. Após verificar a migração dos fibroblastos, os sobrenadantes dessas células foram submetidos à detecção de oito citocinas, no qual foram detectadas duas citocinas durante a incubação com os meios condicionados de macrófagos por 24 e 48 horas. Após 24 horas, a IL-6 foi detectada em todos os grupos, porém não houve diferença significativa na produção. Por outro lado, após 48 horas houve um aumento de IL-6 para todos os grupos comparados ao tempo dos grupos após 24 horas. No grupo fibroblastos incubados com sobrenadante de macrófagos infectado com $L$. braziliensis após 48 horas a produção foi 1,7 vezes maior quando comparada ao grupo fibroblastos incubados com o meio condicionado de macrófagos não infectados.

Conclusão: Até o presente momento, concluímos que os grupos de fibroblastos incubados com macrófagos infectados com $L$. braziliensis apresentaram a menor migração para o centro da lesão in vitro, aparentemente associada à produção de IL-6.

\section{Referências bibliográficas:}

1- Brasil, Ministério Da Saúde. Manual de Vigilância da leishmaniose tegumentar americana. 4 ed. Brasília: Fundação Nacional de Saúde, 2017.

2- Bogdan, C.; Donhauser, N.; Doring, R.; Rollinghoff, M.; Diefenbach, A.; Ritting, M.G. Fibroblast as Host Cells in Latent Leishmaniosis. J. Exp. Med.n.12, p. 21212130, 2000.

3- Nylén, S. e Eidsmo, L. Tissue damage and immunity in cutaneous Leishmaniasis. 
Parasite Immunol. n.34, p.551-56, 2012.

4- Scott, P.; Novais, F. O. Cutaneous leishmaniasis: immune responses in protection and pathogenesis. Nature Reviews Immunology. n. 16(9), p. 581- 92, 2016.

Palavras-chave: Co-cultura; fibroblastos; macrófagos. 


\title{
ESTUDO METAGENÔMICO DO VIROMA DE MARSUPIAIS E ROEDORES ORIGINÁRIOS DO MUNICÍPIO DE SANTA BÁRBARA DO PARÁ.
}

\author{
Nome do(a) Bolsista: Thito Yan Bezerra da Paz \\ Nome do(a) Orientador(a): Ana Cecília Ribeiro Cruz
}

Resumo: A biodiversidade amazônica é a mais abundante do planeta, especialmente a de microrganismos. É ainda mais proeminente a diversidade viral, visto que os vírus são a maior fonte de material genético da Terra e infectam todos os organismos celulares conhecidos. Roedores e marsupiais estão inseridos em ciclos de transmissão de muitas zoonoses de etiologia viral como as arboviroses, hantaviroses e arenaviroses. Por essa razão, o desenvolvimento de comunidades humanas próximas à habitats de animais silvestres configura um fator de risco para tais doenças, dado o desenvolvimento de comportamento sinantrópico desses animais. A investigação do viroma de mamíferos amazônicos favorece o entendimento da ecologia desses vírus e a sua influência sobre a saúde humana e animal. Assim, este trabalho objetiva realizar análise metagenômica em amostras de marsupiais e roedores em busca de vírus de interesse humano e animal bem como realizar estudo filogenético para determinar a classificação taxonômica viral. Órgãos de 11 de roedores e 11 de marsupiais foram coletados no município de Santa Bárbara do Pará. As amostras serão maceradas e submetidas à extração do RNA total e avaliação de qualidade, após o que será realizada a síntese de cDNA. Após purificado e aferida sua qualidade, será feita a biblioteca genômica e aferidos os tamanhos dos fragmentos gerados e sua concentração. As amostras serão distribuídas de maneira equimolar na plataforma de sequenciamento NextSeq (Illumina). Os dados gerados no formato .bcl serão convertidos para o formato .fastq e os programas metaSPAdes e IDBA-UD farão a montagem das leituras brutas em contigs. Estes serão alinhados pelo programa Lasergene Molecular Biology e unidos em sequências consenso. Em seguida o arquivo será alinhado contra banco de dados viral pelo programa DIAMOND e visualizado no programa MEGAN6 para seleção de sequências de interesse. Estas serão importadas para o programa Geneious Prime onde os contigs serão organizados em scaffolds contra um genoma de referência. As sequências serão traduzidas e comparadas no banco de dados Swiss-Prot para curadoria manual. O programa ProtTest v.3 fará a seleção do melhor modelo de substituição aminoacídica para a construção da árvore filogenética por meio do pipeline RAXML fixando-se 1000 réplicas para a aplicação do teste estatístico de bootstrap. Espera-se que este estudo traga maior conhecimento sobre o viroma de marsupiais e roedores da região e auxilie a vigilância de vírus zoonóticos e potenciais patógenos humanos e animais.

Introdução: A biodiversidade amazônica é a mais abundante do planeta, especialmente a de microrganismos. A maior parte dela permanece ainda oculta, em parte pela escassa representação de algumas espécies, vieses geográficos durante a aplicação de estudos e ainda os insuficientes esforços de pesquisa em relação ao vasto território amazônico (MAGNUSSON et al., 2016). 
Os vírus são a maior fonte de material genético da Terra e infectam todos os organismos celulares conhecidos, o que torna a virosfera ainda mais diversa. A descoberta de novas espécies virais tende a acompanhar o potencial desses agentes de causarem doenças humanas ou em animais de importância econômica. Por essa razão, grande proporção dos vírus permanece ainda desconhecida (ZHANG; SHI; HOLMES, 2018).

Uma estimativa da diversidade total dos vírus que infectam mamíferos realizada por Anthony et al. (2013), demonstrou que haja cerca de 320.000 destes ainda não descobertos. Essa estimativa chama atenção para o fato de que muitos mamíferos selvagens albergam patógenos de interesse humano em potencial, tendo em vista que as zoonoses de importância para a saúde pública na atualidade são originárias de desequilíbrios ecológicos em ambientes selvagens (VASCONCELOS; CALISHER, 2016).

O desenvolvimento de comunidades humanas e o oferecimento de condições propícias de abrigo e excedentes alimentares criou uma relação denominada sinantropia com as populações de roedores e marsupiais, muitos deles transmissores de zoonoses, que comprometem a saúde humana e de animais domésticos e de criação como as arboviroses, hantaviroses e arenaviroses (FERNANDES et al., 2018; GUTERRES; DE LEMOS, 2018).

A importância de se investigar o viroma mamíferos amazônicos, especificamente marsupiais e roedores reside no melhor entendimento da ecologia desses vírus e a sua influência sobre a saúde humana e animal. Os habitats dessas populações se sobrepõem espacialmente aos territórios de ocupação ou visitação esporádica humana, algo observável no município de Santa Bárbara do Pará onde será conduzido o estudo.

Objetivos: Realizar análise metagenômica em amostras de marsupiais e roedores em busca de vírus de interesse humano e animal; Realizar estudo filogenético para determinar a classificação taxonômica viral.

Material e Método: Trata-se de um estudo observacional, analítico e transversal, haja vista que será estudada a distribuição de populações virais em roedores e marsupiais cujas amostras, obtidas por captura aleatória, foram coletadas em instantes temporais determinados.

Os materiais biológicos foram coletados no assentamento Expedito Ribeiro localizado no município de Santa Bárbara do Pará, pertencente à região Metropolitana de Belém, distanciando-se aproximadamente $40 \mathrm{~km}$ da capital. De acordo estimativas do Instituto Brasileiro de Geografia e Estatística (IBGE), o município possui, em 2019, uma população de 21.079 habitantes (IBGE, 2019). As áreas no assentamento foram escolhidas segundo o critério de presença de primária de com o mínimo de seis hectares nas proximidades de habitações humanas.

As amostras do estudo foram coletadas para a realização do projeto Pró-Amazônia, que contou com a equipe técnica da Seção de Arbovirologia e Febres Hemorrágicas (SAARB) do Instituto Evandro Chagas (IEC). As armadilhas foram posicionadas dentro da floresta e nas áreas limítrofes. Foram realizadas em períodos seco e chuvoso, de 15 a 31 de outubro de 2014 e 06 a 17 de abril de 2015, respectivamente. Contabilizam amostras de órgãos de 22 espécimes, 11 de roedores e 11 de marsupiais. 
Para a extração de RNA das amostras de órgãos, será utilizado um pequeno fragmento de cada órgão (aproximadamente $5 \mathrm{mg}$ ) inserido em um microtubo de polipropileno com capacidade de $2 \mathrm{ml}$, estéril e livre de DNases e RNases, macerados juntamente com 350 $\mu l$ do tampão de homogeneização que acompanha o kit de extração e uma esfera de tungstênio com $3 \mathrm{~mm}$ de diâmetro no equipamento TissueLyser /I (Qiagen) numa frequência de $25 \mathrm{~Hz}$ durante um minuto. No processo de extração do RNA total será utilizado o kit Maxwell 16 LEV simplyRNA Tissue Kit, com o sistema de extração e purificação automatizado Maxwell ${ }^{\circledR} 16$ (Promega) de acordo com as instruções do fabricante.

O RNA extraído seguirá para a etapa de síntese de cDNA (ácido desoxirribonucleico complementar). Ela será realizada a partir do kit cDNA Synthesis System (Roche Diagnostics) e de iniciador randômico, seguindo as instruções do fabricante. O cDNA, então, será purificado com o auxílio de esferas magnéticas AMPure bead, que o separa do restante da reação.

Por conseguinte, será realizada a etapa de preparação da biblioteca genômica empregando a metodologia descrita no kit Nextera XT DNA Library Preparation (Illumina). A quantidade de moléculas de cDNA será estimada usando o Qubit ${ }^{\circledR} 2.0$ Fluorometer e o kit Qubit ${ }^{\circledR}$ dsDNA HS Assay Kits, e os tamanhos dos fragmentos obtidos na biblioteca serão mensurados usando o kit High Sensitivity DNA Analysis Kits (Agilent Technologies) no equipamento Bioanalyzer 2100 (Agilent Technologies), bem como a sua concentração para direcionar a distribuição equimolar de cada amostra na plataforma de sequenciamento.

O sequenciamento será realizado utilizando a plataforma NextSeq (Illumina) com a utilização do kit NextSeq 500/550 Mid Output (300 ciclos) de acordo com as orientações do fabricante.

Os dados gerados pelo NextSeq (Illumina) em formato .bcl serão transformados em formato .fastq usando o programa bcl2fastq2 (Illumina, 2019), resultando, assim, em no mínimo dois arquivos R1 e dois arquivos R2, que serão concatenados em um único R1 e um único R2. Estes servirão de entrada para os programas de processamento de dados. Não se pretende, a priori, realizar o tratamento dos dados brutos a fim de evitar perdas de sequências que possam ser relevantes à pesquisa; entretanto, não se descarta a possibilidade de tratamento nestes dados caso sejam observadas bases com qualidade reduzida - através do programa FastQC (Babraham bioinformatics, 2019).

Posteriormente, serão utilizados os programas metaSPAdes (Bankevich et al., 2012) e IDBA-UD (Peng et al., 2012) para montagem das leituras brutas. Os arquivos de saída de ambos, que contam com as leituras organizadas em contigs, serão alinhados no programa Lasergene Molecular Biology (DNASTAR, 2019), unidos por merge, retirandose a redundância e extraindo-se a sequência consenso.

$\mathrm{O}$ arquivo unido contendo contigs das montagens, será alinhado junto às sequências de referência para vírus disponíveis no banco de dados do RefSeq (NCBI, 2019) usando o programa DIAMOND (Buchfink; Xie; Huson, 2015). O produto do alinhamento será, então, importado em formato .daa para o programa MEGAN6 (Huson et al., 2007; Huson, 2019) para visualização dos contigs que apresentarem correspondência com algum genoma viral já descrito e depositado no banco de dados. A mesma visualização no MEGAN6 também será feita diretamente do arquivo de dados brutos, também 
alinhados no DIAMOND, apenas para verificar a presença de possíveis leituras para vírus que não foram montados pelo SPAdes e IDBA-UD.

No MEGAN6, os contigs que apresentarem identidade com algum grupo viral conhecido (segundo as sequências de referência) serão extraídos e exportados para o programa Geneious Prime 2019 (Biomatters, 2019) para que possam ser ordenados (scaffolding) de acordo com um genoma de referência (map to reference). Este tipo de alinhamento baseado em referência também nos permitirá observar regiões de $\mathrm{N}$ (gaps), que poderão ser estendidos a partir de interações múltiplas contra as leituras brutas.

Todas as sequências curadas manualmente serão traduzidas no próprio Geneious Prime 2019 e comparadas no banco de dados de proteínas Swiss-Prot, que consiste em uma base fidedigna que fornece um elevado nível de anotação de proteínas, mínima redundância e alto grau de integração com outras bases (Bairoch; Apweiler, 2000).

Para realizar a seleção estatística do melhor modelo de substituição aminoacídica que será aplicado na análise filogenética, será utilizado o programa ProtTest v.3 (Darriba et al., 2012). Posteriormente será empregada a metodologia de estimação de Máxima Verossimilhança (MV) por meio do pipeline RAxML (Randomized Axelerated Maximum Likelihood) utilizado para a construção da árvore filogenética (Stamatakis, 2014). No processo de construção, será feito o uso do teste estatístico de bootstrap, fixando-se 1000 réplicas para testar o grau de confiabilidade das árvores agrupadas na árvore consenso (Felsenstein, 1985).

Resultados esperados: A grande biodiversidade amazônica somada aos fatores ambientais, epidemiológicos como a incidência de arboviroses, assim como o avanço dos limites urbanos sobre regiões com cobertura vegetal, o extrativismo existente na maioria das comunidades, como as presentes em Santa Bárbara do Pará, tornam esperado que este estudo traga maior conhecimento sobre o viroma de marsupiais e roedores da região e auxilie a vigilância de vírus zoonóticos e potenciais patógenos humanos e animais.

Referências bibliográficas: BABRAHAM BIOINFORMATICS. FastQC. Disponível em: http://www.bioinformatics.babraham.ac.uk/projects/fastqcl. Acesso em: 03 mar. 2019.

BAIROCH, A; APWEILER, R. The SWISS-PROT protein sequence database and its supplement TrEMBL in 2000. Nucleic Acids Research, [s.I.], v. 28, n. 1, p. 45-48, 2000.

BANKEVICH, A. et al. SPAdes: a new genome assembly algorithm and its applications to single-cell sequencing. Journal of Computational Biology, Nova Rochelle, v. 5, p. 455-477, 2012.

BIOMATTERS. Geneious Prime 2019. Disponível em: https://www.geneious.com/academicl. Acesso em: 03 mar. 2019.

BUCHFINK, B.; XIE, C.; HUSON, D. H. Fast and sensitive protein alignment using DIAMOND. Nature Methods, Nova lorque v. 12, n. 1, p. 59-60, 2015.

DARRIBA, D. et al. jModelTest 2: more models, new heuristics and parallel computing. Nature Methods, Nova Iorque, v. 9, n. 8, p. 772-772, 2012.

FELSENSTEIN, Joseph. Confidence limits on phylogenies: an approach using the bootstrap. Evolution, Hoboken, v. 39, n. 4, p. 783-791, 1985.

FERNANDES, J. et al. Detection of Latino virus (Arenaviridae: Mammarenavirus) 
naturally infecting Calomys callidus. Acta Tropica, v. 179, p. 17-24, mar. 2018.

GUTERRES, A.; DE LEMOS, E. R. S. Hantaviruses and a neglected environmental determinant. One Health, [s.I.], v. 5, p. 27-33, jan. 2018.

HUSON, D. H. et al. MEGAN analysis of metagenomic data. Genome research, Woodbury, v. 17, n. 3, p. 377-386, 2007.

HUSON, Daniel H. User Manual for MEGAN V6.15.0. 2019. E-book (74 p.). Disponível em: http://ab.inf.uni-tuebingen.de/data/software/megan6/download/manual.pdf. Acesso em: 07 mar. 2019.

ILLUMINA. bcl2fastq2 conversion software v2.20. Disponível em: https://support.illumina.com/downloads/bcl2fastq-conversion-software-v2-20.html. Acesso em: 30 ago. 2019.

INSTITUTO BRASILEIRO DE GEOGRAFIA E ESTATÍSTICA. IBGE. Santa Bárbara do Pará: histórico. Disponível em: https://cidades.ibge.gov.br/brasil/pa/santa-barbara-dopara/panorama. Acesso em: 07 mar. 2019.

MAGNUSSON, W. E. et al. A linha de véu: a biodiversidade brasileira desconhecida. Parcerias Estratégicas, Brasília, v. 21, n. 42, p. 45-60, jan./jun. 2016.

NATIONAL CENTER FOR BIOTECHNOLOGY INFORMATION. NCBI. RefSeq: NCBI Reference Sequence Database. Disponível em: https://www.ncbi.nlm.nih.gov/refseq/. Acesso em: 04 mar. 2019.

PENG, Y. et al. IDBA-UD: a de novo assembler for single-cell and metagenomic sequencing data with highly uneven depth. Bioinformatics, [s.l.], v. 28, n. 11, p. 1420-1428, 2012

STAMATAKIS, Alexandros. RAXML version 8: a tool for phylogenetic analysis and postanalysis of large phylogenies. Bioinformatics, [s.I.], v. 30, n. 9, p. 1312-1313, 2014.

VASCONCELOS, P. F. C.; CALISHER, C. H. Emergence of human arboviral diseases in the Americas, 2000-2016. Vector-borne and Zoonotic Diseases, Nova Rochelle, v. 16, n. 5, p. 295-301, maio 2016.

ZHANG, Y. Z.; SHI, M.; HOLMES, E. C. Using Metagenomics to characterize an expanding virosphere. Cell, [s.l.], v. 172, n. 6, p. 1168-1172, 8 mar. 2018.

Palavras-chave: Metagenômica; marsupiais; roedores; viroma Grande área: Ciências Biológicas

Área: Ciências Biológicas III 


\section{PROGRAMA DE PÓS- GRADUAÇÃO EM CIÊNCIAS AMBIENTAIS}




\section{DISPOSIÇÃO A PAGAR PELA CONSERVAÇÃO DO PARQUE MUNICIPAL DA ILHA DE MOSQUEIRO, BELÉM-PA}

Nome do(a) Bolsista: Edyrlli Naele Barbosa Pimentel

Nome do(a) Orientador(a): Manoel Tavares de Paula

Resumo: As áreas de vegetação nativa têm sido extensivamente degradadas ao longo dos tempos. Para evitar que os recursos naturais e serviços ambientais dessas áreas se esgotem devido ao uso excessivo criou-se as áreas protegidas, dentre as quais estão as Unidades de Conservação (UC). Embora sejam protegidas por lei, as UC no Brasil defrontam problemas aliados à degradação devido principalmente à falta de fiscalização e de estrutura e, por conseguinte são alvo de ocupação desordenada e sofrem impactos ambientais. Em decorrência disso, baseia-se a necessidade de atribuição de valor econômico a essas áreas que pode ser usado como base para a formulação de políticas públicas. Desse modo, este estudo teve como objetivo realizar a valoração ambiental do Parque Municipal da llha de Mosqueiro, Belém-PA utilizando o Método de Valoração Contingente. Para tanto foram aplicados questionários a 200 entrevistados. Ao fim da análise encontrou-se um valor médio de por pessoa de $R \$ 2,63$, sendo o valor total de $\mathrm{R} \$ 7.1010,00$. Com este estudo, espera-se fornecer informação de base para criação de políticas específicas para o parque.

Introdução: A preservação da biodiversidade é essencial para manter o equilíbrio das espécies presentes nos ecossistemas bem como os serviços ambientais por ele fornecidos. É um desafio conservar os recursos naturais que ainda restam, usando estratégias para lograr a sustentabilidade. Assim, os recursos protegidos por Unidades de Conservação (UCs) ganham importância mundial (LIMA, 2010). As UCs são um tipo específico de Áreas Protegidas (APAs), com características naturais relevantes, objetivos de conservação e com limites definidos, que estão submetidas a um regime especial de administração, às quais se aplicam garantias adequadas de proteção (BRASIL, 2000).

As áreas protegidas foram instituídas no Brasil em 1981 e regulamentadas pelo Sistema Nacional de Unidades de Conservação (SNUC) por meio da Lei Federal no 9.985 de 2000 (SOUZA, 2014). O SNUC é constituído pelo conjunto das Unidades de Conservação federais, estaduais e municipais enquadradas em 12 categorias, as quais possuem objetivos particulares a cada uma delas e que permitem usos diferentes de sua área. O SNUC é composto por dois grupos principais de UCs: UC de Proteção Integral e UC de Uso Sustentável. (MINISTÉRIO DO MEIO AMBIENTE, 2019).

A partir da criação da lei, os parques passam a assumir um novo significado em favor da preservação da biodiversidade e do bem coletivo. Tornam-se então o locus da preservação e contemplação do ambiente e do bem estar dos usuários e/ou das pessoas que vivem ao redor dos parques. Ainda tratando de bem coletivo, surge a necessidade da democratização da criação e da gestão desses espaços, incluindo a participação da sociedade (COSTA CARDOSO, 2015).

A llha de Mosqueiro é um distrito administrativo do município de Belém e possui aproximadamente 28 mil habitantes, uma média populacional próxima dos municípios 
paraenses de médio porte (BELÉM, 2018). Grande contribuição à preservação da cobertura vegetal total da ilha é dada pelo parque. O PMIM tem área de 190 ha sendo limitado pelo igarapé Tamanduá e pelo rio Murubira, e por uma linha seca demarcatória. O parque não possui Plano de Manejo também não possui administração e /ou gerência regular com equipe técnica e recursos necessários a gestão ambiental (FIGUEREDO, 2015).

Embora possua valor ambiental, atualmente apresenta um quadro de impactos considerável, tendo como principais problemas a falta de infraestrutura e ausência parcial de delimitação da área, falta de conhecimento da população local sobre o parque, falta de plano de manejo e a falta de informações a respeito de suas características físicas, químicas e biológicas sofrendo loteamento e urbanização desordenados (MENEZES et al., 2013).

Nesse contexto fundamenta-se a importância de valorar a APA para fornecer subsídios para elaboração de um plano de manejo e demais políticas públicas para a área. Em UCs, o desafio em realizar a valoração econômica está na mensuração monetária de bens e serviços, pois não possuem preço de mercado (MEDEIROS et al, 2011).

A valoração ambiental é fundamentada em estimar valores dos benefícios advindos do uso dos recursos naturais (OLIVEIRA JÚNIOR, 2004). De acordo com Motta (1998), calcula-se o valor econômico dos recursos ambientais a partir de seus atributos, os quais podem ou não estar associados a um uso.

O método de valoração contingente procura mensurar monetariamente o impacto no nível de bem-estar dos indivíduos decorrentes de uma variável quantitativa ou qualitativa dos bens ambientais. Esse método é utilizado para estimar o valor de bens públicos que não possuem mercado, ou seja, não há como comparar suas oscilações de preço baseadas no mercado do produto final ou no mercado de bens substitutos ou complementares (MOTTA, 2006).

Objetivo: Esse estudo tem como objetivo realizar a valoração contingente da área Parque Municipal da ilha do Mosqueiro, Distrito Municipal de Belém-PA. A fim de estabelecer a disposição média a pagar (DAP) dos habitantes e visitantes da ilha de mosqueiro para manter o parque e traçar o perfil socioeconômico dos entrevistados.

Material e método: O Parque Municipal da llha do Mosqueiro está localizado na referida ilha no município de Belém e delimita uma área de 190 ha (Figura 2). O distrito de Mosqueiro, localizado a $70 \mathrm{~km}$ da Capital, possui densidade demográfica de 1.315,26 $\mathrm{hab} / \mathrm{km} 2$, ocupando área territorial de 1.059,458 km2 com Índice de Desenvolvimento Humano (IDH) Municipal de 0,746 (IBGE, 2018).

A população amostral foi calculada a partir da fórmula utilizada por Silva (2001), na qual se adotou um limite de confiança de $95 \%$, com um coeficiente de confiança equivalente a 1,96. O tamanho da amostra foi dado por: $n=\left(Z^{\wedge} 2\right.$.p.q.N)/( $\left.e^{\wedge} 2 .(N-1)+Z^{\wedge} 2 . p . q\right)$

Onde, $\mathrm{n}=$ tamanho da amostra que se deseja encontrar; $\mathrm{N}=$ número total de moradores; p e q = probabilidades adotadas no estudo (como não há uma proporção determinada entre p e q, adotou-se o valor de 0,5 para ambos, como recomendado por Silva (2001)). $Z$ = nível de confiança adotado, indicando a porcentagem que os dados obtidos sejam 
válidos para a população total (considera-se Z=1,96 (grau de confiança de 95\%)); e = erro máximo utilizado, estipulado em $7 \%$.

Para atingir o objetivo proposto, aplicaram-se questionários estruturados contendo perguntas sobre a relação do entrevistado com o PMIM (visitação, importância) e informações socioeconômicas (sexo, idade, escolaridade, renda).

Por meio do método de valoração contingente (MVC), foi calculada a disposição a pagar (DAP) dos entrevistados para a conservação do parque. O método foi realizado por meio da técnica conhecida como bidding games escolhida através de levantamento bibliográfico de estudos com objetivos e áreas semelhantes, a fim de captar a máxima DAP.

Resultados e discussão: Encontrou-se um valor de 197 indivíduos como espaço amostral, a partir do número total de moradores da llha de Mosqueiro que é de aproximadamente 27.000 moradores segundo o IBGE (2016). Foram então aplicados 200 questionários considerando-se eventuais perdas.

Desse modo o estudo constatou que $68 \%$ dos entrevistados estão dispostos a pagar um valor médio de $\mathrm{R} \$ 2,63$ pelo uso e conservação do PMIM enquanto $32 \%$ não se dispuseram a pagar. Considerou-se então os $68 \%$ que se dispuseram a contribuir com algum valor para estimar a DAP em conformidade com Motta (1997) em que a DAP m= 2,63; $\mathrm{ni}=136, \mathrm{~N}=200$ e $\mathrm{X}=27.000$. Encontrou-se o valor de $\mathrm{R} \$ 4.828,68$, mensais e $\mathrm{R} \$$ 57. 944,16 , anuais.

Foram entrevistadas 64 pessoas sem qualquer disposição a pagar pelo uso e conservação do PMIM. A justificativa da maior parte desses que não se dispuseram a pagar foi que o parque não tem nenhuma função na área, que tem estado ociosa e sem cuidado algum por muito tempo e que esta é uma obrigação que cabe ao governo.

Se tratando do nível de instrução dos entrevistados predomina o ensino médio com (52\%) dos indivíduos. Em seguida (42\%) dos entrevistados estudaram até o ensino fundamental e a minoria, (4\%) dos entrevistados tem até o curso superior completo e (2\%) cursaram pós-graduação.

No caso do PMIM, a maior disposição a pagar foi encontrada entre os entrevistados que tinham nível superior (75\%) seguida pelos entrevistados que tinham ensino médio completo (71\%). Este resultado foi compatível com o de Silva (2004) onde a DAP/nível de escolaridade indicou que os entrevistados que tinham o segundo grau estavam mais propensos a contribuir para conservar um ativo ambiental (75\%).

Com relação à renda familiar, $(37,5 \%)$ dos entrevistados, exatamente 75 , têm renda de até um salário mínimo e 76 (38\%) de até dois salários mínimos enquanto 38 entrevistados (19\%) tem renda de até três salários e apenas 11 entrevistados (5,5\%) pertencem à classe com renda acima de três salários mínimos.

A maior disposição a pagar foi encontrada na faixa de renda de até 1 salário mínimo seguido pela faixa de mais de 3 salários mínimos.

Outros aspectos foram levantados durante o estudo. Constatou-se que a maioria é natural da ilha de mosqueiro, porém uma parte relevante veio de cidades próximas em busca de trabalho e se instalou na ilha, a maior parte pertencia ao sexo feminino, embora essa diferença entre os sexos tenha sido pequena. 112 entrevistados nunca 
estiveram no parque enquanto 88 já estiveram dentre os quais a frequência de visitação é principalmente de uma vez ao mês ou uma vez ao ano.

Quando questionados sobre quais os motivos de visitação ao parque, foram citados principalmente o contato com a natureza e o lazer. É importante frisar que a área não tem estrutura para a prática de muitos esportes. É possível a realização de trilhas, porém não há tanta procura devido à falta de segurança.

Ainda nesse sentido, alguns entrevistados atentaram ao fator segurança, tendo em vista que a área é aberta e pode ser usada como esconderijo e abrigo de assaltantes e usuários de entorpecentes. Assim, é formada uma percepção negativa de uma parte dos moradores a respeito do parque, influenciando na Disposição A Pagar.

Percebeu-se que quase a totalidade dos entrevistados desconhece que o PMMIM é uma Unidade de Conservação de Proteção Integral. Do mesmo modo, o estudo feito por Silva \& Silva (2013) em uma unidade de conservação semelhante constatou que entre os moradores que viviam no seu entorno, $79 \%$ não conheciam a existência da UC no local, o que demostra a ausência de participação da população na criação e gestão da área. Isto também demonstra a falta de conhecimento da população acerca dos benefícios ambientais que essas áreas proporcionam e da necessidade e obrigatoriedade legal de conservá-las.

Conclusão: Este estudo buscou estimar um valor diretamente relacionado aos serviços ambientais proporcionados pela conservação do Parque Municipal da llha de Mosqueiro através da disposição a pagar dos moradores do entorno. Ainda que o valor encontrado não corresponda ao valor exato da área, este poderá ser usado como base para futuros projetos públicos ou privados voltados para a exploração sustentável da potencialidade do ecoturismo em áreas de unidade de conservação e também no projeto do plano de manejo da área, até momento inexistente.

As variáveis socioeconomicas encontradas (especialmente renda e escolaridade) indicam um padrão de vida baixo, o que pode estar relacionado com o resultado obtido. Para estudos futuros propõe-se estimar um valor total para a APA Parque Municipal da ilha de Mosqueiro a partir de outros métodos de valoração, a fim de verificar se há diferenças relevantes no valor obtido com a metodologia obtida neste estudo.

Referências: BRASIL. Sistema Nacional de Unidades de Conservação da Natureza: Lei n. ${ }^{\circ}$ 9.985, de 18 de julho de 2000. Disponível em: Acesso em: 27 nov. 2018 COSTA CARDOSO, S. L.; VASCONCELLOS SOBRINHO, M.; DE ALBUQUERQUE, A. M. Gestão ambiental de parques urbanos: o caso do Parque Ecológico do Município de Belém Gunnar Vingren. Revista Brasileira de Gestão Urbana, [S.I.], v. 7, n. 1, p. 74-90, out. 2017. ISSN 2175-3369. Disponível em: <https://periodicos.pucpr.br/index.php/Urbe/article/view/22046/21156>. Acesso em: 10 jun. 2019.

FIGUEIREDO, S. L.; AZEVEDO, F. F.; NÓBREGA, W. R. M. Perspectivas contemporâneas de análise em turismo. NAEA. Belém, Pará, 2015.

INSTITUTO BRASILEIRO DE GEOFRAFIA E ESTATÍSTICA - IBGE. Censo demográfico - 2010. Disponível em: https://biblioteca.ibge.gov.br/index.php/bibliotecacatalogo?view=detalhes\&id=42472. Acesso em: 22 nov. 2018. 
LIMA, A. F. A importância de uma gestão sustentável em unidades de conservação - o caso do parque ecológico Altamiro de Moura Pacheco - Goiás. Dissertação de mestrado. Brasília-DF, 2010.

MEDEIROS, R.; YOUNG; C.E.F.; PAVESE, H. B.; ARAÚJO, F. F. S. Contribuição das unidades de conservação brasileiras para a economia nacional: Sumário Executivo. UNEP-WCMC, 44p. Brasília, 2011.

MENEZES, L. B. C.; CARVALHO, E. A. de; NUÑEZ, Y. T.; BRITO, L. B.; SEMBER, N. B. G.; VASCONCELOS, E. F. Parques urbanos de Belém (PA): situação atual e problemáticas sócio-ambientais. Revista Ciência e Tecnologia. v. 1, n. 1, 2013.

MOTTA, R. S. da. Economia ambiental. FGV, 228 p Rio de Janeiro ,2006.

MOTTA, R. S. Manual para valoração econômica de recursos ambientais. Ministério do Meio Ambiente, dos Recursos Hídricos e da Amazônica Legal, 218 p. 1998.

OLIVEIRA JUNIOR, A. F. Valoração econômica da função ambiental de suporte relacionada às atividades de turismo, Brotas, SP. São Carlos: UFSCar, 2004. Tese de doutorado.

SILVA, N.N. Amostragem probabilística. $2^{\mathrm{a}}$ ed. São Paulo: EDUSP; 2001

SNUC - Sistema Nacional de Unidades de Conservação; Lei 9.985 de 18 de julho de 2000; Ministério do Meio Ambiente.

SOUZA, D. E. Aspectos socioambientais e a gestão da apa estadual das águas vertentes Daniella Eloi de Souza. Dissertação de mestrado. Universidade Federal de Minas Gerais, Belo Horizonte, 2014.

Palavras-chave: Valoração contingente. Serviços ambientais. Sustentabilidade. 


\section{DIAGNÓSTICO SOCIOECONÔMICO E AMBIENTAL DA PRODUÇÃO DE AÇAí (Euterpe oleracea Mart.) NO MUNICÍPIO DE IGARAPÉ-MIRI, PARÁ}

Nome do(a) Bolsista: Hellem Pinheiro Almeida

Nome do(a) Orientador(a): Alfredo Kingo Oyama Homma

Resumo: O município de Igarapé- Miri é conhecido como a capital mundial açaí devido ser um dos maiores produtores e exportadores do fruto, sendo marcado por modelos de exploração extrativista e agrícola, que provocaram mudanças econômicas e ambientais. O estudo visa realizar o diagnóstico socioeconômico e ambiental da produção de açaí em Igarapé-Miri. Para tanto, será realizado pesquisas bibliográficas, bem como atividades de campo valendo-se de entrevistas e formulários semiestruturados, além de utilizar imagens de satélite com o intuito de relacionar o aumento da expansão do açaí com o desmatamento. Portanto, o trabalho busca verificar se a rentabilidade e o custo total da produção é um fator determinante da sustentabilidade dos produtores de açaí do município de Igarapé-Miri, bem como se indicadores socioeconômicos e sustentáveis influenciam na produtividade.

1 Introdução: O açaizeiro (Euterpe oleracea Mart.) é uma palmeira que se destaca entre as plantas da biodiversidade das matas de várzeas, igapós e terra firme da região amazônica. No Brasil, a Amazônia é a região que concentra o gênero Euterpe com destaque para os Estados do Pará, Amapá e Maranhão que possuem as maiores populações, com predominância da espécie Euterpe oleracea Mart., embora seja encontrado ainda no Amazonas, Mato Grosso, Acre, Roraima e Tocantins (REIS, 2015).

Compõe naturalmente a paisagem das áreas de várzea da Amazônia, onde a concentração de açaizais manejados ocorre principalmente na desembocadura dos rios Tocantins, Pará e Amazonas sendo este último, seu centro de origem, apresentando grande diversidade populacional e genética (JARDIM et al., 2004).

A região do Baixo Tocantins, no estado do Pará, apresenta dinâmicas de ocupação e de desenvolvimento socioeconômico diferenciadas, uma vez que a dinâmica de ocupação territorial mais frequente é a ribeirinha, que depende da acessibilidade fluvial e utiliza as cidades circunvizinhas como entrepostos de troca da sua produção e se ocupa de pluriatividades baseadas no agroextrativismo de várzea, principalmente na extração do fruto açaí (Euterpe oleracea Mart.); na pesca e na agricultura familiar (SILVA; AMORIM 2017).

O açaí, fruto do açaizeiro, apresenta grande importância econômica e, sobretudo, alimentar para as populações ribeirinhas e urbanas, por disponibilizar nutrientes para suprir, juntamente com a farinha e o peixe, a dieta alimentar dessa população em níveis superiores aos recomendados pela Organização Mundial da Saúde (NOGUEIRA, HOMMA 2014).

O município de Igarapé-Miri destaca-se por ser um dos maiores produtores e exportadores do fruto, sendo conhecida como capital mundial açaí. A produção advém das áreas de açaizais nativos das ilhas de várzea, manejadas por ribeirinhos. No entanto, o aumento da demanda pelo fruto do açaí associada ao aumento de valor 
mercadológico ocasionou alterações no sistema de produção, bem como colaborou para que as áreas de várzeas tenham se transformado em áreas homogêneas de açaí. Logo, objetiva-se realizar o diagnóstico socioenômico e ambiental da produção de açaí em Igarapé-Miri.

\section{OBJETIVOS}

2.1 GERAL: Realizar diagnóstico socioenômico e ambiental da produção de açaí em Igarapé-Miri.

\subsection{ESPECÍFICOS:}

- Identificar as alterações econômicas;

- Investigar as modificações sociais;

- $\quad$ Analisar as alterações ambientais;

- Verificar as mudanças no sistema de produção.

\section{MATERIAL E MÉTODO}

\section{1 ÁREA DE ESTUDO}

\subsubsection{Localização}

O município de igarapé- Miri/PA, está localizado na mesorregião do Nordeste Paraense (Baixo Tocantins), a uma latitude $01^{\circ} 58^{\prime} 30^{\prime \prime}$ sul e a uma longitude $48^{\circ} 57^{\prime} 35^{\prime \prime}$ oeste, estando a uma altitude de 17 metros, com uma área de aproximadamente 1.996,790 km2, à $78 \mathrm{~km}$ de Belém, capital do estado. O território é composto por áreas de várzea (ilhas) e terras firmes, caracterizadas por uma extensa relação da população com o meio natural (SILVA, 2016).

Figura 01: Localização do município de Igarapé-Miri
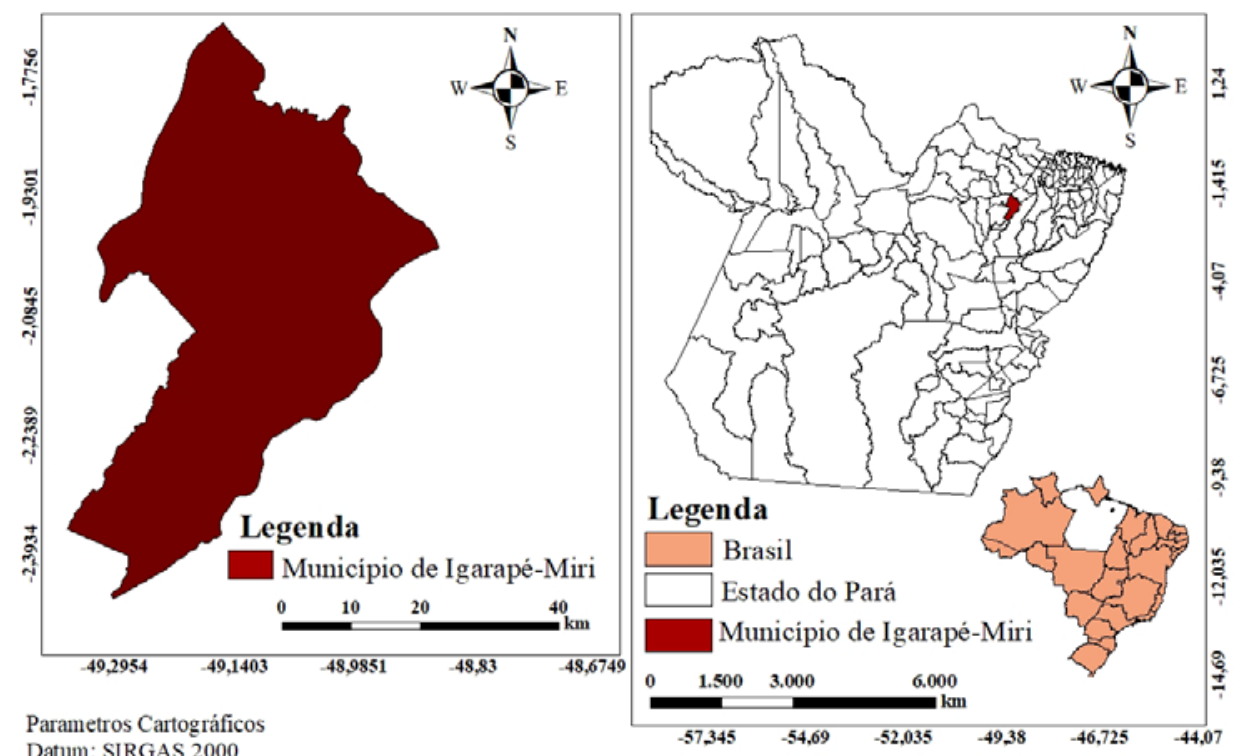

Darametros Cartograficos

Sistemas de Coordenadas: Lat, $\mathrm{Log}$

Base Cartográfica: IBGE

MAPA DE LOCALIZAÇÃO DO MUNICÍPIO DE IGARAPÉ-MIRI-PA

Fonte: Almeida, 2018 


\subsection{PROCEDIMENTO EXPERIMENTAL}

\subsubsection{Coleta das amostras}

A coleta das amostras foi realizada, no município de Igarapé-Miri, abrangendo três comunidades de açaí (núcleos produtivos), tais como: Anapú, Caji e Meruú. A primeira etapa do trabalho foi iniciada com pesquisas bibliográficas com o intuito de obter informações sobre o tema abordado, buscando aprofundar os conceitos necessários para o entendimento do tema. Em seguida, foram realizadas 2 visitas, sendo a primeira para seleção das comunidades estudadas e a segunda para obtenção dos dados.

É importante ressaltar que o projeto foi submetido ao Comitê de Ética e Pesquisa.

\subsubsection{Descrição das atividades}

A pesquisa apresenta abordagem quanti-qualitativa e classifica-se como exploratória e descritiva.

No que tange a obtenção de dados, foi realizado um levantamento bibliográfico em fontes que versam sobre o tema (livros, artigos, dissertações). Para análise socioeconômica, foram realizadas entrevistas e questionários com o intuito de obter informações tais como: idade, escolaridade, renda, produtividade etc.

Após a coleta de dados, os mesmos serão submetidos a tratamentos estatísticos por meio dos software excell e past.

Para o aspecto ambiental, serão obtidas imagens de satélite do PRODES que realiza o monitoramento por satélite do desmatamento por corte raso na Amazônia Legal e produz as taxas anuais de desmatamento na região, que são usadas pelo governo brasileiro para o estabelecimento de políticas públicas. O PRODES utiliza imagens de satélites da classe LANDSAT (20 a 30 metros de resolução espacial e taxa de revisita de 16 dias) em uma combinação que busca minimizar o problema da cobertura de nuvens e garantir critérios de interoperabilidade. O objetivo da utilização do PRODES é verificar a alteração da cobertura vegetal no período de 2008 à 2018 e relacionar com a expansão do açaí no município.

\section{Resultado e discussão}

Com a realização da pesquisa, espera-se verificar se a rentabilidade e o custo total da produção é um fator determinante da sustentabilidade dos produtores de açaí do município de Igarapé-Miri, bem como se indicadores socioeconômicos e sustentáveis influenciam na produtividade.

Pretende-se desenvolver um artigo sobre o consumo de açaí (Euterpe Oleraceae Mart) pelos produtores de açaí do município de Igarapé-Miri. Outro artigo que será gerado, será sobre o Perfil socioeconômico dos produtores de açaí do município de Igarapé-Miri e o terceiro será Avaliação do desmatamento no município de Igarapé-Miri por meio de imagens de satélite.

\section{Conclusão:}


A pesquisa visa contribuir para o planejamento ambiental, fornecendo subsídios para o desenvolvimento de medidas mitigadoras dos impactos ambientais gerados, bem como subsidiando a tomada de decisões pelos órgãos de monitoramento e fiscalização, visando identificar e quantificar os impactos gerados e suas consequências para o bemestar da população. Além de auxiliar em processos capazes de melhorar os indicadores socioenômicos e sustentáveis.

Portanto, pretende-se compreender a relação existente entre homem e meio ambiente e contribuir para que os impactos ambientais sejam atenuados, bem como fornecer um retorno à sociedade melhorando o seu bem-estar.

Referências bibliográficas: JARDIM, M. A. G.; MOURÃO, L.; GROSSMANN, M. (Ed.) Açaí (Euterpe oleracea Mart.): possibilidades e limites para o desenvolvimento sustentável no estuário amazônico. Belém: Museu Paraense Emílio Goeldi, 2004.

NOGUEIRA, O. L.; HOMMA, A. K. O. Importância do manejo de recursos extrativos em aumentar a capacidade de suporte: o caso de açaizeiros (Euterpe oleracea Mart,) no estuário amazônico. In HOMMA, A. K. O. (Ed.). Extrativismo vegetal na Amazônia: história, ecologia, economia e domesticação. Brasília: Embrapa, 2014.

REIS, Adebaro Alves dos. Desenvolvimento sustentável e estratégias de uso dos recursos naturais em área de várzea no Baixo Tocantins, Amazônia. Tese (PósGraduação em Desenvolvimento Sustentável do Trópico Úmido) _ Universidade Federal do Pará, Belém, 2015.

SILVA, Acenet Andrade et al. Sistemas agroflorestais nas ilhas de várzea, município de Igarapé-Miri, Pará. In: CONGRESSO BRASILEIRO DE SISTEMAS AGROFLORESTAIS, 10, 2016, Cuiabá. Anais... Cuiabá: SBSAF, 2016.

SILVA, Bruno da; AMORIM, Tanielle Santos. A produção, venda e renda do açaí: um estudo no município de Igarapé-Miri /PA. In: SIMPÓSIO INTERNACIONAL DE GEOGRAFIA AGRÁRIA, 8, 2017, Curitiba. Anais... Curitiba: SINGA, 2017

Palavras-chave: Açaí. Desmatamento. Sensoriamento Remoto.

Grande-área: Ciências Agrárias

Área: Ciências Ambientais 


\title{
RECURSOS DA SOCIOBIODIVERSIDADE AMAZÔNICA: ETNOCONHECIMENTO DO TUCUMÃ (ASTROCARYUM VULGARE MART.) E DO "ÓLEO DE BICHO", SALVATERRA, PARÁ, BRASIL
}

\author{
Nome do(a) Bolsista: Igor dos Santos Soares \\ Nome do(a) Orientadora: Flávia Cristina Araújo Lucas
}

\begin{abstract}
Resumo: Recursos da sociobiodiversidade são bens e serviços (produtos finais, matérias primas ou benefícios) oriundos de recursos da biodiversidade, voltados à formação de cadeias produtivas de interesse dos povos e comunidades tradicionais e de agricultores familiares, onde se prima pela valorização de práticas, saberes, garantia de direitos, além da geração de renda e promoção da melhoria da qualidade de vida destes povos. Na Amazônia brasileira, um desses recursos é o tucumã do Pará (Astrocaryum vulgare Mart.), por sua vez, muito utilizado pelas comunidades tradicionais da região, entretanto, pouco estudado quanto aos seus usos culturais e potenciais. $O$ presente trabalho apresenta resultados sobre o etnoconhecimento do tucumã e de seu principal subproduto, o "óleo de bicho do tucumã", em 12 comunidades, mais a sede municipal, do município de Salvaterra, Pará.
\end{abstract}

Introdução: A sociobiodiversidade é definida como inter-relação entre a diversidade biológica e a diversidade de sistemas socioculturais (BRASIL, 2018). Nela, recursos e subprodutos naturais que carregam importante carga cultural, devido aos usos tradicionais diversos, são denominados produtos da sociobiodiversidadede, pois congregam a conservação e valorização integral da biota in situ e do acervo de saberes e conhecimentos a ela associados (DIEGUES, 2005).

As palmeiras, (Arecaceae Schultz), apresentam gêneros e espécies bem distribuídas nas regiões tropical e subtropical, principalmente na Ásia, Indonésia, Ilhas do Pacífico e nas Américas (CAXAMBÚ et al., 2015). Só no Brasil, ocorrem cerca de 296 espécies em 47 gêneros (CAXAMBÚ et al., 2015), cuja maior diversidade se concentra na Amazônia brasileira, com cerca de 200 a 250 espécies de palmeiras (LORENZI et al., 2010). Onde, além de desempenharem funções ecológicas como moradia e fontes de alimento para diferentes grupos animais, também apresentam reconhecida importância cultural e econômica no emprego de biomassa para comunidades tradicionais locais (BATTIROLA et al., 2014), como é o caso do tucumã do Pará e do seu principal subproduto, o "óleo de bicho do tucumã", produzido de larvas de besouros que predam a semente do tucumã. Muito embora da importância para a Microrregião do Arari, Ilha de Marajó, estudos que visam catalogar e salvaguardar o acervo de informações tradicionais a respeito de usos do tucumã e do "óleo de bicho do tucumã" são pouco explorados. Sobre a palmeira, somente Menezes et al. (2014) descrevem usos para o município de Soure. Sobre o óleo, investigações realizadas nos trabalhos de Luz (2011), Menezes et al. (2012; 2014), Rocha et al. (2014), Rocha; Tavares-Martins; Lucas (2017) e Silva (2016), registram a aplicação medicinal caseira do óleo no tratamento de doenças e sua contribuição com o fortalecimento de renda, no mesmo município. Assim, os demais municípios se tornam campos propícios a investigações mais aprofundadas. 
Pressupondo que o tucumã e o "óleo de bicho" das comunidades rurais do município de Salvaterra são notórios recursos da sociobiodiversidade amazônica, constituídos de importância cultural, econômica e etnofarmacológica singular, a pesquisa centrou-se em responder as seguintes questões: 1. Quais os usos gerais indicados pelas comunidades para o tucumã e o "óleo de bicho" em Salvaterra? 2. Quais as indicações medicinais e sistemas corporais da Classificação Estatística Internacional de Doenças - CID 10/OMS, são atendidos pelo "óleo de bicho" na medicina tradicional? 3. Qual o grau de conhecimento e importância do "óleo de bicho" no município de Salvaterra?

Objetivo: Investigar os conhecimentos e formas de uso do tucumã (Astrocaryum vulgare Mart) e do "óleo de bicho do tucumã", em comunidades tradicionais de Salvaterra, Pará, Brasil, com ênfase nos conhecimentos tradicionais associados ao uso medicinal do "óleo de bicho do tucumã".

Material e Método: A pesquisa foi realizada no município de Salvaterra llha de Marajó, Pará, entre julho de 2018 e julho de 2019, nas comunidades de Água Boa, Bairro Alto, Caldeirão, Cururu Grande, Deus Me Ajude, Joanes, Jubim, Mangueiras, Maruacá, Paixão Providência, Vila Santo Antônio e sede do munícipio de Salvaterra. Seguindo a Resolução 466/2012, o TCLE e o projeto de pesquisa foram cadastrados na Plataforma Brasil e encaminhados para apreciação do Comitê de Ética em Pesquisas com Seres Humanos - CEP/UEPA/CCBS/CESEM, com permissão de ${ }^{\circ}$ CAAE:03.375.234. A partir de então, foram consultados 279 participantes selecionados pelas técnicas bola de neve e seleção racional. Destes, 29 são 'especialistas', que são pessoas cultivam saberes culturais da tradição de usos do tucumã, além de experiência na extração e práticas terapêuticas com o "óleo de bicho do tucumã", já os outros 250 , constituem pessoas da população geral (moradores das comunidades e sede municipal), a fim de verificar o grau de conhecimento e importância do óleo de bicho entre uma parcela de usuários não especialistas do município. A coleta de dados se deu visitas prévias, observação não participante e entrevistas semiestruturadas aplicadas aos dois grupos de participantes. Os dados qualitativos, foram analisados pela técnica Análise de conteúdo, já os quantitativos, por testes não paramétricos de Mann Whitney, Kruskal wallis e correlação de Person.

\section{Resultado e Discussão}

\section{Perfil dos participantes}

Dos 279 participantes consultados, $(90,6 \%)$ vive no espaço rural, $(70,9 \%)$ são mulheres, $(57,3 \%)$ católicos, com idade variando de 18 a 94 anos e maioria (66,6\%) estudaram do pré-escolar à oitava série do ensino fundamental (9 anos de estudo). São pluriativos, desenvolvendo atividades agroextrativistas de subsistência como a pesca artesanal, extrativismo vegetal de frutos, sementes e madeira; cultivo de monocultura de mandioca e abacaxi; atividade autônomas como comércio e venda de produtos de beleza; trabalho braçal, entre outras

\section{Usos culturais do Tucumã}

Em Salvaterra, o tucumã é explorado de manchas naturais distribuídas em campos naturais, matas, áreas de pasto, quintais e apresentou 36 formas diferentes de usos, alocadas em 16 categorias. Os principais usos são: uso da larva das larvas de besouros predadores das sementes como alimento, uso da polpa in natura do fruto para a 
elaboração de pratos tradicionais como a "Cunhapira" e uso das partes da planta em construções rurais como casas de pau a pique e cercas de quintal.

\section{Usos culturais do óleo de bicho do tucumã}

O óleo de bicho é versátil, com usos distribuídos em três categorias, a alimentar, a cosmética e a medicinal, com destaque para a aplicação terapêutica do mesmo. Na alimentação o óleo é consumido puro, com pão, na fritura de ovos e carnes, e compondo pratos regionais como a tapioquinha e o mingau caribé. Nenhum destes usos foi registrado para outro tipo de óleo animal na Amazônia, o que logo os caracteriza como formas de usos peculiares locais.

Como cosmético, a aplicação é mais reportada entre mulheres mais idosas, que o utilizavam como produto de beleza nos cabelos e pele, pelo potencial hidratante do óleo. Já na medicina caseira, o óleo alcança amplitude terapêutica no tratamento e cura de 46 doenças e 23 indicações de sintomas, sinais, achados anormais, lesões e consequências de causas externas, atendendo 16 subcategorias dos sistemas corporais, dentro da classificação Estatística Internacional de Doenças (CID-10), da OMS. Entre participantes especialistas, as indicações do OB mais citadas estão a inflamação (21), garganta inflamada/amigdalite (16), baque/contusão (15), ferimento e inchaço/edema (13). Na população geral, repercutem o baque/contusão (151), inflamação (105), inchaço (79), ferimento (52), garganta inflamada/ amigdalite (45) e dor (geral) (39). Com exceção da dor, os usos medicinais reportados são idênticos em ambos os grupos.

Nessa categoria de uso, o óleo de bicho também pode ser misturado com outros remédios naturais como plantas medicinais (16 espécies), outros gorduras (8 espécies) e remédios homeopáticos. Pela amplitude terapêutica apresentada, o óleo é tido como o "santo remédio" das comunidades pesquisadas, e nesse aspecto, não foi encontrado nenhum outro tipo de larva com a mesma finalidade pelo mundo, principalmente para tratamento de doenças inflamatórias.

\section{Grau de conhecimento e importância do óleo de bicho}

Quanto ao nível de conhecimento de usos alimentares do óleo de bicho na alimentação, se constatou que entre especialistas, a variável 'gênero' influenciou o número citações de usos, sendo significativamente maior entre mulheres $(p=0,01)$. Como remédio, entre especialistas, o número de doenças citadas como tratadas com óleo do bicho é significativamente menor, em relação aos informantes extrativistas e os outros participantes, que exercem outras atividades de trabalho. Já na população geral, a 'origem do informante' influenciou o nível de conhecimento, com número de citações significativamente maior ( $p=0.002)$ entre nativos originários das comunidades estudadas, da sede municipal e demais municípios do Marajó, em relação aos informantes de outros municípios do estado do Pará. No mesmo grupo de informantes da população geral, o número de citações de uso medicinal foi significativamente maior entre os nascidos em outras regiões do Marajó, quando comparado àqueles de outros municípios do Pará $(p=0.04)$ e os nascidos em na sede Salvaterra $(p=0.04)$.

Conclusão: Os dados apresentados evidenciam que a tradição de usos do tucumã e do "óleo de bicho do tucumã" é singular e bem desenvolvida nas comunidades investigadas, pela importância alimentar, fortalecimento de renda e, principalmente, o destacado uso medicinal do óleo de bicho. Por isso, a partir do inventário de etnoconhecimento levantado, se aponta como necessários, incentivos direcionados ao estabelecimento da 
cadeia de valor do óleo de bicho, caracterização físico-química dos óleos produzidos, constituição química das larvas, e, principalmente, testagem do potencial de atividade biológica do óleo de bicho contra os principais problemas de saúde encontradas. Tudo isso, a fim de orientar a população na forma mais adequada de preparação e uso, além de contribuir com o visibilidade do óleo de bicho e do tucumã, como recursos da sociobiodiversidade amazônica, com importância cultural, econômica e medicinal. Desse modo, os resultados retornaram para as comunidades meio dos artigos produzidos e de oficinas e minicursos voltados ao fortalecimento e visibilidade da cadeia produtiva da Sociobiodiversidade do tucumã, como: boas práticas de manipulação, melhoramento da qualidade sensorial dos produtos, padronização de embalagens (rotulagem, layout, marca etc.), incentivo à aquisição do Selo Nacional da Agricultura Familiar (SENAF) para os produtos que se enquadram nos tipos SENAF Sociobiodiversidade e Quilombola, além de incentivo a circulação comercial dos produtos.

\section{Referências bibliográficas:}

BATTIROLA, L. D. et al. Coleoptera (Arthropoda, Insecta) Associados às Copas de Attalea phalerata Mart. (Arecaceae) no Pantanal de Mato Grosso, Brasil. EntomoBrasilis, v. 7, n. 1, p. 20-28, 2014.

BRASIL. Ministério do Meio Ambiente - MMA. Plano Nacional de Promoção de Cadeias de Produtos da Sociobiodiversidade - PNPPSB. Plano de ação 2018. MDA; MMA; MDS. Brasília (DF), 2009. Disponível em: < http://www.mda.gov.br/sitemda/ sites/sitemda/files/user_arquivos_64/PLANO_NACIONAL_DA_SOCIOBIODIVERSIDAD E-julho-2009.pdf >. Acesso em: 19 fev. 2019.

CAXAMBÚ, M. G. et al. Palmeiras (Araceae) nativas do município de Campo Mourão, Paraná, Brasil. Revista do Jardim Botânico do Rio de Janeiro, v. 66, p. 259-270, 2015.

DIEGUES, A. C. S. Sociobiodiversidade. In: FERRARO-JUNIOR, L. A. (Org.). Encontros e caminhos: formação de educadoras(es) ambientais e coletivos educadores. Brasília: MMA, 2005. v. 1, p. 303-312.

LORENZI, H. et al. Flora brasileira - Arecaceae (Palmeiras). Nova Odessa: Plantarum. 384p., 2010.

LUZ, N. C. Sustentabilidade socioambiental a partir do uso de alternativas locais: o caso da exploração do tucumã (Astrocaryum vulgare Mart.). 2011. 101 p. Dissertação (Mestrado) - Universidade Federal do Pará, Núcleo de Meio Ambiente, Programa de Pós-Graduação em Gestão de Recursos Naturais e Desenvolvimento Local na Amazônia, Belém, 2011.

MENEZES, A. J. E. A. et al. Etnocultivo do tucumã do pará (Astrocaryum vulgare Mart.) na mesorregião da ilha do Marajó-município de Soure-Pará. In: Embrapa Amazônia Oriental-Artigo em anais de congresso (ALICE). In: CONGRESSO BRASILEIRO DE RECURSOS GENÉTICOS, 2., 2012, Belém, PA. Anais... Brasília, DF: Sociedade Brasileira de Recursos Genéticos, 2012. 
ROCHA, T. T.; TAVARES-MARTINS, A. C. C.; LUCAS, F. C. A. Traditional populations in environmentally protected areas: an ethnobotanical study in the Soure Marine Extractive Reserve of Brazil. Boletín Latinoamericano y del Caribe de Plantas Medicinales y Aromáticas, v. 16, n. 4, 2017.

Palavras-chave: Ilha de Marajó. Comunidades tradicionais. Palmeira tucumã. Óleo medicinal.

Grande-área: Ciências Biológicas

Área: Etnobiologia 


\title{
AVALIAÇÃO DA QUALIDADE DA H2O DE POÇOS DOMÉSTICOS EM COMUNIDADES RURAIS NO MUNICÍPIO DE SALVATERRA, ILHA DE MARAJÓ- PA
}

\author{
Nome do(a) Bolsista: Marcelo Coelho Simões \\ Nome do(a) Orientador(a): Cléa Nazaré Carneiro Bichara
}

RESUMO: Objetivou avaliar a qualidade da $\mathrm{H} 2 \mathrm{O}$ de poços domésticos utilizados pelas comunidades rurais do município de Salvaterra, a partir de avaliação dos parâmetros físico-químicos e microbiológicos, sendo as comunidades São Veríssimo, Ceará e julho. Realizou-se observações prévias que visavam avaliar a infraestrutura física dos poços locais, para posteriormente definir os pontos de coletas. As amostras de água dos poços foram coletadas manualmente no período mais chuvoso da região, com temperatura entre $23^{\circ} \mathrm{C}$ e $32{ }^{\circ} \mathrm{C}$. Nas análises microbiológicas, utilizou-se frascos plásticos de $200 \mathrm{ml}$ esterilizados. Para cada amostra físico-química analisou-se: Potencial de hidrogênio $(\mathrm{pH})$, Temperatura ( $\mathrm{T}$ ), Oxigênio Dissolvido (OD), Sólido Totais Dissolvidos (STD) e Condutividade Elétrica (CE). A análise microbiológica consistiu-se em análise de membrana para identificar a presença de coliformes totais e Escherichia coli, por meio de Placa de Alta Sensibilidade $3 \mathrm{M}^{\mathrm{TM}}$ Petrifilm ${ }^{\mathrm{TM}}$. Na análise estatística, realizou-se teste de variância (ANOVA) e equivalentes não paramétricos (Mann Whitney e Kruskal wallis) para calcular o índice de correlação entre as variáveis. A partir de cada análise, os valores de CE e STD apresentaram-se relativamente baixos, o que implica em níveis de contaminação nesses poços, além da presença de c. totais e E. coli, fato que limitaria o uso deste recurso para consumo humano. Os parâmetros em desacordo com valores de potabilidade podem estar relacionados com hábitos e manuseio inadequado na captação de água, além da falta de proteção desses poços com profundidade rasa de aquífero livre, pois, estão susceptíveis à entrada de poluentes, confirmando a problemática socioambiental local.

1. Introdução: Durante muitos séculos a humanidade considerou a água como um recurso inesgotável e utilizou-a de forma irracional e insustentável, refletindo hoje em consequências negativas à população $(\mathrm{CECH}, 2013)$. Segundo a Constituição Federal Lei $n^{\circ}$. 11.445/2007, do Ministério da Saúde, todo cidadão tem direito a água potável, entretanto, muitas regiões carecem de redes de abastecimento hídrico, fazendo-se valer de fontes alternativas sem nenhum tratamento (ALMEIDA, 2019).

No Brasil, a água subterrânea é fonte de abastecimento em aproximadamente 39\% dos municípios brasileiros, principalmente assentamentos rurais onde é capitada através de poços ou cisternas (ANA, 2012; VITÓ et al., 2016), porém, por vezes construídos sem critérios técnicos adequados, tornando-se suscetíveis à contaminação.

Para ser consumida, a água deve cumprir exigências rigorosas no controle de qualidade, pois, não é de proibição o uso de águas naturais, seja de quaisquer fontes hídricas, porém, é importante a ausência total de agentes contaminantes para que não comprometa a integridade e componentes da água, advindas principalmente de ação antropogênicas (BUCCl et al., 2015). 
Sabendo da necessidade de abastecimento de rede de água pública de qualidade, o estudo teve como embasamento de que algumas comunidades rurais do município de Salvaterra carecem de uma água de qualidade, visto que os poços são utilizados tanto para o consumo humano como nas atividades dentro das propriedades rurais. Com base nisso, objetivou avaliar a qualidade da $\mathrm{H} 2 \mathrm{O}$ de poços domésticos utilizados pelas comunidades rurais do município de Salvaterra, a partir dos parâmetros físico-químicos e microbiológicos.

\section{Materiais e métodos}

\subsection{LOCOS E POPULAÇÃO DO ESTUDO}

Previamente ao início da coleta de dados, o estudo foi aprovado pelo Comitê de Ética em Pesquisa da Universidade do Estado do Pará, do Centro de Ciências Biológicas e Saúde (CCBS), com Certificado de Apresentação para Apreciação Ética (CAAE) 11810919.3.0000.8767.

O estudo foi conduzido em três comunidades rurais do município de Salvaterra, Comunidade São Veríssimo, Comunidade Ceará e Comunidade Julho. O município encontra-se na Mesorregião do Marajó, inserido geopoliticamente na Microrregião Geográfica do Arari, na parte meridional da llha de Marajó, de latitude " $00^{\circ} 45^{\prime} 12^{2}$ " sul e "longitude 4831'00" oeste, a 5 metros acima do nível do mar (GEOGRAFOS, 2012).

\subsection{ESTUDO DE CAMPO}

Realizou-se observações prévias que visavam avaliar a infraestrutura física das comunidades, para posteriormente serem definidos os pontos de coletas. Em cada comunidade, selecionou-se cinco residências por amostra de conveniência.

\subsection{COLETA E FREQUÊNCIA DA AMOSTRAGEM}

As amostras de água dos poços foram coletadas manualmente no mês de fevereiro de 2019, período mais chuvoso na região, com temperatura mínima de $23^{\circ} \mathrm{C}$ e máxima de $32{ }^{\circ} \mathrm{C}$ (INMET, 2019). Para cada coleta, utilizou-se balde de inox com capacidade de $1 \mathrm{~L}$, cordas do tipo barbante e luvas, conforme os métodos de coleta (APHA, 2012). Para as análises microbiológicas, foram utilizados frascos plásticos de $200 \mathrm{ml}$ esterilizados em autoclave. Após, o material coletado foi identificado e acondicionada em caixas isotérmicas contendo gelo e transportada para o laboratório de Ciências Naturais, da Universidade do Estado do Pará, Campus XIX- Salvaterra- PA, analisando-as de acordo com a Funasa (2005). Para inoculação das diluições em placas Petrifilm ${ }^{\mathrm{TM}}$ todas as análises foram realizadas em triplicata.

\subsection{ANÁLISES FÍSICO-QUÍMICAS}

Para cada amostra de água coletada analisou-se: Potencial de hidrogênio $(\mathrm{pH})$, Temperatura (T), Oxigênio Dissolvido ppm (OD), Sólido Totais Dissolvidos (STD) e Condutividade Elétrica (CE), seguindo os critérios oficiais mediados pela American Public Health Association e Companhia Ambiental do Estado de São Paulo (APHA, 2012; CETESB, 2017). Para as análises foi utilizada uma sonda móvel Multiparameter, Hi 9829- HANNA, calibrada, de acordo com o determinante de estudo.

Para avaliação da potabilidade da água para consumo humano, os resultados foram comparados aos parâmetros de potabilidade da Portaria de Consolidação No. 5/2017 do Ministério da Saúde (BRASIL, 2017). 
A metodologia aplicada para análise microbiológica consistiu em análise de membrana para identificar a presença de coliformes totais e Escherichia coli, por meio de Placa de Alta Sensibilidade, onde para cada amostra de água foi feito triplicata. Utilizaram-se Placas $3 \mathrm{M}^{\mathrm{TM}}$ Petrifilm ${ }^{\mathrm{TM}}$ específica para cada microrganismo avaliado, baseando-se nos métodos do "Manual Prático de Análise de Água", elaborado pela Fundação Nacional de Saúde (FUNASA, 2005). O método de análise resume-se em três passos: 1) Inoculação e espalhamento do inoculo em meio de cultura apropriado; 2) Incubação; 3) Contagem de microrganismos patogênicos.

\subsection{ANÁLISE ESTATÍSTICA}

As diferenças do nível de contaminação entre as áreas amostradas foram testadas usando modelos de análise de variância (ANOVA). Quando os pressupostos da análise não foram atingidos, foram utilizados testes equivalentes não paramétricos (Mann Whitney e Kruskal wallis). Para testar a correlação entre as variáveis independentes, como: (distancia, renda, entre outros) com quantidade de c. totais e E. coli, foi aplicado a Correlação de Person, por meio do programa PAST version 3.18.

\section{RESULTADOS E DISCUSSÃO}

Foi observado que as três comunidades pesquisadas necessitam de abastecimento de rede pública de água, sendo poços domésticos individuais (poço amazonas) principal fonte de abastecimento dos entrevistados. De modo geral, a capitação dessa água é utilizada para suprir todas as necessidades humanas desses moradores. Não houve diferença na quantidade de microrganismos presentes nas amostras entre as três localidades de acordo com o confidente de correlação, onde o valor de $p$ não foi significativo (Totais: $H=0,86, p=0,65 / E$. coli: $F=0,74, p=0,49$ ).

Quanto aos resultados higiênico-sanitários das amostras, não houve diferença significativa em nenhuma das variáveis analisadas nas três comunidades ( $p>0,05)$.

A partir da caracterização, foi possível verificar as reais condições higiênico-sanitárias dos moradores, para que então pudesse ser feito as coletas de água e posteriormente as análises físico-química (in loco) e microbiológica (em laboratório).

No estudo, a média do $\mathrm{pH}$ foi de 4,15, havendo variação de medida, onde na amostra cinco da comunidade Julho apresentou o menor valor, $\mathrm{pH}$ 3,69 e o maior na comunidade São Veríssimo, pH 5,34. Todas as amostras estão fora dos padrões de potabilidade recomendados pela Portaria de Consolidação No. 5 de 2017, que recomenda um valor de $\mathrm{pH}$ 6,0 a 9,5 próprias para consumo humano (BRASIL, 2017).

As amostras foram coletadas no período de maior índice pluviométrico na região, o que pode ter contribui para uma maior acidez, uma vez que, os processos de lixiviação dos solos ácidos e grande concentração de matéria orgânica dissolvida, características comuns aos solos amazônicos, promove uma diminuição do pH das águas subterrâneas e superficiais.

A concentração de oxigênio dissolvido OD nas amostras apresentou média de $3,35 \mathrm{mg} /$ $\mathrm{L}$, variando entre 2,03 e 4,8 mg/ $\mathrm{L}$. Todas as amostras analisadas tiveram baixa taxa, em virtude a que a água subterrânea não apresente fontes de oxigenação como algas e turbulência. Outra causa dos baixos valores do OD pode estar relacionado à quantidade de matéria orgânica dissolvida. 
O parâmetro de condutividade elétrica CE foram registrou valores entre 15,00 a 64,15 $\mu \mathrm{S} / \mathrm{cm}$, com média de $32,80 \mu \mathrm{S} / \mathrm{cm}$, valores característicos de poços da região amazônica. A CE está relacionada com a presença de íons dissolvidos na água, tais como: $\mathrm{Na}+, \mathrm{K}+, \mathrm{Ca} 2+, \mathrm{Mg} 2+, \mathrm{NH} 4+, \mathrm{Cl}-$, SO42-, NO3-, NO2-, HCO3-, que são substâncias carregadas eletricamente, e que determina o estado e qualidade de um corpo hídrico (PIÑEIRO DI BLASI et al., 2013).

Para sólidos totais dissolvidos (STD), o valor médio foi de 19,08 ppm mg/ L-1, variando de 14,8 a 21,50, respectivamente. Os valores dos STD exibiram valores relativamente baixos se comparados como padrão organoléptico da potabilidade de $1000 \mathrm{mg} / \mathrm{L}$ definido pela Portaria de Consolidação No.5/2017.

A média da temperatura das amostras de água coletadas foi de $27,29^{\circ} \mathrm{C}$, com variação de 25,73 a $28,48{ }^{\circ} \mathrm{C}$, respectivamente, sendo que a temperatura não está incluída dentro dos parâmetros organolépticos de potabilidade definidos pela portaria de Consolidação No. 5/2017.

Para a conformidade dos padrões microbiológicos das amostras de água, foram realizadas técnicas para verificar o índice de c. totais e E. coli. Nos resultados obtidos nesta investigação, foi possível verificar a presença de microrganismos em quase todas as amostras da água de poços das três comunidades estudadas. Chama a atenção a presença de c. totais, e também de E. coli (subgrupo das bactérias do grupo coliforme) em $65 \%$ das amostras analisadas, por serem altamente patogênicos, o que pode trazer malefícios à saúde da população. A portaria de Consolidação No. 5/2017 estabelece que, em águas procedentes de poços e outras fontes alternativas de abastecimento, poderá ocorrer a presença de c. totais, no entanto, recomenda-se ausência total para $E$. coli (BRASIL, 2017).

4. Conclusão: $O$ estudo realizado a partir de análises físico-químicas e microbiológicas de amostras de água captada de poços em espaços rurais apresentaram valores característicos da região amazônica, em especial com valores de CE e STD relativamente baixos e característicos das águas da região amazônica, com presença de c. totais e E. coli, fato que estaria limitando o uso deste recurso para o consumo humano de acordo com a Portaria de Consolidação N. 5/2017.

Os parâmetros em desacordo com valores de potabilidade estão mais relacionados com hábitos e manuseio inadequado de recipientes utilizados para a captação do recurso hídrico e pela vulnerabilidade dos poços tipo amazonas de profundidade rasa de aquífero livre e vulnerável à entrada de poluentes por infiltração e falta de estrutura higiênico-sanitária como rege a NBR12244. Portanto, o uso contínuo destes recursos pode estar diretamente relacionado com doenças recorrentes nessas localidades, levando até mesmo a futuros agravos de doenças por veiculação hídrica, respondendo as propostas do presente estudo.

\section{REFERÊNCIAS}

ALMEIDA, WRF; SOUZA, FM. Análise Físico-Química da Qualidade da Água do Rio Pardo no Município de Cândido Sales - BA. Id on Line Rev. Mult. Psic., Iguatu - CE, v. 13, n. 43, p. 353-378, 2019. 
AGÊNCIA NACIONAL DE ÁGUAS (Brasil). Conjuntura dos recursos hídricos no Brasil: informe especial 2012. Brasília- DF, 2012. Disponível em: < http://www.snirh.gov.br/portal/snirh/centrais-de-conteudos/conjuntura-dos-recursoshidricos>. Acesso em: 10 fev. 2019.

AMERICAN PUBLIC HEALTH ASSOCIATION- APHA. Microbiological examination of water. In: Standard methods for the examination of water and wastewater. 19. ed. Washington, D.C.: APHA, 1995.

BRASIL. Ministério da saúde. Portaria de consolidação $n^{\circ}$ 5, de 28 de setembro de 2017. Dispõe sobre os procedimentos de controle e vigilância da qualidade da água para consumo humano e seu padrão de potabilidade. Diário Oficial da União, Poder Executivo, Brasília- DF, Seção 1, Capítulo V, 28 set. 2017, p. 37.

BUCCI, MMHS; DELGADO, FEF; SANTOS, DS; OLIVEIRA, LFC. Análise de metais, agrotóxicos, parâmetros físico-químicos e microbiológicos nas águas da Represa Dr. João Penido, Juiz de Fora, MG. Revista Ambiente \& Água, v. 10, n. 4, p. 804-824, 2015. http://dx.doi.org/10.4136/ambi-agua.1534.

CECH, T. V. Recursos hídricos: história, desenvolvimento, política e gestão. Rio de Janeiro: LTC, 2013.

COMPANHIA AMBIENTAL DO ESTADO DE SÃO PAULO. Qualidade das águas interiores no estado de São Paulo 2017 [recurso eletrônico] / CETESB; Coordenação geral Maria Helena R.B. Martins; Coordenação técnica Nelson Menegon Jr., Marta Condé Lamparelli, Fábio Netto Moreno; Coordenação cartográfica Carmen Lúcia V. Midaglia; Equipe técnica Cláudio Roberto Palombo [et al.]; Colaboradores Gisela de Assis Martini [et al.] - São Paulo: CETESB, 2018.

FUNDAÇÃO NACIONAL DA SAÚDE (Brasil). Saneamento rural, 2017. Disponível em: $<w w w . f u n a s a$. gov.br/site/engenharia-de-saude-publica/saneamento-rural >. Acesso em: 4 jan. 2019.

GEOGRAFOS. Coordenadas Geográficas. Salvaterra, Para, 2012. Disponível em: <https://www.geografos.com.br/cidades-para/salvaterra.php>. Acesso em: 30 out. 2018.

INSTITUTO NACIONAL DE METEOROLOGIA. Website. 2019. Disponível em: $<$ www.inmet.gov.br<. Acesso em: 22 fev. 2019.

PIÑEIRO DI BLASI, JI; MARTÍNEZ TORRES, J; GARCÍA NIETO, PJ; ALONSO FERNÁNDEZ, JR; DÍAZ MUÑIZ, C; TABOADA, J. Analysis and detection of outliers in water quality parameters from 'different automated monitoring stations in the Miño river basin (NW Spain). Ecological Engineering, v. 60, p. 60-66, 2013. http://dx.doi.org/10.1016/j.ecoleng.2013.07.054. 
VITÓ, C. V. G.; SILVA, L. J. B. F.; OLIVEIRA, K. M. L.; GOMES, A. T.; NUNES, C. R. O. Avaliação da qualidade da água: determinação dos possíveis contaminantes da água de poços artesianos na região noroeste fluminense. Acta biomédica brasiliensia, v.7, n. 2, p. 59-75, 2016.

Palavras-chave: espaço rural, recurso hídrico, vulnerabilidade.

Grande-área: Ciências Ambientais

Área: Saúde Pública. 


\section{A CONDIÇÃo AMBIENTAL DA PRAIA DO ATALAIA, SALINÓPOLIS, PA: BIOINDICAÇÃO POR ZOOPLÂNCTON}

Nome do(a) Bolsista: Marcos Felipe Bentes Cansanção Pereira.

Nome do(a) Orientador(a): Ana Lúcia Nunes Gutjahr.

Resumo: Zooplâncton são todos aqueles organismos heterotróficos pertencentes ao plâncton, ou seja, possuem mobilidade restrita sem capacidade de ir contra as correntes marítimas. São importantes na cadeia alimentar, pois são considerados o elo entre produtores e consumidores sequentes, além de refletirem de forma eficiente e imediata às alterações do meio ambiente, sendo considerados como bioindicadores. $\mathrm{O}$ objetivo deste trabalho foi realizar um estudo sobre a condição ambiental da praia do Atalaia, região litorânea do município de Salinópolis, Pará, considerando a bioindicação por organismos zooplanctônicos. Para a coleta, foi utilizada uma rede cônica de malha de $180 \mu \mathrm{m}$ em profundidade a $4 \mathrm{~m}$ para captura dos organismos na praia do Atalaia, no município de Salinópolis, PA. Também foram coletados os dados abióticos (temperatura, salinidade, turbidez, oxigênio dissolvido e condutividade). As coletas foram realizadas nos meses de fevereiro (AT1), abril (AT2), junho (AT3) e agosto (AT4) de 2019. Os organismos coletados foram conservados a formoldeído a 4\%. Foram amostrados na praia do Atalaia, um total de 1846 organismos zooplanctônicos, pertencentes a um total de 30 táxons, sendo destes 14 Copepoda, 5 Cnidária, 4 Decapoda, 2 Cirripedia, 1 Foraminifera, 1 Polychaeta, 1 Chaetognatha, 1 Ectoprocta e 1 Ostracoda. Pôde-se observar que Copepoda é o grupo marinho mais generalista, abundante e resistente. De acordo com outros grupos estudados, observou que há uma grande descarga de nutrientes na praia do atalaia e que a salinidade é o fator abiótico que mais influencia na distribuição espacial dos organismos zooplanctônicos. Larvas de Decapoda e nauplius de crustácea indicam que esta praia também pode ser considerada um berçário para espécies marinhas, o que torna necessária sua preservação para manutenção de um ecossistema equilibrado.

Introdução: Os organismos zooplanctônicos são a parte heterotrófica do plâncton, que compreende tanto organismos unicelulares quanto pluricelulares denominados protozoários e metazoários, respectivamente, possuindo, a maioria de seus representantes, poucos milímetros (AGOSTINI; RITTER; MAXUGATA, 2017). A locomoção dos organismos planctônicos é restrita, o que não thes conferem a capacidade de ir contra a correnteza oceânica. Além disso, a maioria dos Filos de animais marinhos conhecidos, com maior ou menor porte, possui representantes no zooplâncton em pelo menos algum estágio de seu desenvolvimento (JOHNSON; ALLEN, 2012).

O zooplâncton de ambientes aquáticos continentais é constituído na sua maioria por organismos da Subclasse Copepoda, os quais desempenham papel importante na cadeia alimentar, sendo considerados um elo por transferirem massa e energia de produtores primários para níveis tróficos superiores (PEREIRA et al., 2011). Como 
resposta a agentes poluentes, espécies sensíveis tendem, geralmente, a serem eliminadas, e as mais resistentes mostram elevadas taxas de crescimento populacional (SANTOS et al., 2009).

Outros fatores como a temperatura da água e salinidade determinam a distribuição geográfica do zooplâncton marinho, relacionada à latitude e as massas de água. Inversamente, a profundidade, a velocidade da correnteza, a energia das ondas e a turbidez afetam mais a distribuição local destes organismos (JOHNSON; ALLEN, 2012). Devido a isso, o zooplâncton tem amplo uso dentro da pesquisa científica como bioindicador de mudanças físicas (correntes oceânicas), químicas (poluição ambiental) e climáticas (aquecimento global) (SANTOS et al., 2009) no meio marinho.

No Pará há uma extensa área litorânea, a qual contribui de forma significativa para o desenvolvimento econômico do Estado. Segundo a Secretaria de Estado de Turismo do Pará - SETUR (2011), uma das regiões mais visitadas neste estado é o município de Salinópolis em virtude de suas belas paisagens com mais de $20 \mathrm{~km}$ de praias e dunas de areia branca e fina, recebendo em alta temporada até 300 mil turistas.

Pelo exposto, pode-se admitir que o turismo é uma atividade de grande impacto ambiental para os ecossistemas marinhos (regiões sobre a influência da água do mar) visto que abrigam uma grande diversidade biológica, sendo por isso de importância extrema e urgente a realização de estudos que avaliem estes ambientes, a fim de que se possa assegurar a sua preservação (CAMPOS; FILHO, 2010).

Objetivo (s): Realizar um estudo sobre a condição ambiental da praia do Atalaia, região litorânea do município de Salinópolis, Pará, considerando a bioindicação por organismos zooplanctônicos.

Material e Método: Foram realizadas coletas na praia do Atalaia, Salinópolis-PA, nos meses de fevereiro, abril, junho e agosto de 2019. Para cada mês de coleta estabeleceu-se os pontos: AT1, AT2, AT3 e AT4.

Para o deslocamento até os pontos de coleta, foi utilizado um bote a motor do $13^{\circ}$ Grupamento de Bombeiros Militar de Salinópolis. Para captura do zooplâncton, utilizouse uma rede cônica padrão de $180 \mu \mathrm{m}$ de malha fazendo um arrasto na vertical nos pontos amostrais com profundidade acima de $4 \mathrm{~m}$. Após a coleta, os organismos foram fixados a formaldeído a $4 \%$ e encaminhados para análise na Coleção Zoológica Didático-Científica Dr. Joachim Adis, da Universidade do Estado do Pará.

Para a identificação dos organismos do zooplâncton foi consultada literatura pertinente, principalmente, Boltovskoy (1999).

Resultado e discussão: Foram coletados na praia do Atalaia um total de 1.846 organismos zooplanctônicos pertencentes a 30 táxons, sendo destes 14 Copepoda, 5 Cnidários, 4 Decapodas, 2 Cirripedias, 1 Foraminifera, 1 Polychaeta, 1 Chaetognatha, 1 Ectoprocta e 1 Ostracoda (Tabela 1).

O grupo de organismos mais encontrado refere-se a Copépoda, sendo também o mais abundante em todos os pontos de coletas mensais. Esses achados estão em consonância com os encontrados por Conceição (2017) em Recife-PE, o qual em sua pesquisa predominou Copepoda, com cerca de $68 \%$ da abundância total de espécimes coletados, o que pode indicar características da Água Tropical e de ambiente marinho 
tropical oligotrófico, havendo destaque também para Chaetognatha, larvas e outros crustáceos. Estudos de Dias \& Bonecker (2009) também registraram este padrão na plataforma continental interna e nas adjacências da Baía de Camamu, Bahia, onde as maiores densidades foram de Copepoda.

Os Cnidários estiveram presentes nos primeiros meses de coleta (fevereiro e abril), onde a água estava com valor baixo de salinidade devido ao alto índice pluviométrico característico deste período, na região amazônica. Cabra \& Nogueira-Júnior (2019) dizem que apesar das espécies de Cnidaria tolerarem ampla variação de salinidade, algumas são exclusivas ou preferencialmente estuarinas e/ou de águas salobras, sendo este o componente abiótico que mais influencia em sua diversidade. Obelia sp. foi observada por Muller (2018) com maior densidade nas estações próximas à costa marítima, no estado do Pará, pois apesar de tolerar altos valores de salinidade, é considerada como táxon costeiro com preferência por águas mais quentes e de baixas salinidades, o que foi observado neste estudo, no qual Obelia sp. obteve maior registro no mês de fevereiro, onde o índice pluviométrico é elevado e, consequentemente, a água do mar está com menor grau de salinidade.

A ocorrência e ao aumento gradativo de nauplius de Crustacea se deve, provavelmente, devido à introdução de matéria orgânica, o que consequentemente provoca um aumento na quantidade de bactérias e protozoários, que são a principal fonte de alimento para as formas jovens de Copepoda estuarinos, causando, portanto, um aumento em sua densidade (SANTOS et al., 2009).

Estágios larvais (zoea) de Brachyura (Decapoda) foram mais evidentes no primeiro mês de coleta, em fevereiro, o que confere, segundo Almeida et al. (2017), captura em período reprodutivo recente e consequente exportação das larvas para a plataforma continental durante a maré vazante, seguida da recolonização do ecossistema manguezal pelas larvas no estágio de megalopa.

Larva de Polydora sp., observado neste estudo em todos os meses de coleta, segundo Santos (2008), pode indicar poluição orgânica, principalmente aquelas ocasionadas por esgotos, já que este gênero é extremamente resistente a mudanças ambientais, sendo considerado oportunista por se proliferar com o aumento da matéria orgânica, baixa salinidade e baixas concentraç̃oes de oxigênio na água. Além disso, Polydora sp. pode ocasionar danos econômicos, pois trata-se de um gênero poliqueta parasita de ostras que são comercialmente exploradas, visto que este anelídeo perfura a valva de bivalves, atingindo a cavidade do manto, acumulando massa de lodo em sua superfície, o que torna o animal impróprio para o consumo humano (ENES, 2017).

Tabela 1 - Composição do zooplâncton nas quatro estações de coleta na praia do Atalaia, Salinópolis, PA, nos meses de fevereiro, abril, junho e agosto de 2019.

\begin{tabular}{|c|c|c|c|c|c|c|c|}
\hline \multirow[t]{2}{*}{ Taxon } & \multirow[b]{3}{*}{ Classe } & \multirow[b]{3}{*}{ Infraclasse } & \multirow[b]{3}{*}{ Espécie } & \multicolumn{4}{|c|}{ Pontos de coleta } \\
\hline & & & & AT & AT & AT & AT \\
\hline Filo & & & & 1 & 2 & 3 & 4 \\
\hline \multirow{3}{*}{ Arthropoda } & \multirow{3}{*}{ Maxillopoda } & & Acartia sp. & 164 & 232 & 64 & 127 \\
\hline & & & Paracalanus sp. & 191 & 74 & 123 & 34 \\
\hline & & & Oithona sp. & * & 3 & 223 & 65 \\
\hline
\end{tabular}




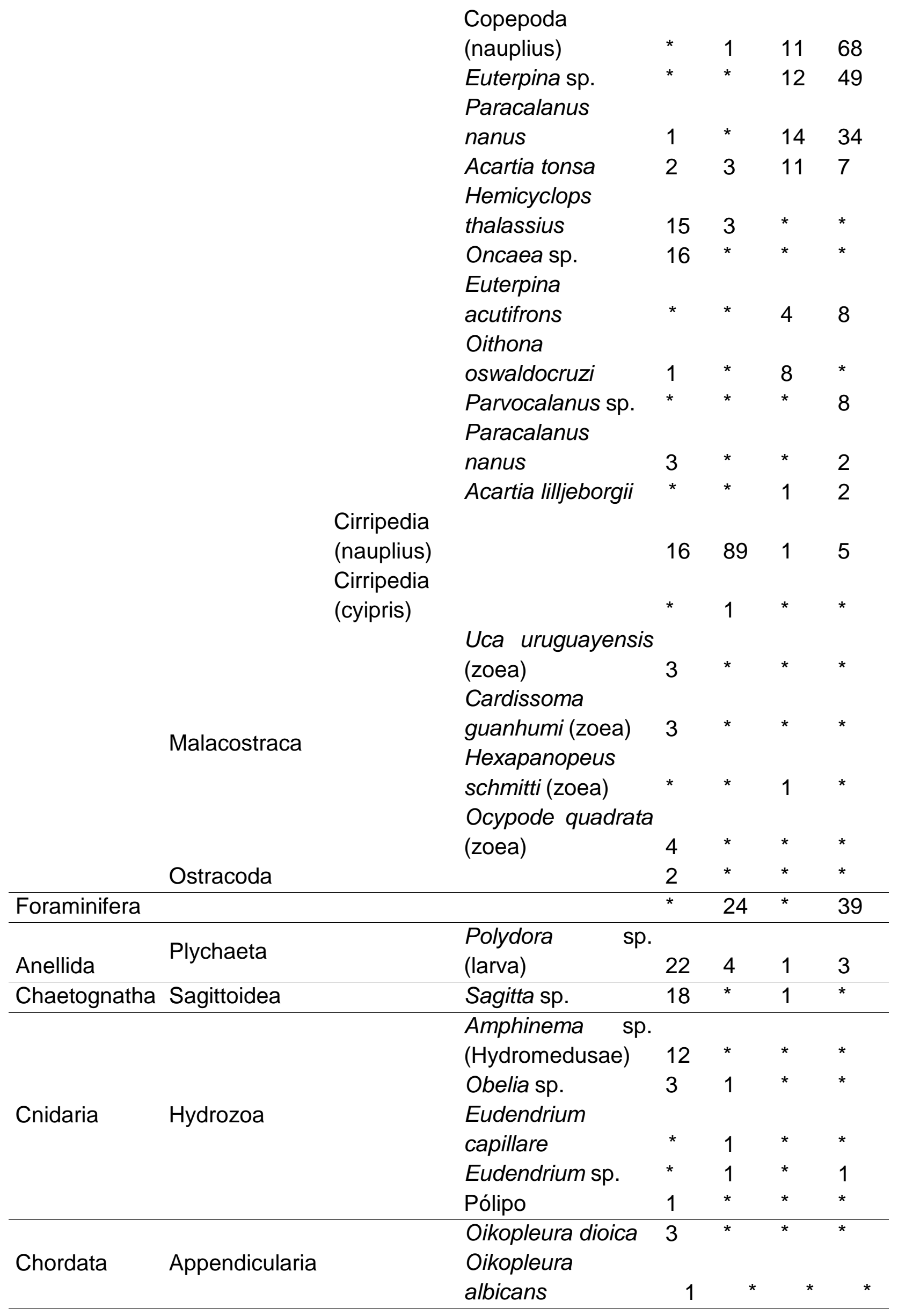


Conclusão: Pôde-se observar que Copepoda é o grupo mais generalista, resistente e abundante dentro do ambiente marinho e que a praia do Atalaia tem característica de ambiente oligotrófico (baixa carga de nutrientes). Entretanto, pode-se observar que no mês de fevereiro houve uma grande descarga de nutrientes para o ambiente marinho, indicada pela presença da espécie Polydora sp., que é extremamente resistente e encontra condições favoráveis ao seu desenvolvimento em ambientes poluídos, e também pela presença das larvas nauplius que se desenvolvem em meio de grande disponibilidade de nutrientes, que pode também haver entrada destes componentes por ação das chuvas.

A salinidade pode ser considerada como principal fator abiótico na influência do aparecimento de cnidários, haja visto que os mesmos foram pouco observados em períodos onde há baixo índice pluviométrico, assim como também no caso de organismos apendiculários.

Larvas de Brachyura demonstram a importância de se preservar as praias, que são ambientes que estão ligados diretamente com manguezais e, por muitas vezes, se tornam berçários de espécies que são exploradas comercialmente, como caranguejos e siris.

Ao observar, neste estudo, todos estes fatores, conclui-se que o zooplâncton está relacionado diretamente com os fatores abióticos do ecossistema marinho, o qual responde, seja de forma positiva ou negativa, a influências externas, o que sustenta seu potencial como principal ferramenta bioindicadora de qualidade ambiental.

\section{Referências Bibliográficas}

AGOSTINI, V. O.; RITTER, M. N.; MAXUGATA, E. Zooplâncton: comunidade-chave nos processos bióticos e abióticos dos oceanos. Ensino de ciências: práticas e exercícios para a sala de aula / org. Cláudia Pinto Machado. - Caxias do Sul, RS: Educs, 2017. ALMEIDA, E. V.; SANTOS, J. O.; SILVA, G. A.; MIRANDA, R. G. B. Distribuição espaçotemporal de crustáceos decápodes meroplanctônicos, com ênfase nas larvas do caranguejo-uçá, na baía de Guanabara, Rio de Janeiro. Revista CEPSUL Biodiversidade e Conservação Marinha. 2017.

CABRAL, A. C.; NOGUEIRA-JÚNIOR, M. Fauna de cnidários do Ecossistema Babitonga: uma revisão crítica. Revista CEPSUL - Biodiversidade e Conservação Marinha. 2017. CAMPOS. J. B.; FILHO. L. S. Ambientes Marinhos.v.9. Curitiba. 2010.

JOHNSON, W. S.; ALLEN, D. M. Zooplankton of the Atlantic and gulf coasts: a guide to their identification and ecology. Baltimore: Johns Hopkins University Press, 2012.

CONCEIÇÃO, L. R. Mesozooplâncton da plataforma continental de Salvador-Bahia (Brasil), com ênfase em copepoda. Dissertação (mestrado) - Programa de PósGraduação em Oceanografia da Universidade Federal de Pernambuco (PPGOUFPE). Recife, 2017.

DIAS, C. O.; BONECKER, S. L. C. The Copepod Assemblage (Copepoda: Crustacea) on the Inner Continental Shelf Adjacent to Camamu Bay, Northeast Brazil. Zoologia, v. 26(4), p. 629-40. 2009. 
ENES, A. C. Cultivo de ostra nativa Crassostrea gasar (Adanson, 1757) em dois ambientes: estuário e viveiros de camarão Litopenaeus vannamei orgânico. Trabalho de Conclusão de Curso (Graduação) - Universidade Federal de Santa Catarina. Florianópolis, 2017.

MULLER, P. C. Comunidade de Hidromedusas em um gradiente costeiro-oceânico na plataforma Amazônica. Trabalho de Conclusão de Curso (Graduação) - Instituto de Geociências, Universidade Federal do Pará, Belém, 2018.

PARÁ. SECRETARIA DE ESTADO DE TURISMO. Companhia Paraense de Turismo (PARATUR). Inventário da oferta Turística de Salinópolis.

PEREIRA, A. P. S.; VASCO, A. N. do; BRITTO, F. B.; MÉLLO JÚNIOR, A. V.; NOGUEIRA, E. M. de S. Biodiversidade e estrutura da comunidade zooplanctônica na Sub-bacia Hidrográfica do Rio Poxim. Revista Ambiente e Água, v. 6, p. 191-205, 2011. SANTOS, T.G. dos; GUSMÃO, L.M.O.; NEUMANN-LEITÃO, S.; CUNHA, A.G. da. Zooplâncton como indicador biológico da qualidade ambiental nos estuários dos rios Carrapicho e Botafogo, Itamaracá-PE. Revista Brasileira Engenharia de Pesca, v. 4, n.1, p. 44-56, 2009.

SANTOS, T. G. Zooplâncton como indicador da qualidade ambiental nos estuários dos rios Carrapicho e Botafogo, Itamaracá - PE. Dissertação (Mestrado) - PósGraduação em Oceanografia da Universidade Federal de Pernambuco. Recife, 2008.

Palavras-chave: Ecossistema; Região litorânea; bioindicadores marinhos.

Grande-área: Ciências Biológicas

Área: Ecologia de ecossistemas. 


\section{PROGRAMA DE PÓS- GRADUAÇÃO EM CIÊNCIAS AMBIENTAIS}




\section{USOS, PERCEPÇÕES E SUSTENTABILIDADE DOS MANGUEZAIS DO MUNICÍPIO DE SALVATERRA}

Nome do(a) Bolsista: Marinele Maria Saraiva Rodrigues

Nome do(a) Orientador(a): Ana Cláudia Caldeira Tavares Martins

Nome do(a) Voluntário(a): Gleiciane Salvador.

Resumo: O manguezal é um dos ecossistemas mais produtivos, o qual oferece inúmeros serviços para a população que vive em seu entorno e mantem estreita relação de dependência com este ambiente. O presente estudo pretende registrar os principais usos, a percepção e a sustentabilidade dos manguezais localizados no município de Salvaterra, Pará, Brasil. Serão realizadas entrevistas por meio de formularios semiestruturados, através de amostragem não- probabilística intencional pelo método "bola de neve". Para acessar a percepção dos entrevistados a respeito dos manguezais será utilizada a escala de Likert, para medir a sustentabilidade da extração do caranguejo-uçá (Ucides cordatus) nos manguezais será utilizada a metodologia MESMIS adaptada para recursos pesqueiros. Espera-se que ao final da pesquisa seja possível descrever os principais usos dos manguezais pelos caranguejeiros e suas famílias, assim como a percepção a cerca da ecologia, biologia do Caranguejo Uçá (U. cordatus) e sobre os manguezais da região. Esse estudo também pretende gerar dados que caracterizem a sustentabilidade da extração do Ucides cordatus.

Introdução: Os manguezais são ecossistemas produtivos, principalmente, por abrigar uma numerosa e diversificada fauna em termos de recursos alimentares e por promoverem a produção de bens e serviços capazes de atrair e manter grupos em suas proximidades (SNEDAKER, 1978; NASCIMENTO, 1995; RIBEIRO et al., 1995; MASCARENHAS E GAMA, 1999).

O ecossistema manguezal é fonte de subsistência e renda para as comunidades que habitam suas áreas de entorno (ALVES E NISHIDA, 2003; GLASER E DIELE, 2004; WALTER et al., 2012). A experiência dos membros da comunidade a partir do trabalho diário das atividades extrativistas permite a aquisição de conhecimento sobre os recursos naturais disponíveis (DIEGUES E ARRUDA, 2001; ROCHA et al., 2008).

Dentre os principais recursos alimentares extraídos dos manguezais estão peixes, moluscos e, principalmente, crustáceos. As espécies de crustáceos braquiúros Ucides cordatus Linnaeus, 1763 (caranguejo-uçá) e Cardisom aguanhumi Latreille, 1825 (guaiamum) são os principais recursos explorados por comunidades extrativistas ao longo dos manguezais da costa brasileira (ALVES e NISHIDA, 2002; FISCARELLI \& PINHEIRO, 2002; ALVES \& NISHIDA, 2003; FIRMO et al., 2011).

O caranguejo-uçá (Ucides cordatus) é um dos recursos pesqueiros mais importantes em toda a sua área de ocorrência nas zonas de mangue do Brasil, entre os estados do Amapá e de Santa Catarina (SOUTO, 2007). Além de ser um dos componentes mais característicos dos ecossistemas manguezal, este crustáceo é bastante abundante e contribui para a geração de emprego, renda e subsistência em comunidades pesqueiras que vivem nas zonas de estuários (IBAMA, 1994; BOTELHO et al., 2000). 
O conhecimento empírico dos catadores sobre a biologia e ecologia do caranguejo-uçá, aliado ao que já se conhece sobre a ecologia dos manguezais, pode afetar o estado de conservação deste recurso, bem como do ecossistema que ocupa (ALVES E NISHIDA, 2003).

A ilha de Marajó, maior ilha fluvio-marinha do mundo, com cerca de $49.606 \mathrm{Km}^{2}$ abriga manguezais que podem ser observados entre os igarapés e nas margens dos rios que a drenam e que deságuam nas baías e no Atlântico, (CRUZ, 1987; LIMA et al., 2001), e juntamente com os do Maranhão formam o maior cinturão continuo de manguezais do mundo que vai desde a baía do Marajó, até a Ponta do Tubarão, baía de São Joséperfazendo cerca de $650 \mathrm{~km}$ de litoral em linha reta (ABREU, 2007).

Em Soure, ilha de Marajó, a tradição da coleta do caranguejo vem de longa data, e na década de 1990 (CARVALHO E JARDIM, 2019). Os caranguejeiros começaram a enfrentar dificuldades na extração do caranguejo uçá devido a redução do estoque por conta da chegada de pescadores advindos da costa atlântica continental paraense que passaram a invadir as áreas, utilizando uma técnica conhecida como "laço, que não era conhecida pelos marajoaras e se mostrava totalmente insustentável, (FALCÃO, 2013)

No trabalho realizado na RESEX de Soure (Pesqueiro e Tucumanduba) por Carvalho e Jardim (2019) os autores revelaram que, dentre os principais usos dos manguezais está a extração do caranguejo- uçá ( $U$. cordatus) e do Turu (Teredo $s p$.). Porém para o município de Salvaterra não há dados na literatura sobre os usos dos recursos dos manguezais, métodos de captura, comercialização e sustentabilidade dessa exploração. Desse modo essa pesquisa pretende registrar os usos, percepções e sustentabilidade dos manguezais do município de Salvaterra.

Objetivos: Objetivo geral

Conhecer os usos que os caranguejeiros fazem dos manguezais da região, a percepção ambiental do mesmo em relação ao ecossistema manguezal, assim como medir a sustentabilidade da extração de caranguejo.

Objetivos específicos

Traçar o perfil socioeconômico dos coletores de caranguejo no município de Salvaterra; Conhecer os principais usos dos manguezais pelos caranguejeiros e suas famílias; Analisar as técnicas utilizadas em Salvaterra para a extração do caranguejo Uçá e de que maneiras elas podem influenciar na sustentabilidade da extração;

Informar se no município de Salvaterra os coletores de Caranguejo utilizam alguma técnica de manejo que vise a conservação da espécie.

Material e Métodos: A presente pesquisa adotará o método de amostragem não probabilística intencional, onde os entrevistados serão selecionados por meio do método 'bola de neve' com ajuda de informante chave, (BAILEY, 1982). Os entrevistados serão extrativistas de caranguejo- uçá,seja para a comercialização ou apenas para alimentação de sua família.

Para a coleta dos dados a respeito dos usos dos manguezais de Salvaterra serão aplicadas entrevistas semi-estruturadas, guiadas por formulários divididos nas categorias: perfil socioeconômico, atividade nos manguezais, cadeia produtiva, biologia e ecologia do caranguejo e extração do caranguejo. Para acessar a percepção dos 
caranguejeiros a respeito da importância dos manguezais será utilizado a escala de Likert de 5 pontos (BERMUDES et al.,2016).

Para medir a sustentabilidade da extração de caranguejo no município de Salvaterra será utilizada a metodologia MESMIS ('Marco para La Evaluación de Sistemas de Manejo de Recursos Naturales incorporando Indicadores de Sustentabilidad') para o contexto da atividade de extração do Caranguejo-Uçá adaptado da pesquisa de Côrtes (2019). A pesquisa será submetida ao comitê de ética e pesquisa da Universidade do Estado do Pará (UEPA) e todos os entrevistados deverão assinar o Termo de consentimento livre e esclarecido antes do início da entrevista.

Resultados Esperados: Com os dados levantados, espera-se conhecer o perfil dos usuários dos manguezais do município de Salvaterra e os usos que eles fazem dessa área, assim como a percepção dos mesmos a respeito da extração (métodos, ecologia e biologia, forma de manejo das áreas de extração) do caranguejo e das relações entre o homem e o manguezal, além de mensurar a sustentabilidade da extração de caranguejo.

Referências: ABREU,M.M.O. Os manguezais da costa amazônica brasileira: uma análise da composiçâo florística, distribuição de espécies arbóreas e estrutura de bosque).Dissertação ( Mestrado). Universidade federal do Pará. 115 f. 2007.

ALVES ,R.R.N; NISHIDA,A.K. Aspectos socioeconômicos e percepção ambiental dos catadores de Caranguejo- Uçá, Ucides cordatus ( L. 1763, Decapoda, Brachyura), no estuário do Rio Mamanguape, Nordeste do Brasil. Interciência.v.28,n.1,p.36-43,2003.

ALVES, R.R.N.;NISHIDA, A.K. A ecdise do caranguejo-uçá,ucides cordatus I. (decapoda, brachyura) na visão dos caranguejeiros. Interciência, v. 27,n.3,p.110-117.2002.

BAILEY,K.1994. Methods of social research. $4^{a}$ Ed. New York: The Free Press, 588p.

BERMUDES,W.L.; SANTANA, B. T.; BRAGA, J. H. O.; SOUZA,P. H. Tipos de escalas utilizadas em pesquisas e suas aplicações. Revista Vértice,v.18,n.2,p.7-20,2016.

BOTELHO, E. R. DE; SANTOS, M. DO C. F.; PONTES, A. C. DE P. Algumas considerações sobre o uso da redinha na captura do caranguejo-uçá, Ucides cordatus (Linnaeus, 1763) no litoral sul de Pernambuco, Brasil. Boletin Técnico Científico do CEPENE, v.8,n. 1,p. 55-71. 2000.

CARVALHO, E. A.; JARDIM, M.A.G. Usos sociais dos manguezais por comunidades tradicionais no estado do Pará, Brasil. Biota Amazônia.v.9,n.2, p.43-46.2019.

CÔRTES,L.H.O. Sustentabilidade da extração do caranguejo-uçá, Ucides cordatus (linnaeus,1763), no norte do Rio de Janeiro. Tese ( Doutorado). Universidade Estadual do Norte Fluminense Darcy Ribeiro-UENF.97 f. 2019.

CRUZ, R. C. A.. Turismo e impacto em ambientes costeiros: Projeto Parque das Dunas - Via Costeira, Natal (RN).Dissertação (Mestrado). Universidade de São Paulo, 1995.

DIEGUES, A.C. e ARRUDA, R.S.V. 2001 Saberes tradicionais e biodiversidade no Brasil. Brasília: Ministério do Meio Ambiente. 176p.

FALCÃO,L.B. Turismo em Resex:perspectivas de desenvolvimento

FIRMO, A.M.S.; TOGNELLA, M.M.P.; CÓ, W.L.O.; BARBOZA, R.R.D.; ALVES, R.N. Perceptions ofen vironmental changes and Lethargic crab disease among crab harve 
sters in a Brazilian coastal community. Journal of Ethnobiology and Ethnomedicine,v.7,n.1,n.,p. 26-34. 2011

FISCARELLI, A. G.; PINHEIRO, M. A. A. Perfil sócio-econômico e conhecimento etnobiológico do catador de caranguejo-uçá, Ucides cordatus (Linnaeus, 1763), nos manguezais de Iguape (240 41'S), SP, Brasil. Actualidades Biológicas,v. 24,n.77,p. 129-142. 2002.

GRASER, M. e DIELE, K. 2004 Asymmetricout comes: assessing central aspect of biological, economica land social sustainability of a mangrove crabfishery, Ucides cordatus (Ocypodidae), in North Brazil. Ecological Economics,v. 49,p.361-373.

IBAMA.1994. Lagosta, caranguejo-uçá e camarão Nordeste. IBAMA, Coleção Meio Ambiente. Série Estudos- Pesca, Brasília, Brasil, 190pp.

MASCARENHAS, R. E. B. \& GAMA, J. R. N. F. Extensão e característica das áreas de mangue do litoral paraense. Embrapa Amazônica Oriental, Belém, Pará, Brasil, 1999. $20 \mathrm{p}$.

NASCIMENTO, I. Projeto: formas de utilização social dos manguezais - coletores e extratores do litoral do Pará. In: III Workshop ECOLAB. Resumos... Belém, Pará, Brasil. 1995. p. 143-144.

RIBEIRO, T. E.; SILVA, J. M. L.; OLIVEIRA JÚNIOR, R. C. \& VALENTE, M. A. Homemmeio: sítios arqueológicos do litoral do Salgado, Pa. In: III Workshop ECOLAB. Resumos... Belém, Pará, Brasil. p.135-137. 1995.

ROCHA, M.S.P.; MOURÃO, J.S.; SOUTO, W.M.S.; BARBOZA, R.R.D.; ALVES, R.R.N. O uso dos recursos pesqueiros no estuário do rio Mamanguape, estado da Paraíba, Brasil. Interciência,v. 33,n.12,p. 903-909. 2008.

SNEDAKER, S. C. Mangroves: Their value and perpetuation. Nature and Resources. UNESCO,v. 14,n.3,p. 6-13. 1978.

SOUTO, F.J.B. Uma abordagem etnoecológica da pesca do caranguejo, Ucidescordatus, Linnaeus, 1763 (Decapoda: Brachyura), no manguezal do Distrito de Acupe (Santo AmaroBA). Biotemas, v.20,n.1,p. 69-80. 2007

WALTER, T.; WILKSON, J. ; SILVA, P.A. A análise da cadeia produtiva dos catados como subsídio à gestão costeira: as ameaças ao trabalho das mulheres nos manguezais e estuários no Brasil. Revista de Gestão Costeira Integrada,v. 12,n.4,p. 483-497. 2012.

Palavras-chave: Etnoecologia. Caranguejeiros. Socioeconomia.

Grande-área: Ciências Biológicas

Área: Etnobiologia 


\title{
AVALIAÇÃO E MAPEAMENTO DOS SERVIÇOS ECOSSISTÊMICOS OFERTADOS PELA RESERVA BIOLÓGICA NASCENTES DA SERRA DO CACHIMBO, PARÁ, BRASIL
}

\author{
Nome do(a) Bolsista: Mayara Gomes da Silva \\ Nome do(a) Orientador: Gundisalvo Piratoba Morales
}

Resumo: Serviços ecossistêmicos - SEs são características, funções ou processos ecológicos que direta ou indiretamente contribuem para o bem-estar humano. A identificação, classificação e mapeamento desses serviços fornecem uma visão geral dos ecossistemas, além de salientar a relevância da biodiversidade e funcionamento dos ecossistemas de forma eficaz. O presente estudo objetivou identificar os SEs e localizálos espacialmente na Reserva Biológica Nascentes da Serra do Cachimbo considerando as condições e classes de uso da terra observadas no ano de 2017. A metodologia escolhida baseou-se no estudo de Burkhard et al. (2009), utilizando levantamento bibliográfico e documental, identificação dos SEs e atribuição de pesos, revisão por especialistas e utilização de técnicas de geoprocessamento para o mapeamento. Os resultados encontrados mostraram um alto potencial de oferta na reserva, principalmente em áreas naturais. As áreas sob pressão antrópica, com práticas agropecuárias, apesar de serem fonte de SEs de provisão, mostraram menor oferta de SEs em geral. Concluise que a área tem seus serviços ecossistêmicos ameaçados e necessitam de atenção para evitar maior comprometimento da dinâmica natural na reserva, dessa forma, sugere-se o aprimoramento da gestão e desenvolvimento de planos de proteção e fiscalização.

Introdução: O capital natural é uma fonte vital para a provisão de diversos serviços ecossistêmicos - SEs, os quais podem ser entendidos como características, funções ou processos ecológicos que direta ou indiretamente contribuem para o bem-estar humano (Constanza et al., 1997; Daily, 1997; Millennium Ecosystem Assessment - MEA, 2005). A identificação e a classificação dos serviços ecossistêmicos fornecem uma visão geral das principais funções e produtos atribuídos aos ecossistemas, tal como suas estruturas ecológicas e processos associados (De Groot et al., 2002). Além disso, a identificação dos SEs contribui para reforçar acerca da relevância da biodiversidade e funcionamento dos ecossistemas, e auxilia na alocação eficientes dos recursos naturais. (De Groot et al., 2010; Alkemade et al., 2014; Heal et al., 2005).

Dessa forma, o mapeamento de serviços ecossistêmicos vem ganhando notoriedade e tem sido cada vez mais utilizado para fornecer informações na tomada de decisão, auxiliando no aumento da conscientização da população e na criação de estratégias para conservação, visto que a perda de SEs implica na perda de benefícios da natureza ao homem, que em muitos casos, impacta os sistemas sociais e econômicos (Burkhard et al., 2013; Burkhard; Maes, 2017; Crossman et al., 2013; Wolff et al., 2015; Malinga et al., 2015; Maes et al., 2011).

Nessa perspectiva, Burkhard et al. (2009) propuseram um método de mapeamento que associa a opinião de profissionais sobre SEs e ferramentas de geoprocessamento na elaboração da matriz de SEs e mapas temáticos (Sohel et al., 2015). Esse mapeamento 
pode revelar consequências decorrentes das mudanças do uso e ocupação do solo, que ocorrem através de atividades antrópicas e geram efeitos nos ecossistemas naturais, afetando diretamente a oferta dos SEs (Kaushal et al., 2017; Crossman et al., 2012).

$\mathrm{Na}$ tentativa de garantir a oferta de serviços ecossistêmicos, as Unidades de Conservação - UCs são espaços territoriais com características naturais relevantes, legalmente instituídas pelo Poder Público (Brasil, 2000). Apesar da grande importância da criação e manutenção das UCs na região Amazônica, elas estão sob constante pressão através de atividades agropecuárias, exploração ilegal madeireira, entre outros (Baima et al., 2018). Tais atividades quando desenvolvidas dentro de áreas protegidas, contribuem para o desmatamento, considerada a principal perda dos SEs na Amazônia brasileira (Castro; Andrade, 2016).

Como recorte amostral para entendimento deste contexto, tem-se a Reserva Biológica Nascentes da Serra do Cachimbo - RBNSC, unidade de conservação de proteção integral, que em 2018 figurou como a 12a UC mais desmatada da Amazônia, onde a exploração madeireira e pecuária são apontados como as principais causas dessas alterações (Baima et al., 2018; Brasil, 2009), e apesar dos dados mostrarem expansão da degradação nessa UC, ainda são escassos os estudos sobre a dinâmica do uso da terra na Rebio.

Objetivo: A pesquisa objetiva identificar o potencial de oferta de SEs e localizá-los espacialmente na Reserva Biológica Nascentes da Serra do Cachimbo considerando as condições e classes de uso da terra observadas no ano de 2017.

\section{Material e Método}

Área de estudo A RBNSC está localizada no sul do Pará, entre as coordenadas geográficas de latitude $8^{\circ} 39^{\prime} 41^{\prime \prime} / 9^{\circ} 22^{\prime} 14^{\prime \prime}$ (Sul) e longitude $54^{\circ} 59^{\prime} 44^{\prime \prime} / 54^{\circ} 22^{\prime} 36^{\prime \prime}$ (Oeste), abrangendo parte dos municípios de Altamira e Novo Progresso, adjacente à BR-163, (Brasil, 2009, p. 24). A reserva, pertencente à categoria de proteção integral, foi criada pelo Decreto de 20 de maio de 2005, com o objetivo de preservar os ecossistemas naturais existentes, possibilitando a realização de pesquisas científicas e o desenvolvimento de atividades controladas de educação ambiental (Brasil, 2005).

Coleta e análise de dados: A metodologia escolhida baseou-se no estudo de Burkhard et al. (2009) utilizando procedimentos importantes para atingir o objetivo da pesquisa, como escolha da área de estudo e da base de dados para análise espacial do uso da terra, levantamento bibliográfico e documental, identificação dos SEs e atribuição de pesos, revisão dos especialistas sobre os pesos de cada serviço associado à classe e uso de técnicas de geoprocessamento para mapear e espacializar as informações.

Resultado e Discussão: A partir do mapa de uso e ocupação da terra, pôde-se atribuir pesos para os SEs de acordo com as classes, variando em uma escala de 0 a 5 , conforme descrito no Quadro 2. Das seis classes identificadas, duas não apresentaram potencial de oferta de serviços ecossistêmicos, "outra área não vegetada" e "não observado", obtendo peso 0 em todos os serviços ecossistêmicos. Dentre as demais, "formação florestal" e "formação natural não florestal" foram as que obtiveram maiores pesos, de acordo com a expertise dos especialistas, por apresentarem maior oferta de SES.

De uma forma geral, percebe-se que apenas as áreas construídas e desflorestadas não possuem ou possuem baixa capacidade de ofertar serviços, o restante da área da Rebio 
apresenta pelo menos relevante capacidade de fornecimento de algum serviço. Dessa forma, observa-se que prioritariamente a alta capacidade de oferta dos SEs concentrase nas áreas naturais, especialmente áreas de vegetação densa, seguido das campinaranas, e são mais escassos em áreas alteradas pelo homem, levando à baixa capacidade de fornecer bens e serviços dos ecossistemas.

Embora a atividade agropecuária serem atividades ilegais dentro de unidades de conservação de proteção integral, ainda assim possuem potencial de fornecer serviços ecossistêmicos. Além dessa, a classe "rio, lago e oceano" também disponibiliza bens e serviços à população, visto que especificamente na RBNSC possui grande relevância de provisão de SEs pelo fato da reserva compreender muitas nascentes, formadoras dos rios das bacias do Xingu e do Tapajós, conforme descreve o Plano de Manejo (Brasil, 2009).

Alguns estudos se mostraram em consonância com os resultados aqui encontrados, exemplo de Zhang \& Ramírez (2019) que encontraram resultados semelhantes em Barcelona, onde áreas artificiais com intervenção humana possuem nenhuma ou pouca capacidade de prover serviços ecossistêmicos. Corroborando também com resultados encontrados por Sohel et al. (2015) sobre Bangladesh, onde destacaram que áreas menos perturbadas e mais naturais são importantes fornecedoras de múltiplos SEs, como por exemplo as florestas. Milheiras e Mace (2019) mostram que áreas cultivadas apresentarem mais serviços de provisão, por outro lado, fornecem menos serviços de regulação e culturais.

Atividades antrópicas, como agropecuária praticada no interior da Rebio, acarretam em prejuízos e na diminuição da disponibilidade de determinadas classes de SEs, de acordo com dados da pesquisa de Silva et al. (2017) e Depellegrin et al. (2016), além do mais, importante enfatizar que são proibidas dentro dessa categoria de UC. Esses autores identificaram maiores prejuízos nos serviços culturais e de regulação, como qualidade do ar e água, e ciclagem de nutrientes, a partir das alterações identificadas no estudo. Da mesma forma ocorreu no mapeamento da RBNSC, que mostrou maior fragilidade nos serviços de regulação e culturais, demonstrando mais sensível às mudanças do uso e ocupação do solo e consequentemente apresentando menor capacidade de oferta. Tal fato provavelmente está relacionado às alterações no meio, tornando a área menos atrativa quanto à informação estética, recreação, outros. Além disso, por estarem menos protegidos pela cobertura vegetal, essas áreas ficam muitos mais susceptíveis às variações climáticas, erosão do solo, a perda da regulação hídrica, diminuição do estoque de carbono e à diminuição da ciclagem de nutrientes (Markewitz et al., 2004; Zimmerman et al., 2006; Solar et al., 2016).

Chen et al. (2019) afirmam que as mudanças no uso do solo como a expansão de áreas urbanas e cultivadas resultam em significativas alterações nos SEs, sendo necessário o controle dessas mudanças como forma de melhorar as funções ecossistêmicas. Ainda segundo estes autores, o desenvolvimento econômico acarreta na intensificação dessas mudanças, causando degradação nos ecossistemas. Logo, análises da relação de uso e ocupação da terra e serviços ecossistêmicos fornecem fortes evidências acerca da necessidade de aplicação de usos sustentáveis, gestão eficiente das áreas, desenvolvimento econômico e proteção do meio ambiente. 
Em relação à metodologia de elaboração de matriz baseada nas classes de uso da terra, Hou et al. (2013) e Jacobs et al. (2015) afirmam que tem se mostrado com um método rápido e válido para medir a oferta dos serviços ecossistêmicos na Europa e Ásia. Kokkoris et al. (2018) adicionam que essa abordagem se mostra relevante na identificação de SEs, produção de informação científica e principalmente destaca a importância de áreas que não vem sendo protegidas de forma eficaz.

Conclusão: A Reserva Biológica Nascentes da Serra do Cachimbo foi caracterizada neste estudo com grande potencial para oferta de todas as classes de SEs, principalmente em áreas naturais preservadas. As áreas modificadas por atividades antrópicas foram identificadas com menor potencial de oferta, sendo basicamente fornecedoras de SEs de provisão e manutenção, destacadas como áreas que necessitam de maior atenção para não comprometer ainda mais a dinâmica natural na reserva, especialmente com relação aos serviços de regulação e culturais.

Destaca-se que, apesar das atividades agropecuárias fornecerem benefícios econômicos a curto prazo, deve-se repensar sobre os desserviços que essas práticas podem gerar a médio e longo prazo à qualidade de vida das populações e ao ecossistema natural. Assim, sugere-se o aprimoramento da gestão e desenvolvimento de planos de proteção para as áreas identificadas com maior potencial de oferta de SEs dentro da RBNSC, com o desenvolvimento e implementação de planos de fiscalização e restauração das áreas com menor potencial, focando na perspectiva da manutenção efetiva dos serviços ecossistêmicos.

\section{Referências bibliográficas}

ALKEMADE, R.; BURKHARD, B.; CROSSMAN, N.; NEDKOV, S.; K. PETZ. Quantifying ecosystem services and indicators for science, policy and practice. Special Issue. Ecological Indicators, v. 37, p. 161-162, 2014.

ARAÚJO, E.; BARRETO, P.; BAIMA, S.; GOMES, M. Unidades de conservação mais desmatadas da Amazônia Legal (2012-2015). Belém. Imazon. 92 pp. 2017. Disponível em:

http://imazon.org.br/PDFimazon/Portugues/livros/UCS\%20mais\%20desmatadas\%20Ama zonia_2012-2015.pdf

BAIMA, S.; BARRETO, P.; MANSUR, A. Nosso patrimônio ameaçado: Como as unidades de conservação na Amazônia estão em risco. Dossiê. Imazon. 48 pp. 2018. Disponível em: https://k6f2r3a6.stackpathcdn.com/wp-content/uploads/2019/01/DossieUCS_Imazon.pdf

BRASIL. Lei $n^{\circ} 9.985$, de 8 de julho de 2000. Institui o Sistema Nacional de Unidades de Conservação da Natureza e dá outras providências. Brasília: DOU de 19/07/2000.

BRASIL. Decreto Federal s/n de 20 de maio de 2005. Institui a criação da unidade de conservação de proteção integral Reserva Biológica Nascentes da Serra do Cachimbo. Brasília: DOU de 23/05/2005.

BRASIL. Plano de Manejo da Reserva Biológica Nascentes da Serra do Cachimbo. Instituto Chico Mendes de Conservação da Biodiversidade. 2009. Disponível em: http://www.icmbio.gov.br/portal/images/stories/imgs-unidades-

coservacao/rebio_nascentes_da_serra_do_cachimbo.pdf 
BURKHARD, B.; CROSSMAN, N.; NEDKOV, S.; PETZ, K.; ALKEMADE, R. Mapping and modelling ecosystem services for science, policy and practice. Ecosystem Services, v. 4, p. 1-3, 2013.

BURKHARD, B.; KROLL, F.; MÜLLER, F.; WINDHORST, W. Landscapes' capacities to provide ecosystem services - A concept for land-cover based assessments. Landscape Online, v. 15, p. 1-22, 2009.

BURKHARD, B.; MAES, J. Mapping Ecosystem Services. Pensoft Publishers, Sofia, 377 pp., 2017.

CARDOSO, D.; SOUZA JR, C. Degradação florestal em áreas protegidas. Imazon. Belém.

em: https://imazon.org.br/PDFimazon/Portugues/outros/OEstadoAPs_DegradacaoFlorestal.p df

COSTANZA, R.; D'ARGE, R.; DE GROOT, R.; FARBERK, S.; GRASSO, M.; HANNON, B.; LIMBURG, K.; NAEEM, S.; O'NEILL, R. V.; PARUELO, J.; RASKIN, R. G.; SUTTONKK, P.; VAN DEN BELT, M. The value of the world's ecosystem services and natural capital. Nature, v. 387, p. 253-260, 1997.

CRESPIN, S. J.; SIMONETTI, J. A. Loss of ecosystem services and the decapitalization of nature in El Salvador. Ecosystem Services, v. 17, p. 5-13, 2016.

CROSSMAN, N. D.; BURKHARD, B.; NEDKOV, S. Quantifying and mapping ecosystem services. International Journal of Biodiversity Science, Ecosystem Services and Management, v. 8, n. 1-2, p. 1-4, 2012.

DAILY, G. C. Nature's services: societal dependence on natural systems. Washington DC: Island Press. 1997.

DE GROOT, R. S.; WILSON, M. A., BOUMANS, R. M. J. A typology for the classification, description and valuation of ecosystem function goods and services. Ecological Economics, v. 41, p. 393-408, 2002.

DE GROOT, R.S.; FISHER, B.; CHRISTIE, M.; ARONSON, J.; BRAAT, L.; HAINESYOUNG, R.; GOWDY, J.; MALTBY, E.; NEUVILLE, A.; POLASKY, S.; PORTELA, R.; RING, I. Integrating the ecological and economic dimensions in biodiversity and ecosystem service valuation. The Economics of Ecosystems and Biodiversity: Ecological and Economic Foundations. P. Kumar. London, Earthscan, p. 3-40, 2010.

DEPELLEGRIN, D.; PEREIRA, P.; MISIUNĖ, I.; EGARTER-VIGL, L. Mapping ecosystem services potential in Lithuania. International Journal of Sustainable Development \& World Ecology, v. 23, n. 5, p. 441-455, 2016.

GÓMEZ-BAGGETHUN, E.; BARTON, D. N. Classifying and valuing ecosystem services for urban planning. Ecological Economics, v. 86, p. 235-245, 2013.

MAES, J.; PARACCHINI, M. L.; ZULIAN, G. Towards an atlas of ecosystem services. A European assessment of the provision of ecosystem services, JRC Scientific and Technical Reports. 2011. 88 pp.

MEA - Millennium Ecosystem Assessment. Ecosystems and Human well-being. Synthesis. Island Press, Washington, DC. 2005. 155 p.

MILHEIRAS, S. G.; MACE, G. M. Assessing ecosystem service provision in a tropical region with high forest cover: Spatial overlap and the impact of land use change in Amapá, Brazil. Ecological Indicators, v. 99, p. 12-18, 2019. 
RAMIREZ-GOMEZ, S. O. I.; TORRES-VITOLAS, C. A.; SCHRECKENBERG, K.; HONZÁK, M.; CRUZ-GARCIA, G. S.; WILLCOCK, S.; PALACIOS, E.; PÉREZ-MIÑANA, E.; VERWEIJ, P. A.; POPPY, G. M. Analysis of ecosystem services provision in the Colombian Amazon using participatory research and mapping techniques. Ecosystem Services, v. 13, p. 93-107, 2015.

SOLAR, R. R. D. C.; BARLOW, J.; ANDERSEN, A. N.; SCHOEREDER, J. H.; BERENGUER, E.; FERREIRA, J. N.; GARDNER, T. A. Biodiversity consequences of land-use change and forest disturbance in the amazon: A multi-scale assessment using ant communities. Biological Conservation, v. 197, p. 98-107, 2016.

TEEB - The Economics of Ecosystems and Biodiversity. Integrando a Economia da Natureza: uma síntese da abordagem, conclusões e recomendações do TEEB. 2010.

YOUNG, C. E. F.; MEDEIROS, R. Quanto vale o verde: a importância econômica das unidades de conservação brasileiras. Rio de Janeiro: Conservação Internacional, 180pp, 2018.

ZHANG, S.; RAMÍREZ, F. M. Assessing and mapping ecosystem services to support urban green infrastructure: The case of Barcelona, Spain. Cities, v. 92, p. 59-70, 2019.

Palavras-chave: Unidades de Conservação. Uso do solo. Capital Natural.

Grande área: Meio ambiente e sustentabilidade.

Área: Serviços ecossistêmicos 


\title{
EXPANSÃO DA MINERAÇÃO EM TERRAS INDÍGENAS NA AMAZÔNIA ORIENTAL BRASILEIRA: VULNERABILIDADE SOCIAL E IMPACTOS SOCIOAMBIENTAIS
}

\author{
Nome do(a) Bolsista: Mônica Moraes Ribeiro \\ Nome do(a) Orientador(a): Altem Nascimento Pontes
}

Resumo: Este estudo tem como objetivo analisar a expansão da atividade mineral em terras indígenas na Amazônia oriental brasileira, focalizando especificamente o estado do Pará, afim de discorrer sobre a vulnerabilidade social das principais etnias localizadas nesta região e os danos socioambientais causados pela mineração. Os dados tratados e discutidos foram adquiridos através de pesquisa bibliográfica, documental e de sítios eletrônicos de órgãos oficiais. A análise descritiva foi desenvolvida pelo código computacional Arcmap ${ }^{\circledR}$ e tratadas no Excel, que permitiram evidenciar através de mapas, tabelas e gráficos a expansão da atividade mineral em terras indígenas, o que pode justificar a agudização dos atuais conflitos locais. Os resultados informam que a partir de 1990 começou ocorrer elevação na quantidade de requerimentos de processos de mineração, havendo sucessivos aumentos até a atualidade. Isto evidencia a grande pressão que essa atividade está causando às terras indígenas e se traduz também na crescente extensão das áreas de mineração na região em análise. Os grupos indígenas mais vulnerabilizados pela expansão da mineração são os que compõem as etnias Wayana, Apalaí e Kayapó. Diante disso, há a necessidade imperiosa de políticas públicas capazes de promover o desenvolvimento econômico alicerçado na manutenção e harmonia entre os componentes econômico, social e ambiental para garantir a integridade da natureza e das comunidades indígenas que dela dependem.

Introdução: Ao longo da década de 1980, a Amazônia - com sua exuberância e também com suas intrincadas problemáticas - fez tomar destaque e consolidar no cenário do debate ambiental internacional as ideias de uso sustentável da natureza e da existência dos "povos da floresta", sendo estes concernentes às diversas comunidades ribeirinhas, a exemplo dos seringueiros, grupos indígenas e demais comunidades tradicionais locais (GARNETT, 2018). Nesse período, os povos da floresta ganharam notoriedade internacional e foram protagonistas no discurso ontológico sobre a dicotomia existente entre sociedade e natureza e na promoção do conceito do desenvolvimento sustentável (HOLDEN et al., 2017).Ocorre que na prática, as discussões sobre a sustentabilidade na Amazônia foram sendo adaptadas para buscar a conciliação entre os interesses econômicos, sociais e ambientais, perquirindo soluções moldadas para atender ao modelo clássico de desenvolvimento econômico, porém com suas demandas atuais (FUKUDA-PARR, 2016). Após quase vinte anos do novo milênio, a Amazônia traz a lume no debate nacional e internacional os velhos conflitos que envolvem a expansão da fronteira minerária em terras indígenas e seus desdobramentos socioambientais (SALMAN; De THEIJE, 2017). Cabe ressaltar que o direito de grupos indígenas no Brasil, o reconhecimento dos seus modos de vida e seu direito de autonomia estão ancorados na Constituição Federal Brasileira de 1988 (BRAGATO; NETO, 2017). 
Há evidências de que existem pressões sociais e econômicas relacionadas às atividades minerais oriundas da insuficiência de fiscalização ou de medidas regulatórias mais eficazes (CARVALHO, 2017). Esse contexto corrobora para a geração de impactos socioambientais negativos às comunidades vulneráveis (indígenas) e ao meio ambiente (OTTO et al., 2017). Desta forma, a análise desse intrincado cenário, capaz de conhecer o atual panorama das comunidades indígenas, se faz necessário e justifica-se pela importância do tema em pauta, não somente para a região, mas também pela sua relevância para o mundo.

Nesta perspectiva, a presente pesquisa propõe analisar a expansão da atividade mineral em terras indígenas na Amazônia oriental brasileira, focalizando especificamente o estado do Pará como área de estudo, para assim discorrer sobre a vulnerabilidade social das principais etnias indígenas desta região e os danos socioambientais causados pela mineração.

Material e Métodos: Para o desenvolvimento da pesquisa foram consideradas as Terras Indígenas - TIs localizadas no estado do Pará, na Amazônia oriental Brasileira. O Pará fica localizado na região Norte do Brasil, sendo o segundo maior estado brasileiro, com uma extensão de 1.245.759,305 km², dividido em 144 municípios com uma população estimada de 8.513.497 habitantes (IBGE, 2018). Neste território existem 55 TIs, com uma extensão total de $340.913,85 \mathrm{~km}^{2}$, o equivalente a $27,3 \%$ da área total do estado do Pará, sendo este o que possui a segunda maior participação no valor da produção mineral brasileira, com cerca de $43 \%$ do total de 88,5 bilhões de reais (ANM, 2018).

Os dados referentes às TIs foram adquiridos através do sítio eletrônico da FUNAI, do Ministério da Mulher, da Família e dos Direitos Humanos. Sendo selecionadas as TIs regularizadas, homologadas, declaradas e delimitadas e que não estejam em etapa de criação, obtendo as informações referentes ao nome das TIs, as etnias que ocupam essas terras e a área total em hectare.

Os dados referentes a processos de mineração para o estado do Pará foram adquiridos através da base de dados da Agência Nacional de Mineração (ANM), que informa todos os dados dos processos de mineração no estado. Dentre as informações contidas neste cadastro estão os dados referentes ao empreendimento (número do processo, ano de requerimento, fase do processo, minério explorado) e os dados vetoriais (área em hectares do processo).

Todos os mapas gerados através de análise descritiva foram desenvolvidos pelo código computacional $\operatorname{Arcmap} \AA$, por meio da ferramenta frequency, mediante a qual foi possível descrever a frequência das categorias de interesse. Utilizando-se a ferramenta statistics, determinou-se a média, desvio padrão, valores máximos e mínimos.

Resultados e Discussão: As TIs são áreas protegidas pela União que abrangem cerca de $27,3 \%$ da área total do estado do Pará. Entre as etnias que mais ocupam essas terras, destacam-se os Mebêngôkre (Kayapó) que ocupam 10.752.504,4 hectares, sendo a etnia que predomina o sul do estado do Pará.

A segunda comunidade indígena de maior expressão territorial é na verdade formada por um grupo de Etnias composto pelos Katuena, Xereu, Wai Wai, Tunayana, Sikiyana, Hixkarvána, nesta área há também grupos isolados como os Karafawyana, Katuena e Waimiri Atroari. Estas diferentes etnias perfazem a área de 5.020.418 hectares e estão localizadas na região noroeste do Pará, conhecida como região do Baixo Amazonas. 
Além destas, ocupam também nessa região os grupos étnicos Apalaí e Wayana com uma extensão total de $4.266 .853,7$ hectares e os Kaxuyana que ocupam a extensão de 2.184.120 hectares.

Na região sudoeste as principais etnias são os Mundurukú com 2.724.422,2 ha, Kaiabi com 1.053.257,7 ha e Sateré-Mawé com 788.528,4 ha. Ao centro do estado estão localizadas as etnias Araweté; Asurini do Xingu com 2.038.773,5 ha, Arara do Pará com 1.033.223 ha e Parakanã com 2.066.068,3 ha.

A expressiva quantidade de requerimentos de processos de mineração representa uma evidência da grande pressão que essa atividade está causando nas TIs e se traduz também na extensão que essas áreas de mineração ocupam, na expansão dessa ocupação decorrente da iminente aceitação dos processos de mineração requeridos, agravando a vulnerabilidade social das etnias nesta região e os danos ambientais causados pela mineração.

As TIs correspondentes à etnia Kayapó, por haver grande concentração de ouro, é onde há a convergência de maior número de requerimentos para a exploração deste minério, sendo a extensão dos processos de mineração requeridos em 2.136.585 hectares, o que representa $50 \%$ de todas as áreas requeridas.

Em relação às etnias vulnerabilizadas, a expansão da mineração está afetando principalmente as TIs em que vivem os Wayana; Apalaí, onde já existe exploração de bauxita, com uma área equivalente a 29.426 hectares, ouro (318,5 hectares), areia $(154,2$ ha) e saibro $(39,3)$. Em seguida vem a etnia Kayapó, onde estão ativos 8699,2 hectares, sendo 7290,7 ha de cobre, ouro (495 ha), areia (464,5 ha), saibro (121, $9 \mathrm{ha}$ ), argila (116,1 ha), cassiterita (111,8 ha) e água mineral (99,4 ha).

O extrativismo mineral, apesar de ser considerado, no paradigma amazônico, como sinônimo de crescimento econômico, configura a atividade econômica com alto potencial de impactos ambientais e sua expansão representa graves ameaças às TIs e a tudo que elas representam (LAWRENCE; MORITZ, 2019). Sabe-se que a mineração deve continuar e crescer no futuro previsível para assegurar os insumos minerais para a produção e consumo de bens finais. Entretanto, deve haver uma trajetória mais responsável para a exploração mineral com práticas ambientais mais justas e conscientes (ALI et al., 2017).

Conclusão: Diante dos resultados obtidos neste estudo, verificou-se a expansão da mineração em TIs, o aumento da vulnerabilidade social das etnias que vivem na região e os impactos socioambientais causados pela mineração. Constatou-se que as etnias mais vulnerabilizadas são os Wayana e Apalaí, onde há a exploração de bauxita, ouro, areia e saibro. Em seguida a etnia Kayapó, onde a maior exploração ocorre nos minerais: cobre, ouro, areia, saibro, argila, cassiterita e água mineral. Por haver grande concentração de ouro nas terras da etnia Kayapó, há, nesta área, o maior número de requerimentos para a exploração deste minério. Com este estudo, espera-se ter contribuído para o interesse do debate nacional e internacional de uma questão de grande relevância socioeconômica e ambiental, que é a busca por políticas públicas constitucionais, eficientes e justas no Brasil, que visem à preservação dos povos indígenas, de sua identidade, cultura e, portanto, de seus territórios frente à expansão das atividades minerárias na Amazônia oriental brasileira. 
Para isso, ressalta-se a imensurável importância ecológica da maior floresta tropical do mundo. Preservar a biodiversidade da Amazônia significa também respeitar a existência e os modos de vida das comunidades indígenas que nela vivem, que dela dependem e que representam os legítimos guardiões da floresta. Defender a floresta amazônica, num sentido mais amplo, significa contribuir para estabilização de outros ecossistemas do planeta.

Referências: ALI, Saleem H. et al. Mineral supply for sustainable development requires resource governance. Nature, v. 543, n. 7645, p. 367, 2017. https://doi.org/10.1038/nature21359

ANM-Agência Nacional de Mineração. Informe Mineral. julho/dezembro de 2017.

Disponível em < $\underline{\text { http://www.anm.gov.br/dnpm/publicacoes/serie-estatisticas-e-economia- }}$ mineral/informe-mineral/publicacoes-nacionais/informe mineral $22017>$. Acesso em 15 mai 2019.

BRAGATO, Fernanda Frizzo; NETO, Pedro Bigolin. Conflitos territoriais indígenas no Brasil: entre risco e prevenção. Revista Direito e Práxis, v. 8, n. 1, p. 156-195, 2017. CARVALHO, Fernando P. Mining industry and sustainable development: time for change. Food and Energy Security, v. 6, n. 2, p. 61-77, 2017.

https://doi.org/10.1002/fes3.109

FUKUDA-PARR, Sakiko. From the Millennium Development Goals to the Sustainable Development Goals: shifts in purpose, concept, and politics of global goal setting for development. Gender \& Development, v. 24, n. 1, p. 43-52, 2016.

https://doi.org/10.1080/13552074.2016.1145895

Funai.gov.br. (n.d.). Povos Indígenas Isolados e de Recente Contato. [online] Available at: http://www.funai.gov.br/index.php/nossas-acoes/povos-indigenas-isolados-e-derecente-contato [Accessed 25 May, 2019].

GARNETT, Stephen T. et al. A spatial overview of the global importance of Indigenous lands for conservation. Nature Sustainability, v. 1, n. 7, p. 369, 2018.

https://doi.org/10.1038/s41893-018-0100-6

HOLDEN, Erling et al. The imperatives of sustainable development: needs, justice, limits. Routledge, 2017. https://doi.org/10.4324/9780203022177

IBGE- Instituto Brasileiro de Geografia e Estatística. Disponível em < https://ww2.ibge.gov.br/home/ > . Acesso em: 20 abr. 2019.

LAWRENCE, Rebecca; MORITZ, Sara. Mining industry perspectives on indigenous rights: Corporate complacency and political uncertainty. The Extractive Industries and Society, v. 6, n. 1, p. 41-49, 2019. https://doi.org/10.1016/j.exis.2018.05.008

OTTO, Ilona M. et al. Social vulnerability to climate change: A review of concepts and evidence. Regional environmental change, v. 17, n. 6, p. 1651-1662, 2017. https://doi.org/10.1007/s10113-017-1105-9

SALMAN, Ton; DE THEIJE, Marjo. Analysing conflicts around small-scale gold mining in the Amazon: the contribution of a multi-temporal model. The Extractive Industries and Society, v. 4, n. 3, p. 586-594, 2017. https://doi.org/10.1016/j.exis.2017.03.007

Palavras-chave: Mineração. Terras Indígenas. Gestão Pública. Amazônia.

Grande área: Ciências Ambientais

Área: Mineração 


\title{
ANÁLISE DA CONCENTRAÇÃO DE METAIS NO LAGO ÁGUA PRETA (BELÉM-PA) USANDO COMO BIOINDICADOR O GAFANHOTO SEMIAQUÁTICO TETRATAENIA SURINAMA (LINNAEUS, 1764)
}

\author{
Nome do(a) bolsista: Wilson Figueiredo de Lima \\ Nome do(a) Orientador(a): Ana Lúcia Nunes Gutjahr
}

Resumo: A Classe Insecta é considerada o maior grupo de animais que existe na terra, sendo de extrema importância para a manutenção do equilíbrio dos ecossistemas naturais. Alguns insetos são bioindicadores de qualidade ambiental, sendo por isso, objeto de estudos que determinam a condição bioindicadora dos mesmos. O gafanhoto Tetrataenias urinama (Linnaeus, 1764) (Orthoptera, Acrididae), se alimenta e desenvolve seu ciclo de vida associado à macrófita aquática Montrichardial inifera (Arruda) Schott, (Araceae) (Aninga), que é considerada tóxica. Essa planta é amplamente distribuída na região Amazônica, inclusive nos centros urbanos, incluindo o Lago Água Preta, que abastece de água potável a cidade de Belém. Considerando que o lago mencionado está em perímetro urbano e, que podem receber o despejo de esgotos doméstico e industrial, torna-se importante a realização de estudos que identifiquem a presença de metais. $O$ presente trabalho tem como objetivo realizar análises químicas para determinar e quantificar a concentração de metais no solo do leito e na água do lago, na macrófita $M$. liniferae no gafanhoto T.surinama, a fim de comprovar a ação bioindicadora deste, frente aos metais pesados. No laboratório, os gafanhotos permanecerão em Insetário na UEPA-CCSE por 30 dias se alimentando exclusivamente de Aninga do lago que serão anestesiados em refrigerador e posteriormente sacrificados. As análises químicas do solo serão realizadas no Laboratório de Análises Químicas da Coordenação de Ciências da Terra e Ecologia (CCTE) do Museu Paraense Emílio Goeldi (MPEG) e da água, macrófita e do gafanhoto no Laboratório de Química do CCNT-UEPA. Ao final desse estudo é esperado que seja determinada a concentração de metais pesados no solo do leito e na água do lago, na Aninga e no gafanhoto e, que através de análises comparativas e estatísticas se possa inferir sobre as concentrações dos metais na Aninga e no gafanhoto, relacionando o nível de toxidade dos metais nesses organismos estudados.

Introdução: A água é um recurso natural fundamental à vida e inúmeras atividades dos animais e seres humanos, tendo um destaque para o abastecimento público (MORAES; JORDÃO, 2002). No entanto, com o crescimento populacional, a industrialização e principalmente a urbanização, os corpos hídricos na cidade de Belém recebem despejo de esgoto doméstico e industrial, o que pode causar a contaminação da água por diversos tipos de metais, um desses corpos d'água é Lago Água Preta, o principal manancial de abastecimento de água da população residencial da Região Metropolitana de Belém, se encontrar localizado a apenas $1,4 \mathrm{~km}$ do "Lixão do Aurá" (SANTANA; BARRONCAS, 2007; FREIRE et al. 2008; BAHIA; FENZEL; MORALES, 2006).

Essa possível contaminação de metais no Lago Água Preta pode ser absorvida pelas macrófitas aquáticas que margeiam o lago, e algumas espécies de insetos possuem preferência alimentar por essas macrófitas. Atualmente a Classe Insecta representa 
mais de $60 \%$ das espécies conhecidas de animais, sendo, o maior grupo existente atualmente no mundo (RAFAEL et al. 2012).

Os insetos possuem grande importância ecológica como base alimentar de outros animais, além disto, podem constituir-se como bons bioindicadores de qualidade ambiental, assim como importantes desfolhadores naturais, contribuindo na reciclagem de matéria orgânica, em decorrência de seus hábitos alimentares (herbívoria), no qual iram se nutrir preferencialmente de folhas (NUNES, 2008).

$\mathrm{Na}$ Classe Insecta se destaca a Ordem Orthoptera, cujos representantes são conhecidos popularmente como esperanças, paquinhas, grilos, manés-magro e gafanhotos. Destacando nesse grupo o gafanhoto amazônico Tetrataenia surinama que é pertencente à família Acrididae, subfamília Leptysminae e tribo Tetrataeniini (NUNESGUTJAHR; BRAGA, 2011). O gafanhoto semiaquático $T$. surinama ocorre na região Amazônica em áreas de várzeas, mangues, igapós, igarapés, lagos e outros corpos d'água inclusive na cidade de Belém, onde vive associado à sua planta hospedeira conhecida como Aninga (Montrichardia linifera), da qual se alimenta (NUNES-GUTJAHR; BRAGA, 2011; LIMA; NUNES-GUTJAHR, 2018).

Objetivo (s): Realizar análises químicas para determinar e quantificar a concentração de metais pesados no Lago Água Preta (solo do leito e água), bem como na macrófita $M$. linifera e no gafanhoto $T$. surinama, a fim de comprovar a ação bioindicadora do gafanhoto, frente aos metais que podem contaminar a água que abastece Belém do Pará.

Material e Método: A área de estudo abrange o Parque Estadual do Utinga onde se encontra o Lago Água Preta, que se estende nos municípios de Belém e Ananindeua.

A coleta de campo ocorrerá no período chuvoso e menos chuvoso, quando serão coletadas amostras de água, solo do leito (fundo do lago), planta hospedeira (M.linifera) e o gafanhoto $T$. surinama. Para a captura do gafanhoto semiaquático será utilizada uma rede entomológica de grande calibre. Após a captura, os gafanhotos serão transportados para o laboratório da Universidade do Estado do Pará (UEPA), Centro de Ciências Sociais e Educação (CCSE), onde permanecerão em insetário. No laboratório os gafanhotos ficarão acondicionados em aquários $(40 \times 30 \times 20 \mathrm{~cm})$ contendo água e folhas de $M$. linifera, que servirão de alimento e substrato.

No insetário, os exemplares de $T$. surinama vão ser alimentados por 30 dias somente com folhas de Aninga, coletadas no lago, conforme a metodologia de Nunes (1989) adaptado. Após os 30 dias os gafanhotos serão depositados em Eppendorfs (3,5 ml) e introduzidos em geladeira para ser anestesiados e, posteriormente, congelados. As análises químicas dos gafanhotos serão realizadas no Laboratório de Química do CCNTUEPA enquanto que o solo do leito e a água serão analisados no Laboratório de Químicas da Coordenação de Ciências da Terra e Ecologia (CCTE), do Museu Paraense Emílio Goeldi (MPEG), seguindo o protocolo para análises químicas de Amarante et al, (2011).

Resultados Esperados: Com o presente estudo, pretende-se gerar informações sobre os tipos de metais e as concentrações destes no leito e água do lago, no gafanhoto e na macrófita hospedeira $M$. linifera, visto que se trata do ambiente hídrico que serve e abastece as pessoas que residem em Belém. 
Como já foi constatado no trabalho de Lima e Nunes-Gutjahr (2018), o gafanhoto semiaquático $T$. surinama metaboliza metais em pequena quantidade, permitindo que possa bioindicar a existência de metais pesados em concentrações que podem ocasionar toxidade. No estudo proposto, será utilizado de forma inovadora um protocolo que possibilitará detectar uma quantidade maior de metais pesados, tanto no gafanhoto quanto na sua planta hospedeira, utilizando soluções com menor concentração destes organismos. Vale ressaltar que estudos como este, agora proposto são inexistentes, tratando-se, portanto, de um estudo pioneiro para o lago estudado.

Referências: AMARANTE, C. B.; SILVA, J. C. F.; MÜLLER, R. C. S.; MÜLLER A. H. Avaliação da composição mineral do chá da folha senescente de Montrichardia linifera (Arruda) schott (Araceae) por espectrometria de absorção atômica com chama (FAAS). Quím. Nova, v. 34, n. 3, p. 419-423, 2011.

BAHIA, V. E.; FENZL, N.; MORALES, G. P. Estudo Hidrogeológico E Hidrogeoquímico Da Área Localizada Entre O Depósito De Lixo Metropolitano De Belém (Aurá) E O Lago Água Preta. GeochimicaBrasiliensis, v. 20, n. 3, p. 296-311, 2006.

FREIRE, M. M.; SANTOS, V. G.; GINUINO, I. S. F.; ARIAS, A. R. L. Biomarcadoresnaavaliação da saúdeambiental dos ecossistemasaquáticos. OecologistaBrasiliensis, v. 12, n. 3, p. 347-354, 2008.

LIMA, W. F.; NUNES-GUTJAHR, A. L. USO DO GAFANHOTO TETRATAENIA SURINAMA (LINNAEUS, 1764) (ORTHOPTERA: ACRIDIDAE) COMO BIOINDICADOR DE METAIS PESADOS NO MEIO AQUÁTICO. In: VII Simpósio de Estudos e Pesquisas em Ciências Ambientais na Amazônia. Belém, PA. Resumo 2018.

MORAES, D. S. L.; JORDÃO, B. Q. Degradação de recursoshídricos e seusefeitossobre a saúdehumana. Revista de SaúdePública, v. 36 n. 3, p. 370-374, 2002.

NUNES, A. L. Estudo sobre o ciclo de vida e fenologia de Stenacrisfissicaudafissicauda (Bruner, 1908) (Orthoptera-Acrididae) em um lago de várzea da Amazônia Central, Brasil, Manaus. Instituto Nacional de Pesquisas da Amazônia/ Universidade Federal do Amazonas. Manaus, AM, Brasil. Tese de Mestrado. p.122, 1989.

NUNES, A. L. Levantamento e diagnóstico de Insecta - Orthoptera (Acridoidea) semiaquático e terrestre da Região do Rio Xingu - AHE Belo Monte. Relatório Final: Museu Paraense Emílio Goeldi. p. 46. 2008.

NUNES-GUTJAHR, A. L.; BRAGA, C. E. S. Gafanhotos da FlonaCaxiuanã: Guia Prático. Museu Paraense Emílio Goeldi. Belém, Pará, p. 62, 2011.

RAFAEL, A, L.; MELO, G, A, R.; CARVALHO, C. J. B.; CASARI, S. A.; CONSTANTINO, R. Insetos do Brasil: Diversidade e Taxonomia. Ribeirão Preto, Holos Editora, p. 810, 2012.

SANTANA, G. P.; BARRONCAS, P. S. R. Estudo de metais pesados (Co, $\mathrm{Cu}, \mathrm{Fe}, \mathrm{Cr}, \mathrm{Ni}$, $\mathrm{Mn}, \mathrm{Pb}$ e $\mathrm{Zn}$ ) na Bacia do Turumã-Açu Manaus - (AM). ActaAmazonica, v. 37, n. 1, p. 111-118, 2007. 
Palavras-chave: Análise química, inseto, planta hospedeira.

Grande-área: Ciências Biológicas

Área: Ecologia de ecossistemas 


\section{A MALÁRIA NO MUNICÍPIO DE CÂNDIDO MENDES, MARANHÃO: DIAGNÓSTICO E MAPEAMENTO DOS VETORES}

Nome do(a) Bolsista: Yuri Freitas da Silva

Nome do(a) Orientador(a): Ana Lucia Nunes Gutjahr

Resumo: A malária é uma doença infecciosa febril aguda, causada por protozoários do gênero Plasmodium e transmitida por mosquitos do gênero Anopheles. No Brasil sua ocorrência é quase restrita a Amazônia Legal, responsáveis por $99 \%$ dos casos no país. No Estado do Maranhão os casos se concentram em sua porção noroeste. O município de Cândido Mendes, situa-se no litoral oeste do Maranhão e que faz parte da Amazônia Maranhense, é considerado como área endêmica da malária. Estudar o vetor e analisar seus aspectos ecológicos é de fundamental importância para se conhecer seu papel no processo saúde - doença, que é relevante aos métodos de combate e controle. $\mathrm{O}$ presente trabalho visa determinar e mapear as espécies de Anopheles, possivelmente associados à transmissão da malária no município Cândido Mendes, a fim de propor o perfil entomológico da malária na região, além de realizar um diagnóstico ambiental e dos fatores de transmissão que podem servir como ferramenta de apoio no combate a essa endemia.

Introdução: No Brasil a partir de 1955 foi adotado o Programa Global de Erradicação da Malária proposto pela Organização Mundial de Saúde (OMS), tal programa orientou avanços na produção de medicamentos e inseticidas, por meio de metodologias estruturadas de combate que logo representaram uma redução significativa nos casos (SILVA et al. 2015). A Região Amazônica apresenta 99\% dos casos registrados, devido o vetor encontra condições mais propícias para seu desenvolvimento e as condições socioeconômicas e ambientais, que também, favorecem a transmissão da doença (LAPOUBLE et al. 2015).

No Maranhão o maior número de registros de casos de malária se concentra na região norte do estado, fato decorrente possivelmente, das condições climáticas e aspectos demográficos similares aos da região amazônica. Tais fatores favorecem a reprodução do mosquito vetor da doença, que encontra condições ideias para seu desenvolvimento (LOPES et al. 2013; MESQUITA et al. 2013).

Os vetores da malária são insetos da ordem Diptera, família Culicidae pertencentes ao gênero Anopheles. São também conhecidos popularmente como pernilongos, carapanãs ou mosquitos-prego. Existem cerca de 400 espécies do gênero, das quais 60 ocorrem no Brasil (BRAGA; FONTES, 2004),

A caracterização entomológica quando realizada de forma regular, permite a obtenção de informação padronizada de parâmetros entomológicos que são úteis para orientar a seleção de intervenções. Por isso, a análise da informação gerada será útil nas diferentes esferas de tomada de decisões (BRASIL, 2009).

Neste contexto, a realização deste trabalho visará suprir a falta de conhecimento das populações de Anopheles no munícipio de Cândido Mendes, localizado em área de potencial endêmico que possui características ambientais propícias à disseminação da doença. Através deste estudo serão analisadas a diversidade e a abundância dos 
mosquitos vetores da malária, assim como a condição ambiental, além do mapeamento das espécies de Anopheles, essas informações auxiliarão a busca de mecanismos mais eficazes que possam reduzir as populações deste vetor e diminuir os índices de malária entre os habitantes do município.

1. Objetivo: Realizar um diagnóstico da malária e o mapeamento das espécies de vetores no município de Cândido Mendes, Maranhão.

2. Material e métodos: $O$ estudo será realizado no município de Cândido Mendes, no Estado do Maranhão, que se encontra localizado na Amazônia Maranhense, região do Estado pertencente à Amazônia Legal. Possui uma área territorial $1.640,756 \mathrm{~km}^{2}$ e população estimada em 20.076 habitantes (IBGE, 2010).

Por se encontrar situado no oeste do Maranhão, o município de Cândido Mendes reflete toda uma estrutura de floresta Amazônica (CANTANHEDE, 2006). Tal região é favorável a proliferação do vetor da malária, que encontra características essenciais para o seu desenvolvimento.

As coletas serão realizadas em quatro pontos de amostragem (cada um correspondente a uma residência), localizados na sede do município de Cândido Mendes, selecionados aleatoriamente entre os bairros que a compõe, de modo a garantir a representatividade espacial da área amostrada.

As capturas dos anofelinos, em cada ponto de coleta, ocorrerá no intradomicílio e peridomicílio de cada residência alvo, durante uma noite e terá a duração de 4 horas (18h00 às 22h00). Tentando determinar o fator entomológico horário de pico, serão realizadas coletas intervalares de 12 horas, em um ponto amostral, sendo uma no período menos chuvoso e outra no período mais chuvoso (TADEl et al 1988).

O protocolo de coleta e notificação segue as orientações da normativa institucional da secretaria de controle de vetores (BRASIL, 2010), da Portaria 45/2007, captura de mosquitos adultos da Secretaria de Vigilância e Saúde, Ministério da Saúde e Nota Técnica $N^{\circ} 12 / 2007$, captura de formas imaturas (larvas e pupas) de mosquitos, da Secretaria de Vigilância em Saúde do Ministério da Saúde.

3. Resultados Esperados: O presente estudo espera contribuir com acréscimo ao conhecimento da biodiversidade de dípteros culicídeos ao gerar informações sobre a comunidade de Anopheles em Cândido Mendes, determinar as espécies que lá ocorrem, identificando sua riqueza e abundância nos pontos de amostragem; além de mapear suas áreas de ocorrências, possibilitando assim relacioná-las aos casos de malária na região. Espera-se ainda contribuir com o aprimoramento de medidas de combate e controle através dos dados obtidos pelo estudo.

\section{Referências}

BRAGA E. M.; FONTES C. J. F. Plamodium - Malária. in: NEVES, D. P. Parasitologia Humana. 11 ed. São Paulo: Atheneu, 2004. 
BRASIL. Ministério da Saúde. Secretaria de Vigilância em Saúde. Diretoria Técnica de Gestão. Guia para gestão local do controle da malária: módulo 2 : controle vetorial. Brasília: Ministério da Saúde, 2009. 59p

BRASIL. Ministério da Saúde. Secretaria de Vigilância em Saúde. Guia para gestão local do controle da malária: controle vetorial / Ministério da Saúde, Secretaria de Vigilância em Saúde, Diretoria Técnica de Gestão. - Brasília: Ministério da Saúde, 2009. 59p. - (Série B. Normas e Manuais Técnicos. Disponível em: <http://bvsms.saude.gov.br/bvs/saudelegis/svs/2007/prt0045 1312 2007.html>Acesso em: 229/12/2018.

BRASIL. Ministério da Saúde. Secretaria de Vigilância em saúde. Departamento de Vigilância Epidemiológica. Guia Prático de Tratamento da Malária no brasil. Brasília, Ministério da Saúde, 2010.

CANTANHEDE, M. V.; A constituição geográfica do município de Cândido Mendes, MA. Ed UFMA, p.138, 2006.

IBGE. População no último censo (2010). Brasil/Maranhão/Cândido Mendes. Disponível em: < https://cidades.ibge.gov.br/brasil/ma/candido-mendes/panorama> Acesso em: $28 / 12 / 2018$

LAPOUBLE, O. M. M. et al. Situação epidemiológica da malária na região amazônica brasileira, 2003 a 2012. Revista Panamericana de Salud Pública, v. 38, p. 300-306, 2015.

LOPES N.F.S.N., TADEI W.P., BRITO L.M.O, BEZERRA J.M.T., PINHEIRO V.C.S. Malária no maranhão: análise dos fatores relacionados com a transmissão no período de 2005 a 2009. RevPesq Saúde, 14(1): 40-44, jan-abr, 2013.

MESQUITA, E. M., MUNIZ, T. F., SOUSA, A. L. S., BRITO, C. X. L., NUNES, S. C. M., GRISOTTO, M. A. G. Levantamento epidemiológico da malária no estado do Maranhão, Brasil nos anos de 2007 a 2012. Rev. Ciênc. Saúde, São Luís, v.15, n.1, p. 11-18, janjun, 2013. 
SILVA, R. PAIVA, C. H. A. O governo JK e o Grupo de Trabalho de Controle e Erradicação da Malária no Brasil: encontros e desencontros nas agendas brasileira e internacional de saúde, 1958-1961. Hist. cienc. saúde-Manguinhos vol.22 no.1 Rio de Janeiro Jan./Mar. 2015.

TADEI, WP, SANTOS, JMM, COSTA, WLS, SCARPASSA, VM. Biologia de anofelinos amazônicos. XII. Ocorrência de espécies de Anopheles, dinâmica da transmissão e controle da malária na zona urbana de Ariquemes, Rondônia. RevlnstMed Trop. 1988 mai-jun;30(3):221-51.

Palavras-chave: Fauna anofelina, Paludismo, Perfil Entomológico. 


\section{PROGRAMA DE PÓS- GRADUAÇÃO EM CIÊNCIAS DA RELIGIÃO}




\section{O JOVEM, A UNIVERSIDADE E A FÉ: UM ESTUDO SOBRE O ETHOS ACADÊMICO E EXPERIÊNCIAS RELIGIOSAS DO ESTUDANTE DE CIÊNCIAS DA RELIGIÃO EM BELÉM (PA)}

Nome do(a) Bolsista: Cristian Sicsú da Glória

Nome do(a) Orientador(a): Donizete Rodrigues

Resumo: A presente comunicação é uma pesquisa desenvolvida no Programa de PósGraduação em Ciências da Religião da Universidade do Estado do Pará. A temática acerca dos estudantes universitários e sua religiosidade é um tema já debatido nos campos das Ciências Humanas, como mostra os estudos de Regina Novaes, Marcelo Camurça, entre outros autores, mas que ainda encontram-se lacunas quando se direciona os olhares para a Região Norte acerca das experiências religiosas de universitários na Amazônia. Portanto, a proposta geral analisar em que medida as experiências e conteúdos oferecidos na universidade influenciam nos valores e comportamentos religiosos dos jovens estudantes Curso de Ciência da Religião do CCSE/UEPA, utilizando como abordagem metodológica uma combinação entre dados quantitativos e qualitativos, com aplicação de questionários e entrevistas de modo a assegurar imagens que correspondam às mudanças na concepção e nas práticas religiosas da juventude universitária. Nossa hipótese inicial é de que os jovens veem na Universidade o momento de maior liberdade em suas trajetórias pessoais - uma etapa em que as identidades herdadas são postas em xeque pelo contato com novos conhecimentos, novos modelos de sociabilidades e novas articulações de saber-poder. Isso não desqualifica os valores que trazem de suas famílias ou comunidades de origem, mas reorganizam o rol de escolhas disponíveis, impactando fortemente nas identidades religiosas (mas não apenas religiosas).

Introdução: A introdução da juventude como um tema caro aos cientistas sociais de religião no Brasil se deu, a partir de finais dos anos 1990, em função de um triplo alargamento. Em primeiro lugar, as mudanças no perfil religioso da população diagnosticadas pelos censos demográficos e pesquisas de opinião impunham aos pesquisadores novos questionamentos, o que incluía a observação das crenças e comportamentos recortados em diferentes faixas etárias. Além disso, o foco deixava paulatinamente de recair sobre as instituições e seus representantes (clérigos e pastores) e se voltava para os fiéis e suas práticas sociais. Por fim, o processo de redemocratização do país e o ímpeto renovado na ideia de cidadania(s) pressupunha analisar com mais cuidado as perspectivas abertas para a juventude, inclusive naquilo que implicava em sua participação no mundo da comunicação e da política (ver Camurça; Perez; Tavares, 2009). 
Tomando por base tanto os recortes geracionais sugeridos pelos órgãos internacionais quanto a discussão acumulada pela sociologia e pela antropologia da juventude, os estudos de Regina Novaes foram pioneiros ao apontar os indivíduos de 15 a 24 anos residentes nas grandes cidades como um grupo sobre o qual "os ventos do secularismo" soprariam possivelmente mais forte. A partir de várias metodologias combinadas - que incluíam survey e análise da trajetória de alguns jovens - a hipótese que se levantava a essa altura era a de que "esta geração vivendo em um tempo em que tanto a obrigação social quanto a partilha dos sentimentos de pertencimento" às instituições religiosas tradicionais "se enfraqueceram pode estar engrossando as fileiras dos sem religião sem deixar de frequentar os centros espíritas, da umbanda e do candomblé" (Novaes, 2006, p. 142).

Muitos outros trabalhos corroboraram essa perspectiva. Afinados a uma sociologia das crises religiosas de matriz francesa (ver Hervieu-Léger, 2008), o que se supunha era que o peso das tradições e das identidades religiosas dos pais pesa cada vez menos sobre os jovens, aumentando assim o rol de escolhas e a mobilidade religiosa (Oliveira; Mori, 2012). Além disso, há indícios muitos fortes de que, diante de um cenário de maior liberdade, os jovens tendem a rechaçar as religiões institucionalizadas (na qual a gestão do sagrado ocorre de maneira burocrática) em nome de experiências individuais que podem ser constantemente refeitas a partir de interesses momentâneos e de crenças menos estruturadas e duráveis (Bauman, 1999; Hervieu-Léger, 2008). Nas palavras de Novaes (2006, p. 142), "para os jovens de hoje existem novas possibilidades de combinar elementos de diferentes espiritualidades, em uma síntese pessoal e intransferível e assim se abre [também] novas possibilidades sincréticas. Expande-se o fenômeno de adesão simultânea a sistemas diversos de crenças, combinam-se práticas ocidentais e orientais, não apenas na dimensão estritamente religiosa, mas também como recurso terapêutico e medicinal".

Especialmente na universidade, as crenças (e descrenças) dos jovens parecem encontrar espaço para uma sistematização mais cuidadosa e (auto)reflexiva (cf. Jungblut, 2001). Frente a currículos que instigam uma percepção crítica dos dogmas e verdades religiosas, uma análise metodologicamente estruturada a partir dos cânones da ciência e mediante uma abertura para o debate quase nunca encontrada nas escolas de ensino básico, os estudantes se sentem à vontade para rever conceitos e efetuar escolhas, levando em consideração a ampliação do leque de possibilidades.

Por tanto, a nossa pesquisa ainda esta em fase de desenvolvimento e analise dos dados já recolhidos, o nossa proposta com esse resumo é mostrar os cominhos que estão percorridos para se alcançar nosso objetivo, como discussões bibliográficas acerca da temática, metodologia e ferramentas utilizadas na pesquisa.

Objetivo geral: Analisar em que medida as experiências e conteúdos oferecidos na universidade influenciam nos valores e comportamentos religiosos dos jovens estudantes Curso de Ciência da Religião do CCSE/UEPA.

\section{Objetivos específicos:}


> Traçar o perfil religioso dos estudantes do Curso de Ciência da Religião do CCSE/ UEPA;

$>$ Discutir em que medida os jovens imputam à experiência universitária ao afastamento, mas também a alto-afirmação de suas crenças e práticas religiosas;

- Constatar eventuais choques entre religião e ciência no curso de graduação, bem como seus impactos sobre as escolhas religiosas dos jovens entrevistados.

Material e Método: A presente pesquisa se estrutura com base em uma combinação de metodologias quantitativas e qualitativas (cf. MARCONI; LAKATOS, 2003), de modo a assegurar imagens que correspondam da maneira mais fiel possível às mudanças na concepção e nas práticas religiosas da juventude universitária.

Em um primeiro momento serão aplicados questionários fechados - elaborados especificamente para esta pesquisa - nas quatro turmas do Curso de Licenciatura em Ciência da Religião do CCSE/UEPA. Não trabalharemos com amostragem, mas com a aplicação do survey no conjunto real dos estudantes.

No momento da aplicação do questionário, serão dadas as instruções necessárias ao preenchimento do formulário, bem como será realizada breve apresentação da temática e do objetivo da pesquisa que está sendo realizada. Nesse primeiro momento de aplicação do questionário, não será necessário à identificação dos alunos. O survey possui ao todo sessenta e uma (61) questões divididas em cinco blocos: 1) Identificação; 2) Crenças religiosas; 3) Universidade; 4) Crenças religiosas e vida acadêmica e 5) Crenças religiosas e participação cívica.

$\mathrm{Na}$ segunda parte, serão realizadas entrevistas com os alunos onde os questionários foram aplicados. Dessa forma, o que nos interessa é captar as representações que esses jovens têm da universidade como espaço que lhes permite reorganizar suas identidades e convicções, com ênfase na discussão sobre religião. Assim como preencher pontos que não puderam ser captados pelo questionário. No momento da entrevista será realizada novamente uma explicação dos objetivos da pesquisa, retirando toda e qualquer duvida, o estudante recebera o Termo de Consentimento Livre e Esclarecido (TCLE), onde constaram todas as informações necessárias que iram garantir a liberdade e proteção dos dados fornecidos pelo participante da pesquisa, garantindo assim seu anonimato se caso for solicitado.

Resultado e Discussão: Os estudos de Regina Novaes na década de 1990 tem sido a porta de entrada para pesquisas envolvendo juventude e religião no Brasil. Suas pesquisas com estudantes têm mostrado que os jovens de hoje não vivem apenas à margem de fronteiras simbólicas rígidas, mas convivem tanto com novas tendências das grandes religiões mundiais quanto com os debates sobre a secularização e a laicidade, articulando formas renovadas de experimentar os valores, crenças e instituições religiosas, sempre em diálogo com as novas demandas sociais e políticas surgidas no seio de culturas juvenis igualmente heterogêneas (NOVAES, 2006).

Outros exemplos podem ser buscados na literatura especializada, como a pesquisa desenvolvida Sposito (2009) que mapeou e realizou um balanço da produção de conhecimento nos programas de pós-graduação em torno da temática da juventude, de 1999 até 2006. Foram levantados cerca de 1.427 trabalhos, das quais apenas 17 teses e dissertações que articulam os temas juventude e religião. 
Vale ressaltar que esse inventário se debruçou apenas sobre as áreas reconhecidas pela CAPES naquele momento (Educação, Serviço Social e Ciências Sociais, esta última compreendendo Antropologia, Ciência Política e Sociologia). Nele chama a atenção para a baixa frequência de estudos sobre o nosso tema, tendo em vista que religião é um elemento estruturante das práticas culturais e políticas brasileiras e, logo, tem influência significativa sobre o jovem. Muitos outros pesquisadores tem se debruçado acerca da temática religião e estudantes universitários com o intuito entender como esse público tem construído suas identidades em um espaço que permite a troca de saberes e experiências raramente encontradas dentro de suas famílias ou grupos sociais.

Em meio a esse cenário grande e diverso a Região Norte apresenta lacunas bastante significativas quanto à temática em cena. Nem em repositórios digitais, nem em portais de periódicos existe material disponível sobre as relações entre os jovens e a religião. Dessa forma, nossa pesquisa vem contribuir para o avanço na compreensão não só do cenário juvenil na Amazônia, mas também das crenças e convicções religiosas desses jovens universitários em uma metrópole da região, a saber, Belém (PA).

Conclusão: Nossa pesquisa ainda esta em processo de desenvolvimento, por tanto, nossa hipótese preliminar (a ser verificada) é a de que os jovens veem na Universidade o momento de maior liberdade em suas trajetórias pessoais - uma etapa em que as identidades herdadas são postas em xeque pelo contato com novos conhecimentos, novos modelos de sociabilidade e novas articulações de saber-poder. Isso não desqualifica os valores que trazem de suas famílias ou comunidades de origem, mas reorganizam o rol de escolhas disponíveis, impactando fortemente nas identidades religiosas (mas não apenas religiosas). O que se pretende com este projeto é averiguar o impacto da Universidade sobre a vida dos jovens, e de modo especial sobre as formas como eles vivenciam a fé.

\section{Referências bibliográficas}

BAUMAN, Zygmunt. Identidade. Entrevista a Benedetto Vecchi. Tradução de Carlos Alberto Medeiros. Rio de Janeiro: Jorge Zahar, 1999.

CAMURÇA, Marcelo. "Religiosidade moderna e esclarecida entre os universitários das Ciências Sociais de Juiz de Fora - MG". In: Debates do NER. Porto Alegre: UFRGS, ano 2, n. 2, agosto de 2001. pp. 37-64.

; TAVARES, Fátima. "Juventudes e religião no Brasil: uma revisão bibliográfica". In: NUPEM. Juiz de Fora: UFJF, v. 7, n. 1, 2004. pp. 11-46.

; PEREZ, Léa Freitas; TAVARES, Fátima (org.). Ser jovem em Minas Gerais: religião, cultura e política. Belo Horizonte: Argvmentvm: FAPEMIG, 2009.

HERVIEU-LÉGER, Danièle. O Peregrino e o Convertido: a religião em movimento. Tradução de João Batista Kreuch. Petrópolis: Vozes, 2008.

JUNGBLUT, Airton Luiz. "A religião entre estudantes de Ciências Sociais hoje: declínio do ateísmo ou despolarização de posicionamentos". In: Debates do NER. Porto Alegre: UFRGS, ano 2, n. 2, agosto de 2001. pp. 133-143. 
MARCONI, Marina de Andrade; LAKATOS, Eva Maria. Fundamentos da Metodologia Científica. $5^{\circ}$ ed. São Paulo: Atlas, 2003.

NOVAES, Regina. "Os jovens, os ventos secularizantes e o espírito do tempo". In: As Religiões no Brasil: continuidades e rupturas. Petrópolis: Vozes, 2006. pp. 123- 134. SPOSITO, Marilia Pontes (coord.). Estado da Arte sobre juventude na pós- graduação brasileira: educação, ciências sociais e serviço social (1999-2006). Belo Horizonte: Argvmentvm, 2009. 2 volumes.

Palavras-chave: Religião. Juventude. Universidade Grande-área: Ciências Humanas

Área: Ciências da Religião 


\title{
O CORPO NEGRO COMO LOCAL DE TEXTO: ESCARIFICAÇÕES REALIZADAS NO JEJE SAVALÚ EM BELÉM/PA E A RESSIGNIFICAÇÃO DESTA PRÁTICA PARA O CANDOMBLÉ.
}

\author{
Nome do(a) Bolsista: Érika Patrícia Negrão da Silva \\ Nome do(a) Orientador(a): Ipojucan Dias Campos
}

Resumo: Vislumbramos em nossa pesquisa realizar um estudo sobre as escarificações enquanto prática africana e afrorreligiosa de construções e reconstruções de identidade, sendo esta, local de texto, de memória corporal, de resistência, tendo como objeto de estudo as escarificações realizadas no JejeSavalú, especificamente no Templo Afrorreligioso Xwè Acè Kpó Sohùn em Belém/PA e suas ressignificações no Candomblé. Os objetivos da pesquisa são: compreender a escarificação como elemento de identidade dos praticantes do Candomblé Jeje Savalú; Identificar características específicas das escarificações em povos africanos; Analisar o processo de construção da identidade dos praticantes do Candomblé Jeje Savalú através das escarificações; Apontar atualmente a prática das escarificações no Jeje Savalú; Durante todo este processo, tivemos a oportunidade de observar que o ato simbólico de escarificar demonstra um reconhecimento e o corpo passa a ser local de identidade dos praticates do Candomblé Jeje Savalú, através da preservação desta tradição. Remotamente, as escarificações faziam parte deste repertório de simbolismo aplicado a partes do corpo com finalidades litúrgicas e identitárias. Em tempos contemporâneos, no Brasil, esses traços étnicos assumem um caráter mais discreto nos adeptos do candomblé. Uma luta de resistência travada por esses afrorreligiosos que se utilizam da arte como meio, e nesse caso, o próprio corpo como suporte, carregando as marcas de uma tradição.

Introdução: Desde os primórdios da humanidade temos usado nossos corpos como meio de comunicação, expressão de individualidade e posição social, seja através de gestos, vestimentas, ou até marcando e decorando a própria pele. Aquilo que fazemos com nossos corpos demonstra quem somos, de onde viemos e pode até determinar uma cultura ou estilo de vida.

Há séculos a linguagem corporal faz parte da criação e da produção material e imaterial na África. Tradicionalmente, os africanos utilizam o corpo como veículo de conexão entre o mundo visível e invisível. As escarificações são exemplos de identidade e resistência. Esses corpos negros escarificados que, durante o período de diáspora africana, ressignificaram suas tradições carregando consigo e utilizando o seu corpo, como ferramenta e linguagem, torna-se receptáculo simbólico e expressivo transcendente neste deslocamento, habitando diferentes geografias no chamado Novo Mundo. Dentre esses lugares está o território brasileiro.

Mesmo distantes de suas terras, os africanos carregaram em seus corpos a memória de suas danças, seus rituais performáticos com objetivo de manter sua identidade cultural. O corpo negro passa a ser o registro de memória e identidade. Assim, suas tradições 
continuaram possuindo valor histórico, sofrendo algumas perdas e consequentes transformações de acordo com a cultural do local onde se encontravam.

Neste trabalho trataremos das escarificações como fator identitário para os negros africanos e como esta prática ganhas novos significados para as religiões de matrizes africanas. Para isso, na primeira parte faz-se necessário compreender a necessidade de se discutir o conceito de identidade para posteriormente verificarmos como as escarificações podem estar relacionadas a fatores identitários a partir dos diversos significados e como o corpo pode ser local de texto dentro de um contexto africano ganhando novas perspectivas a partir da diáspora forçada para nosso território.

Essas novas perspectivas são encontradas nas religiões de matrizes africanas são descritas de forma a compreender a prática da escarificação e os novos (re) arranjos. Além da pesquisa bibliográfica, onde também buscamos descrever de forma sucinta o campo afrorreligioso na cidade de Belém, dando ênfase ao Candomblé Jeje Savalú, adentramos à pesquisa de campo na associação ARFUOJY e do Templo Afrorreligioso Xwè Acè Kpó Sohùn, com a sacerdotisa Jokolosy e demais sujeitos participantes das entrevistas.

Objetivos Geral: Compreender a escarificação como elemento de identidade dos praticantes do Candomblé Jeje Savalú;

\section{Específicos:}

Identificar características específicas das escarificações em povos africanos;

Analisar o processo de construção da identidade dos praticantes do Candomblé Jeje Savalú através das escarificações;

Apontar atualmente a prática das escarificações no Jeje Savalú;

Material e método: O estudo do corpo negro como local de discurso e elemento identitário dos praticantes do Candomblé Jeje Savalú como qualquer pesquisa científica deve levar em consideração alguns procedimentos que permitam levantar informações, cruzar dados, fazer inferências necessárias ao alcance dos objetivos propostos. Desta forma, alcançar os objetivos anteriormente citados, adotaremos os seguintes procedimentos metodológicos neste estudo:

Inicialmente, registraremos, através de entrevistas não estruturadas, depoimentos, histórias de vida de alguns sujeitos produtores do espaço, no sentido de nos aproximar da condição social destes sujeitos e da realidade espacial configurada; Também será destinado à realização de entrevistas gravadas semiestruturadas com os agentes produtores do espaço, com vistas a identificarmos as organizações existentes neste espaço, bem como conhecermos as lideranças destas organizações e suas principais dificuldades, de forma a obtermos dados sistemáticos qualitativos sob 0 potencial destas no processo de gestão democrática.;

Em seguida será feito um levantamento de caráter bibliográfico acerca das produções acadêmicas nacionais e internacionais sobre o assunto abordado. Nesta revisão serão abordados trabalhos que enfatizam as questões de identidade, discurso e as escarificações através de pesquisas na Biblioteca Central da Universidade Estadual do Pará da Universidade Federal do Pará, e das Bibliotecas Setoriais destas universidades 
e do NEAB/IFPA e acesso à Internet (através de e-mails, fóruns de discussão e sites) com a finalidade de se obter uma gama significativa de bibliografias e informações sobre o assunto abordado.

O terceiro momento iniciará o estudo e elaboração da revisão bibliográfica, conceituando a variedade de assuntos que fazem parte do tema principal deste trabalho. Depois será feito um levantamento documental de dados secundários em instituições públicas, como, bem como toda e qualquer instituição que permita subsidiar informações importantes para análise da problemática levantada.

O quarto momento está reservado para o registro fotográfico da realidade observada, com o propósito de registrar práticas cotidianas, bem como o sistema de objetos que compõe esse espaço;

Durante todo este processo estaremos analisando, discutindo e elaborando a redação que constituirá esta pesquisa.

Resultados e discussão: Além da pesquisa bibliográfica, onde também buscamos descrever de forma sucinta o campo afrorreligioso na cidade de Belém, dando ênfase ao Candomblé Jeje Savalú, adentramos a pesquisa de campo na associação ARFUOJY e do Templo Afrorreligioso Xwè Acè Kpó Sohùn, com a sacerdotisa Gàniyakú Jokolosy e demais sujeitos participantes das entrevistas.

Espaço de acolhimento e sendo muito bem vindos, coletamos os relatos e depoimentos durante as entrevistas e estes se constituem o principal material de análise, associado às observações realizadas no campo afrorreligioso, juntamente com a revisão bibliográfica.

A primeira entrevista com a Sacerdotisa Jokolosy e a comunidade da Associação Funderê Oyá Jokolosy ocorreu no dia 26/04/19 as 16:00 horas, conforme combinado por telefone pelo seu neto Kpèdjigàn ${ }^{1}$ Aldryn e, inicialmente fomos recebidos por membros da comunidade, que foram bem receptivos. Aguardamos em uma área próxima à entrada principal da casa, aguardando a chegada da Gàniyakú 2 Jokolosy, que nos recebeu de forma acolhedora e muito receptiva. Em seguida fomos convidados para entrar em uma sala mais reservada para iniciarmos a conversa sobre a temática proposta. A sacerdotisa colaborou com nossa pesquisa e convidou Kpèdjigàn Aldryn para participar da entrevista, que contribuiu com informações precisas sobre a Nação Jeje Savalú. Além dele também foi convidada a Mãe Pequena Mèhùnàn Rìnòhòdeci (Nalva) para contribuir.

Assim a coleta dos dados referente à temática pesquisada foi contemplada devido à grande quantidade de informações que facilitou o desenvolvimento da pesquisa e respeitando a fala dos sujeitos que participaram das entrevistas realizadas em 2019 no Templo Savaluno.

Apesar de não adentrarmos nos pormenores dos atos litúrgicos realizados no templo, com as informações obtidas nota-se a presença das escarificações como prática no Templo Religioso Xwè Acè Kpó Sohùn, da Nação Jeje Savalú pertencente ao Candomblé enquanto religião de matriz africana cujo ato ritualístico de escarificar nos remete aos rituais de passagem realizadas em algumas tribos africanas e como esta prática ganhou novos significados. 
As religiões de matrizes africanas são, sem dúvida alguma, um dos maiores legados culturais africanos para a sociedade brasileira. Carregada de traços culturais, onde a identidade é e precisa ser preservada sendo uma das formas de manter vivo o pertencimento no íntimo dos filhos da Mãe África.

Dentre essas práticas ressignificadas temos as escarificações realizadas durante os rituais de iniciação, com a prática da "feitura" onde realizam-se escarificações. Os rituais de feitura, ou seja, processo de iniciação, onde os iniciados se refazem para a sua divindade por meio de ritos como dar de comer a cabeça, entre outros ritos relativos a esse processo, ainda hoje são executados em todos os cultos africanos e são a prova de que a memória, embora diluída e o corpo africano como local de discurso, ainda sobrevive

Conclusão: Esta pesquisa apresenta um breve panorama da arte africana, através as escarificações e como esta carrega elementos identitários para compreendermos a diversidade de elementos culturais, estéticos e sociais africanos que trouxeram suas vivências, construindo no Brasil um pouco de sua africanidade.

Procuramos, ao longo deste trabalho, abordar uma das tantas contribuições culturais de herança africana trazida para o Brasil pelos escravos africanos. Tivemos a oportunidade de observar ao longo do trabalho como a escarificação expressa em planos diversos, um complexo sistema de afirmações coerentes sobre a identidade, sendo assim, tivemos a oportunidade de penetrar de uma certa maneira no significado de um símbolo como o ato de escarificar e, não podemos deixar de observar, que essa estética africana demonstra um reconhecimento e o corpo passa a ser local de identidade dos povos afrodescendentes através da preservação desta tradição.

Diferentes corpos, portadores de memória, história, experiência, da herança de seus antepassados e que contem signos a serem decifrados e decodificados expressos como "tradição viva". É nesta perspectiva que o corpo negro torna-se local de discurso através das escarificações. Resultantes de uma tradição, essa memória corporal ultrapassabarreiras continentais e torna-se parte, assim como inúmeras tradições africanas da história e do processo de formação social do Brasil.

Remotamente, as escarificações faziam parte deste repertório de simbolismo aplicado a partes do corpo com finalidades litúrgicas e identitárias. Em tempos contemporâneos, no Brasil, esses traços étnicos assumem um caráter mais discreto nos adeptos do candomblé. Do ponto de vista cultural, nenhum contexto permite que o corpo humano permaneça o mesmo desde o nascimento. Tais práticas decorrem de diversas necessidades desde a proteção até a um simples exercício artístico ou representações culturais. As escarificações indicam o contexto e a cultura a qual pertence o indivíduo, são conjuntos de traços, formas e cores carregados de símbolos e conteúdos históricos. Uma luta de resistência travada por esses africanos e afro-brasileiros que se utilizam da arte como meio, e nesse caso, o próprio corpo como suporte, carregando as marcas de uma tradição. E nesse novo contexto, o corpo é ressignificado, tornando-se local de discurso dentro da sociedade em que vivemos. 


\section{Referências bibliográficas:}

AUGRAS, Monique. "A construção da pessoa no candomblé". In: Alteridade e dominação no Brasil. Psicologia e cultura. Rio de Janeiro: NAU Editora, 1995

CAMPELO, M. M. MONTEIRO, A. Mediunidade e iniciação: notas sobre a iniciação de crianças na Umbanda. Revista do NUFEN , v. 09, p. 108-126, 2017.

Os Candomblés de Belém: história, origens, conflitos intrareligiosos. In: Wilma Marques Leitão; Raymundo Heraldo Maúes. (Org.). Nortes Antropológicos - trajetos, trajetórias. 1ed.Belém: EDUFPA, 2009, v. 1, p. 29-40.

CHAGAS, Manoel Roberto Ferreira. O candomblé Jeje Savalú na Amazônia. 1. ed. Porto Alegre: BUQUI Editora, 2016. v. 1. 160p .

EVANS-PRITCHARD, Edward. Os nuer: uma descrição do modo de subsistência e das instituições políticas de um povo nilota. São Paulo: Perspectiva, 2007.

FREYRE, Gilberto.O escravo nos anúncios de jornais brasileiros do século XIX: tentativa de interpretação antropológica, através de anúncios de jornais brasileiros do século XIX, de característicos de personalidade e de formas de corpo de negros ou mestiços, fugidos ou expostos à venda, como escravos, no Brasil do século passado. Ed. Nacional, 1979.

GEERTZ, C. A interpretação das culturas. LTC: Rio de Janeiro,1989.

HALL, Stuart. Identidade Cultural. São Paulo: Fundação Memorial da América Latina, 1997 (Coleção Memo).

PARÉS, Luis Nicolau. A formação do Candomblé: história e ritual da nação Jeje na Bahia. Campinas: Editora da Unicamp, 2006.

PEIRANO, Mariza (Org.). O dito e o feito: ensaios de Antropologia dos Rituais. Rio de Janeiro: Relume-Dumará: Núcleo de Antropologia da Política/UFRJ, 2002. v. 12 (Coleção Antropologia da Política).

SILVA, A. V.; LUCA, T. T.; CAMPELO, M. M. . Religiões Afro-paraenses na atualidade: história e ritual no plural. 2008. (Apresentação de Trabalho/Conferência ou palestra).

VALLE, Camila do. Cartografia Social dos Afrorreligiosos em Belém do Pará Religiões afrobrasileiras e ameríndias da Amazônia: Afirmando identidades na adversidade. Rio de Janeiro: IPHAN, 2012.

VAN GENNEP, Arnold. Os Ritos de Passagem. Petrópolis: Vozes, 2011. 
VERGOLINO E SILVA, A. 2000. Religiões africanas no Pará: uma tentativa de reconstrução histórica. Revista Amazônia IPAR: Os Outros 500 Anos na Amazônia. Belém, IPAR, 2(2).

Palavras-Chave: Escarificações, Candomblé, JejeSavalú, Identidade. Grande área: Ciências Humanas Área: Ciências da Religião 


\title{
TUDO O QUE MEU AMOR DESEJAR: UM ESTUDO SOBRE OS TRABALHOS DE MAGIA NOS TERREIROS EM BELÉM DO PARÁ
}

\author{
Nome do(a)Bolsista: Fabio Oliveira de Sena \\ Nome do(a) Orientador: Taissa Tavernad de Luca
}

Resumo: Esta pesquisa consiste em um estudo sobre os trabalhos mágicos de amor que são realizados por Pais de Santo nos espaços dos terreiros afro religiosos em Belém do Pará. A referida pesquisa se objetifica em compreender como se configuram esses trabalhos de amor que são praticados dentro dos espaços dos terreiros e fora deles. A pesquisa se construiu a partir de procedimentos baseados na etnografia dos serviços realizados nos terreiros, e utilizando técnicas como entrevista com os pais de santo, e um diálogo com clientes que acessam os trabalhos de amor. Os serviços de amor são muito procurados por pessoas que visam acessar esses mecanismos de magia para atender seus desejos e resolver seus conflitos relacionais e amorosos. E mesmo que de maneira preconceituosa há uma forte crença dos clientes quanto ao que os sacerdotes realizam para atender as demandas amorosas dos que os procuram.

Introdução: Os trabalhos de feitiço de amor se apresentam como uma das configurações de serviços prestados no espaço do terreiro por pais e mães de santo pode-se dizer que essa forma mágica de serviço se apresentou a mim a partir do meu debruçar sobre o campo dos trabalhos de serviço realizados pelos pais de santo, e entender a complexidade e a diversidade de funções desses feitiços de amor realizados, como também uma ausência de pesquisa voltada para essa temática dentro do contexto da Amazônia. Há dentro desse fenômeno uma grande procura de clientes interessados em acessar esses mecanismos de magia para atender seus desejos e resolver seus conflitos relacionais e amorosos.

Foi-se observados em caráter inicial alguns feitiços que compõem as magias de amor realizadas nos terreiros, os quais são: Trabalhos de atração, os de amarração, pontos de união e os designados de cunho sexual. Os feitiços de atração visam promover a aproximação de uma pessoa à outra, seja por um intuito afetivo, sexual ou até pelo próprio desejo em si, os de amarração tem o propósito de unir (ou separar) principalmente casais que já tenham um relacionamento estável, ou fazem a manutenção da união desse relacionamento. Os pontos de união são trabalhos que possuem o propósito de trazer cura para uma questão conflituosa,

seja de cunho amoroso como também familiar. Já os trabalhos de cunho sexual são voltados a resolver questões de interesse sexual, impotência e libido sexual.

Dentro dessas subclassificações dos trabalhos mágicos de amor há o uso de diversos elementos os quais são utilizados para a realização dos feitiços de amor, que no caso posso citar alguns como o mel, a maçã, órgãos de animais, urina, água da chuva, peças de roupa, entre tantos outros elementos Essa pesquisa nos apresenta um campo vivenciado pelas religiões de matriz africana em Belém do Pará, e nos leva a compreender as linguagens dos rituais praticados pelos afro religiosos em seus 
espaços religiosos e entendendo como os mesmos, partindo do serviço, acessar a ação mágica em seus rituais.

Objetivos: A referida pesquisa tem como objetivo geral a de compreender a configuração dos trabalhos voltados à magia de amor no que tange os rituais realizados dentro/fora do terreiro e suas ações mágicas visando a solução dos problemas dos indivíduos clientes.

E possui seus objetivos específicos que tangem construir uma narrativa histórica sobre os processos e conflitos da prática da magia de amor nas sociedades; analisar os conceitos de magia de amor na sua teoria e na observação de aplicabilidade ritualística em determinadas matrizes religiosas, como também a pesquisa se propõem em analisar os trabalhos de magia de amor realizados nos terreiros partindo da sua ação ritual e do uso magico de seus elementos.

Material e Método: Voltado para a necessidade da complexidade do objeto de pesquisa e de suas problemáticas, este trabalho se volta a compreender o campo em sua diversidade, por esse motivo esta se realizará a partir da observação de campo de três pais de santo: Pai Alfredo Costa (Tambor de Mina); Pai Luciano Teixeira (Candomblé) e Pai Antônio Marcos (Umbanda). A proposta de trabalhar com três Pais de Santo de matrizes religiosas diferenciadas se dá em função do interesse de observar as particularidades de cada matriz religiosa em suas práticas rituais do gênero apontado. A forma pela qual se dá a minha observação sobre os trabalhos de amor tem sido como eu chamaria de "observação pelas tangentes", onde partindo da minha rede de relação eu procuro conhecer sobre os trabalhos de amor partindo dos diálogos com esses pais de santo. E como na sua maioria os trabalhos são realizados na presença dos clientes, isso de certa forma inviabiliza minha observação de caráter direto.

Diante dessas circunstâncias, me atenho observar os demais trabalhos realizados pelos pais de santo nos seus rituais e serviços prestados, e assim poder estar mais próximos dos mesmos para construir uma relação de confiança com os mesmo. Tenho feito de caráter preliminar conversas com pessoas que já acessaram

algum terreiro para esses trabalhos de amor, o que me confere analisar a relação cliente/pai de santo.

Faz-se importante para a pesquisa entender como se dá essa dinâmica da relação Pai de Santo e Cliente, e como a mesma se diferencia a partir de sua vertente religiosa. Para tal faz-se necessário observar esses fenômenos e suas dinâmicas.

- Para isso me utilizarei como metodologia a pesquisa etnográfica no que tange a observação das atividades de serviço realizadas pelos referidos pais de santo. Farei uso de técnicas como entrevista para coleta de informações sobre os rituais de magia de amor e observação direta de seus trabalhos realizados em suas casas com objetivo de descrever o processo ritual, os elementos simbólicos utilizados e as fórmulas mágicas proferidas.

Resultado e Discussão: Desde o início da pesquisa já foram realizadas 16 entrevistas com os pais de santo e 3 entrevistas com determinados pessoas que já acessaram os serviços de amor prestados nos terreiros. Já foram realizadas 05 Etnografias no que tange há alguns trabalhos realizados pelos sacerdotes dentro de seus espaços de 
trabalho, sendo que de uma maneira limitada, pois muito desses trabalhos já haviam sido realizados com a presença dos clientes, o que me coube a etnógrafar foram os trabalhos já em sua realização final.

Também houve etnografias as quais realizei que são referentes a celebrações destinadas a cabocos e exus, mas que houveram em suas doutrinas (musicas entoadas no momento do ritual) que abordavam sobre as questões amorosas vivenciadas pelas entidades em um outro espaço temporal.

Partindo do material já coletado para a pesquisa posso trazer algumas ponderações já analisadas, mesmo que de maneira inicial, mas que são relevantes no que tange aos resultados da pesquisa. O que pude perceber em minha pesquisa até aqui sobre as magias de amor é que, cada elemento usado no trabalho tem sua relevância, sua função específica, como qualquer outro ritual, esse elemento não está ali aleatoriamente, sua posição torna-se uma funcionalidade, tem um efeito mais que natural naquele processo, todos eles fazem parte de um grande conjunto de significativos, são elementos naturais que dentro do círculo do ritual ganham e emana magia.

E como estamos polemizando sobre um espaço sagrado e mágico, não posso deixar de falar sobre a presença das divindades que tornam esse ambiente propício e orgânico para a realização da magia. Não que obrigatoriamente em um trabalho de amor precise de uma presença espiritual (ou física) de uma entidade, mas para que o referido trabalho seja executado é preciso à emanação de energia, logo, as entidades são detentoras de uma poderosa força imanente.

Sobre esses aspectos de construção que permite ao indivíduo crer no poder que opera dentro de um local religioso, e no caso do terreiro, mesmo que muitas vezes o cliente não acredite que esse espaço seja santo, e quando falo sobre "espaço santo" me refiro a compreensão de um local puro e de energia positiva, porém ele confia na possibilidade de ter seu objetivo amoroso atendido. Esse cliente

pode não ver o terreiro e as entidades como seres de luz e positividade, mas acreditam no poder desse serviço de amor.

Conclusão: São diversos os motivos que levam uma pessoa a buscar os trabalhos de amor de um pai de santo, e precisamos abordar que, as intenções são de indivíduos diversos e humanos, fazendo assim serem seus sentimentos inconstantes, principalmente no que tange ao desejo de ter (ou te tomar) uma pessoa para si, pois em um dado momento se quer essa pessoa tão perto, e em outro, se quer longe, não se deseja mais, ou seja, são os devaneios amorosos de pessoas puramente humanas.

Dentro dessa pesquisa estou a perceber como esses trabalhos de amor evidenciam o quanto as pessoas amam e o quanto elas desejam, esses trabalhos evidenciam como o ser humano, por mais que negue a prática da magia e seus misticismos, o mesmo se lança em usar as magias de amor para ter seus amores. Os trabalhos de amor se apresentam como um serviço muito procurado por pessoas que visam acessar esses mecanismos de magia para atender seus desejos e resolver seus conflitos relacionais e amorosos.

As práticas mágicas realizadas nos terreiros estão voltadas para dar um auxílio nas questões amorosas e familiares dos clientes, estes vão em busca de acessar o sobrenatural para obter aquilo que se deseja e necessita, porém pelos meios naturais 
não se consegue. Dentro dessa atmosfera de indivíduos com seus amores e seus desejos querendo realizá-los através dos rituais.

Referências Bibliográficas: CHAVES, Kelson Gérison Oliveira, QUEIROZ, Marcos Alexandre de Souza. Dilemas morais de amor: controle, conflitos e negociações em terreiros de umbanda. Dilemas: Revista de Estudos de conflito e controle social- vol. 6no 4- Out/Nov/Dez, 2013. Pag 603-624 (Artigo)

CHAVES, Kelson Gérison Oliveira. Os trabalhos de amor e outras mandingas: a experiência mágico-religiosa em terreiros de umbanda. Programa de Pós-Graduação em Ciências Sociais da Universidade Federal do Rio Grande do Norte: Natal, 2010 (Dissertação).

CROATTO, José Severino. As linguagens da experiência religiosa: uma introdução a fenomenologia da religião. São Paulo: Paulinas, 2001

DURKHEIM, Emile. As formas elementares da vida religiosa: o sistema totêmico na Austrália. São Paulo: Martins Fontes, 1996

FRAZER, Sir James George. O ramo de ouro. Versão Ilustrada. São Paulo: Zahar Editores. 1982 (Pag 83- 115)

GEERTZ, Clifford. A interpretação das culturas. Rio de Janeiro: Editora Guanabara, 1989

GENNEP, Arnold Van. Os ritos de passagem: estudo sistemático dos ritos da porta e da soleira, da hospitalidade, da adoção, gravidez e parto, nascimento, infância, puberdade, iniciação, coroação, noivado, casamento, funerais, estações, etc. Tradução: Mariano Ferreira. Petropolis: Vozes, 1977

LEVI-STRAUSS, Claude. O feiticeiro e sua magia. Rio de Janeiro: Antropologia Estrutural- Tempo Brasileiro, 1975

MAUSS, Marcel. Sociologia e antropologia. São Paulo: EDUSP, VOL 1, 1994 MALINOWSKI, Bronisław. Magia, ciência e religião. Ed. Edições 70: Lisboa, 1984

Os argonautas do pacifico ocidental. Editora Abril: São Paulo, 1984

OLIVEIRA, Roberto Cardoso de. O trabalho do antropólogo. 2. Ed. São Paulo: UNESP, 2000

PEIRANO, Mariza (Org). O dito e o feito: ensaios da antropologia dos rituais. Rio de Janeiro: Releme Dumará- Núcleo de Antropologia da Política/UFRJ, 2002 Etnografia e rituais: relato de um percurso. Brasília: Anuário Antropológico- UNB- v41, nº 1: 237-248, 2016.

TURNER, Victor. Floresta de símbolos: aspectos dos rituais de Ndembu. Niterói: Editora Universidade Federal Fluminense, 2005.

Palavras-chave: Magias, Amor, Terreiro, Rituais.

Grande Área: Ciências Humanas

Área: Ciências da Religião 


\title{
A CRÍTICA DA RELIGIÃO EM KANT: CONTRIBUIÇÕES PARA O DEBATE ACERCA DA INTOLERÂNCIA RELIGIOSA
}

\author{
Nome do(a) Bolsista: Heloísa Helena Silva dos Santos \\ Nome do Orientador(a): Manoel Ribeiro de Moraes Junior
}

Resumo: O presente trabalho propõe destacar algumas das principais contribuições teóricas promovidas pelo filosofo Immanuel Kant (1724-1804) ao longo de seus escritos críticos à religião, apresentando como esses argumentos podem nos ajudar no debate sobre tolerância e liberdade religiosa. Para tanto, o trabalho está dividido em três conceitos centrais: maioridade (autonomia), as fórmulas do imperativo categórico, e o conceito de fé racional. Partimos do conceito de maioridade, exposto no opúsculo Resposta à pergunta: o que é esclarecimento? (1784), onde Kant evidencia a necessidade do exame dos assuntos da religião pela crítica. No segundo momento, com a obra Fundamentação da metafísica dos costumes (1785), retomamos as bases da moral kantiana através da segunda formula do Imperativo categórico evidenciando o caráter moral da religião. Por fim, a análise focará na discussão entre fé e razão, elencada no opúsculo $O$ que significa orientar-se no pensamento? (1786) pautando o conceito de fé racional como uma grande contribuição para o debate inter-religioso, na medida em que guiaria a ação moral dos indivíduos evitando fanatismos ou fundamentalismos dogmáticos. Assim, o filosofo entende a religião não como mandamentos divinos de obediência cega a uma divindade ou poder estatal, mas sim como uma exigência prático-moral da razão, na medida em que estabelece deveres ético-civis dos indivíduos na esfera pública, defendendo assim a liberdade religiosa contra a intolerância e suas mazelas.

Introdução: Ao longo do séc. XVIII o Estado Prussiano foi fortemente influenciado pelo movimento iluminista francês, levando a Prússia a ser um dos Estados mais progressistas e tolerantes de sua época. Immanuel Kant (1724-1804) nasceu e cresceu em meio a esse cenário de progresso, se tornando mais tarde o principal filósofo do esclarecimento Alemão. Dentre os diversos temas pelos quais se debruçou, a crítica da religião tem destaque por ter sido o motivo pelo qual em 1794, aos 70 anos, ser censurado. Nesse ano, o Rei Frederico Guilherme II (1786-1797), o sucessor de Frederico - O grande, intervém contra o filosofo e põe fim ao estado de tolerância prussiano, censurando-o logo após a publicação da obra $A$ Religião nos limites da simples razão (1793) e do opúsculo O fim de todas as coisas (1794).

A partir daí o filosofo acompanhou o processo de endurecimento da Prússia, acusado de abusar da filosofia para deturpar e menosprezar doutrinas religiosas, sendo obrigado a abandonar a temática sob pena de ser destituído da Universidade de Koningsberg, só voltando a escrever sobre o tema onze anos após a morte do rei. O fato é que, diferente do que se pode esperar de um filosofo iluminista, Kant não declarou guerra à religião e suas doutrinas, tampouco a negou como sendo uma das principais manifestações 
humanas com importância fundamental na formação dos indivíduos e do próprio progresso da sociedade. Ao contrário, o filosofo sempre reconheceu o caráter moral que religião desempenhava, mas também denunciava em seus escritos seus extremismos como a dogmatização, o fundamentalismo, a tutela sobre os devotos, o rigor e os claros desvios da essência da atividade religiosa visando beneficiar e atender aos caprichos e egoísmos humanos em nome de divindades.

Logo, as acusações que foram feitas pelo sucessor e fundamentalista Rei Frederico II, foram infundadas, sendo uma clara demonstração de censura por parte do Estado ao impor sua própria religião e indo contra a liberdade de pensamento, não tolerando nenhum questionamento ou reflexão no que tange aos assuntos religiosos.

Ainda que esse recorte histórico tenha acontecido no séc. XVIII, o tema da intolerância religiosa sempre esteve presente ao longo da história da humanidade. Seja por um dos seus mais claros exemplos como as Cruzadas na idade média, ou como no cenário político atual brasileiro, onde grupos religiosos no Rio de Janeiro se reúnem para destruir centros de outras crenças. Dentro dessa zona de conflito, a crítica fomentada por Kant, mesmo com o passar do tempo, ainda permanece atual e adota uma posição consciente frente a esses extremismos, apresentando um modo de dialogar partindo dos indivíduos e suas práticas religiosas, os lembrando que assim como a dele, existem outras, e que precisam ser respeitadas na medida em que convivem no espaço público.

Objetivo: Evidenciar as contribuições que crítica kantiana a religião podem ajudar no debate acerca da intolerância e liberdade religiosa, entendendo a religião não como mandamentos divinos de obediência cega a uma divindade ou poder estatal, mas sim como uma exigência prático-moral da razão, na medida em que estabelece deveres ético-civis dos indivíduos uns com os outros, sustentando assim a liberdade e tolerância religiosa.

Material e método: Enquanto procedimento metodológico, a análise é bibliográfica e parte de conceitos centrais do filósofo em três obras, além de comentadores.

Partimos do conceito de maioridade, exposto no opúsculo Resposta à pergunta: o que é esclarecimento? (1784). Kant evidencia a necessidade do exame dos assuntos da religião pela crítica, uma vez que há maior resistência quando a tutela religiosa é dogmática nos indivíduos, prejudicando assim o desenvolvimento da autonomia neles.

No segundo momento, com a obra Fundamentação da metafísica dos costumes (1785), retomamos as bases da moral kantiana através da segunda formula do Imperativo categórico. Estabeleceremos aqui a relação entre a moral e a religião que partem do mesmo domínio, o ético-moral, na medida em que ambas fundamentam e promovem o desenvolvimento dos indivíduos e refletem em suas ações coletivas.

Por fim, a análise focará na discussão entre fé e razão, elencada no opúsculo Que significa orientar-se no pensamento? (1786) pautando o conceito de fé racional como uma grande contribuição para o debate inter-religioso, na medida em que guiaria a ação moral dos indivíduos evitando fanatismos ou fundamentalismos dogmáticos. O filósofo não está elevando a razão acima da fé, mas sim reconhecendo-a como uma necessidade da razão pura prática, deixando bem claro que a mesma não está desvinculada da consciência dos indivíduos. 
Os comentadores utilizados são o Prof. Dr. Jair Antônio Kraussuki, da Pontifícia Universidade Católica do Rio Grande do Sul - PUCRS, com o livro "Crítica da Religião e sistema em Kant: um modelo de construção racional do cristianismo." O Prof. Dr. Allen W. Wood, da Universidade de Cambridge, com o texto: Teologia racional, fé moral e religião. E por último no artigo: Liberdade e Religião: Reflexões kantianas sobre a não coercitividade, a veracidade e a publicidade na relação entre religião e política do Prof. Dr. Thiago Joel Klein da UFSC.

Resultado e discussão: Identifica-se que a crítica da religião proposta por Kant está disposta em vários escritos do filosofo, tanto críticos quanto pré-críticos, e que mesmo assim há uma consonância de ideias. Destacamos, de acordo com a nossa leitura, as grandes contribuições que crítica kantiana proporciona na medida em que: a) ressalta a importância da crítica da religião para autonomia e liberdade da prática religiosa; b) evidencia tanto a moral quanto a religião como promotoras do desenvolvimento dos indivíduos e seus reflexos em suas ações coletivas; c) e principalmente que fé e razão não são conceitos indissociáveis, mas que precisam estar lado a lado para que o fenômeno religioso não seja dogmático ou fundamentalista.

Logo percebemos que a posição de Kant não pende nem para um lado e nem para o outro, mas deixa muito claro que os temas da religião não estão isentos da crítica e reflexão filosófica, além de indicar a necessidade imprescindível de se dialogar sobre suas diferenças e pautar a liberdade religiosa no espaço público, respeitando as individualidades de crença de cada grupo.

Conclusão: A crítica kantiana nos ajuda a refletir sobre a necessidade de mantermos o senso crítico voltado para toda e qualquer ação humana, e fomenta o diálogo interreligioso na medida de em que fornece argumentos sobre a liberdade religiosa, o respeito e cooperação para o bem comum em nossa sociedade. Em uma conjuntura como brasileira, onde cada vez mais os noticiários trazem casos de intolerância e violência motivados por religião, e onde até mesmo o governo trás traços de fundamentalismo e dogmatismo religioso, a retomada desses argumentos na discussão contemporânea se torna indispensável.

Com isso, o nosso olhar recai sobre o modelo cosmopolita kantiano, onde a ação política e a construção de uma sociedade civil que administre o direito de modo universal são seus objetivos.

\section{REFERÊNCIAS BIBLIOGRÁFICAS}

HÖFFE, O. Immanuel Kant. Trad. Christian Viktor Hamm e Valerio Rohden. São Paulo: Martins Fontes, 2005.

KANT, Immanuel. Crítica da Razão Pura. 5a Edição. Trad.: Manuela Pinto e Alexandre Morujão. Lisboa: Fundação Calouste Gulbenkian, 2001.

Fundamentação da Metafísica dos costumes. In: CHAUÍ, M. (Org.): Coleção Os pensadores - São Paulo: Abril Cultural, 1980. 
0 que significa orientar-se no pensamento? $3^{\circ}$ Edição. Tradução: Floriano de Souza Fernandes. Ed.: Vozes. Petrópolis, 2005, 108 p.

. Resposta à pergunta: $O$ que é esclarecimento? In: Fernandes, F. S. (trad.). Kant - textos seletos. Petrópolis: Vozes, 1985.

KLEIN, T. Liberdade e Religião: Reflexões kantianas sobre a não coercitividade, a veracidade e a publicidade na relação entre religião e política. ethic@ Florianópolis, Santa Catarina, Brasil, v.14, n.2, p.222 - 251, Dez. 2015.

KRASSUKI, J. Crítica da religião e sistema em Kant: Um modelo de reconstrução racional do cristianismo. Porto Alegre: EDIPUCRS, 2005.

LEBRUN, G. Uma escatologia para a moral. In: TERRA, Ricardo (Org.). Ideia de uma história universal de um ponto de vista cosmopolita. 2a ed. - São Paulo: Martins Fontes, 2003, 69 - 106.

MUCHNIK, P. Kant Theory of evil. Maryland: Rowman \& Littlefield Publishers, 2009.

SALGADO, J. C. A ideia de justiça em Kant: seu fundamento na liberdade e na igualdade. 2. ed. Belo Horizonte: Editora UFMG, 1995.

WOOD, A. Teologia racional, fé moral e religião. In: GUYER, P. (org.). KANT. 4ed. Aparecida - SP. Ideas \& Letras, 2009. 471 - 498.

YOVEL, Y. Kant and the Philosophy. Princeton: Princeton University Press, 1980.

Palavras-chave: Crítica da religião, Intolerância religiosa, liberdade religiosa. Grande área: Ciências Humanas.

Área: Ciências da Religião/ Filosofia da Religião 


\author{
Nome do(a) Bolsista: Ingrid Larissa Santana Heinen \\ Nome do(a) Orientador (a): Donizete Aparecido Rodrigues
}

Resumo: A partir da perspectiva e concepções da religião como fenômeno social e como sistema simbólico (Durkheim, Bourdieu, Geertz), a pesquisa intitulada "Religiosidade na Amazônia Paraense: uma etnografia da comunidade quilombola Vila do Cravo, Concórdia - PA" objetiva discutir teoricamente sobre comunidades quilombolas, sincretismo religioso e catolicismo popular. O referido estudo encontra-se em curso e intenta estudar a diversidade de práticas e crenças religiosas existentes na comunidade, a importância de tais práticas para o convívio social do grupo e o seu universo simbólico. Para tanto, está sendo realizada uma etnografia na Vila do Cravo, a fim de compreender a coesão social, vivenciada e refletida no catolicismo popular por meio das festas de santo, da prática do benzimento e das demais formas de manifestação da religiosidade, que venham a ser identificadas durante a pesquisa.

Introdução: A pesquisa visa estudar a religiosidade expressa no cotidiano dos moradores da comunidade quilombola Vila do Cravo, tendo como norte a relação entre a diversidade de práticas e crenças religiosas existentes na localidade e a importância de tais práticas para o convívio social do grupo.

A comunidade está interligada, com relação aos seus aspectos administrativos, a Concórdia do Pará. Mais precisamente, encontra-se situada na divisa entre os municípios de Bujaru e Concórdia (mesorregião nordeste paraense), afastada 112 quilômetros da capital Belém. Um pequeno ramal de terra, com início no $\mathrm{Km} 35$ da PA140, viabiliza o acesso à localidade.

O reconhecimento do Cravo como remanescente de quilombo ocorreu no ano de 2006. Porém, a comunidade ainda não possui título de terra reconhecido pelo Instituto Nacional de Colonização e Reforma Agrária (INCRA). Segundo dados de 2010 do Instituto Brasileiro de Geografia Estatística (IBGE), a comunidade é habitada por cerca de 200 famílias.

$\mathrm{Na}$ Vila do Cravo as crenças religiosas são de base católica, evangélica e afroameríndia, sendo a população predominantemente católica. Festas de santo são muito frequentes na comunidade e a festividade mais tradicional ocorre no mês de maio, em homenagem a padroeira da localidade, Nossa Senhora das Graças.

No início da década de 2000, alguns moradores da Vila do Cravo passaram também a seguir os preceitos protestantes-evangélicos. Em 2001, foi construído um templo da Igreja do Evangelho Quadrangular (IEQ). Apresentando uma rigidez moral que condiz com os interesses pessoais de determinados indivíduos da comunidade, até os dias atuais, continua angariando adeptos.

As crenças baseadas na cultura afro-ameríndia são expressas pelas práticas de cura como os benzimentos, voltados para curar enfermidades espirituais e físicas. 0 
benzimento é realizado por meio de orações, geralmente de ritos católicos, e do uso de ervas medicinais associadas ao conjunto de saberes da cultura afro- ameríndia.

Assim, é possível constatar que a religiosidade da comunidade estudada é constituída por um ecletismo de práticas, processualmente constituídas pela composição de elementos de diversas origens, de maneira que atualmente a religiosidade local é expressa através do catolicismo popular.

A partir deste contexto, o estuda busca compreender as práticas da vida religiosa local e os princípios de constituição do seu universo simbólico. Consequentemente, a pesquisa volta-se para a análise da relevância de tais práticas na vivência em comunidade e o seu papel na coesão social do grupo.

\section{Objetivo(s):}

Geral: Investigar, por meio da elaboração de etnografia das práticas religiosas, de que maneira a religiosidade se expressa e qual seu impacto social no cotidiano dos moradores da comunidade remanescente de quilombo Vila do Cravo, tendo como norte a coexistência na localidade das crenças católica, evangélica e afro-ameríndia.

\section{Específicos}

- Analisar as características práticas e simbólicas do fenômeno religioso que constituem e influenciam a vivência na comunidade;

- Entender como a religião promove a união social entre os moradores da comunidade.

- Verificar se há uma relação pacífica ou conflituosa entre os adeptos das três crenças religiosas identificadas na Vila do Cravo.

- Identificar novas práticas de expressão do sincretismo religioso.

Material e Método: A pesquisa, já em andamento, tem caráter etnográfico, contando com a realização de entrevistas semiestruturadas pela perspectiva da história oral, observação participante e uso do caderno de campo, Oliveira (2012). O método etnográfico adotado é o da "descrição densa", desenvolvido por Geertz (1989), que objetiva proporcionar ao etnógrafo a compreensão das estruturas significantes implicadas na ação observada.

A observação participante está sendo concretizada com a participação ativa nas festas de santo, nos cultos evangélicos e na prática do benzimento. As entrevistas semiestruturadas, pela perspectiva da história oral, têm como base um roteiro previamente estabelecido e estão sendo feitas com o auxílio de equipamentos audiovisuais (gravador e máquina fotográfica), objetivando a coleta de informações importantes junto aos quilombolas da comunidade, pertinentes para a consecução dos objetivos propostos.

A população alvo do estudo é composta pelos moradores da comunidade quilombola Vila do Cravo. Pretende-se entrevistar os interlocutores, que sejam reconhecidos na comunidade, com relação as práticas religiosas, ligados às vertentes religiosas existentes no local. O universo amostral será não probabilístico e a seleção 
dos participantes se dará pelo método de amostragem intencional (OLIVEIRA, 2012). O uso do caderno de campo será uma ferramenta de pesquisa indispensável para construir a etnografia das práticas religiosas na Vila do Cravo, além do registro descritivo da realidade observada durante o período de imersão na comunidade.

\section{Resultados e Discussão:}

Até o ponto alcançado por essa pesquisa junto à comunidade quilombola Vila do Cravo, percebeu-se que o sincretismo religioso, elemento característico de grande parte das práticas religiosas nos quilombos, está intrinsecamente presente na religiosidade local. As festas de santo e a prática do benzimento são exemplificações da religiosidade sincrética vivenciada na comunidade. Para Ferreti (1998), as festas religiosas constituem componente fundamental das religiões populares, em que o sincretismo se encontra intimamente relacionado e pode ser visto como um paralelismo entre rituais de origens africanas, indígenas, católicas e de outras procedências.

À vista disso, é possível constatar que nos quilombos predominava, e ainda predomina, a reinvenção e a mistura de valores e instituições. Reis (1996) elucida que essa disponibilidade para mesclar culturas era um imperativo de sobrevivência, exercício de sabedoria, também, refletida na habilidade demonstrada pelos grupos quilombolas de constituir alianças sociais, as quais inevitavelmente se traduziam em transformações e interpenetrações culturais.

Tendo como base tais elementos à argumentação teórica objetiva mostrar como o fenômeno religioso é articulado no meio social. Assim, para fundamentar a análise da religiosidade expressa na Vila do Cravo serão utilizadas as definições propostas por Durkheim, Bourdieu e Geertz, sobre religião.

A religião, segundo Durkheim (1996), pode ser caracterizada como um conjunto de complexos sistemas de práticas rituais e representações simbólicas, fenômeno essencialmente humano que opera na constituição de categorias do pensamento que orientam a vida social.

Para Bourdieu (2004) o fenômeno religioso é um sistema de comunicação e pensamento que utiliza os bens simbólicos de caráter sagrado como estruturantes das relações sociais na esfera religiosa. Portanto, a religião pode ser definida como um conjunto de signos da linguagem através dos quais o homem transmite suas ideias e atribui sentido a tais signos, construindo um imaginário de mundo com suas acepções simbólicas.

Segundo Geertz (1989), religião é um sistema de símbolos que tem como função estabelecer a harmonia na vida e nas relações sociais. A religião, sob esta perspectiva, estabelece disposições e motivações através de um sistema de símbolos que têm a capacidade de internalizar em seus adeptos um "ethos" e uma "visão de mundo" específicos.

Levando em consideração as formulações propostas por esses autores, depreende-se que o catolicismo popular, expresso na comunidade estudada, é repleto de simbologias, que têm sua forma materialmente estabelecida. Exemplo disso é a santa padroeira (Nossa Senhora das Graças), que têm ligação direta com seus devotos. O meio transcendente e o comportamento simbólico são claramente observados nas festas em homenagem a essa santa. 
Desse modo, através da etnografia foi identificado que nos festejos em homenagem a Santa padroeira da localidade, existe uma ordem de acontecimentos que aproximam o sagrado do profano, pois o Círio é constituído dentro de uma conjuntura que oscila entre estas duas esferas: são misturas de situações espirituais e materiais, exteriorizadas de diversas maneiras através dos inúmeros modos de rezar, falar, louvar, comer, brincar, etc. Dessa maneira, sobreposta à festa sagrada, acontece, sem a rigidez do controle eclesiástico, o festejo profano.

$\mathrm{Na}$ Vila do Cravo, as atividades que compõem a festividade em homenagem a Nossa Senhora das Graças, padroeira local, têm sua programação regulada de maneira oficial pela Igreja Católica, representada pelo pároco local. Entretanto, os devotos estabelecem uma dinâmica comemorativa própria: o Círio e a romaria definem-se, em todo o seu processo, de um lado, pelas situações que expressam um profundo respeito pelo sagrado e, de outro (profano) por uma euforia festiva marcada pelo arraial, pelas músicas, pelas comidas típicas da região, pelas brincadeiras e pelas apresentações culturais.

Neste contexto, como representações e práticas religiosas no âmbito do catolicismo popular, a comunhão das crenças e valores devocionais, dos que participam das festas de Santo, evidencia a força do processo que envolve o devotamento, haja visto que, durante as festividades, os fiéis se unem em torno de uma finalidade comum. Nesse sentido, a exteriorização da religiosidade popular, por meio da festa, estabelece relações de solidariedade, uma temporalidade favorável à reciprocidade social entre os fiéis devotos, que partilham as mesmas convicções e graças alcançadas, devido a ação da Santa de devoção.

Conclusão: A análise de grupos religiosos possibilita compreender a experiência religiosa enquanto um mecanismo que programa e orienta o comportamento humano de forma específica, haja vista que a religião é essencialmente prática (DURKHEIM, 1996). A religião, então, é uma tentativa implícita e diretamente sentida, em vez de explícita e conscientemente pensada, de conservar a provisão de significados gerais em termos dos quais cada indivíduo interpreta sua experiência e organiza sua conduta. (GEERTZ, 1989). Desse modo, a análise do fenômeno religioso, em suas especificidades, é fundamental para entender a relação do homem com o meio social.

A religiosidade é parte fundamental dos referenciais identitários da população quilombola brasileira, de modo que "os elementos de caráter religioso foram fundamentais no processo de resistência ao sistema escravagista no Brasil" (MOURA, 1993, p.44). Através de tais elementos, os povos escravizados encontraram forças para sobreviver aos maus tratos e lutar pela sua liberdade, tendo sido a religião essencial na vida desses indivíduos. Desse modo, espera-se que tal estudo promova uma reflexão sobre as manifestações religiosas dos remanescentes de quilombo da Vila do Cravo, contribuindo para a salvaguarda das memórias, dos costumes e das práticas religiosas da comunidade estudada.

Nas comunidades rurais/campesinas, onde o catolicismo oficial não apresenta força institucional, os fieis exteriorizam sua adoração a uma entidade religiosa repleta de fatores ligados a tradições e crenças da cultura local. Os devotos, nesse sentido, vivenciam, cotidianamente, um catolicismo popular com características particulares, 
onde a ritualidade é construída sincreticamente, associando os costumes locais com os preceitos do clero. Em conformidade com tal assertiva

Donizete Rodrigues (2007) explica que:

Em muitos contextos sociais, as práticas e as superstições populares estão misturadas com os dogmas oficiais das Igrejas/religiões instituídas. De acordo com os meios e as circunstâncias, tanto as crenças como os ritos, preconizados pelas instituições religiosas oficiais, são praticados e sentidos de maneiras diferentes (p. 93).

O catolicismo popular presente na região amazônica, segundo Galvão (1955) e Maués (1990), apresenta suas especificidades centradas nos cultos e nas crenças aos santos, nas práticas de curas, nas promessas, nas festas e procissões, entre outros rituais e representações, de modo que as festividades organizadas em homenagem aos santos padroeiros possibilitam encontros e reencontros e um fortalecimento dos vínculos sociais entre os indivíduos que participam ativamente do seu processo.

Consoante ao observado, o campo religioso da comunidade quilombola Vila do Cravo se configura a partir de elementos peculiares que identificam a mentalidade dos sujeitos que residem neste espaço. Assim, a produção da pesquisa se mostra de significativa relevância para a compreensão da interação que há entre religião e indivíduo, haja vista que a análise do fenômeno religioso, em suas especificidades, é fundamental para compreender a relação do homem com o meio social.

Referências bibliográficas: PIERRE, Bourdieu. A Economia das trocas simbólicas. São Paulo: Perspectiva, 2004.

DURKHEIM, Émile. As Formas elementares da Vida Religiosa: o sistema Totêmico na Austrália. São Paulo: Martins Fontes, 1996.

FERRETTI, S. F. Sincretismo afro-brasileiro e resistência cultural. Horizontes Antropológicos, n. 8, p. 182-198, jun. 1988.

GALVÃO, Eduardo. Santos e visagens: um estudo da vida religiosa de Itá; Amazonas. 2. ed. São Paulo: Ed.Nacional; Brasília: INL, 1955.

GEERTZ, Clifford. A Interpretação das Culturas. Rio de Janeiro: LTC - Livros Técnicos e Científicos Editora, 1989.

MAUÉS, Raymundo. Heraldo. A ilha encantada: medicina e xamanismo numa comunidade de pescadores. Belém: Edufpa, 1990.

MOURA, Clóvis. Quilombos: resistência ao escravismo. 3. ed. São Paulo: Editora Ática, 1993.

OLIVEIRA, M. M. Como fazer pesquisa qualitativa. 4. ed. Petrópolis: Vozes, 2012. REIS, J. J. Quilombos e revoltas escravas no Brasil. Revista USP, n. 28, p. 14-39, 1996.

REIS, J. J. Quilombos e revoltas escravas no Brasil. Revista USP, n. 28, p. 14-39, 1996. Disponível em: http://www.revistas.usp.br/revusp/article/view/28362/30220. Acesso em: 20 fev. 2018.

RODRIGUES, Donizete. Sociologia da religião: uma introdução. Porto: Edições Afrontamento, 2007.

Palavras-chave: Vila do Cravo; Comunidades quilombolas; Religiosidade; Catolicismo popular; Sincretismo religioso. 
Grande-área: Ciências Humanas

Àrea: Ciências da Religião 


\title{
RELIGIÃO E MIDIA: UM ESTUDO DO IMAGINÁRIO TELEVANGÉLICO DA IGREJA UNIVERSAL DO REINO DE DEUS.
}

\author{
Nome do (a) Bolsista: João Afonso Dos Santos Lobato Pantoja \\ Nome do(a) Orientador(a): Katia Marly Leite Mendonça
}

Resumo: Este trabalho tem por finalidade compreender os meios em que se cruzam o televangelismo da Igreja Universal do Reino de Deus, em especial no programa do templo exibido todos os domingos das 08:00 as 09:00 da manhã pela Record Tv e o imaginário religioso construído dentro daquele espaço, que a cada ano atraí um número crescente de fiéis. Neste sentido, a partir da perspectiva de autores como Gilbert Durand que procuram traçar um grande panorama acerca do papel desempenhado pela imagem na modernidade a partir dos significados simbólicos, o que para ela marca o nascimento de uma nova relação entre o tempo e o espaço, o que significa uma transformação no modo como as pessoas se relacionam.

Introdução: O imaginário tem sido um elemento chave no processo de construção das inúmeras identidades religiosas, o que revela um elemento distintivo do ser humano em relação aos outros animais, afinal de contas a capacidade conceber imagens mentais foi determinante para a sobrevivência de nossa espécie. E com o advento da técnica de reprodução de imagens, o imaginário cuja a função é a capacidade seja individual ou coletiva de dar sentido ao mundo, ou seja, o conjunto das relações de imagens que constituem todo o capital pensado do ser humano modificou-se de modo estrondoso.

Dentro do cenário religioso brasileiro, em especial do neopentecostal, a Igreja Universal do Reino de Deus (IURD), tem assumido um papel chave, o que veem ocasionam diversos debates entre os estudiosos, que veem no crescimento evangélico, nas ultimas décadas uma mudança no panorama político, social e cultural do país, marcado principalmente pela crescente aquisição e uso de meios de comunicação de massa por esses grupos religiosos.

A partir dessa perspectiva a relação entre o imaginário e o simbólico a IURD, por meio dos seus programas televangélicos, em especial o programa do templo permitem entender a construção e a volatilidade do seu imaginário religioso. Pois o próprio local aonde são realizados os cultos já apontam uma grande carga simbólica, construído no bairro do Brás em São Paulo, o templo de Salomão procura ser uma réplica do antigo templo judaico destruído primeiramente pelos babilônios e em seguida pelos romanos, o que levou a diáspora judaica. A magnitude da obra chama atenção, com capacidade para mais de dez mil pessoas, a construção teve um custo aproximado de 680 milhões de reais e levou quatro anos para ser erguido. Portanto, é inegável a grande carga simbólica que coincide na construção do imaginário dos fiéis.

OBJETIVOS

GERAL:

Compreender a construção do imaginário religioso presente no televangelismo da Igreja Universal do Reino de Deus.

ESPECÍFICOS: 
Entender utilizando como estudo de caso o programa do templo da Igreja Universal exibido aos domingos pela Record tv.

Analisar os elementos ritualísticos presentes no programa que contribuem na construção do imaginário.

Apontar os fatores que promovem a aceitação das práticas de evangelização contidas nos programas destinados ao público-alvo.

Material e método: Afim de estabelecer uma análise e compreensão do imaginário do televangelismo da IURD, deve-se estabelecer uma série de procedimentos metodológicos, que culminaram no alcance do objetivo apresentado. Assim sendo, utilizar-nos-emos das técnicas de observações e análises do programa televisivo com a finalidade de identificar os principais elemento que compõem os rituais durante os cultos, assim como as falas dos líderes e a reação dos fiéis durante a execução

Posteriormente, será realizado um levantamento bibliográfico, na tentativa mensurar as principais, produções acadêmicas, entre os quais livros, artigos, monografias, teses com objetivo de nortear a pesquisa científica com informações fundamentais sobre a temática proposta e também para a fundamentação teórica. Além disso, a pesquisa realizada poderá resultar em uma nova abordagem sobre a relação entre a IURD e a mídia moderna.

resultados e discussão: Durante o seu processo de desenvolvimento a pesquisa contou com um número bastante significativo, de material, principalmente no que diz respeito, a sua teologia, as suas práticas rituais e também de seu principal líder religioso o bispo Edir Macedo, que coleciona um grande número de polêmicas ao longo de sua atividade religiosa, o que lhe acarretou em uma série de processos na justiça tanto no Brasil como no exterior.

Inicialmente, a pesquisa realizaria incursões no principal templo da Igreja Universal em Belém, ou seja, na catedral da fé que fica localizado no bairro do castanheira, na BR $316, \mathrm{Km}$ no entroncamento, a fim de realizar uma análise comparativa entre o programa do templo transmitido pela Record tv e os cultos realizados naquele espaço. Contudo, os dirigente da igreja não permitiram a minha pesquisa no local, pós não estavam convencidos da minha pesquisa. Dito isso, a pesquisa precisou passar um por uma alteração, em vez de realizar uma análise comparativa, decidir me concentrar apenas nos programas veiculados pela igreja que são transmitidos diretamente do templo de Salomão.

Essa mudança no percurso, não trará grande impacto na pesquisa, que agora poderá se concentra em apenas um vetor, desse grande objeto, que é o imaginário da Igreja Universal do Reino de Deus a partir de seu programa televangélico o que significará uma maior consistência o trabalho final.

Conclusão: Desse modo, para o mundo acadêmico e seus pesquisadores o empenho na busca de depreender os elementos que compõem a formação do imaginário evangélico, sobretudo o da IURD por meio de seus programas televangélicos se mostra essencial, na intenção de oferecer contribuições cientificas que possam explicar na atual conjuntura do Brasil. Por consequência, estabelecer as formas de como essas identidades são construídas e ressignificada, pois estando o imaginário alicerçada por 
âmbitos sociais, culturais e religiosas, que se cruzam e modelam o nosso pensar cotidiano. Assim os ensinamentos adquiridos pelos fiéis moldam as ações e que mais tarde serão fonte de aspiração de outros fiéis. Essa dinâmica de fé é denominada pelos dirigentes da Igreja Universal como "fé inteligente", em outras palavras é o exercício de uma fé que não deixa o coração domina-la, por sentimentos traiçoeiros, que podem por vezes serem fruto das ações de foças malignas.

A consequência disso, são as inúmeras campanhas que são dedicados a vida financeira, o que veio a ser denominado por Teologia da Prosperidade isso significa, que a vida do fiel precisa atestar, a ação de Deus, pois do contrário ele é um "crente fracassado", dito de outra forma, são aqueles que estão na igreja, porém não prosperam na vida material e espiritual, o que para dirigente da Igreja Universal é considerado algo abominável.

Esse cenário emblemático, constitui uma mudança cultural sem paralelo na história religiosa do Brasil atual, cujo o resultado final desse fenômeno é imprevisível, o que abre espaço para os mais diversos discursos e intepretações.

REFERÊNCIAS BIBLIOGRÁFICAS

BAPTISTA, Paulo Agostinho Nogueira; SILVA, Wellington Teodoro (Org). O Sagrado e o Urbano: Diversidades, Manifestações e Análise. São Paulo, Paulinas, 2008.

BAUMAN. Zygmunt. Modernidade Líquida. Rio de Janeiro, Editora Zahar, 2001.

BARROS, Ana Taís Martins Portanova, (Org) A Teoria Geral do Imaginário 50 anos depois: Conceitos, Noções, Metáforas, Porto Alegre, Imaginalis, Anais do II Congresso Internacional do Centre de Recherches Internationales sur l'Imaginaire, 2015,

CAMPOS, Leonildo Silveira. Evangélicos, Pentecostais e Carismáticos na Mídia Radiofônica e Televisiva. REVISTA USP, São Paulo, n.61, p. 146-163, março/maio 2004.

CASSIRER, Ernst. Linguagem e Mito. 3a Ed. São Paulo, Editora Perspectiva S.A. 1992. CUNHA, Christina Vital da. "Televisão para Salvar": Religião, Mídia e Democracia no Brasil Contemporâneo. Revista Antropolítica, n. 42, Niterói, 1. sem. 2017.

DURAND, Gilbert. O Imaginário: Ensaio Acerca das Ciências e da Filosofia da Imagem. Rio de Janeiro, Difel,1998.

ELIADE, Mircea. O Sagrado e o Profano. São Paulo, Martins Fontes, 1992.

FIGUEIREDO, Marcelo da Silva; STORTO, Letícia Jovelina. Templo de Salomão: Arquitetura, Argumentatividade e Midiatização, Anuário Unesco/Metodista de Comunicação Regional, Ano 19 n.19, p. 259-273 jan/dez 2015

GIRARDET, RAOUL. Mitos e Mitologias Políticas, São Paulo, Companhia das Letras, 1997.

GONÇALVES, Delmo. Neopentecostalismo, São Paulo, Fonte Editorial, 2013.

LANZA, Fabio. (et al). Cultura e Religiões na Contemporaneidade, Londrina, Universidade Estadual de Londrina -UEL, 2013.

PASSOS, João Décio. Pentecostais: Origens e Começos, São Paulo, Paulinas, 2005.

ROCHA. Danielle Perin Rocha. Iniciação à Teoria do Imaginário de Gilbert Durand, 2. Ed Curitiba: CRV. 2017.

TRINDADE, Liana: LAPLANTINE, François. O que é imaginário. Editora: Brasiliense, 2017. 
TORRES, João Victor; ROSSETTI, Êmili Adami, O Reino Simbólico de Edir Macedo, Intercom - Sociedade Brasileira de Estudos Interdisciplinares da Comunicação XV Congresso de Ciências da Comunicação na Região Nordeste - Mossoró - RN - 12 a $14 / 06 / 2013$

Palavra chaves: Igreja Universal, Imaginário, Neopentecostalismo, Televangelismo Grande área: Ciências Humanas

Área: Ciências da Religião 


\title{
PÓS-SECULARIDADE: UMA REVISÃO CRÍTICA DO CONCEITO DE SECULARIZAÇÃO FRENTE AO PLURALISMO
}

\author{
Nome do(a) bolsista: Luanara Gabrielly da Silva Ribeiro \\ Nome do(a) Orientador: Manoel Ribeiro de Moraes Júnior
}

Resumo: $O$ presente trabalho é fruto da pesquisa desenvolvida no mestrado em Ciências da Religião e tem por foco a questão da religião na esfera pública, um tema relevante para a análise dos caminhos das crenças religiosas na sociedade contemporânea, cuja discussão é marcante para as Ciências da Religião por suscitar discussões sobre as conseqüências da presença dos conteúdos religiosos no espaço público. Diante disso, propomos a seguinte ordem: I) Primeiramente, partiremos do âmbito político como ponto de partida para a secularização: a crescente autonomia adquirida pelos Estados em relação à Igreja marca a modernidade através do processo de destranscendentalização. A autonomização atinge as esferas culturais (Arte, Direito, Moral, etc...) cujo funcionamento se torna gradativamente independente dos fundamentos religiosos, resultando em uma perspectiva de declínio da religião diante da modernização das sociedades. II) Em seguida, abordaremos como a autonomização em relação ao âmbito religioso se torna um elemento relevante para compreendermos o pluralismo presente em nossas sociedades, a partir do conceito de relativização dos modos de vida. III) Por fim, trataremos da falibilidade da definição da secularização como derrocada da religião e sua redefinição a partir da noção de sociedades pósseculares: sociedades onde os conteúdos religiosos permanecem no âmbito político, exigindo um entendimento mútuo entre cidadãos religiosos e não-religiosos. A interpretação da esfera pública como um elemento constituído de forma discursiva e linguística: de um lado inúmeros indivíduos, grupos com seus interesses privados e, por outro o ordenamento político democrático que requer interesses coletivos. Portanto, a esfera pública requer um ajuste entre as demandas dos indivíduos (religiosos ou não) e da própria democracia, mediante a construção de uma racionalidade política inclusiva que reconhece a religião como portadora de um papel importante na formação da opinião e da vontade política, mas, sem cair no risco de um Estado teocrático opressivo em relação à liberdade.

Introdução: O tema da religião na esfera pública gira em torno da presença e influencia dos conteúdos religiosos na formação da opinião dos cidadãos e no interior de discussões sobre assuntos relevantes para as sociedades democráticas contemporâneas. Essa temática é importante para inúmeros campos como a sociologia, filosofia e as ciências da religião na medida em que a relação entre a religião e a esfera pública problematiza o papel exercido pelos conteúdos religiosos na contemporaneidade: sob o ponto de vista teórico se debruça sobre a razoabilidade da religião como fundamento do pensamento político dos indivíduos na medida em que a influencia religiosa pode significar:

Em seu papel de cidadãos do Estado, os cidadãos secularizados não podem nem contestar em princípio o potencial de verdade das visões religiosas do mundo, nem negar aos concidadãos religiosos o direito de contribuir para os debates públicos 
servindo-se de uma linguagem religiosa. Uma cultura política liberal pode esperar dos cidadãos secularizados que participem de esforços de traduzir contribuições relevantes para uma linguagem que seja acessível publicamente. (HABERMAS, 2007,p.57)

A discussão acerca da religião na esfera pública envolve a questão da secularização que, normalmente, se refere a separação entre Igreja e Estado no âmbito político e a possibilidade de construir fundamentos não-religiosos em outras esferas( Arte, Direito, Ética, ...). A noção de secularização se torna então sinônimo de declínio das crenças e instituições religiosas nas sociedades devido a modernização societária, mas, a permanência das religiões gera discussões sobre a necessidade de redefinir o entendimento sobre a secularização em contextos onde os conteúdos religiosos continuam marcantes na formação dos modos de vida de grupos e indivíduos. A póssecularidade trata justamente sobre uma sociedade com uma esfera pública na qual a religião permanece, juntamente com a secularização enquanto possibilidade de construir modelos não-religiosos e não de declínio.

Objetivo(s): A pesquisa consiste em enfrentar os seguintes problemas: primeiro, verificar a crítica ao conceito de secularização como declínio e a busca por outro sentido de secular capaz de reconhecer a permanência das religiões nas sociedades contemporâneas. Segundo, enfatizar a importância do conceito de pós-secularidade para compreender a continuidade das religiões e definir a secularidade como formação de conteúdos e princípios não-religiosos no âmbito político, mas, sem ignorar que os conteúdos religiosos ainda possuem um impacto significativo na esfera pública como fonte de valores que influenciam na formação da opinião política e da própria razão pública (racionalidade que rege o ordenamento político). Terceiro, apresentar o pluralismo como categoria chave para entender o papel da religião nas sociedades contemporâneas multiculturais. Por fim, realizar uma leitura da esfera pública como um elemento constituído de forma discursiva a partir de uma socialização comunicativa.

Material e Método: O material utilizado são obras, artigos, teses, orientações, palestras, seminários que permitam formar o conteúdo e as discussões necessárias para a construção da dissertação. A seleção dos autores que compõe a bibliografia ocorre da seguinte forma: obras que permitam trabalhar o conceito de secularização e o tema da religião na esfera pública; obras de autores contemporâneos cujas teorias podem auxiliar na compreensão do par religião/modernidade e apontar as críticas da visão tradicional sobre a secularização, indicando novos horizontes acerca da permanência da religião nas sociedades contemporâneas, sobretudo no âmbito político e obras referentes ao conceito de pós-secularidade para verificar suas possibilidades e limites. $\mathrm{O}$ método utilizado é pautado na teoria reconstrutiva.

Resultados e Discussão: Atualmente, a pesquisa está na etapa de construção do terceiro capítulo, a partir de um esboço teórico que permita a compreensão da presença da religião na esfera pública como necessidade de um conceito de racionalidade política e razão pública que seja inclusiva (inserida na pós-secularidade) para compreender a demanda dos cidadãos e grupos religiosos, mas também capaz de trabalhar a inclusão a partir de uma tradutibilidade na qual as razões privadas são transformadas para a linguagem acessível de uma razão pública democrática. As discussões giram em torno da avaliação do papel político da religião e o desafio de estabelecer um Estado 
democrático laico, sem ignorar a força exercida pelas crenças religiosas na conjuntura política atual.

Conclusão: A religião não declinou e continua exercendo um papel de fonte moral das imagens de mundo que norteiam a formação de indivíduos e grupos na sociedade contemporânea. Entendemos o conceito de pós-secularidade como uma contribuição que reconhece a sociedade atual como marcada pela permanência dos conteúdos religiosos e, ao mesmo tempo, por uma secularidade que permite a constituição de modos de vida não-religiosos. Contudo, verificar o papel da religião na esfera pública não consiste somente em uma dupla aprendizagem, um ajuste na demanda entre cidadãos (religiosos ou não), mas traz as democracias contemporâneas o desafio de construir uma racionalidade política capaz de lidar com uma esfera pública plural onde os interesses caminham entre consensos e dissensos.

Referências Bibliográficas: ARAUJO, Luiz Bernardo Leite; MARTINEZ, Marcela Borges; PEREIRA, Taís Silva (Org.). Esfera Pública e Secularismo: Ensaios de Filosofia Política. Rio de Janeiro: uerj,2012.

Pluralismo e Justiça: estudos sobre Habermas. São Paulo: Loyola, 2010.

ARAÚJO, Inês Lacerda. Do discurso ao signo. Introdução à filosofia da linguagem. São Paulo: Parábola editorial, 2004.

BERGER, L. Peter. Modernidade, Pluralismo e Crise de Sentido: A orientação do homem moderno. Petrópolis: Vozes, 2012.

BERGER, L. Peter. Os Múltiplos Altares da Modernidade: rumo a um paradigma da religião na modernidade. Petropólis: Vozes, 2017.

BERGER, L. Peter. O Dossel Sagrado: Elementos para uma teoria sociológica da religião. São Paulo: Paulus, 1985.

BERNARDI, Bruno. La démocratie. Paris: Flammarion, 1999.

BELLAH, Robert. Religion in the human evolution. London: Cambridge ,2011.

CASANOVA, José. Public religions in the Modern World. Chicago: University of Chicago Press, 1994.

CASANOVA, José. Reconsiderar la Secularización: uma perspectiva comparada

EISENSTADT, Shumael Noah. Modernidades Múltiplas. Revista Sociologia, Problemas e Práticas, v. 35, p. 139-163, 2001.

FUKUYAMA, Francis. Origens da ordem política: dos tempos pré-humanos até a revolução Francesa. São Paulo: Rocco, 2013.

FRED, Rush (org.). Teoria Crítica. Aparecida: Idéias \& Letras, 2004.

FORST, Rainer. Contextos da Justiça. São Paulo: Boitempo, 2010.

BINOCHE, Bertrand. Religion privée, opinion publique. Paris: LIBRAIRIE PHILOSOPHIQUE J.VRIN 6, place de la Sobonne, V, 2012.

GAUCHET, Marcel. El Desencantamento del Mundo: una história política de la religión. Madrid: Trotta, 2005.

HABERMAS, Jürgen; RATZINGER, Joseph. Dialética da Secularização: sobre razão e religião. Aparecida: Ideias \& Letras, 2007.

A Inclusão do Outro: Estudos de teoria política. São Paulo: Loyola, 2002.

Entre Naturalismo e religião: estudos filosóficos. Rio de Janeiro: Martins

Fontes, 2012.

.Mundo de la vida, política y religión. Madrid: Trotta, 2015. 
. Fé e Saber. São Paulo: Unesp, 2013

Teoria do Agir comunicativo. (Vol. 1 e 2). Rio de Janeiro: Martins Fontes,

2012.

Mudança estrutural da esfera pública: investigações sobre uma categoria da sociedade burguesa. São Paulo: Unesp, 2014.

.Agir comunicativo e Razão Descentralizada. Rio de Janeiro: Tempo Brasileiro, 2003.

Palavras-chave: Religião; Esfera pública; Pós-secularidade.

Grande área: Ciências Humanas

Área: Ciências da Religião 


\title{
"PODER DA MATA": UMA ANÁLISE SOBRE A DIMENSÃO CONFLITUOSA NO CAMPO PENTECOSTAL NO CONTEXTO DAS VIGÍLIAS DA MATA
}

\author{
Nome do(a) bolsista: Luís Rodolfo da Silva Moura \\ Nome do (a) Orientador (a): Saulo de Tarso Cerqueira Baptista
}

Resumo: A pesquisa desenvolvida no Programa de Pós-Graduação em Ciência da Religião - UEPA, busca contribuir para com as discussões acerca dos conflitos simbólicos recorrente na relação de poder no campo religioso pentecostal, no contexto da vigília da mata. Dessa forma, a pesquisa faz referências a pensadores como Max Weber, Pierre Bourdieu, como aporte teórico de análise no que se refere à relação de poder e poder simbólico. Consequentemente autores que versam sobre a temática do pentecostalismo serão essenciais para essa abordagem, assim como, trechos de entrevistas dos que integram a vigília da mata, objetivando elucidar a questão do conflito simbólico que há nesse campo.

Introdução: Para quem acompanha o movimento religioso protestante, principalmente o processo histórico do pentecostalismo brasileiro, pode ter percebido que, ao passar do tempo, o seu aspecto multiforme ainda cresce no contexto das igrejas evangélicas, proporcionando inúmeros debates a respeito dessas manifestações religiosas, provenientes do mover pentecostal em algumas reuniões compreendidas e defendidas pelos seus idealizadores como sendo hegemonicamente pentecostais. Nesse contexto, vale lembrar as observações de Paul Freston, quando diz que:

As igrejas pentecostais enquanto instituições em evolução dinâmica (...) não são organizações estáticas que incham numericamente; estão em constante adaptação, e as mudanças são frequentemente objeto de lutas. Ademais, o pentecostalismo possui grande variedade de formas, e cada nova espécie vai enterrando mais alguns mitos a respeito de o pentecostalismo" (FRESTON, 1993. p. 64).

Logo deduzimos que essas recorrentes variações, fruto do dinamismo pentecostal, promove o ambiente de conflito no jogo da disputa de poder.

Sendo assim, a pesquisa se debruça analisar a disputa de poder simbólico que a experiência religiosa possa originar com a vigília da mata, nessa análise, esse poder será visto na perspectiva bourdiana, na qual, poder simbólico é entendido quando alguém se torna sujeito à outra pessoa por acreditar que esta pessoa exerce um poder, o que gera uma confiança e uma relação de sujeição (BOURDIEU, 1989, p.177), sendo assim, este poder busca construir uma realidade que tenta estabelecer uma ordem social. "O poder simbólico é, com efeito, esse poder invisível o qual só pode ser exercido com cumplicidade daqueles que não querem saber que lhe estão sujeitos ou mesmo que o exercem" (Ibid.,p.7-9).

O referencial de abordagem serão as reuniões desenvolvidas pela pastora Débora Silva, que é pastora presidente da "Igreja Evangélica Tabernáculo de Deus" ${ }^{1}$, uma vez que a

${ }^{1}$ A Igreja Evangélica Tabernáculo de Deus é o nome fictício de uma pequena congregação pentecostal com cerca de 50 membros, presidida pela pastora Débora Silva (nome fictício), pastora que conhecemos nas visitas de campo, no caso, a mata da 
referida pastora, semanalmente realiza a vigília da mata. O local onde se realizam essas vigílias é de propriedade da Marinha do Brasil localizada às margens da Avenida Independência, no bairro de Val-de-Cães em Belém- $\mathrm{Pa}^{2}$.

Consequentemente, a pesquisa abordará os efeitos dessa reunião na mata, a qual para alguns se torna sinônimo de experiência pessoal com o poder espiritual do pentecostalismo, enquanto que para outros, nada mais é do que um conjunto de sincretismo religioso ${ }^{3}$ que destoa do que acreditam ser o "pentecostalismo clássico" 4 em referência ao movimento do início do século XX, que Freston (1994, p.70) classificou como sendo o da "primeira onda", reportando-se à implantação no Brasil das igrejas "Congregação Cristã do Brasil", em 1910, e "Assembleia de Deus", em 1911.

Há intensas discussões acerca dessas reuniões nas matas que provocam divergentes opiniões entre vários agentes religiosos de inúmeras denominações evangélicas, gerando acalorados conflitos internos em algumas igrejas, a ponto de muitos desses posicionamentos nem sequer considerarem tais vigílias como pertencentes ao quadro do movimento protestante, ou até mesmo pentecostal, pois muitos acreditam que os sincretismos religiosos, que consideram estar presentes nelas, descaracterizam a essência do pensamento protestante e do próprio pentecostalismo em uma clara disputa de poder simbólico.

Marinha no bairro de Val-de-Cães. Acompanhada por alguns membros e não membros de sua igreja. Relatou-nos que o grupo realiza os encontros na mata regularmente aos sábados. A igreja é localizada no bairro da Marambaia em Belém-Pa próximo à mata onde são realizadas as vigílias.

${ }^{2}$ A mata da Marinha foi escolhida como campo para o projeto de pesquisa, dado ao fato de no local haver diariamente reuniões (na maioria dos casos de forma independente) de pequenos grupos pentecostais, em pontos referentes ao que eles denominam de monte de oração.

${ }^{3}$ Sincretismo religioso é entendido como a reunião de forma implícita ou explícita de distintas influências religiosas que estão presentes na forma de expressão religiosa de determinado grupo religioso (FERRETTI, 1995), que em muitos casos é visto de forma depreciativa. Aqui é compreendido como uma forma pela qual um grupo tenta desqualificar outro na tentativa de tirar sua legitimidade associando-o à heresia.

4 Segundo Freston(1994), as três ondas do movimento pentecostal no Brasil se estabelecem da seguinte forma: a primeira onda ou pentecostalismo clássico, correspondem ao período de 1910 a 1950, no qual os missionários italianos e suecos fundam as primeiras igrejas pentecostais no Brasil. Em 1910, com a Congregação Cristã do Brasil é fundada em São Paulo pelos italianos, e no ano seguinte, os suecos fundam a Assembleia de Deus em Belém-Pa. A segunda onda ou pentecostalismo neoclássico se configura como o segundo momento no qual se destaca a ênfase nos dons de línguas como sinal de batismo e a cura divina, e marca o momento de emancipação das organizações estrangeiras, surgindo igrejas como: Igreja do Evangelho Quadrangular (1951, São Paulo), Igreja Brasil Para Cristo (1955, São Paulo), Deus é Amor (1962, São Paulo), Casa da Benção (1964, Minas Gerais) e outras. Consequentemente, a terceira onda ou neopentecostalismo surge a partir da segunda metade da década de $70 \mathrm{com}$ uma liderança nacional que faz uso intenso da mídia, e tem como exemplos: Igreja Universal do Reino de Deus (1977, Rio de Janeiro), Igreja Internacional da Graça de Deus (1980, Rio de Janeiro), Renascer em Cristo (1986, São Paulo). 
Sendo assim, o projeto se debruçará em analisar a dimensão conflituosa gerada por esse tipo de reunião no campo religioso pentecostal, no intuito de buscar entender as relações de poder e dominação dos agentes que integram esse campo.

Objetivo (s): A pesquisa tem como objetivo adentrar no debate sobre o conflito nas relações de poder entre os agentes que compõem o campo religioso pentecostal de Belém, sobretudo no contexto da vigília da mata, uma vez que esse tipo de segmento religioso é comumente alvo de questionamento por parte das igrejas majoritárias ${ }^{5}$ desse campo religioso.

Dessa maneira, com o auxilio da observação participante a pesquisa se debruçará sobre a vigília da mata a fim de compreender as razões que corroboram para o crescimento dessa forma de manifestação religiosa.

Sendo assim, a pesquisa objetivará compreender o seu arranjo político/religioso e sua representatividade simbólica, com o intuito de esclarecer e contribuir com a discussão sobre essa disputa por legitimação pentecostal dentro desse campo. Vale lembrar que essa forma de manifestação religiosa apesar de sofrer muita resistência por parte de muitas igrejas, segue crescendo e se tornando autônomo e com isso desenvolvendo o seu capital simbólico (BOURDIEU,2007), que em virtude desse crescimento, naturalmente pode potencializar a formação de novas e igrejas pentecostais, notadamente com mais força nas periferias, dessa maneira a pesquisa buscará compreender o papel da vigília na dinâmica de formação de novas igrejas. Em razão desse objetivo, justifica-se a escolha do grupo de oração liderado pela pastora Debora Silva, visto que além de vários outros motivos, segundo a pastora a sua pequena e nova congregação surge a partir de encontros de orações liderada por ela.

Portanto, a pesquisa tem como proposição analisar esse conflito procurando entender a dimensão simbólica como mecanismo de poder entre os agentes que integram o campo religioso pentecostal.

Material e Método: A metodologia que será aplicada a pesquisa atende a perspectiva da observação participante, sendo a vigília da mata o universo que consistirá o trabalho de campo. Com o propósito de alcançar um aspecto descritivo dos significados que os indivíduos e os grupos dão aos fenômenos humanos ou sociais, optou-se pelo método qualitativo (ENGLER ; STAUBERG, 2013, p. 65), dessa forma torna-se indispensável para essa pesquisa, em um primeiro momento, o emprego de entrevistas exploratórias que contribuam para uma melhor observação do objeto a ser pesquisado Por conseguinte, a pesquisa seguirá na esteira da abordagem metodológica qualitativa, que faz dela uma pesquisa interpretativa (CRESWELL, 2007, p.188) que terá como caminho investigativo; a observação participante, coletas de dados, entrevistas dos sujeitos religiosos e o levantamento bibliográfico que verse sobre a temática da pesquisa.

Resultado e Discussão: Atualmente a pesquisa está na etapa de construção do terceiro capítulo, cuja titulo é: "a mata enquanto espaço sagrado". O primeiro capítulo com o titulo: "panorama do movimento pentecostal em Belém" objetivou contextualizar

\footnotetext{
${ }^{5}$ Entendem-se como igrejas pentecostais majoritárias em Belém-PA, igrejas que de alguma forma exercem maior influência no campo religioso pentecostal, como exemplo: as Assembleias de Deus, Igreja do Evangelho Quadrangular, Igreja Pentecostal Deus e Amor, dentre outras.
} 
parte do movimento pentecostal pela qual a vigília da mata está inserida, neste caso, conhecido entre os pentecostais como "movimento do reteté". O segundo capítulo buscou compreender o valor simbólico que a vigília da mata representa na relação de poder do campo pentecostal.

Conclusão: A Vigília da mata, não diferente de qualquer outra expressão religiosa, agrega uma diversidade de códigos de matrizes religiosas, neste caso, ao beber desse repertório, sobretudo da religiosidade africana, ameríndia, dentre outras, faz dela um rico campo a ser pesquisado. Uma vez que as ressignificações desta expressão religiosa são marcadas por conflito dentro do jogo da relação de poder do campo pentecostal, que faz destas vigílias uma manifestação de caráter herético e popular frente às forças estabelecidas, ou seja, as igrejas majoritárias que trabalham no sentido de desqualificala em um processo de descapitalização simbólica, uma vez que esses movimentos de caráter marginalizados proporcionam um campo fértil a formação de lideranças emergentes, fato estes que justificam até certo ponto este tipo de manifestação religiosa crescer nas grandes periferias e gerar conflitos no campo pentecostal.

\section{Referências bibliográfica}

BOURDIEU, Pierre. A economia das trocas simbólicas. 6.ed. São Paulo: Perspectiva, 2007.

O poder simbólico. Rio de Janeiro: Bertrand Brasil, 1989.

CRESWELL, John.W. Projeto de pesquisa: método qualitativo, quantitativo e misto. 2. ed. Porto Alegre, RS: Artmed, 2007.

ENGLER, Steve; STAUBERG, Michael. Metodologia em Ciência da Religião. In: PASSOS, João D.; USARSKI, Frank (Orgs.). Compêndio de Ciência da Religião. São Paulo: Paulinas/Paulus, 2013.

FERRETTI, Sérgio F. Repensando o Sincretismo: Estudo sobre a Casa das Minas. São Paulo/ São Luís: Editora da Universidade de São Paulo/ FAPEMA, 1995.

FRESTON, Paul. Breve história do pentecostalismo brasileiro. Em: ANTONIAZZI, Alberto et al. Nem anjos nem demônios: interpretações sociológicas do pentecostalismo. Petrópolis: Vozes, 1994.

Protestante e a política no Brasil: da Constituinte ao impeachment. $304 \mathrm{f}$. Tese (Doutorado em Ciências Sociais) - Instituto de Filosofia e Ciências Humanas, Universidade Estadual de Campinas, Campinas-SP, 1993.

Palavras-chave: Vigília. Conflito. Campo Pentecostal. Poder Simbólico

Grande área: Ciências Humanas

Área: Ciência da Religião 


\section{RESSONÂNCIAS DO ENTRELAÇAMENTO DA CONVERSÃO COM A ESCRITA AUTOBIOGRÁFICA EM CONFISSÕES DE SANTO AGOSTINHO}

Nome do(a) Bolsista: Marílya Caldas Barros

Nome do(a) Orientador(a): Douglas Rodrigues da Conceição

Resumo: O presente trabalho, que encontra-se em fase dissertativa de seus resultados, concentra esforços na análise da conversão de Santo Agostinho atrelada ao fazer autobiográfico, considerando os aspectos linguísticos e estilísticos da autobiografia, noções de identidade no que diz respeito constituição da personagem que se escreve, e a noção de conversão enquanto fenômeno religioso e impulso a escrita de si.

Introdução: A presente pesquisa tem como objeto central a análise da conversão agostiniana relatada em suas Confissões, obedecendo como impulso para sua realização a escrita de si, a autobiografia, procurando demonstrar como esse processo permite articular um olhar introspectivo sobre si e a escrita sobre si em um movimento de conversão.

Nos relatos, encontra-se a mudança progressiva de comportamento, pensamento, e o consequente estímulo a escrita que se dá por meio da vontade, caracterizando uma cisão volitiva na vida do escritor. Trata-se de examinar a conversão como um processo no qual se busca reorientar o sentido para o qual se direciona a vida, tendo por finalidade, em Agostinho, Deus. O propósito de mostrar esse processo de redirecionamento concerne a compreensão do caráter paulatino da conversão para além do ato singular, apesar da experiência vivenciada no Jardim de Milão. Os processos narrados por Agostinho estabelecem ressonância com a compreensão de conversão elaborada por William James (1995), tornando um dos principais teóricos de análise da pesquisa.

Em uma perspectiva unilateral, a conversão de Agostinho é concretizada por meio da autobiografia, por meio do processo introspectivo de análise e busca de reordenamento interior, do reconhecimento do Eu que era com o Eu que se almeja. Categorias como Eu e Outro emanam do texto agostiniano no mesmo regime que compreende os trabalhos de Gambert (2014).

É possível elucidar, ainda, o encadeamento entre relato e conversão, uma vez que, Agostinho tem como receptor de sua obra não só Deus, mas também o bom cristão que busca a mesma aproximação divina que a dele: ao apresentar a sua conversão, o bispo tem como objetivo estimular a conversão também do seu leitor, nesse sentido, do relato resulta a conversão e a conversão gera o relato.

A perspectiva analítica do processo autobiográfico se torna imprescindível para reconhecer os aspectos caros a escrita autobiográfica das Confissões. Para tanto, faz-se 
presente os textos de Gusdorf, Lejeune e Conceição como aporte teórico.

A relevância desta pesquisa encontra-se aportada na necessidade de produção científica sobre o tema no cenário brasileiro. Estudar a conversão religiosa nos dias atuais, tem sido uma tarefa desempenhada por seguimentos atrelados a motivações institucionais, de cunho estatístico, entre outros, que não assentam suas inquietações em analises do comportamento humano, principalmente em conjunto com o fazer literário. Analisar a autobiografia e o processo de conversão ainda apresenta deficiências nos grupos de pesquisas que se propõem a fazê-lo, embora tenha tomado ritmo crescente, com traduções de obras renomadas e comentários contundentes que fomentam mais analises críticas.

Objetivos: Objetivo geral da pesquisa

A presente pesquisa pretende investigar o fenômeno da conversão como principal impulso à escrita autobiográfica de Santo Agostinho, e suas ressonâncias na compreensão de sua identidade.

Objetivos específicos da pesquisa

a) Analisar o problema da conversão em Agostinho.

b) Depreender da obra de Agostinho, Confissões, a sua noção de conversão.

c)Determinar os aspectos da conversão que impulsionam a escrita autobiográfica.

Material e Métodos: A pesquisa se deterá na decupagem das obras agostinianas que de maneira significativa corroborem para a compreensão do livro VIII de suas Confissões, utilizando, principalmente, a tradução da obra Confissões realizada por Lorenzo Mammì, e a tradução realizada por Frederico Ozanam Pessoa de Barros, a pesquisa não possui caráter comparativo entre traduções da mesma obra, apenas se utiliza interpretações diferentes afim de somar informações que possibilitam atestar de maneira positiva as hipóteses deste trabalho. As investigações acerca das noções de conversão se tornam imprescindíveis uma vez que se pretende determinar os traços particulares da conversão de Agostinho. São apresentados, ainda, modelos que incidem na conversão de Agostinho e realizam tanto o movimento de aversão a Deus quanto o de adesão. Dos relatos, destacam-se os pontos mais relevantes, que perpassam todas as conversões narradas no livro VIII das Confissões, e que funcionam como elementos comuns. As interpretações de diferentes teóricos agostinianos e da autobiografia5, sobretudo Bronw, Nokc, Novaes, Conceição, Gambert e James que, por sua vez, cria um terreno sólido sob as considerações que se estabelecem a partir de suas leituras.

Resultados e Discussão: A pesquisa está na fase dissertativa do texto final, isto é, está na fase da compilação dos resultados das análises empreendidas anteriormente. A discussão que se segue compete a análise, primeiro, da autobiografia, do fazer autobiográfico.

A principal perspectiva sobre a qual se analisa a escritura autobiográfica, isto é, que uma pessoa que escreve sobre sua própria vida, pode ser comprovada ou não quando relacionados os três elementos que formam o nome e que representam, segundo Georg Misch, a definição básica do gênero autobiográfico (MISCH, 1949, p. 7): 1) a grafia, como meio linguístico de representação; 2) o auto, prefixo que indica a 
identidade de um sujeito consigo mesmo, ou seja, uma instância coerente e inteira; e 3) o bios, a vida como algo que possui existência real fora da escritura.

No que se refere à dimensão linguística, vale dizer que a escritura autobiográfica, na medida em que pretende estabelecer referências a uma realidade externa ao texto, vinculada à pessoa que também é autor, e ao passado desta, pertence ao discurso pragmático, e não ao ficcional. Nesse sentido, recebe o mesmo tratamento da historiografia, das ciências naturais, ou qualquer outra área que esteja inserida no quesito "verdade".

Outra perspectiva é analisada a partir do lugar do sujeito. Desde o século XX, o sujeito é colocado em destaque pelos principais estudiosos da autobiografia, considerando aspectos como a consciência de si, o uso da memória como parte integradora da vida do escrevente e sua capacidade de carregar elementos divergentes numa narração, como o próprio sentido do eu-narrador e o eu-narrado apontando, por sua vez, uma instabilidade do pensamento impossibilita, à primeira vista, "a ideia de uma 'substância' do eu que se mantém fiel a si mesma através do tempo" (GALLE, 2006, p. 68)

Partindo da perspectiva estabelecida por Lejeune, tem-se o pacto autobiográfico, conceito que confere veracidade ao texto autobiografado; entre Agostinho de Hipona e Confissões ele é identificado 1) ao sinalizar seu nome na capa de sua obra, estabelecendo um contrato com o leitor - quando o narrador se comporta como o autor, de tal maneira que o leitor não duvide que o "eu" tratado no livro seja o mesmo que o assina; 2) ao reconhecer "rastros" autobiográficos como a fala em primeira pessoa, a ressonância de seus textos com fatos da vida do autor; e 3) e a experiência religiosa presente, destacando, no ato de sua conversão.

O problema ao eleger Lejune para análise da obra de Agostinho reside no fato de que o teórico francês determina o nascimento do gênero autobiográfico no século XVIII com a aparição das Confissões de Rousseau, portanto toda a escrita de si que se deu antes do determinado é inválida. Georges Gusdorf, porém, adverte para uma literatura do eu em toda sua amplitude: "os estudos das escrituras do eu devem abraçar sem discriminação todos os textos em que o sujeito escrevente toma a si mesmo por objeto de sua escrita". Gusdorf defende que ainda na Grécia antiga já existiam correntes de pensamentos responsáveis pela origem da noção de identidade, característica fundamental para o autor, que acredita que a jornada autobiográfica nasce da necessidade do esclarecimento daquilo que se é: o esclarecimento do homem voltada para a sociedade e do homem voltado para o transcendental. Estabelece, ainda, analises a respeito do uso da memória como ferramenta de reconstituição na personagem que se escreve.

Mais tarde, discute-se a noção de identidade narrativa que, nas Confissões, é acompanhada do dinamismo do Eu que escreve, isto é, o estado do Eu das Confissões tende a sua dissolução no Outro, O Eu é sempre um estado de Intervalo, em constante dissolução até a presença do Outro. Aí reside a autenticidade de Agostinho, não há a tentativa de cristalização do Eu que é narrado, mais adiante, no Outro; a presença do Outro não é definida porque há a necessidade de se estabelecer uma identidade que só pode ser contada por Agostinho, a presença do Outro reside no dinamismo estabelecido pela sua própria existência, há um Eu que se conhece, há a vontade de mudança, e a há um Eu somado de um Outro que é o mesmo Eu, porém dinâmico. Analisa-se o texto 
agostiniano e os rastros linguísticos que permitem essa abordagem; isso não quer dizer que há a tentativa de identificar uma abordagem linguística no texto autobiográfico, o que se realiza é a depreensão dos conceitos no próprio texto, isto é, analisa-se o texto e chega-se a conclusões por meio e do próprio texto, sem amarras conceituais.

A respeito da conversão, as analises dirigiram-se para as concepções de William James, as quais aportam-se nas Confissões, extraindo do texto aspectos compatíveis as contribuições de James, as ressonâncias as quais se estabelecem somam esforços para a compreensão do fenômeno da conversão aliado a escrita autobiográfica.

Conclusão: As conclusões as quais se chegam nesta etapa da pesquisa ratificam as hipóteses previamente estabelecidas. A obra Confissões é um claro exemplar do gênero autobiográfico, porém carrega sob suas linhas não só as características estilísticas necessárias para tal denominação, mas um relato marcado pela experiência religiosa, pelo exercício introspectivo do reconhecimento de sua natureza, pelo reconhecimento de si enquanto sujeito, impulsionado pela experiência religiosa de sua conversão. É, então, a conversão agostiniana que se dá de maneira paulatina, ultrapassando a noção de apenas um ato singular de manifestação religiosa, a responsável pela escrita do íntimo: o relato autobiográfico é o resultado de sua conversão. Considerações seguem a partir dessa premissa: a) a experiência particular, quando manifestada na escrita de si, possibilita a experimentação universal do ato de conversão; e b) a conversão que se dá de maneira segmentada possibilita o reconhecimento real do Eu que se escreve.

\section{Referências Bibliográficas}

AGOSTINHO, Santo. Confissões. Trad.: Frederico Ozanam Pessoa de Barros, introdução Pe Riolando Azzi, S.D.B - [Ed. Especil]. - Rio de Janeiro: Nova Fronteira, 2012.

. Confissões, Tradução e Prefácio de Lorenzo Mammi. Revisão por Moacyr A. Novaes. São Paulo: Pinguin Companhia, 2018.

. A doutrina cristã: manual de exegese e formação cristã. São Paulo: Paulus (coleção Patrística, volume 17), 002.

. "De Mendacio" e "Contra Mendacium", In: Obras de San Agustin: tratados morales. Madrid: Biblioteca de Autores Cristianos, 1954, v.12. 995 p. Edição bilíngüe: espanhol e latim.

Alberti, V. Literatura e autobiografia: a questão do sujeito na narrativa. Estudos Históricos, Rio de Janeiro, vol. 4, n7, 1991, p. 66-81.

ARAUJO, P. G. TRATO DESFEITO: o revés autobiográfico na literatura contemporânea brasileira. Dissertação (mestrado) - Universidade de Brasília, Departamento de Teoria literária e Literaturas, 2011.

BUARQUE, V. de A. de C. Uma história moral, apologética e... moderna? A escrita católica do século XVIII ao início do século XIX. História da historiografia, Ouro Preto, n.6, p. 142-157, mar. 2007.

- Autobiografias eclesiásticas: para além da representação de si. Revista Brasileira de História das Religiões. ANPUH, Ano III, n. 9, Jan. 2011. Dossiê Questões teórico-metodológicas no estudo das religiões e religiosidades. Disponível em <http://www.dhi.uem.br/gtreligiao> Acesso em 2 de novembro de 2017. 
BROWN, P. R. L. Santo Agostinho, uma biografia. Tradução de Vera Ribeiro. $7^{a}$ ed. Rio de Janeiro: Record, 2012.

CONCEIÇÃO, D. R. da. Levar a mão sobre si: Religião e literatura autobiográfica. In: Religião e linguagem: abordagens teóricas interdisciplinares. Paulo Augusto de Souza Nogueira (org.). - São Paulo: Paulus, 2015. - (Coleção Sociologia e religião) p.143178.

FILOMENA, N. O "cuidado de si na hermenêutica do sujeito de Michel Foucault. Palestra apresentada no II Encontros com a Filosofia, em 9 de novembro de 2006.

FOUCAULT, M. A Hermenêutica do Sujeito: curso dado no Collège de France (19811982). Edição estabelecida por Frédéric Gros. Trad.: Márcio Alves da Fonseca e Salma Tannus Muchail - 2a edição. São Paulo: Martins Fontes, 2006.

GALLE, H. Elementos para uma nova abordagem da escrita autobiográfica. Revistacdo Programa em Pós-Graduação em Letras. Universidade do Estado do Rio de Janeiro: UERJ. vol. 13. 2006.

GAMBERT. J. Confession et Autobiographie: Regards croisés sur saint Augustin et Rousseau. Distribution électronique Cairn.info pour Le Seuil. 2014, p. 221-242.

GENETTE, Gérard. Palimpsestes. La littérature au second degré. Paris: Seuil, 1982. . Introduction à l'architexte. Paris: Seuil, 1979.

GOMES, A. M. A (2011). Um estudo sobre a conversão religiosa no protestantismo histórico e na psicologia social da religião. Ciências da Religião - História e Sociedade, 9(2), p. 148-174.

GUSDORF, George. Lignes de vie II. L'auto-bio-graphie.Paris: Odile Jacob,1991.

JAMES, W. As variedades da experiência religiosa: um estudo sobre a natureza humana (O. M. Cajado, Trad.). São Paulo: Cultrix, 1995.

. Condiciones y limites de la autobiografia. Suplementos Antropos, Madrid, n.29,

p.9-20, 1991. <https://pt.scribd.com/document/265567507/Condiciones-y-limites-de-laautobiografia-PDF-Georges-Gusdorf>. Versão eletrônica. Visitado em 18 de setembro de 2019.

Hervot, B. M. Georges Gusdorf e a autobiografia. UNESP - Universidade Estadual Paulista Júlio de Mesquita Filho. Faculdade de Ciências e Letras de Assis Departamento de Letras Modernas. Assis - SP - Brasil.

LEJEUNE, Philippe. O pacto autobiográfico. Belo Horizonte: UFMG, 2008.

NOCK, A. D.. Conversion: the old and the new in religion from Alexander the Great to Augustine of Hippo. Oxfort University Press. 1933

RICOEUR, P. O si-mesmo como um outro. Trad. Luci Moreira Cesar. Campinas: Papirus, 1991. Letras de Hoje, Porto Alegre, vol. 43, n. 4,p. 99-122, out./dez. 2008.

RODRÍGUEZ, R. El género autobiográfico y la construcción del sujeto autorreferencial. Filología y Lingüística XXVI (2): 9-24, 2000.

SOTE, R. F..O livro VIII das Confissões de Agostinho de Hipona a partir das noções de caritas e cupiditas. Universidade de São Paulo, Faculdade de Filosofia, Letras e Ciências Humanas, Departamento de Pós-graduação em Filosofia. São Paulo, 2017.

Palavras-chave: Autobiografia. Conversão. Santo Agostinho. Literatura.

Grande-área: Ciências Humanas

Área: Ciências da Religião 


\title{
BANJO, UM OGAN BAIANO EM BELÉM DO PARÁ
}

\author{
Nome do(a) Bolsista: Patrícia Moreira Perdigão dos Santos \\ Nome do(a) Orientador(a): Taissa Tavernard de Luca
}

\begin{abstract}
Resumo: O ente desta pesquisa é Ivonildo dos Santos, o ogan ${ }^{1}$ Banjo, natural de Acupe, interior de Santo Amaro na Bahia, homem negro que chegou na década de 80, na mesma época que sacerdotes candomblecistas baianos intensificaram suas visitas a Belém ou estabeleceram moradia, além de ter acompanhado de perto os primeiros candomblecistas que foram buscar iniciação na capital baiana, após o retorno de Salvador. A pesquisa objetiva reconstruir a trajetória de vida do ogan, com ênfase na trajetória religiosa, na busca por mapear as relações que estabeleceu com os primeiros terreiros de candomblé de Belém e a contribuição que deu para a organização e expansão dessa identidade afro-religiosa; tem caráter etnográfico, contando com a realização de entrevistas semiestruturadas, levantamento documental e observação participante.

Nascido na terra que exportou o candomblé para o Pará, contemporâneo dos fundadores do candomblé local e um ogan cujo conhecimento foi referência nos terreiros por onde passou, foi morto no ano de 2016, em frente à sua residência, alvejado por tiros que parecem ter motivação numa briga, deixou um legado que merece ser estudado com o fim de registrar essa parte importante da memória paraense e afro-religiosa, e porque é mote que pode revelar fatos desconhecidos sobre a chegada do candomblé no Pará e como essa religião constrói os seus ícones.
\end{abstract}

\section{Introdução:}

O ente desta pesquisa é Ivonildo dos Santos, o ogan ${ }^{2}$ Banjo, natural de Acupe, interior de Santo Amaro na Bahia, homem negro que chegou na década de 80, na mesma época que sacerdotes candomblecistas baianos intensificaram suas visitas a Belém ou estabeleceram moradia, além de ter acompanhado de perto os primeiros candomblecistas que foram buscar iniciação na capital baiana, após o retorno de Salvador. A pesquisa objetiva reconstruir a trajetória de vida do ogan, com ênfase na trajetória religiosa, na busca por mapear as relações que estabeleceu com os primeiros terreiros de candomblé de Belém e a contribuição que deu para a organização e expansão dessa identidade afro-religiosa; tem caráter etnográfico, contando com a realização de entrevistas semiestruturadas, levantamento documental e observação participante. 
1 Cargo da hierarquia candomblecista dada a homens impassíveis ao transe que se tornam responsáveis pelos instrumentos musicais e cantos litúrgicos, imolação de animais, entre outras funções. Além do cargo, recebem um título que determina a função específica a qual deve se dedicar no culto.

2 Cargo da hierarquia candomblecista dada a homens impassíveis ao transe que se tornam responsáveis pelos instrumentos musicais e cantos litúrgicos, imolação de animais, entre outras funções. Além do cargo, recebem um título que determina a função específica a qual deve se dedicar no culto.

Ji Gongonji ${ }^{3}$, Nidinho, Baiano, Banjo ou Nego Banjo são os outros nomes pelos quais Ivonildo era conhecido. No trabalho, utilizarei o nome Banjo por ser o mais popular na rede de relações do pesquisado, no entanto, nas citações de entrevistas, os outros nomes aparecerão. $\mathrm{O}$ interesse em escrever a biografia dele não foi espontâneo. Por falta de experiência acadêmica, mesmo intuindo que a figura desse homem ainda poderia ser explorada por outros enfoques por ser uma figura muito conhecida no candomblé paraense, foi a minha orientadora, professora Taissa Tavernard, quem sugeriu a biografia. Sempre confiei no conhecimento e experiência dessa africanista local, no entanto, eu ainda não tinha bem definido o porquê de escrever sobre a vida dele e nem da relevância que um trabalho como esse teria para a academia. Passei algum tempo amadurecendo a ideia, mas foi certamente depois da leitura de dois artigos que a proposta se tornou uma certeza.

Os textos foram da antropóloga Lilia Schwarcz (2013) e Benito Schmidt (1996), estes autores me deram o panorama que eu precisava sobre os riscos que o método biográfico impõe ao pesquisador e esclarecem que a biografia pode servir como via de observação da realidade. Pareceu-me viável, então, que através das narrativas dos informantes sobre Banjo seria provável apreender e compreender o contexto em que o candomblé começou a expandir-se em Belém, convenci-me, também, de que o receio de prejudicar a análise dos dados e contextos é uma preocupação epistemológica de qualquer biógrafo e um risco ao qual todos estão expostos: o de inventar trajetórias, conferir evidência aos sujeitos que tiveram pouco destaque e o de não registrar as ambivalências da vida do biografado (SCHWARCZ, 2013).

$O$ fato de ser nativa e escrever sobre alguém que eu conheci, e que fez parte do grupo religioso em que me insiro, pode aumentar o riscos de uma análise sob viés político/ideológico, mas também traz benefícios para a coleta de dados, uma vez que eu já conhecia os informantes e onde poderia encontra-los. De antemão, afirmo que investigar a trajetória religiosa de Banjo, se constitui uma atividade científica que considerei relevante porque pode ajudar a refletir e/ou levantar informações para outras investigações sobre o candomblé paraense.

Conhecer a rede de relações construídas em torno dele me dá pistas de onde posso começar a pesquisa e dos entraves que posso encontrar. Se por um lado, conhecer o campo pode ser um ponto positivo, por outro, biografar um sacerdote que me era familiar é um desafio pois me conduz a investigar as minhas próprias lembranças e as do grupo que faço parte, tendo ciência de que preciso transformar o familiar em exótico 
e domesticar o olhar fazendo uso das categorias científicas, além de empregar a descrição densa para interpretar o que foi dito, os silêncios e outras atitudes para salvar no discurso social o que "pode extinguir-se e fixá-lo em formas pesquisáveis" (GEERTZ, 1989, p. 31).

Em muitos anos de candomblé, a referência que sempre vi e ouvi nas festas foi Banjo. $\mathrm{Na}$ pesquisa do trabalho de graduação, abordei um dos fatos mais polêmicos de sua vida: por ser ogan, não tinha o direito de iniciar uma pessoa na religião, no entanto, fez. Isso gerou conflitos e abriu precedentes, a filha de santo precisou validar a feitura passando para a tutela espiritual de um babalorixá 4 , a quem compete a realização desse ritual no candomblé. No ano de 2011, gravei entrevista, quando Banjo, além de explicar esse fato, fala sobre as suas origens religiosas na Bahia e sobre a trajetória do candomblé no Pará. Esse material foi o ponto de partida para

3 Orukó de Ivonildo. Nome que todo iniciado no candomblé recebe. O orukó é anunciado pelo orixá no dia da festa em que a pessoa é apresentada à comunidade religiosa como um iniciado, passando a ser chamado por esse nome posteriormente.

4 Cargo mais alto da hierarquia candomblecista, o dirigente masculino de um terreiro. Pai-de-santo.

construir o trajeto da pesquisa, considerando os nomes e lugares por ele citados como potenciais informantes.

\section{Objetivos GERAL}

Reconstruir a trajetória de vida de Ivonildo dos Santos, com ênfase na religião, para investigar as contribuições desse ogan ao candomblé paraense.

Específicos: Mapear as relações que estabeleceu com os primeiros terreiros de candomblé de Belém;

Analisar a formação e as influências religiosas que recebeu na Bahia através das relações familiares e dos grupos religiosos que transitou antes de vir para Belém.

Apreender, através das narrativas de informantes da pesquisa, e descrever as contribuições do ogan para a radicação e expansão do candomblé de Belém do Pará.

Material e Método: A pesquisa se insere no método biográfico pois compreende o período de vida de Banjo, analisando os contextos que influenciaram as suas escolhas e a sua trajetória. Tem caráter etnográfico porque propõe enfoque na trajetória religiosa, sendo necessário compreender e descrever o ethos religioso que serviu de base para o comportamento, valores e crenças do pesquisado e dos grupos candomblecistas nos quais ele transitou. Captar a importância dos conhecimentos trazidos pelo ogan em um contexto em que a religião era carente de sacerdotes experientes e em qual medida esses conhecimentos e a experiência de Banjo ajudou a radicar e expandir a religião é o cerne deste trabalho.

Por ser pesquisadora nativa e por ter escrito um trabalho anterior que circulou nas 
comunidades candomblecistas que estão sendo revisitadas para este trabalho, utilizei a minha rede de relações para me reaproximar dos informantes, previamente listados com base na entrevista de Banjo em abril de 2011. O começo foi pela pessoa que mais conviveu com ele nos últimos anos de sua vida, a companheira de Banjo, Maiume, que foi o elo com Mameto Nangetu, amiga de longa data. A terceira entrevista foi com a lyalorixá ${ }^{5}$ do pesquisado, mãe lyanarê, que me convidou para as festas de candomblé em seu terreiro, na ocasião da festa em homenagem ao orixá Ogun, ao fim da cerimônia, aproveitei a oportunidade para fazer o convite para o ogan que realizava a cerimônia, seu nome não será citado porque a entrevista ainda não foi realizada. Esse ogan foi citado nas entrevistas realizadas como tendo sido amigo e aprendiz. Ainda nessa festa religiosa, onde reencontrei e conversei com pessoas que tive contato na minha trajetória no candomblé, fui convidada por mãe Obasanji, lyalaxé 6 do templo, a Ihe entrevistar. Grata surpresa porque ela se propôs a contar as muitas histórias de Banjo que conhecia. Ela foi a quarta entrevistada, ficando o ogan agendado para ser o próximo.

Concomitante às entrevistas, foi realizada busca na internet utilizando os termos "Nego Banjo", "Ivonildo dos Santos", "mestre da cultura afro-brasileira" entre outros, encontrando nessas buscas alguns vídeos em que ele toca e canta músicas autorais, propagandas de oficinas e rodas de conversas sobre a religiosidade e cultura

5 Dirigente Feminino de um terreiro. Mãe-de-santo.

6 Cargo dado à sucessora de um terreiro. Zeladora do axé. O masculino é Babálaxé. afro-brasileira, notícias sobre a sua morte no ano de 2016 e uma entrevista no ano de 2008 ao Instituto Nangetu, tendo como entrevistador o professor da Faculdade de Artes Visuais da Universidade Federal do Pará (UFPa) Arthur Leandro Maroja, também conhecido como Táta Kinamboji (filho do Mansu Nangetu e colaborador do instituto). Nessa entrevista, Banjo fala sobre a sua origem religiosa, os motivos que o trouxeram para Belém, a dificuldade financeira que enfrentava e o legado que deixaria para a religião e para a cultura afro.

A coleta de dados é realizada através de entrevistas semiestruturadas, levantamento documental e observação participante, fazendo uso da descrição densa para o melhor entendimento dos contextos encontrados na trajetória da pesquisa e dos dados coletados. As entrevistas são gravadas em aparelho celular, posteriormente transcritas e entregues aos informantes na ocasião em que eles assinam o Termo de Compromisso Livre Esclarecido (TCLE). Durante a entrevista, é solicitado ao informante fotos ou outro tipo de documento sobre o biografado, tais documentos são digitalizados e devolvidos na ocasião da assinatura do TCLE.

Resultado e Discussão: As entrevistas realizadas, com os informantes listados anteriormente, reafirmam a rede de relações apontadas por Banjo na entrevista concedida a mim no ano de 2011 e o tipo de relação que estabeleceu com os principais 
terreiros ligados à tradição candomblecista paraense das três nações ${ }^{7}$ desde a Bahia. $\mathrm{Na}$ ocasião, ele também falou sobre as identidades candomblecistas no Pará, fazendo comparações com Salvador, sendo tais relatos registros das construções e reconstruções dessas identidades e da historicidade da religião, considerando que o jogo das identidades do candomblé paraense sempre foi e ainda se acirra.

Foi possível verificar nas narrativas e documentos levantados até agora que o pesquisado deu grande contribuição para o candomblé local porque se propôs a ensinar os conhecimentos da tradição candomblecista baiana desde a sua chegada em Belém até a sua morte, principalmente aqueles relacionados à musicalidade da religião. Por outro lado, as narrativas sugerem a interpretação de que na medida em que o candomblé foi se estabelecendo no Pará, os conhecimentos religiosos se popularizando, o interesse dos terreiros em relação a Banjo pareceu declinar. Mas essa não é a única análise possível a partir dos dados. Traços da personalidade de Banjo, a maneira de ensinar e fatores socioeconômicos também podem ser pensados para analisar porque a baianidade do pesquisado, fonte de capital simbólico nos candomblés de Belém, foi perdendo força com o passar do tempo. Tal análise pode ser uma boa via para entender como o candomblé paraense criou seus ícones.

Outra importante descoberta feita através de buscas na internet foi a entrevista no ano de 2008 concedida ao professor Arthur Leandro. Na introdução da entrevista, Banjo é apresentado como mestre na musicalidade da religiosidade afro-brasileira, o documento também cita que ele foi reconhecido pelo Departamento de Patrimônio Histórico da Fundação Cultural do Município de Belém (FUMBEL) como a matriz geradora da musicalidade do candomblé praticado em Belém sem citar o ano que isso ocorreu. No rastro de documentação que pudesse comprovar essa informação, estive

7 Vertentes rituais que se diferenciam pelos traços étnicos preservados preponderantemente e que caracterizam a identidade do culto e dos praticantes.

na FUMBEL onde obtive a informação de que o arquivo desse departamento foi realocado e a documentação não estava organizada para consulta.

Ainda na internet, no blog do Instituto Nangetu, descobri que Banjo recebeu a "Comenda Mãe Doca de Mérito Afro-religioso" no dia 23 de Abril de 2012. Trata-se de uma condecoração realizada pela Assembleia Legislativa do Pará (ALEPA) em reconhecimento pelo esforço em promover, proteger e difundir a cultura afro-religiosa.

Conclusão: A rede de relações de Banjo com os terreiros de candomblé que são referências de suas nações em solo paraense e a vinda para Belém no período de radicação da religião sugerem ser importante a investigação sobre as contribuições de Banjo para a expansão da religião na medida em que as festas de candomblé são parte essencial da liturgia e o nome dele figura como referência desses conhecimentos, que aliados à sua baianidade, fonte de prestígio entre os paraenses, o tornou reconhecido 
pelos terreiros por onde passou.

As entrevistas até aqui realizadas e os dados coletados na internet confirmam que, pelo conhecimento que possuía e pela iniciativa que teve de ensinar a tradição candomblecista baiana desde a sua chegada em Belém até a sua morte, principalmente aqueles relacionados à musicalidade da religião, ele foi um nome importante para a organização e expansão do candomblé no Pará. No entanto, a pesquisa ainda está levantando dados para melhor documentar e registrar esses fatos, na tentativa de demonstrar de forma mais precisa quais foram essas contribuições.

Referências: GEERTZ, C. Por uma teoria interpretativa da cultura. In: A interpretação das culturas. I.ed. Rio de Janeiro: LTC, 2008.

PERDIGÃO, P. O Candomblé em Cima do Muro: reafricanização ou ressignificação?. Trabalho de Conclusão do Curso de Ciências da Religião. Belém: UEPA, 2011. 68 p.

SCHMIDT, B. O gênero biográfico no campo do conhecimento histórico: trajetória, tendências e impasses atuais e uma proposta de investigação. Anos 90: revista do Programa de Pós-Graduação em História. Porto Alegre. n. 6 (dez. 1996), p. 165-192.

SCHWARCZ, L. Biografia como gênero e problema. História Social, 2013, n. 24, p. 51-73.

Palavras-chave: Ogan; Candomblé; Religião; Musicalidade; Belém.

Grande-área: Ciências Humanas Área:

Ciências da Religião Teologia 


\title{
O BELO RELIGIOSO CONVENIENTE DE ARNOLD SCHÖNBERG
}

\author{
Nome do(a) Bolsista: Sergio William Damasceno da Silva \\ Nome do(a) Orientador(a): Manoel Ribeiro de Moraes Junior
}

\begin{abstract}
Resumo: A pesquisa surgiu sob os estudos sobre Teoria crítica, arte e religião. A primeira intenção é desenvolver um argumento que torne possível a articulação de conceitos da Escola de Frankfurt para o enfrentamento do objeto de pesquisa, a ópera denominada Moses und Aron do compositor austríaco Arnold Schönberg. Para que o objeto em questão seja enfrentado, os estudos do filósofo Teodor Adorno são importantes para a suspeita acerca do problema da conveniência estética de Schönberg aos preceitos de composição provenientes de uma tradição cultural que não permite o progresso do material musical. Sob a hipótese do belo conveniente ao status quo da reprodução técnica e acerca da concepção fetichista que a religião confere ao desenvolvimento estético da ópera, o presente estudo se desenvolveu.
\end{abstract}

Introdução: A atual pesquisa se desloca para além da compreensão estética do material per se. Direciona-se para a contradição social moderna entre religião e arte autônoma que gera a repressão de uma e a liberdade de outra na tentativa de união sintética, de acordo com a compreensão adotada por Theodor W. Adorno (2010). Visa enfrentar, para termo de delimitação de objeto de estudo, a ópera bíblica inacabada Moses und Aron de Arnold Schönberg que data dos anos 1930 e 1932. Delineia-se tanto em seu enredo dramático, quanto em seu material estético, para a busca do elemento de contradição entre a autonomia do belo e o caráter dogmático de leis religiosas. Esse objeto se trata de uma ópera inacabada que contém em seus nome doze letras em referência ao método dodecafônico de composição (MENEZES, 2001, p. 14). Como referência clássica de estudos sobre o tema, e por reconhecimento dos estudos sociologia da música, serão útil os textos sobre a condição social da música no teórico de Frankfurt supracitado, em especial o Sakrales Fragment (ADORNO, 1978, p. 454475), nos Musikalische Schriften II, Quase una fantasia, para entender de que maneira o belo autônomo se encontra imerso a valores absolutos que impedem os momentos parciais de liberdade na referida ópera. "Com efeito, a liberdade absoluta na arte, que é sempre a liberdade num domínio particular, entra em contradição com o estado perene da não-liberdade no todo" (ADORNO, 2015, p. 358).

Objetivo: Detectar traços da dialética entre a religião e arte na ópera Moses und Aron de Arnold Schönberg que sejam convenientes ao projeto do esclarecimento.

\section{Específicos}


- Identificar o panorama normativo da teoria crítica da arte de Adorno, principal comentador da ópera bíblica.

- Levantar conceitos de teoria estética e nos autores referenciais, apontando os limites da teoria crítica de Adorno para abordar a arte religiosa.

- Entender quais elementos nos personagens religiosos e no material estético da ópera podem ser identificados enquanto repressores da arte autônoma a partir do libreto e da partitura.

Material e método: A partir da divisão de leitura do referencial da Escola de Frankfurt, uma série de leituras foi desenvolvida desde a graduação de tal forma que fosse possível entender os fenômenos estéticos peculiares ao fim do século XIX e início do século XX. Entendendo-se que é difícil negar os estudos de Walter Benjamin e Theodor Adorno no que diz respeito à arte no contexto da reprodutibilidade técnica e os modos de fetichização da cultura. A divisão da obra de Adorno em duas fases fica clara. Primeiramente, uma crítica à indústria cultural a partir da metodologia da teoria crítica da sociedade. Em segundo momento, a constatação de como em diversos setores a reificação dos objetos e da subjetividade acontecem por meio da conveniência organizada pelo projeto dominante na sociedade capitalista. Dentro desses estudos de crítica ao projeto iluminista, encontrou-se uma abordagem crítica de Adorno em relação as composições do músico austríaco Arnold Schönberg enquanto uma alternativa de fuga dos momentos de submissão ao projeto do capital industrial. No entanto, a tentativa é frustrada a partir do momento em que o autor confirma que a própria música de Schönberg é conveniente com elementos coisificantes, especificamente na ópera Moses und Aron. Ela apresenta dois elementos que proíbem sua progressão racional: a metrificação e a submissão do material à religião.

Com critério de respeito científico e pelo caminho que já foi traçado na pesquisa, opta-se pelos estudos dos textos adornianos como fonte primária para se entender a dialética entre arte e religião na referida ópera, constatando elementos que são convenientes para com o projeto desenvolvido pelo iluminismo e com elementos religiosos que influenciam na metrificação dos elementos musicais de acordo com leis matemáticas absolutizantes.

Resultado e discussão: A pesquisa encerrou o levantamento das fontes que pesquisaram a referida ópera dentro da metodologia da teoria crítica. Entende-se que a composição possui elementos de conveniência para com o status quo, mesmo com a aparência dodecafônica que revela uma crítica ao modelo tonal de composição. Os resultados estão sendo preparados para serem inseridos no corpo do texto da dissertação.

O primeiro capítulo da dissertação será destinado à revisão metodológica da teoria crítica da indústria cultural, apontando os conceitos lançados por Horkheimer, o qual encontra na religião uma possibilidade de expressão do espírito livre do ser humano. Mesmo assim, Horkheimer lança a categoria da "conveniência", que busca os elementos que são ligados ao processo de coisificação do conhecimento, que em grande parte são mantedores do status quo. Com a mesma concepção do parceiro a respeito da consideração de fatores sociais ligados à cultura humana, porém com a diferença de enxergar na arte, e não na religião, a possibilidade de um terreno de liberdade que 
possibilita a manifestação livre, Adorno apresenta a sua concepção do belo autônomo, isto é, a obra de arte mantém a possibilidade renovação. Isso implica dizer que não deve estar submetida a critérios de mercado ou a elementos prescritivos da religião.

O segundo capítulo abordará uma temática estética voltada para as contribuições de Adorno para a interpretação da realidade econômica que condiciona a produção artística no mundo contemporâneo. Uma releitura das obras tradicionais concernentes à estética e a teoria estética da sociedade será um elemento importante nesse capítulo. Por fim a releitura da ópera a luz da teoria crítica será realizada com vistas nos elementos que afirmam o status quo da produção reificada da obra de arte. A escrita da dissertação está em momento inicial. A partir do texto referente a metodologia no presente projeto será desenvolvido o primeiro capítulo da mesma, bem como os elementos apresentados no referencial teórico. O segundo capítulo partirá das considerações apontadas na justificativa e no concernente ao campo de pesquisa escolhido, a saber, a ópera de Schönberg a partir de interpretações estéticas. O terceiro trabalhará com o libreto e o material musical da referida ópera, objeto de estudo.

Conclusão: A partir do desenvolvimento da pesquisa supracitado, pode-se entender que a pesquisa proposta se encaminha para o desfecho, pelo qual se alcançará resultados empíricos acerca do material da ópera bíblica, objeto deste estudo.

Entende-se que uma reorganização da escuta e da análise objetiva do material musical, leia-se partitura, bem como do libreto, revelarão detalhes acerca da conveniência de Schönberg para com os modos dogmatizantes da religião presentes na cultura. A influência da religião monoteísta de Moisés revelará que o material do compositor austríaco depende de elementos que são apresentados nas leis judaicas, as quais são fontes para a composição da música, porém condicionam a produção estética a um efeito que respeita uma causa absoluta, isto é uma regra geral.

Referências bibliográficas: ADORNO, T. W. \& HORKHEIMER, M. Dialética do Esclarecimento: fragmentos filosóficos. Tradução de Guido Antonio de Almeida, Rio de Janeiro: Zahar, 1985.

ADORNO, T, W. \& MANN, T. Correspondecia: 1943-1945. 1.ed. trad. Nicolás Gelormini. Buenos Aires: Fondo de Cultura Económica, 2006.

ADORNO, T. W. Dialética Negativa. Tradução de Marco Antonio Casanova, 1. Ed. Rio de Janeiro: Zahar, 2009.

Experiência e criação artística: paralipomenos à 'teoria estética'. trad. Arthur Morão. Lisboa: Edições 70, 2003.

Perspectiva, 1974.

Filosofia da nova música. Tradução de Magda França. São Paulo:

. History and Freedom: Lectures 1964-1965. Translate by Rodney Livingstone. Cambridge: Polity Press, 2008.

Introdução à sociologia da música: doze preleções teóricas. Tradução Fernando de M. Barros. São Paulo: UNESP, 2011.

La idea de historia natural. In Actualidad de la filosofia. Tradução de José Luis Arantegui Tamoyo. Barcelona: Paidós, 1991. 
. Mínima Moralia. Tradução de Artur Morão. São Paulo: Edições 70, 2001. - O fetichismo na música e a regressão da audição. In: Textos escolhidos. Trad. Zeljko Loparic... [et al]. São Paulo: Nova Cultural, 1989. (Os Pensadores).

. Prismas: crítica cultural e sociedade. trad. Augustin Wernet e Jorge Mattos Brito de Almeida, São Paulo: Ática, 1998.

Sakrales Fragment. In Musikalische Schriften I-III: Klangfiguren, Quasi

una Fantasia, Musikalische Schriften III. Frankfurt am Main: Suhrkamp, 1978.

Teoria estética. Lisboa: edições 70, 2015.

. Teses sobre religião e arte. Tradução de Newton Ramos de Oliveira.

Disponível em: bibliotecasocialvirtual.files.wordpress.com/2010/06/adorno-tesessobrereligiao-e-arte.pdf

Palavras-chave: Teoria crítica. Religião. Arte. Shönberg.

Grande área: Ciências Humanas

Área: Ciências da Religião e Filosofia 


\title{
O SACRIFÍCIO E O SACRIFICADOR: UM ESTUDO ETNOGRÁFICO NO TERREIRO DE CANDOMBLÉ ILÊ AXÉ OYÁ NIROLÊ IGBALÉ (KWE ZANVIS AVESSAN), ANANINDEUA-PA
}

\author{
Nome do(a) Bolsista: Wellington Ramos de Carvalho \\ Nome do(a) Orientador(a): César Carbullanca Nuñez
}

Resumo: O Candomblé é uma das religiões que mantém diversas modalidades de prática sacrificial, dentre elas e provavelmente a mais importante, o sacrifício de sangue. Tal prática é responsável pela manutenção do equilíbrio das energias (Axé) que sustentam cada indivíduo e o mundo em si. Porém, com se processam as visões daqueles que estão diretamente envolvidos no processo ritual? Quem são os responsáveis pela prática? Como se dá sua escolha, iniciação e pedagogia necessária para assumir tal cargo?

Buscando solucionar estes questionamentos e quaisquer outros que possam vir a surgir, se faz necessária uma análise mais aprofundada acerca de como o sacrifício se desenvolve, processa e alimenta a cosmovisão dos principais envolvidos, sobretudo dos sacerdotes responsáveis pela imolação, os chamados Pejigans, bem como a escolha deste, processo iniciático, pedagogia e corpo hierárquico.

Introdução: O sacrifício é, seguramente, uma das práticas mais antigas utilizadas pelos diversos sistemas religiosos ao longo da história e acompanha a humanidade na sua jornada por "agradar", "retribuir" e "pedir" aos deuses e deusas entre outras entidades que regulam o cotidiano de cada comunidade, cada indivíduo. Tais ritos, ainda hoje, dão sentido e estabilidade ao cotidiano de religiões e, como já dito, à vida de cada um dos praticantes destas.

O Candomblé tem em seu corpo de tradições e ritos, diversos tipos de elementos, objetos de sacrifícios, desde as ervas que, quando maceradas darão origem a "banhosde-cabeça" ou que servirão ao propósito das "camas-de-folha" para Orixás e iniciados, até aquele que seja, provavelmente o mais importante dos elementos sacrificiais, o sangue animal. As práticas sacrificiais são tão importantes para o Candomblé contemporâneo quanto o foram para o culto judaicos, do qual deriva o cristianismo e saber sobre o que sustenta, justifica e perpetua tais práticas, é compreender, entre tantas coisas, como as percebem os adeptos da religião de forma geral, o sacrificante ou, até mesmo, aquele para o qual o sacrifício teria efeito direto, já que esta prática é a parte fundamental da cosmogonia das religiões de tradição africanas e sustentam todos os processos desde a iniciação de um membro, até seu ritual fúnebre.

OBJETIVOS: Muita coisa se tem escrito e documentado acerca do Candomblé, porém muito ainda se tem por fazê-lo, o que se deve ao fato de ser esta uma religião "do segredo" e de, por um longo tempo, não ser do interesse científico que muito privilegiou temas sobre religiões hegemônicas. O sacrifício animal é parte fundamental para a manutenção do Axé, da força vital e de todas as energias que cercam o mundo físico e 
espiritual. Tanto humanos quanto deuses se alimentam e compartilham desta emanação.

Por conta disso, objetivo, lançar um olhar mais específico sobre o tema "sacrifício", dentro do Candomblé, em um Terreiro de Ananindeua-Pa (Yllê Axé Oyá Nirolê Igbalé), área metropolitana de Belém, descrevendo dentro do que me é possibilitado pelas preceitos religiosos, os ritos sacrificiais, seus preparos pré e pós ritualísticos, os tabus e interditos inerentes a eles.

Meu principal motivador é buscar compreender como se organiza a casa em torno das práticas sacrificiais de animais não-humanos, cruzando a essas, alguns dos diversos tipos de sacrifício praticados seja durante as grandes "Obrigações" (rituais que duram dias, com propósito iniciático, ou de "manutenção"), seja no processo de "limpezas" espirituais, frequentemente realizados.

Outro objetivo é o de conhecer mais sobre a função do sacrificador, como se dá a escolha e iniciação, como se desenvolve o processo de aprendizado e como este se encaixa no corpo hierárquico da Casa e deste que cumpre um papel liminar entre a vida e a morte, entre a extinção e a restauração.

Sobre o olhar daqueles que são direta e indiretamente envolvidos no ritual, pretendo demonstrar que, sob hipótese, existem compreensões diferentes entre os diversos membros (e, quem sabe, alguns clientes) da Casa e que nem todos, apesar de entenderem o sacrifício como algo de grande importância, têm a dimensão de como a religião se estrutura em torno dele.

Material e método: Dados os tipos de indagações que surgem da observação do campo de pesquisa, bem como pelas necessidades apresentadas pelos objetivos, como método científico elegi a etnografia, que será realizada a partir não apenas das observações, que estão sendo catalogadas em caderno de campo, mas também das entrevistas, também organizadas em manuscritos e coletadas através de gravações de áudios, devidamente autorizados pelos seus cedentes, que serão posteriormente transcritas e também catalogadas em cadernos específicos para este fim.

O recurso à autoetnografia é um ponto especial do método utilizado, tendo por justificativa a minha pertença no campo e na própria função de sacrificador que vai ao encontro de um dos objetivos da pesquisa que propões uma análise mais aprofundada do papel do principal responsável pelas imolações, o Pejigan. Para tal, recorrerei ao levantamento das memórias pessoais sobre o processo que vai, desde a eleição ao cargo, ao corpo hierárquico ao qual pertenço. Entretanto, como não sou o único que ocupa ou desempenha cargo de Pejigan na Casa observada, também pratico as entrevistas com os outros membros citados.

Resultados e discussão: Ao longo da caminhada da pesquisa, várias foram as dificuldades encontradas, o que não é "privilégio" meu, mas sim uma constante em todo e qualquer processo de análise, seja em campo, seja teórica. Entretanto, essas dificuldades não são desculpa para o não desenvolvimento do trabalho, pelo contrário, devem integrar-se aos elementos motivadores.

Até o momento pude observar, dentro dessas "dificuldades", uma questão que ainda não havia cogitado que é resultado das incursões ao campo onde, mesmo sob a "roupa" de 
religioso, passei a ter um olhar mais criterioso, o do pesquisador. Esta nova hipótese que surge é a de que haja a possibilidade de que alguns indivíduos, membros da Casa, seja em início da trajetória religiosa ou mesmo em algum alto posto hierárquico, apesar de entenderem o sacrifício como algo necessário e que deva ser respeitado, não compreendem a real dimensão do mesmo ou, de alguma forma, relativizam em alguns arquétipos de divindades, como acontece durante os sacrifícios a Exu / Padilha. Por serem estes, Orixás (na verdade Padilha é a projeção feminina de Exu) ligados à sexualidade, à comunicação, ao movimento e, por consequência da alegria, alguns dos que participam parecem não se importar, por exemplo, com os risos menos contidos, conversas paralelas ou com as brincadeiras, algumas delas de cunho "sexuais" enquanto o sacrifício acontece no local reservado a isso.

Outra coisa que consegui perceber é que, apesar de haver uma hierarquia rígida a ser respeitada, em alguns momentos, esta acaba por afrouxar-se, seja pela necessidade, conveniência, proximidade afetiva e/ou confiança elevada em algum indivíduo. É o caso daqueles que, mesmo não pertencentes ao cargo responsável pelo sacrifício, acabam sendo autorizados pela Sacerdotisa do Terreiro, a praticar a imolação, seja por falta de quem de direito possa fazê-lo ou por conveniências a serem levantadas posteriormente no decorrer da pesquisa. No caso de sacrificadores de outras casas que, porventura possam executar o sacrifício na Casa estudada, o que é provável que reja esta autorização, sejam os laços afetivos ou de confiabilidade, seja partindo da Sacerdotisa, seja a pedido daquele(a) que está em "Obrigação".

Entretanto, esses são questionamentos a serem mais cautelosamente investigados já que, no seio de uma religião, nem tudo o que se vê ou como se vê, pode ser levado "ao pé da letra", muito pode ser relativizado, ressignificado.

Conclusão: O sacrifício de animais não-humanos sustenta a cosmovisão do Candomblé e toda o desenvolvimento da vida de seus membros, aproximando os humanos das divindades e afastando-os da animalidade (SILVA, 2012), elevando-o espiritualmente. Por isso, se faz tão importante compreender como se desenvolve este ritual, como alguns indivíduos e a própria Casa se organizam em torno do ritual, como pensa acerca disso cada envolvido direta ou indiretamente envolvido, sobretudo aqueles que são os principais responsáveis pelo ato em si, os Pejigans.

Se há o sacrifício e o sacrificador, há também a necessidade de se compreender como estes se assentam no corpo hierárquico do Terreiro de forma geral ou entre si e as relações de necessidades, conveniências, afetos que são geradas a partir das práticas sacrificiais no llê Axé Oyá Nirolê Igbalé (Kwe Zanvis Avessan), uma Casa de Candomblé em Ananindeua-Pa.

Referências bibliográficas: BENISTE, José. Òrun-Àiyé: o encontro de dois mundos: o sistema de relacionamento nagô-yorubá entre o céu e a terra. $2^{\mathrm{a}}$ ed. Rio de Janeiro: Bertrand Brasil, 2008.

BERKENBROCK, Volney J. A experiência dos orixás: um estudo sobre a experiência religiosa no Candomblé. 4ª ed. RJ: Vozes, 2012. 
CABRERA, Lydia. Yemayá y Ochún. Kariocha, lyalorichas y Olorichas. 2a ed. Prólogo y bibliografía de Rosario Hiriart. Distribución exclusiva E. Torres. Eastchester, New York: Ediciones C.R., 1980.

CHAGAS, Manoel Roberto Ferreira. O Candoblé Jeje Savalu na Amazônia. 1. ed. Porto Alegre: Buqui Editora, 2016. v. 1. 160p.

ELBEIN, Juana dos Santos. Os Nàgó e a Morte. Rio de Janeiro: Vozes, 1976.

GAMA, Lígia Barros. KOSI EJÉ KOSI ORIXÁ: Simbolismo e representação do sangue no Candomblé / Lígia Barros Gamas. Recife: O autor, 2009.

GEERTZ, Clifford. A religião como sistema cultural. In: A Interpretação das Culturas. Rio de Janeiro: LTC, [1973] 1989.

. Uma Descrição Densa: Por uma Teoria Interpretativa da Cultura. In: A Interpretação das Culturas. Rio de Janeiro: LTC, [1973] 1989.

GIRARD, René. O sacrifício / René Girard; Tradução Margarita Maria Garcia Lamelo. São Paulo: É Realizações, 2011.

MACEDO, Bispo. O perfeito sacrifício: o significado espiritual do dízimo e das ofertas. Bispo Macedo / Rio de Janeiro: Unipro Editora, 2012.

MALINOWISK, Bronislaw. Os argonautas do Pacífico Ocidental. In: Os Pensadores. São Paulo: Abril Cultural, 1983.

MAUÉS, Heraldo. Almoço do Círio: um banquete sacrificial em homenagem a Nossa Senhora de Nazaré. In: XVII Jornadas sobre Alternativas Religiosas da América Latina GT Religião, festa e comida. Porto Alegre, 2013.

MAUSS, Mauss; HUBERT, Henri. Sobre o sacrifício. São Paulo: Cosac \& Naify, 2005. . Análise e explicação da magia. In: Sociologia e antropologia. São

Paulo: Cosac \& Naify, 2003 . Ensaio sobre a dádiva. In: Sociologia e antropologia. São Paulo: Cosac

\& Naify, 2003.

OLIVEIRA, Roberto Cardoso. O trabalho do Antropólogo. Brasilia: UNESP (Co-edição: Paralelo 15 Editora), 1998.

SILVA, Vagner Gonçalves da. Concepções religiosas Afro-brasileiras e Neopentecostais: uma análise simbólica. In: REVISTA USP, São Paulo, n.67, p. 150-175, setembro/novembro 2005

TURNER, Victor. Floresta de Símbolos. Rio de Janeiro: Eduff, 2005.

VAN GENNEP, Arnold. Os Ritos de Passagem: Estudo sistemático dos ritos da porta e da soleira, da hospitalidade, da adoção, gravidez e parto, nascimento, infância, puberdade, iniciação, ordenação, coroação, noivado, casamento, funerais, estações, etc. Petrópolis: Vozes, 1977. 181 p. Mariano Ferreira.

Palavras-chave: Sacrifício, sangue, religião, cosmovisão, Pejigan.

Grande área: Ciências Humanas.

Área: Ciências da Religião. 


\title{
RELIGIÃO E PODER: A VISÃO CELULAR NA PRIMEIRA IGREJA BATISTA EM ICOARACI
}

\author{
Nome do(a) Bolsista: Wilson Alves Batista \\ Nome do(a) Orientador: Saulo de Tarso Cerqueira Baptista
}

Resumo: A PIBI (Primeira Igreja Batista em Icoaraci) ao adotar o movimento da Visão Celular M12 (Modelo dos 12) apresenta hoje estruturas e relações sócio religiosas muito significativas. Este movimento religioso na PIBI, como estratégia de evangelismo, se caracteriza por um tipo de gestão eclesial que visa o crescimento numérico de seus membros. Possibilita, também, uma nova estrutura de poder entre seus membros, nos quais se cria uma espiritualidade emotiva e entusiasmada para conquistar e o objetivo de se tornarem notórios líderes para ganharem e fazerem novos discípulos. O que chamou a atenção e que trouxe motivo para a implementação desta pesquisa foi a constatação das relações de poder exercidas de forma hierárquica e piramidal. Desta forma, formulou-se o seguinte problema: De que maneira o poder é exercido entre o líder e o discípulo da PIBI? A hipótese levantada é que o poder exercido na PIBI quando o líder é reconhecido como autoridade espiritual sobre seu discípulo, o qual tem o compromisso de obedecê-lo, respeitá-lo, ser fiel e ter a dedicação em servi-lo. O líder tem a convicção da fidelidade e obediência de seu discípulo e consegue, em certa medida, ter um controle espiritual e material da sua vida. O resultado parcial desta pesquisa mostra que este fenômeno religioso contém um tipo de gestão que se utiliza de estratégias de relações de poder que geram conflitos, determinam as posições de indivíduos e grupos, incluem e exclui indivíduos, demarca espaços, cria uma divisão do trabalho religioso. Portanto, entende-se que há uma relevância acadêmica e social na possibilidade de investigar tal fenômeno.

Introdução: $\mathrm{Na}$ trajetória histórica da PIBI, mudanças ocorreram nas suas práticas religiosas, com a chegada do pentecostalismo no final da década de 1980, porém foi com chegada da visão celular no final da década de 1990 que a Igreja experimentou e experimenta até hoje, suas mudanças mais significativas. A visão celular no Modelo dos 12 possibilitou uma nova estrutura de poder e, consequentemente, novas relações de poder entre seus membros: líderes e discípulos. A PIBI foi fundada em 20 de junho de 1958 no Distrito de Icoaraci pelo pastor Orlando Figueiredo oriundo da Igreja Batista da Pedreira, com missionário Paul Sanderson da Junta de Richmond ou Junta de Missões Estrangeiras da Convenção Batista do Sul dos EUA e com as primeiras famílias batizadas que já formavam a congregação.

As características da PIBI desde o seu nascimento até a chegada dos movimentos se alinhavam com a identidade batista do Brasil. Com a chegada da renovação espiritual e, posteriormente, da Visão Celular, a PIBI agrega práticas religiosas pentecostais e neopentecostais, uma estrutura eclesiástica centralizada no líder no formato piramidal, estratégia ou modelo de crescimento eclesial com ênfase nas células. Delimitou-se, portanto, o campo de estudo da pesquisa a PIBI que utiliza a Visão Celular no Modelo dos 12, pois percebe-se que no jogo do poder implícito nas relações entre os membros, 
a liderança religiosa consegue influenciar, exercer e representar simbolicamente o poder.

\section{OBJETIVOS}

\section{GERAL}

Analisar a relação de poder entre o líder e o discípulo da PIBI na Visão Celular.

\section{ESPECÍ́FICOS}

- Entender o início da Visão Celular e as relações de poder por meio das práticas religiosas na $\mathrm{PIBI}$;

- Analisar o estabelecimento da estrutura de poder e seus beneficiários na Visão Celular e as estratégias de poder utilizadas nas relações entre líder e discípulo;

- Compreender de que maneira o líder religioso da PIBI detém o poder;

- Analisar os conflitos sócio religiosos gerados das relações de poder entre líder e discípulo e as ressignificações dos elementos religiosos resultantes das diversas práticas religiosas na Visão celular;

Material e método: Já existem algumas produções acadêmicas sobre as Igrejas Batistas no Brasil e sua inserção na Visão celular no Modelo dos 12. A Dissertação de Mestrado em História da Caroline Luz e Silva Dias, "Os Neopentecostais em Feira de Santana: Da Visão Celular no Modelo dos 12 ao Mover Celular do Fruto Fiel" de 2009 do Programa de Pós-graduação em História da UEFS (Universidade Estadual de Feira de Santana), discute sobre comunidades que aderiram ao G12 em Feira de Santana entre os anos 1983 e 2005. O G12 que teve sua origem na América Latina a partir da Colômbia, como uma estratégia de evangelismo em massa, chega ao Brasil na década de 1990 e atinge ou influencia muitas Igrejas históricas, pentecostais e neopentecostais. Eliana Santos Andrade na sua Dissertação de Mestrado em Ciências Sociais da Universidade Federal da Bahia em 2010, "A Visão Celular no Governo dos 12: Estratégias de crescimento, participação e conquista de espaços entre os batistas soteropolitanos de 1998 a 2008", faz um estudo das práticas e representações presentes na estratégia de crescimento e gestão de igrejas protestantes na "Visão Celular no Governo dos 12" na Primeira Igreja Batista do Brasil - PIBB e na Primeira Igreja Batista de Pernambués- PIBAPE. A Dissertação de Mestrado em Sociologia Política, "Religião e classe social: Uma análise dos especialistas religiosos de diferentes segmentos evangélicos sob a influência do Pentecostalismo" de João Ricardo Boechat Pires de Almeida Sales em 2017 da Universidade Estadual do Norte Fluminense - Darcy Ribeiro, analisa como as mudanças religiosas refletem as mudanças sociais, como as organizações religiosas e os especialistas religiosos, influenciados pelo pentecostalismo, adaptam suas pregações e demandas a distintos interesses sociais, atendendo a diferentes anseios e elaborando estratégias da Visão Celular para sobreviver e competir em uma sociedade secularizada. Entretanto, não se encontrou, com exceção da dissertação em História da Caroline Luz e Silva Dias, nas pesquisas bibliográficas uma análise sobre as relações de poder entre os membros de uma Igreja Batista inserida na Visão Celular.

De acordo com o objetivo da pesquisa: analisar a relação de poder entre o líder e o discípulo da PIBI e que este objetivo seja alcançado, utilizou-se da pesquisa 
exploratória, já que existe uma facilidade na aproximação do objeto de estudo e com o problema que foi formulado. De acordo com Gil (2002, p. 43), "O delineamento refere-se ao planejamento da pesquisa em sua dimensão mais ampla, que envolve tanto a diagramação quanto a previsão de análise e interpretação de coleta de dados", se atentou para a necessidade de, primeiramente como coleta de dados, fazer uma pesquisa bibliográfica, ainda em andamento, em diversas fontes bibliográficas como em livros de leitura corrente, cujas obras possibilitaram os conhecimentos teóricos acerca da Sociologia da Religião, em livros de referência informativa e remissiva por conta da dificuldade de obter obras importantes não acessíveis para a pesquisa, mas que informam referências teóricas importantes.

Segundo Richardson (2012, p. 90), "A pesquisa qualitativa pode ser caracterizada como a tentativa de uma compreensão detalhada dos significados e características situacionais apresentadas pelos entrevistados". Portanto, se utilizando da pesquisa participativa na observação das relações de poder, se utilizará de técnicas de observação e, principalmente, de entrevistas abertas e não estruturadas para a compreensão da complexa relação de poder entre os membros da PIBI. O material utilizado para a realização da pesquisa de campo é o caderno de campo onde os dados são registrados de forma escrita. As entrevistas gravadas em celular foram, primeiramente, na Igreja e nas casas dos membros e ex membros

Resultado e discussão: Com a chegada da renovação espiritual a PIBI agregou práticas religiosas pentecostais como a ênfase no batismo no ou com o Espírito Santo. Posteriormente com a chegada da Visão Celular, adota uma estrutura eclesiástica centralizada no líder no formato piramidal, em que o líder detém a unção espiritual (poder e autoridade) que recebe de Deus e que pode transferir aos seus discípulos. Estratégia ou modelo de crescimento eclesial com ênfase nas células ou reuniões de cultos familiares com ensinos bíblicos nas casas que remontam a época da igreja primitiva, porém nestas reuniões como também nos cultos da Igreja, é notório algumas práticas do neopentecostalismo, como a batalha espiritual, a teologia da prosperidade e a confissão positiva. Utiliza um método de ensino e aprendizagem aos novos discípulos com base em 4 degraus da chamada escada de sucesso que são o ganhar, o discipular, o consolidar e o enviar que começam no retiro espiritual (evangelismo em massa) do pré-encontro, encontro e pós-encontro com Deus com o objetivo de transformar vidas. Os novos discípulos com as vidas transformadas já podem ingressar na escola de líderes e fazer o reencontro com Deus que é uma renovação ou fortalecimento espiritual para liderança.

Na Visão Celular, todo líder é um discípulo e vice-versa. As motivações que são dadas tanto para líderes, como para discípulos, que partem do casal de apóstolos que lideram cada um 12 discípulos ou governos, por meio do ensino bíblico ou pregações, gera uma espiritualidade com base emocional e um entusiasmo para o trabalho da Igreja que tem como expectativa individual alcançar posições ou cargos com a notoriedade ou reconhecimento, por exemplo, de ações do discípulo em honrar seu líder de alguma forma. Mas, esta prática, como uma ferramenta de poder, tem o interesse e o desejo de quem honra da reciprocidade entendida como o mérito de ser, também, honrado ou por seu líder, ou por seu discípulo, ou por Deus. 
As consequências dessas relações de poder provocam disputas entre os discípulos que buscam o reconhecimento recíproco conforme o nível de autoridade que possuem e que determina da sua posição no campo religioso. Os cargos eclesiásticos almejados são ocupados pelos discípulos que mais se destacam pelo trabalho, unção ou quantidade de discípulos que possui. Entretanto, as disputas por cargos ou discípulos provoca a dissidência de membros insatisfeitos ou decepcionados por não serem reconhecidos reciprocamente como autoridade.

Os eixos teóricos principais definidos pelo objeto da pesquisa tratarão da relação entre religião e poder. Portanto, se fundamentará nos conceitos que se apoiam ao entendimento de Max Weber sobre a religião. Ao comparar diferentes racionalidades religiosas, Weber (2013) constrói a específica racionalização ocidental para entender a função da religião. Ao criar o recurso metodológico de tipos ideais, Weber analisa que tipos ideais de indivíduos ou grupos promovem ações sociais, produtos de racionalizações que, no âmbito da religião como um modo de regulamentar a vida, se entende as motivações e intenções do indivíduo ou grupo religioso. O raciocínio de Weber pode contribuir na pesquisa no sentido em que a função da religião é dar sentido a existência concreta dos indivíduos ou grupos sociais em determinada ordem ou realidade social, onde a razão de existir de indivíduos ou grupos depende da revelação que os bens de salvação proporcionam.

As bases conceituais determinadas pelo objeto da pesquisa, com a finalidade de analisar e entender as relações de poder na PIBI, estão em teorias de Pierre Bourdieu. As relações ou disputas de poder entre líderes e discípulos por posições na PIBI podem ser analisadas pelos conceitos de habitus, capital e campo de Bourdieu (2015) ao argumentar que o campo religioso é constituído de especialistas religiosos, detentores do capital religioso e dos leigos profanos, destituídos deste capital.

Conclusão: A pesquisa encontra-se na elaboração do Projeto Final mais dois capítulos da Dissertação com as informações conseguidas na investigação. Pretende-se ampliar a investigação as Igrejas que estão aliançadas a PIBI, pois entende-se que essas relações e poder vão além da Igreja principal. A limitação da pesquisa científica, primeiramente, se deu pelo difícil acesso às fontes de pesquisa de ordem teóricas que até o momento se conseguiu apenas Dissertações que abordam a temática, nenhuma Tese que discute o assunto não foi encontrada, ainda. Entretanto, há um avanço na pesquisa teórica em obras de referência que contribuem com conceitos para interpretação do objeto estudado. Outra limitação se refere às entrevistas no campo de pesquisa onde há certas resistências ou rejeições de algumas lideranças no sentido de contribuírem à pesquisa o que causa um gasto de tempo considerado precioso.

REFERÊNCIAS BIBLIOGRÁFICAS: ANDRADE, Eliana Santos. A Visão Celular no Governo dos 12: estratégias de crescimento, participação e conquista de espaços entre os batistas soteropolitanos de 1998 a 2008. 2010. Dissertação (Mestrado em Ciências Sociais) - Faculdade de Filosofia e Ciências Humanas da UFBA, Salvador, 2010, 156 f. BOECHAT, João. Religião e Classe Social: uma análise dos especialistas religiosos de diferentes segmentos evangélicos sob a influência do Pentecostalismo. Mestrado em Sociologia Política. Universidade Estadual do Norte Fluminense. Campos dos Goytacazes. 
BOURDIEU, Pierre. A economia das trocas simbólicas. São Paulo: Perspectiva, 2015. DIAS, Caroline Luz e Silva. Os neopentecostais em Feira de Santana: "Da Visão Celular no Modelo dos 12 ao Mover Celular do Fruto Fiel". 2009. Dissertação (Programa de Pós-graduação em História) - Universidade Estadual de Feira de Santana, Feira de Santana, 2009.

GIL, Antonio Carlos. Como elaborar projetos de pesquisa. 4. ed. São Paulo, Atlas, 2002.

RICHARDSON, Roberto Jarry; PERES, José Augusto de Souza. Pesquisa social: métodos e técnicas. 3. ed. São Paulo, Atlas, 4012.

WEBER, Max. A ética protestante e o espírito do capitalismo. Tradução Mário Moraes. São Paulo: Martn Claret, 2013.

Palavras-chave: Religião; Poder; Igreja Batista; Visão Celular.

Grande área: Ciências Humanas.

Área: Ciências da Religião e Teologia 


\title{
ENTRE O ÓRUN E O AYÊ: OS ATABAQUES COMO REFLEXO DA COSMOVISÃO IORUBÁ NO TERREIRO ILÉ ASÉ IYÁ OGUNTÉ
}

\author{
Nome do(a) Bolsista: Yasmin Estrela Sampaio \\ Nome do(a) Orientador(a): Taissa Tavernard de Luca
}

Resumo: Esta pesquisa interconecta os estudos da Geografia Cultural às Ciências da Religião com base na análise do fenômeno religioso em relação ao espaço sagrado e o fazer musical nos cultos afro-religiosos na Amazônia. Realizar-se-á trabalho etnográfico buscando compreender a religião como um sistema cultural estruturado a partir de "significado", "símbolo" e "concepção" que englobam o conceito de cultura descrito por Geertz como um padrão de significados transmitidos historicamente. Compreende-se que o espaço religioso a partir de territorialidades refletem um conjunto de práticas desenvolvidas por uma instituição ou grupo com a finalidade de controlar um território (ROSENDAHL, 1995). Portanto, o Candomblé assume determinadas práticas de cultos que se utilizam de representações musicais, transmitindo por meio de cantigas letras e ritmos que reproduzem memória, mito e cosmogonia africana e reforçam a existência do espaço sagrado.

Introdução: Esta pesquisa vinculado à linha de pesquisa Linguagens da Religião apresentado ao Programa de Pós-Graduação em Ciências da Religião da Universidade do Estado do Pará (UEPA), discute a música como elemento estruturante dos cultos de candomblé Ketu, bem como "elo" de comunicação entre os orixás e seus descendentes buscando compreender relação entre o fenômeno da possessão e as práticas musicais presentes nos cultos a partir do estudo dos instrumentos de percursão conhecidos por Atabaques, buscando compreender sua identidade como elemento divino no terreiro e seu propósito no Espaço Sagrado junto ao fazer musical.

Objetivos: O objetivo central desta pesquisa é buscar compreender a conexão entre os planos Orún e Ayê, revelando uma ligação entre dois lugares a partir do fazer musical, no qual as canções carregam nas suas letras elementos simbólicos transmitindo imagens que revelam o caráter e a identidade do lugar, sendo possível compreender que "a construção e o fortalecimento de identidades por meio dos textos musicais (o ritmo, as letras e os diferentes estilos)" (KONG, 2009, p. 156).

Materiais e Métodos: Nesta pesquisa utilizaremos como procedimento de análise metodológica o trabalho de campo a fim de elaborar uma etnografia sobre o terreiro escolhido como locus de pesquisa. Penso a etnografia a partir de Clifford Geetz (1997) que a clafssifica a partir do conceito de descrição densa. Ou seja um texto escrito a partir da observação das atividades culturais bem como de seus significados.

Entre as tecnicas utilizadas destaco a da observação direta e da entrevista. A técnica de entrevista dos membros do terreiro escolhido como lócus deste trabalho, que se destacam entre a dirigente da casa, a Yalorixá lyá Ejité e os alabês responsáveis por orquestrar as demais cerimônias e rituais que ocorrem no templo, por meio de procedimentos qualitativos de investigação com o objetivo de coletar dados importantes 
acerca da temática escolhida, no que diz respeito aos aspectos musicais de uma casa de candomblé de nação ketu, buscando compreender a música como elemento sagrado que expressa um sentido estabelecendo uma relação entre sagrado e profano que vai além da subjetividade humana e dos limites da ontologia onde "o sagrado se dá como uma experiência de excesso de sentido que ultrapassa o limite da existência doadora de sentido" (HIGUET, 2015, p. 33).

A observação direta será realizada em rituais públicos e privados a fim de interpretar o significado deste instrumento musical para a casa e para a nação pesquisada. Desta forma, este trabalho pode ser considerado um estudo de caso, uma vez que irá centrar os seus estudos em uma casa de Candomblé Ketu: Ilé Asé Iyá Ogunté, levando em consideração que cada terreiro possui suas especificidades, em certo ponto são independentes no que se referem a alguns dos procedimentos rituais até organização espacial. Portanto, para a construção do presente trabalho irá ser levantada uma bibliografia específica sobre Candomblé onde existem inúmeras fontes, na qual duas delas irão nortear este trabalho por meio dos estudos realizados por Vergolino (1976) e Tavernard (2003:2007) sobre o percurso histórico das religiões afro-brasileiras no Pará e as memórias africanas na região, e de fontes de estudos de etnomusicólogos especificamente da música de Candomblé como Lühning (1990) e Cardoso (2006) que abordam a complexidade da temática e centram em aspectos de gênero e rituais.

Resultado e Discussão:Foi possivel compreender que a música junto às letras e danças corresponde a uma forma de expressão manifestando a identidade cultural do lugar - neste caso, o terreiro - e das relações sociais que se estabelecem no espaço desenvolvendo práticas e comportamentos que preservam e dão suporte ao território religioso. Pinto (2001) classifica a música como um processo de significado social capaz de gerar sistemas que ultrapassam seus aspectos sonoros e que complementam um conjunto de elementos como a performance, a corporalidade, e as estruturas musicais como simbolismo que delimitam o território e o classifica como espaço religioso. Portanto a música se apresenta como elemento sacralizador do espaço do terreiro, pois se faz presente em todas as celebrações dentro da casa, desde a iniciação de um novo membro, até no cotidiano dos integrantes da comunidade. É a partir das canções que o indivíduo se conecta com o orixá por meio do fenômeno da possessão cria uma íntima ligação entre sagrado e profano, visto que "o som, assim como a palavra, é importante, pois conduz e proporciona o axé. Acompanhado ou não de instrumentos musicais, possui uma força especial que é zelosamente guardada na memória" (PESSOA DE BARROS, 2000, p. 39).

Conclusão: A pesquisa interconecta os estudos da Geografia Cultural às Ciências da Religião com base na análise do fenômeno religioso em relação ao espaço sagrado e o fazer musical nos cultos afro-religiosos na Amazônia. Realizar-se-á trabalho etnográfico buscando compreender a religião como um sistema cultural estruturado a partir de "significado", "símbolo" e "concepção" que englobam o conceito de cultura descrito por Geertz como um padrão de significados transmitidos historicamente, descrevendo a religião como: 
Um sistema de símbolos que atua para estabelecer poderosas, penetrantes e duradouras disposições e motivações nos homens, através da formulação de conceitos de uma ordem de existência geral e vestindo essas concepções com tal aura de fatualidade que as disposições e motivações parecem singularmente realistas (2008, p. 67).

Compreende-se que o espaço religioso a partir de territorialidades refletem um conjunto de práticas desenvolvidas por uma instituição ou grupo com a finalidade de controlar um território (ROSENDAHL, 1995). Portanto, o Candomblé assume determinadas práticas de cultos que utilizam-se de representações musicais, transmitindo por meio de cantigas letras e ritmos que reproduzem memória, mito e cosmogonia africana e reforçam a existência do espaço sagrado.

Referências Bibliográficas: ELIADE, Mircea; TAMER, Sonia Cristina; DUMÉZIL, Georges. Imagens e símbolos: ensaio sobre o simbolismo mágico-religioso. 1991. ELIADE, Mircea. O sagrado e o profano. Tradução de Rogério Fernandes. 1992.

GIL FILHO, Sylvio Fausto. Espaço de representação e territorialidade do sagrado: notas para uma teoria do fato religioso. Raega-O Espaço Geográfico em Análise, v. 3, p. 91120, 1999.

GIL FILHO, Sylvio Fausto. Espacialidades de conformação simbólica em Geografia da Religião: um ensaio epistemológico. Espaço e Cultura, n. 32, p. 78-90, 2012a.

GIL FILHO, Sylvio Fausto. Geografia das formas simbólicas em Ernst Cassirer. Visões do Brasil: estudos culturais em Geografia. Salvador: EDUFBA, p. 47-66, 2012b.

KONG, Lily. Música popular nas análises geográficas. Corrêa, Roberto. L.; Rosendahl, Zeny (Org.). Cinema, espaço e música. Rio de Janeiro: EDUERJ, p. 129-175, 2009.

PESSOA DE BARROS, J. F. Mito, memória e história: a música sacra. Espaço e Cultura, $\mathrm{n}^{\circ} 9$ e 10, p. 35-48, 2000.

GEERTZ, Clifford, 1926- A interpretação das culturas / Clifford Geertz. - I.ed., IS.reimpr. - Rio de Janeiro : LTC, 2008.

HIGUET, Etienne Alfred. O lugar da religião no pensamento de Paul Ricoeur. Revista Observatório da Religião, v. 2, n. 2, p. 22-45, 2015.

LUCA, Taissa Tavernard de. Revisitando o Tambor das Flores": a Federação Espírita e Umbandista dos Cultos Afro-Brasileiros do Estado do Pará como guardiã de uma tradição. Dissertação de Mestrado, Programa de Pós-Graduação em Antropologia, Universidade Federal do Pernambuco, Recife, 2003.

LUCA, Taissa Tavernard de. Por uma sociedade de corte nos terreiros de Belém. Revista Estudos Amazônicos, vol. XI, n. 2, p. 156-189, 2014.

LÜHNING, Angela. Música: coração do candomblé. Revista Usp, n. 7, p. 115-124, 1990. PEREIRA, Clevisson Junior; GIL FILHO, Sylvio Fausto. Geografia da Religião e Espaço Sagrado: Diferenças entre as noções de lócus material e conformação simbólica. Ateliê geográfico, v. 6, n. 1, p. 35-50, 2012.

PINTO, Tiago de Oliveira. Som e música. Questões de uma antropologia sonora. Revista de Antropologia, v. 44, n. 1, p. 222-286, 2001. 
PRANDI, Reginaldo. De africano a afro-brasileiro: etnia, identidade, religião. Revista Usp, n. 46, p. 52-65, 2000.

ROSENDAHL, Zeny. Espaço \& Religião: uma abordagem geográfica. EdUERJ,NEPEC 1996, 92 p. - (livros; v.1).

ROSENDAHL, Zeny. Território e territorialidade: uma perspectiva geográfica para o estudo da religião. Geografia: temas sobre cultura e espaço. Rio de Janeiro: EdUERJ, p. 191-226, 2005.

ROSENDAHL, Zeny. História, teoria e método em geografia da religião. Espaço e Cultura, n. 31, p. 24-40, 2012a.

ROSENDAHL, Zeny. O sagrado e sua dimensão espacial. CASTRO, IE; GOMES, PC; CORREAA, RL Olhares geográficos: modos de ver e viver o espaço. Rio de Janeiro: Bertrand Brasil, 2012b.

Palavras-chave: Espaço sagrado, candomblé, Geografia, Cultura, religião.

Grande Área: Ciências Humanas

Área: Ciências da Religião 


\section{PROGRAMA DE PÓS- GRADUAÇÃO EM EDUCAÇÃO}




\title{
EDUCAÇÃO AMBIENTAL EM COMUNIDADES TRADICIONAIS PESQUEIRAS DA AMAZÔNIA: UM ESTUDO SOBRE A EXPERIÊNCIA DO GRUPO AMBIENTAL DE FORTALEZINHA (GAF)
}

\author{
Nome do(a) Bolsista: Adriele de Fátima de Lima Barbosa \\ Nome do(a) Orientador(a): Sérgio Roberto Moraes Corrêa
}

Resumo: A presente texto faz parte de uma pesquisa de mestrado em andamento vinculada ao Programa de Pós-Graduação em Educação da Universidade do Estado do Pará. Esse resumo adentra-se no campo de estudo da ação coletiva de uma comunidade tradicional pesqueira da microrregião do salgado paraense, tendo como eixo temático a educação ambiental inscrita a partir da experiência da atuação do Grupo Ambiental da comunidade de Fortalezinha, localizada no município de Maracanã, nordeste do Estado do Pará. Trata-se de uma pesquisa intitulada "Educação Ambiental" em comunidades tradicionais pesqueiras da Amazônia: um estudo sobre a experiência do grupo ambiental de Fortalezinha (GAF)", com o objetivo de identificar e analisar o que a ação coletiva do GAF, na comunidade tradicional (pesqueira) de Fortalezinha, tem a revelar sobre a sua experiência de "educação ambiental" a partir das narrativas dos moradores da comunidade e de outros agentes institucionais que compunham o GAF. Torna-se de extrema relevância epistemológica, por conduzir a possibilidade de construir uma compreensão intercultural acerca das experiências, memórias, identidades, territorialidade, temporalidade e saberes de uma comunidade tradicional pesqueira que esteve envolvida em uma organização coletiva, configurada por diversos sentidos e significados culturais e políticos. Alicerçada numa abordagem qualitativa com perspectiva histórica, cujo o trabalho vem envolvendo pesquisa bibliográfica, documental e de campo.

Introdução: O desenvolvimento de uma proposta que se encaminha no interior da linha de pesquisa sobre os "Saberes Culturais e Educação na Amazônia, defini como área de interesse estudar a experiência de educação ambiental em uma ação coletiva de comunidade tradicional pesqueira, tomando como objeto de estudo o Grupo Ambiental de Fortalezinha, localizada em uma Área de Proteção Ambiental, contemplando assim, o eixo temático em torno dos Saberes, cultura e educação inclusiva na Amazônia.

Trata-se de uma pesquisa intitulada "Educação Ambiental" em comunidades tradicionais pesqueiras da Amazônia: um estudo sobre a experiência do grupo ambiental de Fortalezinha (GAF)", que torna-se de extrema relevância epistemológica, por conduzir a possibilidade de construir uma compreensão intercultural acerca das experiências, memórias, identidades, territorialidade, temporalidade e saberes de uma comunidade tradicional pesqueira que esteve envolvida em uma organização coletiva, configurada por diversos sentidos e significados culturais e políticos.

Fundamentada em uma relação direta com a questão ambiental, a vila de Fortalezinha, está localizada na Área de Proteção Ambiental de Algodoal/Maiandeua (APA), no município de Maracanã, litoral do Nordeste do Estado do Pará. O Grupo Ambiental de 
Fortalezinha (GAF) foi uma entidade civil, de caráter socioambiental, sem fins econômicos, que estabelecia em suas diretrizes do seu respectivo Estatuto Social certificado no ano de 2006, como uma entidade democrática, constituída por membros da comunidade e outros agentes externos, a ATA da Assembleia Geral da Fundação do Grupo Ambiental de Fortalezinha, designa no Capítulo 1 que compreende aos termos de denominação, da sede, duração e finalidade, destacam em seu seguinte artigo sobre o grupo:

Art.1 ${ }^{\circ}$ o Grupo Ambiental de Fortalezinha também denominado por GAF, localizado na vila de Fortalezinha, na ilha de Maiandeua município de Maracanã, com sub-sede na Rua Pariquis, Vila Luzitana, 81, Cremação, cidade de Belém Estado do Pará, tendo seus trabalhos iniciados em 18 de fevereiro de 1997, tem como finalidade promover a integração e contribuir com a proposição elaboração e implementação de ações educativas que busquem a melhoria da qualidade de vida da Comunidade de Fortalezinha, com extensão para outras comunidades da Ilha de Maiandeua, o GAF trata-se de uma entidade civil, de direito privado, de caráter socioambiental, sem fins econômicos, por tempo indeterminado regido pelo presente estatuto e pelas demais disposições legais que lhes forem aplicadas (ESTATUTO SOCIAL DO GAF, 2006).

O GAF é o objeto de estudo desta pesquisa e atualmente se encontra desativado, durante sua atuação na Vila foi uma organização sem fins lucrativos certificada em 10 de março de 2006 o seu Estatuto Social e ATA da Assembleia Geral da Fundação do Grupo Ambiental de Fortalezinha.

Grupo foi criado pelos moradores da comunidade que ao perceberem a problemática sobre as questões socioambientais da localidade promoveram no ano 1997 o protagonismo das mulheres e dos jovens pescadores, que observaram a situação da Vila de Fortalezinha e refletiram estratégias na perspectiva da educação ambiental de forma sustentável que pudesse garantir a forma de vida dos pescadores locais, tradições, saberes e vivências e principalmente na área de proteção ambiental (APA). Centravam suas atividades na valorização do saber, construção de uma educação sociambiental voltada para autonomia, reflexão e participação de homens e mulheres da comunidade.

Ressaltam-se também alguns relatos de moradores da vila que foram apresentados na primeira visita à comunidade, como exemplo "Gafiano", nativo da ilha, artesão e sufista, filho de pescador e foi também membro do GAF. Quando foi interpelado sobre sua relação com o Grupo Ambiental, o mesmo salientou a importância do GAF na construção de sua formação socioambiental e sua relação com a natureza e a comunidade.

"Gafiano" apontou ainda que o Grupo Ambiental foi marcante para Fortalezinha, em que oportunizou a participação da comunidade no envolvimento de práticas educativas que deram visibilidade para os saberes culturais da vila, como o artesanato, pesca, práticas educativas com a natureza, além de campanhas da área da saúde e coleta seletiva. "Gafiano" relembrou com certa nostalgia a atuação do Grupo Ambiental de Fortalezinha na comunidade.

Considerando os fatores revelados acerca do que foi o GAF e sua relação com a comunidade de Fortalezinha, suas ações coletivas, quais foram os avanços e limitações da perspectiva de uma proposta de educação socioambiental e as informações dos 
moradores, a pesquisa é relevante por buscar investigar a história do grupo a partir das narrativas da comunidade, procurando compreender quais eram as possíveis relações de saber da população tradicional da Vila que atravessaram as ações coletivas do Grupo Ambiental de Fortalezinha.

Desse modo a pesquisa orienta-se pela seguinte pergunta: O que a ação coletiva do GAF, na comunidade tradicional (pesqueira) de Fortalezinha, tem a revelar sobre a sua experiência de "educação ambiental" a partir das narrativas da comunidade e de outros agentes institucionais que compunham o GAF?

Algumas questões "Sul", que ajudem a interrogar e a responder essa questão central: Qual a origem do GAF e o que levou a sua constituição? Que papel a Comunidade Tradicional Pesqueira de Fortalezinha teve em sua constituição? Que saberes e concepções são possíveis identificar nessa experiência de "educação ambiental" do GAF e que lhe atribuem sentidos e inscrevem sua posição? O que é possível aprender com essa experiência de ação coletiva de educação ambiental oriunda de comunidades tradicionais pesqueiras da Amazônia sob o enfoque das epistemologias do Sul? Quais os avanços e limites dessa ação coletiva do GAF no tocante à sua proposta de "educação ambiental" na comunidade pesqueira de Fortalezinha na perspectiva das epistemologias do Sul?

A partir dessa problematização pretendo desvelar as questões sobre as práticas educativas do Grupo Ambiental de Fortalezinha.

Objetivos: O objetivo geral deste projeto é identificar e analisar o que a ação coletiva do GAF, na comunidade tradicional (pesqueira) de Fortalezinha, tem a revelar sobre a sua experiência de "educação ambiental" a partir das narrativas da comunidade e de outros agentes institucionais que compunham o GAF.

Em decorrência desse objetivo geral, definiram-se os seguintes objetivos específicos: caracterizar historicamente a origem do GAF e o que levou a sua constituição, bem como o papel que a Comunidade Tradicional Pesqueira de Fortalezinha teve em sua constituição. Cartografar que saberes e concepções são possíveis identificar nessa experiência de "educação ambiental" do GAF e que lhe atribuem sentidos e inscrevem sua posição. Identificar o que é possível aprender com essa experiência de ação coletiva de educação ambiental do GAF, oriunda de comunidades tradicionais pesqueiras da Amazônia sob o enfoque das epistemologias do Sul. Identificar os avanços e limites dessa ação coletiva do GAF no tocante à sua proposta de "educação ambiental" na comunidade pesqueira de Fortalezinha na perspectiva das epistemologias do Sul.

Material e Método: Reconhece nos preceitos do enfoque da decolonialidade o direcionamento epistêmico deste estudo, tangenciando de forma significativa na ruptura do pensamento abissal, estabelecido pela ciência moderna e sua concepção eurocêntrica de interpretação do mundo. A pesquisa é abordada de forma qualitativa, direcionada em uma perspectiva histórica, pois discorre a partir das narrativas dos sujeitos que participaram do Grupo Ambiental de Fortalezinha, atualmente desativado, buscando referendar através das fontes orais as experiências individuais e coletivas de seus narradores, identificando assim, as características principais e a função do Grupo na comunidade. 
Utilizando ainda os procedimentos metodológicos da pesquisa documental, segundo Marconi e Lakatos (2010), tendo como técnica de levantamento de dados, a observação na comunidade por meio da pesquisa de campo na vila de Fortalezinha, através da observação não participante na comunidade e a inserção da entrevista semi-estruturada, com os sujeitos da pesquisa que serão os moradores e ex-integrantes do GAF, assim como alguns agentes externos que participaram de forma voluntária na ação coletiva da comunidade.

Resultado e Discussão: Os resultados parciais da pesquisa evidenciam a partir das narrativas dos entrevistados, que a experiência da ação coletiva do Grupo Ambiental Coletiva foi significativa para comunidade, uma vez que a atuação dos moradores era de extrema importância na promoção de ações educativas no campo da educação ambiental da vila, que atualmente encontra-se tangenciadas por negligências na questão da preservação ambiental e pela ausência do poder público estadual.

Conclusão: Nesse sentido, a pesquisa encontra-se em andamento para o fechamento das últimas entrevistas e suas respectivas análises, buscando encontrar possíveis caminhos para a compreensão dos questionamentos em torno da experiência de educação ambiental a partir das narrativas dos moradores da vila e de outros agentes externos, propondo assim, analisar em uma perspectiva do Sul para o Sul e dialogar em uma ecologia de saberes, que se constrói no reconhecimento de uma pluralidade de conhecimentos e experiências de uma realidade específica amazônica e de sua comunidade tradicional pesqueira, invisibilizada historicamente pela monocultura da ciência moderna.

Referências: CALDART, Roseli Salete. Dicionário da Educação do Campo. $2^{\mathrm{a}}$. ed.Rio de Janeiro, São Paulo: Escola Politécnica Joaquim Venâncio, Expressão Popular, 2012.

GOHN, Maria da Glória. Movimentos sociais na contemporaneidade. Revista Brasileira de Educação. v. 16, n. 47. maio-ago. 2011. Disponível em:

<http://www.scielo.br/pdf/rbedu/v16n47/v16n47a05.pdf>. Acesso em: 18/06/2018.

Gohn, Maria da Glória. O protagonismo da sociedade civil: movimentos sociais, ONGs e redes solidárias. 2. ed. São Paulo: Cortez, 2008.

GOHN, Maria da Glória. Educação não formal e o educador social: Atuação no desenvolvimento de projetos sociais. São Paulo: Cortez, 2010.

SANTOS, B. S.; MENESES, M. P. (Org.). Epistemologias do Sul. São Paulo: Cortez, 2010. $637 \mathrm{p}$.

SANTOS, B. S. Para Além do Pensamento Abissal: das linhas globais a uma ecologia dos saberes. In SANTOS, B. S.; MENESES, M. P. Epistemologias do Sul. São Paulo: Cortez, 2010b, p. 31-83. 
MINAYO, Maria Cecília de Souza. Pesquisa social: teoria, método e criatividade. 23. ed. Petrópolis, RJ: Vozes, 1994.

THOMPSON, Paul (1935-). A voz do passado - História Oral. Rio de Janeiro: Paz e Terra, 1992. $388 \mathrm{p}$.

Palavras - chave: Educação Ambiental, Comunidade Tradicional Pesqueira, Grupo Ambiental de Fortalezinha (GAF), Epistemologias do Sul.

Grande Área: Ciências Humanas

Área: Educação 


\section{ESPAÇO E FORMA NA EDUCAÇÃO BÁSICA}

Nome do(a) Bolsista: Elyane Cristine Ferreira Mota

Nome do(a) Orientador(a): Pedro Franco de Sá

Resumo: Este trabalho apresenta os resultados parciais de uma pesquisa sobre o Ensino de Espaço e Forma na Educação Básica. A abordagem metodológica da pesquisa é Quanti-qualitativa, de campo com a função prática diagnóstica, que tem como objetivo diagnosticar um problema para com isso intervir na realidade. $O$ desenvolvimento da pesquisa está sendo realizados por meio dos seguintes procedimentos metodológicos: Revisão de Estudos; elaboração dos instrumentos de pesquisa; Validação dos instrumentos; Ajuste dos instrumentos; determinação da amostra; aplicação dos instrumentos; Sistematização; Análise; elaboração do texto e divulgação. O instrumento utilizado para coleta de dados foi um questionário que será aplicado a docentes que já lecionaram e lecionam na educação básica e discente do $1^{\circ}$ ano do Ensino Médio de escolas públicas da Cidade de Ananideua. Os resultados da análise dos questionários possibilitarão alguns apontamentos sobre a abordagem inicial dos conteúdos, forma de ministrar os exercícios, utilização de experimentos didáticos e livro didático em sala de aula.

Introdução: O ensino de Matemática atual, apesar de muitas tentativas de mudanças por profissionais comprometidos com a educação, ainda tem sido alvo de muitas críticas, os conteúdos ensinados pelos professores nas escolas são considerados distantes da realidade do aluno, dificultando o aprendizado do educando. Quando falamos em ensino de Geometria, a mesma é considerada uma facilitadora de aprendizagem na educação básica, com seus conteúdos aplicáveis, ela possibilita um intercambio entre números e espaço. Por outro lado, o ensino defasado no nível fundamental acarreta sérios obstáculos epistemológicos que os alunos apresentam no Ensino Médio, as relações geométricas, embora sejam aplicáveis, "quando o aluno se depara com cálculos de área e volume, o entendimento torna-se ainda mais complicado, realiza-os por mecanização, não entendendo a aplicação em novas situações". (ROGENSK e PEDROSO s/d pág. 2). No estudo de Rogeski e Pedroso (s/d), eles fazem uma reflexão sobre o ensino de espaço e forma atual, dando ênfase nas suas dificuldades e possibilidades, nesse estudo utilizam como recurso metodológico obras de artes, pinturas para relacionar a História, Artes e a Matemática, fazendo uma análise das figuras geométricas presentes nas obras, explorando suas propriedades das figuras planas e espaciais, outra atividade foi levar materiais concretos para o laboratório de Matemática e fazer a análise das suas propriedades matemáticas, através de atividades propostas pelos professores. Com a proposta mencionada, tiveram resultados bastante satisfatórios, onde os alunos conseguiram relacionar o estudo de espaço e forma com outras áreas do conhecimento, e "criar relações sociais constituídas de sensibilidade, criatividade e criticidade".

Uma pesquisa sobre ensino de espaço e forma bastante relevante para acrescentar foi o de Almouloud, Manrique, Silva e Campos (2004) em que a mesma teve como objetivo fazer uma investigação sobre as questões relacionadas com a aprendizagem da geometria nas séries finais do ensino fundamental e reconhecer as representações dos 
professores dessas séries no que se refere ao papel da geometria no processo de formação do aluno.

Para alcançar os objetivos da pesquisa, os autores optaram por uma metodologia de pesquisa-ação, integrando pesquisadores e professores e alunos, as suas concepções sobre importância do estudo de geometria e suas formas de analisar os erros dos alunos em resoluções de problemas envolvendo geometria, entre outros assuntos relacionados a docência. Depois disso, foram aplicados testes diferentes, de acordo com os conteúdos das séries, para as turmas em que esses professores envolvidos lecionavam para fim de identificar as concepções dos alunos sobre geometria, suas principais dificuldades, e por fim esse questionário foi analisado e confrontado com outras informações obtidas por outros procedimentos metodológicos. como:

a) Entrevistas com os professores objetivando discutir possíveis mudanças que estavam ocorrendo em suas concepções e práticas; b) documentos escritos individualmente pelos professores em que comentavam fatos ocorridos nos encontros de formação e no seu contexto escolar; c) mapas conceituais elaborados pelos professores para evidenciar inter-relações entre seus conhecimentos, suas concepções, suas emoções e seus sentimentos pesquisados em relação à geometria, ao seu ensino e à aprendizagem desta. (ALMOULOUD, MANRIQUE, SILVA E CAMPOS. 2004, p.2)

Os principais resultados foram obtidos em vários fatores, entre eles vamos destacar sobre a formação de professores, onde destaca que a mesma é muito precária em relação a Geometria e seu ensino, o que reflete diretamente na sua prática docente, outro fator é em relação ao tratamento do livro didático nos conteúdo de Geometria onde é comentado que os mesmo dificilmente propõe problemas para desenvolver o raciocínio dedutivo e lógico do aluno, privilegiando as resoluções algébricas, além de poucos problemas envolvendo textos para incentivar a leitura e a interpretação envolvendo Matemática.

Desde quando estava na educação básica, sempre gostei de geometria, quando entrei na graduação que tive a experiência da disciplina de desenho geométrico onde pude me aprofundar desse conhecimento. Então, a partir da experiência de observação nos estágios supervisionados, nas turmas que já lecionei e correção de provas e exercícios, no qual verifiquei que muitos alunos ainda sentem dificuldade em resolver problemas matemáticos envolvendo espaço e forma, devido a muita abstração, eles decoravam as fórmulas sem fazer uma construção do conhecimento, reconheciam a figura geométrica espacial, mas tinham dificuldades de relacionar com as figuras planas presentes e com situações do dia a dia, problemas em identificar as propriedades dos sólidos geométricos entre outros conceitos.

Além disso, o bloco de conteúdos vinculado ao ensino de espaço e forma está presente em pesquisas diagnósticas de avaliação como as que estão presentes nos órgãos de avaliação nacional, como o Instituto Nacional de Pesquisas Educacionais Anísio Teixeira (Inep), exemplos dessas avaliações são: Exame Nacional de Ensino Médio (ENEM), Provinha Brasil, Sistema Nacional de Avaliação de Educação Básica (SAEB), Programa Internacional de Avaliação de Alunos (PISA). Os resultados das provas do SAEB, por exemplo, falando de Matemática e na região Norte, a última análise de desempenho feito por uma escala de proficiência em 2015, os resultados tem sido mostrados não 
muito satisfatórios, praticamente todos os municípios estão inferior a média Nacional, como segue a imagem a seguir

Resumo do resultado do SAEB- Proficiências médias por município- Matemática

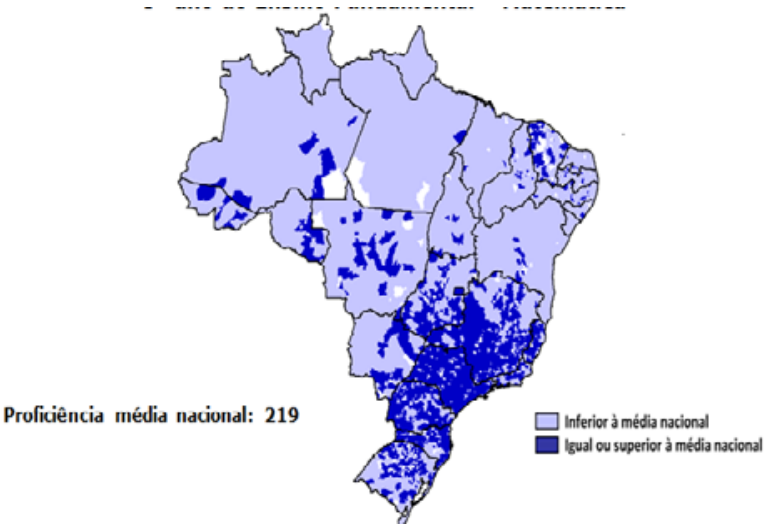

Fonte: Diretoria da Avaliação da Educação Básica- DAEB/INEP, pg 25.

O SAEB avalia as habilidades que o educando deve ter para o entendimento e resolução das questões propostas nas provas e deixa claro que o docente que deve desenvolver essas habilidades nas aulas de Matemática tendo isso como fator essencial para o bom êxito dos educandos nas avaliações. As habilidades cobradas dos alunos nas provas são apresentadas por descritores e divididas por temas com bloco de conteúdos, um deles é Espaço e forma, que é o foco da nossa pesquisa. Então isso nos leva a refletir na importância de um estudo sobre o ensino de Matemática, quais são as suas dificuldades e procurar encontrar metodologias para o seu aperfeiçoamento.

Com a intenção de aprofundar o conhecimento sobre os problemas relacionados ao ensino de Espaço e forma na Educação básica apresentamos o presente projeto que tem como questão norteadora: Como as percepções dos docentes e discentes sobre o ensino de Espaço e forma são relacionadas? Para alcançar ema resposta a questão a pesquisa tem como objetivo geral realizar um diagnóstico do ensino de Espaço e Forma no Ensino Fundamental a partir de das opiniões de docentes de Matemática e discentes de Ensino Fundamental. Os objetivos específicos da pesquisa são:

Desenvolver os estudos de natureza bibliográfica; 2) Investigar as percepções dos professores de Matemática acerca do ensino de espaço e forma; 3) Investigar as percepções dos estudantes do Ensino fundamental acerca do ensino de Espaço de forma; Coletar e apresentar os dados; Analisar os dados obtidos e fazer a divulgação.

Material e método: A pesquisa será de campo. Com os procedimentos metodológicos dados pelas seguintes etapas:

Revisão de Estudos: Nesta etapa será realizada uma revisão de estudos sobre o ensino de espaço e forma de um levantamento bibliográfico sobre o tema visando obter informações relativas a estudos sobre o tema;

Elaboração dos instrumentos de pesquisa: Neste momento serão elaborados com instrumentos de produção de informações da pesquisa, que poderão ser questionários, roteiros de entrevista ou de observação; Validação dos instrumentos e Ajuste dos instrumentos: a etapa da validação dos instrumentos será promovida por meio da aplicação dos instrumentos produzidos para cinco docentes e cinco discentes com a 
finalidade de obter informações sobre a adequação dos instrumentos no que diz respeito a forma, clareza e conteúdo dos mesmos com o objetivo de subsidiar possíveis ajustes. A etapa dos ajustes dos instrumentos ocorrerá com base nas informações obtidas na etapa de validação; Determinação da amostra: A determinação da amostra ocorrerá a partir do estudo de informações sobre o quantitativo de escolas públicas da Grande Belém bem como de sua distribuição; Aplicação dos instrumentos: Esta etapa será destinada a aplicação dos instrumentos de pesquisa quando serão consultados docentes e 100 estudantes da educação básica de rede publica sobre o ensino de Espaço e forma. Sistematização e Análise: A sistematização das informações ocorrerá por meio da organização das mesmas em planilhas para viabilizar as análises. A análise dos resultados sistematizados se dará por meio da análise das correlações entra as informações produzidas e os resultados dos estudos sobre o tema; Elaboração do texto e divulgação: Nesta etapa, as atividades serão escritas no texto detalhadamente. Após a elaboração do relatório da análise sobre a aplicação dos questionários, o texto será divulgado.

Considerações: O resgate histórico do ensino e a constituição do modelo pela visão curricular possibilitaram ter uma visão de como foram mudando as finalidades do ensino de Matemática ao longo dos anos. As pesquisas atuais que envolveram a temática nos indicaram que algumas características marcantes enfatizadas nos trabalhos coletados, como o pouco e superficial conhecimento pelo professor sobre a diversificação de procedimentos metodológicos para o ensino de Geometria, os docentes consultados permanecem ministrando aulas de maneira tradicional com o modelo de conceito, exemplos e exercícios, a falta de conhecimento dos conceitos de geometria, sobre os experimentos didáticos e com uso de tecnologia, a aproximação com o cotidiano é muito aceita pelos alunos e muito proveitosa em todos os estudos e a tecnologia vem agregar mais uma experiência de tentar aproximar a relação casa e mundo externo.

Com a consolidação da estrutura do instrumento de pesquisa, ficaram definidas as perspectivas de investigação das percepções dos professores e alunos, para os professores: Suas características de formação acadêmica e experiência profissional, com o objetivo de obter características desse profissional e verificar se tem alguma relação com a sua abordagem dos conteúdos e sua forma de avaliar. Para os alunos, conhecer o ambiente familiar e escolar de esse aluno está inserido é essencial para relacionar com seu rendimento em sala de aula, visto que a educação é um processo social que envolve vários meios sociais.

Referências bibliográficas: ALMOULOUD, Saddo Ag. MANRIQUE, Ana Lucia. SILVA, José Ferreira da. CAMPOS, Tânia Maria Mendonça. A geometria no ensino fundamental: reflexões sobre uma experiência de formação envolvendo professores e alunos. São Paulo: PUC, 2004.

BRASIL. Secretaria de Educação Fundamental. Parâmetros curriculares nacionais: Matemática. Brasília: MEC/SEF, 1997.

FERREIRA, Aurélio B. de H. Novo dicionário Aurélio da Língua Portuguesa. 2.ed. Curitiba: Nova Fronteira, 1999.

ROGESKI, Maria Lucia Cordeiro e PEDROSO, Sandra Mara Dias. O Ensino da Geometria Na Educação Básica: Realidade e possibilidades. Ponta Grossa. Disponível 
em <http://www.diaadiaeducacao.pr.gov.br/portals/pde/arquivos/44-4.pdf> Acesso em 14/12/2016 ás 18:30 horas.

Palavras chave: Educação Matemática, Espaço e Forma, ensino de Matemática. Grande-área: Educação

Área: Formação de Professores e Práticas Pedagógicas 


\title{
A CHAMA DA ESTRELA QUE PULSA E ARDE: EDUCAÇÃO SENSÍVEL NA PROSA POÉTICA DE ABGUAR BASTOS
}

\author{
Nome do(a) Bolsista: Evellin Natasha Figueiredo da Conceição \\ Nome do(a) Orientador(a): Josebel Akel Fares
}

Resumo: Inundada de rios, cores, matas, aromas, etc. a Amazônia é uma região extremamente multifacetada. Os nativos estabelecem uma relação diferenciada com o meio no qual estão inseridos, em um espaço que se torna estetizado a partir de uma estreita ligação com o natural (LOUREIRO, 2015). É neste contexto que está imerso o livro "Somanlu, O Viajante da Estrela" de Abguar Bastos, publicado em 1953. Um ponto crucial, que constitui o cerne da narrativa, é o fato de as explicações para a gênese das coisas serem tecidas a partir de mitopoéticas. Durante vinte luas, Abguar nos mostra outra percepção a respeito do nascimento dos seres existentes no mundo. Nesse sentido, proporciona um forte jogo imagético que sensibiliza o olhar do leitor, em um estado expressivo de fruição estético-literária. Somanlu, o protagonista da narrativa, é categórico ao fincar suas redes de comunicação com o outro a partir de uma conduta sensível pautada na relação com a natureza. O contato com a estrela é fundamental para o seu fluir humano. $O$ astro é o condutor de viagens as quais proporcionam ao menino o reconhecimento de verdades muitas vezes difíceis de serem compreendidas. Cada vez que viaja em seu interior compreende ainda mais o sentido da vida e entende o quanto é necessário o ato de desacelerar sua existência, a fim de ter uma percepção mais aguçada acerca das coisas ao seu redor. Meu intento, neste espaço, é refletir sobre os saberes pelos quais perpassam as narrativas mitopoéticas geradoras da história, a partir de uma concepção de educação que reconhece a sensibilidade corpórea enquanto elemento fundante na construção do conhecimento.

Introdução: Rios, mares, lagos, oceanos: águas, que de tão abundantes parecem infindas e são pungentes no imaginário amazônico em suas múltiplas representações. É este o cenário o qual se inicia a narrativa de Somanlu, nativo do rio, que desde a mais tenra idade explora suas profundezas e limites.

Com um olhar prenhe de sensibilidade acerca da região, Abguar Bastos, por meio das aventuras narradas pelo menino Somanlu, convida-nos a uma reflexão crucial sobre este espaço enquanto seio de instâncias sociais cunhadas por uma vivência sensível, essencialmente marcada pela dinâmica interação com a terra. Deste modo, encontram na Mãe Terra um ponto de origem comum. Embebidos nas imagens dos rios, das plantas, do céu, dos astros em movimento, das ondulações das nuvens que perpassam por entre várias nuances, potencializam um sentimento de integração a algo maior. 0 outro é visto como extensão de tudo que rege o universo e, assim, o afeto do amor permeia com real força tais relações sociais, tecidas sob os passos paulatinos do devir. Loureiro (2000) discorre sobre a iluminação poética dos mitos na Amazônia. Ao cair por terra o aspecto sacro, com um fim puramente prático, essas narrativas abarcam um caráter essencialmente estético, sinalizando uma movência de função. Mito e Poesia 
são fundidos e transformados em Mitopoética. Para o autor, um dos principais pilares dessa potência mítica impressa no solo amazônico é o estado de contemplação devaneante pulsante na existência do caboclo, impregnada por uma forte potência criadora. Isso proporciona um sentimento estetizador propulsor de coesão social, um comportamento moral capaz de ligar os indivíduos, não só pela sensibilidade estética, mas pela conduta moral e afetiva, as quais dão vida aos índios, caboclos, encantados e tantas mais figuras propulsoras da multiplicidade de saberes aqui constituídos.

As mitopoéticas se constroem a partir de metáforas e envolvem os seres que povoam a natureza, fruto da amplitude dos saberes poéticos oriundos do imaginário cultural impresso na região amazônica. Há uma explicação sensível para a gênese de todos esses seres e abarca uma gama de imagens e sensações, nas quais por vezes estão presentes a luz, o rio, o fogo,etc., gerando um jogo imagético fortíssimo que sensibiliza o nosso olhar.

Dessa forma, a pesquisa focaliza a discussão pautada nos saberes expressos na narrativas mitopoéticas presentes em "Somanlu, O Viajante da Estrela" de Abguar Bastos, com vistas a refletir acerca do modo como a educação é tecida a partir da rede de sociabilidade construída entre Somanlu e os seres da floresta na história, a partir de experiências ancoradas na sensibilidade.

Geral: Refletir sobre uma educação sensível a partir das peculiaridades que compõem a tessitura narrativa do livro "Somanlu, O Viajante da Estrela" de Abguar Bastos.

Específicos: Interpretar os saberes das mitopoéticas presentes no livro; Compreender o caráter de resistência intrínseco a esta narrativa; Discutir formas de notoriedade da Literatura de Expressão Amazônica por meio do livro em questão.

Material e Método: A discussão pauta-se em abordagem qualitativa e, portanto, trabalha com o universo de significados, motivos, aspirações, crenças, etc. correspondentes a um espaço profundo de relações sociais, que não podem ser reduzidas à operacionalização de variáveis (MINAYO, 2002). Destaco que por se tratar de um texto literário a problemática deve levar em consideração suas especificidades, compreendendo as motivações estéticas que norteiam a obra.

A pesquisa é de cunho bibliográfico, uma vez que lanço mão de artigos, dissertações, teses, etc. para compor a argumentação. Também é caracterizada como documental, pois o livro em questão circunscreve-se como documento material basilar nos apontamento realizados, fincados tanto no discurso intrínseco à narrativa, quanto nas ilustrações presentes no conjunto deste objeto estético-literário. Parte-se de um enfoque fenomenológico, uma vez que "[...] se ocupa da realidade cognitiva incorporada aos processos de experiências humanas subjetivas" (SCHUTZ, 1979, p. 15).

A modalidade de estudo é de caráter interpretativo, pois contribui para o diálogo com o texto bem como a apreensão dos significados essenciais inseridos dentro do discurso expresso na obra, pois interpretar pressupõe tomar uma posição própria a respeito das ideias enunciadas, de modo a superar a estrita mensagem do texto, ler nas entrelinhas, forçar o autor a um diálogo capaz de explorar toda a fecundidade das ideias expostas (SEVERINO, 2007). Isso me conduz a uma apreciação ampla das especificidades do 
livro sempre em articulação com as proposições acerca da Educação Sensível e, nessa ótica, as reflexões realizadas sempre estarão articuladas de maneira estreita e indissociável com a narrativa.

As imagens presentes na narrativa serão de suma importância na feitura desta pesquisa pois abrangerão um caráter muito mais que ilustrativo. As ilustrações dão vida à história e dialogam o tempo todo com os pormenores que a compõem. Discorro sobre a sensibilidade e essa é uma forma eficaz de mostrar a efervescência de sentidos que são aguçados a partir da leitura desse texto literário.

O diálogo com o texto literário é realizado a partir de levantamento bibliográfico e documental. Além disso, a tecitura deste estudo pauta-se na sua reunião e classificação em unidades temáticas oriundas de ideias fundantes, notadamente articuladas ao conteúdo das mitopoéticas encontradas na narrativa. Esse procedimento dará coerência à disposição dos principais elementos inerentes à problemática lançada. Para tal, utilizo a Estética da Recepção:

Corresponde à concretização das potencialidades de leitura que cada criação artística carrega consigo; não quer dizer que sejam sempre iguais, uma vez que olhar do leitor é importantíssimo na construção da mensagem estruturada a partir da leitura do texto literário (ZILBERMAN, 1999, p. 7).

A estética da recepção me ajudará a compreender as peculiaridades que marcam as vozes imersas no discurso de Abguar Bastos a partir dos seus múltiplos significados. Logo, a partir de minha recepção e de minha orientadora acerca da obra elencamos os pontos essenciais a serem discutidos.

Resultado e discussão: Somanlu empreende uma jornada de muitas (auto)descobertas que perpassam pela frequente interação com o meio natural. Logo, há uma forte intenção de explorar as potencialidades da nossa terra. Tudo aquilo presente na natureza, a sabedoria do seu povo e a fortíssima e vasta relação com esta, um chamado esperançoso à ancestralidade pela qual perpassa o estar no mundo desses seres. Nutridos de uma conexão profunda com as vozes da floresta, carregam um olhar inteligível direcionado ao natural e ao sobrenatural. Os saberes construídos dia após dia, nas mais sutis manifestações, amplificam a noção de que a existência humana está para além daquilo que é palpável. Interagem, portanto, com divindades detentoras de um expressivo pluralismo de ensinamentos morais e éticos reguladores de suas vidas.

Nesse contexto, as explicações oriundas de narrativas míticas intrínsecas à história de Somanlu são permeadas por elementos fantásticos e sobrenaturais, que conduzem ao poético e, logo, inscrevem-se no plano literário enquanto mitopoéticas. As plantas, os rios, os animais, etc. são personificados de tal maneira de modo a dar uma nova dinamicidade ao espaço e conduzir a um olhar ímpar em relação a determinado fenômeno natural. Apresento a seguir alguns mitos de origem fundamentais dentro da feitura estética geradora da narrativa. 
Para que as coisas reservadas à sua fome estivessem sempre bem nutridas e tratadas, Caru-Saca-lbo ${ }^{6}$ fez nascer feiticeiras que deveriam governar a terra, pois, para governar o céu, bastavam Tatamanha e Caru-Saca-lbo. Deu vida a cinco figuras: Nunó, Paqueima, Ceuci, Aiá e Nonhom, nascidas de Tatamanha. Observamos que o equilíbrio fundante no modo como as coisas eram tecidas passava pelo poder dessas cinco feiticeiras. Cada uma, a seu modo, era responsável por articular uma espécie de bem viver condutora do existir dos elementos naturais. Elas estavam organizadas sistematicamente para proporcionar harmonia ao mundo.

Nunó deteve profunda atenção por tudo aquilo que era feminino, de modo a conseguir por em ordem os rios e todas as águas. Tudo que habitava as suas profundezas passava pela existência sensível de Nunó como protetora dessas criaturas. Assim ficou sendo seu destino.

Paqueima logo teve um interesse especial pelas luzes. Queria arrumá-las e dar lógica a sua dinâmica impregnando-as de cores. Era uma forma de evitar que os bichos se soltassem à noite fora de tempo apropriado e, assim,

Passou logo a mandar não só nas luzes como nas sombras. E enquanto a escuridão marchava de um lado para outro [...] Paqueima soltava vagalumes no espaço, que acendiam suas luzes, apagando-as quando a escuridão já se achava escondida (BASTOS, 1953, p. 40).

Ceuci, por sua vez, olhou para os animais e desde o primeiro momento nutriu grande afeição por eles, devotando um carinho muito sincero. Viu que estes eram dotados de uma completa assimetria e logo quis fazer algo para deixar ainda mais exuberantes aqueles seres cheios de luz. Assim, redimensionou estas existências colorindo ainda mais suas formas:

Ceuci achou ruim o que viu: pássaros que tinham dentes, mamíferos que punham ovos, peixes e lagartas que tinha asas, pássaros que tinham mãos, cobras com duas cabeças, animais que cresciam demasiadamente e outros que, podendo viver em toda parte, não sabiam qual a sua verdadeira morada: se o ar, a terra ou as águas. No entender de Ceuci, cada coisa devia ter o seu lugar e a sua condição de vida. Passou então a dar formas definidas aos bichos [...] Mas não se limitou aos bichos, passou a equilibrar a existência de tudo o que possuía movimento e que podia ir de um lugar para o outro. E assim ficou sendo seu destino (BASTOS, 1953, p. 40-42).

Aiá olhou para as florestas e enxergou um fortíssimo potencial de vida. Conseguiu compreender a unidade que este espaço representava para todos os seres, sendo casa que abriga e ao mesmo tempo edifica, compilando essas vidas, ao ser sua extensão. Corporificou e ajudou a manter o equilíbrio entre os elementos que a constituíam, contribuindo para a manutenção da simetria entre estes corpos:

\footnotetext{
${ }^{6} \mathrm{O}$ mundo já estaria criado quando apareceu Caru-Saca-lbo. Na novela, por necessidade do argumento, ele surge incorporando o mito dos heróis cósmicos criadores. Personagem celestial, grande caçador do fabulário mundurucu. O céu de Caru-Saca-lbo é uma enorme pedra polida segundo a lenda.
} 
"Aiá ficou encantada com as florestas. Passava dias e noites colorindo as plantas e as flores. Queria ver o mundo enfeitado. E ajudava Nunó a pôr ordem nos rios, porque Aiá ficava furiosa quando um rio lhe derrubava uma árvore [...]" (BASTOS, 1953, p. 42).

Deste modo, proporciona à natureza grande parte daquilo que há de mais belo em seu meio.

Nonhon se encantou com os minerais preciosos os quais encontrava na medida em que explorava as vastidões da Terra. Viu logo o potencial que aqueles brilhantes tinham ao carregar uma beleza única comparável à dos astros. Isso possibilita a iluminura de algumas regiões da floresta, tal como rios e montanhas, preocupando-se incessantemente com as profundezas, o subterrâneo:

Nonhon maravilhou-se com o oiro, a prata, as pedras coloridas e brilhantes que ia encontrando. Pôs-se a iluminar as montanhas e os rios com essas pedras e metais, pôsse igualmene a alumiar o interior da terra com os minerais preciosos [...](BASTOS, 1953, p. 42).

São existências entrelaçadas em uma relação indissociável. Tudo aquilo que existe está dentro do todo por mais complexa que seja sua forma de vida individual. Vemos, portanto, uma dinâmica pautada na ideia de globalidade, um fluir existencial cravado por uma ampla gama de sujeitos naturais e sobrenaturais

As mitopoéticas apresentadas em Somanlu, o Viajante da Estrela sugerem uma perspectiva existencial diversa e expressiva. O saber construído pelos personagens integrantes da narrativa percorre uma razão a qual explora de forma ampla a sensibilidade humana. Abguar tece diversas imagens de cunho poético, fundamentadas pela interação frequente do homem com a terra em seu sentido totalizante. Há sempre uma forma diferenciada de aprendizado. Um saber que dá vazão ao sentir do corpo em todas suas magnitudes, aprendizagem configurada pela exploração ampla dos sentidos, a educação sensível, com forte estímulo à imaginação, pois tem uma "função transcendental, ou seja, ela permite que se vá além do mundo material objetivo e se crie o que Bachelard chamava de 'suplemento da alma'" [Grifos da autora] (PITTA, 2005, p. 38).

Estamos, portanto, diante de uma experiência cosmogônica, epistemológica e ontológica completamente diferenciada. Encontra no natural os principais indícios de feitura do mundo. Além disso, explica coerentemente a origem dos seres, resgatando a tradição oral impressa na vivência dos povos originais da Amazônia. Isso contribui para a afirmação da identidade desse povo, pois com seus ensinamentos nutre de saberes as experiências fincadas no cotidiano, saberes estes que estão para além de um conhecimento científico de cunho moderno, marcado por uma grade disciplinar. Abguar nos mostra o quanto é possível aprender interagindo com a natureza e os seres que a povoam, o que identifico como uma atitude marcada por fortes traços decoloniais, uma vez que é atravessada por uma ótica de existência distante do padrão de saber hegemônico moldado pela lógica moderna eurocêntrica. As mitopoéticas ilustradas aqui nos possibilitam pensar sob perspectivas outras a gênese do Universo. 
Palavras-Chave: Amazônia. Mitopoética. Imaginário. Educação Sensivel.Grande Área: Literatura

Área: Literatura Brasileira de Expressão Amazônica 


\title{
NARRATIVAS DE MORADORES DA BAÍA DO SOL-MOSQUEIRO- PA: ATITUDES ÉTICAS E SABERES CULTURAIS
}

\author{
Nome do(a) Bolsista: Fábio da Conceição Câmara \\ Nome do(a) Orientador(a): José Anchieta de Oliveira Bentes
}

Resumo: Este projeto tem como objetivo analisar a relação entre as histórias contadas por moradores da Baía do sol-Mosqueiro-PA com seus saberes culturais e com os tipos de éticas envolvidas nas mesmas. A metodologia de pesquisa ocorre por meio da análise dialógica das narrativas, que se utiliza de três rodas de conversas, que são encontros organizados pelo pesquisador para que os participantes contem suas narrativas e avaliem a ação dos personagens, estabelecendo relações com suas vidas e proporcionando espaço e tempos de interação. As gravações dessas rodas constituem o corpus de análise, que tem como autores de base Bakhtin (2003) e Paulo Freire e utilizase de diversas tipologias éticas para a análise das narrativas.

Introdução: Esta proposição de pesquisa tem relevância para o campo de pesquisa em educação na atuação de saberes amazônicos, pois trata de narrativas vividas ou repassadas de geração a geração por familiares para as crianças, adolescentes e adultos. São relações sociais presentes na vida dos participantes, no que concerne à cultura da localidade da Baía do sol-Mosqueiro-PA, com o intuito de entender os posicionamentos éticos.

Em virtude disso, é imprescindível problematizar as narrativas no que diz respeito a ética dos participantes em relação as atitudes dos personagens das narrativas, com os saberes culturais envolvidos. Faz-se necessário promover um diálogo entre diferentes saberes desses participantes, que dialoguem com a realidade destes a partir de sua historicidade, partindo do pressuposto da valorização da cultura local e dos saberes amazônicos que emergem a partir das narrativas.

Vale ressaltar o diálogo acerca dos autores referentes aos saberes contidos nos relatos orais desses enunciadores, com relação as narrativas, bem como a inserção a qual se dá em um tempo, espaço e relações sociais em que o sujeito se reconhece por meio da linguagem e é por meio dela que se mostra atuante a ponto de interferir na vida do outro, ou seja, a linguagem é uma criação coletiva em que se manifesta a ontologia do eupara-mim, do eu-para-o-outro e do outro-para-mim conforme os termos utilizados por Bakhtin (2003).

\section{Objetivos}

\section{GERAL}

- Analisar as atitudes éticas e os saberes culturais a partir de narrativas de moradores da Baía do Sol-Mosqueiro-PA.

\section{ESPECÍFICOS}

- Investigar a relação das narrativas com os saberes culturais dos participantes, considerando-se o contexto amazônico;

- Compreender os tipos de éticas envolvidos nos atos de fala das narrativas contadas, a partir do ponto de vista dos participantes da pesquisa. 
materias e métodos: A abordagem da pesquisa será de caráter qualitativa, pois a mesma investigará as narrativas, contadas pela comunidade, envolvendo de maneira participativa os participantes - a partir de suas narrativas - e o pesquisador no processo da pesquisa, isto é, com o intuito de promover um diálogo dinâmico e também epistemológico (SEVERINO, 2017).

Para o desenvolvimento desta pesquisa, optamos pelos pressupostos da metodologia de uso das rodas de conversas, que são relevantes para o processo da pesquisa, que segue uma perspectiva emancipatória, libertadora e significativa para os envolvidos, tendo em vista o diálogo como pressuposto fundamental nos encontros. Pois, por meio dessa metodologia, proporcionaremos momentos de interação por meio da dialogicidade, acerca de suas narrativas que se relacionam aos seus saberes.

Para isso organizaremos três encontros ou rodas de conversas, conforme a descrição a seguir:

A partir do uso das rodas de conversas, é possível construir um corpus de pesquisa para ser analisado. As rodas estão pautadas, por princípios, em processo dialógico e emancipatória, pautadas nos pressupostos da metodologia narrativa, visto que as histórias apresentarão suas especificidades e posterior, contribuirão para os estudos nesse campo do conhecimento das ciências humanas.

A partir da realização das rodas, que serão filmadas e posteriormente transcritas transformando o evento oral em escrito - para a problematização e sistematização das narrativas em textos acadêmicos, identificando os saberes desses enunciadores e classificando os tipos de atitudes éticas que ocorreram nas rodas, e com isso gerando conhecimentos.

No que concerne a metodologia narrativa de pesquisa em educação, na perspectiva de gênero do discurso estamos nos pautando principalmente em Bakhtin, e considerando essa metodologia como uma forma do educador assumir o papel também de pesquisador- narrador no evento de contar.

Portanto, após as rodas de conversa, realizaremos o levantamento bibliográfico, a transcrição das falas que ocorreram e a análise dialógica das narrativas, com a categorização e a reconstrução analítica de organização dos dados.

Resultado e discussão: Manter o diálogo entre saberes diferentes, bem como as histórias lendárias amazônicas e locais dessa comunidade, é de suma importância para preservar e divulgar esse conjunto de construções culturais - principalmente centrado em narrativas orais - que vem de geração em geração. Assim, podemos perceber uma riqueza de relatos desses participantes, na qual constroem cada dia sua história como ser histórico-cultural e com isso mantem viva toda essa diversidade de saberes populares. Pois, "O diálogo traz a marca não de uma, mas de várias individualidades" (BAKHTIN, 2016, p. 15).

Contribuir na criação de um banco de dados referente as narrativas locais para os moradores locais e a discussão a respeito dos posicionamentos éticos dos personagens da história, sobretudo no contexto da educação na Amazônia. Esse trabalho, junto às demais iniciativas existentes, irá ampliar o conteúdo das reflexões no campo teórico a partir de uma análise dos saberes culturais de narrativas da Baía do Sol-Mosqueiro-PA, por meio de relatos dos moradores, posteriormente sistematizadas, a fim de contribuir 
com o campo de pesquisa e aprofundar os estudos, no que concerne aos saberes amazônicos.

A análise dos dados será realizada pela análise dialógica das narrativas após a transcrição das rodas de conversas, de maneira que seja possível coletar suas narrativas e seus posicionamentos éticos, no qual são pautadas em seu cotidiano, pois, serão registradas as informações a partir de sua leitura de mundo.

Conclusão: No que concerne ao ouvir os relatos orais desses participantes será possível entender e compreender seu contexto social e valorizar seus saberes populares, que estão cheios de sabedorias, bem como histórias que eles contam com maior mistério, dramatização e convicção.

O diálogo é fundamental durante todo o processo de conversação, nos aproxima das suas formas de ser, pensar, viver, na qual não há quem sabe mais ou quem sabe menos, pois, todos sabem uma história e do seu jeito contribuem com seus saberes diferentes para explicar acontecimentos e atitudes éticas que tomam nos seus cotidianos.

A partir da reflexão acerca da valorização dos saberes populares e do conhecimento das atitudes éticas em ambientes sociais e específicos, observaremos um cenário diversificado que resulta na riqueza sobre as práticas sociais e o cotidiano, especificamente em contextos de grupos e sujeitos históricos, que constroem e reconstroem seus saberes em meio as suas vivências e práticas cotidianas específicas, como todos os povos da Amazônia.

Referências: BAKHTIN, Mikhail. Diálogo I: a questão do discurso dialógico. In: BAKHTIN, M. Os Gêneros do discurso. Organização, Tradução, posfácio e notas Paulo Bezerra. Notas de edição russa Serguei Botcharov. São Paulo: Ed. 34, 2016. P. 113124.

BAKHTIN, Mikhail. Estética da criação verbal. São Paulo: Martins Fontes, 2003 PRADO, Guilherme do Val Toledo et al. Metodologia narrativa de pesquisa em educação: uma perspectiva bakhtiniana. São Carlos: Pedro \& João Editores, 2015.

SERODIO, Liana Arrais; PRADO, Guilherme do Val Toledo. Metodologia narrativa de pesquisa em educação na perspectiva do gênero discursivo bakhtiniano. In: PRADO, Guilherme do Val Toledo et al. Metodologia narrativa de pesquisa em educação: uma perspectiva bakhtiniana. São Carlos: Pedro \& João Editores, 2015.

SEVERINO, Antônio Joaquim. Metodologia do trabalho científico. 23. ed. ver. E Atual. São Paulo: Cortez, 2000.

VOLÓCHINOV Valentin. A interação discursiva. VOLÓCHINOV Valentin. Marxismo e filosofia da linguagem: Problemas fundamentais do método sociológico na ciência da linguagem Tradução, notas e glossário de Sheila Grillo e Ekaterina Vólkova Américo. Ensaio introdutório de Sheila Grillo. São Paulo: Editora 34, 2017. p. 201-225.

Palavras-chave: Diálogo; Narrativas; posicionamentos éticos

Grande - área: Ciências Humanas

Área: Educação 


\section{ALUNOS COM DEFICIÊNCIA NA EJA: REALIDADES DIVERSAS}

Nome do(a) Bolsista: Iranildo da Silva Oliveira

Nome do(a) Orientador(a):Ana Paula Cunha dos Santos Fernandes

Resumo: Este trabalho é um recorte da pesquisa de mestrado em andamento que versa sobre a Pessoa com Deficiência na Educação de Jovens e Adultos - EJA. Tendo o objetivo de conhecer por meio da história de vida como os alunos com deficiência vivenciam o processo de inclusão na modalidade EJA no município de Santa Maria do Pará, nordeste do estado do Pará. A questão que busca responder é: de que forma os alunos com deficiência vivenciam a inclusão e a escolarização nas turmas de Educação de Jovens e Adultos no município de Santa Maria do Pará? Trata-se de uma pesquisa com abordagem qualitativa e a metodologia é História de Vida. As participantes da pesquisa são três alunas com deficiência matriculada na EJA. Os resultados iniciais dão conta que existe duas realidades no Atendimento Educacional Especializado, sendo oferecido na sede do município, enquanto há ausência no oferecimento no que se refere ao campo.

Introdução: Este trabalho é um recorte da pesquisa de mestrado em andamento que versa sobre a Pessoa com Deficiência na Educação de Jovens e Adultos - EJA. Essa pesquisa faz a interface de duas modalidades de ensino consolidadas na Lei de Diretrizes e Bases, Lei No 9.394 de 1996, onde o Art. 37 discorre sobre a EJA e o Art. 58 trata da Educação Especial.

A Lei 13.146 de 2015, conhecida com Estatuto da Pessoa com Deficiência, considera no Art. $2^{\circ}$ que Pessoa com Deficiência é:

aquela que tem impedimento de longo prazo de natureza física, mental, intelectual ou sensorial, o qual, em interação com uma ou mais barreiras, pode obstruir sua participação plena e efetiva na sociedade em igualdade de condições com as demais pessoas. (BRASIL, 2015)

Sobre a Pessoa com Deficiência na EJA, Fernandes e Gonçalves (2013) informam que a Educação de Jovens e Adultos que tem como alunos com deficiência matriculados, a reprovação e o analfabetismo se aproxima a 80\%, e isso é um fato a ser repensado não apenas nas instituições de ensino, mas também os pesquisadores da área, colocando em cheque a formação dos docentes atuantes na EJA.

Segundo Arroyo (2008) é complexo criar modelos de formação para professores que envolvam a diversidade, no sentido de que o país é rico no que se refere à diversidade, mas ainda quando se leva em consideração as singularidades regionais. Albuquerque e Cunha (2011) acrescentam a ausência de ações efetivas na formação de professores que levem em consideração a especificidade da Educação de Jovens e Adultos.

Sobre o processo de inclusão no Brasil, Farias e Oliveira (2016) destacam que não existe inclusão de fato, e sim há legislações que normatizam a inclusão, que sugere mudança de postura da sociedade. 
Essa interface está sendo problematizada e evidenciada por meio da História de Vida de alunas com deficiência que estão devidamente matriculadas na modalidade da Educação de Jovens e Adultos - EJA. A questão que busca ser respondida é: de que forma os alunos com deficiência vivenciam a inclusão e a escolarização nas turmas de Educação de Jovens e Adultos no município de Santa Maria do Pará? O objetivo da pesquisa é conhecer por meio da história de vida como os alunos com deficiência vivenciam o processo de inclusão na modalidade EJA no município de Santa Maria do Pará, nordeste do estado do Pará.

A Educação de Jovens e Adultos é um terreno diversificado, envolvendo sujeitos com graus e conhecimentos variados, soma-se a especificidade existente nos alunos público alvo da Educação Especial que fazem parte dessa primeira modalidade de ensino.

Material e Método: A metodologia utilizada foi a História de Vida na perspectiva de Thompson (1992, p. 44) por se tratar da subjetividade, esse autor afirma que é "uma história construída em torno de pessoas. Ela lança a vida para dentro da própria história e isso alarga seu campo de ação. Admite heróis vindos não só dentre os líderes, mas dentre a maioria desconhecida do povo".

Tendo como abordagem a qualitativa, na perspectiva de Goldenberg (2004). E para a análise dos dados foi utilizado às categorias de análise. De acordo com Oliveira e Mota Neto (2011, p. 163) "a partir das categorias de análise construídas é possível ao pesquisador refletir criticamente sobre a análise das informações obtidas na investigação".

$\mathrm{O}$ instrumento de coleta de dados foi à entrevista com roteiro semiestruturado, que versa sobre: Atendimento Clínico; Educação Infantil; Ensino Fundamental e por último a Educação de Jovens e Adultos.

Essa pesquisa buscou atender todos os rigores éticos em pesquisa envolvendo seres humanos preconizado na Resolução No 466 de 12 de dezembro de 2012 do Conselho Nacional de Saúde - CNS e a Resolução 510 de Abril de 2016 do CNS. O projeto foi submetido ao Comitê de Ética (CAAE: 04352518.9.0000.8767). A pesquisa está sendo realizada no município de Santa Maria do Pará, nordeste do estado do Pará, cerca de $100 \mathrm{Km}$ de distância de Belém (capital do Estado).

As participantes são três alunas com deficiência que estão matriculadas na Educação de Jovens e Adultos e estão representadas por: P01; P02 e P03. Isso no sentido de preservar suas identidades.

Resultado e Discussão: A pesquisa conta com três participantes, são discentes da Educação de Jovens e Adultos, onde duas possuem Deficiência Intelectual e uma possui Deficiência Física provocada pela Neuropatia Progressiva. Duas participantes possuem 16 anos e uma tem 23 anos de idade.

Moram no município desde que nasceram, sendo que apenas uma mora na sede do município. Uma mora na comunidade de São José, distante cerca de $10 \mathrm{~km}$ da sede da cidade. E a outra, no Distrito de Taciateua, distante cerca de 20 km do município.

Estudam em escolas públicas. P01 estuda na EJA no turno da manhã e faz Atendimento Educacional Especializado - AEE uma vez por semana na mesma escola no turno da tarde. P02 frequenta a EJA noturna e também o AEE uma vez por semana na mesma escola em que estuda. Já P03 participa da EJA noturna, mas em sua escola na oferece o AEE e nem é atendida por professores itinerantes. 
Conclusão: Essa pesquisa objetiva conhecer por meio da história de vida como os alunos com deficiência vivenciam o processo de inclusão na modalidade EJA no município de Santa Maria do Pará, nordeste do estado do Pará.

A pesquisa ainda está em curso, mas observa-se que existe uma participante que não frequenta o Atendimento Educacional Especializado por não ser oferecido em sua escola. Mostra-se desafiador frequentar a Educação de Jovens e Adultos, sendo Pessoa com Deficiência. Outros dados irão surgir a partir das futuras análises da pesquisa.

Referências bibliográficas: ALBUQUERQUE, André Souza de; CUNHA, Emmanuel Ribeiro. Reflexões a respeito da formação continuada de professores da EJA. In: TÁVORA, Maria Josefa de Souza; BENTES, Nilda de Oliveira. (Orgs.). Estudos sobre Formação de Professores. Belém: Eduepa, 2011.

ARROYO, Miguel G. Os coletivos diversos repolitizam a formação. In: DINIZ-PEREIRA, Júlio Emílio; LEÃO, Geraldo. (Orgs.). Quando a diversidade interroga a formação docente. Belo Horizonte: Autêntica, 2008 - (Docência), p. 11-36.

BRASIL. Lei 9.394 de 1996. Estabelece as Diretrizes e Bases da Educação Nacional. Disponível em: < http://www.planalto.gov.br/ccivil_03/leis/19394.htm>. Acesso em: Novembro de 2019.

. Lei 13.146 de 2015. Institui a Lei Brasileira de Inclusão da Pessoa com Deficiência (Estatuto da Pessoa com Deficiência). Disponível em: <http://www.planalto.gov.br/ccivil_03/_ato2015-2018/2015/lei/l13146.htm>. Acesso em: Novembro de 2019.

FARIAS, Roseane Rabelo Souza; OLIVEIRA, Ivanilde Apoluceno de. Representações sociais de professores sobre a inclusão escolar de educandos com necessidades educacionais especiais. In: OLIVEIRA, Ivanilde Apoluceno de; OLIVEIRA, Waldma Maíra Menezes de (Org.). Representações Sociais, Identidades e Educação Inclusiva na Amazônia Paraense. Belém: UEPA, 2016. p. 26-46.

FERNANDES, Ana Paula. GONÇALVES, Taísa Grasiela Gomes Liduenha. Alunos com deficiência na educação de jovens e adultos: e a formação para os professores? In: RESENDE DA COSTA, Maria da P. (Org.). Educação Especial: Sugestões de recursos para os ambientes educacionais inclusivos. São Carlos: Pedro \& João Editores, 2013. p. 29-50.

GOLDENBERG, Mirian. A Arte de Pesquisar: Como fazer pesquisa qualitativa em Ciências Sociais. 8ª Ed. Rio de Janeiro: Record, 2004.

OLIVEIRA, Ivanilde Apoluceno de; MOTA NETO, João Colares da. A construção de categorias de análise na pesquisa em Educação. In: MARCONDES, Maria Inês; OLIVEIRA, Ivanilde Apoluceno de; TEIXEIRA, Elizabeth (Org.). Abordagens teóricas e construções metodológicas na pesquisa em Educação. Belém: EDUEPA, 2011. p. 161-179. 
THOMPSON, Paul. A voz do passado: História Oral. tradução Lólio Lourenço de Oliveira. Rio de Janeiro: Paz e Terra, 1992.

Palavras-chave: Educação de Jovens e Adultos. Educação Especial. História de vida. Grande-Área: Ciências Humanas Área: Educação 


\title{
SABERES DAS ERVEIRAS DO VER-O-PESO: CONTRIBUIÇÕES À EDUCAÇÃO INTERCULTURAL NA AMAZÔNIA
}

\author{
Nome do(a) Bolsista: Louise Rodrigues Campos \\ Nome do(a) Orientador(a): Ivanilde Apoluceno de Oliveira
}

Resumo: Neste trabalho apresentam-se os resultados parciais da pesquisa intitulada "Saberes das erveiras do Ver-o-Peso: contribuições à educação intercultural na Amazônia". O objeto de estudo desta pesquisa consiste nos processos educativos produzidos no trabalho realizado pelas erveiras do Ver-o-Peso, no qual são construídos e circulam saberes culturais, e a contribuição destes processos educativos à educação intercultural na Amazônia. A problemática de investigação é: "Como as mulheres erveiras desenvolvem o seu saber-fazer na feira do Ver-o-Peso, as dimensões educativas e sociais desses saberes e práticas e as contribuições aos estudos da educação intercultural na Amazônia?" Adotou-se como estratégia metodológica a cartografia de saberes para identificar e mapear os saberes que perpassam o trabalho das erveiras do Ver o Peso, com base na cartografia simbólica de Boaventura de Sousa Santos. Trata-se de uma pesquisa de campo qualitativa com os seguintes procedimentos metodológicos: levantamento bibliográfico e entrevista semiestruturada. A sistematização e a análise dos dados serão realizados por meio da técnica de categorização. Assim, o intuito é analisar como as erveiras desenvolvem o seu saberfazer, mediante a dimensão educativa nas práticas de trabalho com os produtos medicinais comercializados no Ver-o-Peso. Esta pesquisa tem como relevância o reconhecimento das mulheres, conhecidas como erveiras, na produção de conhecimentos. E a importância destes na vida delas. Identificar os modos como socializam as suas sabedorias, os seus modos de ensinar e aprender, diz respeito à afirmação destas como representantes dos seus saberes, importantes às suas sobrevivências e da construção de uma cultura curativa que compõe a trama cultural amazônica.

Introdução: Pensar a existência de outros espaços pedagógicos, além dos escolares, na configuração sócio-territorial amazônica, diz respeito à atenção e ao diálogo com os modos como agem e refletem os sujeitos amazônidas nas suas práticas cotidianas, referente às suas concepções de mundo, suas expressões religiosas, políticas, artísticas, os imaginários construídos, por exemplo, a partir da relação com recursos da fauna e da flora.

Vejo o forte uso de recursos da fauna e da flora no âmbito da saúde na Amazônia, como no trabalho das mulheres conhecidas como erveiras, que fazem produtos, como os banhos feitos com vegetais. O Ver-o-peso é o local de Belém, onde são comercializados os banhos - inclusive outros produtos, como óleos, ervas com propriedades medicinais. É no setor das ervas que os erveiros e, em maior quantidade, as erveiras desenvolvem o seu cotidiano de trabalho com a produção de banhos para atrair bons fluidos; a produção dos perfumes como abre-caminho, desatrapalha, chama do amor; e a indicação de ervas com propriedades medicinais o preparo de chás para diversas enfermidades. 
Por meio do manuseio de ervas com propriedades medicinais, as mulheres erveiras expressam os seus modos de interpretar o mundo, suas leituras sobre o uso de recursos naturais, da fauna e da flora, quanto a problemáticas de saúde física e sentimental; expressam também suas percepções estéticas, como na elaboração dos nomes e na ornamentação dos seus produtos.

Diante da diversidade sociocultural amazônica é importante a construção de práticas educativas interculturais, visibilizando os saberes que são produzidos como inexistentes, visto que:

as populações da Amazônia produzem uma gama de tradições culturais e de saberes que se diferenciam da lógica da cultura capitalista moderna e que, por isso, sofrem a invisibilidade de seus saberes e o não reconhecimento da sabedoria construída em suas práticas sociais. Portanto, dar visibilidade a estes saberes dimensiona-se como uma estratégia de luta política contra o sistema capitalista. (OLIVEIRA; MOTA NETO, 2015, p. 30)

Desse modo, a investigação sobre as especificidades educativas que podem constituir o saber-fazer das erveiras atuantes no Ver-o-Peso diz respeito ao potencial de criação e criativo que emerge das sabedorias destas mulheres e do modo como se expressam detentoras de conhecimentos tradicionais de cura a males físicos e sentimentais.

Mediante o exposto delineou-se como problemática de investigação: Como as mulheres erveiras desenvolvem o seu saber-fazer na feira do Ver-o-Peso, as dimensões educativas e sociais desses saberes e práticas e as contribuições aos estudos da educação intercultural na Amazônia?

Objetivos: Para atender a problemática do estudo, delineou-se o seguinte objetivo geral: analisar como as erveiras do Ver-o-Peso desenvolvem o seu saber-fazer, as dimensões educativas e sociais desses saberes e práticas no seu viver cotidiano e as contribuições aos estudos da educação intercultural na Amazônia.

Os objetivos específicos são:

1) Identificar e mapear os saberes que perpassam o trabalho cotidiano das erveiras do Ver o Peso, utilizando a estratégia metodológica da cartografia de saberes;

2) Descrever e analisar o processo educativo produzido no saber-fazer das erveiras do Ver o Peso;

3) Identificar as contribuições dos saberes e práticas produzidas pelas erveiras do Ver o Peso na construção da educação intercultural na Amazônia.

Material e método: Trata-se de uma pesquisa de campo, cujos dados serão coletados no próprio ambiente de trabalho das/dos erveiras/os, visto que "na pesquisa de campo, o objeto/fonte é abordado em seu meio ambiente próprio. A coleta de dados é feita nas condições naturais em que os fenômenos ocorrem, sendo assim diretamente observados" (SEVERINO, 2007, p. 123).

Esta pesquisa apresenta abordagem qualitativa, referente às significações que as erveiras atribuem às suas formas de ensino e aprendizagem que perpassam a sua dinâmica de trabalho, visto que esta abordagem "trabalha com o universo de significações [...] valores e atitudes, o que corresponde a um espaço mais profundo das relações, dos processos e dos fenômenos que não podem ser reduzidos à operacionalização de variáveis" (MINAYO, 2009, p. 22). 
Diante da especificidade da realidade investigada que consiste na dimensão educativa presente no trabalho de um grupo de erveiras do Ver-o-Peso, a pesquisa caracteriza-se também como um estudo de caso.

O enfoque do estudo é o crítico-dialético, fundamentado teoricamente no materialismo histórico, sendo que "a concepção materialista funda-se no imperativo do modo humano de produção social da existência" (FRIGOTTO, 1989, p.75). Este enfoque contribui ao intuito de analisar as características educativas que perpassam o saber-fazer das erveiras, isto é, problematizar o que nos revela esta educação, mediante a sua intencionalidade, a sua organização, sua politicidade, às concepção de mundo (de natureza, de cura, de ser humano) que caracterizam esta educação.

Adotou-se como estratégia metodológica a cartografia de saberes para identificar e mapear os saberes que perpassam o trabalho das erveiras do Ver o Peso, com base na cartografia simbólica de Boaventura de Sousa Santos. Nesse sentido, entende-se que a opção pela cartografia diz respeito à compreensão dos modos como os sujeitos representam os seus espaços-tempos em que tecem as suas relações sociais, constroem próprias com especificidades aos seus modos de ser, moventes nas histórias, culturas e espaços amazônicos.

No desenvolvimento da pesquisa também tem sido realizado levantamento bibliográfico e desenvolvidas entrevistas semiestruturadas individuais com as erveiras, a fim de investigar como ocorre o seu processo de trabalho com as ervas, as etapas, e como aprendem e ensinam. Compreende-se a entrevista como um processo dialógico, no qual, ambos sujeitos, entrevistados e entrevistadores ocupam posições essenciais na construção do processo investigativo.

Este procedimento é entendido, portanto, como momento em que os sujeitos entrevistados também dialogam, ou seja, também podem problematizar as situações, conforme as perguntas, e não somente recebe-las da entrevistadora. Além disso, no processo da pesquisa também ocorre a observação in loco, visando observar o contexto em que ocorrem as relações de comercialização e indicações dos produtos das erveiras. Para a sistematização e análise dos dados serão construídas categorias analíticas e temáticas. As categorias analíticas são construídas a partir do referencial teórico e vão auxiliar na reflexão crítica das informações (OLIVEIRA; MOTA NETO, 2011). A construção das categorias tem como referência técnicas da análise de conteúdo, com o agrupamento de conceitos, elementos a partir de suas relações, das características em comum que apresentam (BARDIN, 2010). Referente aos cuidados éticos foi elaborado o Termo de Consentimento Livre e Esclarecido (TCLE) para a leitura e possível concordância das erveiras participantes da investigação. Para realizar o processo metodológico são utilizados gravador de áudio, câmera fotográfica, celular, notebook e diário de campo.

Resultados e discussão: Dialogar com os modos de ensino-aprendizagem que constitui o saber-fazer das erveiras atuantes no Ver-o-Peso, envolve o saber apreendido na vida, como notado durante conversa no setor das ervas, ou seja, processos construídos além do espaço escolar. Nesse sentido, compreende-se que se formam processos educativos, conforme a perspectiva de que: 
existe a educação de cada categoria de sujeitos de um povo; ela existe em cada povo, ou entre povos que se encontram. Existe entre povos que submetem e dominam outros povos, usando a educação como um recurso a mais de sua dominância. Da família à comunidade, a educação existe difusa em todos os mundos sociais, entre as incontáveis práticas dos mistérios do aprender; primeiro, sem classes de alunos, sem livros e sem professores especialistas; mais adiante com escolas, salas, professores e métodos pedagógicos. (BRANDÃO, 1981, p. 4)

Desta forma, posiciona-se com a perspectiva de que há territórios outros de conhecimentos, e educações tecidas na vivência cotidiana dos sujeitos históricos, culturais e criativos, como as erveiras, que constroem saberes na dinâmica do seu trabalho. No entanto, no campo educacional, uma gama de processos e espaços com dimensão educativa são avaliados a partir de critérios de cientificidade, pautados na racionalidade moderna ocidental. Os conhecimentos, sabedorias, educações, lógicas, espaços educativos que não correspondem a esse modelo de racionalidade são vistos como inexistentes.

Estes processos de inexistência ocorrem no âmbito de uma disputa epistemológica entre o científico e o não-científico, em que opera uma lógica abissal. Esta lógica configura-se por meio da separação da realidade social em dois mundos diferentes, sob linhas que demarcam processos de (in) visibilidade, "que dividem a realidade social em dois universos distintos: 'o universo deste lado da linha' e o 'universo do outro lado da linha'. A divisão é tal que 'o outro lado da linha' desaparece enquanto realidade, tornando-se inexistente" (SANTOS, 2010, p. 23).

Ao serem produzidos e socializados conhecimentos e saberes - como os construídos nos contextos amazônicos - constituem-se também formas de avaliação sobre essas produções, no que consiste às suas características e impactos sobre o mundo. Estas formas de refletir criticamente sobre a gênese e estruturas dos conhecimentos produzidos, caracterizam uma diversidade epistemológica (SANTOS, 2006). Diversidade esta não reconhecida, mediante o monopólio conferido à Ciência Moderna. Segundo Santos (2006) ocorre um privilégio epistemológico, referente à distribuição dos conhecimentos existentes no mundo, de modo que "o conhecimento científico é hoje a forma oficialmente privilegiada de conhecimento" (SANTOS, 2006, 137).

Esse exclusivismo conferido à ciência moderna se impôs sobre outras formas de conhecimento, consolidando-a como modo universal de compreender/interferir no mundo. Essa universalidade caracteriza-se pela forma autônoma como a ciência cria suas próprias lógicas no mundo, sendo que se estrutura como independente às interferências do mundo, ou seja, paradoxalmente, "para maximizar a sua capacidade de transformar o mundo, pretendeu-se imune às transformações do mundo" (SANTOS, 2006, p. 138).

Arroyo (2014) assinala que o pensamento abissal opera no campo educacional em que determinados saberes e processos pedagógicos são produzidos como inexistentes, mediante a legitimação de Pedagogias e de instituições do conhecimento. Desse modo, é importante reconhecer práticas educativas como das erveiras, com os seus modos próprios de saber-fazer, sobre o qual foi possível observar as suas práticas voltadas a indicações dos remédios naturais condizem com a saúde e bem-estar corporal e emocional. Além disso, há integrantes de uma mesma família que administram 
diferentes barracas, e as atividades desenvolvidas consistem em uma das formas de sustento para as/os mulheres e homens que desenvolvem este ofício no Ver-o-Peso.

Conclusão: Assim, buscou-se discutir sobre a presença e a importância das erveiras no contexto sociocultural amazônico, diante do reconhecimento que nas práticas socioculturais cotidianas destas mulheres são delineadas possiblidades de ensinos e aprendizagens, como, por exemplo, a importância da relação entre natureza e saúde às sobrevivências e vivências ambientais e sociais.

O objetivo é analisar como as erveiras do Ver-o-Peso desenvolvem o seu saber-fazer, referente às dimensões educativas e sociais dos seus saberes e das suas práticas cotidianas impulsiona o desenvolvimento desta pesquisa, a qual perpassa os campos teóricos da medicina popular, da educação como cultura, do trabalho feminino e a sua relação com a natureza.

Busca-se na investigação apresentar a dimensão educativa no saber-fazer das erveiras do Ver-o-Peso, com o detalhamento dos processos de produção, de orientação sobre os produtos, no caso, referente aos modos como são aprendidos e ensinados os seus saberes, em quais espaços, as intencionalidades e estruturas de organização e as especificidades dos saberes presentes no fazer das erveiras.

Referências: ARROYO, Miguel G. Outros sujeitos, Outras Pedagogias. 2 ed. Petrópolis, RJ: Vozes, 2014.

BRANDÃO, Carlos Rodrigues. O que é Educação. São Paulo: Brasiliense, 1981.

BARDIN, Laurence. Análise de conteúdo. São Paulo: Edições 70, 2011.

FRIGOTTO, G. O enfoque da dialética materialista histórica na pesquisa educacional. In: FAZENDA, I. (Org.). Metodologia da pesquisa educacional. São Paulo: Cortez, 1989.

MINAYO, CECÍLIA de Souza. Trabalho de Campo: contexto de observação, interação e descoberta. In: DESLANDES, Suely; GOMES, Romeu. (Orgs.). Pesquisa social: teoria, método e criatividade. 28 ed. Petrópolis, RJ: Vozes, 2009.

OLIVEIRA, Ivanilde Apoluceno de; MOTA NETO, João Colares da. A Construção de categorias de análise na pesquisa em educação. In: OLIVEIRA, Ivanilde Apoluceno de; MARCONDES, Maria Inês; TEIXEIRA, Elizabeth (Org.). Abordagens teóricas e construções metodológicas na pesquisa em Educação. Belém: EDUEPA, 2011.

OLIVEIRA, Ivanilde Apoluceno de; MOTA NETO, João Colares da. A Construção de categorias de análise na pesquisa em educação. In: OLIVEIRA, Ivanilde Apoluceno de; MARCONDES, Maria Inês; TEIXEIRA, Elizabeth (Org.). Abordagens teóricas e construções metodológicas na pesquisa em Educação. Belém: EDUEPA, 2011.

SANTOS, Boaventura de Sousa. Para além do pensamento abissal: das linhas globais a uma ecologia de saberes. In: MENESES, Maria Paula (Orgs.). Epistemologias do Sul. São Paulo, Cortez: 2010.

SANTOS, Boaventura de Sousa. A gramática do tempo: para uma nova cultura política. São Paulo: Cortez, 2006.

Palavras-chave: Educação. Interculturalidade. Saberes. Erveiras

Grande-area: Educação

Área: Interculturalidade 


\title{
NA BARRA DE SUA SAIA: D. MARIA PADILHA, A MULHER QUE EDUCA
}

\author{
Nome do(a) Orientador(a):Josebel Akel Fares \\ Nome do(a) Bolsista: Mailson Soares
}

Resumo: Vislumbrar os saberes de D. Maria Padilha, entidade afro religiosa, é o que pretende esta pesquisa: por meio de metodologia autobiográfica, com base nas Poéticas Orais; a costurar redes do Imaginário junto à tessituras da Memória e História do povo do Axé; a construir pontes entre saberes de Terreiro e um educar para o sensível; ao enredar conceitos e perspectivas decoloniais que insurjam um educar mais feliz, mais humano; que por meio da Voz se faz fenômeno a ser captado pelos sentidos e descrito por uma escrita com traços etnográficos e autopoiética. Assim, pretendo descrever ações em contexto afro religioso, e analisar, qualitativamente, as falas/informações obtidas, que vindas como narrativas do sujeito pesquisado, D. Maria Padilha, quando manifesta em transe mediúnico, possam ser destecidas em elos de uma educação sensível, que para além, do que suponham saber seus inquisidores, ensinam o povo de santo para uma cultura de resistência.

Introdução: O vento é mulher, assim canta uma das rezas do povo lorubá. Este sopro como hálito divino que dá vida ao homem, historicamente ressoa no posicionamento de mulheres: criando, acalantando, advertindo, educando. Em contexto afro amazônico mulheres trazem em sua oralidade marcas de uma cultura milenar, ecos de uma voz ancestre. Nessa conjuntura, as mulheres de Terreiro são testemunhas da ação educadora feminina no mundo, ao se dispor com determinação e graça, a vencer obstáculos, transpor barreiras. E assim, assinalar seu destino, e o de seus filhos e seguidores, guiando-os e educando-os nas veredas da vida. Desse modo, como as mulheres de Terreiro, as entidades femininas que ali se fazem presente, nos transes mediúnicos de seus filhos e filhas, também resguardam presença, força e ensinamentos concernentes somente a elas. Dentre tantas, fulgura no imaginário e templos afro amazônicos: D. Maria Padilha ou Maria de Castilha; mulher austera, bela, sábia e sedutora. Como seu filho, tenho a sorte e privilégio de por ela ser educado em minha constituição de membro do Ilê Alaketu Asé Omindê, em Belém do Pará.

Quando recebe o fino adorno do corpo humano e se faz presente no terreiro, essa deidade de forte apelo popular se destaca por sua altivez, maneira de vestir-se, portar, falar e ensinar. Mulher de gestos distintos e de personalidade incisiva, ela teria vivido em Sevilha, Espanha por volta do século XIV. Após sua morte, teria recebido a missão espiritual de "baixar" nos terreiros para ensinar homens e mulheres a equilibrar a balança da vida. Na Amazônia paraense ela vem se alocar em diversas afro ambiências, dentre elas a de matriz lorubá, anteriormente mencionada, lócus de minha pesquisa. Aos ouvidos leigos a educação pela voz de Maria Padilha é "guetificada" como acontece com tudo o que vai na contramão do erudito. E assim, as idiossincrasias educativas presentes naquele ensinar parecem fazer pertinência apenas ao universo religioso, ou mesmo estar restrito aquele vértice. Entretanto, a educação como enfatiza Brandão (2002) não apresenta apenas uma natureza, ou se restringe a espaços e culturas; muito 
pelo contrário, ela transcende! Nesse contexto me questiono: que saberes estão imersos na oralidade, que símbolos culturais se preservam na fala poética de Maria de Castilha? Pressuposto que pretendo investigar; ato desafiador de estudar a educação por um viés não escolar, depositado na oralidade contida e mantida na memória cultural dos filhos e adeptos do terreiro; educação que tem como conjectura a religião, mas que não deixa de ser educação.

Aos ouvidos leigos, a educação pela voz de D. Maria Padilha paira entre o conhecido e o obscuro, como que, em meio a uma faixa turva, entre o que ainda é dicotomizado como: erudito e popular, pois segundo Paul Zumthor, embora a oralidade preceda a escrita, há ainda quem pense o contrário, "esquecendo-se que a voz modula os influxos cósmicos que nos atravessam" (ZUMTHOR, 2010 p.09). Nessa ressonância posso, à luz do que poetiza Guimarães Rosa no conto "O Espelho", Primeiras Estórias (1962), dizer também, que ao ouvir a voz de D. Maria de Castilha "parece que o tempo muda de direção e de velocidade".

Assim, embrionado por juízo rigoroso das culturas que me perfazem, me lanço ao desafio de investigar uma educação plural, que traz nas suas "bordas" tessituras profundas de um saber poético e sensível da vida. Nesse sentido, esta proposta de estudo perfaz três dimensões do proponente pesquisador: pessoal, acadêmica e social. O âmbito pessoal condiz com a forma como fui educado pela oralidade de mulheres, seja através de lendas e mitos, proferidos por minha mãe, pelos provérbios "familiares" ditos por minha avó marajoara, ou mesmo pelo convívio com tias, professoras, amigas, sacerdotisas que nas encruzilhadas da vida encontram ressonância nas falas de $D$. Maria de Castilha, deidade feminina que orienta os filhos e adeptos do lócus que pretendo pesquisar.

Vozes femininas que no decorrer da minha graduação repercutem para além das linhas literárias e, assim, perfazem a motivação acadêmica desta inquirição; uma vez que enquanto bolsista de iniciação científica, faço parte (hoje como voluntário) de um projeto que pesquisa a expressão artístico literária de autores paraenses. E, assim, percebo convergências entre as vozes que me formam e as tessituras literárias paraenses, sobre tudo, a feminina, como: Dulcinéa Paraense, Lindanor Celina e Maria Lúcia Medeiros. Das vozes, então, ouvidas, saliento os espaços a elas destinados, como o próprio lugar reservado a mulher na sociedade; ainda cerceada por preconceitos combatidos dia a dia. Desse modo, em via de meu percurso acadêmico, e de maneira especial, pelo contato com as Poéticas Orais, pude entender que a educação ocorre de diversas formas e lugares, tendo a escola como uma de suas instâncias. O que me faz perceber que as narrativas, mitos e provérbios familiares e seus respectivos ecos em $D$. Maria Padilha, compunham cernes de saberes "marginais". Daí, que dar voz e vez a eles é o que constitui a dimensão social desta pesquisa. Por conseguinte, em consonância com o que foi exposto acima, estabeleço os seguintes

objetivos: Geral - Investigar os saberes contidos na oralidade de D. Maria Padilha, transmutados na voz de uma sacerdotisa afro quando essa a recebe em transe mediúnico. 
Objetivos Específicos:1). Identificar os saberes imersos na oralidade poética de D. Maria Padilha de Castilha. 2). Analisar os elementos éticos, estéticos e identitários imersos ou não, no texto oral de D. Maria Padilha. 3). Descrever de que forma esses saberes educam o povo de santo e frequentadores da casa, mantendo a cultura de resistência afro amazônica.

Material e método: Na escrita acadêmica, um dos anseios é o de encontrar companheiros que ajudem a alinhavar as ideias. Mãos experientes que, no entalhe do texto, irão me conduzir, pois: "a vida da gente é como um anzol que se atira no rio, pra pescar o único peixe que pode trazer, em suas tripas, a resposta pra tantas perguntas que a gente faz, quando pula na água e não sabe nadar" (ALBERTO 2014, p.147). Assim, nas páginas desta pesquisa, pretendo "fisgar" indícios de uma educação pela cultura da voz a partir de referenciais metodológicos das Poéticas Orais, em pressupostos teóricos construídos por Paul Zumthor (2010), e estudos desenvolvidos por Pierre Nora (1993) e Maurice Halbwach (1990), sobre História e Memória respectivamente; alinhavados aos constructos sobre Imaginário tecidos por Bachelard (1997), e trago à baila as ponderações de Maffesoli (1998), a favor de uma "razão sensível". Assim, situo a pesquisa dentro de uma perspectiva fenomenológica a partir de Merleau-Ponty (1999), em que estabeleço a educação como cultura segundo Santos (2008) e Brandão (2002). Realizada dentro de um terreiro de candomblé a pesquisa caracteriza-se por um estudo de campo, com traços etnográficos, Clifford (1998). A partir de narrativas de vida Bertaux (2008) e observação participante, Margareth (1979). Caracterizando-se como um estudo autobiográfico Passegi (2017), de cunho qualitativo, Minayo (2001); em que estabeleço diálogos entre os saberes de terreiro e perspectivas decoloniais Quijano (2004).

Resultado e discussão: A oralidade em suas mais diversas práticas, antes de tudo, é uma expressão composta dentro do suporte corpo; corpo que em seu tempo e espaço é matéria viva de cultura, história, memória e identidade. Dimensões que resguardam por meio da voz, poéticas a se espalharem pelos espaços, até onde ecos conseguem ressoar. Na tradição das religiões afro, a oralidade é esse veículo essencial, em que se repassam saberes, valores socioculturais, éticos e estéticos, que de outra maneira se perderiam. Princípio educativo que Brandão (2002, p. 04) reitera constituir a cultura enquanto educação, pois "ninguém escapa à educação. Em casa, na rua, na igreja ou na escola, de um modo ou de muitos, todos nós envolvemos pedaços da vida com ela". Sendo assim, de boca em boca, de ouvido em ouvido, fragmentos de um saber antigo que parece não pertencer ao conhecimento clássico, transita fora dos muros da escola inferindo noções de uma "não educação". Todavia, Castro; Fagundes e Ferraz (2014) informam que, educar não é uma questão de escola ou de currículo, mas de épocas e culturas. Assim, ao presentear seus filhos e admiradores com sua maneira peculiar de ensinar, por um falar especialmente composto por: parábolas, metáforas, provérbios e enigmas, D. Maria de Castilha se enquadra nessa educação poética, tão bem definida pelo arcabouço teórico das Poéticas Orais.

No rastro dessas poéticas nômades que viajam da boca para os ouvidos e da mão para os olhos, dentro de seus múltiplos suportes, chegamos aos terreiros, associações litúrgicas organizadas que segundo Muniz Sodré (1988), são o lugar de uma cultura 
fragmentada, e espaço em que o indivíduo encontrará o sentido de pertencimento, em processos de uma educação pela cultura. Educação que segundo Forquim (1993), não se restringe a conotação de ensino escolar, mas também a operações de socialização. Sendo assim, os ensinamentos de D. Maria de Castilha seriam um discurso prenhe de simbologia a compor, segundo Fábio Lucas (1976), dentre os âmbitos literários, sejam escritos ou oralizados: uma modalidade especial de comunicação. Portadora de força comunicativa polivalente, com um potencial de grande vigor conotativo, o que torna, a educação de terreiro uma forma de conhecimento e aprofundamento no mundo real; com efeito direto, sobre a psicologia individual e sobre a organização social dos sujeitos. Assim, os saberes contidos em mitos, lendas e provérbios suscitam um educar para o sensível e articulam uma rede de valores simbólicos, sujeitos a uma organização arbitrária, no que diz respeito, a modelos impostos pela sociedade ocidental. Podendo atender a outras necessidades poéticas e estéticas de vida. Destarte, ao proferir seus provérbios, ditos e lições $\mathrm{D}$. Maria de Castilha aciona reminiscências, recorda tradições que perfazem o individual e o coletivo (HALBAWACHS, 2004). O estudo de sua oralidade suscita novos paradigmas educacionais, bem como diz respeito aos deslocamentos de uma tradição que vem se apoderando de variados suportes para perpetuar-se.

Conclusão: As vozes da pesquisa que me conduziram até aqui sopram desde Marajó até estas paragens de Santa Maria de Belém do Grão Pará. São emanações de cantos femininos, que me principiam a educação e nutrem esta escrita. Nascentes de um educar pelo sensível, estas vozes de mulheres, acompanham e traçam minha trajetória até o terreiro. Assim, dos "mantras" maternos familiares, às amigas, mestras e confidentes, passo à oralidade poética da senhora por quem traço estas linhas: D. Maria Padilha. Evidencio assim, meu percurso de vida, as conduções no achado da pesquisa de mestrado em educação em andamento, e deixo a porta aberta para o que ainda virá. Estabelecida a metodologia, teóricos e conceitos chaves desta inquirição e apresentado meu objeto de pesquisa e alguns de seus "interstícios", antecipo o que ainda não há: A) a contextualização histórica de D. Maria Padilha; possíveis relações dos achados biográficos da rainha espanhola e a entidade que "baixa" no terreiro: implicações entre história, cultura e imaginário, este último essencial - para a saga da rainha castelhana que atravessa sete séculos de venturas - como um "mar de saias" a desaguar na praia das mentalidades. B) Minha entrada no terreiro e sua relação direta com a entidade afroreligiosa D. Maria Padilha, seus primeiros ensinamentos, ao recém-chegado; e a relação numa casa de Axé com estes aprendizados, uma casa composta em sua maioria por mulheres, conduzida e organizada por mãos de "fiandeiras". C) As reflexões travadas entre conceitos da decolonialidade, educação sensível e os saberes de D. Maria Padilha, mistérios e sussurros, que a meia luz, desatam nós de existência afro na Belém de nossos dias.

Referências: ALBERTO, Raimundo. Aquarela amazônica. Rio de Janeiro: Taba Cultural, 2014.

BACHELARD, Gaston. A água e os sonhos: ensaio sobre a imaginação da matéria. Tradução Antônio de Pádua Danesi. São Paulo: Martins Fontes, 1997. 
BERTAUX, D. Narrativa de vida: a pesquisa e seus métodos. Natal, RN: Ed. UFRN, São Paulo: Paulus, 2008.

BIÃO, Armindo. Padilla: história, mito e teatro. Universidade Federal da Bahia. http://www.portalabrace.org/vcongresso/textos/etnocenologia/Armindo

BRANDÃO, Carlos Rodrigues. A Educação como cultura. 2.ed. são Paulo: Brasiliense, 2002.

CASTRO, Manuel Antônio de; FAGUNDES, Igor; FERRAZ, Antônio Máximo Ferraz (org.) Educar Poético. Rio de Janeiro: Tempo Brasileiro, 2014.

CLIFFORD, J.; GONÇALVES, J. R. S. A experiência etnográfica: antropologia e literatura no século XX. Rio de Janeiro: UFRJ, 1998.

HALBWACHS, Maurice. A memória coletiva. Trad. Lais Teles Benoir. São Paulo: Centauro, 2004.

LUCAS, Fábio. O caráter social da literatura brasileira. São Paulo: Quíron, 1976.

MEAD, Margareth. Anthropologie visuelle dans une discipline verbale. Paris, Mouton, 1979.

MERLEAU-PONTY. Maurice. Fenomenologia da percepção. Tradução de Carlos Alberto Ribeiro de Moura. São Paulo: Martins Fontes, 1999.

MINAYO, M. C. de S. (Org.). Pesquisa social: teoria método e criatividade. $17^{\mathrm{a}}$ ed. Petrópolis, RJ: Vozes, 2001.

NORA, Pierre. Entre memória e história: a problemática dos lugares. Projeto História, São Paulo, n.10, dez. 1993, p.7-28.

PASSEGI, Maria da Conceição. SOUZA, Elizeu Clementino. 0 Movimento (Auto)biográfico no Brasil: Esboço de suas configurações no Campo Educacional. $\begin{array}{llllll}\text { Revista Invesgation } \quad \text { Cualitativa, } & 2 & \text { (1) } & \text { pp. }\end{array}$ (2017).https://ojs.revistainvestigacioncualitativa.com/index.php/ric/article/view/56

QUIJANO, Aníbal. "Colonialidaddel poder, eurocentrismo y América Latina". In READ, H. A Educação pela Arte. Portugal, Lisboa: Edições 70, 1982. Revista Venezolana de Economia y CienciasSociales. Enero/abril, Año/Vol.10, Número 001. Caracas, Venezuela: Universidad Central de Venezuela, 2004.

ROSA, Guimarães. Primeiras estórias. São Paulo: José Olympio, 1962.

SODRÉ, Muniz. O terreiro e a cidade, a forma social negro-brasileira. Petrópolis: Vozes, 1968.

ZUMTHOR, Paul. Introdução à poesia oral. Trad. Jerusa Pires Ferreira et al. Belo Horizonte: UFMG, 2010.

Palavras chave: D. Maria Padilha. Educação sensível. Poéticas Orais. Memória.

Grande área: Educação

Área: Saberes culturais 


\section{GABINETE DE LEITURA DO GRÊMIO LITERÁRIO PORTUGUÊS: SABERES E PRÁTICAS EDUCATIVAS (1868-1889)}

Nome do(a) Bolsista: Maria José da Silva Corrêa Boulhosa

Nome do(a) Orientador(a): Dra. Maria do Perpétuo Socorro Gomes de Souza Avelino de França.

Resumo: Este trabalho tem como objetivo geral analisar como se constituiu a formação do público leitor luso-paraense no gabinete Português de leitura do Grêmio Literário Português, na província do Pará, nos anos de 1868 a 1889. E como objetivos específicos: identificar as práticas educativas desenvolvidas no GLP, descrever os tipos de leitura que eram ofertadas aos frequentadores do GLP, bem como analisar alguns aspectos da cultura material institucional que nortearam a educação do público leitor que frequentava esse espeço de leitura, mais precisamente no fim do século XIX e início do século XX. O estudo está sendo realizado a partir de pesquisa documental e bibliográfica, segundo conceitos de Severino (2007), Bloch (2001), Burke (2001), sob uma abordagem qualitativa a partir de conceitos de Minayo (2001), Goldenberg (1997) e outros autores. Como base teórica pra este estudo, elegeu-se a História Cultural, que tem em Roger Chartier (1990) seu maior expoente, em razão do próprio caráter social e histórico dos sujeitos dessa pesquisa: portugueses, paraenses, moradores da província do Pará, nos séculos XIX e XX, todos, que de alguma forma estavam imbricados no processo de instrução desenvolvido no gabinete de leitura do GLP. No intuito de conhecer aspectos históricos, sociais, econômicos e culturais que perfaziam a cidade Belém na Belle Époque, como também dissertar acerca do gabinete de leitura a partir da história das instituições educativas no Brasil, elencou-se os seguintes autores: Le Goff (2013), Burke (2008), Sarges (2010), Brito (1994), Cancela (2012), Sanfelice ( 2007), Saviani (1980), entre outros. O Gabinete Português de Leitura do Grêmio Literário Português de Belém do Pará, foi criado em 29 de setembro de 1867, por inciativa de um grupo de 64 portugueses que residiam no Pará, com a finalidade de concretizar a fundação de uma entidade de caráter cultural, que instruiria os associados nas língua local e estrangeira, como também proporcionaria distração por meio da leitura dos melhores impressos e livros abrigados em sua rica biblioteca. Inicialmente, o GLP teve como primeira sede social, um prédio localizado na Rua Belém, $\mathrm{n}^{\circ} 1,1^{\circ}$ andar. Em abril de 1870, passa a funcionar no largo da Independência e posteriormente em 03 de abril de 1906, inaugura-se o então prédio da sede social do Grêmio Literário Português, localizado na Rua Senador Manoel Barata. Dentre as relevantes contribuições do GLP, pode-se dizer que o mesmo favoreceu a expansão do público leitor, impulsionou o comércio livreiro, auxiliou na legitimação e fixação da colônia portuguesa no Pará. Como também, desenvolveu diversas atividades educativas, como o ensino primário e secundário, ministrou aulas de línguas estrangeiras e um reconhecido curso de contabilista. 
Introdução: A Independência do Brasil ocorrida em 1822 e o advento da República proclamada em 15 de novembro de 1889 representam marcos histórico que provocaram muitas transformações no Brasil, e Belém do Pará não poderia ficar indiferente.

Este período bastante emblemático na nossa história foi marcado pelo embelezamento e tentativas de sanitarização e europeização da cidade, que era conhecida como "Paris na América". Este período se alinhou ao que conhecemos como o Ciclo da Borracha, ou a Belle Epoque (1879 a 1912), que coincidiu com as gestões de Augusto Montenegro, governador e José Antônio Lemos, Intendente, dois grandes benfeitores de Belém.

Particularmente no caso de Belém é possível destacar a realização de vários eventos, dentre os quais podemos destacar a fundação de importantes instituições de caráter educativo, cultural ou de pesquisa, tais como: Liceu Paraense (1841), Grêmio Literário e Recreativo Português (1861), Biblioteca e Arquivo Público do Pará, do Museu Paraense e da Escola Normal do Pará (1871), Theatro da Paz (1878), Imprensa Oficial do Estado (1890), Instituto Carlos Gomes (1895) e Instituto Lauro Sodré (1899), entre outros (ROCQUE, 1967).

No contexto da Independência do Brasil, o Pará foi a província que mais resistiu a separação dos lusitanos, prova disto foi a Adesão do Pará à Independência do Brasil, ocorrida um ano depois de todas as províncias brasileiras. Obviamente estes acontecimentos foram marcados por uma série de tensões, mas inegavelmente passamos a ter um novo povo - os Paragueses, termo cunhado pelo literato Orlando Carneiro, para se referir aos Portugueses que continuaram residindo no Pará mesmo após a proclamação da Independência e os filhos de portugueses nascidos no Pará (CARNEIRO, 1990).

E foram justamente estes Paragueses os responsáveis por criar e desenvolver instituições culturais ou assistenciais que mantivessem viva a cultura e a identidade lusitana e os laços entre Portugal e o Pará. Apesar de todos os esforços o Pará ainda carecia de bens culturais e os portugueses viram neste expediente uma maneira de se manterem na extinta colônia da América Portuguesa (CANCELA, 2011).

O Grêmio Literário e Recreativo Português (GLRP) emerge nesse contexto como uma das associações culturais mais antigas e que ainda se encontra em atividade em Belém do Pará. E mesmo aos seus 150 anos existem poucos estudos sobre sua história e importância para a comunidade luso-paraense, analogamente é exígua também a quantidade de fontes para seu estudo, fato que não inviabiliza essa pesquisa, mas nos motiva ainda mais a buscar compreender tanto o processo de criação da agremiação, como também desenvolver um estudo que demonstre a relevância dessa associação cultural no processo de formação intelectual dos portugueses e paraenses que habitavam na região de Belém, nos anos de 1868 a 1889.

Ao desenvolver esse estudo sobre o Gabinete Português de Leitura do Grêmio Literário Português, acredito contribuir para o fortalecimento das pesquisas no campo da História da Educação na Amazônia. Especialmente, nas pesquisas realizadas no GHEDA (Grupo de Pesquisa e História da Educação na Amazônia), do qual faço parte. Criado em 2010, na Universidade do Estado do Pará. 
Objetivos: O objetivo geral dessa pesquisa é analisar como se constituiu a formação do público leitor luso-paraense no Gabinete de leitura do GLP, na província do Pará, nos anos de 1868 a 1889.

E, como objetivos específicos, em consonância com a questão norteadora e o objetivo geral, têm-se:

- Identificar as práticas educativas desenvolvidas no GLP.

- $\quad$ Descrever os tipos de leitura que eram ofertadas ao público leitor do GLP.

- Analisar alguns aspectos da cultura material institucional que nortearam a educação do público leitor do GLP.

Material e Método: Partindo desse pressuposto, iniciei a pesquisa sobre o Gabinete de Leitura Português, buscando estudos acadêmicos já produzidos sobre o próprio. Inicialmente, realizei no ano de 2018, um levantamento nos bancos de dados da Coordenação de Aperfeiçoamento de Pessoal de Nível Superior (CAPES), priorizando as grandes áreas: Ciências Humanas; Ciências Sociais Aplicadas; Linguística, Letras e Artes, por meio dos descritores: Gabinetes de Leitura, Gabinetes de Leitura no Império, Práticas de leitura no Gabinete de Leitura; considerando a princípio o que havia sido produzido nos últimos dez anos.

E posteriormente, também realizei buscas nos programas de Pós-graduação de Universidades locais como o Programas de Pós-graduação em Educação da Universidade Federal do Estado do Pará (UFPA) e da Universidade do Estado do Pará (UEPA).

Esta pesquisa inscreve-se no campo histórico, pois se utilizará de dados coletados em fontes documentais e bibliográficas, como a análise de cartas, jornais, fotos, leis, relatórios e documentação pessoal existente no Arquivo Público do Pará, na Hemeroteca da Fundação Cultural do Pará, no Instituto Histórico e Geográfico do Pará, no Centro de Memória da Amazônia e na própria sede do Grêmio Literário Português de Belém do Pará.

Resultado e Discussão: A História Cultural foi eleita para ser o fio condutor desta pesquisa. Trata-se de uma matriz teórica implementada por um grupo de historiadores franceses, que tem em Roger Chartier seu maior expoente, cuja principal contribuição a este estudo reside na elaboração das noções complementares de "práticas" e "representações", pois Chartier (1990), concebia que os objetos culturais seriam produzidos "entre práticas e representações", como os sujeitos produtores e receptores da cultura circulariam entre estes dois polos, que tem correspondência com os "modos de fazer" (as práticas) e os "modos de ver" (as representações).

Adotou-se como um dos aportes teóricos para essa pesquisa, as obras de Cancela (2011, 2012) e Sarges (2010), dada a importância da leitura destes autores a fim de compreender os fatores, políticos, sociais e econômicos que contribuíram para o surgimento dos "parágueses".

Essa pesquisa encontra-se em andamento, com provável defesa no $1^{\circ}$ semestre de 2020. Dessa maneira, como resultados parciais desse estudo, têm-se a noção de que o Grêmio Literário Português, criado em 29 de setembro de 1867 por iniciativa de um grupo de 64 portugueses que residiam em Belém do Pará, cujo principal intuito era se congregarem 
para matarem saudades da Pátria e do lar e se elevarem pelo estudo (GLRP, 2017); foi muito mais do que uma simples biblioteca. Essa agremiação também promoveu outras atividades, como bem enfatiza Brito: "numa oportunidade, Fran Paxeco lembrou que o Grêmio, era o único Gabinete Português de Leitura, do Brasil, que além da biblioteca, também se dedicava ao ensino primário e secundário, o que era deveras importante principalmente na época em que se iniciaram. " (BRITO, 1994, P. 69).

Por meio da pesquisa bibliográfica, pode-se atestar que de 1868 a 1951, existiu a prática de aulas diversas, no espaço do Gabinete Português de Leitura do Pará, tais como: auxílio ao ensino primário e secundário, por meio de aulas de português, aulas de francês, inglês, cursos de contabilidade, aritmética, escrituração mercantil, datilografia, desenho, caligrafia, dentre outros.

Conclusão: A partir do estudo acerca do Grêmio Literário Português nas últimas décadas do Oitocentos, podemos perceber que essa instituição educativa, essa associação portuguesa no Pará, exerceu fundamental importância no que diz respeito ao processo de modernização.

O GLP abrigou o terceiro Gabinete Português de Leitura do Brasil e o primeiro na Província do Grão-Pará. Altera o caráter solidário em que os portugueses se reuniam para congregarem entre si no afã de amenizar a saudade de sua pátria, quando instala um gabinete que oferecia aos colonos, acesso à diversas informações, num período em que o processo de modernização se intensifica na região, ganhando mais força a partir da criação de espaços destinados a "civilizar" e "instruir".

Dentre as diversas ações "modernizantes" passíveis de serem observadas nas suntuosas construções (palacetes, praças, teatros), têm-se a implantação de gabinetes de leitura e bibliotecas.

Além do caráter social e modernizante que o GLP possuía, havia em seu interior uma valiosa amostra de cultura material que permitiu a propagação de ideias circulantes advindas da Europa, o fortalecimento da identidade lusófona na Amazônia e a contribuição significativa no cerne do desenvolvimento cultural de Belém, propiciada pela implementação de ações educativas que ofereceram atividades na educação formal dos cidadãos lusoparaenses, como o ensino primário e secundário, por exemplo.

Referências bibliográficas: AZEVEDO, Fernando. A Transmissão de Cultura. São Paulo: Melhoramentos, 1976.

AZEVEDO, Fabiano Cataldo de. TROTTA, Luís Felipe Dias. A FORMAÇÃO DO ACERVO DO GABINETE PORTUGUÊS DE LEITURA NO SÉCULO XIX REVISTA IHGB, Rio de Janeiro, a. 174 (volume 459):43-76, abr./jun. 2013

BACELLAR, Carlos. Fontes documentais: Uso e mau uso dos arquivos - In: PINSKY, Carla Bassanezi. Fontes Históricas. São Paulo. Contexto, 2005;

BASTOS, TATIANA QUINTELA DE AZEREDO. "GABINETE PORTUGUÊS DE LEITURA: CONSTRUÇÃO DE UMA IDENTIDADE PORTUGUESA (1837- 1893)". 149 f. Dissertação de Mestrado. Programa de Pós-Graduação em História social. UNIVERSIDADE FEDERAL DO RIO DE JANEIRO. 2007 
BRITO, Eugénio Leitão. História do Grémio Literário e Recreativo Português. Belém: Gráfica Santo António Editora e Papelaria, 1994.

BUFFA, Ester, NOSELLA, Paolo. Instituições educativas: Porque e como pesquisálas. Campinas, SP: Editora Alínea, 2009.

BURKE, Peter. A Escrita da História: novas perspectivas. São Paulo: Editora UNESP, 1992

BURKE, Peter. O que é história cultural. 2. ed. Rio de Janeiro: Zahar, 2008

BURKE, Peter (org.). A Escrita da História: novas perspectivas. Tradução de Magda Lopes. 2a ${ }^{a}$ ed. São Paulo, Editora da UNESP, 1992.

BRITO, Eugênio Leitão de. História do Grêmio Literário e Recreativo Português.1994.

CANCELA, Cristina Donza. A imigração portuguesa no Pará. Belém: Estudos Amazônicos, 2012.

CHARTIER, Roger. A história cultural entre práticas e representações. Rio de Janeiro: Bertrand Brasil; 1990.

GIL, Antonio Carlos. Métodos e técnicas de pesquisa social. 6. ed. - São Paulo : Atlas, 2008.

GRÊMIO LITERÁRIO E RECREATIVO PORTUGUÊS. Nossa história. 2017. Disponível em: http://gremioportugues.com.br/sobre. Acesso em: 05.10.2018.

MINAYO, M. C. de L. (Org.) Pesquisa social: teoria, método e criatividade. 19. Petrópolis: Vozes, 2001.

NOBRE, Izenete Garcia. Leituras a vapor: a cultura letrada na Belém oitocentista. 2009. 128 f. Dissertação (Mestrado em Letras: Linguística e Teoria Literária) - Instituto de Letras e Comunicação, Universidade Federal do Pará, Belém, 2009.

PESAVENTO, Sandra Jatahy. História\&história cultural. 2a Edição. Belo Horizonte: Autêntica, 2005. 132p.

Grande-área: Ciências Humanas.

Área: Educação 


\title{
LETRAMENTO RELIGIOSO: UMA ANÁLISE DAS PRÁTICAS EDUCATIVAS E SOCIAIS VIVENCIADAS NA COMUNIDADE CATÓLICA SÃO FRANCISCO XAVIER EM BELÉM/PA
}

\author{
Nome do(a) Bolsista: Priscila Deoamara Assunção Magalhaes \\ Nome do(a) Orientador(a): Maria do Perpétuo Socorro Cardoso da Silva
}

Resumo: Neste estudo, investigou-se o cotidiano da comunidade católica São Francisco Xavier com o objetivo de identificar as práticas de letramento religioso dos idosos que dela participam. De abordagem quantiqualitativa, partiu-se das seguintes questões norteadoras: Quais as práticas de letramento religioso existem na comunidade São Francisco Xavier? Como essas práticas educativas e saberes se desenvolvem na comunidade? Que saberes emanam das práticas de letramento religioso no contexto social da comunidade? O lócus da pesquisa é uma comunidade católica, localizada no bairro do Marco em Belém/PA, os sujeitos das pesquisas são os idosos. Para a produção dos dados, foram usados observação direta; registro fotográfico das práticas de letramento religioso dentro da comunidade; e entrevistas semiestruturadas. Os teóricos de base da pesquisa são Street (2014), Bakhtin (2016) e seus interlocutores. Os dados obtidos para a composição do corpus revelam relações de sabares e práticas religiosas no contexto dessa comunidade, constituindo assim o reconhecimento do Letramento religioso entre os sujeitos da pesquisa. Configurando-se, dentro das práticas e eventos que os idosos particam na comunidade: peregrinações, encontros para rezar o terço, encontros para leituras da bíblia, adorações, velórios, peregrinações de Natal, o mês de Maria, entre outros.

Introdução: O interesse por esse tema surgiu das vivências de minha mãe, de minha tia e de minhas próprias vivências dentro da comunidade durante o meu percurso de vida até então, em virtude de toda minha família ser religiosa e católica. Pude observar que na comunidade haviam muitos idosos que viviam em comunhão com a vida social e presentes na igreja por meio de orações, peregrinações, estudos religiosos, eventos religiosos e outros. Fora da igreja apresentavam as práticas religiosas que desempenhavam no espaço religioso para todos de uma maneira geral.

É preciso entender que estas vivências se tratam de letramento, o que compreende todos os usos sociais da escrita, leitura e oralidade. É possível inferir que letramento não significa saber ler e escrever, mas conseguir empregar conhecimentos para propósitos específicos em determinadocontextos. Desta forma, o letramento não envolve apenas uma habilidade ou competência do leitor, mas também múltiplas capacidades e conhecimentos os mobilizem.

De tal modo, este estudo alinha-se a um conjunto de pesquisas realizadas no Programa de Pós-Graduação em Educação da Universidade do Estado do Pará (PPGED-UEPA), sobre o contexto de práticas educativas em espaços não formais de educação, apresentando uma concepção de educação e coadunando saberes provenientes da vida social e conhecimentos acadêmicos dos idosos, aliando assim, na realização do mesmo, 
a conexão entre práticas educativas não escolares e rigor cientifico da pesquisa em educação, demarcando, desse modo, um campo de investigação na Amazônia.

Objetivo: O objetivo geral é investigar o cotidiano da comunidade São Francisco Xavier para identificar as praticas de letramento religioso dos idosos.

Os objetivos específicos são: identificar às práticas de letramento existentes na Comunidade São Francisco Xavier. Verificar como essas práticas desenvolve-se na comunidade São Francisco Xavier. Compreender a importância das práticas de letramento por meio das ações pedagógicas de catequese considerando a relevância para o contexto social da comunidade São Francisco Xavier

Material e método: Para compreender aos objetivos propostos, utilizei como técnica de produção de dados entrevistas semiestruturadas, cujo as entrevistas foram parcialmente realizadas, carecendo da feitura de novas entrevistas para apreciação da análise integral da pesquisa, com intuito de fazer um levantamento das vivências dos sujeitos da pesquisa

Os instrumentos de análises serão; observação, entrevista narrativa dialogada - gravada em áudio e a transcrição das entrevistas, com uma análise dialógica Bakhtiniana, a partir de trechos que serão chamados de atos comunicativos, categorização e a reconstrução analítica de organização das materialidades como corpus.

Neste sentido, teremos como base metodológica a análise do discurso Bakhtiniana, ou seja, o texto vai para além da escrita, nos permitido observar toda a arquitetônica da discussão entre as práticas com os idosos na comunidade.

De acordo com Gil (2002), as etapas exploratórias apontam para o pesquisador como conduzir o processo investigativo do objeto de pesquisa esta etapa representa um período de investigação informal e relativamente livre, no qual o pesquisador procura obter, tanto quanto possível, entendimento dos fatores que exercem influência na situação que constitui o objeto de pesquisa. Constitui, portanto, uma etapa cujo objetivo é o de descobrir o que as variáveis significativas parecem ser na situação e que tipos de instrumentos podem ser usados para obter as medidas necessárias ao estudo final.

A sistematização e análise dos dados processar-se-ão após os momentos sequenciais dos procedimentos metodológicos, observações, entrevistas, transcrição das falas, interpretação, análise dos dados e categorias analíticas e temáticas que evidenciaram as questões norteadoras da pesquisa.

Segundo Minayo (2011), há necessidade de "estabelecer uma compreensão dos dados produzidos, confirmar ou não os pressupostos da pesquisa, e/ou responder às questões formuladas, e ampliar o conhecimento sobre o assunto pesquisado, articulando-o ao contexto cultural da qual faz parte".

Resultado e discussão: Street (2014) e Bakhtin (2016) que fundamentam a discussão sobre os dois campos de estudo. Desse modo, o conceito de Letramento é discutido a princípio nesta pesquisa em educação na perspectiva interdisciplinar, dialogando com amplitude do conceito. O termo letramento surge pertencente às Ciências Linguísticas, mas dialoga para construir as aproximações necessárias à investigação na perspectiva do campo da educação. 
Bakhtin (2017) assenta que a ideia da construção linguística está ligada ao contexto social, isto é, ao modo de vida das pessoas e nas relações dialógicas estabelecidas para anunciar o enunciado dos atos comunicativos. Dessa maneira, os participantes sociais imediatos determinam a forma e o estilo do enunciado, camada mais profunda de sua ligação social, assim: "cada enunciando particular é individual, mas cada campo de utilização da língua elabora seus tipos relativamente estáveis de enunciados, o qual denominou o gênero do discurso". (p. 19).

No tocante à questão do escrito, Street (2014) afirma que estamos assistindo, nos últimos trinta anos, a obra e o fortalecimento de um campo de pesquisa sobre a cultura escrita. A cultura escrita tem sido objeto de muitas disciplinas como: história, antropologia, sociologia pedagogia, psicologia, linguística, entre muitas outras, desenvolvendo-se, também, assim, a pesquisa sobre o letramento em diversas línguas e países.

O autor também menciona a discussão do campo da linguística a partir da relação fala e escrita, abordando, assim, as diversas indagações sobre situações de aprendizagem da escrita como algo primordial na escola, problematizando, também, como adultos não alfabetizados convivem em contexto diferentes e, como estes, lidam com a escrita da palavra e do mundo. Street nos diz que "O maior esforço, então, consiste em avaliar o que os sujeitos sabem sobre alguns textos escritos com raras preocupações sobre como as pessoas os usam e o que fazem com eles em diferentes contextos históricos e culturais" (2014, p. 9).

Evidenciamos a constituição do corpus da pesquisa dividindo-a em três momentos: observação dos eventos cíclicos na comunidade católica, acompanhamento das peregrinações, círculo de orações, círculos de terços, velórios, visitas e novenas e o registro das práticas religiosas, sociais e educativas dos idosos na comunidade católica pesquisada.

Partimos para analisar o objeto de investigação com base em Street (2014), Bakhtin (2017) e Albuquerque (2016), evidenciando nas práticas religiosas e sociais dos idosos, que há uma concepção de educação que fundamenta a concepção de letramento religioso que está tecido nos saberes dos idosos para expressar sua religiosidade.

Albuquerque (2016) esclarece que os saberes que emanam da possibilidade de diálogo em diferentes formas de conhecimentos e contextos sociais de um indivíduo, e que cada saber destes sujeitos colabora com o diálogo que estimula assim uma dada prática.

Essa pesquisa encontrasse em andamento com provável defesa no primeiro semestre de 2020 , tem como resultados passeais que os saberes e as praticas educativas estão inseridas na vida cotidiana dos idosos da comunidade, por meio de observações feitas dos eventos e peregrinações e conduz a todos a prática da religiosidade, observando os discursos que permeiam os encontros, na perspectiva dialógica no que se refere ao discurso aplicado nas práticas religiosas realizadas cotidianamente.

Conclusão: Pesquisar sobre letramento religioso em uma comunidade não significa verificar o que é ensinado por meio de uma hierarquia literária de conhecimentos científicos e epistemológicos inseridos nos ensinamentos religiosos, como os da igreja 
católica, mas sim buscar uma questão mais ampla em virtude da convivência social que está para além dos muros da sua comunidade.

A presente pesquisa tem como intuito contribuir para discussão teórica acerca do letramento, do letramento religioso, das práticas educativas e da análise do discurso imbricada nos enunciados e discursos dos idosos, participantes da comunidade católica São Francisco Xavier, relacionados a seus saberes e conhecimento individual e coletivo. O letramento religioso contribui para o desenvolvimento do idoso, proporcionando assim seu crescimento cognitivo, religioso e social, através das práticas educativas sociais e religiosas que são proporcionadas para além de um conhecimento e experiências de vida dos idosos.

Com esta discussão teórica pode-se encontrar autores no âmbito teórico educacional e epistemológico que abordam o letramento como uma questão fundamental para transformação do indivíduo na sociedade, recriando-se seus saberes, vivências e experiências, ressaltando assim suas práticas de eventos, ensinamentos vividos, para desvelar a prática educativa, para além dos conhecimentos bíblicos, como, também, trazendo conhecimentos da vida cotidiana sempre presentes nas práticas religiosas.

Há muito o que se desvelar sobre o letramento religioso no campo educacional, pois pouco se fala sobre o letramento para além dos ensinamentos religiosos tradicionais trazidos pela igreja católica, em que muitas pessoas fazem uso deste letramento no seu cotidiano religioso, sem perceber sua importância para as práticas sociais educativas e religiosas.

A pesquisa me leva a perceber como educadora a importância do letramento e do letramento religioso que estão imbricados nas práticas educativas da comunidade São Francisco Xavier, sendo essenciais para os momentos de socialização dos idosos e na comunicação e extensão de seus saberes difundidos nos eventos cíclicos da igreja.

Os resultados preliminares da pesquisa apresentam novas incursões do que foi apresentado neste corpo do texto sobre a constituição do letramento social, prática educativa e a narrativa da análise, com base na perspectiva Bakhtiniana, na medida em que a palavra visibiliza outras vozes que se intercruzam - família, amigos, vizinhos e toda a comunidade.

Referências bibliográficas: ALBUQUERQUE, Maria Betânia B. Saberes da experiência, saberes escolares: diálogos interculturais. Org. Belém: EDUEPA, 2016. BAKHTIN, M. Por uma metodologia das ciências humanas. In: BAKHTIN, M. Notas sobre leitura, cultura e ciências humanas. Organização, tradução, posfácio e notas de Paulo Bezerra. Notas da ed. Russa SegueiBotcharov. São Paulo: Editora 35, 2017.

GIL, Antônio Carlos. Como elaborar projetos de pesquisa. 4. Ed. - São Paulo: Atlas, 2002.

MINAYO, Maria Cecília de Souza. Pesquisa social: teoria, método, e criatividade. Editora Vozes Limitada, 2011.

STREET, Brian V. Letramentos sociais: abordagens críticas do letramento no desenvolvimento, na etnografia e na educação.Trad.MarcosBagno. São Paulo: Parábola, 2014.

Palavras-chave: Análise do Discurso. Letramento social. Práticas religiosas de idosos. Letramento religioso. 
Grande-área: Eduação

Área: Linguagem 


\title{
RELAÇÕES DE ALTERIDADE: OS ALUNOS COM DEFICÎENCIA EM TURMAS DO ENSINO MÉDIO NA PERSPECTIVA DO SER MAIS DA DIFERENÇA
}

\author{
Nome do(a) Bolsista: Ronielson Santos das Mercês \\ Nome do(a) Orientador(a): José Anchieta de Oliveira Bentes
}

Resumo: Esta dissertação tem por objetivo analisar as relações de alteridade a partir do constructo teórico-epistemológico de Paulo Freire, investigando tal tema de pesquisa em turmas do Ensino Médio de uma escola pública do Distrito de Icoaraci, buscando analisar como as relações entre eu e outro se configuram em praticas dialógicas para a vocação do ser mais da diferença no contexto escolar. Assim, a presente pesquisa tem como questão problema: Quais as contribuições de Paulo Freire para vocação do ser mais da diferença na perspectiva de alteridade no contexto escolar? O caminho metodológico desta pesquisa tem por base a abordagem qualitativa, destacando as relações de alteridade, as quais apresentam aspectos qualitativos entre o "eu" e o "outro" que subjaz as relações dialógicas, as narrativas que anunciam o reconhecimento do ético do outro como alteridade. O tipo de pesquisa tem por base o metódo dialógico, que considera a vivacidade, a extensão da palavra e a dimensão social e política do diálogo como fonte de análise da intercomunicação entre o "eu" e o "outro" no ambiente escolar. As técnicas de pesquisa utilizadas foram o diário de pesquisa, observações e entrevistas semiestruturadas, visando analisar as narrativas dialógicas que elucidavam questões atinentes da realidade pesquisada. O referencial teórico base: Freire (1992, 1996,1987, 2011, 2014), e os interlocutores: Oliveira (2002, 2015), Fleuri (2018) e outros. Os resultados preliminares obtidos no corpus de pesquisa para o exame de qualificação revelaram que as relações de alteridades entre "eu" e o "outro" anunciam o outro como alteridade na contexto escolar em sua complexidade e integralidade da pessoa com deficiência, interssecionado questões de raçã, gênero, classe e deficiência que constituem a vocação do ser mais da diferença. As situações educativas observadas, analisadas, sistematizadas e categorizadas apontaram que as práticas dialógicas expressam a vocação do aluno com deficiência no contexto do ensino médio, as quais esse processo de comunicação entre eu e o outro promovem relações mais éticas, democráticas, humanas e plurais entre os sujeitos sociais.

Introdução: Partindo das narrativas e das relações de alteridade numa perspectiva dialógica, compreendemos como situação existencial dialética, analisando as contradições da vocação das alteridades como presentes e concretas na enunciação teórica, mas construída na ação dos sujeitos sociais no contexto escolar. Assim, esta pesquisa emerge com a significação das palavras e narrativas dos sujeitos na constituição do eu -identidade como um ser relacional em construção existencial com os outros- alteridades no mundo. Logo, Freire (2014) atenta que a palavra tem sentido e significação que se constitui em sua intenção significante, coincidente com intenções de outros que significam o mesmo mundo. Este fundo é o lugar de encontro de cada um consigo mesmo e os demais. 
Nesta andarilhagem acadêmica assumimos o lugar de fala com a perspectiva epistemológica de reconhecer a importância social dos grupos em situação de ser estar de marginalização, opressão, segregação e discriminação, categorizadas como diferença, incluindo as pessoas com deficiência, na qual viabilizamos por meio desta pesquisa, promover oportunidades de acesso aos lugares de cidadania e fomentar a discussão para as relações de alteridades num reconhecimento ético-político e plural das relações sociais presentes na escola.

A referida pesquisa tem intencionalidade política de contribuir com o rompimento da assimetria, a qual a sociedade está familiarizada, em que as pessoas com deficiência são discriminadas, estigmatizadas e excluídas, sejam de forma verbal, física e simbólica no cotidiano escolar. Por causa da violência e do preconceito, acredita-se ser fundamental discutir as relações de alteridade no cotidiano escolar com o objetivo de possibilitar a emancipação e reconhecimento social das pessoas com deficiência, ou seja, falar de sujeitos discriminados em razão de sua distinção física, sensorial e psíquica no campo da pesquisa em educação.

Objetivo (s):Objetivo Geral Discutir as contribuições de Paulo Freire para o reconhecimento do outro como alteridade no espaço escolar e suas implicações na vocação do ser mais da diferença, considerando as relações dialógicas e antidialógicas no processo educativo.

Os Objetivos Específicos são: Analisar o processo educativo como espaço de constituição das relações de alteridades, considerando as relações dialógicas, éticas e humanizadas emergidas entre as diferenças.

Perceber nas narrativas dos educandos e professores as relações de alteridades anunciadas e denunciadas por meio de relações dialógicas e antidialógicas no contexto escolar

Fomentar o debate da importância da escola como espaço de alteridade e na premissa de formação escolar, social e política dos educandos com deficiência.

Material e Método: Metodologicamente a pesquisa é do tipo de campo e dialógica. Fazemos isso tomando como base o método dialógico fundamentado nos escritos de Freire; Faundez $(1985 ;$ 2017) que consideram a vivacidade, a dimensão social e política do diálogo como fonte de análise da intercomunicação entre o "eu" e o "outro" constituído no ambiente escolar. Refletir sobre novas compreensões teóricas metodológicas na pesquisa em educação nos leva a (re) pensar as novas formas de produção do conhecimento.

Oliveira (2017), fundamentando-se na obra de Freire, acentua que o método dialógico é o de intercomunicação entre os indivíduos mediatizados pelo mundo e que estes se apresentam como ativos, críticos e criticizadores da realidade cotidiana, na elaboração dos objetos de investigação.

A pesquisa dialógica assume o labor científico e metodológico para a compreensão do objeto de pesquisa que nos propomos investigar, caracterizando, metodologicamente, vocação do ser mais da diferença no espaço escolar, relacionando temáticas que se fundam na realidade concreta dos sujeitos. 
Resultado e Discussão: As narrativas dialógicas analisadas constituem-se em 04 acontecimentos atinentes as categorias analíticas e temáticas emergidas a partir do estudo das obras de Freire e empreendidas nas situações educativas do contexto escolar, intentando nas análises dos dados à curiosidade e epistemológica para relações de alteridade entre "eu" e o "outro" em turmas do Ensino Médio. Foram realizadas 05 entrevistas dialógicas com os alunos do Ensino Médio e mais 01 entrevistas com a professora de Educação Especial. Dentre estas seis, selecionamos, para o texto de qualificação, somente duas 02 duas entrevistas para constituição corpus de pesquisa.

Nos encontros dialógicos com os sujeitos da pesquisa adentramos nos acontecimentos para além do movimento de interpretação, escuta e análise das narrativas; constituímos elos de anúncio da vocação do ser mais, por meio da palavra e do diálogo, como seres comunicativos que somos instigandos a dizer o mundo comum que estão inseridos.

Neste vir a ser no mundo, a narrativa da Elza nos envolve com suas palavras a curiosidade para as relações de alteridades de presentes em turmas do Ensino Médio, percebendo à luz de pensamento de Paulo Freire. Neste sentido, a aceitação ética do outro com deficiência considera elementos constitutivos do "eu" que está constituído no "outro", considerando que a posição ética da educanda Elza face a problematização da situação de opressão ocasionada pelo "colega" em sala, ao rejeitar a pessoa surda, o que pode resultar em um mundo comum de libertação frente as situações de opressão.

Por sua vez, a educanda Elza rejeita o posicionamento desse colega, estabelecendo uma nova relação, desta feita de dialogicidade, conforme nosso entendimento. Há relação de alteridade na perspectiva dialógica entre os alunos com deficiência e sem deficiência, ou seja, há o "eu dialógico" que transforma o mundo em colaboração com os outros e que respeita e aceita a diferença da pessoa com deficiência.

O trecho a que nos referimos:

EL: Eu me senti mal, porque, poxa, vamos respeitar o colega, né? Porque ele nasceu assim, né? não é porque ele queria ser assim. Tudo vai conforme a vontade do criador, ele tem que respeitar às limitações do próximo. (Entrevistada com aluna Elza realizada no dia 17 jan de 2019).

Nota-se que o posicionamento ético de Elza frente a situação de rejeição do colega de turma para com o aluno Renan, por ser surdo, evidencia que há o "eu dialógico" se vê constituído no outro, constituindo-se em comunhão com as pessoas com deficiência, respeitando a condição ontológica da diferença, reafirmando em sua narrativa que os homens se encontram em situações de opressões para dizer as verdadeiras palavras de libertação e o reconhecimento do outro. De acordo com Freire (2014) é na confiança que os homens e mulheres se fortalecem e lutam por um mundo comum contra a opressão dos oprimidos, mas uma resultante do encontro em que os homens e mulheres se tornam sujeitos da denúncia do mundo, para a sua transformação.

Conclusão: Os resultados preliminares da pesquisa apresentam novas incursões do que foi apresentado e analisado no corpo do texto da dissertação, apontando para as relações de alteridade entre os alunos com e sem deficiência são efetivadas nos encontros dialógicos para anuncio do outro como alteridade no contexto escolar. 
- Referências bibliográficas

Paulo. Pedagogia do Oprimido. 29 ed. Rio de Janeiro: Paz e Terra. 1987.

, Paulo. Pedagogia da autonomia: Saberes necessários à prática educativa.

São Paulo: Paz e Terra, 1996.

Paulo. Pedagogia da autonomia: Saberes necessários à prática educativa.

São Paulo: Paz e Terra, 2011.

FREIRE, Paulo. Pedagogia do Oprimido. 57 ed. São Paulo: Paz e Terra. 2014. , Paulo. FAUNDEZ, Antônio. Por uma Pedagogia da pergunta. 8 ed. São Paulo: Paz e Terra. 2017.

Ivanilde Apoluceno de. Paulo Freire: gênese da educação intercultural no

Brasil. 1 ed. Curitiba: CRV, 2015.

, Ivanilde Apoluceno de. A dialogicidade na educação de Paulo Freire e na prática do ensino de filosofia com crianças. Movimento Revista de Educação. Niterói. Ano 4, n.7, p. 228-253, jul-dez. 2017

Palavras-chave: Relações de alteridade. Eu e o Outro. Alunos com deficiência.

Grande-área: Educação

Área: Educação Especial 


\title{
EDUCAÇÃO, RESISTÊNCIA E TRADIÇÃO ORAL: UMA FORMA OUTRA DE ENSINAR E APRENDER NA COMUNIDADE QUILOMBOLA VILA UNIÃO ICAMPINA- SALVATERRA-PARÁ
}

\author{
Nome do(a) Bolsista: Shirley Cristina Amador Barbosa \\ Nome do(a) Orientador(a): João Colares da Mota Neto
}

Resumo: O presente resumo é referente a um recorte da pesquisa de mestrado em andamento, vinculada ao Programa de Pós-Graduação em Educação (PPGED) da Universidade do Estado do Pará (UEPA). Neste estudo investiga-se a tradição oral de matriz africana e afro-brasileira e os processos educativos que ocorrem na comunidade quilombola Vila União/ Campina, Salvaterra-Pará. A ideia de educação utilizada nesta investigação é justamente aquela que vivenciamos no território, ao longo do processo de transmissão dos saberes e conhecimentos tradicionais. Esses saberes e conhecimentos não estão inseridos no lócus de valorização acadêmica, nos planos de ensino, embora alguns documentos legais, tais como a lei 10.639/2003 e a Resolução n 8/2012 apresentem a necessidade de diálogos das escolas com os saberes tradicionais e afrobrasileiros. O estudo tem como objetivo geral analisar como a prática da tradição oral de matriz africana se constitui em uma pedagogia decolonial no contexto da comunidade quilombola Campina/Vila União, Salvaterra-Pa. Como objetivos específicos: a) Cartografar os saberes da herança africana e afro-brasileira que estão expressos na oralidade dos sujeitos quilombolas; b) Analisar os processos educativos presente na comunidade que se ancoram na oralidade de matriz africana; c) Compreender como a oralidade contribui para a preservação e ressignificação do conhecimento tradicional; d) Identificar elementos expressos nos processos educativos comunitários que contribuem para uma formação de uma pedagogia decolonial e antirracista na Amazônia. Este trabalho parte de uma tentativa de estabelecer o diálogo entre o pertencimento da pesquisadora enquanto quilombola no tocante à percepção dos processos educativos praticados na comunidade citada que se localiza no Território quilombola de Salvaterra, arquipélago marajoara, Estado do Pará. O Estudo revela, que nesta comunidade quilombola a educação está vinculada ao território e vai ocorrendo no fluxo da vida, no dia a dia, através da roça, da feitura de farinha, nos rituais de cura, das práticas culturais realizadas, nas festas de santos, das ervas medicinais usadas por benzedores, doutores do mato, parteiras e curadores e das várias reuniões e encontros realizados nesta comunidade. Neste contexto, a tradição oral se apresenta como uma pedagogia que abarca um processo amplo de educação, indissociado das narrativas, histórias contadas, gestos e símbolos que constituem um campo de saber, aquele que está associado às lutas pela permanência de práticas culturais, lutas em defesa da terra, da saúde e da educação. Desta forma, as narrativas ditas pelos agentes sociais da comunidade Vila União /Campina nos levam a desvelar a maneira como as pessoas aprendem e como se constituem os acervos de conhecimentos e processos educativos desencadeados pelo poder da palavra. 
Introdução: O presente trabalho dissertativo, apresenta e discute a tradição oral e os processos educativos desencadeados pela transmissão dos conhecimentos no cotidiano da comunidade quilombola Vila União/Campina, em Salvaterra-Pará. Segundo Hampaté Bâ (2010), a tradição oral é uma prática educativa ressignificada, e reinventada, no falar, no agir, no viver, no aprender, no desaprender e reaprender, na resistência dos povos e comunidades tradicionais como os quilombolas os quais tomam a oralidade como forma de ensino-aprendizagem que engendra significados e orientações para a vida.

No município de Salvaterra, encontra -se a comunidade quilombola Vila União/Campina com suas práticas e manifestações culturais a fazerem parte da fonte intelectual tradicional quilombola. Deste ponto, apresento as histórias de vida e luta dos quilombolas, agricultores e pescadores da referida comunidade, através de suas narrativas, cantigas, poesias, orações, rituais de cura, e uso das plantas medicinais.

Apresento os conflitos que se alargam entre fazendeiros e quilombolas no território de Salvaterra, que é articulador de 17 comunidades que se formaram a partir do processo de escravidão, das fugas dos escravos, das insurgências e insubordinação dos negros aos fazendeiros da região. Tais comunidades são : Bacabal, Santa Luzia, Rosário, Vila União-Campina, Boa Vista, Deus Ajude, Bairro Alto, Caldeirão, Pau Furado, São Benedito da Ponta, Salvá, Mangueiras, Providência, Siricarí, Paixão essas comunidades vêm resistindo com suas práticas culturais, lutando pela titulação dos seus territórios, por acesso à educação escolar, e por melhorias na saúde.Partimos da constatação de que os saberes dos grupos subalternizados não são valorizados na história da ciência, nos planos curriculares, no território, as escolas não contribuem para perpetuação dos nossos saberes.

O desenvolvimento da presente pesquisa me levou a problematizar a seguinte questão: Como a prática da tradição oral de matriz africana se constitui em uma pedagogia decolonial no contexto da comunidade quilombola Campina/Vila União, SalvaterraPa?

Objetivos: Diante da perspectiva do trabalho, busco compreender, no decorrer da pesquisa, alguns questionamentos: Quais são os saberes que circulam no cotidiano da comunidade quilombola Campina/Vila União- Salvaterra/Pará? Como essa pedagogia se caracteriza dentro da comunidade Campina/Vila União-Salvaterra/Pará? Como a oralidade contribui para a preservação e a ressignificação do conhecimento tradicional?Explicitando a ideia acima, delineamos como objetivo geral : Analisar como a prática da tradição oral de matriz africana se constitui em uma pedagogia decolonial no contexto da comunidade quilombola Campina/Vila União, Salvaterra-Pará; e como objetivos específicos: Cartografar os saberes da herança africana e afro-brasileira que estão expressos na oralidade dos sujeitos quilombolas; analisar os processos educativos presente na comunidade que se ancoram na oralidade de matriz africana; Compreender como a oralidade contribui para a preservação e ressignificação do conhecimento tradicional; Identificar elementos expressos nos processos educativos comunitários que contribuem para uma formação de uma pedagogia decolonial e antirracista na Amazônia. 
Material e método: Para responder às questões colocadas, foi necessário desenvolver uma pesquisa teórica e empírica .Caminho com a etnografia e a história oral , que em suas premissas reflete crenças nos dados orais expressos a partir das percepções dos indivíduos, os quais se inscrevem em um contexto mais amplo, de animação do campo epistemológico, ao serem inseridos em temas postos no lócus científico, o que antes seria inegociável por pertencerem a conhecimentos subalternizados.

Para (OLIVEIRA, 2005, p. 94)." A história oral recupera aspectos individuais de cada sujeito, mas ao mesmo tempo ativa uma memória coletiva, pois, à medida que cada indivíduo conta a sua história, está se mostra envolta em um contexto sócio histórico que deve ser considerado". A pesquisa de campo foi acontecendo na comunidade, incluído vários espaços como a escola: Maria Lúcia Ledo, a escola de educação infantil de Vila União /Campina. As entrevistas foram realizadas em locais como residências, quintais , na roça, casas de farinha, eu como pesquisadora, moradora do local, e também quilombola procurei estabelecer uma boa interação com os narradores da pesquisa, isso me possibilitou obter discursos espontâneos além da confiança e a disponibilidade dos informantes para os mementos de visitas, entrevistas ou conversas e confecções de materiais para a pesquisa. Os dados foram sendo coletados a partir de observações e anotações no diário de campo, conversas ou entrevistas com moradores da comunidade. Diante disso, partir para as análises, busquei organizar os dados da pesquisa - entrevistas, imagens, mapas e objetos. por ser sujeito e objeto desta pesquisa é que ao fazer a análise dos dados, não posso impedir que minha memória também funcione como dado e como um mecanismo de interpretação dos mesmos. Os informantes que fortalecem a escrita deste trabalho são: Maria Castorina Amador Cantão, Solange Maria Amador Cantão, juvano Reis, Maria Nazilda Gonçalves Amador, Joseane Reis Amador, Danilo Cantão Reis, George Waldo Bruno dos Santos, Ana Maria Chaves Amador e as professoras Cleonice, vera Lúcia e Isabela Portal. Em conversas breves, trago a contribuição de Henrique Amador, Raimundo dos Santos, Roseli Moreira, Sônia Maria Cantão Reis, e Safiro dos Santos.

Resultado e discussão: Mediante a pesquisa na comunidade quilombola Vila União/Campina, apresento os diálogos ocorridos os quais possibilitaram revelar os seus sagrados saberes e conhecimentos tradicionais fincados e transmitidos através da tradição oral. Diante disso os informantes relatam que:

Os pais do meu avô eram escravos, vieram de Mangueiras. O meu bisavô Manoel Alves Amador veio de Mangueiras, e se casou com uma senhora chamada rosa, lá de Rosário. Depois os filhos foram casando-se, formando família, fazendo suas casas aqui, faziam onde queriam, era uma terra sem dono e tudo era parente, tudo era Amador. E agora minha filha, tem gente que eu nem conheço.

A pajelança era forte, a mamãe gostava, a tia Guelmar era pajé, fazia os trabalhos, o pajé é aquele que faz as consultas, ensina os remédios, os chás, banhos de plantas , não tinha esse negócio de comprimido , os remédios eram só das plantas, eles recebiam os cabocos e ai ensinavam os remédios. Tinha o mestre Raimundinho e o mestre Modesto. Depois veio a Cleonice e a Dora que dançavam, eram batuquiras. os curandeiros, curavam as pessoas, se vestiam de branco, dançavam cantavam, tinham 
muitos santos, Mariana, Yemanjá, Jarina, Zé Raimundo, e outros. Hoje tem o Elton que tem todos esses Santos. (Maria Castorina Amador)

O meu trabalho como parteira, é assim, quando a mulher está pra ter o neném ai eu vou atender na hora necessária, hoje elas já fazem o pré-natal mas elas não faziam o prénatal, isso tornava dificultoso pra gente mas a gente dava o jeito, levava tudo na minha bolsa pra fazer o parto da criança, eu vim aprender na prática , eles me chamam ali pra Chiquita, pro Rosário, lá pro outro lado pro Camará me chamam, quando vai chegando perto eles já contratam logo, eu tenho um parto pra fazer em agosto a partir do dia 15 em diante já está certo pra ir fazer esse serviço .No meu trabalho eu uso as plantas, eu trabalho com as plantas. (Ana Maria Chaves Amador)

Vemos, nas narrativas desses entrevistados, a transmissão do conhecimento tradicional preservado por parteiras, benzedeiras e pajés em seus trabalhos e rituais de cura fazem o uso das plantas medicinais. Percebe-se no território uma rica diversidade cultural, muitas tradições foram se perdendo ao longo do tempo, no entanto os quilombolas através das ações coletivas lutam para preservar o que ainda resta de suas tradições.

Conclusão: A nossa história de luta não é de hoje, ela tem muitos anos, olhamos para os antepassados, vemos o tronco e as correntes, hoje olhamos para as crianças vemos o presente e o futuro, temos que continuar lutando, para que elas não passem o que nós estamos passando, a negação de direitos.

No município de Salvaterra somos 17 comunidades quilombolas reconhecidas e certificadas pela Fundação Cultural Palmares. Nenhuma dessas comunidades possui a titulação definitiva, permanecemos encurralados pelas cercas, pelos rebanhos bovinos e bubalinos, que devastam os nossos campos, destruindo os plantios de mandioca. $O$ agronegócio está tomando conta, os fazendeiros e grileiros ameaçam as lideranças quilombolas. somando-se as lutas pela educação diferenciada.

A educação da qual falo nesta pesquisa é o próprio quilombo que abarca um conjunto de saberes que já existe e já educa, há várias gerações, os moradores do quilombo. A partir das narrativas dos meus entrevistados, e a partir de minha própria experiência, a maneira como aprendi tudo que está inserido nessa educação é o quilombo. Neste contexto, a tradição oral de matriz africana se caracteriza como uma prática pedagógica decolonial, pois dela vem a força da tradição estabelecida pela relação do homem e da mulher com a palavra mantida pela resistência dos negros até os dias atuais (WALSH, 2013).

\section{REFERENCIAS BIBLIOGRÁFICAS}

ARIAS, Patricio Guerreiro. Corazonar una antropología comprometida con la vida: Miradas otras desde Abya-Yala para la decolonización del poder, del saber y del ser. ABYA-YALA: QuitoEcuador, 2010.

AIRES, Geovania Machado. EDUCAÇÃo A CÉU ABERTO E ESCOLARIZAÇÃo NO TERRITÓRIO DO FORMOSO - um estudo etnográfico a partir dos saberes e conhecimentos tradicionais locais como contribuição para as escolas estabelecidas nas comunidades quilombolas Olho D’água e Lagoa Mirim. São Luís - MA 2016.dissetação de mestrado.

OLIVEIRA, Valeska Fortes de. Educação, memória e histórias de vida: usos da história oral. História oral, v. 8, n. 1, p. 91-106, 2005. 
PORTELLI, Alessandro; JANINE RIBEIRO, Tradução: Maria Therezinha; RIBEIRO FENELÓN, Revisão Técnica: Déa. O Que Faz a História Oral Diferente. Projeto História: Revista do Programa de Estudos Pós-Graduados de História, [S.I.], v. 14, set. 2012.

HAMPATÉ BÁ, A. A tradição viva. In: KI-ZERBO, Joseph (Ed.) História Geral da África, I: Metodologia e pré-história da África. 2ª ed. Brasília: UNESCO, 2010.

WALSH, Catherine. Lo pedagógico y lo decolonial: Entretejiendo caminos. In: WALSH, Catherine (Ed.). Pedagogías decoloniales: Prácticas insurgentes de resistir, (re)existir y (re)vivir. Quito: Ediciones Abya-Yala, 2013.

Palavras-chaves: Educação Quilombola. Tradição Oral. Pedagogia decolonial. Grande área: Ciências humanas

Área: Educação 


\title{
EDUCAÇÃO DO CAMPO NA AMAZÔNIA: UM ESTUDO SOBRE A ASSOCIAÇÃO DE MULHERES AGRICULTORAS (AMACAMPO).
}

\author{
Nome do(a) Bolsista:Victória Santos de Abreu \\ Nome do(a) Orientador(a): Sérgio Roberto Moraes Corrêa
}

Resumo: A presente proposta de estudo está vinculada à pesquisa de mestrado em desenvolvimento no Programa de Pós-Graduação em Educação da Universidade do Estado do Pará (PPGED-UEPA). Temos como objetivo principal, neste estudo, refletir sobre a Educação do Campo no contexto histórico brasileiro, apontando algumas epistemologias e lutas que fundamentam essa educação, analisando esse movimento a partir do protagonismo das mulheres no Movimento de Trabalhadores Rurais Sem Terra (MST), por meio das práticas de produção e educação da Associação de Mulheres Agricultoras (AMACAMPO) na Amazônia.

Introdução: Neste ensaio, delimitaremos o objeto de estudo e a problemática que nos provoca a pesquisa de mestrado em desenvolvimento no Programa de Pós-Graduação em Educação da Universidade do Estado do Pará (PPGED-UEPA), assim como os argumentos teóricos metodológicos que a sustentam. No presente estudo, buscaremos discutir o protagonismo das mulheres no MST, por meio dos saberes e das práticas de produção agroecológica da Associação de Mulheres Agricultoras (AMACAMPO) e suas implicações para o debate da ressignificação do repertório de educação do campo e produção agroecológica na Amazônia. O interesse pelo tema em questão surgiu a partir das vivências proporcionadas pelo Grupo de Estudo e Pesquisa em Desenvolvimento, Educação e Trabalho na Amazônia (GEPDETAM) ${ }^{7}$, no qual atuo desde 2015. Da mesma maneira que as práticas como educadora popular, por meio do Núcleo de Educação Popular Paulo Freire $(\mathrm{NEP})^{8}$, as quais possibilitaram o contato com discussões e problematizações sobre a educação, o desenvolvimento, o trabalho e as ações coletivas na Amazônia paraense, assim como, os diversos debates acerca da educação popular, educação do campo e gênero. As práticas como educadora e pesquisadora da educação me direcionaram às reflexões acerca da educação popular e do campo como direito. Para Caldart (2012) a Educação do Campo constitui-se por um fenômeno necessário na realidade brasileira, vivenciado pelas comunidades do campo, suas organizações e manifestações, buscando incidir sobre a política de educação e interesses sociais de trabalhadores do campo, onde os movimentos sociais camponeses se destacam como protagonistas dessa educação, podendo apontar o MST, como movimento social de luta pela reforma agrária. E ao refletirmos sobre a atual conjuntura da Amazônia paraense, um território marcado por lutas e choques políticos, resultado de inúmeros fatores históricos, culturais, sociais e econômicos, podemos destacar o Movimento de Trabalhadores Rurais Sem Terra (MST) como um movimento social de 
resistência que, apesar do processo de exclusão e expropriação de terras que sofre, constitui a continuidade e a intensidade das lutas camponesas pela reforma agrária (REFAT; FABRINI; MARSCHNER, 2017). Nesse sentido, nos questionamos também, quanto ao protagonismo das mulheres do Movimento nessa discussão. Para Daron (2012), a luta das mulheres não é algo recente, há décadas reivindicam por muitos direitos tolhidos, afirmando que na realidade brasileira, mas não só nela, em diferentes períodos da história foi e continua sendo possível constatar a presença das mulheres nas lutas pela conquista de direitos e no enfrentamento a inúmeras violências, opressões e desigualdades. Partimos do pressuposto que as mulheres do Movimento também reinventam o repertório do MST, pois ao ocuparem esses espaços, e lutarem por reconhecimento, e por emancipação, elas emergem outras pedagogias, reinventando a própria Educação do Campo, por meio do seu protagonismo. Dessa forma, é possível perceber a necessidade de se estudar o MST na realidade amazônica, sob o ângulo das mulheres do Movimento. Assim, o presente trabalho busca estudar o protagonismo dessas mulheres, a partir do coletivo de agricultoras AMACAMPO. A Associação de Mulheres Agricultoras AMACAMPO é formada por um coletivo de mulheres dos assentamentos Mártires de Abril, Paulo Fonteles e Elisabete Teixeira, localizados na llha do Mosqueiro, em Belém (PA). As primeiras ações do AMACAMPO iniciaram em 2007, mas nesse período a associação teve algumas dificuldades, e por falhas em suas articulações, o coletivo se enfraqueceu e cessou suas atividades. Em 2014, uma das agricultoras dos assentamento supracitados e, precursora da iniciativa, percebeu a necessidade de retomar as ações do coletivo, ao realizar um pesquisa sobre a vida das mulheres assentadas na ilha de mosqueiro, durante o curso de Residência Agrária promovido pelo Programa Nacional de Educação na Reforma Agrária (Pronera/ INCRA), com a participação do Ministério do Desenvolvimento Agrário e com o Conselho Nacional de Desenvolvimento Científico e Tecnológico (CNPq). Dessa forma, a AMACAMPO surge a partir da emancipação dessas mulheres, que ao perceberem o seu lugar no assentamento e se alto-reconhecerem, passaram a lutar por esse reconhecimento dentro do MST, segundo a agricultora, ao relatar os motivos que impulsionaram a retomada do movimento, assim como suas novas ações e desafios. Diante das questões supracitadas, nos propomos pesquisar o seguinte problema: é possível afirmar que existe uma particularidade e reinvenção do debate da educação do campo e do desenvolvimento rural no MST, por meio dos saberes e das práticas de produção agroecológica protagonizada pelas mulheres da AMACAMPO da Amazônia paraense? Partindo das narrativas acima levantadas, assim como, reconhecendo a relevância da AMACAMPO para o MST, em particular na Amazônia, levantamos algumas perguntas que servirão de "norte" para a análise da questão-problema: é possível afirmar que existe uma particularidade e reinvenção do debate da educação do campo, no MST, por meio dos saberes e das práticas de produção agroecológica protagonizada pelas mulheres da AMACAMPO? Assim, temos como objetivo geral: analisar as contribuições dos saberes e das práticas das mulheres - AMACAMPO - para o debate da Educação do Campo e da produção agroecológica nos assentamentos rurais da Amazônia paraense. Como materiais e métodos, neste trabalho estamos desenvolvendo uma pesquisa de campo. Uma vez que, buscamos discutir o protagonismo das mulheres no MST, por meio da prática de produção agroecológica da 
Associação de Mulheres Agricultoras (AMACAMPO), partindo das diferentes realidades vivenciadas por essas mulheres. E para Cruz Neto (2002, p. 51), o trabalho de campo se apresenta: [...] como uma possibilidade de conseguirmos não só uma aproximação com aquilo que desejamos conhecer e estudar, mas também de criar um conhecimento, partindo da realidade presente no campo. Utilizamos uma abordagem qualitativa, uma vez que compreendemos tal abordagem como um instrumento para o processo de análise e problematização da realidade, podendo-se empregar técnicas e métodos que auxiliem na compreensão do objeto de estudo de forma um a contextualizada e detalhada (MINAYO, 2002). Almejamos um estudo sensível e comprometido, não somente com o rigor acadêmico, mas também com os conhecimentos, saberes e experiências que os/as participantes da pesquisa nos confiarão. O enfoque dessa pesquisa fundamentar-se por um viés decolonial, partindo das perspectivas das Epistemologias do Sul e do Pensamento Pós-abissal de Boaventura de Sousa Santos (2010). Uma vez que, percebemos que, a partir dos debates, reflexões e lutas da Educação do Campo, não é possível refletir sobre as lentes de uma "epistemologia geral" (SANTOS, 2010), de uma "memória oficial", ou seja, uma única forma de conhecimento, uma única forma de ser lembrada, um saber dominante, mas considerar as especificidades próprias do campo, desses sujeitos que, segundo Santos (2010), estão de forma invisível no outro lado da linha. Nesse estudo, buscaremos refletir sobre a invisibilidade desses e outros povos, apontando a para necessidade de um pensamento pós-abissal, por meio de uma "ecologia de saberes" (SANTOS, 2010). Dessa forma, ainda que uma certa verdade, tida como "oficial", pelos grupos dominantes, apresentando-nos uma "epistemologia geral", um paradigma dominante (SANTOS, 1997), buscamos, nesse trabalho, contrapor-nos à essa concepções, compreendendo a Educação do Campo pensada e construída por/para os diferentes grupos e práticas sociais, que não reproduz no campo a lógica de uma educação dos grupos dominantes, ela contrapõe-se ao particularismo do conhecimento, resistindo à imposição de um "mirante epistemológico único", de uma "memória oficial", de uma "história opressora". Inicialmente, o lócus da investigação, dar-se-á em três assentamentos localizados na Ilha de Mosqueiro - Assentamentos Mártires de Abril, Paulo Fonteles e Elisabete Teixeira -, uma vez que a AMACAMPO é constituída por mulheres agricultoras que residem e trabalham nesses três cenários. $E$ para investigação, estão sendo utilizadas estratégias para a coleta de dados, passos que consideramos muito importante para uma pesquisa de campo, onde, o primeiro momento da coleta de dados, consiste-se em fazer um levantamento bibliográfico, estudar as produções acadêmicas encontradas sobre a pesquisa em questão, assim como o levantamento documental. Em seguida, realizamos a observação participante durante todas as ações acompanhadas. Para Gatti e André (2011, p. 32) a técnica da observação participante "envolve registro de campo, entrevistas, análise documental, fotografias, gravações [...]". Sendo um método em que o observador utiliza para compreender determinados problemas, descrevendo suas especificidades, apresentando os diferentes significados que a pesquisa possa vim a revelar (GATTI; ANDRÉ, 2011). Sendo também realizadas entrevistas semiestruturadas que, para Oliveira et al (2010), se constitui por uma entrevista flexível, a qual, mesmo com roteiro pré-estabelecido, permite ao entrevistador acrescentar outros questionamentos, 
dependendo das circunstâncias que envolvem o entrevistado e o tema abordado. Dessa forma, tais entrevistas estão se dando de forma individual e coletiva, com mulheres jovens e adultos/as que se enquadrem no perfil da pesquisa. Para a sistematização e análise dos dados, tudo o que for escutado, registrado e observado, está sendo explicado e pensado a partir do contexto em que vivem as participantes da pesquisa, levando-se em consideração as suas características culturais, políticas e sociais. Assim, recorremos às técnicas da Análise de Conteúdo, entre as quais a técnica de interpretação dos dados coletados no decorrer da pesquisa, com o uso de categorizações analíticas e temáticas. Dessa forma, tecermos reflexões sobre a Educação do Campo no contexto histórico brasileiro, apontando algumas epistemologias e lutas que fundamentam essa educação, sob o ângulo das mulheres, a partir da experiência de uma associação de agricultoras que caminham ressignificando a produção e a educação do campo, no Movimento de Trabalhadores Rurais Sem Terra, na Amazônia Paraense, podemos apontar algumas considerações: onde compreendemos que a Educação do Campo surge quando grupos de movimentos sociais traçam, como contrapontos às propostas governamentais, a ideia de acesso dos trabalhadores do campo à uma educação pública em todos os níveis, feita por e para esses homens e mulheres. Partindo dessa compreensão, entendemos o Movimento de Educação do Campo como uma expressão de resistência e luta por libertação dos camponeses, uma manifestação real da proposta de construção de uma Pedagogia do Oprimido, pensada por Freire (1987). Uma educação para a constituição do campo como lugar de vida digno e significativo, para que a mulher e o homem do campo, por meio de sua própria cultura, valores e um olhar crítico sobre o contexto em que eles/as vivem, compreendam-se como sujeitos pedagógicos, como aquele/a que provê as próprias condições materiais de vida. Diante dessas reflexões acerca da Educação do Campo, apontamos para a importância de se pensar essa educação sob o ângulo das mulheres, a partir da experiência de uma associação de agricultoras que caminham ressignificando a produção e educação do campo, no Movimento de Trabalhadores Rurais Sem Terra, na Amazônia Paraense.

\section{Referências Bibliográficas:}

CALDART, Roseli Salete. Educação do Campo. . In: CALDART, Roseli Salete; PEREIRA, Isabel Brasil; ALENTEJANO, Paulo; FRIGOTTO Gaudêncio (Orgs.) . Dicionário da Educação do Campo. Rio de Janeiro, São Paulo: Escola Politécnica de Saúde Joaquim Venâncio, Expressão Popular, 2012.

CRUZ NETO, Otávio. O trabalho de campo como descoberta e criação. In: MINAYO, Maria Cecília; GOMES, Suely Deslandes (Org.). Pesquisa Social: Teorias, métodos e criatividade. 28a ed. Petrópolis: RJ: Vozes, 2002

DARON, Vanderleia Laodete Pulga. Movimento de Mulheres Camponesas (MMC Brasil). . In: CALDART, Roseli Salete; PEREIRA, Isabel Brasil; ALENTEJANO, Paulo; FRIGOTTO Gaudêncio (Orgs.). Dicionário da Educação do Campo. Rio de Janeiro, São Paulo: Escola Politécnica de Saúde Joaquim Venâncio, Expressão Popular, 2012.

GATTI, Bernardete; ANDRÉ, Marli. A relevância dos métodos de pesquisa qualitativa em Educação no Brasil. In: WELLER, Wivian; PFAFF, Nicolle (Org.). Metodologia da Pesquisa Qualitativa em Educação. 2a ed. Petrópolis, RJ: Vozes, 2011. 
MINAYO, Maria Cecília; GOMES, Suely Deslandes (Org.). Pesquisa Social: Teorias, métodos e criatividade. 28ª ed. Petrópolis: RJ: Vozes, 2002.

OLIVEIRA, Ivanilde Apoluceno de. Et al. Entrevista na Pesquisa Educacional. In: MARCONDES, Maria Inês; OLIVEIRA, Ivanilde Apoluceno de; TEIXEIRA, Elizabeth. (Org.). Metodologias e técnicas de pesquisa em educação. Belém: EDUEPA, 2010.

REFATI, Daiana; FABRINI, João; MARSCHNER, Walter. O trabalho das mulheres nos assentamentos Antonio Companheiro Tavares em São Miguel do Iguaçu e Ander Rodolfo Henrique em Diamante do Oeste - Paraná. Revista Nera - ano 20, nº 35 janeiro/abril de 2017.

SANTOS, Boaventura de Sousa; MENESES, Maria Paula. Epistemologias do Sul. São Paulo: Cortez, 2010. . Um discurso sobre as ciências. 9. Ed. Porto: Afrontamento, 1997

Palavras-chave: Educação do Campo. Mulheres. MST. Agroecologia. 


\section{PROGRAMA DE PÓS- GRADUAÇÃO EM ENFERMAGEM}




\title{
HANSENÍASE E REPRESENTAÇÕES SOCIAIS: O OLHAR E O CUIDAR DE QUEM VIVENCIA A DOENÇA
}

\author{
Nome do(a) Bolsista: Camila Carvalho do Vale \\ Nome do(a) Orientador(a):Iací Proença Palmeira
}

Introdução: A hanseníase é uma das mais antigas doenças que acometem o homem (BRASIL, 2015). O Brasil carrega a classificação de segundo colocado no mundo em número absoluto de casos novos registrados e é considerado um dos países endêmicos das Américas quanto à prevalência e detecção de casos (OMS, 2016). O doente de hanseníase ainda participa da construção das representações sociais sobre o "ser leproso", mesmo hoje, quando a doença deixou de ser "lepra" e passou a ser hanseníase. Assim, os conceitos, crenças e valores sobre a hanseníase constroem suas representações e podem se transmutar em ações, tanto positivas como negativas, perante a doença (BITTENCOURT et al., 2010). Objetivo: Conhecer as representações sociais da hanseníase de pessoas que vivenciam a doença e as formas de cuidados de si. Metodologia: Trata-se de uma pesquisa qualitativa e descritiva com base na TRS de Moscovici (2015) na abordagem processual que foi realizada em quatro unidades de saúde, onde funcionam 12 equipes de Estratégia de Saúde da Família (ESF) localizadas na zona urbana do município de Marabá-PA. A pesquisa respeitou os princípios éticos contidos na resolução $n^{\circ}$ 466/2012. Após aprovação do CEP (Parecer n 3296983), a pesquisadora teve um primeiro momento de ambientação e conhecimento das equipes de cada ESF. Nesse momento, foram feitas as apresentações e a exposição do projeto às equipes, solicitando apoio de todos, pois eles seriam os elos interpessoais entre a pesquisadora e os potenciais participantes da pesquisa. Em cada ESF foi solicitada uma sala para realização das entrevistas, explicitando-se os dias da semana que iriam ocorrer e o melhor horário para tal, tudo isso em anuência com as direções das unidades, de modo a não atrapalhar a dinâmica dos trabalhos Participaram 41 pessoas que vivenciam (doentes) a hanseníase no município de Marabá-PA. A opção pelos participantes decorreu por estes terem a representação do fenômeno, visto vivenciarem a hanseníase em seus múltiplos aspectos, como o sentimento de medo, rejeição familiar, estigma, preconceito, dando indícios de representações sociais acerca da doença. A coleta de dados foi realizada por meio de entrevista com um questionário semiestruturado composto por dados sociodemográficos e perguntas específicas. Os textos obtidos na entrevista estão sendo organizados e transcritos individualmente, preservando-se a expressão verbal dos participantes; Serão realizadas revisões e correções gramaticais e ortográficas; Nessa etapa de organização das informações, os textos (entrevistas) serão unidos em um texto único, corrido, materializando o corpus textual para a realização da análise e discussão dos resultados. Resultados: A pesquisa ainda se encontra na fase de análise, os dados sociodemográficos serão analisados pela estatística simples e percentual. As entrevistas serão submetidas ao software Iramutec para a análise de Classificação Hierárquica Descendente (CHD) 
baseada no método de Reinert. Conclusão: Os resultados do estudo podem suscitar reflexões para uma assistência de enfermagem mais humanizada, que priorize as reais necessidades de saúde do paciente, tendo-se em vista tratar-se de seres bio-psicohistórico-social, portanto, contextualizado e indissociável de seu meio, cujos saberes devem ser acessados e respeitados.

REFERÊNCIAS

BRASIL. Conselho Nacional de Secretários de Saúde. A Atenção Primária e as Redes de Atenção à Saúde I Conselho Nacional de Secretários de Saúde. - Brasília: CONASS, 2015. 127 p.

MOSCOVICI, S. Representações sociais: investigação em psicologia social. Tradução: Pedrinho A. 11. ed. Petrópolis, RJ: Vozes, 2015.

OMS. Estratégia global para hanseníase 2016-2020: aceleração rumo a um mundo sem hanseníase. [s.l.]: OMS, 2016. Disponível em: https://apps.who.int/iris/bitstream/handle/10665/208824/9789290225201pt.pdf?sequence=17. Acesso em: 23 nov. 2018.

Palavras-chaves: Hanseníase. Psicologia Social. Autocuidado.

Grande-área: Saúde Pública

Área: Enfermagem; Psicologia Social; Doenças endêmicas e negligenciadas 


\title{
AVALIAÇÃO DO ENFERMEIRO AOS SINTOMAS FÍSICOS E PSICOLÓGICOS DE PACIENTES ONCOLÓGICOS EM CUIDADOS PALIATIVOS
}

\author{
Nome do(a) Bolsista: Danielle Etienne de Oliveira Bezerra Lima \\ Nome do(a) Orientador(a): Mary Elisabeth de Santana
}

Introdução: O câncer é um problema de saúde pública e está agrupado ao conjunto de Doenças e Agravos Não Transmissíveis (DANT) responsável pelo adoecimento e óbito da população mundial. As transições demográficas e epidemiológicas globais sinalizam um crescente número de casos de câncer nas próximas décadas afetando principalmente populações dos países em desenvolvimento, especialmente por mortes prematuras. Nestes países estima-se que impacto do câncer na população corresponda a $80 \%$ dos mais de 20 milhões de casos novos estimados para 2025. Para o Brasil estima-se, para o biênio 2018/2019, a ocorrência de 600 mil casos novos de câncer, para cada ano (INCA, 2015; 2017). É neste contexto do crescimento das doenças crônicas, dentre elas o câncer, que a Organização Mundial de Saúde preconiza e orienta a implementação dos cuidados paliativos em serviços de hospitais e instituições oferecendo cuidados voltados à garantia da qualidade de vida e alívio do sofrimento dos adoecidos e seus familiares (ANDRADE et al., 2019). Os Cuidados Paliativos são definidos como uma abordagem comprometida em promover a qualidade de vida de pacientes e seus familiares diante de doenças que ameaçam a continuidade da vida através de prevenção e alívio do sofrimento. Neste intuído as equipes multidisciplinares trabalham para identificar precocemente, avaliar e tratar adequadamente a dor e outros problemas de natureza biopsicossocial e espiritual (WHO,2004). Apesar dos avanços diagnósticos e terapêuticos na oncologia, em alguns casos os pacientes evoluem para um estadiamento avançado de doença, em que o prognóstico se torna desfavorável e as chances de cura tornam-se reduzidas. Neste momento são evidenciados sinais e sintomas que podem ocorrer de forma isolada ou em manifestação múltipla, comprometendo a qualidade de vida não somente do paciente, mas de todos envolvidos no processo de adoecimento, como os cuidadores e familiares. Nestes casos as práticas dos profissionais de saúde devem integrar ações paliativas, com adoção de medidas que visem minimizar as repercussões negativas da doença como a carga de sintomas, que podem ocorrer em multiplicidade, além do sofrimento de ordem psicossocial e espiritual (VISENTIN et al, 2018). Entretanto a literatura aponta para lacunas no conhecimento dos profissionais de saúde com relação aos cuidados peculiares ao público oncológico, devido até mesmo a falhas na formação profissional, o que gera dificuldades para a execução de cuidados oncológicos e cuidados paliativos, no que se refere dentre outros aspectos a adequada avaliação e manejo de sinais e sintomas, muitas vezes negligenciados pelas equipes de saúde (SILVA et al., 2015). Diante da complexidade da área de oncologia e cuidados paliativos, é que os pesquisadores veem realizando estudos com a meta de melhorar assistência de enfermagem prestada aos pacientes em cuidados paliativos, em especial com o uso da escala de Edmonton Symptom Assessment System (ESAS) que tem por meta avaliar os sintomas a fim de conduzir a terapêutica apropriada ao quadro clínico. A ESAS possibilita avaliar os 
sintomas psicobiológicos frequentemente referidos pelos pacientes oncológicos, graduando-os conforme a intensidade relatada pelo paciente. Essa avaliação permite que a equipe de enfermagem e de saúde planeje a terapêutica adequadamente (MONTEIRO; KRUSE; ALMEIDA, 2010). No Brasil em 2014 Manfredini realizou a tradução validação do referido instrumento que recebeu o nome de Escala de Avaliação de Sintomas de Edmonton (ESAS-Br) contemplando os sintomas dor, cansaço, náusea, tristeza, ansiedade, sonolência, apetite, bem-estar, falta de ar e sono. Na referida Escala os sintomas são quantificados em escores que variam entre 0 e 10, conforme mencionado anteriormente e ao final avalia-se o escore total (ESAS-Total), considerando a soma de todos os sintomas. Este instrumento demonstrou-se de boa confiabilidade e fácil aplicabilidade, sendo considerado de grande valia para identificação de sintomas em pacientes oncológicos em fase avançada. Vale destacar que na prática assistencial o enfermeiro utiliza ferramentas de trabalho que possibilitam a sistematização do cuidado, fundamentada em evidências científicas, proporcionando qualidade e cientificidade no seu cuidar. A Sistematização da Assistência de Enfermagem (SAE) é uma metodologia científica que confere maior segurança à prática profissional, melhorando a assistência e permitindo autonomia aos profissionais de enfermagem. A SAE organiza o trabalho do enfermeiro quanto ao método, pessoal e instrumentos, tornando possível a operacionalização do Processo de Enfermagem que consiste em cinco etapas distintas, porém interdependentes e inter-relacionadas: Coleta de dados, Diagnóstico de Enfermagem, Planejamento, Implementação e Avaliação. O rigor no sequenciamento dessas etapas é imprescindível para o desenvolvimento do raciocínio sobre dada realidade, desenvolvendo pensamento crítico-reflexivo, por meio do julgamento e raciocínio clínico, para melhor interpretação das informações obtidas nos achados (SANTOS et al., 2017; TANURE; PINHEIRO, 2010). Em oncologia o enfermeiro pode fazer uso de instrumentos que o auxiliem no desenvolvimento do Processo de Enfermagem, que consta da investigação, em que o enfermeiro coleta dados sobre o paciente, aplicando instrumentos que permitam a obtenção de dados de maneira rápida e simples. Destacamos a Escala de Avaliação de Sintomas de Edmonton, já utilizada em vários países, mostrando-se um instrumento eficaz e importante para o cuidado de enfermagem.

Objetivos: Avaliar os sintomas físicos e psicológicos relatados pelos pacientes oncológicos em cuidados paliativos. Os objetivos Específicos incluem: Caracterizar o perfil sociodemográfico e clínico dos pacientes oncológicos em cuidados paliativos; Identificar através da aplicação da ESAS-BR os sintomas físicos e psicológicos relatados pelos pacientes oncológicos em cuidados paliativos; Propor intervenções de enfermagem a partir dos sintomas físicos e psicológicos relatados pelos pacientes oncológicos em cuidados paliativos.

Material e Método: Trata-se de um estudo descritivo transversal com abordagem quantitativa. O local da pesquisa será o Hospital Ophir Loyola (HOL), principal hospital público de referência em oncologia de Belém do Pará, especificamente na Clínica de Cuidados Paliativos Oncológicos (CCPO) e na Clínica Cirúrgica Abdominal Oncológica. Os participantes serão os pacientes com câncer avançado, isto é, aqueles em 
estadiamento avançado de doença, com presença de metástases, sintomas psicológicos e físicos que podem ocorrer de forma isolada ou em múltiplos sintomas decorrentes do avanço da doença ou do próprio tratamento, atendidos no referido hospital. Para o cálculo amostral considerou-se a população de de 300 pacientes com câncer atendidos nas clinicas supracitadas. Adotou-se o nível de confiança de 95\% desvio padrão de 1,96 e a margem de erro de 10\%. Após o calculo de amostra simples obteve-se o total de 73 participantes. Serão incluídos no estudo pacientes de ambos os sexos, maiores de 18 anos, com câncer avançado que possuam metástase a distância ou recorrência local, sem condições de cura; pacientes que estejam realizando algum tipo de tratamento adjuvante ou neoadjuvante (quimioterapia, radioterapia e cirurgia), ou em cuidados paliativos exclusivos, cujo acompanhante/cuidador esteja presente durante a participação neste estudo. Serão excluídos os pacientes que apresentarem algum comprometimento clínico incapacitante (dor, dispneia severa, ou outro sintoma desconfortante severo), ou cognitivo (confusão mental ou sedação) que os impeçam de responder adequadamente às perguntas do estudo e pacientes idosos. A coleta de dados será feita através da abordagem aos participantes à beira do leito e acontecerá em dois momentos a saber: primeiro momento ocorrerá preenchimento de um formulário sobre a caracterização sociodemográfica e clínica do participante. No segundo momento será aplicada a escala de avaliação de sintomas de Edmonton traduzida e validada por Manfredini em 2014, ESAS-Br, para avaliação dos sintomas, graduado de 0 a 10 , representando a ausência do sintoma e a manifestação máxima dele respectivamente. Após a abordagem, visando complementar as informações clínicas obtidas, serão coletados dados do prontuário do paciente. Os dados serão analisados de maneira quantitativa será elaborado um banco de dados e submetidos a tratamento estatístico pelo SPSS (Statistical Package for Social Science). Realizaremos análise descritiva para os dados sócio demográficos e clínicos. Será elaborado um banco de dados com dupla digitação planilha no Excell 2016. Ao final os dados serão apresentados em tabelas, com valores absolutos e percentuais, e as variáveis numéricas. A partir dos resultados obtidos será elaborado um plano de intervenções de enfermagem do tipo nota técnica. Este estudo obedecerá aos aspectos éticos conforme estabelece Resolução 466/12 que trata das Normas de Pesquisa envolvendo Seres Humanos. A coleta de dados será iniciada após a aprovação dos Comitês de Ética em Pesquisa da Escola de Enfermagem "Magalhães Barata" da Universidade do Estado do Pará e do Hospital Ophir Loyola e as abordagens aos participantes e acesso aos dados do prontuário ocorrerão após assinatura do Termo de Consentimento Livre e Esclarecido (TCLE) e do Termo de Consentimento de Utilização de Dados (TCUD). Para manter o anonimato do usuário será empregado o sistema alfanumérico, com a adoção da letra $\mathrm{P}$ (Participante) seguido de numeração sequencial $(P 1, P 2, P 3, \ldots)$ e assim sucessivamente. A pesquisa trará fundamentação científica para a prática clínica de enfermagem baseada na realidade dos pacientes oncológicos em cuidados paliativos atendidos no estado do Pará, considerando não apenas as características clínicas, mas outros aspectos inerentes a regionalidade desses pacientes. As novas descobertas darão subsídio para o desenvolvimento das práticas avançadas em enfermagem, permitindo o cuidado holístico aos pacientes na realidade local. 


\section{Referências:}

ANDRADE, G.B; PEDROSO, V.S.M.; WEYKAMP, J.M.; et al. Cuidados Paliativos e a Importância da Comunicação entre o Enfermeiro e Paciente, Familiar e Cuidador. Rev Fund Care Online.2019. abr./jun.; 11(3):713-717. DOI: http:// dx.doi.org/10.9789/21755361. 2019. v11i3.713-717

INCA. Ministério da Saúde. Instituto Nacional de Câncer José Alencar Gomes da Silva. Estimativa 2016: incidência de câncer no Brasil. Rio de Janeiro: INCA, 2015.

INCA. Ministério da Saúde. Instituto Nacional de Câncer José de Alencar Gomes da Silva. Estimativa 2018: Incidência de câncer no Brasil. Rio de Janeiro: INCA: 2017.

WORLD HEALTH ORGANIZATION (Organização Mundial da Saúde). Better palliative care for older people. Geneva: WHO; 2004.

MANFREDINI, L.L. Tradução e validação da Escala de Avaliação de Sintomas de Edmonton (ESAS) em pacientes com câncer avançado. Dissertação (Mestrado em Ciências da Saúde) - Fundação Pio XII - Hospital de Câncer de Barretos. Barretos, 2014. MONTEIRO, D.B.; KRUSE, M.H.; ALMEIDA, M.A.; Avaliação do instrumento Edmonton Symptom Assessment System em Cuidados Paliativos: revisão integrativa. Rev Gaúcha Enferm., Porto Alegre (RS) 2010 dez;31(4):785-93.

SANTOS, M.G. et al. Etapas do processo de enfermagem: Uma revisão narrativa. Enferm. Foco 2017; 8 (4): 49-53

SILVA, M.M., et al. Cuidados paliativos na assistência de alta complexidade em oncologia: percepção de enfermeiros. 2015; Escola Anna Nery Revista de Enfermagem19(3):460-466.Jul-Set 2015. Disponível em: <http://www.scielo.br/scielo.php?script=sci arttext\&pid=S1414-81452015000300460>. Acessado em: 02/08/2017.

TANURE, M.C.; PINHEIRO, A. M. SAE: Sistematização da Assistência de Enfermagem: Guia prático. 2.ed. - [Reimpr.] - Rio de Janeiro: Guanabara Koogan, 2011. VISENTIN, A.; MANTOVANI, M.F.; KALINKE, L.P.; BOLLER, S.; SARQUIS, L.M.M. A terapêutica paliativa em adultos com câncer: um estudo transversal. Rev Bras Enferm [Internet]. 2018;71(2):252-8. DOI: http://dx.doi.org/10.1590/0034-7167-2016-0563.

Palavras-chave: neoplasias, cuidados paliativos, enfermagem oncológica, cuidados de enfermagem e avaliação de sintomas.

Grande área: Ciências da Saúde.

Área: Enfermagem. 


\title{
QUALIDADE DE VIDA RELACIONADA A SAÚDE DE CRIANÇAS E ADOLESCENTES EM HEMODIÁLISE: PRODUÇÃO E TESTAGEM DE UMA ESTRATÉGIA GAMIFICADA
}

\author{
Nome do(a) Bolsista: Fernanda de Nazaré Almeida Costa \\ Nome do(a) Orientador(a): Paulo Elias Gotardelo Audebert Delage
}

Resumo: A mensuração da Qualidade de Vida Relacionada à Saúde (QVRS) é considerada um importante indicador na avaliação de intervenções e tratamentos de saúde. A gamificação é a utilização de elementos de jogo como estratégia para aumentar o engajamento e contribuir para mudança de comportamentos desejáveis. Objetivo: produzir e testar uma estratégia gamificada voltada à melhoria da QVRS de crianças e adolescentes em hemodiálise. Método: A pesquisa envolveu a produção de uma estratégia gamificada no formato de um Role Play Game (RPG) de mesa e a avaliação da QVRS antes e após a introdução dessa estratégia com um grupo de oito crianças e adolescentes em tratamento hemodialítico. Resultados: O jogo retratava fantasiosamente situações potencialmente reais vividas por esses pacientes e buscava melhorar sua resiliência, autopercepção e aceitação do tratamento, tendo sido bem recebido. A correlação entre os escores mensurados pré e pós testagem demostrou melhora significativa nas dimensões independência e emocional após introdução do jogo. Conclusão: a estratégia produziu melhoria na QVRS e tem potencial de favorecer mudanças de comportamento e postura no contexto da saúde.

Introdução: O termo Qualidade de Vida é definido como sendo "a percepção do indivíduo sobre a sua posição na vida, dentro do contexto dos sistemas de cultura e valores nos quais está inserido e em relação aos seus objetivos, expectativas, padrões e preocupações" ${ }^{\prime 1)}$. Existem duas perspectivas para conceituação desse termo: Qualidade de Vida (QV) como um conceito genérico, influenciado por aspectos sociológicos e Qualidade de Vida Relacionada à Saúde (QVRS), um subconjunto do termo QV utilizado para distinguir a QV em seu conceito amplo e QV relacionada a parâmetros clínicos ${ }^{(2)}$.

Devido aos avanços da medicina e ao progresso tecnológico, determinadas doenças letais passaram a ter tratamentos que não curam, mas permitem o controle dos sintomas, resultando no aumento da expectativa de vida da população. Diante disso, tornou-se importante o desenvolvimento de maneiras para mensurar de que forma as pessoas convivem com sua nova condição de saúde ${ }^{(2)}$.

Crianças e adolescentes em hemodiálise demandam uma assistência condizente com as especificidades de sua faixa etária, a qual vai além de cuidados puramente biológicos, sendo indispensável o desenvolvimento de estratégias que busquem alcançar a real necessidade desses pacientes e contribuir para seu processo adaptativo diante das limitações impostas pela DRC e pela hemodiálise ${ }^{(3)}$.

Os indivíduos são seres adaptáveis que estão em constante interação com estímulos internos e externos. Quando corretamente estimulados os indivíduos respondem de forma positiva desenvolvendo mudanças de comportamento favoráveis, denominadas de 
retroalimentação. A assistência em enfermagem deve ser desenvolvida de modo a oportunizar ao paciente respostas adaptativas favoráveis à sua condição de saúde ${ }^{(4)}$.

A Gamificação, é uma metodologia que tem sido aplicada como estratégia de inovação em diversos contextos: na educação, no marketing, nas empresas e na saúde. Trata-se de uma estratégia voltada a aplicar mecanismos de jogos à resolução de problemas em contextos diversos, despertando engajamento ou gerando motivação em públicos de diferentes perfis ${ }^{(5)}$. Essa motivação pode ser extrínseca, quando se baseia em fatores externos ao indivíduo, como recompensas financeiras, ou intrínseca, quando a motivação se origina de fatores internos, como a própria realização das tarefas ${ }^{(6)}$.

A proposta desta pesquisa foi avaliar se é possível melhorar a QVRS de crianças e adolescentes, usando para isto uma estratégia gamificada. Sendo assim, foi elaborada a seguinte questão de pesquisa: "A introdução de uma estratégia gamificada de desenvolvimento de Qualidade de Vida com crianças e adolescentes renais crônicos em hemodiálise produz diferenças significativas nos escores de QV?".

Objetivo: Produzir e testar uma estratégia gamificada de desenvolvimento de QV com crianças e adolescentes renais crônicos em hemodiálise.

Materiais e métodos: Pesquisa metodológica, aplicada e quase experimental. Realizada em duas etapas, a saber: produção da estratégia gamificada; e testagem da estratégia gamificada com o público-alvo em três fases: pré-teste, testagem e pós-teste em um grupo único.

Foi realizada com 8 crianças e adolescentes que realizam tratamento hemodialítico no Setor de Terapia Renal Substitutiva Pediátrica da Fundação Santa Casa de Misericórdia do Pará. Critérios de inclusão: idade entre 8 e 18 anos incompletos, em tratamento regular na instituição há pelo menos três meses. Critérios de exclusão: pacientes que não apresentavam condições cognitivas para participar do jogo.

Para a produção do jogo foram utilizados softwares específicos como: Azallea's Dolls, para criação dos avatares; Dungeon painter e Inkarnate para a criação dos mapas; também foram utilizados dados de 10 faces, ficha do personagem, lápis colorido, adesivos, representando as armas e as poções de cura rápida, miniaturas de vilões em MDF e cubos plásticos coloridos.

Os dados coletados foram organizados em um banco de dados modelado no Microsoft Office Access ${ }^{\circledR}$ 2016. A análise estatística foi realizada nos programas GraphPad Prism $6.0^{\circledR}$ e Biostat $5.0^{\circledR}$. Foi aplicado o teste paramétrico $t$-student pareado para correlação dos escores mensurados nos momentos pré e pós teste. Em todo trabalho foi utilizado o nível de significância de 5\%.

Resultados e discussões: A primeira etapa da pesquisa consistiu na produção de um jogo chamado Nefro Hero, modelo simplificado de RPG, adaptado para retratar o cotidiano de crianças e adolescentes que realizam a hemodiálise. Em um primeiro momento, foi realizada uma revisão narrativa da literatura sobre o cotidiano de crianças e adolescentes que realizam hemodiálise. As principais limitações impostas pelo tratamento relatadas em pesquisas por crianças, adolescentes e por seus cuidadores foram: (1) dificuldade de adaptação as restrições alimentares e hídricas, principalmente 
a ausência de sal nos alimentos; (2) o volume de líquido ingerido pelo paciente portador de DRC, que deve ser mínimo para evitar desequilíbrio hídrico que pode levar a edema pulmonar; (3) sentimentos de medo, vergonha e discriminação percebido por essas crianças/adolescentes em relação aos seus pares; e (4) prejuízos em sua inserção na sociedade em função da rotina e limitações do tratamento, que os impede de desfrutar e um cotidiano próprio dessa fase da vida ${ }^{(7)}$. Essas dificuldades elencadas foram trazidas para um cenário de fantasia, formado por sete continentes onde em cada um desses cenários buscava-se retratar de forma lúdica situações semelhantes as enfrentadas por essas crianças em seu tratamento.

Os elementos de gamificação introduzidos no jogo Nefro Hero buscavam incentivar nesse público mudanças favoráveis de comportamento incentivando-os na adoção de práticas que contribuam com o seu tratamento. Para isso foram estabelecidas relações entre as atitudes do paciente em seu tratamento e desfechos do seu avatar dentro do jogo. Optou-se por utilizar essa relação nas seguintes situações: ganho de peso interdialítico; comportamento da criança durante as sessões de hemodiálise; e cuidados com o aceso vascular. Mediante a avaliação desses cuidados eram estipulados bônus ou retirado pontos dos jogadores. Esses elementos de gamificação do são um recurso para melhorar a adesão e adaptação de crianças e adolescentes ao tratamento hemodialítico e consequentemente desenvolver melhorias em sua QVRS.

A segunda etapa da pesquisa consistiu na testagem da estratégia, que foi realizada em três momentos: em um primeiro momento foram mensurados os escores de QVRS, através do instrumento DCGM $37^{\circledR}$. Os escores de QVRS pré-teste mostraram prejuízo em todos os domínios, sendo a independência a que apresentou valor médio mais baixo (21), seguida da dimensão inclusão social com valor médio $(21,6)$. A dimensão emocional apresentou escore mais elevado $(26,1)$, revelando menores impactos nessa dimensão.

O segundo momento foi a introdução do jogo, por um período de dois meses, realizado durante as sessões de hemodiálise, com nove partidas de aventuras narradas, com duração média 30 minutos por partida.

O terceiro momento aconteceu após a última partida do jogo com segunda medida de escore de QVRS. A dimensão "limitação física" apresentou escore mais baixo $(22,9)$ e 0 escore mais elevado foi das dimensões "independência" $(24,5)$ e "emocional" $(28,8)$. Após o processo de testagem foi realizada a comparação estatística dos escores pré e pós-teste, observou-se que houve aumento discreto em todas as dimensões, sendo que, nas dimensões "independência" e "emocional" esse aumento teve significância estatística.

O domínio mental da QVRS revelou ter sofrido maior impacto pela gamificação, que se mostrou uma estratégia eficaz, capaz de desenvolver mudanças de comportamento e contribuir para a adesão ao tratamento e melhorais nos domínios da QVRS.

Conclusão: Este estudo demonstrou que a gamificação é uma estratégia eficaz para proporcionar mudanças de comportamento favoráveis, contribuindo para adaptação de crianças e adolescentes em hemodiálise e a alteração de sua percepção de QVRS.

Contribui com a enfermagem na medida em fornece subsídios para o desenvolvimento de novas estratégias que possam contribuir para a assistência em enfermagem, 
favorecendo a adaptação dos pacientes renais crônicos ao tratamento hemodialítico e contribuindo para melhora de sua QV.

Também serve como sugestão de que novas estratégias gamificadas possam ser desenvolvidas e aplicadas a outros contextos de cuidado com a saúde e no enfrentamento de outras doenças e seus procedimentos.

\section{Referências}

1. OMS. Promoción de la salud: glosario. Genebra: OMS, 1998. Disponível em:http://apps.who.int/iris/bitstream/handle/10665/67246/WHO_HPR_HEP_98.1_spa.pdf ;jsessionid=66B6AC24ECABD12F66DCECEAC4198205? sequence=1. Acesso em: 11 out 2017.

2. Lira CLOB, Avelar TC, Bueno JMMH. Coping e qualidade de vida de pacientes em hemodiálise. Est. Inter. Psicol.[Internet] jun 2015 6(1)Disponível em: http://pepsic.bvsalud.org/scielo.php?script=sci_arttext\&pid=S2236-64072015000100007. Acesso em: 22 nov. 2017.

3. Bozzini ABR. Qualidade de vida relacionada à saúde de crianças e adolescentes portadores de hepatite autoimune [Dissertação]. [Faculdade de medicina]: Universidade de São Paulo; 2017, 68 p

4. George JB, et al. Teorias de enfermagem: os fundamentos a prática profissional. 4. ed. Porto Alegre (RS) Artmed, 2000. 355p.

5. Viana I, Viana M, Medina B, Tanaka S. Gamification, Inc: como reinventar empresas a partir de jogos. $1^{\mathrm{a}}$ ed. Rio de Janeiro: MJV Press; 2013.

6. Nascimento MB, Albuquerque ES. Uso de gamification para melhorar adesão ao tratamento. In: Brasilian Symposium On Information System, 11, Goiânia. Anais eletrônicos. Goiânia: Go, 2015. Disponível em: http://www.lbd.dcc.ufmg.br/colecoes/sbsi/2015/052.pdf. Acesso em: 02 fev2018

7. Abreu IS et al. Crianças e adolescentes em hemodiálise: atributos associados à qualidade de vida. Rev. Esc. Enf. USP.[Internet] maio 2015 48(6) São Paulo, Disponível em:http://www.scielo.br/scielo.php?pid=S008062342014000400602\&script=sci_arttext\&\%20tlng=pt. 25 marc 2018

Palavras chave: Qualidade de vida relacionada a saúde; hemodiálise; gamificação, criança, adolescente.

Grande área: Ciências da Saúde.

Área: Enfermagem 


\title{
ANÁLISE DO CUIDADO ÀS CRIANÇAS EXPOSTAS AO RISCO DE INFECÇÃO PELO HIV
}

\author{
Nome do(a) Bolsista: Fernanda Araújo Trindade \\ Nome do(a) Orientador(a): Mônica Custódia do Couto Abreu Pamplona
}

Resumo: A pandemia da infecção pelo vírus da imunodeficiência humana (HIV) representa uma das crises mais graves de saúde pública em todo o mundo. No Brasil, nos últimos cinco anos (2013 a 2017), a região Norte apresentou uma média de 4,4 mil casos ao ano. Destaca-se a detecção em gestantes apresentando uma tendência de aumento de $118,5 \%$ nos últimos dez anos, e com isso, o aumento do número de infecções pelo HIV tem determinado o nascimento de crianças expostas ao vírus que podem desenvolver a doença caso não sejam realizados cuidados específicos. Devido aos altos índices por transmissão vertical registrados no estado, e a necessidade de conhecer a eficácia dos cuidados domiciliares prestados às crianças expostas ao risco, tem-se como tecnologia avaliativa a Escala de Avaliação da Capacidade do Cuidar de Crianças Expostas ao Risco do HIV (EACCC-HIV). O objetivo deste trabalho é analisar os cuidados prestados por cuidadores às crianças expostas ao risco do HIV segundo aplicação da Escala de Avaliação da Capacidade do Cuidar de Crianças Expostas ao Risco do HIV. Trata-se de estudo descritivo transversal com abordagem quantitativa. $O$ local de realização da pesquisa será a Unidade de Referência Materno Infantil (UREMIA), especificamente no Departamento de Atenção à Doenças Infecciosas e Parasitárias Especiais (DIPE) pediátrica. Os participantes do estudo serão cuidadores de crianças expostas ao risco do HIV, cujo os filhos estejam em controle regular na URE DIPE PEDIÁTRICA, com amostra calculada em 139 participantes. A coleta de dados ocorrerá entre os meses de dezembro de 2019 e maio de 2010, e só ocorrerá após aprovação do Comitê de Ética e Pesquisa da Universidade Estadual do Pará e declaração de aceite da Secretaria Estadual do Pará.

Introdução: A pandemia da infecção pelo vírus da imunodeficiência humana (HIV) representa uma das crises mais graves de saúde pública em todo o mundo. No Brasil nos últimos cinco anos (2013 a 2017), a região Norte apresentou uma média de 4,4 mil casos ao ano; o Nordeste, 9,0 mil; o Sudeste, 16,1 mil; o Sul, 8,2 mil; e o Centro-Oeste, 2,9 mil (BRASIL, 2018 a). Dentre os casos é importante destacar a detecção em gestantes, que vem apresentando uma pequena tendência de aumento nos últimos anos, devido ao grande incremento de testes rápidos distribuídos pela estratégia Rede Cegonha. No Brasil, as regiões Norte e Nordeste foram as que apresentaram maiores incrementos na taxa, de $118,5 \%$ e $87,5 \%$ respectivamente, nos últimos dez anos (BRASIL, 2018 b). O aumento do número de mulheres em idade fértil infectadas pelo HIV tem determinado o nascimento de crianças expostas ao vírus, e a probabilidade de ocorrer a transmissão vertical e de desenvolvimento da aids que pode chegar a 25,5\% sem qualquer intervenção (MIRANDA et al., 2016). É sabido que recém-nascidos e crianças vivendo com o vírus do HIV apresentam demandas específicas de sua condição sorológica, necessitando de acompanhamento nos serviços de saúde, para 
prevenção de agravos e manutenção da saúde, além de orientações sobre cuidados específicos domiciliares a serem realizados pelos responsáveis. A contraindicação da amamentação e substituição por fórmula láctea até os 6 meses de idade, dado o risco de transmissão de carga viral, a indicação de administração de AZT xarope para profilaxia antirretroviral do HIV e de Sulfametoxazol e Trimetoprima para profilaxia primária de Pneumocystis Jirovecii são exemplos dentre as diversas recomendações de cuidados específicos tidos até o fechamento do diagnóstico (12 a 18 meses) que devem ser apontados e detalhadamente discriminados na educação em saúde (NASCIMENTO et al., 2016). Para melhor identificar essas peculiaridades e traçar cuidados específicos de acordo com a necessidade percebida mediante a alimentação complementar, realização da terapia antirretroviral (TARV), quimioprofilaxia da pneumonia, dentre outros fatores que influenciam no diagnóstico de crianças expostas ao risco de HIV, destaca-se na literatura científica a Escala de Avaliação da Capacidade do Cuidar de Crianças Expostas ao Risco do HIV (EACCC-HIV), criada em 2008 e já validada no Brasil. Devido aos altos índices de HIV em crianças registrados na região e no estado do Pará, a responsabilidade do cuidador em aplicar os cuidados supracitados, a necessidade do conhecimento de sua eficácia, e a escassez de publicações realizadas com temática semelhante na região norte, tem-se a seguinte questão de pesquisa: qual o grau de capacidade do cuidador responsável em assistir as crianças expostas ao risco de HIV, desde o nascimento até os 12 meses de idade de acordo com aplicação da EACCC-HIV?

Objetivo: Analisar os cuidados prestados por cuidadores às crianças expostas ao risco do HIV segundo aplicação da Escala de Avaliação da Capacidade do Cuidar de Crianças Expostas ao Risco do HIV; Os específicos incluem: Caracterizar dados socioeconômicos de mães com crianças expostas ao risco de HIV por transmissão vertical; Descrever a situação vacinal da criança exposta ao risco; Descrever os cuidados realizados em crianças expostas ao risco de HIV até o encerramento do diagnóstico; Avaliar o acompanhamento laboratorial de crianças expostas verticalmente ao HIV e outras coinfecções.

Materiais e métodos: Trata-se de estudo descritivo transversal com abordagem quantitativa. O local de realização da pesquisa será a Unidade de Referência Materno Infantil (UREMIA), especificamente no Departamento de Atenção à Doenças Infecciosas e Parasitárias Especiais (DIPE) pediátrica. Os participantes do estudo serão cuidadores de crianças expostas ao risco do HIV, cujo os filhos estejam em controle regular na URE DIPE PEDIÁTRICA. Foi realizada a determinação do tamanho da amostra com base na estimativa da média populacional utilizando-se a fórmula para cálculo de amostragem aleatória simples, tendo como base $95 \%$ de grau de confiança e o valor de 0,05 como estimativa de erro, obteve-se o valor amostral de 139 participantes. Para seleção de participantes tem-se como critérios de inclusão somente as mães ou pessoas sendo os principais cuidadores de crianças expostas ao Risco do HIV, que estejam em controle na URE - DIPE com idade até 24 meses, desde que seja possível as informações serem coletadas presencialmente por este responsável. Serão excluídas mães ou cuidadores de crianças cujo o ingresso na URE - DIPE PEDIÁTRICA seja inferior a 6 meses, pois 
não seria possível coletar informações sobre o seguimento posterior da criança uma vez que a mesma fecha o encerramento dos casos após 18 meses. A coleta de dados ocorrerá entre os meses de dezembro de 2019 e maio de 2010, e só ocorrerá após aprovação do Comitê de Ética e Pesquisa da Universidade Estadual do Pará e declaração de aceite da Secretaria Estadual do Pará, respeitando as diretrizes e normas regulamentadoras de pesquisa envolvendo seres humanos, expressos através da resolução no 466 de 12 de dezembro de 2012 do Conselho Nacional de Saúde/Ministério da Saúde. Após a liberação, os cuidadores serão individualmente abordados na sala de espera de atendimento da URE-DIPE, onde Ihes será apresentado o objetivo da pesquisa e realizado o convite a participação da mesma mediante assinatura do Termo de Consentimento Livre e Esclarecido e Termo de Consentimento de Uso de da Dados para a realização da pesquisa em duas etapas. A primeira etapa consiste no preenchimento de formulário elaborado pela pesquisadora sobre dados sócio econômicos dos cuidadores de crianças expostas ao risco. A segunda etapa consiste em aplicação de escala EACCC-HIV, abordando o cuidado domiciliar prestado por mães à criança exposta o risco desde o nascimento até os 18 meses. A escala avalia os cuidados em saúde direcionados às crianças nascidas expostas ao HIV, do nascimento até 12 meses de idade, mediante cinco fatores: capacidade para administrar o AZT xarope, para crianças com até 42 dias de vida; capacidade para preparar e administrar leite em pó, para crianças de até um ano de idade; capacidade para preparar e administrar alimentação complementar, para crianças acima de quatro meses de idade; capacidade para administrar a profilaxia com sulfametoxazol-trimetoprima, para crianças com mais de 42 dias de vida até um ano; e capacidade para garantir a adesão ao acompanhamento clínico e vacinação. A escala geral possui pontuação própria a qual a qual a somatória pode variar de 52 a 260 pontos, distribuídos em três níveis de capacidade para cuidar: Baixa capacidade para o cuidar: 52 a 121 pontos; Moderada capacidade para o cuidar: 122 a 191 pontos; Alta capacidade para o cuidar: 192 a 260 pontos. Os resultados obtidos a partir da coleta de dados serão agrupados e quantificados em meio eletrônico sendo analisados cuidadosamente, preservando os detalhes destacados de cada entrevistada. As informações serão transcritas e inseridas em planilhas, tabelas e gráficos no software Microsoft Excel e Microsoft Word, para posterior uso de Teste $G$, que possibilita o agrupamento e interpretação de dados estatísticos.

\section{Referencias:}

BRASIL. Ministério da Saúde. Secretaria de Vigilância em Saúde. Boletim Epidemiológico - HIV Aids. Brasília, DF: Ministério da Saúde, 2018 a. Disponível em: http://www.aids.gov.br/pt-br/pub/2018/boletim-epidemiologico-hivaids-2018. Acesso em: 04 abr. 2019.

BRASIL. Ministério da Saúde. Secretaria de Vigilância em Saúde. Protocolo Clínico e Diretrizes Terapêuticas para Manejo da Infecção pelo HIV em Crianças e Adolescentes. Brasília, DF: Ministério da Saúde, 2018 b. Disponível em: http://www.aids.gov.br/pt-br/pub/2017/protocolo-clinico-e-diretrizes-terapeuticas-paramanejo-da-infeccao-pelo-hiv-em-criancas-e. Acesso em: 13 abr. 2019. 
MIRANDA, A. E. et al. Avaliação da cascata de cuidado na prevenção da transmissão vertical do HIV no Brasil. Cad. saúde pública, Rio de Janeiro, v. 32, n. 9, 10 p., set., 2016. Disponível em: https://www.scielosp.org/pdf/csp/2016.v32n9/e00118215/pt. Acesso em: 10 abr. 2019.

NASCIMENTO, L. et al. Qualidade da Atenção Primária à Saúde de crianças e adolescentes vivendo com HIV. Revista Latino-Americana de Enfermagem. Ribeirão Preto, v. 24, n. 02, p. 01-10, ago 2016. Disponível em: http://www.scielo.br/pdf/rlae/v24/pt_0104-1169-rlae-24-02720.pdf. Acesso em: 11 fev. 2019.

Palavras-chave: Transmissão Vertical de Doença Infecciosa; HIV; Cuidado da Criança. Grande área: Ciências da Saúde.

Área: Enfermagem. 


\title{
CARACTERIZAÇÃO CLÍNICO-EPIDEMIOLÓGICA DE MULHERES COM LESÕES PRECURSORAS DO CÂNCER DO COLO DO ÚTERO EM UM SERVIÇO DE ATENÇÃO SECUNDÁRIA.
}

\author{
Nome do(a) Bolsista: Karina de Oliveira Freitas \\ Nome do(a) Orientador(a): Mônica Custódia do Couto Abreu Pamplona
}

Resumo: Este estudo objetiva conhecer o perfil clínico-epidemiológico de mulheres com lesão precursora do câncer do colo do útero com relação as suas variáveis sociodemográficas e reprodutivas, assistidas em um serviço de atenção secundária. Trata-se de um estudo de delineamento transversal correlacional com abordagem quantitativa, realizado na Unidade de Referência em Belém do Pará com 196 mulheres, diagnosticadas com lesão intraepitelial escamosa de alto grau. A coleta de dados ocorreu no período de outubro de 2018 a fevereiro de 2019, através da aplicação de um formulário e da leitura do prontuário clínico de cada participante. Os dados foram condensados em uma planilha e as análises foram realizadas com o apoio do programa Bioestat 5.0. Desta maneira foram identificadas as seguintes características: Mulheres adultas na faixa etária de 18 a 30 anos, de cor autodeclarada parda, católicas, casadas/união estável, de baixa escolaridade, baixa renda, oriundas de municípios de interior do Estado, com início da atividade sexual com idade média de 16,18 anos, com média de 5,42 parceiros sexuais, multíparas, não tabagistas e sem atividade laboral entre outras. Por meio da identificação destas características, será possível o direcionamento de ações voltadas a educação sexual e reprodutiva, além de estimular novos estudos na área que tenham o intuito de otimizar os serviços de saúde.

Introdução: O câncer do colo do útero (CCU) também conhecido como câncer cervical, é um tumor maligno de desenvolvimento lento, que inicialmente pode apresentar-se assintomático e evoluir para quadros de sangramento vaginal intermitente ou após a relação sexual à presença de massa palpável no colo de útero. Durante sua fase assintomática, o CCU passa por fases ditas pré-clínicas detectáveis e curáveis, perto de $100 \%$ quando diagnosticado e tratado precocemente. Essas fases são conhecidas atualmente como Lesão Intraepitelial Escamosa de alto Grau (HSIL), anteriormente conhecidas como Neoplasias Intraepiteliais Cervicais (NIC) de graus II, III e o adenocarcinoma in situ, que podem levar um período de 10 a 20 anos para evoluir para um processo invasor em caráter assintomático (DIAS, 2019).

Dentre os diversos fatores envolvidos na etiologia das lesões precursoras do CCU, a infecção persistente pelo HPV é considerada a principal, sendo os tipos oncogênicos mais comumente relacionados com o aparecimento da doença, o HPV16 e o HPV18 (INCA, 2016). No Brasil, o controle das lesões precursoras do câncer do colo do útero ( $L P C C U$ ) constitui uma das prioridades da agenda de saúde do país e integra o Plano de Ações Estratégicas para o Enfrentamento das Doenças Crônicas Não Transmissíveis. $O$ Ministério da Saúde, por meio da publicação "Diretrizes para o Rastreamento do Câncer do Colo do Útero 2016", recomenda o exame citopatológico em mulheres assintomáticas 
com idade entre 25 e 64 anos, a cada três anos, após dois exames anuais consecutivos normais (INCA, 2016).

Apesar da existência de estratégias de controle eficazes que incluem ações de promoção, prevenção e diagnóstico precoce da doença, observa-se a cada ano um elevado número de novos casos. Uma provável explicação para as altas taxas de incidência desta doença, pode estar ligada ao perfil epidemiológico que ela adquire nos países da américa latina, frente a frequência de exposição aos fatores de risco, ao grau de implementação de ações efetivas no diagnóstico precoce e ao acesso do tratamento das lesões detectadas (INCA, 2016).

Justifica-se a realização deste estudo pela necessidade de se construir maiores conhecimentos acerca dos hábitos e condições de saúde das mulheres paraenses, assim como a frequência de exposição aos fatores de risco existentes para o desenvolvimento das lesões que precedem ao CCU. Onde tais informações poderão contribuir para criação e/ou fortalecimento de estratégias de prevenção, controle, diagnóstico e tratamento precoce da doença.

Objetivo: Conhecer o perfil clínico-epidemiológico de mulheres com lesão precursora do câncer do colo do útero com relação as suas variáveis sociodemográficas e reprodutivas, assistidas em um serviço de atenção secundária de Belém do Pará.

Material e método: Trata-se de um estudo de delineamento transversal com abordagem quantitativa, realizado na Unidade de Referência materno infantil e adolescente (UREMIA) de Belém do Pará com 196 mulheres diagnosticadas com lesão intraepitelial escamosa de alto grau. Como critério de inclusão utilizou-se: mulheres com idades a partir de 18 anos diagnosticadas com lesão intraepitelial escamosa de alto grau (HSIL), cadastradas e em acompanhamento na UREMIA. Foram excluídas mulheres grávidas, histerectomizadas e mulheres com distúrbios da linguagem incapacitadas de responder as perguntas.

A coleta de dados ocorreu no período de outubro de 2018 a fevereiro de 2019, através da aplicação de um formulário e da leitura do prontuário clínico de cada participante. Os dados foram condensados em uma planilha e as análises foram realizadas com o apoio do programa Bioestat 5.0. Foi realizada a estatística descritiva por meio de frequências absolutas e relativa, as quais foram apresentadas em forma de tabelas.

Este estudo respeitou o previsto na Resolução $n^{\circ} 466 / 12$, do Conselho Nacional de Saúde/Ministério da Saúde, que dispõe sobre as normas de pesquisas envolvendo seres humanos e foi aprovado pelo Comitê de Ética em Pesquisa da Universidade do Estado do Pará - UEPA, Escola de Enfermagem Magalhães Barata (Campus IV) sob o número de parecer 2.956 .455

Resultados e Discussões: Diante da caracterização das mulheres portadoras de LPCCU, os resultados revelam que 30,10\% das participantes, estavam na faixa etária de 18 a 30 anos. Fato que chamou a atenção, pelo número de mulheres relativamente jovens (abaixo dos 25 anos) realizando o exame Papanicolau e que estão sendo diagnosticadas com LPCCU. De acordo com Guimarães e seus colaboradores (2012), a idade é um fator de risco para o desenvolvimento o câncer devido sua relação com o 
processo de envelhecimento. De acordo com as estimativas do Instituto Nacional do Câncer (INCA), a faixa etária prioritária para a detecção precoce do câncer do colo do útero se encontra entre 35 a 49 anos, período este correspondente ao pico de incidência das lesões precursoras (INCA, 2017).

No quesito cor, $72,95 \%$ das mulheres de nosso estudo se autodeclaram pardas, dado que se aproxima com os dados do IBGE, que apontam que a maior parcela $(69,5 \%)$ da população paraense se autodeclara parda (IBGE, 2011). Achado semelhante ao de Martins et al. (2017), que evidenciou que $78,7 \%$ de suas participantes com alteração pré-maligna ou maligna no exame citológico eram pardas ou pretas. A cor da pele é um fator este que eleva em até duas vezes o risco para mulheres negras quando comparadas com mulheres de cor branca, para o desenvolvimento do CCU

No que se refere ao estado conjugal e uso do preservativo, observamos que das 196 mulheres participantes do estudo, 73,46\% conviviam com seus parceiros, ou seja, eram casadas ou conviviam em união estável. Quanto ao uso do preservativo, observou-se que apenas 1,53\% mulheres faziam uso da proteção em todas as suas relações sexuais. Informações que se repete no estudo de Dias et al. (2019), que também evidenciou a presença majoritária de mulheres casadas $(74,5 \%)$ e um pequeno percentual $(13 \%)$ de mulheres que utilizavam o preservativo.

No que se referente à classe econômica e a escolaridade, a maioria das participantes de nosso estudo pertencia às classes com extrato social mais baixo $(63,26 \%)$, com ensino fundamental incompleto como principal nível escolaridade (36,22\%). Dados semelhante aos de Lombelo-Campos et al. (2018), onde a maioria de suas participantes também informaram possuir baixa situação econômica (83,5\%) e baixa escolaridade (52,6\%), na análise do mesmo, foi informado que as participantes de baixa renda apresentaram probabilidade $12 \%$ maior para o exame citopatológico do colo do útero alterado quando comparadas às de renda superior.

No quesito procedência 70,40\% mulheres informaram residir em municípios do interior do Pará, sendo a zona de localização da residência de maior predominância a zona urbana com 68,88\% mulheres. Achado semelhante ao de Teles e Ferrari (2012), onde informam a prevalência $82,2 \%$ de mulheres residentes da zona urbana de seus municípios. Apesar da maioria das mulheres deste estudo residirem na zona urbana de seus municípios, entende-se que a zona rural, possui uma das maiores dificuldades para a implantação de um rastreamento efetivo nas Estratégias de Saúde da Família (ESF), dado a inexistência de um banco de dados de base populacional, com informações específicas do rastreamento do CCU entre outros programas (ROSS; LEAL; VIEGAS, 2017).

Em relação ao perfil ginecológico e obstétrico das participantes, a idade da menarca entrou como variável para o estudo, uma vez que as práticas sexuais podem ser mais precoces e consequentemente ocorrer maior exposição sexual, visto que nesta fase há o desenvolvimento e a liberação de hormônios que intensificam o desejo sexual. Frente a esta variável, pode-se observar em nosso estudo que 50\% das entrevistadas, tiveram menarca entre as idades de 12 e 13 anos, com média de idade de 13,04 anos, que é considerada normal para a faixa etária. Tal achado se aproxima ao apresentado por Teles e Ferrari (2012), onde a idade predominante da menarca de suas participantes foi de 12 anos, com média de 12,6 anos. 
Em relação a antecipação do coito em virtude da precocidade da menarca, nosso estudo concorda com o exposto por Oliveira, Carvalho e Silva (2008), pelo fato de evidenciar que das 196 mulheres, 65,81\% iniciaram suas atividades sexuais com idades entre 15 e 20 anos, com média de idade 16,18 anos, sendo cabível aqui destacar aquelas 27,55\% mulheres que iniciaram sua atividade sexual antes dos 15 anos, nas quais a idade variou de 6 a 14, visto que quando mais precoce a sexualidade maior o potencial de risco para o desenvolvimento das LPCCU.

Em comparação com nosso estudo, temos o estudo de Conde, Lemos e Ferreira (2018) no qual também se pôde evidenciar dentre as características individuais das participantes, o predomínio da coitarca (52,5\%) entre 15 e 18 anos, com 21,2\% de mulheres que iniciaram sua atividade sexual com idade inferior ou igual a 14 anos.

Com relação a rotatividade de parceiros, pôde-se evidenciar em nosso estudo a predominância de 1 a $3(49,49 \%)$ parceiros sexuais, com média no decorrer da vida de 5,2 parceiros. Achado semelhante ao de Conde, Lemos e Ferreira (2018) onde 57,6\% de suas participantes informara ter tido de dois a cinco parceiros. Esta rotatividade de parceiros sexuais é apontada como um dos principais fatores de risco para o surgimento da LPCCU em mulheres solteira e sem parceiro fixo, dada a alta exposição a vírus e demais microrganismos causadores de IST, e indicam como uma forma de prevenção "possuir apenas um único parceiro sexual".

No que concerne ao uso de métodos hormonais, 49,48\% das mulheres participantes de nossa pesquisa, informaram usar ou ter usado anticoncepcional em algum momento de sua vida, com tempo de uso variável entre dois meses a 22 anos. Dado semelhante ao de Dias et al. (2019) onde 52\% de suas participantes informaram usar ou ter usado anticoncepcional. Uma análise de 24 estudos publicada em 2007, apontou que o risco de desenvolver o câncer do colo do útero entre usuárias de anticoncepcionais orais é de 1,9 vezes (APPLEBY et al., 2007).

Frente ao número de gestações e paridade, encontramos em nosso estudo 41,84\% participantes que tiveram 4 ou mais gestações, enquanto $31,63 \%$ informaram ter parido 4 ou mais filhos. No estudo de Conde, Lemos e Ferreira (2018) também observamos a predominância de mulheres (55,6\%) que tiveram quatro gestações ou mais, dado que é considerado como um fator de risco para o $\mathrm{CCU}$, assim como a iniciação precoce da atividade sexual, por proporcionar o aumento de sua incidência.

A despeito da caracterização clínica, verificou-se que, boa parte das participantes apresentaram em seus exames preventivos, a ação viral do HPV $(57,14 \%)$ nas lesões cervicais, sendo poucas as que apresentaram IST como HIV $(4,08 \%)$, sífilis $(5,61 \%)$ e gonorreia $(0,51 \%)$, além das infecções ginecológicas comuns a mulheres como candidíase e gardenerella (53,12\%). De acordo com Ceolin et al. (2018) mulheres com infecções persistentes do HPV, podem desenvolver lesões intraepiteliais que evoluirão até o câncer, caso não sejam detectadas e tratadas em tempo hábil.

Entre outros fatores apontados como de risco para o desenvolvimento das LPCCU, temse também o tabagismo, que é responsável por diminuir de forma significativa a quantidade e desempenho das células de Langherans, as quais são responsáveis pela defesa (ativação dos linfócitos TCD4) e conservação do tecido epitelial, além do cigarro/tabaco possuir mais de trezentas substâncias cancerígenas. Apesar de ser pequeno, o percentual de mulheres fumantes $7,65 \%$ neste estudo, com tempo de fumo 
predominante de 47,62\% para o intervalo de 6 e 10 anos, os números são considerados relevantes, frente aos malefícios que o tabaco/cigarro pode ocasionar.

Conclusão: Por meio deste estudo foi possível identificar as características de 196 mulheres paraenses portadoras de lesões intraepiteliais de um serviço de atenção secundária do município de Belém do Pará. Verificou-se que essas mulheres são adultas, com predominância na faixa etária de 18 a 30 anos; de cor autodeclarada parda; casadas ou em união estável; com renda familiar predominante, de menos de um salário mínimo; com ensino fundamental incompleto; executando atividades do lar; procedentes de municípios do interior do Estado e com residência na zona urbana dos municípios; menarca na idade de 12 anos; coitarca entre as idades de 15 a 20 anos; um a três parceiros sexuais; uma a três gestação/partos; não tabagista e com história de IST prévia.

Esperamos com este estudo, contribuir para a construção do conhecimento e para reflexão quanto a importância do conhecimento do perfil epidemiológico e as características das mulheres com LPCCU para o estabelecimento de diretrizes públicas em todas as esferas de saúde, bem como o planejamento de ações de prevenção e controle do câncer do colo do útero. O presente estudo foi realizado com o apoio da Coordenação de Aperfeiçoamento de Pessoal de Nível Superior - Brasil (CAPES) Código de Financiamento 001.

Referências: APPLEBY, P. et al. Cervical cancer and hormonal contraceptives: collaborative reanalysis of individual data for 16,573 women whit cervical cancer and 35,509 women without cervical cancer from 24 epidemiological studies. Lancet, v. 370, n. 9599, p. 1609-21, nov. 2007.

CEOLIN, R. et al. Perfil de Mortalidade Por Câncer de Colo do Útero no Período de 2005-2014. Revista de Enfermagem do Centro-Oeste Mineiro, v. 8, p. e1806, 2018.

CONDE, C. R.; LEMOS, T. M. R.; FERREIRA, M. L. S. M. Características sociodemográficas, individuais e programáticas de mulheres com câncer de colo do útero. Enfermería Global, n. 49, p. 359-69, enero 2018. Disponível em: http://dx.doi.org/10.6018/eglobal.17.1.301041. Acesso em: 15 jul. 2019.

DIAS, C. F. et al. Perfil de exames citopatológicos coletados em estratégia de saúde da família. Revista de Pesquisa: Cuidado é Fundamental Online, v. 11, n. 1, p. 192-8, jan./mar. 2019.

INSTITUTO BRASILEIRO DE GEOGRAFIA E ESTATÍSTICA. Censo demográfico 2010. Características da população e dos domicílios: resultados do universo. Rio de Janeiro: IBGE, 2011.

INSTITUTO NACIONAL DE CÂNCER. Diretrizes brasileiras para o rastreamento do câncer do colo do útero. 2. ed. Rio de Janeiro: INCA, 2016.

INSTITUTO NACIONAL DE CÂNCER. Estimativa 2018: incidência de câncer no Brasil. Rio de Janeiro: INCA, 2017.

LOMBELO-CAMPOS, A. A. et al. Fatores Associados ao Risco de Alterações no Exame Citopatológico do Colo do Útero. Revista de Enfermagem do Centro-Oeste Mineiro, v. 8, p. e2330, mar. 2018. 
MARTINS, L. T. F. et al. Caracterização de mulheres com lesão pré-maligna ou maligna no exame Papanicolau. Revista de enfermagem - UFPE on line, Recife, v. 11, n. 9, p. 3360-8, 2017.OLIVEIRA, T. C.; CARVALHO, L. P.; SILVA, M. A. O enfermeiro na atenção à saúde sexual e reprodutiva dos adolescentes. Revista Brasileira de enfermagem, v. 61, n. 3, p. 306-11, 2008.

ROSS, J. R.; LEAL, S. M. C.; VIEGAS, K. Rastreamento do câncer de colo de útero e mama. Revista de enfermagem UFPE on line, Recife, v. 11, Supl. 12, p. 5312-20, 2017.

TELES, CCGD, FERRARI, R. Lesões precursoras para câncer de colo uterino e os aspectos sociodemográficos das portadoras. Revista Eletrônica Gestão \& Saúde, v. 3, n. 3, p. 865-79, 2012.

Palavras-chave: Neoplasias do colo do útero. Lesões precursoras. Perfil epidemiológico.

Grande-área: Enfermagem.

Área: Saúde Coletiva. 


\title{
COMPREENSÃO FENOMENOLÓGICA SOBRE O COTIDIANO DE MULHERES COM DIAGNÓSTICO DE LESÃO INTRAEPITELIAL ESCAMOSA ALTA
}

\author{
Nome do(a) Bolsista: Nicole Jucá Monteiro \\ Nome do(a) Orientador: Antônia Margareth Moita Sá
}

Resumo: compreender o sentido do cotidiano de mulheres diagnosticadas e em tratamento de Lesão Intraepitelial Escamosa Alta em Unidade de Referência Materno Infantil no Município de Belém do Pará. Método: Estudo de abordagem fenomenológica, baseado no referencial teórico de Martin Heidegger. Foram realizadas 30 entrevistas com mulheres com mais de 24 anos de idade que não estivessem em sua primeira consulta na uremia, diagnósticas e em tratamento para as Lesões Intraepiteliais Cervicais de Alto Grau.

Resultados e Discussão: por se tratar de um estudo que ainda está em processo de análise das falas, acredita-se que surgirão classes discursivas sobre o medo da morte, alterações biopsicossociais decorrentes do diagnóstico, falta de esclarecimento efetivo por parte dos profissionais sobre as lesões cervicais e pouca legitimação sexual feminina. Conclusão: Os profissionais de saúde precisam repensar suas práticas cotidianas referentes ao diagnóstico das lesões cervicais intraepiteliais alta, pois isso gera uma repercussão em todas esferas da vida dessa mulher

Introdução: O câncer é uma doença conhecida de longa data e os seus primeiros registros são datados do período antes de Cristo (a.C). A palavra deriva do grego karkínos, que quer dizer caranguejo e foi utilizada pela primeira vez por Hipócrates, pai da medicina que viveu entre os anos 460 e 377 a.C para designar um tumor duro. ${ }^{1}$ Dentre os vários tipos de câncer existentes, o câncer de colo de útero desponta como um dos mais incidentes na população feminina brasileira e paraense. $O$ último banco de dados fechado do DATASUS referente ao ano de 2016 para o estado do Pará, nele constam 771 óbitos considerando todos os tipos de neoplasias, e destes, 339 óbitos só por câncer de colo de útero no Estado e 216 óbitos considerando só o município de Belém-PA. $^{2}$ Assim, o câncer de colo uterino é tido como afecção progressiva e caracterizado por alterações intraepiteliais cervicais que podem se desenvolver para um estágio invasivo ao longo de uma a duas décadas. Essas alterações podem ser classificadas em três tipos e são caraterizadas principalmente por uma desordem das células epiteliais pavimentosas que vão desde núcleos mais corados até figuras atípicas de divisão celular, são elas: Neoplasia Intraepitelial Cervical Grau I (NIC I), Grau II (NIC II) e Grau III (NIC III).Como forma de padronização da nomenclatura em nível internacional, o Ministério da Saúde em 2006 estipulou a mudança do termo NIC (I, II e III) em favor dos termos Lesão Intraepitelial Escamosa Baixa (LSIL) e Lesão Intraepitelial Escamosa Alta (HSIL) para designação de alterações encontradas em exames de colpocitologia oncótica referentes as lesões cervicais. ${ }^{3}$ 
Objetivo: compreender o sentido do cotidiano de mulheres diagnosticadas e em tratamento de Lesão Intraepitelial Escamosa Alta em Unidade de Referência Materno Infantil no Município de Belém do Pará.

Método: Estudo de abordagem fenomenológica, baseado no referencial teórico de Martin Heidegger. $O$ estudo foi desenvolvido na Unidade de Referência Especializada Materno-Infantil localizada no município de Belém - PA mais especificamente no setor de patologia cervical. Foram listados os seguintes critérios para obtenção das participantes do estudo: mulheres com mais de 24 anos de idade que não estivessem em sua primeira consulta na uremia, diagnósticas e em tratamento para as Lesões Intraepiteliais Cervicais de Alto Grau. Como critério de exclusão: mulheres que apresentem alterações cognitivas, comunicativa e/ou auditivas para participar da entrevista. Foram realizadas 30 entrevistas, pois como trata-se de um estudo com abordagem fenomenológico, há um ponto em que as falas começam a ser repetir, não havendo a necessidade de muitas participantes. A análise dos discursos segue os pontos de referência da trajetória fenomenológica que são divididos em três momentos, a saber: a descrição, a redução, a compreensão e a hermenêutica. ${ }^{4}$

Resultados e Discussão: por se tratar de um estudo que ainda está em processo de análise das falas, acredita-se que surgirão classes discursivas sobre o medo da morte, alterações biopsicossociais decorrentes do diagnóstico, falta de esclarecimento efetivo por parte dos profissionais sobre as lesões cervicais e pouca legitimação sexual feminina. Conclusão: Os profissionais de saúde precisam repensar suas práticas cotidianas referentes ao diagnóstico das lesões cervicais intraepiteliais alta, pois isso gera uma repercussão em todas esferas da vida dessa mulher. Além disso, notou-se que essas mulheres carecem de maiores informações sobre a forma de transmissão, informações sobre o HPV, a importância do uso de preservativo nas relações sexuais para evitar não só as lesões cervicais, e sim, as doenças sexualmente transmissíveis em geral.

\section{Referências}

1. INSTITUTO NACIONAL DO CANCER(INCA/MS). Controle do câncer do colo do útero, In: Legislação - Controle do Câncer do Colo do Útero, 2018. Disponível em: https://www.inca.gov.br/controle-do-cancer-do-colo-do-utero/legislacao-controle-cancercolo-utero. Acesso em 17 Jan 2019.

2. MINISTÉRIO DA SAÚDE. Sistema de Informações sobre Mortalidade - SIM. Disponível em: http://tabnet.datasus.gov.br/cgi/tabcgi.exe?sim/cnv/obt10pa.def. Acessado em: 27 Out 2018.

3. INSTITUTO NACIONAL DE CÂNCER (INCA/MS). Nomenclatura brasileira para laudos citopatológicos cervicais. 3.ed. Rio de Janeiro: INCA, 2012. 23 p.

1. KAHLMEYER-MERTENS, R.S. 10 lições sobre Heidegger. $1^{a}$ Reimpressão. Rio de Janeiro: Vozes, 2015. 
Palavras-chaves: Lesões Intraepiteliais Escamosas Cervicais; Saúde da Mulher; Fenomenologia.

Grande Área: Enfermagem

Área: Saúde da Mulher; Saúde Coletiva 


\title{
ESPACIALIDADE DO HIV ENTRE DOADORES DE SANGUE ASSOCIADO AOS FATORES DE RISCO
}

\author{
Nome do(a) Bolsista: Rosane Vieira Lobato \\ Nome do(a) Orientador(a): Ângela Maria Rodrigues Ferreira.
}

Introdução: A Organização Mundial da Saúde (OMS) estima em mais de 1 milhão, o número de pessoas que adquirem infecções sexualmente transmissíveis (IST) diariamente (OKANGO; MWAMBI; NGESA, 2016). A pandemia do vírus da imunodeficiência humana (HIV) com mais de 36,7 milhões de pessoas infectadas em todo o mundo e 1,1 milhões de mortes somente em 2015, é um dos maiores desafios de saúde pública do século XXI (ZELENEV et al., 2016).

No Brasil, entre 2007 e junho de 2018, segundo dados do Boletim epidemiológico (BRASIL, 2018) foram notificados no Sistema de Informação de Agravos de Notificação (SINAN) 247.795 casos de infecção pelo HIV, sendo 19.781 (8,0\%) na região Norte. As regiões Norte e Nordeste apresentaram tendência de crescimento na detecção, em 2007 tiveram taxas registradas de 16,4 e 12,7 casos por 100 mil habitantes, respectivamente, enquanto em 2017 de 23,6 (Norte) e 15,7 (Nordeste), representando aumentos de $44,2 \%$ (Norte) e $24,1 \%$ (Nordeste).

O Pará é o quarto estado com maior índice de casos de aids, com cerca de 1961 casos, no ano de 2017, o que corresponde a mais de cinco notificações por dia. Entre as capitais, Belém está em segundo lugar com as maiores taxas de detecção do país, perfazendo uma taxa média de 53,71 casos por 100 mil habitantes com aids na população geral nos últimos 3 anos (BRASIL, 2018).

Nas grandes cidades do Brasil, os centros de testagem e aconselhamento voluntário (CTA) são os responsáveis por oferecer os testes gratuitos de HIV, entretanto, historicamente os bancos de sangue foram as primeiras instituições públicas a realizar esses testes, isso porque, o desenvolvimento de tecnologias para reduzir o risco de transfusão de doenças infecciosas é uma das principais características da hemoterapia. Assim, cada doação é submetida a testes clínicos e sorológicos para garantir que o sangue doado não ofereça riscos ao receptor (ALMEIDA-NETO et al., 2013; MONICH et al., 2017).

Os bancos de sangue têm sido uma importante fonte de dados sobre a epidemiologia de agentes infecciosos para os quais a triagem é realizada rotineiramente. Os hemocentros podem oferecer uma oportunidade única para contribuir para a compreensão dos fatores de risco para infecção, porque as pessoas que se apresentam para doar sangue refletem um corte transversal diversificado da população em geral (LEVI et al., 2017; ALMEIDA-NETO et al., 2013).

A avaliação de dados sobre a prevalência dessa infecção entre doadores de sangue pode fornecer informações sobre a epidemiologia da infecção na população em geral (KARABAEV et al., 2017).

A infectividade pelo HIV rege sua ocorrência, mas isso também está relacionado ao ambiente local, economia social e cultural, entre outros fatores. O conhecimento da distribuição geográfica da epidemia de HIV/aids é necessário para sua prevenção e 
controle (WANG et al., 2016). Assim como, a estatística espacial pode ser usada para analisar as correlações no espaço e a análise de agrupamento pode ser empregada para descrever a ocorrência da infecção pelo HIV em áreas específicas (QIAN et al., 2014).

\section{Objetivos:}

Objetivo Geral: Avaliar as tendências espaçotemporais dos casos positivos para HIV e a associação com os comportamentos de risco nos doadores de sangue do hemocentro coordenador do estado do Pará, entre 2014 e 2019.

Objetivos Específicos: Descrever a ocorrência do HIV nos doadores de sangue segundo perfil sociodemográfico e epidemiológico; Fazer a distribuição espaçotemporal dos casos de HIV e; Associar a distribuição espaçotemporal dos casos de HIV com os comportamentos de risco.

Material e Método: Trata-se de um estudo de caráter ecológico, retrospectivo e de abordagem quantitativa, que será desenvolvido mediante a utilização de técnicas de análise espacial de dados de área. Os estudos ecológicos são caracterizados por abordarem áreas geográficas e blocos de populações bem delimitadas, com a comparação de variáveis, como, por exemplo, a existência de correlação entre indicadores de condições de vida e situações de saúde/doença (ROUQUAYROL; GURGEL, 2017).

Os dados serão trabalhados pelos municípios atendidos pelo hemocentro de Belém, incluindo a sede do hemocentro e as unidades de coleta dos shoppings Castanheira e Pátio Belém.

A população compreenderá a todos os casos positivos para o HIV, identificados pelo hemocentro de Belém (sede e unidades de coleta dos shoppings Castanheira e Pátio Belém), por meio da doação de sangue, entre $1^{\circ}$ de janeiro de 2014 e 31 de agosto de 2019.

Critério de inclusão: doadores de sangue positivos para HIV na faixa etária 16 anos a 69 anos (faixa etária de doação), que foram atendidos pelo hemocentro de Belém (sede e unidades de coleta dos shoppings Castanheira e Pátio Belém) no período de 2014 a 2019.

Critério de exclusão: dados incompletos e com inconsistências no banco de dados disponibilizado pelo hemocentro de Belém.

As variáveis do estudo serão divididas em dois grupos, a saber: a) sociodemográficas, que abrangem aspectos importantes para a caracterização dos estudados; b) epidemiológica, que oferece uma descrição mais detalhada sobre fatores de risco associados à doença em questão. Dessa forma, serão selecionadas para o estudo:

Variáveis sociodemográficas: idade, sexo, escolaridade, estado civil, endereço, data e doador novo ou doador de repetição.

Variável epidemiológica: profissão, uso de tatuagem, uso de material de manicure/pedicure compartilhado, uso de droga proibida, uso de droga injetável de forma compartilhada, três ou mais parceiros nos últimos 12 meses, relação com parceiro eventual e/ou desconhecido nos últimos 12 meses, uso de preservativos nas relações sexuais, experiência sexual com outro homem (se do sexo masculino), presença de coinfecção (hepatite B, C, sífilis e HTLV). 
A coleta de dados será realizada junto ao Hemocentro coordenador por meio de duas etapas:

$1^{\circ}$ etapa: Será realizada obtenção dos dados dos casos positivos para o HIV junto ao Hemocentro de Belém, através do SBS. O banco de dados será organizado em planilhas e depurado por meio do software Microsoft $\AA$ Excel 2010. Após a coleta dos dados, as informações serão organizadas para construção de um Banco de Dados Geográfico (BDGeo).

$2^{\circ}$ etapa: com o intuito de levantar os fatores de risco que serão utilizados neste estudo, para coleta de dados da variável epidemiológica, se utilizará um formulário para coletar dados, que será preenchido com base no formulário epidemiológico, impresso, estruturado, padrão da instituição. O mesmo é preenchido na consulta de acompanhamento quando o doador apresenta reatividade sorológica confirmada, sendo convidado a retornar ao banco de sangue para ser entrevistado por um médico.

Previamente a essas etapas, será apresentado ao Hemocentro o Termo de Compromisso de Utilização de Dados-TCUD para acesso ao banco de dados e ao formulário padrão da instituição.

A análise dos dados, será realizada em duas fases, na primeira, para descrever a população estudada, serão realizadas análises univariadas e bivariadas das variáveis sociodemográficas e epidemiológicas. Para verificar a associação através de uma correlação, será utilizado o teste de correlação de Pearson ou o teste t.

$\mathrm{Na}$ segunda fase, para subsidiar a construção dos mapas temáticos capazes de expressar visualmente relações espaciais relacionadas aos casos de HIV investigados, será realizado o georreferenciamento dos casos, onde serão convertidos em coordenadas geográficas de longitude e latitude usando o www.addres4.com/services/address-geocodin. Quanto à base cartográfica será considerada a base dos bairros segundo dados dos setores censitários do censo demográfico de 2010 disponibilizado pelo Instituto Brasileiro de Geografia e Estatística (IBGE). Para análise espacial, será utilizado um SIG para fazer a distribuição espacial dos casos de HIV por bairro; verificar a autocorrelação dos casos pela técnica de Moran; localizar os aglomerados pela Estimativa de Densidade Kernel (EDK); e criar mapas temáticos \{fatores de riscos\}.

Essa pesquisa possui riscos mínimos por se tratar de uma pesquisa em base de dados secundários. No entanto, poderá ocorrer a perda de informações e a quebra do anonimato devido ao manejo dos dados. Para isso, todas as informações serão organizadas em planilhas e armazenadas de forma segura, através de senha de acesso, de uso exclusivo da equipe de pesquisa, e ainda, os doadores serão identificados através do código do doador (código numérico). A autora do projeto compromete-se a não repassar os dados coletados ou o banco de dados em sua íntegra, ou parte dele, às pessoas não envolvidas na equipe da pesquisa e, a manter sigilo com relação aos dados obtidos.

Em relação ao formulário epidemiológico padrão da instituição, para evitar danos às fichas e possíveis extravios, a pesquisadora se compromete a não manipular alimentos durante a pesquisa e trabalhar com um impresso de controle de entrega e devolução das fichas, por fim, ressaltamos que os dados coletados serão arquivados e o material será destruído após cinco anos. 
Para a pesquisadora, os riscos envolveram doenças dermatológicas e respiratórias devido à manipulação dos formulários durante a execução do trabalho, bem como dores ósteo-musculares ao realizar pesquisa. Como medidas de prevenção de tais riscos, serão usadas medidas de higiene, como lavagem das mãos, ao manusear material didático, pausa e exercícios laborais entre a digitação dos dados das fichas para criação do bando de dados.

Como benefício, a equipe de saúde da instituição poderá avaliar suas práticas em relação ao aprimoramento da triagem de doadores, a partir da ótica dos resultados, pois, permitirão conhecer a espacialidade dos casos de HIV associados aos fatores de risco. A gestão pública, a nível de serviços de saúde, tomará conhecimento acerca do panorama do HIV e sua dinâmica espacial na região metropolitana de Belém, possibilitando potencializar as ações de saúde em espaços territoriais, onde se apresentam os maiores índices, para reduzir tais números, contribuindo assim para as politicas públicas. Além disso, a pesquisa pode trazer subsídios para novos estudos, adquirindo mais conhecimento sobre o assunto.

O estudo cumprirá com as exigências éticas, obedecendo às normas da Resolução $n^{\circ}$ 466/12 do CNS/MS que normatiza a pesquisa com seres humanos.

\section{Referências bibliográficas}

ALMEIDA-NETO, C. et al. Risk factors for human immunodeficiency virus infection among Brazilian blood donors: a multicentre case-control study using audio computerassisted structured interviews. Vox Sang, v.105, n.2, p.91-99, 2013.

BRASIL. Boletim Epidemiológico- HIV AIDS 2018. Secretaria de Vigilância em Saúde Ministério da Saúde .v. 49, n. 53, 2018.

KARABAEV, B. et al. Seroprevalence of hepatitis B, hepatitis C, human immunodeficiency virus, Treponema pallidum, and co-infections among blood donors in Kyrgyzstan: a retrospective analysis (2013-2015). Infect Dis Poverty, v. 6, n.1, p. 45, fev. 2017.

LEVI, J. et al. Contrasting HCV and HIV seroepidemiology in 11 years of blood donors screening in Brazil. Transfus Med, v. 27, n. 4, p.286-291, 2017.

MONICH, A. et al. Blood discard rate in a blood center in Curitiba - Brazil. Ten years of study. Transfus Apher Sci, v. 56, n.2. p.130-134, 2017.

OKANGO, E.; MWAMBI, H.; NGESA, O. Spatial modeling of HIV and HSV-2 among women in Kenya with spatially varying coefficients. BMC Public Health, v. 16, p. 355, 2016.

QIAN, S. et al. Diversity of HIVIAIDS epidemic in China: a result from hierarchical clustering analysis and spatial autocorrelation analysis. AIDS, v. 28, n.1805-13, 2014. 
ROUQUAYROL, M.; GURGEL, M. Epidemiologia \& Saúde. 8. ed. Rio de Janeiro: MedBook, 2017.

WANG, Y. et al. The spatial distribution pattern of human immunodeficiency virus/acquired immune deficiency syndrome in China. Geospat Health, v.11, n. 2, p. 414, 2016.

ZELENEV, A. et al. The complex interplay of social networks, geography and HIV risk among Malaysian Drug Injectors: Results from respondent-driven sampling. Int J Drug Policy, v. 37, p.98-106, 2016.

Palavras-chave: Infecções por HIV, Análise espacial, doadores de sangue, fatores de risco.

Grande área: Ciências da saúde

Área: Epidemiologia e saúde pública 